\title{
Collectieve besluiten, belangen en wetgeving : de totstandkoming van tarieven voor medisch specialisten in Nederland tussen 1986 en 1992
}

Citation for published version (APA):

Lieverdink, H. J. (1999). Collectieve besluiten, belangen en wetgeving : de totstandkoming van tarieven voor medisch specialisten in Nederland tussen 1986 en 1992. [Doctoral Thesis, Maastricht University]. Universiteit Maastricht. https://doi.org/10.26481/dis.19990129hl

Document status and date:

Published: 01/01/1999

DOI:

10.26481/dis.19990129hl

Document Version:

Publisher's PDF, also known as Version of record

Please check the document version of this publication:

- A submitted manuscript is the version of the article upon submission and before peer-review. There can be important differences between the submitted version and the official published version of record.

People interested in the research are advised to contact the author for the final version of the publication, or visit the DOI to the publisher's website.

- The final author version and the galley proof are versions of the publication after peer review.

- The final published version features the final layout of the paper including the volume, issue and page numbers.

Link to publication

\footnotetext{
General rights rights.

- You may freely distribute the URL identifying the publication in the public portal. please follow below link for the End User Agreement:

www.umlib.nl/taverne-license

Take down policy

If you believe that this document breaches copyright please contact us at:

repository@maastrichtuniversity.nl

providing details and we will investigate your claim.
}

Copyright and moral rights for the publications made accessible in the public portal are retained by the authors and/or other copyright owners and it is a condition of accessing publications that users recognise and abide by the legal requirements associated with these

- Users may download and print one copy of any publication from the public portal for the purpose of private study or research.

- You may not further distribute the material or use it for any profit-making activity or commercial gain

If the publication is distributed under the terms of Article 25fa of the Dutch Copyright Act, indicated by the "Taverne" license above, 


\section{Collectieve besluiten, belangen en wetgeving}

De totstandkoming van tarieven voor medisch specialisten in Nederland tussen 1986 en 1992 
Collectieve beshiten, belangen en wetgeving

De totstandkoming wan tarieven voor medisch specialisten in Nederland tussen 1986 en 1992

(c) 1999 H. Lieverdink, Maastricht

isbun 90-9012293-1

Drukwerk: Datawyse, Maastricht

Omslagontwerp: Annet Lieverdink, Grave

Lay»out: Jan van Emmerik, Maastricht 


\section{Collectieve besluiten, belangen en wetgeving}

De totstandkoming van tarieven voor medisch specialisten in Nederland tussen 1986 en 1992

\section{PROEFSCHRIFT}

Ter verkrijging van de graad van doctor aan de Universiteit Maastricht, op gezag van de Rector Magnificus, Prof. Dr. A.C. Nieuwenhuijzen Kruseman, volgens het besluit van het College van Decanen, in het openbaar te verdedigen op vrijdag 29 januari 1999 om 14.00 uur

door

Harm Jan Lieverdink

geboren op 16 februari 1963

te Winterswijk 


\section{Promotores:}

Prof dr. J.AM. Maarse

Prof.dr. A.J.A. Godfroij (Katholieke Universiteit Nijmegen)

\section{Beoordelingscommissie:}

Profmr. F.C.B. van Wijmen (voortiter)

Prof.dr. T.E.D. van der Grinten (Erasmus Universiteit Rotterdam)

Prof.dr. W.N.J. Groot

Profdr. M. Herweijer (Rijksuniversiteit Gromingen)

Prof.dr. A.F.A. Korsten 


\section{Voorwoord}

Er waren tijden waarin een patiènt de hulp van zijn arts kon betalen met een halve vette gans of ander eetwar. Of waarin hem een gedeelte van zijn rekening werd kwijtgescholden omda zijn palard was komen te overlijden (Fuldauer, 1998). De besluitvorming over tarieven voor medisch specialisten is de laatste tijd minder romantisch. Een gesprek over de betaling hoort allang niet meer thuis in de praktijkruimte wan de arts. Allerlei persoonlijke onstandigheden doen en niet meer toe. Is thet vaststellen van tarieven voor medische hulp daardoor saal geworden? Ikzelf antwoord natuurlik met een stellig nee! Het drukke en ingewikkelde bestuurlijke gedrag dat zich tond de tarieven afspeelt is daarwoor veel te boeiend. Ik heb geprobeerd de intrigerende bestuurlijke activiteiten in een attractief verhaall naar voren te laten komen. of mijn stilistische kwaliteiten daarvoor toereikend waren moet de lezer maar beoordelen. Een waarschuwing is wel op zijn plaats. Het is een onvangrijk boek geworden. Volgens Ian MoEwan hoeft de beste beschrijving wan de werkelijkheid niet haar snetheid na te bootsen (Ziek wan liefde, p. 26). Aan zijn mening heb ik mij maar vastgehouden. Bij de tariefvorming voor medisch specialisten gebeurde eenwoudigweg teveel om er snel verslag van te kunnen doen. Uithoudingsvermogen word bij hef lezen van dit boek dus wel gevraagd.

Verschillende mensen hebben dit al getoond toen zij versies van stukken van het proefschrift lazen en van commentaar voorzagen. Hen wil ik daarvoor bedanken. Ten eerste mijn promotores, Hans Maarse en Amold Godfroij. Zij hebben beiden op hun eigen manier voortdurend suggesties voor verbetering gedaan. Hun bijdrage was onmisbaar. Ik ben hen bovendien dankbaar voor hum vertrouwen en geduld.

Naast de promotores hebben anderen meegelezen en hun commentatar gegeven. Vooral Nico Baakman heeft een zeer waardevolle bijdrage aan het schrijven van dit boek geleverd. Nico was altijd eerlijk en stelde meer dan eens de vreselijke maar onvermijdbare vraga: wat wil je nu eigenlijk? Ik vond zijn opmerkingen soms behoorlijk lastig maar zij kwamen gelukkig voort wit een door mij zeer gewaardeerde authentieke wetenschapsopvatting: vaak cynisch met een scherp oog voor ongefundeerde pretenties maar met liefde woor het vak. Jan van der Made dank ik voor zijn optimüsme en positieve houding als tegenwicht voor de onzekerheid die mij bij tijd en wijle kwelde. Einte Elsinga dank ik voor zijn commentaar op de eerste hoofdstukken. De onderzoekers van Zorg, Technologie en Culturir hebben mij eveneens voorzien van suggesties voor verbetering.

Tijdens het onderzoek ben ik bij werschillende organisaties op bezoek geweest. De mensen die mij geholper hebben toegang tot de archieven te krijgen wil ik hierbij danken. De gastvrijheid Was vaak groot. Met Henk van Vliet, Bert Blokland, Henk Vermeulen, Veronica van Nederveen, Jos Becker Hoff, Popke Wagenaar en Floor Goudriaan heb ik tevens meerdere keren van gedachten mogen wisselen over mijn onderzoek. Daarvoor dank.

Ook binnen de universiteit heb ik steun gekregen. Frits wan Merode heeft een zeer bruikbare methodiek ontworpen die wij naar ik hoop nog kunnen ontwikkelen. Jan vam Emmerik heef zich bezig gehouden met de vormgeving van het proefschrift. Maud Damme heef mij veel geholpen bij de verzameling van data on de invulling van de schema's van Toulmin hetgeen niet eenvoudig bleek te zijn.

Ik ben mijn ouders dankbaar voor veel maar ook voor dal ze mij niet teruglloten toen ik . wellicht enigszins naief en onwetend - besloot de toen nog net marxistisch gekleurde studie 
politicologie in Nijmegen te gaan doen. Hierdoor kon ik het doctoraal programma bestururskunde volgen waardoor ik toch nog een prachtig vak heb geleerd.

Lieve Liesbeth. Dit proefschrift ging bij ons thuis lange tijd door het leven als mijn 'broddelwerkje'. Niet zozeer vanwege de inhoud maar wel vanwege de taal die in jouw ogen nogal houterig en bestuurlijk was. Met verbeteringen heb je mil veel geholpen hoewel ik natuurlijk geen Hanlo ben geworden. Jouw steun en aarzwezigheid waren mij nog veel dierbatarder.

Maastricht, oktober 1998 


\section{Inhoudsopgave}

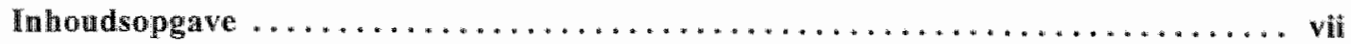

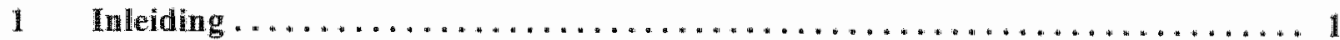

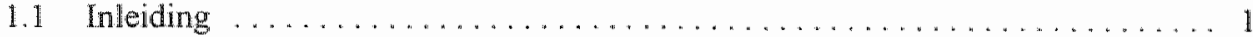

1.2 Het belang van de besluitvorming over tarieven $\ldots \ldots \ldots \ldots \ldots \ldots \ldots 2$

1.3 Het belang van instituties voor besluitvorming: de Wtg als institutionele

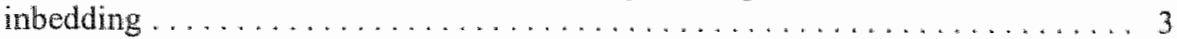

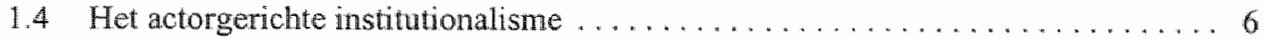

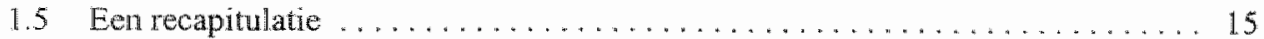

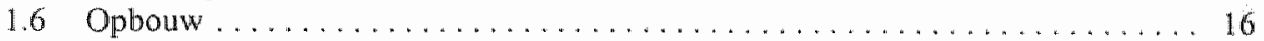

2 Concepten, methodologie en methoden $\ldots \ldots \ldots \ldots \ldots \ldots \ldots \ldots \ldots \ldots$

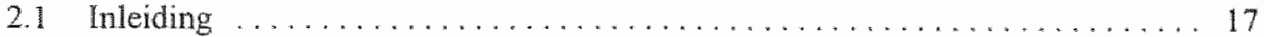

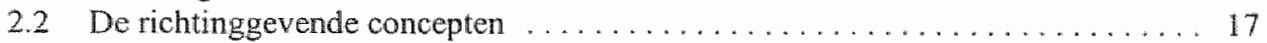

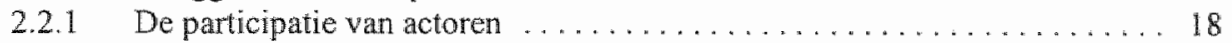

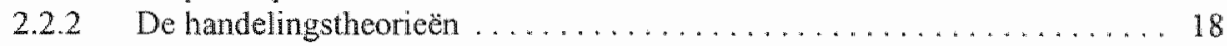

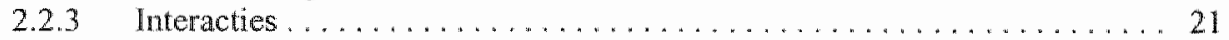

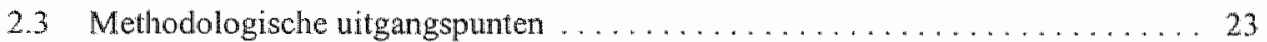

2.3.1 Besluitvorming als proces: een reeks van gebeurtenissen $\ldots \ldots \ldots \ldots 23$

2.3 .2 Inductief onderzoek ............................ 26

2.3.3 De inperking van het aantal gebeurtenissen: casuïstiek en analyseniveau $\ldots 27$

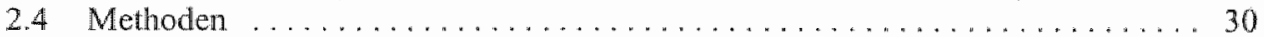

2.4.1 Het algemene databestand ....................... 30

2.4.2 Methoden ten behoeve van het onderzock naar de participatie van actoren . 30

2.4.3 Methoden ten behoeve van het onderzoek naar de handelingstheorieën ... . 31

2.4.4 Methoden ten behoeve van het interactieonderzoek . . . . . . . . . . . 32

2.5 Samenvatting . . . . . . . . . . . . . . . . . . . . . . 33

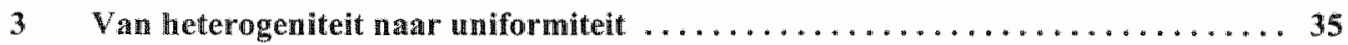

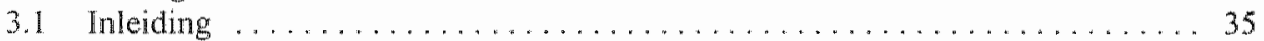

3.2 Tariefvorming in deze eeuw: de voorbereidingen $(1900-1940) \ldots \ldots \ldots \ldots 36$

3.2.1 De structuur van de financiering en betaling van artsen ........... 36

3.2.2 De betaling van en tariefvorming voor medisch specialisten ......... 41

3.3 Tariefvonning in deze eeuw: het fundament $(1945-1982) \ldots \ldots \ldots \ldots \ldots 45$

3.4 Tariefvorming in deze eeuw: de politisering (vanaf 1982) . . . . . . . . 52

3.4.1 Het herontwerp van structuren: de invoering van de $\mathrm{Wtg}, \ldots \ldots, \ldots, 52$

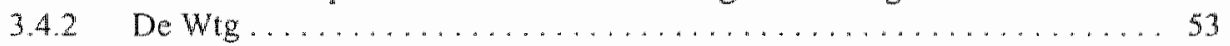

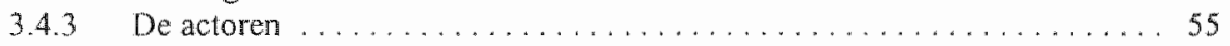

3.4 .4 Veranderingen door de $W \operatorname{tg} ? \ldots \ldots \ldots \ldots \ldots \ldots \ldots \ldots \ldots \ldots$

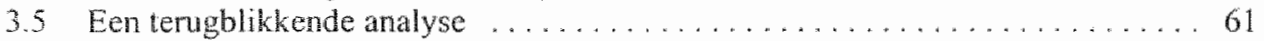

3.6 Op zoek naar het pad der ontwikkeling ........................ 65

4 Besluitvorming over tarieven voor medisch specialisten tussen 1986-1992: het

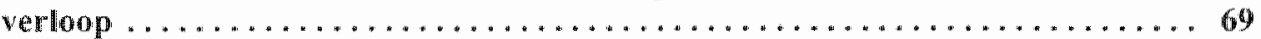

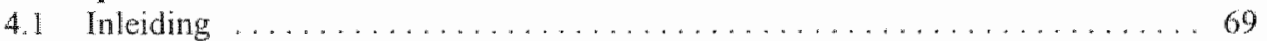

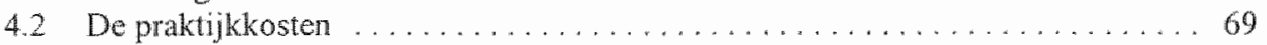




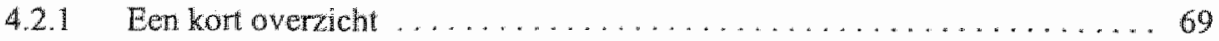

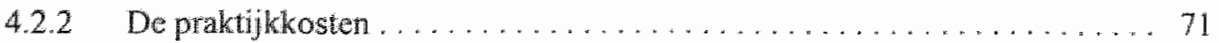

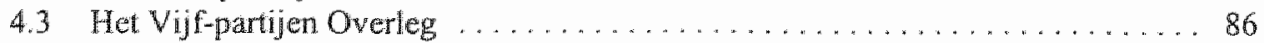

4.3 .1 Inleiding . . . . . . . . . . . . . . . . . . . . . . . . . . 86

4.3.2 Geleide onderhandelingen en en incomplete ruil . . . . . . . . . . 87

4.4 De dans met de inkomensverschillen: de reshuffing . . . . . . . . . . . . 94

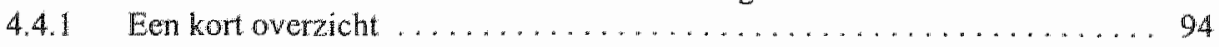

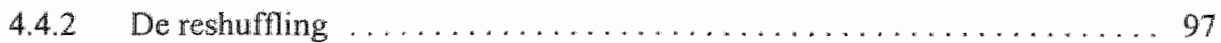

4.5 Straf voor onwillige speciallisten de tweeslag ... . . . . . . . . . . . . 109

4.5 .1 Een kort overzicht ............................... 109

4.5 .2 De tweeslag ............................. 110

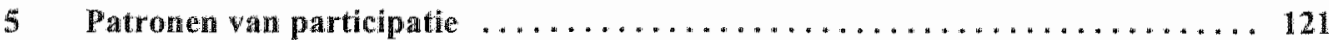

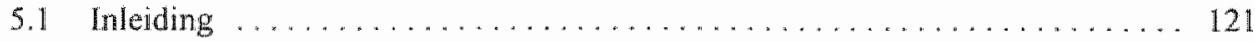

5.2 Methodologie . . . . . . . . . . . . . . . . . . . . . . . . . 122

5.3 De participatie in de besluitworming over tarieven . . . . . . . . . . . 123

5.4 Patronen van participatie . . . . . . . . . . . . . . . . . . . . 124

5.5 De participatic op basis van formele regels en de noodzaak van additionele

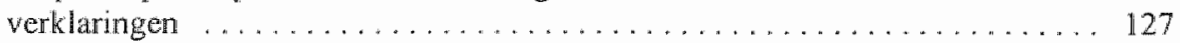

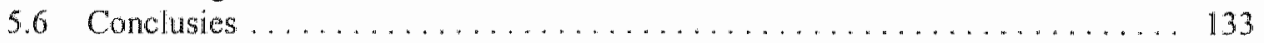

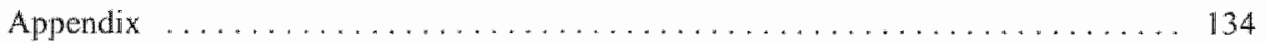

6 De handelingstheorieën en hum logica $\ldots \ldots \ldots \ldots \ldots \ldots \ldots \ldots \ldots \ldots$

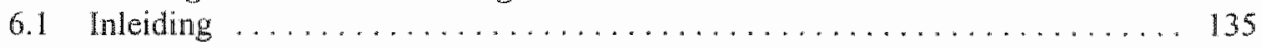

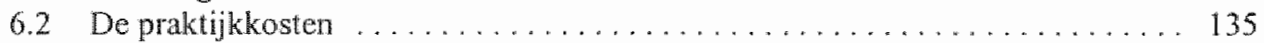

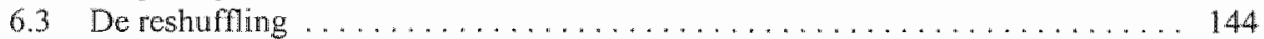

6.4 De tweeslag . . . . . . . . . . . . . . . . . . . . . . . . . . . 148

6.5 De handelingstheorieën en de institutionele context $\ldots \ldots \ldots \ldots \ldots \ldots \ldots \ldots$. $\ldots 5$

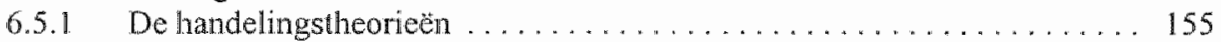

6.5.2 De logica van de handelingstheorieén . . . . . . . . . . . . . . 160

6.5 .3 De invloed wan het institutionele kader . . . . . . . . . . . . . 162

6.6 Conclusies .................................... 164

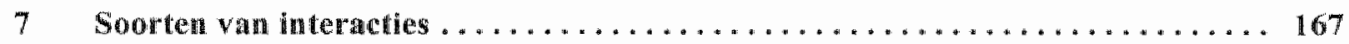

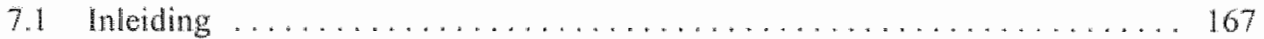

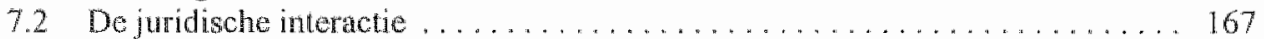

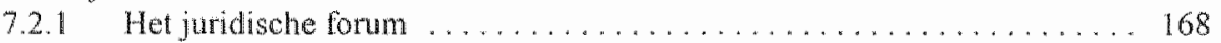

7.2.2 Het toenemend belang van de juridische argumentatie . . . . . . . . . 169

7.3 De technocratische interactie $\ldots \ldots \ldots \ldots \ldots \ldots \ldots \ldots \ldots \ldots \ldots \ldots$

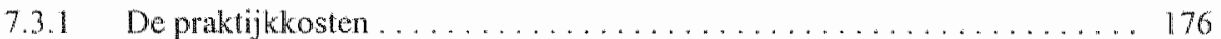

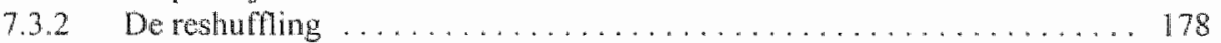

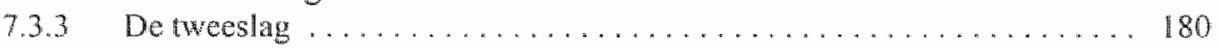

7.3 .4 Verhullende technocratie .......................... 180

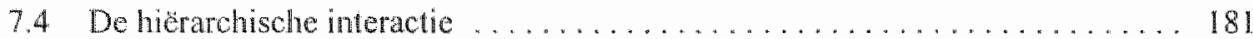

7.4. Hierarche in de daarvoor bestende fora? ................ 183

7.4.2 WVC: neerderheidsbeslissingen en vooronderstelde unanimiteit .... 183

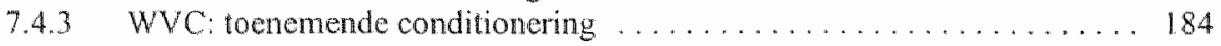

7.4 .4 COTG: eigen verantwoordelijkheid $\ldots \ldots \ldots \ldots \ldots \ldots \ldots \ldots \ldots \ldots$

7.4 .5 Hierarchische argumentatie in beperkte mate $\ldots \ldots \ldots \ldots \ldots \ldots \ldots \ldots$

7.5 De onderhandelingsinteractie ..................... 186 
7.5.1 Onderhandelingen binnen het forum $\ldots \ldots \ldots \ldots \ldots \ldots \ldots \ldots$

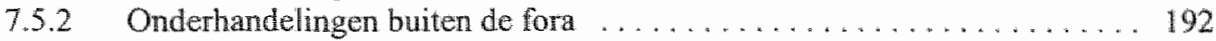

7.6 Conclusies ................................... 193

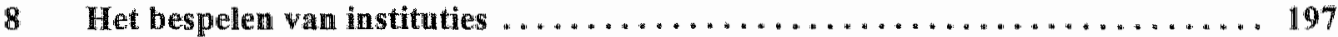

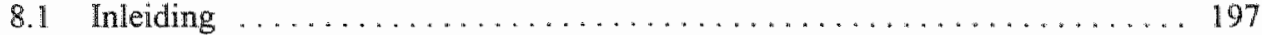

8.2 Ontwikkelingen in de participatie van actoren en hun oorzaken . . . . . . . . 198

8.3 De handelingstheorieèn $\ldots \ldots \ldots \ldots \ldots \ldots \ldots \ldots \ldots \ldots \ldots \ldots \ldots \ldots$

8.3.1 De elementen van de handelingstheorieèn ................. 199

8.3.2 De logica van de handelingstheorieên . . . . . . . . . . . . . . 201

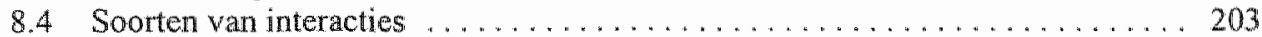

8.5 De noodzaak van het bespelen van de instituties . . . . . . . . . . . . 206

8.5 Conclusies ten aanzien van het actorgerichte institutionalisme . . . . . . . 210

8.6 De besluitvorming na 1992: het hangt er maar van af... . . . . . . . . 211

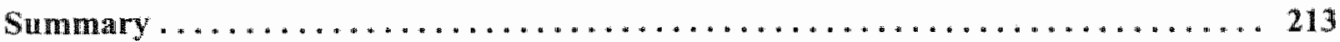

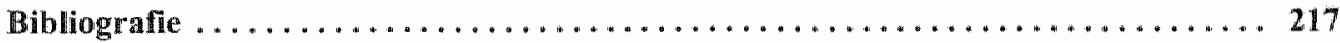

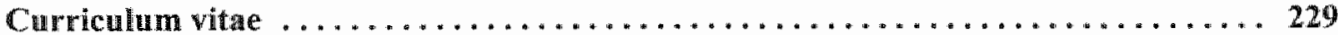





\section{Inleiding}

\subsection{Inleiding}

"In 'Den Haag' staat men er nief bij stil dat bijwoorbeld overleg met een oncologische patiënt en zijn familie of een verzoek om euthanasie uren onbetaalde arbeid vergen. Ook het ziekenfondstarief dat de longarts mag berekenen voor korte opnante bij een acute astma-aanval of 4.50 voor $6-12$ wur intensieve begeleiding om te voorkomen dat een aanval slecht afloopt), staat in geen verhouding tot het werk. Voor de beoordeling van een allergene huidtest, die slechts mimuten vergt, statat darentegen f 100,-. Geen wonder dat de zaken dan scheef groeien." (Een arts, in Gezondheidsrad, 1991: 71)

De arts van het bovenstaande citaat denkt dat "Den Haag'de tarieven voor medisch specialisten bepaalt zonder daarbij rekening te houden met de werkduur. Ongeveer dezelfde mening heeft de Koninklijke Maatschappij ter bevordering van de Geneeskunde (KNMG) die stelt dat het gaat om "...'administratieve tarieven" die nauwelijks gerelateerd zijn aan de reële kosten" (KNMG, geciteerd in: Commissie modernisering curatieve zorg, 1994: 46). Zijn dit juiste veronderstellingen? Is het zo dat 'Den Haag'de tarieven voor medisch specialisten vaststelt en dat de beslissers zich niets gelegen laten liggen aan de werkelijke kosten die een medisch specialist maakt?

Deze vragen vormen de basis voor mijn onderzoek. Er bestaat veel onduidelijkheid over de totstandkoming van tarieven voor medisch specialisten. Door te analyseren hoe in de Nederlandse praktijk tarieven tot stand komen hoop ik inzicht te verschaffen in tariefvorming. Daarbij beperk ik mij tot de periode na de inwoering van de Wet tarieven gezondheidszorg in 1982. Dit is evenwel niet mijn enige doel. Er is nog een tweede meer theoretische doelstelling. Ik zal eveneens de mate van en de manier waarop beshuitvormingsprocessen beinvloed worden door de daarvoor ontworpen formele regels verhelderen. Het hiervoor benodigde theoretische kader wordt gevornd door het actorgerichte institutionalisme (paragraf drie). Op basis van deze onderzoeksheuristiek zijn de onderzoeksvragen geformuleerd (paragraaf vier). Het hoofdstuk wordt afgesloten met een leeswijzer voor de rest van het boek. $\mathrm{k}$ begin met een uiteenzetting van de relevantie wan het onderzoek naar de totstandkoming van larieven voor medisch specialisten. 


\subsection{Het belang van de besluitvorming over tarieven}

In deze eeuw zijn de medisch specialiston in Noderland er in geslaagd belangrijke vootrechten len aanzien van hun betaling erkend te krigen door de overheid. Deze voortechter werden eerst bewerkstelligd in het zich ontwikkelende overleg met ziektekostenverzekeraars waama zij in wetgeving werden vastgelegd. Een van deze voorrechten is het systeem van de betaling per verrichting. Dit systeem is de basis voor het zelfstandig ondememerschap dat ook nu nog door vertegenwoordigende organisaties van medisch specialisten streng wordt bewaakt. Hierin is Nederland niet unick. Ook in andere landen war in de loop van deze eeuw een sociaal zicktekostenverzekeringstelsel tot ontwikeling kwam, is de politieke beslutworming over de betaling van artsen in grote mate bepaald door in het verleden gemaakte keuzen van artsen en ziektekostenverzekeraars (Glaser 1989a, 1990).

In de huidige discussie over de bekostiging van de medische zorg speelt deze wijze van betaling van medisch specialisten een belangrijke rol. De owerheid veronderstelt dat deze artsen beslissingen owar de behandeling van patiënten nemen die grote invloed hebben op de kosten van de zorg. Een verandering in de betalingssystematiek van artsen zou er toe kunnen leiden dat het aantal vertichtingen beperkt wordt waardoor in de gehele gezondheidszorg een daling van de uitgaven zal optreden. Bovendien vinden velen dat een betaling per verrichting bijna anachronistisch wan aard is. Daarom zijn recente regionale afspraken met enthousiasme begroet. Volgens deze afspraken worden medisch speciatisten niet meer per verrichting betaald, maar krijgen zij een jaarljks budget dat tot stand komt in regionaal overleg met ziekenhuizen en zorgverzekeraars. Voor de verdeling wan het budget over de medisch specialisten hanteert men andere cenheden dan het antal verrichtingen (Ziekenfondstaad 1998). De regionale afspreken hebben echter nog niet geleid tot de formele afschafing van het vermichtingensysteem. Ook zijn vrijgevestigde medisch specialisten nog steeds zelfstandig ondeneners die op tariefbasis declareren.

Een politiek besluit om de manier van betaling wan medisch specialisten op grondige wijze the veranderen, verdient wetenschappelike aandacht. Het honoreringssysteem van artsen is namelijk éen van de bepalende kenmerken van een gezondheidszorgsysteem. Veranderingen daarin zijn belangrijke momenten in de ontwikkeling van dergelijke systemen, temeer omdat ze vaak een verandering wan machtsverhoudingen aangeven. De invoering van bijvoorbeeld een algemeen geldende loondienstregeling warbij medisch specialisten in dienst komen van het ziekenhuis war zij werken, duidt op verlies van autonomie van de medisch specialist en een locname van de mogelijkheden tot beheersing door het ziekenhuis (Harrison 1993, 1994).

In het verichtingensysteen dienen geregeld besissingen genomen te worden over de hoogte van de betaling per verrichting. Voor dergelije besluitwotming bestaat in het wetenschappelijk onderzoek minder belangstelling dan voor besluiten over het honoreringsysteem vari atsen (Glaser 1970, Wilsford 1991, lmmergut 1992a/b). De vaak grote symbolische warde van deze besluiten roept veel reacties op. Maar kleinere beslissingen die regelmatig genomen moeten worden zijn niet minder belangrijk en interessant dan de unieke en weinig voorkomende ondat ook deze besluiten belangrijke politieke en matschappelijke effecten kumnen oproepen (Edelion 1980, Baakman, 1990: 11). In dit opzicht doet de besluirvoming over de hoogle wan tarieven in principe niet onder voor de besluitvonming over het systeem van honorering. Met een verandering van tarieven zijn eveneens grote belangen gemoeid.

Nu heeft de klassieke belangentegenstelling tussen de arts die als aambieder van zorg een 20 hoog mogelijke prijs voor zijn product wil en de patiënt die als consument de zorg voor veel minder zou willen aanschaffen, zich in de Nederlandse gezondheidszorg nooit volledig ontwikkeld. Niot alleen de ahankelijkheid van de patient heef hierbij een rol gespeeld, maar ook de in Nederland lang gebrukelijke praktijk van artsen om aan rijke patiënten hogere tarieven in 
rekening te brengen dan an minder welgestelden. Er werd dus rekening gehouden met de dragkracht van de patient. Maar de belangrijkste oorzaak van de afwezigheid wan hoogloponde conflicten ussen artsen en patienten over de hoogte van de betaling is dat deze vak gedaan wordt door zorgverzekeraars, die hun uitgaven financieren via premiehefring bij de angesloten clienten. Met name particuliere zorgverzekeraars hebben de mogeljkheid de kosten van tariefstigingen af te wentelen door hun premies te verhogen om aan de financiële wensen van de medisch specialist tegemoet te komen. Deze ontwikkelingen voltrekken zich buten het zicht van de patient. In tijden van economische groei bestaat weinig reden on vaagtekens te stellen bij premie-en tariefsijgingen. Bovendien heeft de permanente groei van de zorg sinds de Tweede Wereldoorlog een discussie over financiele beperkingen bemoeilijkt.

Met name in de decennia na de Tweede Wereldoorlog ontbrak door de aanwezigheid van deze conflictdempende omstandigheden zowel bij patiënt als verzekeraar de prikkel om de veranderingen van de tariewen kritisch te beoordelen. In de jaren tachtig kwam het darentegen tol grote onenigheid tussen betrokken organisaties op nationaal niveau. Over het algemeen wordt deze verandering toegeschreven aan de achteruitgang van de financiële mogelijkheden in de gezondheidszorg. Al in de jaren zestig wees een verontruste overheid op de snelle stijging van de uilgaven voor gezondheidszorg. In de jaren tachtig zou zjj op verschillende manieren proberen hieraan een einde te maken. De medisch specialistische zorg was één van de sectoren van de gezondheidszorg waarop hel oog viel vanwege de belangrijke positie van de medisch specialist in de zorg. Omdat beperking van het volume van specialistische zorg moeilijk werd geacht, riclitte de overheid haar aandacht op de beheersing van de tariefontwikkeling. De besluitvorming over tarieven leidde tot conflicten. Er ontwikkelden zich tegenstellingen die aanleiding waren tot felle reacties van alle betrokkenen. De medisch specialisten dreigden met zondagsdiensten op doordeweekse dagen, spanden procedures tegen de overheid aan, patièntenorganisaties begonnen op hun beurt een juridisch proces om de artsen van hun voomemens af te brengen, de medewerkersovereenkomsten tussen medisch specialisten en ziekenfondsen werden voor jaren opgezegd, en de overheid en medisch specialisten pratten nawwelijks nog met elkat. De belangstelling in de media groeide dienovereenkomstig. De hoogte van de betaling van de medisch specialist groeide vit tot een 'hot item'.

Tot dusver ontbreekt inzicht in de besluitvoming over tarieven. Het gebrek aan openbaarheid van de besprekingen over de tarieven heeft daartoe zeker bijgedragen. Maar daarnaast is ook de wetenschappelijke aandacht beperkt gebleven. Er zijn weliswaar studies over de beslutvorming over de honorering van de medisch specialist verschenen maar daarin stond het inkomensoverleg tussen de overheid en de medisch specialisten centraal (Baajens 1988 , Schollen 1994). Daamaast bestaan vergelikende studies warvan de Nederlandse praktik deel uitmaakte (Glaser 1970, 1994); deze bieden vanwege hun invalshoek slechts echter een cerste houvast voor meer diepgaande analyses. Al met al zou een uiteenzetting ower de lotstandkoming van de tarieven voor medisch specialisten kunnen bijdragen tot meer kennis van een besluitwoningsproces dat een grote maatschappelijke relevantie heeft. Daarvoor is het nodig te achterhalen hoe de besluitvorming over tarieven voor medisch specialisten in. Nederland verloopt. Met deze vragstelling is de eerste doelstelling wan deze studie geintroduceerd: inzicht verschafen in de totstandkoming van tarieven woor medisch specialistische hulp.

\subsection{Het belang van instituties voor besluitvorming: de $\mathrm{W}$ tg als insticutionele inbedding}

Hef verschaffen van inzicht in de lotstandkoming van tarieven voor medisch specialisten is niet rnijn enge doelstelling. Ook wil ik weten hoe de besluitworming over tarieven beïnvloed werd 
door het bestande wetteljke kader. Het antwoord op de bowen gefomuleerde vraagstelling zon immers kunen lüden: zoals het in de Wet taneven gezondheidszorg (Wh) is vastgelegd. Deze wet, die in 1982 werd ingevoerd, bepaalt namelik welke procedures gevolgd moeten worden bij de totstandkoming van tariefbesluiten in de gezondheidszorg. Met name de ondoorzichtigheid van de beshitworming over tariewen woor de medisch specialistische zorg was de overheid in de jaren zeventig en doon in het oog. De jaarijkse besprekingen tussen de verengde zekenfondsen en medisch specialisten hadden hun oorsprong weliswaar in formele wetgeving (de Ziekenfondswet van 1964), maar onttrokken zich aan exteme controle. Voor de particuliere tarieven bestond zelfs geen enkele publiekrechtelijke regulering. Het gevolg was een ongebreidelde groei wan de ziekenfondstarieven en een onwikkeling van de particuliere tarieven, die weliswar gerelateerd was aan die wan de ziekenfondstarieven, maar voor het overige plaatsvond in grote vrijheid.

Met de Wh moest dit gaan veranderen. De opstellers van de wet hechtten zeer aan het ondering overleg tussen organisaties van ziekenfondsen, particuliere verzekerars en medisch specialisten. Dit moest evenwel doorzchtiger zijn dan het vanouds bestaande overleg tussen ziekenfondsen en medisch specialisten. Daarom werd een controlerend orgaan in het leven geroepen, het Centraal Orgaan Tarieven Gezondheidszorg (COTG). Het COTG zou met behulp wan richtijinen de uitkomsten van het overleg tussen de representatieve organisaties moeten beoordelen. Daamaast $\mathrm{kreeg}$ de overheid een belangrijke rol toebedacht. $\mathrm{Zij} \mathrm{kreeg}$ de bevoegdheid anwijzingen an het COTG te geven on richtijnen met een bepaalde intioud te ontwikkelen en bowendien elke richtlijn goed te keuren. Door het College van Beroep woor het Bedrijfsleven (CBB) als beroepsinstantie in de wet op te nemen werd tenslotte de mogelijkheid. tot juridische procedures geschapen.

Het hierbowen omschreven verloop van de fotstandkoming van tarieven voor medisch specialisten door toepassing wan de daarvoor geschapen wettelijke procedures zou door beleidswetenschappers tot voor kort zijn afgedaan als een formalistische invalshoek die geen recht doet aan wat er werkelijk plaats heef. In het algemeen werd de uilkomst van collectieve besluitwoming geanalyseerd als een uhtvloeisel van machtswerhoudingen (Hendriks, 1996a: 25). Het nieuwe institutionalisme weerspreekt deze eenduidige relatie tussen maatschappelijke Julpbronnen en collectieve besluitvoming. Het vraggt daarentegen juist aandacht voor de wisselwerking tussen bestutvormingsprocessen en de daarvoor bestaande instituties. Het is echter vrijwel onmogelijk zondar keuze voor een school binnen het institutionalisme een minder algemene aanduiding van de invalshoek te geven. Hall en Taylor stellen dat de politieke wetenschap met wel vier scholen van nieuw institutionalisme te maken heeft. Elke school baseert zich op een eigen paradigna (Hall en Taylor, 1994: 22).

Ondanks deze verscheidenheid van invaishoeken kan worden gesteld, dat de wisselwerking lussen lijd- en platsgebonden instituties en daabinnen plaatsvindende interacties centraal staat. On deze te kumen begrijpen, zullen de lijd-en plaatsgebonden instituties in de analyse van beshitvorming moeten worden betrokken. Voor de totstandkoming van beshiten over tarieven voor medisch specialisten geldt de Whg dus als de tijd-en plaatsgebonden institutionele inbedding. Deze was nieuw maar vormde de neerslag van al in gang gezette ontwikkelingen. Met de Wh werd een proces van centralisatie gecodificeerd warin het overleg over tarieven transfomeende van decentrale besprekingen, in het begin van deze eeuw, tot complexe onderhandelingen ower velerlei zaken in en netwerk van corporatieve actoren. Daarnaast was sprake van modificatie. Aan de reeds ontwikkelde structum werden nieuwe elenenten toegevoegd. Vooral van belang waren de goedkeuringsbevoegdheid van het COTG, de loegenomen mogelijkheden to overheidsingrijpen en rechisbescheming (zie hoofdstuk drie).

Op het belang wan de veranderlijkheid van de institutionele inbedding van collectieve besiutvorming on de gevolgen daarvan voor het besluitwormingsproces is door onder meer Wilke (1982, 1989, 1992) gewezen. Met behulp van zijn argumentatie kan het belang van de 
Wtg als institutionele inbedding verduidelijkt worden. Willke analyseert de eigenheid van zogenaamde onderhandelingsystemen (Verhandungssysteme). ${ }^{1}$ Hij stelt, ten eerste, dat een antagonistische verhouding tussen belangrijke maatschappelijke partijen als werkgevers en werknemers in ontwikkelde samenlevingen miet meer als een éndinensionele tegenspraak kan worden geconceptualiseerd. Een dergelijke werhouding ontwikkelt zich datarentegen "...(z)u einem durch organisierte Komplexität gekennzeichneten Beziehungsgeflecht." (1989: 101). Daarbij is sprake van een raamwerk van conflicten en samenwerking die simultaan optreden. Ten tweede bliyven de gevolgen van conflict of samenwerking tussen twee partijen niet tot deze twee beperkt. Er ontstaat een meer-partijen-spel. In Duitsland maken de werkgevers en werknemers kapital en arbeid - deel uit van een neoconporatistisch onderhandelingssysteen. In dat systeem gelden nieuwe spelregels voor het uitvechten van conflicten en voor coöperatie. Met name de omstandigheid dat allerlei nieuwe belanghebbenden, waronder de overheid, deel uituaken van een dergelijk onderhandelingssysteem, stelt grenzen aan de rol van de belangenorganisaties. Eenduidige strategieen wanuit tegengestelde belangen voldoen niet meer maar moeten worden vervangen door overleg waarvoor zowel conflicten als compromissen kenmerkend zijn en waarin over een weelheid van ondenwerpen gesproken wordt (Wilke, 1989: 102-103).

Deze ontwikkeling wan ankelvoudige belangentegenstellingen naar collectieve notwerken van relaties tussen belanghebbenden is ook te herkennen in de beshutvorming over tarieven voor medisch specialisten. Er heeft zich een arena op nationaal niveau gevormd met eigen unieke regels waarin niet alleen de ziekenfondsen en artsen, maar tevens andere actoren spelen. De locus van besluitvorming over tarieven voor medisch specialisten is in de loop van deze eeuw verschoven van de artsenpraktijk en het plaatselijk overleg naar het centraal nationaal niveau. Hierdoor sloot de tariefvorming aan bij het ontstaan van een neocorporatistische structutur van beslutvorming in Nederland. Representatieve organisaties die elk een monopolie hebben op het vertegenwoordigen van een functioneel belang, overleggen met elkaar en met de overheid over velerlei beleidsthema's binnen een specifick beleidsterrein. Met de verschuving van de locus heeft zich ook een hiërarchisering van beslisrelaties ten aanzien van tarieven voltrokken. Er is een nationaal organisatorisch netwerk ontstaan dat gemachtigd is dwingend tarieven aan medisch specialisten, ziekenfondsen en ziektekostenwerzekeraars op fe leggen. Deze hierarchie is zo sterk, dat het declareren van andere tarieven dan de tariefboeken van het COTG voorschrijven, als een economisch delict word beschouwd. Naast het ontstaan van een meer-partijen-spel en hiërarchische relaties is ook sprake van een toename van het aantal onderwerpen waarover gesproken wordt. De agenda van het overleg over tarieven voor medisch specialisten is aanzienlijk uitgebreid (Lieverdink, Van der Made en Van Merode 1995).

De Wtg speelde in deze ontwkkeling een belangrijke rol omdat met deze wet bepaalde ontwikkelingen gecodificeerd werden. De collectivisering van de bestuitvoming over tarieven werd in 1982 gedeeltelik formeel bekrachigd door de invoering van de Whg. Daarbij werd voortgebouwd op het reeds tanger bestaande centrale overleg tussen ziekenfondsen en medisch specialisten. Bovendien werd het proces wan centralisatic van de besluitworming in de particuliere sector versneld. Het centrale overleg ussen medisch specialisten en particuliere werzekeraars, dat zich in de jaren zestig langzamerhand had ontwikkeld, kreeg formeel vorm door onderhandelingen tussen particuliere verzekeraars en de Landelije Specialisten Vereniging (LSV) in de Wig op te nemen. Met de collectivisering werden de taken van het openbaar bestuur

Wilke bekrinseert wooral het marxisme als theorie die naar zijn inzichten de kenmerken van de politieke bestuitwonming binnen systemen ontkent. De politieke economie van het (neo)marxisme wormt voor veel institutionalisten binnen de Europese politicologie een voorbeeld van het structuralistisch-theoretisch kader waartegen men zich kan afzetten. De Angelsaksische variant van de institutionele school zet zich veel meer af tegen de belsavioristische, pluralistische harde politicologie die van Amerikaanse oorsprong is (Mayntz en Scharpf, 1995a: 11, 1995b: 43). 
uitgebreid. Er kwam een strenger toezicht tol stand doordat bevoegdheden aan de overheid en het COTG werden gegeven. De overheid kon amwijzingen ten aanzien van de ontwikkeling wan tarieven geven en he COTG diende richlijmen op te stellen. Mede door het grote belang dat de overheid hechtte aan het inkomensbeleid betekende dit, dat tarieven voor medisch specialisten een belangrijk beleidsinstrument van de overheid werden. Tevens werd de aanzet tot een juridisering van de besluitworming over tarieven gegeven door beroepsmogelijkheden te scheppen.

In het begin van deze eetw was de situatie heel anders. De medisch specialisten vormden slechts een kleine groep binnen de artsenstand, moesten zich nog waarmaken en waren niet georgamiseerd in een machtige landelijke organisatie. Gestructureerde onderhandelingen met goed georganiseerde ziekenfondsen kwamen nawwelijks voor. De arts bepaalde, daarbij niet gehinderd door collectieve arrangementen, veelal op basis van eigen overwegingen, voor elke patient en apart tarief. De regel was dat patiènten in goede doen (veel) meer moesten betalen dan minder welgestelde patiënten. Van overheidsinterventic was geen sprake. Dit had een grote differentiatie in tarieven tot gevolg die gezien de institutionele vormgeving van de besluitvorming over tarieven echter heel begrijpelijk was.

\subsection{Het actorgerichte institutionalisme}

De vaststelling dat de besluitvorming over tarieven voor medisch specialisten zich heeft gevormd naar de tijd- en plaatsgebonden institutionele inbedding, geeft dus aanleiding tot het formuleren wan de tweede doelstelling wan dit onderzoek. Niet alleen wil ik weten hoe tarieven voor medisch specialisten onder het regime van de Wtg tot stand zijn gekomen, ook onderzoek ik hoe een formeel institutioneel kader de daarbinnen plaatsvindende besluitvormingsprocessen beînvloedt. Theorievortming over het materielle object van deze studie, de besluitvorming over tarieven voor medisch specialisten in Nederland, waaraan veronderstellingen over de relatie tussen instituties en besluitvormingsprocessen zouden kunnen worden ontleend, bestaat nauwelijks. Er zijn studies verschenen met feitelijke beschrijvingen wan de besluitvoming over tarieven voor medisch specialisten. Deze hebben echter betrekking ap andere tijdsperioden dan waarin ik geïnteresseerd ben (Juch 1997) of blijven - wellicht noodgedwongen - juist vaag over de afgelopen jaren (Compagne 1997). Exclusieve aandacht woor de werking wan de formele regels ontbreekt vrijwel in zijn geheel. Roscam Abbing (1987) heeft gewezen op buttenwettelijke afspraken tussen de overheid en belangenorganisaties. Scholten (1994) heeft duidelijk gemaakt dat bif de besluitworming over inkomens voor medisch specialisten telkens nieuwe (informele) spelregels werden ontworpen. De Algemene Rekenkamer (1995) heeft vastgesteld dat overheid en COTG in het begin van de jaren negentig verschillende doelstellingen van de Wtg nastreefden. Deze studies behandelen elk een aspect van de beshitvorming over tarieven voor medisch specialisten, maar een coherente theorie is daaruit niet voortgekomen. Een beperking is dat de positie en het handelen van de overheid in relatie tot én of meer beleidsactoren centraal staan, zonder dat recht gedaan wordt an het gehele netwerk van betrokkenen. Baaijens (1988) heeft dat netwerk wel centraal gesteld, maar hij beperkt zich tot het inkomensoverleg. De voomaamste studies zijn gedaan door een buitenlander, William Glaser, maar zijn meest diepgaande onderzoek stamt uit 1970 en is dus gedateerd terwijl zijn meest recente publicaties (1993, 1994) te globaal van aard zijin.

Het formele object biedt evemmin veel aanknopingspunten als het gaat om substantiële theorievorming. Er zijn weliswaar "gereedschapskisten' met concepten die sturing kunnen geven aan onderzoek naar besluitvorming binnen netwerken wan organisaties en een institutionele inbedding, maar een "grand theory" met te toetsen hypothesen ontbreekt (Kenis en Schneider 1991, Van Tatenhove en Leroy 1995). Daarom heb ik mij beperkt tot een studic waarin de relatie 
tussen de besluitvorming over tarieven en de institutionele inbedding wordt onderzocht zonder theoretische veronderstellingen in de vorm van te toetsen hypothesen. In plats daarvan hanteer ik enkele richtinggevende theoretische concepten die nader zullen worden gespecificeerd om ze bruikbaar te laten zijn voor empirisch onderzoek. De gehanteende invalshoek gaat er vanuit dat besluitvoming binnen een bepaalde institutionele context plaatsvindt. Groepen van mensen en organisaties nemen binnen deze context collectieve beslissingen, daarbij gemotiveerd door hun belangen. In hun overwegingen en interacties worden ze tevens beïvloed door de heersende regels. Deze regels geven niet alleen aan hoe besluiten tot stand moeten komen, maar ook waaróver besloten moet worden en welke standpunten daarbij toelaatbar zijn. Aan de organisatie van de besluitvorming over de tarieven voor medisch specialisten wordt dus een belangrijke rol toegeschreven (Eckstein 1960, Stone 1980, Immergut 1992a/b).

Dit uitgangspunt ontleen ik aan auteurs die het nieuwe institutionalisme op besluitvorming hebben toegepast en die aangeven dat studies van de instituties van (politieke) besluitvorming op zich gerechtvaardigd zijn vanwege bun invloed op de inhoud van de tot stand gekomen beshiten. Volgens Immergut hebben instituties invloed op het beslechten van (politieke) conflicten, omdat zij een aanzet geven tot de vorming van constellaties van actoren. Bovendien hebben zij invloed op de interacties tussen deze actoren (1992a: 25). Anderen onderstrepen dit maar voegen enaan toe, dat instituties ook problemen en belangen creëren die centraal komen te staan. Zo stelt Peterson, voortbouwend op March en Olsen:

"Conditions become perceived as problems, problens attract attention, and popular. sentiment motivates adjustments in policy only through mediating institutions, which are, additionally, players in their own right." (1993: 407)

Over de inwloed op belangen- en probleemformuleringen zegt Scott dat het in bepalde institutionele omgevingen vanzelfsprekend wordt gevonden, dat sommige belangen voorop worden gesteld, terwijl in andere omgevingen het vooropstellen van andere belangen geaccepteerd wordt. Daarom zijn belangen niet exogeen aan de situatie waarin zij worden genit. Zij dienen te worden beschouwd als te verklaren typerende elementen van interacties binnen een specifieke institutionele context (1995: 43). Met andere woorden, belangenformulering heeft een endogeen karakter.

Door de nadruk op het endogene karakter van belangenformullering wijkt het nieuwe institutionalisme af van beraderingen, die de uitkomst van publieke besluitvorming als een weerspiegeling van maatschappelijke verhoudingen omschrijven. Zo wordt in de zogenaamde aanbiedersmachthese gesteld dat de betaling van het werk van de artsen een afgeleide is van de sociale machtspositie van de arts (Marmor en Thomas 1972, Freidson 1970). Marmor en Thomas formuleren het als volgt.

"As producers of" a crucial service in industrial commies, and a service for which govemments can seldom prowide shom-run substitutions physicians have overwhelwing political resources to infuence decishons regarding payments methods quite apart fiom the form of bargaining their organizations employ." (1971: 436)

De oorsprong van de aanbiedersmachthese ligt in de structuralistische sociologische theorieen waarin onder meer de (politieke) besilvorming op verschillende beleidsterreinen cen athankelike is van matschappelijke belangentegenstelingen. De belangen zouden objectief geformuleerd kunnen worden en zijn exogeen aan de context van besluitvorming. Het duidelijkst zijn politieke economen die de besluitworming in de gezondheidszorg analyseren (Van Mierlo 1988, Zweifel en Eichenberger 1992). Ik deel de opvatting van het maatschappelijk determinisme die uit de polntieke economie spreekt niet. Het problematische is dat de vaak politieke discussie over verschillende aspecten van de gezondheidszorg een afgeleide wordt van de botsing van sociale preferenties die objectief vast te stellen zouden zijn. Dit leidt tol een weinig verhelderende analytische logica die door Schattschneider is omschreven als "to identify the origins of conflict and to assume the conclusion". Deze analytische logica schiet met name tekort 
orndat geen invloed an besluitvormingsprocessen en hun structuur wordt toegekend $(1975: 36)$. Uiteraard is het zo dat een belangenorganisatie vanuit haar aard bepaalde belangen vooropstelt, maar het algemene belang van een bepaalde groep actoren binnen de gezondheidszorg moet de bij besluitvoming betrokken vertegenwoordiger vertalen in motieven die hem een leidraad bieden in een specifieke stuatie. ${ }^{2}$ Daarbij spelen niet alleen de belangen van de achterban een rol, maar ook de intenties van andere besluitwormers en de heersende regels voor interacte. "Die zuschreibbaren Standardinteressen sind konkretisierungsbedüftig, ehe sie handlungsleitend werden können." (Mayntz en Scharpf, 1995b: 55). Volgens Schmitter (1.986) komt het endogene karakter wan belangenarticulatie in collectieve overlegstructuren voort uit de strategische interdependentie van collectieve actoren, en ontlenen deze actoren hun motieven aan de organisatorische context die hen tevens voorziet van hulpbronnen. De relatieve autonomie in belangenbehartiging is ook door Offe aangegeven. Een analyse van de activiteiten van belangengroepen dient zich naar zijn mening te richten op drie soorten parameters. De ideologische parameters verwijzen naar de wensen van de leden van de belangengroep. De vraag is dan wat hun belangrijkste waarden zijn en in hoeverre er sprake is van een collectieve identiteit. De economische parameters omvatten de mogelijkheden var een belangengroep in de maatschappelijke context. Zij werwijzen naar de hulpbronnen en hoe zij door de belangengroep ingezet worden. Tenslotte gat het om de rol die door politieke instituties aan de belangengroep wordt toegeschreven. Dit betreft de politieke parameters. Offe stelt dat belangenvertegenwoordiging meer beinvloed wordt door veranderingen in de politieke parameters dan in de ideologische of economische parameters. Voor inzicht in de betrokkenheid wan belangengroepen bij (politieke) besluitvorming dient dan ook de volgende vraag gesteld te worden: "How can the specific articulation and definition of those demands be understood that an interest organization puts forward as being in 'the interest' of those represented by the organization." (Offe, 1985: 222).

Kort samengevat gaat men er in het nieuwe institutionalisme dus van uit dat unstituties besluityormingsprocessen niet determineren maar wel actoren in constellaties samen brengen, interacties beinwloeden en de formulering van problemen en belangen mede gestalte geven. Door vooruit te lopen op de komende analyses kan ik de aanname van deze uitgangspunten hier al rechtvaardigen. Een belangrijke regel in het begin van deze eeuw was, dat de medisch specialist de patiënt die niet via een ziekenfonds verzekerd was een bedrag in rekening bracht dat de draagkracht van de patiènt niet te boven ging. Deze regel gaf ten eerste de constellatie (individuele arts-individuele patient) aan en ten tweede de interactie (tussen arts en patient onderling, waarschijnlijk een lichte vorm van onderhandeling). In deze context waren de belangen wooral indivdueel van aard. De medisch specialist was wrij in zijn prijsbepaling, hij kon door middel van het opbouwen wan een particulier patientenbestand zijn inkomsten aanzienlijk verhogen, en was tevens in staat on de hulp aan minder rijke patienten te bekostigen

2 I $\mathrm{ga}$ hier nog maar even voorbij aan de immense problemen die spelen bij het waststellen van het belang van de arts. Het wheoretisch debat over het vaststellen van belangen heef nog niet tot cen oplossing gevoerd (zie bijvoorbeeld Stone 1997), en het objectieve belang van de arts is evenmin eenduidig definiecrbar. Subjectieve en objectieve belangen hoeven absoluut niet overeen te komen, lllustratief is de weerstand van artsen tegen de invoering van sociale ziektekostenverzekeringen vanwege de veronderstelde controle door de overheid op hun inkomsten, terwijl dergelijke stelsels hen uiteindelijk wel zekerheid van inkomsten hebben. verschaft. Bovendien blijken medisch specialisten geen uniforme groepering te vormen. Recente enquetes in Nederland hebben een grote variatie in voorkeuren van artsen ten opzichte wan hum betaling laten zien. Het schisma in de kringen van specialisten wordt nog het duidelijkst aangegeven door de wens van de Vereniging van Kinderantsen om loondienst na te streven terwijl andere groepen (bijw. de thoraxchirurgen) de betaling per verrichting tot het uiterste verdedigen. 
met de opbrengsten van de behandelingen van rijkere patienten. Voor de patient die in goede doen was, deed het er weinig toe, voor de minder welgestelde was het zak zich zo am mogelijk voor te doen. Dit veranderde weliswar in de eerste helf van deze eeww onder meer doondat plaatselike specialstenverenigingen tariefrichthinen ontwikkelden, maar de arts behield een grote mate van vrijheid om particuliere tarieven vast te stellen. Pas in de jaren zestig werd de tariefbepaling van boven af meer gedisciplineerd en voltrok zich cen langzame centralisatie van besluitvorming toen de LSV richtijnen voor de tariefstelling voor particuliere hulp ging opstellen. De autonomie van de individuele specialist en de plaatselijke specialisten verenigingen werd minder vanzelfsprekend. Er ontstond matschappelijke en politieke wrevel vanwege de scheefgroei tussen de tarieven voor particuliere patienten en ziekenfondspatiemten. Als antwoord bierop zag de LSV zich gedwongen de tariefontwikkeling te gaan beinwloeden. In de jaren zestig kwam dus niet alleen een nieuwe regel tot stand - de LSV mag grenzen aan de lokale tariefvorming stellen - maar ook vornden zich nieuwe constellaties en kwamen bijbehorende belangenformuleringen tot stand. In de jaren tachtig trad wederom een verandering op. De besluiten over tarieven moesten tot stand komen binnen de context van de Wtg. De LSV kreeg te maken met het Kontaktorgaan Landelijke Organisaties Ziektekoslenverzekeraars (KLOZ) als vertegenwoordiger van de particuhere verzekeraars en het COTG. Zoals in de analyse zal blijken was het niet langer mogelijk de particuliere tarieven zelf vast te stellen; ze bleken alleen nog tot stand te kunnen komen door overleg waarbij ook de ziekenfondsen en ziekenhuizen betrokken waren. De belangen veranderden overeenkomstig.

In het actorgerichte institutionalisme van Mayntz en Scharpf, dat als de dominante theoretische invalshoek zal dienen, zijn de boven beschreven uitgangspunten van het nieuwe institutionalisme verenigd. Zij leggen de nadruk op de interacties tussen groepen van actoren binnen een institutionele context die van invloed kan zijn op het formuleren van belangen en strategieën. Mayntz en Scharp f (1995b: 39) pretenderen niet een inhoudelijk verklaringsmodel te hebben ontwikkeld, matar well een heuristiek voor onderzoek (Forschungsheuristik) die de onderzoeker opmerkzatm moet maken op bepaalde aspecten van het materiele object wan onderzoek. Uit het werk van zowel Mayntz als Scharpf blijkt dat het actorgerichte institutionalisme niet sleclits een theoretische oorsprong heef. Beide auteurs hebben zich in het algemeen bezig gehouden met de relatie tussen beleid en instituties (Hanl en Toonen 1988 , Maarse 1988). De laatste jaren onderzoeken ze de pogingen van overheden om de samenleving te besturen en het vermogen van bestuurlijke sectoren om zich zelf te organiseren en zo tot besluitwoming te komen. Zij concluderen op basis van empirisch onderzoek dat hierarchische beslisrelaties tussen overheid en maatschappij de vaak complexe bestuurlijke processen niet kunnen verklaren. Vaak is er sprake van meer hotizontale relaties waarbij een ingewikkeld geheel van interacties uiteindelijk de uitkomst bepaalt. Deze horizotitale relaties zijn kenmerkend woor de moderne maatschappij waarin van groepen van beleidsactoren verwacht wordt dal zij gezamenlijke oplossingen lormuleren voor bepaalde maatschappelijke problemen. Bestuurlike netwerken kunnen zich alteen ontwikkelen als wan deze netwerken verwacht mag worden dat zij in stat zijn collectieve besissingen le nemen (Mayntz, 1992: 23-24).

In navolging van Mayntz en Scharpf zal ik de volgende analytische elementen onderscheiden: de instiutionele inbedding wan besluitvorming, de participatie van actoren, de door hen gebruikte handelingstheorieen en de plaatsvindende imteracties. Er is tevens plaats ingeruima voor de omgeving (zie figuur 1.11).

\section{De institutionele inbedding}

De institutionele inbedding heeft bij de besluitvorming over tarieven voor medisch specialisten na 1982 cen specifieke vorm. Hoewel in de institutionele theorievorning vele soorten regels worden onderscheiden, stat in dit onderzoek het formele weltelijke kader centrati. Dat betekent dat de nadruk ligt op de wettelijke regels die aangeven welke procedures gewolgd moeten 
worden. Bovendien zijn daarin allerlei bevoegdheden vastgelegd. Voor het overgrote deel waren deze procedures en bevoegdheden opgenomen in de Wet tarieven gezondheidszorg maar daamaast waren uiteraard allerlei bestuursrechtelijke bepalingen van belang.

bredere context

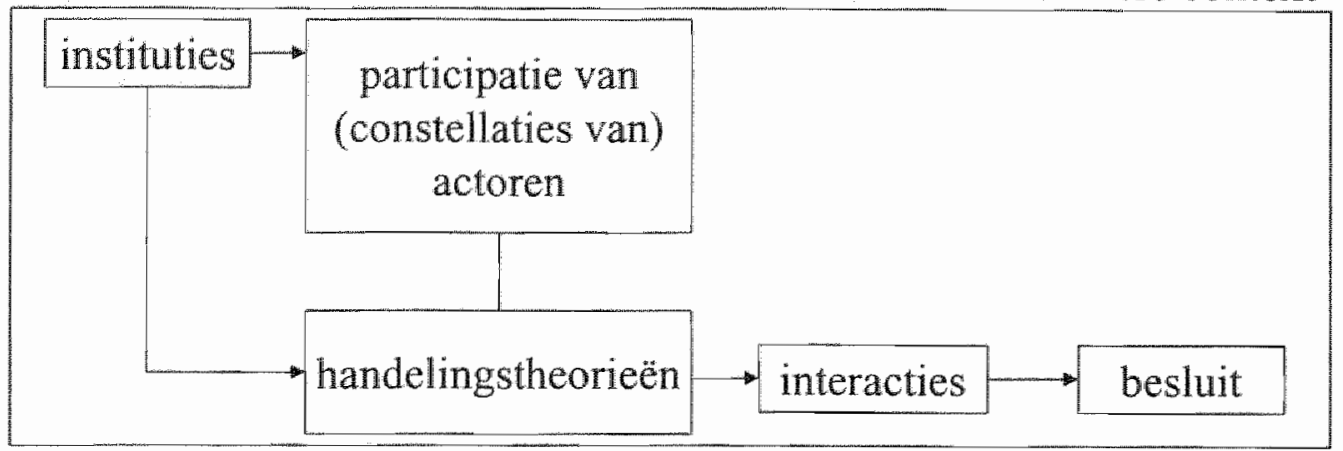

Figutur I.1: De elementen wan het aciorgerichte instimionalisme

De aranwezigheid van bepaalde regels heeft niet tot gevolg dat het handelen van actoren gedetermineerd is. Het actorgerichte institutionalisme gaat ervan uit dat actoren door middel van hun strategieèn mede de werking wan de bestaande regels vormgeven. Zoals Gäfgen (1988. 7273) bij zijn beschrijving van corporatieve onderhandelingen aangeeft, impliceert hel strategische karakter van onderhandelingssituaties dat regels niet van te voren vaststaan en dat het zelfs zo kan zijn dat regels worden gebruikt om het eigen belang te dienen. Hij spreekt van een vrijwel ongelimiteerde institutionele creativiteit (institutionellen Phantasie). Strategisch gedrag, informele interacties, nieuwe informatie, gedrag op de grenzen wan de legitimiteit, coalities met actoren die voorheen niet betrokken waren, juridische procedures, dit zijn allemaal vomen van institutionele creativiteit waarbij strategisch gebruik wordt gemaakt van formele regels. Anderen hebben duidelijk gemaakt dat bijvoorbeeld de dualiteit van neocorporatistische structuren het mogelijk maakt dat belangenorganisaties een formele positie in de besluitvormingsstructuur van een bepaalde maatschappelijke sector toegewezen hebben gekregen, zonder dat de daadwerkelijke interacties gekenmerkt worden door het streven naar overeenstemming via overleg en onderhandeling (Frouws, 1994: 47-48). Het is noodzakelijk dat actoren het eigen belang bevorderd zien worden door het gebruik van neocorporatistische regels.

"De moodzakelike infrastructur en belendswinte kumnen de sociale partwers alleen stimuleren, met dwingen, tor publiek-verantwoorde collectieve actie. Steun vamuit de ongamisatie en motwatiestructuren wan de dechemende functionele belangen is een enen noodzakelike noorwarde voor het wetslagen wan comporalistisch beleid." (Hewerijck, 1994: 27).

Kemelijk is niet te voorspellen hoe en wanneer onderhandelende organisaties bestaande regels volgen, er vanaf wijken, gebruiken of veranderen. Deze maatschappelijke omgang met regels is in het rechtssociologisch onderzoek nar de uitvoering van beleidsregels niet onbekend. Ik hanteer hier het algemene rechtssociologische uitgangspunt dat door interactie vorm wordt gegeven aan de invloed van fomele wetgeving. De invloed van wettelijke regulering binnen een bepald beleidsveld kan beter verklaand worden door te kijken naar de manier waarop organisaties, in hun onderlinge relaties, reageren op de wetgeving dan door vast te stellen of men zich wel of niet houdt aan de wettelijke bepalingen. Door "...(t)he process of response to law, organizations...mediate the impact of law on society." (Edelman, 1992: 1532). Hiermee sluit ik aan bij de dominante dualistische visie op de rol wan het bestuursrecht in de netwerkliteratuur, 
zoals onder andere door Teisman (1992:38-40) is verwoord. Zich daarbiy baserend op Van Gunsteren stelt Teisman dat "...(g)edrag regelsgeleid is, maar ook dat actoren daarbij kumen kiezen aan welke regels zij refereren." (1992: 40). Daandoor zijn slechts die regels die de actoren volgen, orm welke reden dan ook, de meest bepalende.

De toepassing van het actorgerichte institutionalisme op het object van dit onderzoek betekent dus dat de besiluitvomingsprocessen zullen worden geanalyseerd om de mate warin en de manier waarop zij beinvloed worden door het geheel wan regels wast te kunnen stellen. Deze regels komen voort uit de Wet tarieven gezondheidszorg (en wit het breden bestuursrecht) en. hebben gestalte gekregen in organisaties als het COTG en het CBB. Het is daarbil de vratg hoe actoren. binnen hun strategische speelruimte omgaan met deze regels. Tijdens hun interactie bepalen de actoren hoe regels gevolgd worden en bewerkstelligen zo de mate wan hun reproductie. Dit heeft belangrijke gevolgen voor de manier van onderzoek doen. Slechts een uitgebreide empirische analyse van de werkelijk platsvindende interacties kan duidelijk maken op welke manier de formele regels gevolgd worden en hoe zij van invloed zijn op de besluitworming.

\section{Participerende actoren}

Aan de besluitvoming over tarieven woor medisch specialisten hebben meerdere actoren deelgenomen. De participatie van actoren in besluitvormingsprocessen is onderwerp wan politicologisch theoretisch debat. Ten eerste geeft een aantal theoretici aan dat een versnippering van beleidsprocessen gaande is (Frissen 1996). Een belangrik kenmerk is dat er veel, verschillende en veelsoortige personen en organisaties aan deelnemen. De modene staat heeft te maken met een vergaande horizontale en verticale fragmentatie (Alford and Friedland, 1985: 420-421). Bovendien zou een machtscentrum in de vorm van een cruciale, centrale en hegemoniscische actor die de gang wan zaken en de uitkomsten bepaalt, ontbreken (Marin and Mayntz, 1991: 17). Ook volgens de socioloog Beck (1992) is het bij de bestudering van besluitvorning niet langer juist uit te gaan wan de klassieke politieke centra. Deze worden vervangen door culturele en sociale centra van zogenaamde subpolitiek waartoe hij de media, juridische instituties en sociale bewegingen rekent. Deze subpolitiek vindt soms plaats binnen bestaande institutionele structuren, maar vaak worden deze kaders genegeerd. Studies van besluitvorming in de Nederlandse gezondheidszorg die de fragmentatie van publieke besluitvonning treffend beschrijven zijn die van De Roo en Maarse (1990) en Baakman (1990).

Samen met deze verandering in de samenleving heeft de politieke wetenschap zich ontwikkeld. De nadruk op herarchische besluitworming en doel-middel schema's is vervangen door aandacht voor overleg binnen een newerk van organisaties warim interacties veelal de vorm aannemen van onderhandelingen in een context van interdependentie. Onderzocht worden processen van samenwerking die zelfs op gespannen woet kunnen staan met fornele hiararchiedn en de verdeling wan formele bevoegdheden (Beck, 1992: 199).

Terwijl bovenstaande auteurs in toenemende mate het belang van de traditionele besluitvomingscentra relativeren, benadrukken andere politieke wetenschappers de invloed van de institurionele structuren op (politicke) besluitvorming (March en Olsen 1994/1996, Immergut $1992 \mathrm{a} / \mathrm{b})$. Deze nadruk lijkt relevant te zijn voor het object van deze studie. In ieder geval geldt voor de besluitworming over tarieven voor medisch specialisten dat de deelname in sterke mate formeel geregeld was. In termen van Kiser en Ostrom (1982) werden door middel van de Wtg zowel de voorwaarden voor deelname door participanten wastgesteld als posities en bevoegdheden verdeeld. In een uitwoeringsbesluit werd vastgelegd wie de representtaticve organisaties waren en wie dus deel mochten nemen aan de onderhandelingen over tarieven. Tevens werd aangegeven welke ministeries goedkeuring mocsten verlenen aan richtlijwwoorstellen van het COTG alsmede welke ministeries aamwijzingen aan het COTG mochten geven. Daamaast was duidelijk dat tariefvaststelling alleen door het COTG mocht 
gebeuren en dat men voor beroep tegen COTG-beslissingen bij het College van Beroep voor het Bedrifsteven terecht kon (zie voor een uitgebreide beschrijving hoofdstuk 3). Voor dit onderzok lijkt de formele regeling van de declname aan beshitvorming van groot belang te zijn

Door participatiepatronen empirisch vast te stellen kan een antwoord gegeven wordem op de vraag of de bepalingen van de Wig werden opgevolgd. Aangezien de Wtg voor de besluitworming over tarieven voor medisch specialisten een institutionele configuratie vormt, kan niet worden uitgegaan van een deteminerende invloed. Een institutionele configuratie brengt een atutal actoren bij elkaar en voorziet deze van een formeel referentiekader. Maar binnen een institutione configuratie hebben actoren de mogelijkheid eigen strategieen te ontwikkelen en tactieken uil te voeren (Immergut, 1992: 24-29). Verklaringen voor de participatie van actoren kunnen dus woor een belanghjk deel gevonden worden in de overwegingen achter het handelen van actoren. Met andere woorden, een analyse van hun handelingstheorieën is gewenst.

\section{Handelingstheorieên}

Eén van de wooronderstellingen van het actorgerichte insitutionalisme is dat in de handelingstheorieên van actoren de invloed van de ter zake doende instituties herkend kan worden. Tegelijk vormen de handelingstheorieèn de basis van de gedragingen van de actoran in de interacties. Hierdoor verbinden de handelingstheorieën de institutionele inbedding met plaatsvindende interacties. In de handelingstheorieèn van organisaties die betrokken zijn bij de totstandkoming van tarieven zou de invloed wan de Wtg herkenbaar moeten zijn.

Onder een handelingstheorie wordt hier verstaan "...(h)et geheel van veronderstellingen achter het handelen van een actor in een concreet geval." (Grin en Van de Graaf, 1994: 350 ). Voor deze veronderstellingen bestaan in de politicologie, bestuurskunde en organisatiewetenschap verschillende noemers. Enkele gezaghebbende zijn de 'conceptual maps' van Axelrod (1984), en de 'frames' van Rein en Schön (1993). Bekend zijn ook de pogingen van Dunn (1993) en Mason en Mitroff (1981) om de argumentatieschema's van Toulmin toe te passen op de overwegingen van deelnemers aan besluitvormingsprocessen. In Nederland heef Hoogerwerf (1984, 1989) aandacht gevragd voor de beleidstheorieen van overheden en is er in de netwerkliteratum aandacht voor de handelingstheorie en Van de Graaf 1994). Zonder aan de verschillen tussen deze noemers recht te doen, leidt een vergelijking tot de conclusie dat actoren op basis wan de hen beschikbare informatie en kennis tot probleemdefinities en oplossingen komen, warbij de achterliggende overwegingen een zekere gelaagdheid kennen. Hoe een actor zich zal opstellen in een bepaalde interactie is niet alleen het gevolg van zijn afweging tussen kosten en baten wan een bepaald standpunt en/of actie, maar zal ook voortvloeien uit zijn meer algemene visies op regels en voorkeuren ten aanzien van de structurering wan relaties. Met andere woorden, de overwegingen zullen een weelheid van motieven herbergen warbij sprake kan zijn van verschillende soorten van rationaliteiten. Strategische doel-middel calculaties constitueren samen met andere overwegingen een motievencomplex (De Beus 1991).

De handelingstheorieèn hebben voor de actoren vooral de functie van het ordenen van de ongeving en zijn daarmee een belangrijk middel om betekenis te verlenen aan de gebeurtenissen die zich woordoen (Weick 1995). Zo scheppen actoren zich een beeld van wat er gebeurt, welke belangen er in het geding zijn, welke handelingsopties er voor zichzelf en voor anderen voorhanden zinn, en ook hoe en met welke regels rekening gehouden moet worden. Door de voortdurende "situationele betekenistoekening" zijn actoren in staat wit te naken hoe met regels on zou moeten worden gegaan (Teisman, 1992: 39).

In het actorgerichte institutionalisme komen de regels van de institutionele context en de handelingstheorieèn niet per definitie overeen. Als regels en handelingstheorieën aan elkaar gelijk zouden worden gesteld, is er geen strategische ruimte voor actoren en wordt geen recht gedaan an de veelsoortige reacties van actoren op institutionele vereisten (Oliver 1991). 
Bovendien zijn handelingstheorieèn subjectief van aard en kunnen zij in een multiactor context van elkaar afwijken. Tevens bestaat de mogeljkheid dat actoren hun handelingstheorieẻn aampassen. Leerprocessen kumen aanleiding zijn voor actoren om inschattingen, verwachtingen en doelstellingen aan te passen (Sabatier 1987). Dat betekent dat de omgang met regels in de loop der tijd kan veranderen.

\section{Interacties}

Constellaties van actoren met handelingstheorieẽn produceren interacties mits zij onderling afhankelijk zijn. Bij publieke besluitwoming is valk van interdependentie sprake en zeker bij de besluitwoming over tarieven voor medisch specialisten. In deze interacties wordt uiteindelijk het besluit gevormd (Knoke, 1990: 62) Bij de poging om de structur van deze interacties te beschrijven verandert het niveau van het object. Niet langer staat de individuele actor met zijn handelingstheorie centraal maar gaat het om systeemkenmerken. Doon deze stap te maken, kan. het actordenken met het systeemdenken worden verbonden (Godfroij, 1981: 170).

Ten behoeve van hef benoemen van optredende interacties doen Mayntz en Scharpf (1995b: 60-65) een voorzichtige poging enkele organisatievormen van interactie te onderscheiden. Zij beschrijven een contimüim waarvan de mate van afhankelijkheid bet voomaamste organiserend principe is. Het continuum begint bij totale individuele autonomie. In situaties warin individuele autonomie overheerst, ontbreken afspraken over interactie en is er dus ook nawweliks sprake van stmcturering. Een markt daarentegen kent al enkele afspraken ower interactie. Zo heeft de relatie alanbieder-vrager kenmerken van een contract. In zogenaamde netwerken wordt de interdependentie vervolgens erkend, maar is het mogelijk dat gezamenlijk besluiten alleen door onderhandelingen tot stand kunnen komen. Er is dan weliswaar een grotere mate van onderlinge afhankeljikheid, maar individuele actoren zijn in stat de totstandkoming van hen onwelgevallige collectieve uitkomsten te verhinderen. Deze relatieve autonomie wordt nog verder ingeperkt als bijwoorbeeld een systeem van meerderheidsbesluiten geldt. Totale afhankelijkheid kont tot stand in geval wari een strikt hiërarchisch interactiestructuur.

I $k$ heb deze poging tot indeling een "woorzichtige" genoend omdat Mayntz en Scharpf zelf aangeven dat dit niet de enige mogelijkheid is. In Nederland heeft Godfroij een opsomming gegeven van zogenoemde speltypen als idealtypische varianten van interactie. De speltypen variëren van fusie, waarin samenwerking tussen actoren uitmondt in samensmelting, tot vermijding, warin actoren interacteren zonder te willen samenwerken of conflicten te willen oproepen (1981: 88-93). Dergelijke opsommingen zouden van groot nut voor deze studie kunnen zijn, zij het dat ze geen handvat bieden om de mate van overeenkomst tussen instituties en werkelik optredende interacties bij besluitvorming in collectieve netwerken vast te stellen. Een omschrijving van interactiesoorten die daartoe wel mogelijkheden biedt, is bijvoorbeeld het interactieregime. Dit begrip werwijst naar de configuratie van sociale regels die interacties in inter bestumlijke netwerken reguleren (Huizenga, 1993; 81, Van Erp, 1997: 262). Een interactieregime bestaat uit gefomuleerde regels waaraan actonen zich daadwerkelijk conformeren, maar ook uit ongearticuleerde regels die onbewust gevolgd worden (Huizenga, 1993: 81). De optredende interactiesoorten noemt Huizenga de sociale praktijk watronder hij de gemeenschappelike typering van de interactie werstaat (1993: 84). In de sociale praktijken komen de regels naar voren die daadwerkeljjk worden gebruikt. Hiermee past deze benadering in die stroming van de netwerktheorie warvan de vertegenwoordigers, in navolging van Giddens, een onderscheid maken tussen sociale praktijken en de onderliggende regels, ofwel tussen systeem en structurur (zie bijv. Klijin, 1996: 44-45). Toegepast op min onderzoek zou bijwoorbeeld het COTG een sociale praktijk creèren die hiërarchie genoend zou kumen worden op het moment dat het gebruk maakt van de bevoegdheid tariefvoorstellen af te keuren. Of als een organisatic de mogelijkheid hanteert juridisch beroep aan te tekenen tegen een besluit wan het COTG, wordt een praktijk van juridische interactie in het leven geroepen. 
In dit onderzok gaat het om deze sociale praktijken, oftewel de gemeenschappelijke typeringen van het activeren van bepaalde regels voor interactie. In de netwerkliteratur worden deze ook wel patronen van interactie genoemd (Khin, 1996: 45). Bovendien gaat het mij om een vergelijking tussen de sociale praktijken en de gewenste sociale praktijken die de basis vormen van de institutioncle kaders. Door sociale praktiken met gewenste sociale praktijken te vergelijken wordt een vergelijking wan de institutionele inbedding met de daadwerkelik optredende soorten van interacties mogelijk. Van Erp (1997) heeft laten zien dat door een reconstructie van de principes van regelgeving de gewenste sociale praktijken zichtbaar gemaakt kunnen worden.

\section{De bredere context}

De nadruk op besluitvorming binnen een institutionele context mag er niet toe leiden dat de invloed wan ontwikkelingen in de bredere context genegeerd wordt. Daaronder versta ik ontwikkelingen die van unvloed kmnen zijn op het proces van totstandkoming van tarieven voor medisch specialisten zonder daarin plaats te hebben. Het radicale neoinstitutionalisme dat zich daaraan nogal eens schuldig maakt, krijgt dan ook terechte kritiek (Hendriks, 1996b: 104-111). In de bredere context van de besluitvorming over tarieven is de afgelopen decennia veel veranderd (Godfroij 1993). De socialeconomische omstandigheden speelden een belangrijke rol. De vanzelfsprekendheid dat alle zorg die verleend kon worden ook moest worden aangeboden was in de jaren tachtig al lang werdwenen. De gezondheidszorg als een sector die de collectieve lasten verhoogt, kreeg daarentegen alle aandacht. Daarmee ontstond voor de besluitvorming over tarieven een belangrijke randvoorwaarde. De stijging van tarieven die in de voorgaande decennia nog gerealiseerd kon worden, werd ondenkbaar. Daamaast was sprake wan een verandering van ideologie. Beleidsmakers lieten de gedachte los dat de overheid zelf de oplossingen voor de problemen in de gezondheidszorg moest verzorgen. De commissie-Dekker (1987) pleitte waar mogelijk in de gezondheidszorg woor deregulering en concurrentie waamee de tijdgeest werd uitgedrukt.Tevens vonden allerlei ontwikkelingen plats in de achterbannen van de belangenorganisaties. Decentrale belangenvertegenwoordiging en aandacht voor de wensen van groepen bimen belangenorganisaties zijn kenmerken van hedendaagse belangenvertegenwoordiging in de zorg. Deze processen van democratisering en individualisering van belangenvertegenwoordiging (Van der Grinten 1993/1994) kunnen ook bij de besluitvorming over tarieven worden geconstateerd.

Mijn invulling van het actorgerichte institutionalisme zou in monocausaliteit vervallen als voorbijgegaan wordt aan de invloed wan dergelijke contextuele factoren (Hendriks, 1996a: $33-$ 36). Het is echter precies de kern van het conceptueel model dat voorondersteld wordt dat de actoren deze factoren binnen de institutionele context als het ware 'verwerken". Ik zal dit met een voorbeld verduidelijken. In de jaren zestig en zeventig vond een explosieve groei van de tarieven voor medisch specialisten plaats. De economische groei in die jaren bood daar uiteraard ruimte voor, marar de groei in tarieven en de uiteindelijke omvang daarvan, was tevens het gevolg van de absentie van criteria on tarieven te beoordelen, de geljikgerichtheid van belangen van organisaties die onderhandelden, en het ontbreken van bevoegdheden en de wens bij de overheid om strenger op de uitgaven aan gezondheidszorg toe te zien. De neerwaartse tendens in de tarieven in de jaren tachtig was eveneens een coproductie van economische conjuncturur en institutionele kemmerken

Het is dus duidelijk dat het actorgerichte institutionalisme geen gesloten model voorstaat. Veranderingen in de institutionele context komen bijvoorbeeld niet vanzelfsprekend endogeen tot stand. Een wijziging van de Wtg of een verandering van de houding van participanten ten opzichte van de bestuurspraktijk kan ook tol stand komen zonder dat de onderhandelaars over tarieven daartoe de aanzet geven. Dit is met name evident bij formele kaders die onderdeel uitmaken van wat de overheid haar beleidsinstrumentarium noemt. Over veranderingen van het 
beleidsinstrumentarium kan in andere fora worden besloten met als gevolg dat deze een opgelegd gegeven voor de interacterende organisaties zijn. Deze ontwikkelingen 'wan buiten' kunnem de positie van actoren binnen het owerleg over tarieven sterk beïnloeden. Overeenkonstig de uitgangspunten van het actorgerichte institutionalisme kan evenwel worden verwach dat zij zich daarvan bewust zijn en zulen inspelen op de nieuwe mogelijkheden en beperkingen (zie ook: Lomas, Charles, Greb, 1992: 174).

\subsection{Een recapitulatie}

In eerste instantie formuleerde ik als algemene doelstelling inzicht te willen verschaffen in de besluitvorming over tarieven voor medisch specialisten. Deze besluitvorming verschilt per institutionele inbedding die zich ontwikkelde tot en nationaal besluntvormingsforum dat gereguleerd werd door de Wtg. De relatie tussen besluitworming en institutionele inbedding staat in het vervolg centraal. Daarom is het nodig de oorspronkelijke doelstelling te preciseren met de toevoeging: sinds de invoering van de Wtg. De doelstelling luidt: het willen verschaffen van inzicht in de besluitvorming over tarieven voor medisch specialisten sinds 1982 . Bij deze doelstelling hoort de volgende vraagstelling: hoe verliep de besiuitvoming over tarteven voor medisch specialisten sinds de invoering van de Wtg in 1982 ?

Dat de besiuitvorming over tarieven voor medisch specialisten verschilt per institutionele inbedding, leidt tot de vTaag in hoeverre instituties de besluitvoming bepalen. De algenene theoretische doelstelling is na te gaan hoe en in welke mate bestuurlijke besluitvorning bepaald wordt door de formele wettelijke regulering ervan. Dat doe ik door het besluitvormingsproces bij de totstandkoming van enkele tarielbesluiten in kaart te brengen. Of, zoals Immergut zou zeggen, ik probeer de effecten van instituties op de besluitvorming te traceren door enkele besluiten te volgen op hun weg door de institutionele configuraties (Immergut, 1992a: 5). De fomele wettelijke regulering die in de bestudeerde cases uit de Wtg bestaat, wordt hier opgevat als een institutie die het gedrag wan de betrokken actoren zou kunnen reguleren. De Wtg zal niet gehanteend worden als een te objectiveren formeeljuridisch beoordelingskader waaraan de handelingen van actoren op hun rechtmatigheid kunnen worden getoetst. Dil zou een juridische vraagstelling, methodologie en methoden vereisen. Maar bovenal zou ik niet in staat zijn de Wtg als variabele te beschouwen warvan de invloed op de beshitvorming afhankelijk is van de manier warop de actoren amee ongaan. Het centrale uitgangspunt van het conceptueel model van dit proefschrift is dat de doorwerking van de Wtg bepaald wordt in interactics waarbij de handelingstheoricèn van de actoren een grote rol spelen. De Wtg als institutic geef mogelijkheden tot bepaalde acties maar sluit ook bepaalde handelingen uit. Centraal staat de wraag hoe actoren omgaan met deze mogelijkheden en beperkingen en niet of wat zij doen rechtmatig is.

De doelstelling na te gaan in hoeverre en op welke wijze een formele regulering een beshutvormingsproces bepalt, leidt tot de wolgende onderzoekswraag: In hoeverre en op welke wijze heeft de Wtg de besluitvoming over tarieven voor medisch specialisten sinds 1982 beinvloed? Op basis van het actorgerichte institutionalisme zijn de volgende deelvragen te formuleren. Ten cerste stel ik de vraag welke actoren in welke constellatie participeerden in de besluitvoming over tarieven voor medisch specialisten sinds 1982 en in hoeverre (het moment waj) hun participatie bepaald werd door de Wtg. Ten tweede wil ik te weten komen welke handelingstheoricern de (constellaties van) actoren hanteerden en welke rol de Wtg daarin speelde. Ten derde wil ik antwoord krijgen op de wrag welke interactiesoorten bij de besluitvorming optraden en in hoeverre deze overeen kwamen mel de principes van de Wtg.

Bij de beantwoording van deze vragen staat de manier waarop de invloed van de Wig in de interacties tussen de actoren vorm kreeg voorop. Omdat in het actorgerichte institutionalisme het 
relatieve belang wan de institutionele inbedding van besluitvormingsprocessen yoorop staat actoren hebben immers een variabele strategische vrijheid . Jeiden de deelvragen vanzelf tot de wolgende vragen. Door welke andere motieven dan de formele verdeling van bevoegdheden lieten actoren zich leiden toen zij besloten te participeren in de besluitvorming over tarieven woor medisch specialisten? Hoe zagen de handelingstheorieen van de actoren eruit die niet op de Wtg gebaseerd waren? Hoe kunnen de interactiesoorten getypeerd worden in zoverre zij niet overeenkwamen met de principes van de Wtg? Deze wragen vormen een complement van de drie hierboven geformuleerde deolvragen. De antwoorden zullen moeten leiden tot een volledige beantwoording valu de centrale vraag naar de relatie tussen instituties en besluitvorming.

\subsection{Opbouw}

In het volgende hoofdstuk zal ik de hier genoemde elementen van het actorgerichte institutionalisme verder uitwerken, ook in methodologisch en methodisch opzicht. In hoofdstuk drie volgt een beschrijving van de ontwikkeling van de institutionele context van de besluitvorming over tarieven voor medisch specialisten. Duidelijk zal worden dat de besluitworming tussen 1986 en 1992 plaatsvond binnen een institutionele context die nog niet eerder bestond. Door deze unieke institutionele inbedding is de nadrik op de Wtg gelegitimeerd. Het verslag van het feitelijk verloop van de besluitvorming over tarieven woor medisch specialisten vindt plaats in hoofdstuk vier. De structuur is voornamelijk chronologisch. Op basis wan een van te voren geconstrueerde lijst van gebeurtenissen is de beshuitvorming beschreven met behulp van drie organiserende dimensies: de betrokken actoren, hun handelingstheorieën en strategieün en de interacties. Deze dimensies zijn naar voren gekomen in de bespreking wan het actorgerichte institutionalisme dat behulpzaam is om de algemene theoretische doelstelling te realiseren. De dimensies organiseren weliswaar het verhaal van hoofdstuk vier maar zij worden omwille van de leesbaarheid nog niet volledig besproken. Het analytisch tekort van hoofdstuk vier wordt gecompenseerd in de hoofdstukken vijf, zes en zeven warin respectievelijk de participatie van actoren, hun handelingstheorieẻn, strategieën en de interacties aan de orde komen. Bij elk van deze dimensies staat de invloed van het institutionele kader centraal. In het laatste hoofdstuk zullen tenslotte de conclusies ten aanzien van de casus van de besluitvorming over tarieven voor medisch specialisten worden getrokken waama een reflectic op de algemene theoretische doelstelling plaatsvindt. 


\section{Concepten, methodologie en methoden}

\subsection{Inleiding}

In dit hoofdstuk staat de wijze waarop de vraagstellingen van mijn onderzoek beantwoord kunnen worden centraal. Daarvoor is het nodig eerst dieper in te gaan op de richtinggevende elementen van het actorgerichte institutionalisme. De bedoeling is een omschrijving te geven die empirisch onderzoek naar het materiële object van onderzoek mogelijk maakt. Daarna zal ik ingaan op de methodologische invalshoek. Van groot belang hierbij is de longitudinale aanpak waarbij een inductieve werkwijze gevolgd wordt. In het onderzoek beperk ik mij tot een aantal tariefbesluiten, waardoor sprake is van een meervoudige gevalstudie. Tenslotte zullen de methoden aan de orde komen, die per element van het actorgerichte institutionalisme besproken worden omdat elk element een eigen methode van onderzoek vereist.

\subsection{De richtinggevende concepten}

De totstandkoming van besluiten over tarieven voor medisch specialisten wordt hier geïnterpreteerd met behulp van het actorgerichte institutionalisme. De centrale gedachte van dit institutionalisme is dat (groepen van) actoren interacteren op basis van hun handelingstheorieën en aldus besluiten produceren. Dit doen zij binnen een bepaald instifutioneel kader. Mayntz en Scharpf zijn zeer voorzichtig in de omschrijving valn hun pretenties met betrekking tot het actorgerichte institutionalisme. Het is geen inhoudelijke theorie over een bepaald matschappelijk verschijnsel, evenmin is het een verklarend model, maar het is 'op $Z$ 'n hoogst' (bestensfalls) een heuristiek voor onderzoek doordat het de wetenschappelijke onderzoeker op bepaalde aspecten van de onderzoeksonderwerp opmerkzaam maakt (1995b: 39). Omdat het nieuwe institutionalisme dus niet gehanteerd mag worden als een algemene theorie over de relatie tussen formele regels en publieke besluitvorming is een deductieve, hypothese toetsende aanpak niet mogelijk. De gevolgde inductieve werkwijze hield in dat ik an het actorgerichte institutionalisme een aantal richtinggevende concepten heb ontleend. Deze inductieve werkwijze werd gecombineerd met bestaande theoretische inzichten. Deze theoretische inzichten zijn zodanig gebruikt dat de richtinggevende concepten weliswaar inhoudelijk werden aangescherpt, maar tegelijk dienst konden blijven doen als concepten die "sensitizing" zijn (Glaser en Strauss, 1967: 38-39). Daardoor behield ik de mogelijkheid tijdens de analyse mijn bevindingen tevens theoretisch nader aan te duiden. 


\section{2.1 De participatie van actoren}

Het eerste efement wan het actorgerichte institutionalisme betreft de actoren die aan de besluitworming deelnamen. Daarbij zijn drie vragen van belang. Ten eerste: welke actoren namen deel? Ten tweede: welke patronen van participatie zijn te constateren? Onder patronen worden constellaties van actoren verstaan. En ten derde: hoe ontwikkelden de patronen van participatie zich tussen 1986 en 1992 ? Bj de beantwoording van elke vraag kan de invloed van de Wtg ter sprake komen. Ten eerste stat in de Wtg en de uitvoeringsbesiuiten welke actoren bij de besluitvorming betrokken dienen te worden. Ten tweede is in de Wtg niet alleen de formele rol van actoren vastgelegd, maar er worden ook combinaties wan actoren gedefinieerd. Zo zijn afhankelijkheidsrelaijes tussen onderhandelende actoren en tevens formele gezagsrelaties gecreererd. Tenslotte wordt in de Wtg een bepaalde volgorde van beshuiten voorgesteld waardoor het moment van participatie eveneens formeel vastgesteld is. De Wtg structureert een besluitvormingsproces. De deelnemers hebben krachtens de wet hun eigen plaats in het verloop van de besluitworming. Fir is geen sprake van contimue betrokkenheid. Het COTG dient te wachten op de resultaten van de onderhandelingen tussen de belangenorganisaties, het ministerie van Welzijn, Volksgezondheid en Cultuur (WVC) op hel aanbieden van een richtlinvoorstel van het COTG, het COTG weer op een aanwijzing van WVC. Aangezien het actorgerichte institutionalisme de actoren een bepaalde mate van vrijheid van handelen binnen een institutionele context toeschrijh, is het niet gerechtvaardigd deze wettelijke toedeling van taken als de enige determinant van de participatie van actoren op te vatten. Bovendien kan worden verondersteld, dat actoren die geen formele rol toegewezen kregen toch invloed op de besluitworming over tarieven wilden uitoefenen. Daarom zal in deze studie empirisch moeten. worden vastgesteld welke actoren in werkelikheid deelnamen aan de besluitvorming en in hoeverre dit afweek van de fornele voorschriften. Bovendien mag worden aangenomen dat zich in de loop der tijd veranderingen in de participatie van (constellaties van) actoren voordeden. Dit vergt een dynanisch perspectief bij de analyse van de betrokkenheid van actoren.

\subsubsection{De handelingstheorieën}

Onder een handelingstheorie wordt hier verstaan "...(h)et geheel van veronderstellingen achter het handelen wan een actor in een concreet geval."(Grin en De Graaf, 1994: 350). Ten behoeve wan het in kaart brengen van een handelingstheorie dienen de verschillende onderdelen te worden bestudeerd: een situatieschets, de handelingsopties (en hun gevolgen) en de gekozen strategie. Een sifuatieschets en een overzicht van handelingsopties stellen een actor in staat een strategie op te stellen. Onder een strategie versta ik de gekozen handeling op basis van een afweging van de handelingsopties. Voor de manier warop een actor komt tot een strategische keuze heeft Offe het begrip de logica van beleidsproductie (logics of policy production) geintroducend (1975: 136). In latere publicaties benoemt hij de logica als de rationaliteit van beleidsmakers (1985: 300 e.v.).

De handelingstheorie wordt door Mayntz en Scharpf de cognitieve orièntatie (Kognitive Orientherung) van een organisatie genoemd. Een handelingstheorie kent verschillende onderdelen: en situatieschets (een waarneming van de situatie en haar causale structuur), de handelingsopties en de te verwachten gevolgen (Mayntz en Scharpf, 1995b: 53). Daaraan voeg ik dus het strategisch element toe. De strategie is als het ware het slotstuk van een handelingstheorie. Deze beschriving van de structuur van een handelingstheorie komen we in een andere terminologie ook tegen bij andere auteurs. Zo beschrijft Sabatier percepties van beleidsmakers van causale relaties en situaties. Deze percepties bestaan uit (1) fundamentele 
nomatieve en ontologische axioma's (nomative core), (2) fundamentele beleidsposities ten anzien van de basale strategieên on de fundamentele nomatieve axioma"s te halen (policy core), en (3) instrumentele beshiten en informatievergaring om de basale strategie uit te kunnen voeren (secondary aspects) (Sabatier, 1987: 650). Fischer maakt een onderscheid tussen beoordelingen van een situatie wit het oogpunt van matschappelijke waarden en doelstellingen en de technisch analytische waardering waarin de effectiviteit van bepaalde concrete beleidsmaatregelen woorop staat (Fischer, 1995: 17-23). Hoewel deze omschrijingen net identiek zijn, komen ze overeen in de marier waarop organisaties hun indrukken van de omgeving concretiseren in voorgenomen handelingen in specifieke situalies.

Handelingstheorieën zijn onvermijdelijk subjectief. Hienut volgt dat situatieschetsen van organisaties niet overeen hoeven te komen. Overeenstemming over handelingsopties en te volgen strategieën is evenmin vanzelfsprekend.

Aan de hand van een beleidsdocument van WVC kumen de onderdelen wan een handelingstheorie worden toegelicht. In het begin van 1987, toen duidelijk werd dat de meningswerschillen tussen de LSV en de Vereniging Nederlandse Ziekenfondsen (VNZ) over tariefvoorstellen aan het COTG zich niet eenvoudig lieten oplossen, schreven ambtenaren van het ministerie van WVC aan de staatssecretaris:

"Ten alamien van de siand van zaken van onderwerper:

* praktijhkasten: VNZ wil de praktijkhosten van specialisten verlagen. Gesproken wordt van 100 a 200 milioen op jaarbasis. Het werlagen vam de prakijkiosten is in lijn met ww werzoek alan he COTG om voor 1987 de praktijklosten met 40 miljoen te korten. Uhebt dus belang bij onderhandelingen over de verlaging van de kosten. Nu de onderhandelingen gestaaki zijn, zal WNZ binnenkor een éexzijdig voorstel aan het COTG doen.

De rol wan de overheid in het conflict hoeft geen actieve re zim. WW heef belang bij de ombuging van 40 miljoen, de rest is meegenomen. Het is le overwegen de markpartijen binnen het Wtg-kader aan elkaar over te laten. en het COTG aijn bevoegdheden wat te laten maken. Foor de korte termin moet het belang van de patiënt voorop staan (hierin wordt voorzien door het restitutiebesluit). Foor de lange termijn zijn veranderingen van de stmchur wan de gezondheidszorg wan groot belang voor WVC: het kruit droog houden. Een oriënterend gesprek met De Viles (VNZ) en Heijen (LSW) zou evenwel goed zijn."

In deze tekst kunnen de elementen van een handelingstheorie worden herkond. WVC geef een sitwatieschets. In het voorbeeld is sprake vain een doelstelling van WVC (veertig miljoen gulden bezumigen op de vergoedingen voor praktijkkosten aan medisch specialisten). Bovendien is er in de ogen van WVC een conflict tussen LSV en VNZ. De uitkomst van hel conflict is onzeker; maar zelfs wanneer de doelstellingen van de VNZ slechis gedeeltelijk gerealiseerd zouden worden, kan de overheid rekenen op een besparing. Ook zijn er plannen bij WVC on de gezondheidszorg te herstructureren. Vervolgens komen de handelingsopties en hu gevolgen aan de orde. WVC zou kunnen interveniëren, maar de ambtenaren achten dit met het oog op de herstructurering van de zorg onverstandig: "het kruit moet droog gehouden worden". Een andere optie is de besluitvorming conform de Wtg te laten verlopen, hetgeen waarschijnlijk zal leiden tot het halen van de bezuinigingsdoelstelling. Voor de nadelige gevolgen voor de patiünt van het

1 Memorandum WVC aan de staatssecretaris, 27 februari 1987. Het betreffende document is 70 nauwkeurig mogelijk weergegeven. Ik sluit echter niet uit dat de originele tekst op details a wijkt ondat ik met handgeschreven samenvattingen heb gewerkt. 
confict tussen zickenfondsen en medisch specialisten is reeds een tijdelike oplossing bedacht in de vorm van het restitutiebeshit.

Op basis van de afweging vain handelingsopties wordt vervolgens een strategie ontvouwd. De hoofddoelstelling van WVC in deze handelingssituatie is op de kosten van medisch specialistische hulp veertig miljoen gulden te bezumigen. On deze doelstelling te halen moet WVC vooral niel actief participeren, maar de VNZ en de LSW laten owerleggen en het COTG toezicht laten houden. Ondat de bevoegdheid van het COTG onder andere een beoordeling van tariefvoorstellen op liun bijdrage aan kostenbeheersing inhoudt, is dit een veilige weg. Een vrijblijvend gesprek voeren is alles wat WVC op dat moment zou moeten doen.

Als de verschillende elementen van een specifieke handelingstheorie in kaart zijn gebracht is de inhoud ervan blootgelegd. De situatieschets geeft informatie over de manier warop de organisatie de omgeving ziet, en de handelingsopties geven aan welke mogelijkheden tot handelen worden overwogen. De strategie geef de voorgenomen handelingen aan. Zoals boven aangegeven kent een handelingstheorie ook een logica. Damamee wordt niet het inhoudelijke proces van strategieformulering bedoeld, maar de manier waarop een actor met behulp van zijn handelingstheorie komt tot een strategie. In het bovenstalande voorbeeld kiezen de ambtenaren van WVC voor besluitvorming conform de Wtg en een terughoudende rol van de overheid. Maar waarom? Niet omdat zij op normatieve gronden de procedures van de Wtg gevolgd willen zien, maar omdat zo de belangen van WVC het beste behartigd worden. Als de partijen onderhandelen en het COTG zijn rol waarmaakt, zal waarschijnlijk een bezuinigirg van meer dan weertig miljoen gulden tot stand worden gebracht. Er is met andere woorden sprake van een grote mate van doetrationaliteit.

Over de logica van hamdelingstheorieën zijn verschillende theoretische opmerkingen gemaakt. In het kader van dit onderzoek is met name van belang in hoeverre er sprake was van een formeel institutionele rationaliteit. Lieten de actoren zich leiden door de bestaaride wettelijke normen? In een ideaaltypische toestand past elke actor bij de conversie van de situatieschets in te ondememen handelingen de bestaande fomele regels toe. De logica bestaat in dit geval uit een volledig onpartijdige toepassing van regels door mensen die daarvoor het inzicht, de macht en de capaciteiten hebben (Stryker, 1989: 342). Volgens. Therborn (1978) bepaalt dan de input de werkwijze van de actor. De resultaten van de regeltoepassing doen er niet toe. In de volledig tegengestelde situatie streven actoren het eigen belang na, waarbij ze zich niets gelegen laten liggen aan de wettelijke bepalingen op het terrein waarin ze werkzaam zijn. Deze logica. is wellicht het best te omschrijven als opportunisme. Hier bepaalt slechts de output de overwegingen van de actor.

Met name onder invloed van de bureaucratietheorieen veronderstelde men lange tijd dat de overheid de eerste logica zou hamteren. Het gedrag van de overheid zou moeten worden verklaard vanuit de input in de vorm van wettelijke bepalingen (Therborn, 1978: 49 e.v.). Van belangenorganisaties werd met name door de politieke economie de tweede logica verwacht. Wati een formele bureaucratie als de overheid zijn handelingen ontwerpt door de ontwikkelingen in de ongeving te interpreteren op basis van formele expertise, zou een belangenorganisatie zich bij een afweging van bepaalde acties laten leiden door de verwachte gevolgen voor de belangen wan het aangesloten lid (output). Meer en meer geven wistenschappers echter aan dat organisaties niet slechis een formeel institutionele of doelrationele logica hanteren. De overwegingen van individuele beleidsmakers warièren en worden aangepast aran de institutionele ongeving (Edelman 1985, Schön 1983). Bovendien worden logica"s gecombineerd. Zo is zowel bij overheden als bij corporatieve organisaties vastgesteld dat hun handelingstheorieèn zich kenmerken door een mix van logica's (Offe 1985, Van Waarden 1989). Het met elkar in overeenstemming brengen van belangen en formeel institutionele vereisten is cen voorbeeld van een mix van logica"s die in het "behavorial institutionalism" in de rechtssociologie benadrukt wordt (Edelman 1996). Belangrijk is de opmerking van Mayntz en 
Scharpf dat naast een nomatieve en sen doelrationele logica het relationele onderded van de owerwegingen van actoren in een netwerk niet mag worden vergeten. Ze tonen een geriohtheid op interacties met anderen (Interactionsorientierung) met gevolgen voor standpunten en strategieen. Zo zullen in coöperatieve relaties andere standpunten en strategieën tot stand komen dan in vijandige relaties (19956:57).

Het vaststellen van de logica van de handelingstheorieèn van de betrokken actoren is in deze studie van groot bellang, omdat hermee de relatie tussen de institutionele context en de overwegingen duidelijk gemaakt kan worden. De logica heeft immers betrekking op het motivationele aspect van de handelingstheorie: waarom trekt een organisatie bepaalde conclusies ten aanzien van het handelen en geen andere?

\subsubsection{Interacties}

Als leidraad woor het onderzoek van de interacties fungeert het onderscheid in de Wtg tussen. soorten wan procedures die gevolgd kunnen worden. Het principe van de wet en de concrete uitwerking hiervan vommen de basis voor een evaluatie van de valk complexe interactioprocessen. Om het principe van de Wtg en de uilwerking daarvan te werhelderen, zullen de overwegingen achter de Wtg geexpliciteerd worden (zie ook: Van Erp, 1997). Hiemee wordt recht gedaan aan de institutionele inwalshoek van het onderzoek.

In de Wig zijn vier soorten van interactie herkennen die in het algemeen als afzonderlijke conflictoplossingsmechanismen worden opgevat (Kagan 1991, Kelman 1992, Schön 1983). Bij het ontwerpen van de wet wilde de overheid de reeds lang bestaande praktijk van onderhandelingen tussen belangenorganisaties behouden. Daamaast streefde zij met de Wtg naar een technocratisering, een hiërarchisering (centralisering) en een juridificering van de besluitvorming over tariewen. Deze combinatie van mechanismen zou de autonomie van de belangenorganisaties bij het onderlinge overleg en onderhandeling moeten verkleinen.

Ten eerste gaat de Wtg uit van onderhandelingen over tarieven tussen zorgverzekeraars en medisch specialisten. Consensus tussen de onderhandelaars is niet noodzakelijk omdat elke partij een eenzifdig verzoek aan het COTG kan richten. Door de betrekkelijke open formulering in de Wtg onbreekt vrijwel elke normatieve bepaling ten aanzien van het verloop van de onderhandelingen. Ten tweede spreekt uit de Wtg geloof in de mogelijkheden tot besluiten te komen via gegevensverzameling en het opstellen wan richtlijnen (technocratisering). Het COTG als onathankelijke instantie heeft hierbij een belangrijke rol. Dit orgaan wordt geacht op een objectieve manier, op basis van richtlinen, tariefvoorstellen te beoordelen met grote aandacht voor het niveau van uitgaven voor gezondheidszorg. De wens tol objectivering was een reactie op de weinig doorzichtige manier van overleg bij de totstandkoming van tarieven voor medisch specialisten in de naoorlogse periode. Ten derde zijn hiërarchische interacties mogelijk om een objectieve controle en invloed van de "politiek' op de besluitvorming over tarieven mogelijk te maken. Door het toedelen van bevoegdheden zin 'rule-and-command'-verhoudingen geschapen. De uitkomsten van de onderhandelingen zijn als gevolg pas rechtsgeldig als het COTG daar zijn goedkeuring aan hecht. Deze goedkeuring dient te gebeuren op basis van richtijnen. De overhejd kan door middel van aanwijzingen de beshitworming door het COTG aan randvoorwaarden binden. Tenslote is de mogelijkheid van een juridische procedure in het leven geroepen. ledereen die in zijn belangen getrofen wordi door tariefbesluiten van het COTG kan daartegen in beroep gaan bij het College van Berroep woor hel Bedrijfsleven (CBB).

In de beleidswetenschap worden de bovenstaande procedures opgevat als alternatieve manieren van publieke besluitvorming. Zo worden technocratie ("het ontwikkelen vari analytische en normatieve methoden"), hiërarchie ("dwangstrategieèn, waarbij van de instemming van participanten wordt afgezien en alan het veld prioriteiten in beleid worden 
opgelegd") en onderhandelen ("via onderhandelingen optimale win-win-resultaten en daamee gelijkijdig de gewenste consensus te verwerven") tegen elkaar afgezet en beoordeeld op hn wensclikheid (Voogd en Woljer 1995). Er is overeenstemming over het feit dat de verschillende soorten van interactieprocessen elkaar slecht verdragen en elkaar kunnen verdringen. Waar bijwoorbeeld onderhandelingen kunnen leiden tot een utkomst waarin de opponenten zich kunnen vinden, leiden hierarchische en jurtdische processen niet zelden tot voordelen voor de ene partij en louter nadelen woor de andere. Vooral de rechter geeft vaak slechts éen wan de partijen gelijk, watmee de ander in het ongelijk wordt gesteld (Snellen 1987, Fischer 1990, Kagan 1991, Kelman 1992). De verscheiderheid aan mogelike interacties is typerend voor de Wtg die veel wrigheid laat aan de organisaties om tot besluiten te komen.

De principes van de Wtg zijn gedeeltelijk te herkennen in de instituties die in het buitenland bestan woor de besluitwoming over tarieven voor artsen. Zo wordt vaak waarde gehechit aan een technocratische vormgeving van besluiten met een bedrifseconomische onderbouwing als resultaat. In landen als de VS en Duitsland wordt er langer dan in Nederland gestreefd naar een bedriffseconomische onderbouwing door kostenfactoren te expliciteren. In de VS is daarvoor de zogenaamde "resource-based relative value scale" (RBRVS) ontwikkeld. De doelstelling wan de RBRVS is de arts te betalen op basis van de relatieve kosten van de hulpbromen die een arts nodig heeft om bepalde verrichtingen wit te voeren. De bedoeling is daarbij een concumerende markt na te bootsen (Hsiao, in: Iglehart, 1990: 1248). Daarvoor was het nodig precicze informatie te hebben over de benodigde tijd en de intensiteit van de activiteiten gedurende die benodigde tijd, de praktijkkosten, en de opleidingskosten. De inspanningen van de onderzoekers hebben onder meer geleid tot meer dan 7500 zogenaamde Current Procedural Terminological codes (CPT-4 codes) die de complexiteit, tijd, training en andere hulpbronmen reflecteren (Dove, 1994: 193)

Een dergelijke vormgeving van de beshuitvorming over tarieven voor medisch specialisten staat volgens Glaser in tegenspraak met de in Nederland ontwikkelde praktijken. Een uitgebreid stelsel van criteria ten aanzien wan bijvoorbeeld de arbeidstijd, de praktijkkosten of andere factoren, dat de bedrijfseconomische kosten van medisch handelen inzichtelijk zou kunnen maken, heeft in Nederland nooit besta.an. ${ }^{2}$ Het onbegrip van artsen ten aanzien van de tarieven die zij mogen declareren (zie bijvoorbeeld het citaat aan het begin van het eerste hoofdstuk) is terug te voeren op het ontbreken van een rechtvaardiging van tarieven - of beter: de verhouding tussen tarieven - in termen van objectiveerbare kostenfactoren. Volgens Glaser is het systeem van onderhandelen over tarieven voor medisch specialisten in Nederland het bijna wetmatige bijprodukt van de ontwikkeling wan het ziektekostenverzekeringsstelse die in de meeste Westerse landen plaatswond. Op het moment dat ergens een ziektekostenwerzekering verplicht wordt gesteld, wordt helt door de medische beroepsgroep zelf ontwikkelde en al langer bestaande tariefstelsel overgenomen. In een daarvoor speciaal ingesteld onderhandelingsorgaan overleggen vervolgens vertegenwoordigers van artsen en verzekeraars (i.c. ziekenfondsen) op basis van de door de medici zelf ontworpen parameters ower de aanpassing van tarieven (Glaser 1990). Deze onderhandelingen hebben maar de mening van Glaser onvermijdelijk een politiek karakter, omdat de belangen van de betrokkenen per definitie tegengesteld zijn. Artsen willen nu cenmaal altujd meer geld dan wat mogelijk is binnen een door premies of belastinggelden gefinancierde gezondheidszorg: Bovendien vinden binnen de organisaties van artsen allerlei politieke processen plaats, die uiteindelijk leiden tot een bepaald standpunt, warin onvemijdelijk de stem van sommige specialisten sterker doorklinkt dan die van andere. Het systeem van onderhandeling biedt volgens Glaser de mogelijkheid deze belangentegenstellingen te 
verwerken. Omdat compromissen noodzakelik zijn, hebben tarieven altijd een politiek karakter. Bovendien erkennen de onderhandelaars het politicke karakter van gebruikte informatie. De zogenaamde input wariabelen die Hsia in de VS via een wetenschappelijke methode will laten vaststellen worden volgens Glaser geproduceerd "..(b)y common sense, debate, and compromise." (Glaser, 1989a: 134). Kortom, niet alleen de hoogte van tarieven is de uitkomst van politiek gekleurde onderhandelingen maar ook de data die gebruikt worden.

Glaser laat na andere interactiesoorten in zijn beschouwing to betrekken. Aandacht voor hiërarchische of juridische besluitworming ontbreekt, hetgeen gezien het samengestelde karakter van de Wtg als institutie bezwaarlijk is. Dat bij het ontwerp van de Wtg voor deze uiteenlopende manieren om tot besluiten te komen werd gekozen lag aan verschillende factoren. Belangrijk was vooral de voorgeschiedenis van de Wtg. Al eerder werd geconstateerd dat de Wtg een comprow mis vormde (Lapre 1985, Lieverdink en Maarse 1995). Bij het ontstaan van de Witg in de periode 1976-1980 zijn namelijk in sterke mate aanpassingen gedaan volgens de wensen van maatschappelijke organisaties. De ruime mate van inspraak waarvoor door de verantwoordelijke bewindslieden gezorgd werd, miste zijn uitwerking niet. Omdat bowendien de overheid haar invloed wilde uitbreiden en een verheldering van de criteria voor aanpassing wan tarieven nastreefde, ontstond en wet, waarin het onderlinge overleg tussen maatschappelijke organisaties, rechtsbescheming en controlemogelijkheden woor de overheid en het COTG en technocratische besluitvorming met elkaar om voorrang streden.

\subsection{Methodologische uitgangspunten}

\subsubsection{Besluitvorming als proces: een reeks van gebeurtenissen}

Sommige wetenschappers menen dat in veel sociologisch onderzoek het temporele karakter van sociale verschijnselen wordt genegeerd. Er word teveel onderzoek gedaan naar de causale relaties tussen variabelen on de eventuele uitkomst te kunnen verklaren, terwijl er te weinig andacht is voor de temporele kenmerken van gebeurtenissen of de manier waarop actoren deze ervaren (Aminzade, 1992: 457). De kritiek luidt dat sociologisch ondetzoek zich veel meer richt op laterale dan op sequentiele relaties. Met behulp van de uitleg van Abbott (1992: 431) kan ik het verschil tussen de nadruk op laterale en sequentiële relaties als volgt duidelijk maken.

Stel dat een aanwijzing van de overheid aan het COTG is omgezet in een beschikking wararin de tarieven voor medisch specialisten worden verlaagd. De aanwijzing noemen we hier wariabele $x$, de verlaging van tarieven variabele $y$. De nitsprakk " $x$ veroorzakt $y$ is dan een correcte uitsprak over de causale relatie tussen $x$ en $y$, en heeft een lateranl karakter. De urtspraak zegt niets over datgene dat tussen het geven van de aanwijzing en deverlaging van tarieven plaatsvindt, noch word duidelijk hoeveel tijd in het omzetten van de aanwijzing in een beschikking is gaan zitten. Volgens Abbott (1992: 431) is de uitspraak ' $x$ verooraakt $y$ 'slechts een middel om de vele gebeurtenissen snel sanen te watten die aangeven hoe de tarieven na thet afgeven van cen aanwijzing worden gekort. Wanneer deze situatie in een sequentięle uitspraak beschreven word is het resultat heel anders: WVC formuleert de anwijzing, eventueel in samensprak met het COTG, waama het COTG advies inwint bij de Kamer $V$ etc. Met andere woorden, een sequentiële analyse geeft de gebeurtenissen weer die plaatsvonden tussen $x$ en $y$.

Met name in de historische sociologie is geprobeerd de tijd als factor in beschrijvingen op te nemen door wit te gaan van reeksen wan gebeurtenissen als een in de tijd geordend proces. (evenemental temporality) (Griffin, 1992: 413). Deze reeksen van gebeurtenissen kunnen van elkaar verschillen. Er kan sprake zijn wan padafhankelijke reeksen, waarbij oen actie of gebeurtenis het aantal daarop volgende acties of gebeurtenissen aanzienlijk beperkt, of wan reeksen van gebeurtenissen die nergens op uit lopen (exit points en dead ends) of die slechts 
leiden tot een herhaling. In deze gevallen kan het verloop van de gebeurtenissen niet verklaard worden uit eerder gebeuttenissen. Gebeurtenissen zijn bovendien niet slechis empirische eenheden, maar constructen waarin actic, structuur en cultuur samenkomen. Daarom is cen gebeurteris als eenheid van analyse zeer geschikt om de stap te maken van beschrijving naar verklaring (Abrams, 1982: 190 e.v.). Zo is een gebeurtenis als de goedkeuring van een tariefvorstel door het COTG nit slechts een formeel tariefbesluit, maar ook het witoefenen van formeel gezag, wellicht de bevestiging van verlies voor de een en winst voor een ander, of wel of nief gematerialiseerde overheidsmacht.

Het verwijt aan de sociologie lijkt niet van toepassing te zijn op de beleidswetenschap. Beleidswetenschappers benadrukken voorturend het belang van de temporele orde van het object wan onderzoek. Beleidsmakers bouwen namelijk woort op een historische erfenis waardoor zij opgesloten zijn gerakt in hun eigen geschiedenis (Rose en Davies, 1994: 12). Beleidswetenschappers zijn misschien wel gepreoccupeerd met het verloop van verschillende processen en hebben dat in hun theoretische modellen verwerkt. Zij bestuderen agendavomimg, besluitwoming, en uitvoering. Bij de theorieen over agendavorming vormen concrete gebeurtenissen indicatoren woor de overgang van fasen in het agendavormingsproces. Zoals het in het sequentiële analysemodel hoort, is agendavoming een proces warin concrete gebeurtenissen als het overwinnen van hindernissen worden geconceptualiseerd, die inzicht verschaffen in het verloop van het proces. Ook voor de studie wan (politieke) besluitvoming wordt een sequentieel uitgangspunt voortdurend aabbevolen. Besluiten zijn een onderdeel van een vakk lang proces dat uit allerlei gebeurtenissen bestaat. Immergut zegt

"...(p)olitical decisions are not single decisions made at one point in time. Rather.

they are composed of sequences of decisions made by different actors at different instimutional locations." (1992; 63).

Hetzelfde geldt voor de algemene modellen van besluitvorming. Vooral in het incrementalisme wordt besluitworming getypeerd in termen van tijd, hetgeen naar voren komt in dit citaat van Lane:

"In terms of the extemal perspective incrementalism claims that decision-making in general and in the public sector in particular is determined by time. Previausly made decisions are crucial determinants of present policies." (1995: 75)

Inzicht in de kleme stapjes en aanpassingen die kenmerkend zijn voor het proces van het 'doomodderen' (muddling through) is onmisbar voor het knnmen begrijpen incrementele besluitworming. In het algemeen vindt bestuurlijke besluitvorming door horten en stoten plaats. Beslutvormingsprocessen worden sterk beinvloed door het strategische en tactische versnellings- en vertragingsgedrag van de betrokkenen waardoor zij een schokkerig werloop vertonen ("t Hart, 1992: 210-212). Illustratief zijn de resultaten van het parlementaire onderzoek naa de besluitvorming over de grote stelselherziening in de Nederlandse gezondheidszorg. Bepalend voor de herziening en het beslutwormingsproces waren de zogenoemde onslagpunten (Onderzoek beslditvorming volksgezondheid 1995). Ook het deelproces van de beleidsuitwoering beschrijven belleidswetenschappers vaak als en reeks van besissingen, waarin de inhoud wan het vastgestelde beleid, maar ook de bijbehorende tijdsplanning aanzienlik kan veranderen (Bardach 1978 , Pressman en Wildawsky 1973 ).

Een heldere theoretische conceptualisering van de temporele orde is binnen de beleidswetenschap nog niet voorhanden. Veel verder dan een aanduiding in termen van processen koml men valk niet. Over wat bijvoorbeeld onder tijd moet worden verstaan, laten wetenschappers zich nict uit, terwijl er toch alle reden voor is de factor tijd te problematiseren en te relateren aan de context van bestuurlike besluitvoming (Idenburg en Van der Loo 1994 , Koppenjan 1993). IK zal de besluitvorming over tarieven voor medisch specialisten bestuderen als reeksen wan gebeurtenissen in een bepaalde tijdelijke volgorde (evenemental temporality). Dit betekent dat ik het besluit over een tarief als het uiteindelijke resultaat opvat van een reeks van 
gebeturtenissen die op de éch of andere manier met elkar in verband stan. Sommige van deze gebeurtenissen zullen bepalend blijken te zijn in die zin dat zij het werdere verloop in belangrijke mate sturen, bij andere is sprake van herhaling of van doodlopende wegen. Deze aanpak is niet ongewoon in de beleidswetenschap, maar hij wordt weinig methodologisch gesxpliciteend. Ook Lammann en Knoke zien weinig anknopingspunten in reeds gedane studies, In en reactie daarop postuleren zij, dat gebeurtenissen een georganiseerde context vommen voor besluitvoming omdat ze institutioneel ziju ingebed en plaatsvinden in een bepalde periode (1987: 29-30). Toegepast op het onderzoek naar collectieve besluitwormingsprocessen geven zij de volgende omschrijving van gebeurtenissen (events). Een gebeurtenis is een chuciaal besinit als onderdeel van een reeks van collectieve besiuiten dat moet vallen wil het uiteindelijke besluit genomen kunnen worden (1987: 251). Teisman gebrukt in zijn studie naar besluitvorming rond infrastructurele werken eveneens een onderscheid in gebeurtenissen, maar hij noemt deze beslismomenten. Volgens Teisman is het van zeer groot belang vast te stellen welke beslismomenten cruciaal zijn. Daarvoor moet nagegaan worden welke beslissingen bindend zijn. Beslissingen zijn bindend als acioren zich daaraan niet kunnen ontrekken. Blke bindende beslissing sluit een zogenaande besluitvormingsronde af (1992: 123). Zowel Laumann en Kinoke als Teisman beperken zich tot een inventarisatie van padahankelijke gebeurtenissen. Beiden concentreren zich immers op die beslissingen die het verdere verloop van de besluitvorming bepalen. Vanwege de vraggstelling van dit onderzoek $\mathrm{zal} i \mathrm{k}$ de andere gebeurtenissen niet negeren, hoewel ook ik de neiging zal hebben om vooral de bepalende besluiten te benadrukken. Als onderzoeker wil je nu eemmaal weten waarom een bepaald besluit genomen wordt. Mar tariefverzoeken die worden afgewezen, aanwijzingen die niet worden uitgewerkt en bemiddelingen zonder resultaat om maar enkele doodlopende reeksen van gebeurtenissen te noemen, kumen eveneens inzicht geven in de interacties in de constellaties van actoren die zich bezig houden met besluitvorming. Daarom richt ik mij niet alleen op padahankelijke gebeurtenissen (of: cruciale gebeurtenissen) maar op alle gebeurtenissen die plaats vinden tijdens de totstandkoming van tarieven.

Voortbouwend op de methodologische en methodische invalshoek wan Laumann en Knoke (1987) heb ik een reeks van gebeurtenissen onderscheiden, die kumen variëren wan het schrijyen van een brief tot het goedkeuren van een larief. Ik ben tot deze reeks gekomen door middel van een analyse van de archieven van de VNZ, de LSV, hel KLOZ, het COTG en het ministerie van WVC. Op basis van wetteksten, artikelen in vier kranten en opiniebladen en secundaire analyses wan de sector heb ik deze vijf organisaties geselecteerd. ${ }^{3}$ Hoewel Knoke en Laumann uitgaan van een engere definitie van gebeurtenissen, geven ze voor de verzameling van gebeurtenissen enkele brukbare richtlignen (1987:254-255). Ten eerste kan de onderzoeker de fomele procedures van besluitworming volgen. Gezien de vraggstelling van dit boek zou dit echter leiden toi tautologische conclusies. Als tweede criterium noemen zij de continuiteit van participerende actoren (participant continuity). Dit houdt in dat die gebeurtenissen centraal staan watin dezelfde groep van actoren participeert. Ook dit criterium stond niet voorop. Hoewel ik op basis van een eerste selectie vijf organisaties centraal hebben gesteld, ben ik er vervolgens toe overgegaan alle betrokken organisaties in kaart te brengen, zonder daarbij te letten op continuteit. In plaats van deze twee criteria te gebruiken heb ik als cerste gebeurtenissen geselecteerd, die inhoudelijk aan elkaar gerelateerd zijn. Laumann en Knoke noemen dit homogeniteit van de inhoud van gebeurtenissen (content homogeneity). Dat wil zeggen dat de geselecteerde gebeurtenissen bij de cases inhoudelijk gerelateerd zijn aan deze kwesties. Daamaast is aansluting gezocht bij de verhalen van beleidsmakers zoals ze terug te vinden zijn in de archieven waamee de beoordeling door experts gevolgd is (expert evaluation).

Het betrefl de Volkskrant, het NRC/Handelsblad, De Tijd en Haagsche Post. 
Beleidsmakers proberen op gezette tijden gebeurterissen te reconstrueren als een onderdeel van een reeds langer lopende geschiedenis. Daarbij geven zij mel name aandacht aan gebeurtenissen die volgens her belangrijk zin geweest.

\subsubsection{Inductief onderzoek}

Historisch sociologen onderschrijven het belang van het leggen van relaties tussen gebeurtenissen. Het leggen van relaties tussen gebeurtenissen is nodig omdat anders een reeks wordi gezien als een geheel van aparte, onsamenhangende gebeurtenissen in plaats van als een geheel warin de afzonderlijke gebeurtenissen een plaats krijgen (Grifrn, 1992: 417). Met name als de onderzoeker vooraf een theoretisch conceptueel model ontwikkelt zullen de te onderscheiden gebeurtenissen in dat model moeten passen. Zij ontlenen hun relevantie daaraan. Abbot maakt dan ook onderscheid tussen gebeurtenissen op conceptueel niveau en indicatoren. Volgens Abbott moet eerst een verhal van gebeurtenissen op conceptueel niveau worden opgesteld waarin relaties worden gelegd. Vervolgens moeten de empirische gebeurtenissen in kaart worden gebracht die en indicatie geven wan het theoretische verhaal wond de gebeurtenissen op conceptueel niveau (1990: 381). Eigenlijk geeft Abbott aan dat gebeurtenissen zowel op conceptueei niveau als op empirisch niveau gedefinieerd moeten worden.

Het onderscheid tussen conceptuele en geoperationaliseerde gebeurtenissen kan hier niet worden gemaakt omdat het nieuwe institutionalisme niet voorziet in een goed ontwikkelde procestheorie over de interactie tussen formele regels en collectieve besluitvoming. Zoals al eerder aangegeven hanteer ik een aantal richtinggevende concepten, die zowel empirisch als theoretisch gaandeweg worden ingewuld. Er is dus inductief onderzoek gedaan met de volgende specificaties. Ten eerste vooronderstelt inductief onderzoek niet het gebruik van kwalitatieve methoden. Zo is voor het vaststellen van de participatie van actoren kwantitatief vastgesteld wie aan welke gebeurtenis deelnam. Dit gaf de gelegenheid ontwikkelingen in de tijd kwantitatief aan te tonen en in de vorm van figuren aanschouwelijk te maken. De handelingstheorieenn en de interacties werden interpretatief onderzocht. Door middel van uitgebreide beschrijvingen (thick descriptions) hoop ik dat mijn conchusies over de beide laatste concepten controleerbaar zijn.

Uiteindelijk moet het aan elkaar relateren van de uitkomsten van het onderzoek var de verschillende richtinggevende concepten meer inzicht geven in het proces van de beslluitvonming over tarieven voor medisch specialisten sinds 1986. Dan zouden ook aanzetten gegeven moeten kumin worden tot een procestheorie waann de verschillende gebeurtenissen tussen 1986 en 1992 hun plaats krijgen. Hoewel dit ambitieus is, zal het latste hoofdstuk dil als doelstelling hebben.

Meer in het algemeen kan worden gesteld dat mensen gewend zijn de samenleving te begrijpen door het opstellen wan verhalen waarin gebeurtenissen aan elkaar worden gekoppeld. Dit geldt zeker voor beleidsmakers. "...(t)he present cannot contain its own explanation; what has happened in the less or more distant past is necessary for understanding the present..."Rationality makes sense of what has been, not what will be" (Weick, qtd. Majone, 1989: 33)...Confronted with an issue, a policymaker needs to ask: "What's the story; how did we get in the mess we are in"? Once this is understood, the question is: "what do we do next?" (Rose en Davies, 1994: 4-5). 


\subsubsection{De inperking van het antal gebeurtenissen: casuistielc en andysenivean}

\section{De casuistiek}

Na de invoering van de Wtg in 1982 zijn vele tarietbesluiten voor medisch specialistische zorg tot stand gekonen. Het aantal te onderzoeken gebeurtenissen zou onhanteebaar groot zijn geworden als niet voor een beperkt aantal tariefbeshiten gekozen was. De selectic is als volgt tot stand gekomen. In eerste instantie zou de studie zich richten op de periode 1982-1992. In overleg met medewerkers van he COTG is toen gezocht naat besluiten die regelmatig over deze tien jam gespreid zijn. Het resultaat was dat zes besluiten tot object van studie werden gekozen. Het archiefonderzoek omvatte alle besluiten maar uiteindelijk is om pragmatische redenen besloten de periode vón 1986 niet verder te onderzoken. De uitgebreide analyse vergde simpelweg teveel tijd. De keuze voor 1986 als begin is echter inhondelijk verdedigbaar. Dit jaar kan namelijk als het beginpunt van veranderingen in de besluitvorming over tarieven voor medisch specialisten worden opgevat. Sindsdien is het inkomensoverleg tussen de onerheid en de LSV, waarvan het tarievenowerleg in de eerste jaren tachtig eigenlik een afgeleide was, van minder bellang geworden. Illustratiof daarvoor is het begin van het conflict over de vergoeding voor praktijkkosten tussen żeken fondsen en medisch specialüsten in 1986.

Figur 2.1: De casustien in de tijd

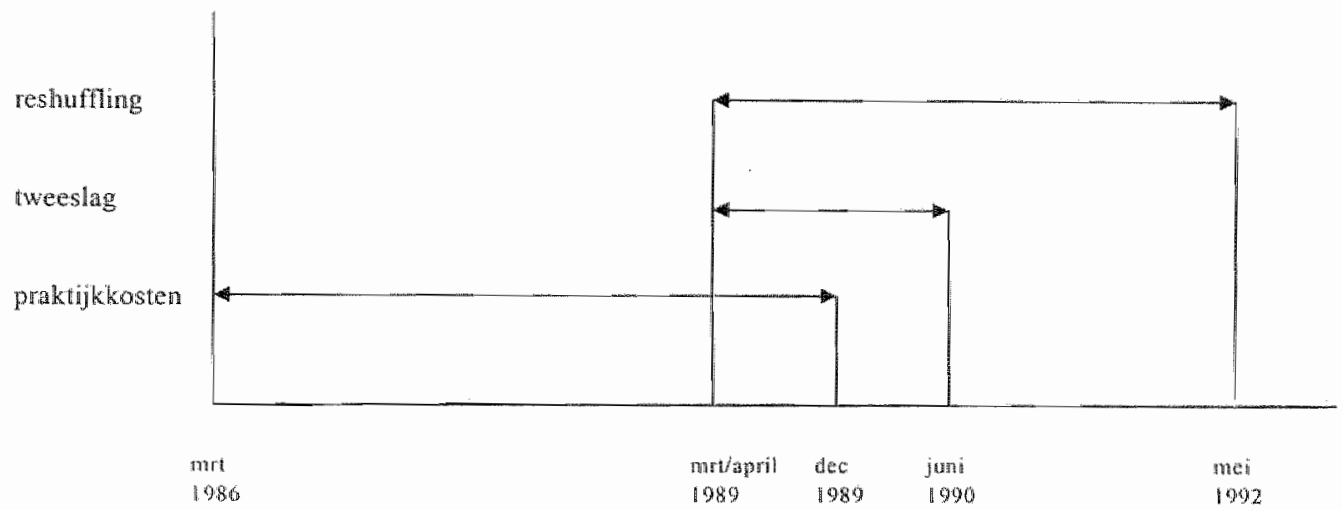

Generalisatie van onderzoeksbevindingen van een gevalsudie is een hachelijke zaak, ook als sprake is van een meeroudige gevalstudic. Bij de selectie van de castusen was het dan ook niet de doelstelling representatieve besluiten te wllen onderzoeken. Het belangrijkste was de spreiding, zodat ontwikkellingen in de beshutvorming over tarieven voor medisch specialisten konden worden bestudeerd. Door verschillende casussen te nemen die elkaar in de tijd opvolgen, worden de mogelijkheden woor de onderzoeker om inzicht in processen te krijgen groter (Miles en Huberman, 1994: 26-27). Deze aanpak is eveneens door Bakman gehanteerd (Baakman 1990). Figuur 2.1 geef het verloop van de casuistiek in de tijd weer.

In box 2.1 staan de besluiten die in dexe studie als casus dienen. Het zal de lezer opvallen dat telkens sprake is van twee COTG-beslissingen. Er zouden dus eigenlijk zes casussen zijn, maar het is zo dat het COTG in de onderzochte periode altijd wee tariefbestuiten moest nemen: 


\section{Box 2.1. De casuistiek}

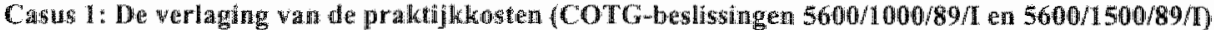

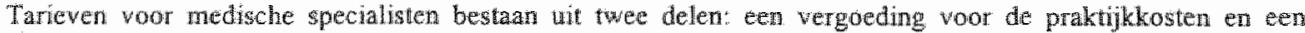
inkontusdeel. In 1936 ontstonden tussen ziekenfondsen en particuliere verzekeraars en specialisten verschillen van mening over de hoogte van de vergoeding woor de praktikkosten. De verzekeraars meenden dat deze vergoding te hoog was: er zou door specialisten op worden verdiend. Zowel doo: de WN als het COTG werden

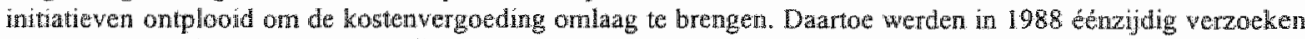

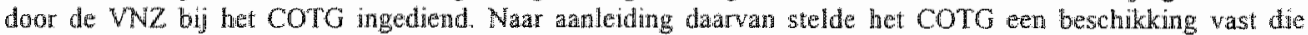
bepalde dat de kostenvergoeding voor elk specilasme gefaseerd, per 1-1-1989, 1-1-1990 en 1-1-1991 zou worden verlagad tot 65.000 , . per jaar. De verschillende juridische procedures van de $\mathrm{LSV}$ leidden er nief toe dat het beshin moest worden ingetrokken.

De werlaging van de praktijkkosten vonte de andeiding tot enome conflicten tussen de WNZ en de LSV, dwe pas wegebden toen bemiddelingspogingen onder te iding van voomalig minster Van Aardene en Philipstopmar Dekker platatsvonden. In het resultat van deze bemiddelingspogingen, het Vijfpartijen Akkoord (december 1989), werd opgenomen dall het besinit to werlaging van de prakifikcosten zou worden witgesteld. Het beslut hing echter steds als en zward van Damocles boven de onderlandelende partijen toen zij het Vijepartijen Akkoord toit stand brachten.

\section{Cagus 2: De rweeslag in tarieven (COTCumeslissimgen 5600/1000/90/1 am 5600/1500/90/1)}

In december 1989 sloten de ziekenhuizen, specialisten, ziekenfondsen en warekeraars cen overeenkomst ide Ramovereenkonst, of het Vijf-partign Akkoordy na mandeniang overleg in het Vijf-partijen Ovenleg onder leidng van Van Aardente. Een wan de onderdelen was dat voor dezelfd werrichng twee tarieven zouden kumen worden gehanteerd. Deze tarieven waren het gewone COTG-tarief en een tarief dat $10 \%$ lager lag. Vandwar dat men sprak van een tweeslag in tarieven. Het lage tarief gold voor specialisten die geen overenkomst wensteri an te gan in de form varn een modelwoverenkonst die was opgesteld als bijage bij de Rannowerenkomst. Dit had een prikkel voor individuele specialisten moeten zijn on een medewerkersoverenkomst met ziekenfondsen an te gaan, die door de artsen was opgezegd naar aanleiding wan het conflict rond de praktikkosten. In 1990 dienden partijen gezamenlijk een werzok in bij het COTG. De juridische onderbouwing was nogal problematisch. Niettemin nam het COTG het besluit om voor én verrichting twee tarieven in te stilen met als gewolg dat per 1 april 1990 een weeslag in tarieven kon worden ingevoerd Individure spectalisten stelden vervolgens beroep in bij het $\mathrm{CBB}$ warin zil gelijk kregen. Dit was in juni 1990 . Het besluit inzake de tweeslag in tarieven was derhalwe geen lang lewen beschoren.

\section{Casus 3: De reshufning van tarieven (COTG-beslissingen 5600/1000/91/ an 5600/1500/91/1)}

In de utwerking van de Ramoverenkomst (zie boven) dienden partien woorstellen bij het COTG in teneinde de ongelijheid in onzetten tussen specialismen te verninderen. Doartoe moestem de tarieven van de

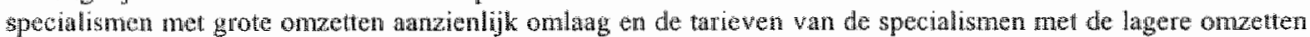
omhowg. Het ging hierbij om anuenlijike bedragen: de voorstellen wan de partijen zonden resulteren im aen verandering wan tarteven met enkele fiemallen procerten voor sommige specialismen, latgen reden was on de reshuthing wit te spreiden over drie jatar.

De organisuties diwden het verzoek in decmber 1990 bij het COTC in; het werd door het bestuur van het COTG nog in diezelfde mand goedgekeurd. Por 1 januari 1991 wend de beschikking wan kracht. Tegen de beschkking werd door individuele specialisten bij het CBB beroep ingesteld naar zonder resullat. De witvoering van de beshiten ower de reshufling kon gewoon doorgang winden. In 1992 vond de laatste anopassingug plasits bij alke casus sprake is wan tientallen tariefbesluiten. 
Zowel bij de beschrijung van actoren als van gebeuntenissen onderscheiden Launuan en Knoke een individueel en systemisch niveau. Zo komen zij tot wier niveaus van analyse (tabel 2.1).

Tabel 2.1: Niveaus van analyse volgens Laumamn en Knoke (1987:20)

\begin{tabular}{|c|c|c|c|}
\hline & & & \\
\hline & & enkelwoudig & reeks \\
\hline \multirow{2}{*}{ actoren } & individu & a & b \\
\hline & $\begin{array}{c}\text { relationeel } \\
\text { systeen }\end{array}$ & $c$ & d \\
\hline
\end{tabular}

In cel a worden onderzoeken geplaatst die zich beperken tot één individuele actor die participeert in één specifieke gebeurtenis. In cel b komt men onderzoeken tegen die én enkele actor gedurende een reeks van gebeurtenissen volgen. Het gaat dan nog steeds on slechts éen actor, maar ook om een geheel van aan elkarar gerelateerde gebeurtenissen. In cel c daarentegen hoort een studie naar de interacties tussen betrokkenen ten tijde van één gebeurtenis. Cel d tenslotte bevat een studie naar de interacties tussen betrokkenen gedurende een reeks van gebeurtenissen. Beleidswetenschappers die onderzoek doen naar het proces vari besivitwoming binnen een netwerk vam actoren vinden zichzelf terug in cel d. Het onderzoek naar de tolstandkoming van tarieven voor medisch specialisten is hiervan een voorbeeld.

Als waarnemingseenheden op het niveau van het netwerk gelden de organisaties. In het algemeen richt het modeme onderzoek nar netwerken voor collectieve besluiten zich op organisaties in plaats van personen, elites of klassen die in eerder onderzoek centraal stonden (Marin en Mayntz, 1991: 14). Over de afgrenzing van organisaties zijn diepgaande theoretische discussies mogelijk, die ik hier echter niet zou kunnen beemdigen. Volgens Godfroij ontbreekt het an strikte demarcatiecriteria. Wel kan volgens hem op basis van een formele omschrijving wan doeleinden, leden en soorten var interactie ten behoevo van de realisering van de doelstellingen een organisatie worden aangeduid (1981: 115). Op basis van deze omschrijving is het gerechtvaardigd fomele organisaties als onderzoekseenheid op te vatten. De participatie in de beshuitvoming, de handelingstheorieen en de deelname en standpunten in interacties zijn kenmerken wan de $\mathrm{VNZ}$, het COTG etc. 


\subsection{Methoden}

\subsubsection{Het algemuene databestand}

Zoals reeds eerder aangegeven werden op basis wan wetteksten, artikelen in vier kranten en opiniebladen en secundaire analyses van de sector viff organisaties geselecteerd. Het betrof het COTG, de LSV, de VNZ, het KLOZ en het ministerie van WVC. Bij deze vijf organisaties werd archiefonderzoek gedaan naar dat wat betrekking had op de bovenstaande casuïstiek. Van elk document werd de datum, het onderwerp en de in het spel zijnde actor(en) genoteerd en werd de inhoud samengevat. De documenten waren werschillend van aard. Er waren interne beleidsdocumenten waarin doelstellingen en strategieën uiteen werden gezet maar vaak werden ook interacties (briefwisselingen, bijeenkomsten, mededelingen) beschreven. Van groot belang waren de referenties aan de Wtg. Deze werden zorgvuldig in kaart gebracht.

Nadat alle documenten waren geregistreerd en samengevat, kon een eerste reconstructie van de besluitvorming plaatsvinden. Het organiserend principe was daarbij dat de sequentie van gebeurtenissen werd gevolgd. Vervolgens werd bij elke gebeurtenis vastgesteld wat er in concrete zin gebeurde, wie daarbij betrokken waren en welke standpunien de betrokkenen innarnen. Zo ontstonden verslagen van de totstandkoming van de besluiten over tarieven voor medisch specialisten.

Deze nog weinig analytische verslagen werden voorgelegd aan vertegenwoordigers van de vijf organisaties waar het archiefonderzoek gedaan werd. Hen werd de vraag gesteld of de reconstructies compleet en juist waren. Na verwerking van hun commentaar was de totstandkoming van de besluiten over tarieven met betrekking tot de door mij geselecteerde casussen volledig gereconstrueerd. Het resultaat van deze reconstructie is te vinden in hoofdstuk wier.

\subsubsection{Methoden ten behoeve wan het onderzoek naar de participatie van actoren}

Eén van de onderzoeksvragen betreft de participatie van actoren. Wie deden er, gedurende een bepaalde periode, mee aan de besluitvorming over tarieven voor medisch specialisten en vonden daarin veranderingen plaats? En in hoeverre werd dit bepaald door de Wtg?

Ten behoeve van het vaststellen van de participatie van actoren volg ik Laumann c.s. (1991) en Laumann en Knoke (1987) en worden kwantitatieve methoden gebruikt. Bij elke casus is een reeks van gebeurtenissen opgesteld. Door optelling kwam ik uit op 443 gebeurtenissen. Bij elke gebeurtenis werd vastgesteld welke actoren daarin participeerden. Hierdoor was ik in staat een actor-gebeurtenismatrix op te stellen. De actor-gebeurtenismatrix geeft een eerste overzicht van de participatie van actoren. Bovendien kan worden vastgesteld of de actoren die in de Wtg genoemd werden, daadwerkelijk participeerden

Op basis van een actor-gebeurtenismatrix is het echter moeilijk vast te stellen of er sprake was van patronen van participatie van actoren. Onder patronen versta ik het systematisch voorkomen van combinaties van actoren. Daarom werd een clusteranalyse uitgevoerd (zie voor een beschrijving van de clusteranalyse de appendix bij hoofdstuk vijf). Het doel van de clusteranalyse was te komen tot klassen (clusters) wan gebeurtenissen die gekarakteriseerd worden door specificke combinaties van actoren. De vraag is of er systematische combinaties van actoren voorkwamen en of er een verband bestond tussen het voorkomen van bepaalde combinaties van actoren aan de ene kant en de periode en/of het soort gebeurtenis aan de andere kant. On dit verband vast te kunnen stellen vormt het al dan niet participeren wan een actor in cen bepaalde gebeurtenis het criterium voor het groeperen van gebeurtenissen. 
Ondat bij een clusteranalyse geen rekening wordt gehouden met de factor tijd (de plaats van een gebeurtenis in de tijd is geen criterim bij de totstandkoming van de klassen) kan worden gesproken van cen statische analyse. In overeenstemming met het principe van do sequentie van gebeurtenissen werden de verkregen klassen op een tijdsas geplatst. Hierdoor zijn uitspraken over de ontwikkeling van patronen van participatie mogelijk.

\subsubsection{Methoden ten behoeve van het onderzoek naar de handelingstheorieün}

Scholtens geeft aan dat een handelingstheorie kan worden gexeconstrueerd:

"Een beleidstheorie is geen wetenschappelike theorie maar een handelingstheorie uit de beleidspraktijk die op wetenschappelijk veramwoorde manior kan worden gereconstrueerd." (1993: 97)

Een beleidstheorie (cen beleidstheorie is een handelingstheorie van een beleidsactor (Grin en De Graaf, 1994: 350)) is nadrukkelijk een reconstructie varn de reconstructie van de wereld door een actor uit de beleidspraktijk en zijn daarop gebaseerde handelingen (Hoogerwerf, 1989: 324). Voor de reconstructie van een handelingstheorie staan de onderzoeker een aantal methoden ter beschikking. Met name de argumentatieanalyses van Toulmin, en de handleiding voor de beleidswetenschapper die Dunn op basis van Toulmin geschreven heef, kennen een grote populariteit (Toulmin, Rieke, Janik 1979. Dunn 1993). Ze zijn toegepast in empirisch beleidswetenschappelijk onderzoek (Van Heffen 1993). Een andere, in Nederland veel gebruikte methode is die van Hoogerwerf $(1984,1989)$.

Naast woordelen kent elk van deze methoden bezwaren. ${ }^{6}$ Het grootste algemene nadeel is de noodzaak tot decompositie. Handelingstheorieen worden ontleed in onderdelen die niet alleen logisch maar vak ook in tijd van elkaar te scheiden zouden zijn. Om de gahanteerde schema's volledig in te kunnen vullen, dienen aanbevolen beleidsacties vooraf gegaan te worden door probleemomschrijvingen, afwegingen tussen de verschillende opties, en de relaties daartussen. Het gebruik van deze methoden bevordent hierdoor weliswaar de betrouwbarineid van de wetenschappelijke reconstructie, maar beperkt het begrijpen van handelingstheorieern, omdat overwegingen die onlosmakelijk met elkaar verbonden zijn los van elkaar moeten worden geanalyseerd. Tevens is het mogelijk dat onderdelen aan elkaar verbonden worden zonder dat de beleidsactor dat heeft gedaan. Ten lweede kunnen de standaardmethoden bij de reconstructie de ampirische handelingstheorie een bepaalde logica en een bepaalde consequentialiteit in denken opleggen. Met name bij pogingen finale en causale relaties in de overwegingen op te sporen bestaat het gevaar dat de onderzoeker zoekt naar instrumentele logica en cognitieve consistentie die in de praktijk ontbreken (zie ook: Sabatier 1987). De onderzoeker moet gevoelig blijven voor strategieèn en instrumentele beslissingen die net refereren an expliciete nomatieve of beleidsmatige overwegingen.

Door verschillende auteurs is bij de ontwikkeling van methoden woor analyse van handelingstheorieèn meer recht gedaan aan het complexe karakter ervan (Sabatier 1987, Fischer 1995). In plaats van het hanteren van de bovengenoemde methoden is de beschrijving van de handelingstheorieèn tot stand gekomen door onderscheid te maken tussen de elementen van een handelingstheorie. Om mijn conclusies over de handelingstheorieen zelf, hun overeenkomsten en tegenstellingen en de relatie met de institutionele omgewing controleerbaar te laten zijn volgt cen "thick description", die een uitwerking is van de motiveringen van de gedragingen van actoren. 


\subsubsection{Methoder ten behoeve wan het interactieonderzoek}

Eén wan mijn respondenten zei eens: wij werken in een industrie van argumenten. Deze karakterisering sluit goed aan bif de groeicnde belangstelling voor argumentatie in bestuur en beleid, die in de polnicke wetenschappen sinds het eind van de jaren tachtig wameenbaar is. Deze belangstelling kont voort uit het besef, dat voor een goed begrip wan beleidsprocessen inzicht in de discussies tussen de participerende actonem en de daabij gebruikte argumentatie vereist is (Fischer en Forester 1993, Majone 1989). Dit is overigens geen nieuw inzicht. Met name Murray Edelman heeft hier al op gewezen.

"If politics is concened with who gets what, or with the authoratative allocation of values, one may be pardoned for wondering why it need involve so much talk (...) The abvious difficulty is the possibility of resistance, and it is counterforce that talk may circumvent. The employment of language to sanctify action is exactly what makes politics different from other methods of allocating walues. "(1985: 114)."

Ook in Nederland kan een groeiende aandacht voor argumentatieanalyse worden geconstateerd. Zo beginian Pröpper en Bleijenbergh hun boek over politiek en bestuurlijk argumenteren met de zin: "Politiek bedrijven en besturen bestaan in een democratie over het algemeen uit praten, discussiëren en argumenteren" ${ }^{*}(1995: 1)$.

Voor het vaststellen van interacties heef deze aandacht woor argumentaties belangrijke gevolgen. Om interacties te kumnen analyseren en te kunnen groeperen, zullen de argumentaties bestudeerd moeten worden. Het geheel van argumentaties zou ik met de woorden wan Própper en Bleijenbergh (1995: 3 ) het betoog van de besluitvorming over tarieven voor medisch specialisten willen noemen, waarin uitspraken worden gedaan om beweringen aanvardbaar te maken of te ontkrachten. Van dit betoog maken zowel de feitelije argumenten alsook de regels daarvoor onderdeel uit. Het betoog wan een bestuurlijke sector bestaat dan uit

"... (t) ine interactions of individuals, interest groups, social movements, and institutions through which problematic situations are converted to policy problens, agendas are set, decisions are made, and actions are taken." (Rein en Schön, 1993: 145).

Het betoog bewat dus zowel de talige interactie als de instituties die daatop van betrekking zijn.

Om de institutionele bepaldheid van een argumentatieve inferactie vast te kumen stellen, voldoet een adequate beschrijving van aspecten wan argumentatieve interactie die ik ontleen aan Toumin e.a. (1979: 14-15). Ten eerste vinden argumentaties altijd plats in een bepaald form. Dat fonm kan bijvoorbeeld een rechbank zajn, of een onderhoud met de staatssecretaris van Volksgezondheid. Rein en Schön noemen het forum de institutionele locus. De plaats waar de argumentatieve interactie zich afspedt, drukt zijn stempel op de interactie zelf. De argumentatie krigt vorm binnen de grenzen die de instituties stellen. De institutionele context legt rollen en nomen op en zet an lot specifreke probleemdefinhties (Rein en Schön, 1993: 156-157). Zo zijn er soorten van politieke taal te onderscheiden die in verschillende contexten worden uitgesproken (Edelman, 1985: 130-151). Bovendien biedt de institutionele context voor de deelnemende actoren middelen on tijdens de argumentatie een rol te kunnen spelen. De onderhandelaat weet dat hij het bod van zijn opponent kan beantwoorden met een tegenbod. De advocaat kan de argumentatie van zijn opponent met juridische argumenten tegenspreken. De institutionele locus van een argumentatie beperkt niet alleen, mar geeft dus ook mogelijkheden tot interactie. Dit betekent dat met een verschuiving van institutionele locus tevens de discursieve en interactionele warm niet de semantische waarde van verbale communicatie voorop staat maar de context on het gebruik van de taal. Zie voor een overzicht Witteveen (1988). 
bromen veranderen, die gehanteerd kunnen worden om bijvoorbeeld conficten te verwoorden en op te lossen (Miller en Holstein, 1995: 38).

Als gevolg van de invloed van een form is een interactie procedureel georganiseerd en kent deze en typerende presentatie en verdediging wan argumenten (Toumin e.a., 1979: 14*15, Pröpper en Blejjenbergh, 1995: 2-4). Ik $20 u$ dit de orgamisate van de interactie of de argumentatieprocedure willen noemen. Pröpper en Blejenbergh definieren de argumentatieprocedure als "...(d)e regels die deehemers tijdens het proces van arguntentatie in acht nemen of behoren te nemen" (1995: 37). Zo verwacht een onderhandelaar op thin bod ean tegenbod, aen rechter en grief en een verdediging, het COTG en in formele temen gefomuleerd tariefvoorstel waarna een formele bevestiging van ontvangst en en af- dan wel goedkeuring volgt, etc. Een rechter verwacht van aanklagers en verdedigers een verwijzing naar regels en nomen in van toepassing zijnde regelgeving, de onderhandelaar een quid pro quo formulering, en het COTG een Wtg-technische onderbouwing van het tariefvoorstel. Een rechter verwacht niet dal éen van de partijen voorstelt om bepaalde feiten door de vingers te zien or een bepaald beslüt te nemen in ruil voor goed gedrag in de toekomst. Dergelijke onderhandelingstaal misstaat en zal de belangen van de biedende actor eerder schaden dan goed doen. Door de hoge mate van institutionalisering zal de interactie voor de rechtbank nauwelijks door andere wormen van organisatie worden bepaald. Andersom is veel meer voorstelbaar. Zo zou kunnen worden verondersteld dat onderhandelingen in een sterk juridisch gereguleerd beleidsveld beinvloed worden door juridische overwegingen, waardoor een formalisering van standpunten fot stand komt die de quid pro quo formuleringen vervangt. Hoewell sommige interacties dus plaats vinden in een sterk geinstitutionaliseerde context is een bepaalde mate van vrijheid voor actoren in andere contexten voorstelbaar. Voor argumentatie geldt dus wat voor andere gereguleerde activiteiten ook geldt: het voortbestaan van regels is afhankelijk van de mate waarin zij gereproduceerd worden. Voor een beschrijving van de interacties voldoet het dan ook niet om de onderverdeling in fora aan te houden en vervolgens de bijbehorende interacties te besclijuen, mar de onderzoeker moet proberen de verschillende vormen van organisatie van de interactie ook op onverwachte platsen aan te treffen.

\subsection{Samenvatting}

In dit hoofdstuk zijn de centrale theoretische concepten nader aangeduid om empirisch onderzoek mogelijk te maken. Bovendien zijn de methodologische uitgangspunten van deze studic besproken. Tenslote heb ik aangegeven welke methoden zijn gehanteerd.

Het actorgerichte institutionalisme stell mij in staat een inductieve werkwijze to wolgen. Door middel van een analyse van de participatic van actoren, hun handelingstheorieen, on soorten van interacties $\mathrm{kan}$ ik aangeven boe de formele instituties (met name de Whg) invloed uitoefenen op beslutvormingsprocessen op collectief niveau. Hierbij hanteer ik een dynamische onderzoeksopzet. De besluitvorming over tarieven voor medisch specialisten wordi bestudeerd als reeksen van gebeurtenissen in een bepaalde tijdsvolgorde. Met het oog hierop zijn elkaar in de tijd opvolgende casussen geselecteerd die zich in de periode $1986-1992$ voordeden.

De participatie van actoren kan kwantitatief onderzocht worden. Het in beeld brengen van de handelingstheorieen en soorten van interacties vereist kwaliatieve methoden. Ten behoeve van de handelingstheorieen volg ik de aanwijzingen van Mayntz en Scharpf, maar ik onderscheid. eveneens de strategieen. Interacties worden onderzocht door argumentatie te bestuderen warbij onderscheid gemaakt word tussen het form en de argumentatieprocedure.

De analyse vind plaats vanaf hoofdstuk vijf Daaran voorafgaand schets ik de ontwikkeling van de instituties wan de tariefvorming in deze eeuw. Vervolgens wordt in het 
wierde hoofdstuk een beschrijving gegeven van de gebeurtenissen tussen 1986 en 1992 bij de geselecteerde tariefbesluiten. 


\title{
Van heterogeniteit naar uniformiteit
}

\author{
Veranderingen in de instituties voor tariefvorming voor medisch \\ specialistische zorg in Nederland sinds 19001
}

\subsection{Inleiding}

In dit hoofdstuk zal de ontwikkeling van de institutionele inbedding van de besluitvorming over tarieven voor medisch specialisten worden geschetst. De Wrtg is daarvan het voorlopige sluitstuk. De Wtg is een formele regeling. In de voigende paragrafen zal duidelijk worden dat de regels voor tariefvorming lang niet altijd formeel werden vastgelegd.

Dat de tarieven een uitvloeisel zijn van besluitvormingsstructuren rechtvaardigt een uitgebreide studie daarvan. Een dergelijke studie mag echter niet contextloos en ahistorisch van karakter zijn. De organisatie van de besluitvorming over tarieven voor medisch specialisten is immers een weerspiegeling van de sociaalpolitieke verhoudingen in de maatschappij. Maatschappelijke veranderingen hebben geleid tot een nieuwe institutionele inbedding van de besluitvorming. In de instituties werden bepaalde tijdelijke principes, uitgangspunten en meningen van overheden en maatschappelijke groeperingen manifest. Hierdoor heeft de institutionele inbedding van de besluitvorming over tarieven een politiek karakter en is zij tevens historisch contingent.

De instituties voor besluitvorming zijn niet alleen historisch contingent maar kennen tevens een patroonmatige ontwikkeling. Vanwege de verbondenheid met de maatschappelijke context weerspiegelden de veranderingen in de regels voor de besluitvorming over tarieven voor medisch specialisten de veranderende sociaalpolitieke verhoudingen, met name die in de gezondheidszorg. Het te herkennen patroon, of pad zoals het hier genoemd zal worden, was echter niet de voortdurend wisselende uitkomst van de strijd tussen de overheid die de economische autonomie van de arts wilde beperken en de georganiseerde medische beroepsgroep dic zijn autonomie zo groot mogelijk wilde houden. Het pad wan de ontwikkeling van de instituties is daarentegen wel te beschrijven als een onderdeel van het proces van collectivisering zoals dat plaats vond in de Nederlandse verzorgingsmaatschappij als geheel. Daarbij was tevens sprake van geleidelijkheid. De veranderingen waren vaak incrementeel en sloten aan op reeds eerder in gang gezette ontwikkelingen. De specifieke kenmerken van dil veranderingsproces werden bepaald door tijd-en plaatsgebonden constellaties. Een beschrijving wan deze constellaties biedt meer inzicht in de veranderingen van de besluitworming over tarieven dan de zogenaamde interventionismethese warin de geschiedenis beschreven wordt in termen van interventie en noninterventie van de staat in de professionele autonomic (Johnson, 1982: 188-189, Johnson,

Delen van dit hoofstuk zijn eerder gepubliceerd (Lieverdink, 1994). Mijn dank gaat uit naar Menk vart der Velden voor zijn commentaar. 
1995: 9, Schepers en Klazinga, 1993:285). Binmen deze constellaties game het bovendien niet on homogene en autonome organisaties, mar om elkar penetrerende organisaties. De grenzen van dexe organisaties zijn doordringbaar en varubel (Johnson 1982, Coburn 1993). Overheden probeerden invloed wit te oefenen op de beleidsvoming van de georganiseerde medische professic, of zelfs op de overwegingen van de individuele arts in zijn praktik. Artsen probeerden zich een plaats te verwerven binnen de (semi-joverheidssfeer. Zlekenfondsen trachtten door te dringen tot de besturen van de door de artsen opgezette fondsen. Deze doordringbaarheid en variabiliteit komen heel duldelijk naar voren in de publikisering en politisering van de bestuitvorming over tarieven voor medisch specialisten, beide belangrijke aspecten van het bredefe proces van collectivisering. Tenslotte is als kenmerk wan deze constellatieg de contextafhankelikke belangenpercepties wan de betrokken actoren te noemen. Studies over de ontwikkeling wan de betaling van artsen laten zien dat de betrokkenen wak ambigue en tegengestelde belangen hadden hetgeen tot onzekerigeid en inteme verdeeidheid leidde. De analytische les die hicmit te trekken wall, is dat de formulering wan belangen nooit vanzelfsprekend is (alsof de arts bijwoorbeeld altijd en overal tegen een sociaal ziektekostenverzekeringsstelsel was) maar afhangt van heersende ideologieên, ervaringen en de politicke context (Starr, 1982:255).

In de hiema volgende paragraaf geef ik een beschrijving van de ontwikkeling van de instituties voor de besluitvorming over tarieven gedurende deze eeuw. Hierbij is sprake van drie te onderscheiden perioden. In de daaropvolgende paragraaf wordt een anallyse van de veranderingen aan de hand wan vier kenmerken gegeven. Tenslotte reconstrueer ik het pad van de geleidelijke ontwikkeling.

\subsection{Tariefvorming in deze ceuw: de voorbereidingen (1900-1940)}

\subsubsection{De structurur van de financiering en betaling van artsen}

De financiering van de gezondheidszorg kende voor de Tweede Wereldoorlog de volgende kenmerken. Rond 1900 werd de gezondheidszorg voomamelijk particulier gefinarierd; de patient betalde zijn rekening direct aan de arts. Daamaast was er sprake van medische armenzorg, gefinancierd en georganiseerd door gemeenten, en een grootstedelijk ziekenfondswezen dat bedoeld was voor de 'minvermogenden': mensen die niet armlastig waren maar de particuliere betaling niet op konden brengen ${ }^{2}$ Ziekenfondsen gaven wooral toegang tot huisartsen. Tijdens de eerste decennia werd in toenemende mate ook poliklinische zorg door medisch specialisten aungeboden. ${ }^{3}$ Klimische zorg door medisch specialisten werd gefinancierd door do gemeenten.

De ziekenfondsverzekering was altijd wijwillig. Ziekenfondsen ontstonden in de loop van de 19 de eeuw, voomameligk uit intiatieven van ondernemingen, groepen vaklieden en de arbeidersbeweging mar ook artsen speelden her en der een belangrijke rol. Ziekenfondsen vormden

2 De mate van verstedelijking bepalde in grote mate de omvang van het ziekenfondsbestand. In de grote steden was het antal ziekenfondsverzekerden veel groter dan elders. In 1898 was in Amsterdam ongeveer 42 procent van de bewolking aangesloten bij een ziekenfonds, 22 procent kreeg hulp wa met name de Medische Armenzorg en 35 procent betaalde particulier (Godefroi. 1963:17).

3 Met name in de 19 de eew boden ziekenfondsen - of beter: ziekenbussen - meer aan dan alleen gezondheidszorg. Veelal bestond het verstrekkingenpakket ook uit ziektegeld bij langdurige ziekte en begratenisgeld (Companje, 1997: 34-36) 
met hun aanvankelijk nit eigen kring samengestelde besturen en met lhum eigen wensen ten aanzien van de honorering vam artsen een "tegenmacht" (countervailing power) ten opzichte wan de artsen. Aanvankelijk ondersteunden artsen het afsiuiten vart contracten met ziekenfoildsen voor degenen die zich geen medische verzorging konden veroorlowen." Hoewel de betaling door ziekenfondsen ver achterbleef bij particulier betalende patiěnten was de contractrelatie noch de lage vergoeding een probleem. De ziekenfondsbetaling stelde met name jonge artsen in staat inkomsten te genereren, in afwachting van een volwaardige, grotendels particuliere praktik. Bovendien waren het met name de min-en onvermogenden die gezondheidszorg nodig hadden (Companje, 1997: 43).

In de eerste decennia begon het ziekenfondswezen te groeien, niet alleen in de grotere steden en nieuwe industriegebieden maar na de Eerste Wereldoorlog ook op het platteland. De poliklinische specialistische hulp ging behoren tot het standaardpakket van een ziekenfonds man dat gold niet voor ziekenhuiszorg. Voor een verzekering tegen de kosten van ziekenhuisverpleging kon men na de Eerste Wereldoorlog met name op het platteland in toenemende mate tereht bij verenigingen voor ziekenhuisverpleging. Een verzekering tegen verplegingskosten werd aanvankelijk echter door slechts weingen afgesloten; pas in de jaren dertig werd deze meer populair. Vermoedelijk speelde de betrekkelijke zeldzaamheid van een ziekenhuisopname hierbij een rol. Hierdoor kwamen de uitgaven wooral woor rekening van de lokale overheden. $\mathrm{Bij}$ opname in een ziekenhuis in de steden werd een eigen bijdrage van de patient verlangd (llapenga en Van der Velden 1992, Van der Velden, 1993a: 212-213). Voor mensen die geen gebruik konden maken van de verzekering van ziekenfondsen, was er het eveneens groeiend aanbod van zicktekostenverzekeringen van particuliere verzekeringsmatschappijen. Het succes van deze verzekeringen was wisselend. Waar huisartsenhulp weinig populair was, werden verzekeringen legen ziekenhuis- en operatiekosten redelijk verkocht. ${ }^{5}$ Overigens is de vooroorlogse positie van de particuliere ziektekostenverzekeraar onvergelijkaar met de huidige situatie waarin een derde van de bevolking zich particulier heeft verzekerd. De sector bevond zich nog in een beginstadium, met de daarbij behorende kinderziekten. Daarbij hoorde een slechte reputatic mede veroorzaakt door het grote aantal failissementen door gebrek aan kennis van risico"s (Schut, 1995: 132).

Evenmin als de financiering was dle bepaling wan tarieven centraal gereguleerd. Tot in deze eeuw was de particuliere honorering van artsen in Nederland heterogeen van aard, zoals laspers (1985: 77) het uitdrukt. Enerzijds was het lang gebruikelijk dat artsen aan de patient bedragen in rekening brachten die correspondeerden met de stand waartoe de behandelend arts behoorde. De doctores, de artsen met een academische vorming, hanteerden hogere tarieken dan de meer praktisch gevomde heemeesters (Van der Velden, 1993a: 49). Anderzijds, en van groter belang in deze eeuw, hing de hoogte van de betaling meer af van de welstand van de individuele patient dan wan de waarde van de diensten die de arts leverde (Jaspers, 1985: 77). Artsen hanteerden een systeem van inkomensafhankelijke tarieven. De arts liet welgestelde patienten aanzienlijk meer betalen dan de minder welgestelden. Van oudsher golden daarvoor regionale bepalingen opgesteld door de afdelingen van de NMG die daartoe de vrijheid hadden sinds de invoering van de Wet betreffende de witoefening der Geneeskunst in 1865 (Companje, 1987: 33). Zo stelde de

Het waren juist niet de allerarmsten die bij de ziekenfondsen waren aangesloten. Hel ledenbestand wan de ziekenfondsen bestond uit lagere ambtenaren, geschoolde vaklieden en de kleme middenstand. De armen, ofwel de onvermogenden, moesten tot in deze eeuw terugvallen op de Armenzorg (Jaspers, 1985; 76). De samenstelling vat het lecembestand van de ziekenfondsen was van oudsher een probleem dat veel artsen zorgen baarde, mede omdat het aantal ztekenfondspatiënten hen al snel te veel werd wardoor de particuliere praktijk in de knel $\mathrm{kwam}$. Vandaar ook dat de NMG altijd heeft geprobeerd veranderingen in de loongrens te beheersen, Comesponcentie met Henk van der Velden, 24 maart 1997 
affeling Utrecht van de $\mathrm{NMG}$ in 1874 de tariewen wast op basis van de soort wernchting en het belastingtarief dat de patient betaalde. Iemand uit de laagste klasse betaalde f 0.50 to f 0.75 per visite en een persoon die verkiesbaar was to leden van de Tweede Kamer tussen $f 1.50$ en $f 5$. Een vaccinatie kostte tussen $f 1.50$ en f 10.00 , terwijl iemand voor I 1 tot $f 5$ een aderlating kon ondergaan. De rekening voor een verlossing, tenslotte, kon oplopen tot f 150 (Companje, 1997 : 482-483). Dit verschil in tarieven, dat eveneens in de VS op grote schaal voorkwam, laat Kessel (1958:22) als volgt door een arts toelichten.

\section{"I don't feel that I am robbing the rich because I charge them more when I Mow they can well afford it; the sliding scale is just as democratic as the income tax. I operated today upon two people for the sane surgical condition one a widow whom I charged $\$ 50$, the other a banker whom I charged $\$ 250$. I let the widow set her own fee. I charged the banker an amount which he probably cawies around in his wallet lo entertain his business friends."}

Dit systeem van taniefdiscriminatie werd door de medische stand gerechtwaardigd door te benadrukken dat de hoge tarieven de arts in staat stelden aan minder rijke patienten een lager tarief, en dus betaalbare zorg, aan te bieden. Men zou kunnen spreken van een organische financiele solidariteit. Het is echter de vrag of dit de voomaamste reden was voor de optredende tariefdiscriminatie. Dat de arts als ondememer handelde en dus probeerde zijn inkomen te vergroten, werd door velen als een meer waxschijnlijke gedragsveronderstelling gezien (Godefroi, 1963: 122-123). In de gezondheidseconomie worden deze betde tegengestelde veronderstellingen respectievelijk de 'charity hypothesis' en de 'maximizing hypothesis' genoemd (Kessel 1958).

Hoewel het systeem van tariefdiscriminatie dus grote voordelen bood voor de arts, leidde het ook tot problemen. Door middel van prijsconcurrentie probeerden artsen zoveel mogelijk welgestelde patienten aan te trekken. Dit resulteerde echter in een verlaging van de hoge tarieven waardoor de financiële mogelikheden om minder rijke patiënten te behandelen kleiner werden. Bovendien was het aanbod van meer welvarende patiënten niet zo groot dal elke arts een evenwichtig patièntenbestand kon opbouwen (Japenga en Van der Velden, 1992: 505, Van der Velden, 1993a: 49-50).

Het systeem van tariefdiscriminatie rendeerde uiteraard het beste zolang het aandeel van de ziekenfondspatiënten in de artsenpraktijk niet te groot werd. Dit nu was echter wel het geval; het aantal ziekenfondsverzekerden steeg nog voor de Tweede Wereldoorlog tot ongeweer 41 procent van de Nederlandse bevolking (1937). 6 Deze groei kan worden toegeschreven aan de lage premiekosten woot de verzekerden (risicogroepen als amen en bejaarden waren uitgesloten en dure zorg als ziekenhuisopname was vaak niet in het pakket opgenomen, hoewel het verzekeringspakket van ziekenfondsen zich uibreidde ${ }^{7}$ ), en aan de groei van het reële inkomen van de Nederlandse bevolking tijdens het interbellum (Japenga and Van der Velden, 1993: 180). Ook werd in de jaren dertig de druk op met name de minvermogenden groter om zich tegen ziektekosten te verzekeren door de noodzaak woor veel gemeentelijke overheden om hun witgaven aan gezondheidszorg te beperken. Bovendien nam het aanbod wan ziekenfondsen snel toe, vooral op instigatie van de vakbeweging en de Nederlandse Maatschappij ter Bevordering van de Geneeskunst (NMG). Deze initiatieven leidden, samen met de ontwikkeling van

Maar nog steeds was er sprake wan verschillen tussen stad en platteland. In 1937 was het aantal ziekenfondsverzekerden in Zuid-Holland tot 52.4 procent gestegen, tegen 23.6 procent en 29.0 procent in Drenthe en Brabant (Van der Hoeven en Van der Hoeven, 1993: 117). Voor de invoering van het Ziekenfondsenbesluit in 1941 bood slechts de helft van de ziekenfondsen ziekenhuiswerpleging aan (Van den Berg, 1966: 865) 
plaatselike regelingen waarbij individuele artsen fondsen oprichten, tot het naast elkaat bestaan wan zon 650 fondsen (Festen, 1974: 380).

De betaling door ziekenfondsen was al net zo heterogeen als de particuliere betaling. Rondom 1900 hanteerden ziekenfondsen veelal een abonnementensysteem. In een dergelijk systeem gingen ziekenfondsen overeenkomsten met artsen - de zogenoende medewerkers - aan waarin een vast bedrag per patient voor een bepaalde periode (bijvoorbeeld per jaar) wart overeengekomen. Een andere manier van betalen was de verdeling van de inkomsten van het fonds over artsen, na aftek van administratiekosten. Slechts enkele ziekenfondsen hanteerden een verrichtingensysteem warbij de arts een bedrag per verrichting kreeg (Godefroi, 1963: 22; Van der Hoeven en Van der Hoeven 1993: 101. Deze variatie was kemmerkend voor de autonomie van de individuele ziekenfondsen. De bepaling van de ziekenfondspolitiek vond decentraal plaats. Verschillen van mening over de inrichting van de gezondheidszorg veroorzaakten verschillende honorariumstructuren ( $V$ an der Velden, 1993: 203). Ziekenfondsen functioneerden ook zonder centrale afspraken over premies of verstrekkingenpakketten (Festen, 1974: 380). De hoogte van de betaling werd evemin centraal vastgesteld. De onderlinge ziekenfondsen, ziekenfondsen voortkomend ait de arbeidersbeweging, werden weliswaar al in 1913 verengd in de Landelike Federatie ter Behartiging van het Ziekenfondswezen die de belangen behartigde op nationaal niveau mar uniformering bleek niet afdwingbaar. Bowendien was in 1937 slechts 31.5 procent van de onderlinge zlekenfondsen (ongeveer 570.000 verzekerden) aangesloten bij de Landelijke Federatie (Van der Hoeven en Van der Hoeven, 1993: 117). Ook was deze Federatie niet acceptabel voor de $\mathrm{NMG}$ om collectieve overeenkomsten nee af te sluiten. Wel was het zo dat het ontbreken van centrale sturing enigzins gecompenseerd werd door onderlinge afstemming op lokaal an regionaal niveau. Bovendien gingen overeenkomsten steeds meer op elkaar lijken. ${ }^{9}$ In deze zin was sprake van beginnende zelfregulering waarbij bestumlijke taken functioneel gedecentraliseerd zijn (Maarse 1990).

De NMG zag in de ontwikkeling van de ziekenfondsen een aantal bedreigingen. Zij wille voorkomen dat de besturen van ziekenfondsen zouden worden samengesteld zonder artsen. Ook zon te allen tijde de vrije artsenkeuze gehandhaafd moeten blijven. Een ander belangrijk aspect was de hoogte van de welstandgrens, oftewel de inkomensgrens wataronder men zich kon verzekeren bij een ziekenfonds. Deze welstandgrens mocht volgens de NMG miet te hoog zijn. Met betaling volgens het abonnementensysteem in de ziekenfondssector, ook woor de medisch specialisten, kon de belangenorganisatie everwel instemmen. ${ }^{10}$ De strategie van de $\mathrm{NMG}$ om deze gevaren te bezweren, was zowel intem als extern gericht. Zij probearde de ontwikkeling van het ziekenfonds te beheersen door de politieke besluityorming aangaande een ziekenfondswetgeving te beinvloeden, door de eigen leden te verbieden contracten af te sluten met fondsen die niet woldeden aan de eisen van de NMG en door het stimuleren wan het ontstaan van onder een eigen reglement werkende ziekenfondsen (de Maatschappij ziekenfondsen). 11 Ook ontwikkelde de NMG in de jaren dertig modelcontracten op basis warvan plaatselijk in te

8 Omstreeks 1900 betaalde het ziekenfonds 'Door en voor werklieden' (Amsterdain) $f$, - per zicken fondswerzekerde per jaar, terwijl he particuliere tarief op ongeveer f 1, per visite lag (Van der Hoeven en Van der Hoeven, 1993: 10).

9 Correspondentie met Ifenk vara der Velden, 24 maart 1997

10 Zie bijwoorbeeld het unificatie-rapport (1925) warm de NMG instemde met $\mathrm{r} 0.90$ en 52.00 per ziekenfondswerzekerde voor respectievelijk poliklinische en kinische specialistische thulp (Van der Hoeven en Van der Hoeven, 1993: 77).

11 Zo nam de NMG in 1912 het bindend besluit dat haar leden geen contracten mochten afsluiten met ziekenfondsen zonder vrije artsenkeuze, met een bestuur waarin artsen in de minderheid waren, met een welstandsgrens hoger dan $(1200,-$ (f 800 ,- voor alleenstaanden), en met een verplichting tot het afgeven van arbeidsongeschiktheidsverklaringen. 
steller commissies met de individuele ziekenfondsen zouden moeten onderhandelen. Deze pogingen waren slechts gedeeltelijk succesvol. Zo bleef de welstandsgrens tot in de jaren zestig wen belangrijk geschipunt (Juch, 1997: 181). Wel slaagde de NMG er in de plaatselijke afhankelijkheid van de arts in de onderhandelingen met ziekenfondsen te verminderen door commissies collectieve contracten te laten afsluiten (Godefroi, 1963: 32). De wegen van de NMG werden echter niet altijd ingeslagen door de individuele ants. ${ }^{2}$ Artsen waren bereid met daadkrachige ziekenfondsen contracten af te sluiten als deze hun economische zekerheid en een onafhankelijke beroepsuitoefening gatandeerden (Festen 1974, Juffermans 1982, De Bruine en Schut 1989, Van der Hoeven en Van der Hoeven 1993, Van der Velden 1993).

Al met al ontstond in de eerste helft van deze eeuw een zeer gediffentieerd financieringsstelsel. Dit veroorzaakte toch enige zorg bij de nationale belangenverenigingen. In de periode tussen 1920 en 1940 ondemamen belangenorganisaties pogingen de versnippering van de ziekenfondssector tegen te gaan door middel van centralle afspraken. Reeds in 1922 spraken vertegenwoordigende organisaties van werknemers, ziekenfondsen en artsen met elkaar in de zogenaamde unificatiecommissie om de grote verschillen tussen ziekenfondsen weg te nemen. In 1927 begon de NMG onderhandelingen met het Rooms-Katholieke Werklieden Verbond (RKWV) watrvan de plaatselijke afdelingen met name in Brabant ziekenfondsen oprichtten. Deze onderhandelingen leidden tot een overeenkomst in 1930 . Ook richtten het Christelijk Nederlands Vakverbond (CNV), het Nederlands Verbond van Vakverenigingen (NVV) en de Landelijke Federatie van Ziekenfondsen een Algemene Raad ter bevordering van het Ziekenfondswezen op die zich ten taak stelde op vele plaatsen ziekenfondsen te stichten. De Algemene Raad poogde zelfs tot afstemming met de NMG te komen teneinde de reeds bestaande Mattschappijfondsen niet in de wielen te rijden. Ook minder gestructureerd owerleg kwam tot stand, zoals bijwoorbeeld besprekingen tussen de NMG en de Landelijke Federatie van ziekenfondsen in 1926-27 over de vrije artsenkeuze, overigens leidend tot direct contact met politici, zoals dat met name voor de NMG niet ongewoon was. Later, in 1935, kwam een Centrale Commissie voor het Ziekenfondswezen tot stand. Daarin waren vertegenwoordigd de NMG, NVV, CNV en RKWV. De Landelijke Federatie bleef buiten spel. De Commissie was overigens van weinig belang (Festen 1974, Van der Hoeven en Van der Hoeven 1993).

Deze bestururlike activiteiten op nationaal niveau werden bevorderd door de lang in de lucht hangende regulering door de overheid. De eerste decennia stonden in Nederland in het teken van sociale wetgeving. De economische gevolgen van ziekte kregen veel aandacht in de zich snel industrialiserende West-Europese landen. Niet alleen het individuele verlies van inkomen van de zieke werknemer en zijn mogelijkheden om zijn ziektekosten zelf te betalen stonden daarbij centraal, maar ook de indirecte kosten van ziekte voor de matschappij als geheel en de door de samenleving op te brengen financiering wan de gezondheidszorg (Starr, 1982: 236). In vel landen werd gestreefd naar regelingen warin een verzekering woor inkomsten voor zieke werknemers gekoppeld werd aan een sociaal ziektekostenverzekeringsstelsel dat de spoedige terugkeer van de zieke arbeider in het productieproces moest garanderen. Ook in Nederland kwam een vezekering tegen ziekte tot stand (Ziektewet 1913, in werking in 1930). Deze moest voorkomen dat zieke werknemers geen inkomsten meer zouden hebben. Maar de volgende stap om cen verzekering tegen ziektekosten wettelijk te verplichten, werd niet meteen gezet. Weliswaar was in de Ziektewet opgenomen dat iemand alleen recht had op ziekengeld indien hij zich bij een erkend ziekenfonds had aangesloten, maar deze bepaling zou nog niet in 1930 in

12 De beschrijuing door Festen (1974) laat een enorme verdeeldheid van meningen zien over kwesties in de relatie tussen artsen en ziekenfondsen bij de leden van de NMG. De mening wan de NMG was dan ook niet de mening van de arts maar een herformulering die bepald werd door inteme discussies, nachtsprocessen en exteme aanpassingen. 
werking treden. Het functioneren van de ziekenfondsen bleef hierdoor lange fijd buiten het bereik van de wetgever.

Onderzoekers benadrukken verschillende factoren ter verklaring van het uitblijven van een wettelijke regehng. Velen wijzen op de tegenstelling tussen ziekentondsen en de NMG. Juffermans (1982: 126-127) ontkent het belang hiervan nict, maar acht de conjuncturele economische toestand die werkgevers schuw makte voor premiebetaling, en dus roor een vargatnde ziekenfondsregeling van groter belang. Dí zou voor de liberal-confessionele regeringen de belangrijkste reden zijn om slechts symbolisch het belang van een wettelijke rageling te onderschrijwen. Japenga en Van der Velden (1992: 503) woegen er echter nog aan toe dat het uiteindelijke financieringssysteem, dat net voor de Tweede Wereldoolog bestond, velen tot tevredenheid stemde. ${ }^{13}$ Zij wijen daarbij op het feit dat de groep verplicht verzekerden, ontstaan nat het Ziekenfondsenbesluit van 1941, overeenkwam met dat gedeelte van de bevolking dat voor de oorlog reeds wijwillig bij een ziekenfonds werzekerd was. Bovendien paste het arnpakken wan problemen, die geen onmiddellijke oplossing woegen, niet in het politieke klimaat dat gedonineerd werd door pacificatie (Japenga en Van der Velden, 1993: 178).

\subsubsection{De betaling van en tariefvorming voor medisch specialisten}

De eerste helf van deze eeww liet dus een toename van de invloed wan zickenfondsen op de betaling van artsen zien. Het aandeel van particuliere betalingen liep snel terug. De NMG wond het zak de economische autonomie van de arts veilig te stellen en tariefafspraken met onahankelijke fondsen slechts toe te staan als het ziekenfonds aan een aantal voorwaarden voldeed. Voor de individuele artsen, en met name de artsen die behoorden tot die groepen die veel minder welgestelde patienten in hun praktijk hadden of die juist begonnen met het opbouwen van een praktijk, bood de opkomst van het ziekenfonds cen warborg voor enige economische zekerheid. Voor de artsen met een praktijk waarin particuliere patienten oxerheersten, vormde de ziekenfondspatiënt echter een bedreiging, niet alleen vanwege de lage betaling maar ook vanwege de verplichtingen die een contract met cen ziekenfonds meebracht. De veranderingen in betalingsrelaties resulteerden in aanpassingen van de machtsverhoudingen. Het min of meer onafhankelijke ziekenfonds werd een maatschappelijke tegenstander waarmee onderhandeld moest worden over zaken die voorheen tot de discretic van de arts en zujn organisatie gerekend werden (Van der Velden, 1993a: 51). De toename van de invloed van zieken fondsen werd echter niet gecompleteerd door een regeling die een einde zou maken aan de diversiteit aan fondsen en betalingsregelingen. Voor zover er sprake was van unifonmering kwam die tot stand doordat de contractanten zelf in toenemende mate met elkar overeenkomende overeenkomsten gingen hanteren. Daarnaast had de witbreiding van het aantal ziekenfondsverzekerden tot gevolg, dat het aandeel van de particulier betalende patienten in de artsenpraktijk snel teruglicp. Daarnee nam ook de heterogeniteit van de tariefvorming af.

In de bovenstaande ontwikkeling speelde de medisch specialist een bijzondere rol. In de negentiende eew was lange tijd sprake wan heemeesters en doctores (Godefroi, 1963: 108). Met de academisering van artsen ontstond de "algemeen bevoegde arts". Pas later ontstonden langzamerhand specialismen, eerst in de steden en later op het platteland. Overeenstemming over

13 Hierbij is wel van belang in de gaten te houden op welke aspecten deze tevredenhoid betrekking had. Wellicht dat Japenga en Van der Velden de consensus te hoog inschatten. Zoals recds eerder aangegeven hebben met name de vertegenwoordigende organisaties wan artsen, ziekenfondsen maar ook werknemers regelmatig pogingen gedaan om door natonale afspraken de enorme diversiteit bij de ziekenfondsen te beperken. Dit wijst op ontevredenheid met de toentertijd structurele inefficientie. 
wat nu een specialist was, en welke specialismen onderscheiden moesten worden, kwam pas geleidelijk tot stand. Eerst in 1931 begon de NMG met het registreren van specialisten.

Medisch specialisten moesten hun plek als aanbieder van zorg veroveren omdat zij met name met de algemene arts in een concumentieverhouding verkeerden. Daartoe richten specialisten rond de eeuwwisseling vooral in de grote steden zogenaamde poliklinieken op waarin amen en minvermogenden woor hulp op een deelterrein van de geneeskunde terecht konden. Om deze activiteiten te rmancieren, werd aan de gemeentebesturen een subsidie gevraagd. Aangevuld met giften en vergoedingen op basis van het maandkaartsysteem kregen de besturen van poliklinieken een budget waaruit het honorarium van de specialisten kon worden betald (Juch, 1997: 135).14

Door middel valn poliklinieken konden specialisten een patiëntenbestand en vervolgens een lonende praktijk opbouwen (Juch, 1997: 134). Zij waren daarvoor op dit soort eigen imitiatieven aangewezen, omdat de NMG bij haar politiek ten aanzien van betalingskwesties met name de belangen van de huisarts voor ogen had (Festen $1964 \mathrm{a} / \mathrm{b} / \mathrm{c} / \mathrm{d}$ ). Dit was begrijpelijk omdat in de eerste decennia van deze eeuw de groep van algemene artsen veel groter was dan de groep vam specialisten. In 1914 was nog slechts 19 procent van de praktiserende artsen een medisch specialist (Japenga en Van der Velden, 1992: 509). Als gewolg van het beleid van de NMG was de behoefte bij medisch specialisten zich bij de NMG aan te sluiten niet zo groot. Zij bleven liever onafhankelijk (Festen 1964a/b/c/d, Van Nieuwenhuizen 1971). Bovendien was medisch specialistische hulp slechts een gering onderdeel van de ziekenfondspakketten. De financiering van medisch specialistische hulp door ziekenfondsen kwam pas in het begin van deze eeuw enigzins op gang. In de beginjaren van het bestaan wan de poliklinieken hanteerden veel ziekentondsen zelfs het beleid dat poliklimische hulp aan ziekenfondspatienten (minvermogenden) gratis diende te zijn. Minvermogenden konden dus terecht in de medisch specialistische poliklinick omdat de medisch specialist gratis hulp bood, niet omdat ziekenfondsen deze hulp op grote schaal in hun pakketten aanboden. De medisch specialist diende door het gering aantal specialistische handelingen dat hij kon verrichten een grote hoeveelheid patiěnten te hebben om een redelijk inkomen te kunnen werwerven. Hierdoor verkeerde hij in een concurrerende verhouding met andere artsen. ${ }^{15}$ Daarnaast betekende de uitbreiding van medisch specialistische zorg een bedreiging voor de generalistische arts, omdat ziekenfondsen over zouden moeten gaan tot een herallocatie van hun financiële middelen. Een verhoging van tarieven voor specialisten betekende een verlaging wan de tarieven voor huisartsen. Ziekenfondsen konden immers niet meer witgeven dan de via premieheffing verkregen inkonsten.

In eerste instantie slaagden de algemene artsen erin de betaling door ziekenfondsen te blijwen beheersen. Over het algemeen was de medisch specialist angewezen op betalingen uit gemeentelijke subsidies, giften en op particuliere betaling. Waar zij wel, bijvoorbeeld door middel van maandkaarten, een vergoeding van ziekenfondsen ontvingen, bleef deze ver achter bij die voor de algemene artsen. Zo bleef de medisch specialist in de eerste decennia afhankelijk van

14 In Utrecht konden patinten vanaf 1865 terecht een specialistische kliniek, de Kliniek tot Herkenning en Genezing van Huidziekten, Keelziekten, Kinderziekten, Oorziekten, en Tandziekten. Rond 1900 werd de zorg door de Kliniek voor onvermogenden en minvermogenden gefinancierd door de gemeente, door donaties, door de Universiteit van Utrecht en door de specialisten zelf. Daarnaast betaalden patienten uiteraard hun particulier tarief, als zij daartoe in stat waren. Ziekenfondsen speelden hier nog geen rol (Companje, 1997: 75).

15 Er kon met recht gesproken worden wan ondememende artsen. Zo lieten medisch specialisten die een poliklinick openden hun patienten weinig of niets betalen, hetgeen voor de minvermogenden zeer antrekkelijk was en een goed altematief vormde voor de algemene arts (Companje 1997 : 47). 
particulier betalende patienten en ander inkomstenbronnen dan het ziekenfonds. Wel waren beginnende specialisten iets meer aangewezen op een ziekenfonds dar specialisten met een al lang bestaande praktijk (zie tabel 3.1).

Tabel 3.1: Herkomst inkomen van medisch specralisten in 1911

\begin{tabular}{c|cccc}
\hline $\begin{array}{c}\text { specialisten met } \\
\text { een praktijk van: }\end{array}$ & aantal & particulier & zickenfonds & rest \\
$<10$ jaar & & & & \\
$10-20$ jaar & 144 & 63.0 & 6.1 & 30.8 \\
$>20$ jaar & 88 & 73.5 & 2.0 & 24.5 \\
\hline
\end{tabular}

Bron: Juch (1997: 373)

In zoverre er sprake was van betaling van specialisten door ziekenfondsen bestond deze uit een bedrag per maandkaart (een verwijskaart) (Festen, 1964a: 646). Door middel van het verwijzen hield de tot dan toe dominante groep van algemene artsen de groeiende vraag naar specialistische hulp nog onder controle. ${ }^{16}$ Het bedrag per maandkaart was evenwel in de ogen van de meeste medisch specialisten veel te laag, zeker in vergelijking met de honoraria van de huisarts. Bovendien vormden specialister een sluitpost voor de meeste ziekenfondsen. De betaling per maandkaart stond niet van te voren vast, maar was afhankelijk van de financiele mogelijkheden wan een ziekenfonds na aftrek van bijvoorbeeld de honoraria van de huisartsen. De medisch. specialisten eisten in de jaren whintig en dertig dan ook dat de ziekenfondsen hun betaling zouden verbeteren (Companje, 1997: 149-151). Hierdoor botsten zill met de huisartsen dic immers uit dezelfde ruif moesten eten. De onenigheid tussen specialisten en huisartsen was ẻen van de belangenstellingen tussen groepen bimen de medische beroepsgroep die leidden tot inteme politieke conflicten. In Nederland resulteerde de interne strijd onder meer in de instelling van lokale 'specialistenpotten". Deze specialistenpotten werden beheerd door lokale specialistenverenigingen die per ziekenfondsverzekerde per jaar een vast bedrag ontvingen. Vervolgens werden de inkomsten verdeeld op basis van het specialisme en het aantal verrichtingen. Deze specialistenpotten konden worden opgericht, doordat de ziekenfondsen voor specialistische hulp een extra premie gingen vragen. Daarvoor bood de algemene loonstiging onder de leden mogelijkheden (Japenga en Van der Velden, 1992: 510, Juch, 1997: 206-207, Companje, 1997: $204-205)$.

Hoewel met de inwoering wan de specialistenpotten, die tot de Tweeds Wereldoorlog zouden blijven bestaan, de ergste kou uit de lucht was, bleef de betaling voor onrust onder de artsen zorgen. En met de voorspoedige ontwikkeling van de specialistische geneeskunde en de groei van het aantal ziekenfondsverzekerden kwamen tevens de verhoudingen tursen specialisten onderling onder druk te staan. Mede onder invloed van de economische teruggang werd elke nieuwe specialist een concurrent voor de zittende specialisten. Bovendien veranderde de organisatic van het ziekenhuis. In toenemende mate werden poliklinieken onderdeel van ziekenhuzen war medisch specialisten steeds meer afhankelijk van rakkten (Juch, 1997: 230231). De betaling voor thun klinische werk veranderde evenwel weinig. Nog steeds hadden ziekenfondsen op het gebied van klinische hulp weinig te bieden. Bovendien werd hat

16 Het economische belang om niet teveel patienten te verliezen aan de nieuwe specialisten was de reden voor veel afdelingsziekenfondsen om, in navolging van de dominerende mening in de $N M G$, vast te houden aan het zogenaamde verwijsbriefje. Een ziekenfondspatient kon hierdoor alleen aen specialist bezoeken als de huisarts dat nodig vond (Juch, 1997: 200-201). 
specialistische werk in ziekenhuzen door de verschillende financiers vooral gezien als een opstapmogelijkheid woor medisch specialisten naar een bloeiende eigen praktijk waarvan de honorening weing proriteit behoefte. Als gevolg hiervan behandelden medisch specialisten hun patienten in ziekewhuzen vaak gratis (Juch, 1997: 273). 17 Wel hadden verenigingen voor ziekenhuisverpleging met name op het platteland vaste voet aan de grond gekregen. In 1936 zouden er al meer dan 550 zijn opgericht (Juch, 1997: 277). Deze verenigingen waren vooral bedoeld voor minvermogenden die zelf de lasten van de steeds populairder wordende ziekenhuisbehandeling nict konden dragen. De betaling en de totsitandkoming van tarieven waren weinig uniform. Soms werd, zoals in de noordelijke provincies, een vergoeding per verrichting vastgesteld in onderhandelingen tussen de provinciale specialistenvereniging, de provinciale federatic van werenigingen van ziekenhuisverpleging, en de provinciale vereniging van gemeenten. 18 Met de komst van de ziekenhuisverplegingsverenigingen verbeterde de betaling wan de medisch specialisten in ziekenhuizen enigzins, omdat de medische handelingen eindelik financieel gewaardeerd werden. Overigens was deze verbetering geheel afhankelijk van de plaatselijk bepaalde verhouding tussen de verenigingen en de lokale specialistenverenigingen (Juch, 1997: 292). Een andere nielwe, zij het een nog niet omvangrijke verandering was de opkomst van landelijke (collectieve) ziektekostenverzekeringen. Onderhandelingen over de tarieven voor de hulp die onder deze nieuwe vorm van ziektekostenverzekering viel, werden gevoerd door de Specialistenorganisatie, een onderdeel van de NMG. In deze onderhandelingen viel echter niet veel te bereiken (Juch, 1997: 229-231).

Ondanks de ontwikkeling van andere financiële bronnen bleef bij de medisch specialist, evenals bij andere artsen, de particulier betalende patient zeer in trek. De particuliere inkomsten moesten de financiele ongemakken van de behandeling van niet-particuliere patiënten compenseren. Owereenkomstig de al langer bestaande activiteiten van plaatselijke artsenorganisaties stellen lokale specialistenverenigingen lijsten met particuliere tarieven op die hoger werden naarmate de patiënt meer verdiende. De lijsten waren niet verplichtend. Slechts een afwijking naar beneden was reden tot zorg omdat dit oneerlijke concurrentie veroorzaakte! Van enige centrale sturing door de Specialistenorganisatie was geen sprake. De vaststelling van de ziekenfondstarieven liet men al over aan de afdelingsbesturen, bemoeionis met de particuliere tarieven werd helemal als ongepast beschouwd. Slechts over de tarieven die betaald werden door de collectieve ziektekostenverzekeraars werd collectief onderhandeld (Juch, 1997: 290293).

De tariefvorming voor medisch specialisten tot aan de Tweede Wereldoorlog werd dus gekenmerkt door een grote heterogeniteit zowel bij de hulp voor ziekenfondspatiënten als bij de zorg voor particulier betalende patienten. Bovendien waren zij aangewezen op nog andere financioringsbronnen waarvoor weer andere regels golden. Deze heterogeniteit werd in de hand gewerkt door de grote mate van decentrale besluitworming waarin wel al vormen wan zelfregulering te herkennen zijn. Daamaast konden in de ziekenfondssector eerste aanzetten tot collectivisering worden geconstateard. Deze collectivisering zou zich na de oorlog voortzetten zoals in de volgende paragraaf zal blijken.

1720 sloot het gemeentebestur wan Utrecht met de particuliere ziekenhuzen een contract af warim werd bepaald dat stadspatienten voor 12.95 per dag werden behandeld en verpleegd. De behandelende artsen werden niet beloond, uitgezonderd de stafspecialisten (Juch, 1997: 279). 


\subsection{Tariefvorming in deze eeuw: het fundament (1945-1982)}

"O tempera, o mores! War gaan wij heen?"

Zijn wij nog frank, wij en onverveerd?

Of zin wij to slaven gedegenereend?"

Deze verzuchting moeten meer artsen hebben geslaakt in de jaren net na de Tweede Wereldoorlog. Het aantal ziekenfondsverzekerden was gegroeid tot 65 procent van de bevolking, en zij zagen medische hulp steeds meer als een sociaal recht in plaats van iets warvoor men zich had verzekerd. Het wrijwillige karakter van de ziekenfondsverzekering was werdwenen ondat het in de oorlog ingevoerde Ziekenfondsenbeshit (1941) verzekering bij een ziekenfonds opgelegd had aan een groot deel van de Nederlandse bevolking. Het besluit verplichtte werknemers die in het kader van de Ziektewet verzekerd waren en inkomsten hadden beneden een bepaalde loongrens, premic te betalen voor een ziekenfondsverzekering. Het Ziekenfondsenbeshuit behelste verder een aanzienljke uitbreiding van het verstrekkingenpakket dat in het vervolg door de overheid zou worden vastgesteld. "Tevens werden de ziekenfondsen onder staatstoezicht geplaatst. Het staatstoezicht zou vanaf 1949 worden uitgevoerd door de Ziekenfondsraad. In de Ziekenfondsraad hadden ambtelijke deskundigen, ziekenfondsen, medewerkers, werkmemers en werkgevers zitting.

Hoewel men over het algemeen het Ziekenfondsenbesluit het begin laat zijn van het sociale ziektekostenverzekeringssysteem in Nederland, dient toch het belang van het besluit nader onschreven te worden. Reeds eerder gaf ik aan dat Japenga en Van der Velden meenden dat er veel owereenkomsten waren tussen de groep mensen die vanaf 1941 verplicht verzekerd was en de groep mensen die reeds vóór 1941 vrijwillig verzekerd was. Ook Van der Hoeven en Van der Hoeven geven aan dat de groei van het aantal verplicht verzekerden niet opzienbarend was. Tussen 1941 en 1943 was er een groei van 15 procent (1993: 142). Een verdere relativering geeft Godefroi. Het besluit betekende volgens hem wel een aanmerkelijke uitbreiding van het verstrekkingenpakket, maar voor de invoering waren reeds 3,5 miljoen mensen vrijwillig verzekerd tegen zickenhuisverpleging (1963: 68). In deze zin codificeerde het Ziekenfondsenbeslut slechts een aantal ontwikkelingen in de dekking van de bevalking door vrijwillige ziektekostenverzekeringen. Het grote belang wan het besluit lag vooral elders. Ten eerste kwam met het Ziekenfondsenbesluit een uniforme structuur van premies, verstrekkingenpakketten en. betalingen voor de ziekenfondssector tot stand. Tarieven voor de ziekenfondssector zouden voortaan landelijk worden vastgesteld. Ten tweede legde het Ziekenfondsenbesluit bestuurlijke verhoudingen voor de komende periode vast. Niet langer waren ziekenfondsen organisaties dic wanuit eigen visies fondsbeleid ontwikkelden, maar onderdelen wan een systeem die met name veran woordelijk waren voor de uitwoering van sen wettelijke ziektekostenverzekering.

In de jaren na de Tweede Wereldoorlog kwam een interdependent gezondheidszorgsysteem tot stand. De ontwikkeling van het sociale ziektekostenverzekeringsstelsel in samenhang met de weranderingen in de medische beroepsgroep en de ziekentiondsen bepaalde de verhoudingen tussen de betrokkenen in zeer sterke mate. De situatie in de jaren vijftig was onvergelijkbaur met die in de eerste decennia van deze eeuw. De betaling van medische beroepsbeoefenaren was meer dan ooit georganiseerd en gereguleerd wardoor een actic van de eün onherroepelijk een reactie wan een ander opriep. In het nieuwjarscommentaar van 1955 schetste Heringa, de hoofdredacteur van Medisch Contact, de veranderde omstandigheden heel treffend (1955: 2).

19. Een gedeelte van een ingezonden brief in Medisch Contact (nr. 2, 1946) van een arts die klaggde over het honorarium per ziekenfondspatiënt dat op dat moment maximaal $f 3$, per jaar bedroeg. 
"Wat 100 jaar geleden nog ruige praine was, war voor iedere mithiefnemer op hel gebied van medische organisatie plaats te over was en ieder mitiatief dus eo ipso goede kams had, is thans intensief bebouwd akkerland. Voor sethers is geen plaats meer.....W Welk een mogelijkheden van conflcten, welk een dagelijks wisselende. problematiek; bovenal, welk een ingripende wijziging moet er zijn ontstan in bestaansideologie. Vergelijk eens die van een setter-generatie en die wan de bewoners wan het dich bevolkte akkerland!"

In dit landschap met afgebakende percelen moest de LSV met de verenigingen van ziekenfondsen overeenkomsten sluiten om een uniforme honorering tol stand te brengen. De zelfregulering die al eerder worm begon te krijgen werd formeel bekrachtigd. Zowel het overleg over de homorering wan medisch specialisten als de beoordeling van de resultaten darvan was de verantwoordelijkheid van ziekenfondsen en medisch specialisten zelf. De onderhandelingen vonden plats tussen de Landelijke Specialisten Vereniging en het Gemeenschappelijk Overleg van Ziekenfondsorganisaties (GOZ), dat verschillende ziekenfondsorganisaties herbergde, en later de Vereniging van Nederlandse Ziekenfondsen (VNZ). Het ging daarbij on jaarlijkse afspraken die vertaald werden in het zogenaamde Tariefboekje met daarin omschrijvingen van verrichtingen en bijbehorende tarieven dat door individuele specialisten en ziekenfondsen bij de afhandeling van declaraties gebruikt kon worden. Het toezicht op de onderhandelingsovereenkomsten werd uitgevoerd door een commissie van de Ziekenfondsraad waar de onderhandelende partijen zelf in vertegenwoordigd waren. Deze overeenkomsten zouden al ras leiden tot alomvattende honoreringsafspraken over zo'n tweeduizend verrichtingen $(1.961){ }^{20}$

Het tot stwid brengen van tariefafspraken was echter in de eerste jaren na de oorlog geen eenvoudige zaak vanwege het strenge beleid van prijsbeheersing dat door de overheid in het kader vande te topbouw werd gevoerd. Bovendien was de LSV niet bereid de honorering wan specialisten blijvend te laten verlopen via het vooroorlogse systeem wan de specialistenpot. De LSV wide daarentegen een honorering per verrichtingseenheid, hetgeen betekende dat de betaling an specialisten in de ziekenfondssector door openeindfinanciering gekenmerkt zou gaan worden (Van Nieuwenhuizen, 1971: 1202-1203). Bij de totstandkoming van de eerste overeenkomsten, die uiteindeljk een verrichtingentarief als uitgangspunt zouden hebben watrvoor de LSV in ruil bereid was tot afspraken over forse tariefkortingen, liepen de meningen van de beide partijen dus vaak sterk uiteen, hetgeen leidde tot een situatie in hei begin van de jaren vijftig die - toen ook al - het 'specialistenconflict' werd genoemd (Jaarverslag van de Secretaris der Landelijke Specialisten Vereniging over het verenigingsjaar 1952, 1953, Companje 1997: 379-381). Eén van de langdurige geschilpunten met de ziekenfondsen was een progressiewe korting op inkomsten boven $\mathrm{f} 10.000^{-}$- per jaar.

De overeenkomsten die noodgedwongen een compromiskarakter hadden lokten protesten van individuele medisch specialisten uit. De eerste tariefbesprekingen na de Tweede Wereldoorlog werden gevolgd door het opzeggen van het lidmaatschap van de NMG, omdat de in 1946 opgerichte LSV de belangen niet goed zou hebben behartigd (Festen, 1974: 526). Daamaast moest de LSV de onderhandelingspositie verdedigen tegenover de wetenschappelijke verenigungen die elk specialisme vertegenwoordigden. Een andere bron van conflict binnen de groep van medisch specialisten was de onwil van plaatselijke verenigingen een landelijk tarief te anvaarden. Zo was er sprake van een wens van een "Fries honorarium voor Friese specialisten" (Var Nieuwenhuizen, $1971: 1205$ ).

20. Sommige bekritiseerden de beschrijwing wan duizenden verrichtingen en hun tarieven omdat "...in deze nawwgezette honorering een stuk knidemiersgeest wastgelegd (ligt), die het officium nobile onwaandig is." (Heijermans, 1961: 435) 
De besluitworming over de progressieve korting veroorzalkte veel spaningen tussen de medisch specialisten en de ziekenfondsen, maar is tewens illustratief woor de vertindering wath klimaat. In 1954 werd in de onderhandelingen overeengekomen dat de progressieve korting zou. vervallen en worden vervangen door een drie-tarievenstelsel waabij de eerste korting pas zou optreden als de inkomsten boven f $22500,-$ lagen. In de onderhandelingen die in 1955 plaats vonden slaagden de medisch specialisten er in ook dit stelsel te laten vervallen (Jaarverslagen van de Secretaris van de Landelijke Specialisten Vereniging). Onder invloed van de langzaam verbeterende economische omstandigheden trad in de tweede helft van de jaren vifftig een rust in watrin noch de hoogte van de tarieven noch de betalingswijze van medisch specialisten ter discussie stonden. Ook de gelederen der medisch specialisten sloten zich weer. Hoewel de onderhandelingen soms niet naar tevredenheid verliepen, was de verhouding tussen de ziekenfondsen en medisch specialisten weinig conflictueus. Overeenstemming over aanpassing, verhoging en veruiming van het aantal tarieven werd vrijwel jaarlijks bereikt. De onderhandelingen resulteerden in forse verhogingen wan de tarieven voor medisch specialisten. Een belangrijke oorzak van deze forse aanpassingen was het in de jaren zestig gehanteerde systematiek van trendmatige aanpassingen. Het tarief volgde de loon- en prijsontwikkeling in de andere economische sectoren. Maar de jaarlijkse aampassingen lagen wel beduidend hoger dan de groei van het algemene prijsniveau, zoals tabel 3.2 laat zien.

In deze periode van economische groei was het niet de taak wan de ziekenfondsen de stijging van de uitgaven voor gezondheidszorg kritisch te beoordelen. Integendeel, zo stelde Anbeek, onder andere penningmeester van de Centrale Bond van Onderlinge Ziekenfondsen (de opvolger van de Landelijke Federatie):

"Als er een niewwe ontwikkeling in de medische verzorging mogelik wordt, die aan de bij de ziekenfondsen ingeschreven verzekerden betere of langere lewenskansen geeft, zin wij als beharigers van de belangen van de verzekerden verplicht deze ontwikkeling zo snel mogelijk onder het bereik van hen allen te brengen." (1965: 294)

Dit gold ook voor het toentertijd nieuwe specialisme revalidatie. De ontwikkeling van een dergelijk specialisme viel toe te juichen omdat "...(z)ij door verder gespecialiseerde medici wordt gegeven, praktisch zeker van een hogere orde (zal) zijn dan voorheen." (1965: 296). Maar bij de honoreringsonderhandelingen konden problemen ontstaan. Echter niet ondat meer betaald zou moeten worden voor handelingen van nieuwe - en dus extra - specialisten, maar omdat niet duidelijk was hoeveel meer betaald moest worden (1965:296).

In formeel juridische zin had de overheid de mogelijkheid on overeenkomsten tussen de ziekenfondsen en de medisch specialisten nietig te verklaren, ook all had de Ziekenfondsraad en zijn goedkeuring reeds aan gegeven. Een enkele keer heeft de owerheid van deze bevoegdheid gebruik gemaakt, ondat de tariefontwikkeling op gespannen voet dreigde te komen stan mot hot prijs- en loombeleid. Zo vroeg de minister van Volksgezondheid en Sociale Zaken aan de LSW om de tariefsverhoging voor 1960 (7 procent) in twee stappen uit te voeren. Ook schorste dezelfde minister dat deel van de overeenkomst voor 1964 warin sprake was dat de jaarlijkse afspraak tussen ziekenfondsen en artsen tussentijds opengebroken kon worden als andere lonen harder stegen dan verwacht (Jaarverslagen van de Secretaris van de LSV over 1959 en 1964). Deze ingreep liep evenwel met een sisser af. In het algemeen gold dat het proces wan onderhandelen in de jaren zestig vrij autonoom verliep, zonder staatsinterventie. 
Tabel 3.2: Procentuele generieke verhogingen van ziekenfondstariever voor medisch specialisten 1960-1970 afgezet tegen de groei van indexcifers

\begin{tabular}{c|cc} 
& $\begin{array}{c}\text { jarlikse groei indexcjifers in } \\
\text { procenten }\end{array}$ & $\begin{array}{c}\text { generieke werhogingen } \\
\text { ziekenfondstarieven in procenten }\end{array}$ \\
\hline 1960 & 2,5 & 7 \\
1961 & 1,7 & - \\
1962 & 3,3 & 7,5 \\
1963 & 3,9 & 5 \\
1964 & 6,1 & 8,8 \\
1965 & 5,0 & 6,3 \\
1966 & 6,1 & 12 \\
1967 & 3,2 & 8 \\
1968 & 3,7 & $10,5^{*}$ \\
1969 & 7,2 & $13,7^{*}$ \\
1970 & 4,5 & $17^{*}$ \\
\hline
\end{tabular}

* Deze werhoging bestond uit een algemene trendmatige werhoging plus een reservering voot een collectieve ouderdagsvoorziening bij de Stichting Pensioenfonds Medische Specialisten (ongeveer 7 procent).

Bron: CBS, Jaarverslagen van de secretaris van de LSV over de jaren 1960-1970

De particuliere tarieven kwamen op een andere mamier tot stand dan de ziekenfondstarieven. Deze werden plaatselijk vastgesteld door de lokale specialistenverenigingen, maar waren niet bindend. ${ }^{21}$ Tariefdifferentiatie bleef ook na de Tweede Wereldoorlog dominant in de particuliere sector. Nog steeds stelde de specialist het honorarium naar draagkracht van de patiënt vast (Heijermans, 1961: 435). Het verschil met de vroegere situatie was dat de verplegingsklasse in plaats van het inkomen van de patiënt de maatstaf voor de hoogte van het tarief werd (Godefroi, 1963: 123). Veelzeggend is tabel 3.3.

Er waren wel initiatieven tot tariefafspraken tussen verzekeringsmaatschappijen en de NMG, maar dit stuitte op verzet van de artsenorganisatie. Om bindende tariefafspraken te maken, zouden contracten tussen verzekeringsmaatschappijen en medisch specialisten moeten worden afgesloten.

2120 advigeerde in 1964 de Amsterdanusche Specialisten Vereeniging de Jeden om de minimum tarieven voor nietziekenfonds-patiènten te werhogen met 20 procent. Dit was ook de minisier var Economische Zaken en de staatssecretaris van Sociale Zaken en Volksgezondheid te gortig in het kader van prijsbeheersing. In een gesprek beloofde de Vereeniging de leden te adviseren de larieven slechts net 10 procent te verhogen (Medisch Contact, 1964: 106). Maar veel meer dan adviseren konden de plaatselijke verenigingen ook niet. 
Tabet 3.3: Ziekenfonds-en particuliche tariewen woo ten bindedam operane in Ansterdam in 1962

\begin{tabular}{|c|c|c|c|}
\hline & $\begin{array}{c}\text { Iste-klasse particulier } \\
\text { tarief }\end{array}$ & $\begin{array}{c}\text { 3de-klasse particulier } \\
\text { tarief }\end{array}$ & $\begin{array}{c}\text { ziekenfonds } \\
\text { tarief }\end{array}$ \\
\hline $\begin{array}{c}\text { tarief blindedarm } \\
\text { operatie in Amster- } \\
\text { dam in 1962 }\end{array}$ & minimaal 700 gld. & $175-300$ gld. & 50 gld. \\
\hline
\end{tabular}

Bron: Godefroi $(1963: 123-126)$

"Het likt ons zeer waarschimlijk dat men, indien deze weg wondt gekozen. witeindelik zal moeten komen tot onderhandelingen met deze verzekeringsmatuschappijen, warbij de financiele relatie tussen arts en patient verloren gaat, waarbij tariefverschillen zullen moeten worden gemivelleerd en warbij het witermate woeilik zal zijn klasseverschillen te handhaven." (Commissie-Ziektekostenvoorziening boven de loongrens, 1957: 366)

In plaats van bindende tariefafspraken zag de NMG liever dat de specialist enigzins voorzichtig zijn tarief bepaalde, en zich hield aan de tarieven die plaatselijk gebruikelijk waren omdat

"...(h)et wan hun werkwije het hetgemeen zal afhangen of deze loestand. waarbij de juiste yerhouding tussen arts en pariënt kan worden bestendigd, kan worden gehandhaafd " (Commissie-Ziektekosten-voorziening boven de loongrens, 1957: $367)$.

Kortom, het werd overgelaten aan de individuele medisch specialist om zich enigzins lerughoudend op te stellen bij het opmaken wan zijn rekening, teneinde patienten en verzekeringsmaatschappijen niet tegen zich in het harmas te jagen.

Uit het citaat van de Commissie-Ziektekosten-voorziening boven de loongrens blijkt overigens wederom, dat de relatie met ziekenfondsen door de georganiseerde medische professie slechts gedoogd werd. Het ziekenfonds was een indringer in de relatie tussen arts en patiënt waarin idealiter alles onderling besloten diende te worden, van behandelplan tot betaling. In tegenstelling tot de opgelegde relatie met de ziekenfondspatiënt was de particuliere relatie de meest optimale voor de uitoefening van de geneeskunst. Dit leidde er toe dat veel artsen particulier betalende patiënten cen voorkeursbehandeling gaven. Huisartsen hielden gescheiden sprekkuren voor beide 'soorten' patiënten en in grote ziekenhuizen werden ziekenfondswerzekerden vaak behandeld door assistenten-specialisten in opleiding in plats van de specialist zelf (Van der Burg, 1966: 305). Deze discriminatie zou tot in de jaren zeventig voortduren (Van Mansvelt, 1974: 305).22 Dat in de particuliere sector tariefdiscriminatie bleef bestatin was cen anachronisme; de noodzaak woor artsen on rijken meer in rekening te brengen dan minder welgestelden on iedereen medische hulp te kunnen bieden was immers met de verplichte socialle zikktekostenverzekering grotendeels verdwenen. Bovendien was door de ontwikkeling van sociale verzekeringen geen sprake meer van armoede. ${ }^{23}$

22 De 'extit-functie van de particuhere sector heeft nog lang een rol gespeeld bij de onderhandelingen over tarieven voor medisch specialisten. Zo bereikten KLOZ en LSV pas in de jaren tachtig overenstemming over het afschaffen van de zogenaamde inleiding in het tariefboek van de particuliere tarieven. In de inleiding stond namelijk dat medisch specialisten het recht hadden naar eigen inzicht binnen een bepaalde bandbreedte af te wijken van het officiêle COrG-tarief.

23 Het voortbestaan van het systeem van taricidiscriminatie na de Tweede Wereldoorlog kan overigens alleen als een anachronisme worden bestempeld als men enige waarde hecht aan de door 
Een verandering van de vrijheid var de individuele medisch specialist om particuliere tarieven vast te stellen wond plats toen de LSV besloot richtlijnen op te stellen. All langer was men binnen de LSV bezig met het beteugelen van de wildgroei van particuliere tarieven. Dit beleid van tariefromalisatiw, zoals het werd genoemd, zou tot stand gebracht kumen worden door het opstellen van nationale richtijnen. Als redenen voerde de LSV op het ontbreken van enig inzicht bij de meeste van de medisch specialisten in de opbow van de tarieven, de ontwikkeling van eigen tarieflisten door platselijke specialisten veremigingen, de klachten over te hoge declaraties die zelfs leidden tot vragen in de. Tweede Kamer, maar ook het bewaren van de eenheid binnen de eigen groepering (Van Giffen, 1965). Met name de wens wanuit de maatschappij de totstandkoming van particuliere iarieven meer controleerbaar te maken, speelde een grote roll in de officiele overwegingen van de LSV. In 1969 werden de richtlijnen ingevoerd, met de bedoeling eerst een jaar te experimenteren. De bindende werking van de richtlinen was overigens beperkt. Ten eerste bestond er een zekere bandbreedte waarbinnen de specialist kon afwijken van de richtlijn (de zogenaamde 'pendel'), en ten tweede liet de definitie van het begrip richtlijn veel vrijheid aan de medisch specialist. Een richtlijn betekende namelijk voor een specialist

"...(d)at de wetenschappelijke groepering, waurtoe hij behoort zich als geheel beraden heefi over her honorarium dat voor een doorsneegeval als redelijk kan worden beschoumd. De specialist bliff daarbij wrij om zich buiten een richtijn te begewen (..) maar wij zal zich wel rekenschap moeten geven waarom hij dit doet en daarbij bereid moeten zijn on daarover aan de patient (of degene die geacht wordt namens deze op te treden) een gemotweerde witleg te geven."

Uit deze definitie vloeide voort dat

"...(d) individuele special ist uiteindelik zijn honorarium witmaakt, zij het dat dit aan

de algemene vereisten van redelijkheid en billikheid zal moeten voldoen."

(Jaarverslag 1968 van de secretaris der Landelike Specialisten Vereniging: 433)

Een belangrijk aspect wan de richtlinen was de zogenaamde vermenigvuldigingsfactor (klassemultiplicator). Deze factor bepaalde in welke verhouding de tarieven per verpleegklasse tot el.kar stonden. De factor werd door de LSV in 1970 veranderd van $1=2.3$ voor de klassen 3 , $2 b$ en $2 a$ in 1-1,5-2. Volgens de richtlijnen van 1970 mocht een medisch specialist aan een patiënt in de hoogste verpleegklasse clus 2 maal zoveel vragen als aan een patiènt in klasse 3 . Volgens Anbeek, voorzitter van de CBOZ, was de particuliere norm voor een patiënt opgenomen in de derde klasse 3 maal het ziekenfondstarief (1969: 1243). Dit zou dus betekenen dat in 1970 een particuliere patiënt, verpleegd in de hoogste klasse, zes keer zoveel inkomsten opbracht als een ziekenfondspatient. Hierbij was nog geen rekening gehouden met de pendel. Deze bedroeg 25 procent voor een patient in de derde klasse.

De bepaling van de particuliere tarieven bleef dus grotendeels in handen van de medisch specialisten zelf. Wel kwam overleg tot stand tussen de LSV en de zich georganiseerde particuw liere verzekeraars (Kontaktorgaan Landelijke Organisaties van Ziektekostenverzekeraars, KLOZ). Zij onderhandelden niet over tarieven, maar allerlei tariefzaken werden op regelmatige basis besproken.

Naast de particuliere verzekeraars begon ook de overheid oog te krijgen voor de besluitvorming over de tarieven voor artsen. In het begin van de jaren zeventig kregen de over tarieven onderhandelende partien in toenemende mate te maken met het loon-en prijsbeleid van de Nederlandse overheid. Een algemene prijzenstop was reeds ingevoerd en de minister van

de medische stand gegeven rechtwatdiging. Als men echter uitgaat van de winst-maximaliserende arts dan is het niet meer dan logisch dat een arts gebruik maakte van de wrijheid om hoge tarieven te vragen. 
Economische Zaken drong ook bij de onderhandelaars aan op matiging. De vrijblivendheid die karakteristiek was voor de jaren zestig, kon niet blyven bestaan. In 1970 werd zelfs een prijzenbeschikking medische hulp aan panticulieren afgekondigd. In het daaropvolgende overleg werden de minister en de LSV het eens over een algemene tariefverhoging van 8 procent (Jaarverslag over het jaar 1970 van de secretaris der LSV: 340). In de jaren daarop toonde de LSV zich bereid de groei van de particuliere tarieven te beperken. ${ }^{24}$

De ontwikkelingen na de oorlog hielden een tweede fase in in het verlies van de financiele autonomie van de artsen. De opkomst wan de ziekenfondsen woor de Tweede Wereldoorlog die leidde tot contracten tussen artsen en ziekenfondsen - de eerste fase - werd gevolgd door de verplichting om op centraal niveau te onderhandelen over tarieven. Met deze institutionalisering van nationale onderhandelingen tussen vertegenwoordigende organisaties nan Nederland intemationaal geen uitzonderlijke positie in. Elk land met een verplichte ziekenfondswerzekering ontwikkelde een onderhandelingssysteem voor overleg tussen asmbieders en kopers (Glaser, 1989a: 129). Wel bleef in Nederland de besluitvoming over tarieven tot de jaren zeventig gevrijwaard van overheidsingrijpen. De bepaling van tarieven was een zaak van de gezondheidszorg zelf.

Hoewel de ziekenfondsen als onderhandelingspartner in principe de groei van tarieven en de expansie van het verrichtingenstelsel hadden kunnen beperken, lukte dit niet (zie tabel 3.2). De sociaal-economische situatie liet een zodanige groei van zowel de waag als het aanbod van gezondheidszorg toe, dat geen grenzen gesteld werden aan de onderhandellingsrumte voor de tariefonderhandelaars op centraal niveau. Integendeel, de ziekenfondsen konden - en wilden hun "countervailing power' niet waarmaken, met name omdat zij hun werzekerden een uitbreiding van voorzieningen niet konden onthouden. Of zoals de arts Van der Wielen het verwoordde:

"Het voor een groot deel bestan wan de inkomsten wit de ziekenfondspraktijk zou cen imperatieve economische factor zijn, die de sterke positie van de medewerkers kon aantasten, indien de vraag naar geneeskundige zorg, ondanks onderhandelingsstrubbelingen, niet onverminderd doorging en de ziekenfondsen zich niet tegenower de verzekerden hadden verbonden die zorg te verstrekken."(1963: 17)

Gevolg was dat de ziekenfondstarieven moesten worden verhoogd. Het gevolg hiervan was weer dat de aloude functie van de betaling door ziekenfondspatiënten als slechts een financiele aanvulling op de particuliere inkomsten langzamerhand verdween (Van der Wielen, 1963: 16), Ook kon door het verhogen van de ziekenfondstarieven tegemoet worden gekomen aan de bezwaren van de georganiseerde specialisten tegen het voortdurend werhogen van de loongrens voor ziekenfondsverzekerden.

Terwijl hij kon profiteren van verhoogde ziekenfondstarieven bleef de medisch specialist in stat om particuliere tarieven zelfstandig vast te stellen. Godefroi conchdeen dan ook:

"Wameer wij de ma-oorlogse shuatie overien, dan blijk dat de artsen erin zin geslangd de voordelen van een wniform tarief op een bijzonder gelukkige wije te combineren met die wan een gedifferentieerd tarief. Foor de kleine middensiond en de arbeidersbevolking (de ziekenfondspopulatie, hl) geldi een eenheidstarief dat thans over het algemeen genomen op een redelijk niveau ligt. Foor de meer welgestelden is het beproefde systeem van prijsdiscriminatie gehandhaafd. Deze word dus juist daar toegepast, wat het af te romen consumentensurplus het grootst is. "(1963: 127.128)

24 Deze beperking betekende dat in de ewrste jaren van de jaren zeventig de tarieven voor particuliere patienten met ongeveer 7 procent stegen, terwijl de ziekenfondstarieven met meer dan 15 procent stegen (Jaarverslagen van de secretaris der LSV over $1970-1975$ ). 
Het particulier tarief bood de medisch specialist economische vrijheid die in toenemende mate bedreigd werd door de opkomst van de ziekenfondsen, contracten en unifome, dwingende tariefafspraken. De woorden van Immergut (1992:36) gebrukend, zou men kunen stellen dat. de Nederlandse artsen de mogelijkheid bleven houden de publieke sector te verlaten ("...to exit from the public sector."). Ook voor Nederland dient de conclusie te zijn, dat het verlies van de funanciêle autonomie door de ontwikkeling van een sociaal zicktekostenverzekeringsstelsel voor de arts te verteren was omdat de gevolgen hiervan gemodificeerd werden door de voordelen van de particuliere sector.

\subsection{Tariefvorming in deze eeuw: de politisering (vanaf 1982)}

\subsubsection{Het herontwerp van structuren: de invoering van de Wtg}

In de jaren zeventig overheersten in de Westerse geindustrialiseerde landen wat Offe het herontwerpen van politieke structuren noemit (1985: 226). In plaats van inhoudelijke probleemoplossing (conjunctural policies) richtten overheden zich op het herontwerpen van politieke structuren voor probleemoplossing, als een reactie op economische en institutionele problemen (structural policies). Het algenene kenmerk van structureel beleid is

"...(t)o establish institutional parameters (...) that guarantee that the problems that have to be dealt with do not exceed te scope of the available resources and strategies of problem solving." (1985:225).

De Nederlandse gezondheidszorg kreeg ook te maken met structureel beleid. Er kwam een uitgebreide planningswetgeving van de grond, met de nadruk op procedures van beshitvorming en competentieverdelingen, en ook werden de besprekingen tussen de organisaties van medisch specialisten en ziekenfondsen over tarieven gereorganiseerd. De invoering van de Wet tarieven gezondheidszorg (Wtg) in 1982 betekende een nadere specificering van de regels die gehanteerd moesten worden bij de bepaling van tarieven woor medisch specialisten. Niet alleen moesten tarieven meer uniform worden, ook zou een uitgebreid stelsel van richtlijnen moeten worden ontwikkeld. Dat het in het geval wan de medisch specialisten volstrekt onduidelijk was waarop de afspraken met de ziekenfondsen gebaseerd waren, zoals de commissie Becht in 1976 constateerde, was een doorn in het oog van de overheid. Een nieuw Centraal Orgaan Tarieven Gezondheidszorg (COTG) kreeg de taak om tariefvoorstellen van de onderhandelaars te beoordelen en een stelsel van richtijnen te ontwikkelen. De rol van de Ziekenfondsraad was hiermee witgespeeld. Bovendien sprak de Wtg van meer 'coördinatie". Dat was immers de Haarlemmer olie voor de Nederlandse gezondheidszorg sinds de probleemschets in de Structurnota van 1974. Meer coordinatie betekende voor de onderhandelingen over tarieven, dat deze niet meer het exclusieve domein van de ziekenfondsen en medisch specialisten vormden. De particuliere zitektekostenverzekeraars en verzekeraars voor ambtenaren werden de nieuwe onderhandelingspartners. Bovendien kreeg de overheid meer mogelijkheden tot interventie door middel van her geven van aawijzingen aan het COTG ten aanzien van de ontwikkeling van richtlijnen voor tarioven. Fenslotte creecerden de wetmakers de mogelijkheid van beroep tegen beslissingen van het COTG. Het College van Beroep voor het Bedrijfsleven (CBB) was daarvoor de geschikte instantie.

De invoering van de Wtg leek te leiden tot een verdere aantasting van de positie van de medisch specialist in de onderhandelingsarena. De reactie van de medische professie op de Wig was afwijzend. In twee memoranda makte de $\mathrm{KNMG}$ in samenspraak met tandartsen en apothekers de bezwaren duidelijk. Er had te weinig wooroverleg plaatsgevonden, er zou een inkomensbeleid in de gezondheidszorg geintroduceerd worden, het beproefde systeem van onderhandelen zou vervangen worden door een door de overheid bepaalde centrale tariefpolitiek 
en de beroepsmogelijkheden waren onvoldoende. Ook na de door statssecretaris Veder-Snit ingelaste inspraakronde bleven de artsen ontevreden. Nog steeds jjverde men voor goede beroepsmogelijkheden voor aanwijzingen en richtlinen en meer rechtszekerheid (KNMGMemorandum 1977; "Beroepsorganisaties handhaven...' 1980), De artsen maakten zich ook zorgen over de samensteling van het COTG. In het bestur van het COTG mochten volgens de Wig geen personen plaats nemen die direct belang hadden bij de onderhandelingen over tarieven. In de Centrale Raad voor de Volksgezondheld pleitte onder meer de KNMG voor directe vertegenwoordiging van aanbieders en financiers in het COTG ondat "...(v)ertegenwoordiging in de zin wan het dragen wan medeverantwoordeljkheid wan degenen die diensten verlenen en van de financiers wezenlijk is voor de maatschappelijke filosofie, die in Nederland wordt gehuldigd" (geciteerd in: Lapré, 1982: 851).25 Maar de maatschappelijke filosohe waar de KNMG naar verwees, was inmiddels verdrongen door een ander beleidsparadigma. De 'maakbaarheid' van de samenleving stond voorop. De politiek moest daarin het voortou nemen, en ook de taineven voor medisch specialisten werden onderdeel van wat men het publieke domein noemt (Schmabel 1988).

\subsubsection{De Wtg}

Sinds 1982 gelden dus de procedures van de Wtg. In de Wtg wordt een tarief omschreven als een prijs voor een prestatie of geheel van prestaties, door een orgaan voor gezondheidszorg geleverd. Met orgaan word hier zowel een instelling als een individuele beroepsbeoefenaar bedoeld. In de praktijk komt het er voor medisch specialisten in het algemeen op neer, dat het tarief het bedrag is dat zij bij ziekenfondsen dan wel particulier verzekerde patienten kunnen declareren voor hun activiteiten. Elke specialist krijgt daartoe een uitgebreid boekwerk (tarieflijst) toegestuurd met daarin vermeld het maximaal te declareren tarief per verrichting, Voor verrichtingen die bij ziekenfondsen in rekening gebracht kumnen worden golden tot 1997 veel lagere tarieven dan voor dezelfde verrichtingen bij particulier verzekerde patienten. Er bestonden dus verschillende tarieflijsten.

In technische zin bestaan tarieven woor medisch specialisten ül twee componenten. $26 \mathrm{Men}$ spreekt van een inkomenscomponent en een kostencomponent. Tarieven bestaan dus voor een deel uit een vergoeding die als inkomen wordt bestempeld, en voor een deel wit een vergoeding voor de kosten die een specialist maakt. Onder kosten worden de kosten voor personeel, administratie, huisvesting etc verstaan. ${ }^{27}$ Het onderscheid tussen de inkomens- en kosten-

25 Overigens ging het eerste ontwerp Wet tarieven gezondheidszorg veel verder dan het definitieve wetsvoorstel wat betreft het weren van directe belangenbehartiging. De uiteindelijke constructic met zogenaamde Kamers warin bij de onderhandelingen over tarieven direct betrokkenen zitting hebben en adviseren over richtlinen, is een compromis tussen cen COTG bestaande uit alleen onafhankelijke deskundigen en een COTG bestaande uit direct belanghebbenden

26 In het algemeen wort een tariefformule gehanteerd die tit drie onderdelen bestaat: een vergoeding woor kosten, een inkomensbestanddeel, en een werkbelasting. Onder de werkbelasting moet het maximaal aantal te declareren eenheden werstan. De formule is: (kosten + inkomen) : werkbelasting.

27 In 1988 werden de volgende kostenposten onderscheiden huisvesting, algemene kosten (telefoon, verzekeringen, werkkleding), oriëntering (nascholing, congressen, literatuur, contribuhes), auministratiekosten (accountaniskosten, facturering), vervoer, interest, diversen en verslaggeving en praktijkorganisatie (personeel en overhead). Brief van het COTG aan de Statssecretaris wan Welzin, Volksgezondheid en Cultum (richtlijnen kostenvergoeding medisch specialisten (ziekenfonds en particuliet), 29 juni 1988 
component was vooral van belang toen de overheid streefde zowel naar cen beheerste onwikkeling van inkomens van medisch specialisten als naar een beperking van de vergoedingen voor praktijkkosten. Voor beide doelstellingen bestonden verschillende besiutvormingsprocedures. Dil zal later nog aan de orde komen.

De structuar van de Wtg laat zich meer precies beschrijyen aan de hand van drie. elementen: de onderhandelingen tussen representatieve organisaties, de goedkeuring van het resultaat wan deze onderhandelingen en de ontwikkeling van criteria om dat resultaat te kunnen. beoordelen. Zoals De Groot en Daalder aangeven, gaat het hier om verschillende elementen die in een aangepaste vorm werden overgenomen uit de systemen van tariefvoming die tot 1982 geldend waren (1985: 15-16). Daarnaast zal hier aandacht geschonken worden aan de beroepsmogeljkheden die de Wtg biedt.

\section{Onderhandelingen}

De Wtg biedt de verzekeraars van ziektekosten (ziekenfondsen, particuliere ziektekostenverzekeraars en publiekrechtelijke ziektekostenverzekeraars) de mogelijkheid met medisch specialisten tariefovereenkomsten af te sluiten. Dit kan zowel op individuele basis, met individuele specialisten, als op collectieve basis met zogenaamde representatieve organisaties. Deze tariefovereenkomsten komen tot stand na onderhandelingen. In het kader van de Wtg zijn representatieve organisaties aangewezen. ${ }^{28}$ Voor de sector wan de medisch specialisten waren dat in de periode 1986-1992:

1. de Landelijke Specialisten Vereniging (LSV)

2. de Vereniging van Nederlandse Ziekenfondsen (na 1992: Vereniging van Nederlandse Zorgverzekeraars) (VNZ)

3. het Kontaktorgaan Landelike Organisaties van Ziektekostenverzekeraars (KLOZ)

4. de Kontaktkommissie Publiekrechtelijke Ziektekostenregelingen voor ambtenaren (KPZ)

\section{De goedkeuring}

De tariefovereenkomst tussen verzekeraar en specialist dient goedgekeurd te worden door het Centraal Orgaan Tarieven Gezondheidszorg (COTG). Daartoe dienen de partijen een voorstel in met het verzoek het tarief goed te keuren. Administratieftechnisch zijn zij ook verplicht aan te geven of zij willen dat het COTG en tarief vaststelt als het voorstel van partijen niet de goedkeuring kringt van het COTG. De onderhandelingen hoeven niet tot een overeenkomst te leiden. In dat geval bestaat de mogelijkheid dat één van de organisaties een éénzijdig verzoek tot vaststelling bij het COTG deponeert. Met ingang van 1 januari 1992 is het echter voor undividuele vrije beroepsbeoefenaren niet mear mogelijk om éenzijdig voorstellen te doen. Dit dient nu samen met een vorzekeraar te gebeuren. Het COTG kan ook ambtshalve een tarief vaststellen, nadat het een verzock tot vaststelling niet heeft goedgekeurd.

\section{De ontwikkeling van criteria: richtlijmen voor tarieven}

Het COTG beoordeelt de tariefvoorstellen aan de hand van richtlinen die het zelf ontwikkelt. Voordat zij rechtsgeldig zijn moet de Minister van Volksgezondheid, Welzin en Sport (VWS, voorthen Welzijn, Volksgezondheid en Cultur (WVC) deze richtijnen goedkeuren. Over de richthinen adviseren de Kamers aan het COTG. Naast het verstrekken wan advies ten aanzien van richllijnen, kunnen de Kamers zelf richtlijnen voorstellen. Advisering door de Kamers is voor het COTG noch verplicht noch bindend. De richtijnzaken met betrekking tot de tarieven ten aanzien van medisch specialistische hulp komen aan de orde in Kamer V.

Besluit representatieve organisaties Wet tarieven gezondheidszorg, 23 mei 1984, Staatscourant 129 
Een belangrijk element wan het wettelijk systeem, en mogelijke aanzet voor het COTG tot het ontwikkelen van richtlinen, is de bevoegdheid voor de owerheid om aamwizingen aan hot COTG te geven. Tot 1992 was sprake van twee soorten arawwjzingen. Aanwijzingen die gebaseerd waren op artikel 14 van de Wtg vereisten overleg tussen overheid en COTG. Aanwijzingen gebaseerd op artikel 15 van de Wtg vereisten overleg tusset overheid en de representatieve organisatie van beroepsbeoefenaren. Deze laatste aanwijingen betroffen namelijk de gevolgen van het vaststellen van een norminkomen voor individuele beroepsbeoefenaars. Overleg over inkomens vond in de jaren tachtig uitgebreid plats op grond van de toen geldende inkomenswetgeving. Het overleg tussen de overheid an de beroepsgroepen over inkomens werd geregeld in de Tijdelijke wet nomering inkomens vrije beroepsbeoefentars (Twn, 1981-1987) en Wet inkomens vrije beroepsbeoefenaren (Wivb, 1987-1992). De Wivb verving de Twn. Tot 1986 heeft de overtheid een intensief inkomensbeleid gevoerd, ook ten atnzien van de medisch specialisten. Tot die tijd was dan ook sprake van een gecombineend prijs-en inkomensbeleid. In het overleg over inkomens dienden de overheid en de beroepsgroepen tot afspraken te komen over de hoogte van het inkomen van een specialist. Dit niveau moest worden vertaald in tarieven. Men sprak dan ook over het overleg over inkomens als 'normatief voorportaal'. Met de wijziging van de Wtg op 1 januari 1992 is een aanwijzing op basis van artikel 15 niet meer mogelijk. Regulering wan de inkomens van medisch specialisten kan niet meer via de Wtg tot stand komen.

Een belangrijke basis voor de overheid voor de beoordeling van richtijnen en het geven van aanwijzingen vormt het Jaaroverzicht Zorg (JOZ, voorheen Financieel Overzicht Zorg, FOZ) en het Budgettair Kader Zorg waarin de uitgaven voor de totale gezondheidszorg, en de medisch specialistische hulp als onderdeel daarvan, een kaderstellend karakter hebben gekregen. Door niddel van het $J O Z$ wordt de financiele randvoorwaarden voor het beleid ten aanzien van de gezondheidszorg bekend gemakt.

\section{Beroepsmogelijkheid}

Naast de drie hierboven beschreven elementen van het wettelik systeem, te wetem onderhandelingen, goedkeuring en ontwikkeling van criteria, wordt de besluitvormingsstructuur van de tariefvorming woor medisch specialisten gekenmerkt door de mogelijkheid beroep aan te tekenen tegen beslissingen van het COTG. Deze mogelijkheid staat open voor zowel de representatieve organisaties als voor individuele beroepsbeoefenaren en verzekeraars. Tot 1 juli 1992 diende het beroep te worden ingesteld bij het College van Beroep voor het Bedrijfsleven (CBB). Momenteel is rechtstreeks beroep bij het CBB niet meer mogelijk in overeenstenming met de bepalingen van de Algemene Wet Bestuursrecht. Als individuele verzekeraars, beroepsbeoefenaren of hun representatieve organisaties menen in hun belang te zijn getroffen door een beslissing wan het $\mathrm{COTG}_{\text {, }}$ kunnen zil daartegen een bewaurschrift indienen bij het COTG zelf. Vervolgens is beroep bij het CBB alsnog mogelijk.

\subsubsection{De actoren}

Zoals in de vorige paragraaf duidelijk werd, heef de Wtg verscheidene personen en organisaties een taak toebedeeld bij de totstandkoming van tarieven voor medisch specialisten. In deze paragraa 1 worden $z i j$ kort toegelicht. $\mathbb{k}$ begin met de representatiewe organisaties waama het COTG, de overheid en het CBB aandacht krijgen.

De Landelijke Specialisten Vereniging (LSV) werd in 1946 opgericht en heeft sindsdien de: belangen van de medisch specialisten verdedigd. Het ledenbestand van de LSV onvatte zowel de arisen in dienstverband als de medisch specialisten die vrigevestigd waren, In de jaren tachtig 
sehatte men het aantal ledten op 8000 terwil de organisatiegraad meer dan 80 procent bedroeg (Commissie Modernisering curatieve zorg, 1994: 29).

Over de kenmerken van de beroepssituatie van medisch specialisten sinds de jaren tachtig zijn betrekkelijk weinig gegevens voorhanden. Ten tijde van de introductie van de Wtg zou iets meer dan tweederde van de medisch specialisten vrigevestigd zijn. Een vijgevestigde medisch specialist heeft door middel van een medewerkersovereenkomst met een ziekenfonds de mogelijkheid zelfstandig zijn verrichtingen te declareren. Na de behandeling van een particulier verzekerde patient stuurt hij een rekening naar de patient zelf die vervolgens zijn uitgaven declareert bij zijn verzekeringsmaatschappij. Een specialist in loondienst heeft daarentegen een vast inkomen, vitbetadd door de instelling war hij werkzaam is. De wrijgevestigde medisch specialisten in Nederland werken nawwelijks buiten en ziekenhuis. Zij hebben hun praktijk in algenene ziekewhuzen waar zij zijn georganiseerd in maatschappen. Dit zijn groepen van artsen van hetzelfde specialisme die afspraken maken over de werk-en inkomstenverdeling. Artsen in andere ziekenhuizen, zoals de academische ziekenhuizen, werken in loondienst. Van de artsen werkzam in algemene ziekenhuizen was aan het einde van de jaren tachtig minder dan tien procent in loondienst. Artsen in loondienst zijn wan oudsher voomamelijk kinderartsen, psychiaters en revalidatieartsen. Cardiologen en chirurgen zijn vrijwel uitsluitend wrijgevestigde artsen (Commissie Modertisering curatieve zorg, 1994: 30).

Sinds het einde van de jaren tachtig zijn weranderingen opgetreden in de vertegenwoordiging van medisch specialisten. Het ledental van de LSV daalde fors en bij haar monopolie op het vertegenwoordigen van de medisch specialisten werden in toenemende mate vraagtekens gestejd. Dit gebeurde voomamelijk door de eigen achterban. Veel specialisten maakten de overstap gemaakt naar andere belangenbehartigende organisaties zoals het Nederlands Specialisten Genootschap (NSG) en de Nederlandse Specialisten Federatie (NSF) die op basis van har ledental (meer dan 2000) in 1995 zelfs representatief werd verklaard. Het ledental van het NSG is beperkt gebleven. Ook een enkele Wetenschappelijke Vereniging meende in aanmerking te komen voor de status van representatieve organisatie. 29 In 1996 heeft een hergroepering plaatsgevonden met als gevolg dat sinds januari 1997 Nederland weer één representatieve specialistenorganisatie kent: de Orde van Medisch Specialisten (OMS).

Tot 1995 vertegenwoordigde het Kontaktorgaan Landelijke Organisaties van Ziektekostenverzekeraars (KLOZ) de particuliere ziektekostenverzekeraars. Het aanbieden van een ziektekostenverzekering kan de enige activiteit van een verzekeraar zijn maar vaak wormt het een onderdeel van een breder aambod waarwan ook schade- en levensverzekeringen deel uitmaken. Het KLOZ bestond tot 1988 uit vier organisaties. Dit waren de Federatie wan Non-Profit Verzekeringsinstellingen voor Ziektekosten in Nederland (VVZ), de Vereniging van Non-Profit Ziektekostenverzekeraars (NPZ) of de Nederlandse Vereniging van Ongevallen- en Ziekteverzekeraars (NVOZ), en de Federatie wan Onderlinge Verzekeringsmaatschappijen in Nederland (FOV). Uh 1988 zin de VVZ en FOV opgegan in de Federatie voor Onderlinge Non Profit Ziektekosten-Verzekeringsinstellingen (FOZ).

Deze particuliere maatschappijen verzekeren gezamenlij ongeveer 37 procent van de Nedertandse bevolking, in absolute temen meer dan 5,6 miljoen mensen (1994). In 1985 lag dat percentage lager ( 33 procent); met name de kleine stelselwijziging heef geleid tot een overgang van groepen verzekerden van de ziekenfondsverzekering naar particuliere verzekeringen.

29 De Nederlandse Vereniging van Thoraxchirurgen heef verzocht aangewezen te worden als representatieve otganisatie omdat zij zich door de LSV onvoldoende vertegenwoordigd achtte. De Statssecretaris van WVC wees het werzoek af. Op 10 nowember 1992 heeft de Raad van State afwijzend gereageerd op het beroep dat de thoraxchirurgen hadden aangetekend tegen de beslussing van de staatssecretaris. 
1985

1990

1994

abs.

perc.

alus

perc

14.952

1.00

9.190

61

5.527

37

4.852

66

$-$

2

perc

100

62

37

Bron: Wektis, Jaaboek 1994

Naast de particulier verzekerde patienten kent Nederland een omyangrijke zekenfondspopulatie, zoals uit tabel 3.4 valt af te lezen. De ziekenfondsen hebben van oudsher de rol gespeeld van belangenvertegenwoordiger van deze populatie. Voor de belangenbehartiging op nationaal niveau waren zij aangesloten bij de Vereniging van Nederlandse Ziekenfondsen (VNZ) die in 1990 de maam veranderde in de Nederlandse Vereniging van Zorgverzekeraars (VNZ). Deze naamsverandering gaf een ontwikkeling an die in de laatste jaren heef doorgezet. Veel ziekenfondsen werden ondergebracht bij werzekeraars die aok de particuliere ziektekostenverzekeringen verzorgden. Daamaast zijn veel ziekenfondsen samengegaan en groter geworden. Telde men in het begin van de jaren zeventig nog bijna honderd ziekenfondsen en tien jaar geleden bijna vijftig ziekenfondsen, tegenwoordig zijn het er om en nabij de wijfentwintig, warvan een substantieel deel een verzekerdenbestand heef van meer dan 400.000. Tabel 3.5 geef de ontwikkeling in de onderzoeksperiode weer. Dezelfde trend kan bij de particuliere verzekeraars worden aangetroffen, zij het dat de concentratie plaats vindt binnen de groep verzekeraars die minder dan 100.000 verzekerden hebben.

Tabel 3.5: De onwikkeling wan het aantal ziekenfondsen en particuliere ziektekostenverzekerars per aantal verzekerden in de periode $1986-1994$

\begin{tabular}{|c|c|c|c|c|c|c|c|c|c|}
\hline \multirow[t]{2}{*}{$\begin{array}{l}\text { verrekerden } \\
\times 1.000 \\
\end{array}$} & \multicolumn{3}{|c|}{ Ziekenfonds } & \multicolumn{3}{|c|}{$\begin{array}{l}\text { Particulier } \\
\text { (priv/publ.) }\end{array}$} & \multicolumn{3}{|c|}{ Totaal } \\
\hline & 86 & 92 & 94 & 86 & 92 & 94 & 86 & 92 & 94 \\
\hline$>400$ & 4 & 11 & 11 & 1 & 2 & 3 & 5 & 13 & 14 \\
\hline $300-400$ & 8 & 6 & 5 & 1 & 2 & 2 & 9 & 8 & 7 \\
\hline $200-300$ & 5 & 3 & 2 & 3 & 1 & 1 & 8 & 4 & 3 \\
\hline $100-200$ & 15 & 3 & 2 & 13 & 13 & 13 & 28 & 16 & 15 \\
\hline \multirow[t]{2}{*}{$\leq 100$} & 16 & 4 & 6 & 57 & 50 & 31 & 73 & 54 & 37 \\
\hline & 48 & 27 & 26 & 75 & 6.8 & 50 & 123 & 95 & 76 \\
\hline
\end{tabular}

Bron: Vektis/Zorguerzekeraars Magazine, mant 1995

De veranderingen in de organisaties van financiers hebben geleid tot een verandering van de organisatie van belangenbehartiging. Met ingang van 1995 zijn het KLOZ en de VNZ samengegaan in Zorgverzekeraars Nederland $(Z N)$.

De KPZ vertegenwoordigt de organisaties die de publiekrechtelijke zicktekosten. werzekeringen uitwoeren. Vanwege overeenkomstige doelstellingen heeft de KPZ zijn belangenbehartiging vaak in handen gegeven van het KLOZ 
Het COTG speeit een belangrike rol bij de totstandkoming van tarieven. Dit orgaan bestaat wit maximaal achtien leden waaronder een onafhankelijke voorzitter. Eénderde van de leden wordt benoemd door de Minister. Daamaast zjn de werknemers- en werkgeversorganisaties elk met twee leden vertegenwoordigd. De overige platsen worden gevuld met personen die de Minister benoemt na overleg mef de organisaties van aanbieders en verzekeraars. In formele zin is dus niet sprake van wertegenwoordiging wan belangen uit de gezondheidszorgsector.

Het is niet verwonderlijk dat de samenstelling van het COTG een belangrijk punt van discussie was bij de invoering van de Wig, gezien de ervaringen met de Commissie Overeenkomsten die op basis van de Ziekenfondswet functioneerde. Verscheidene organisaties achtten het gewenst de betrokkenheid wan matschappelijke organisaties die gewaarborgd was in het bestaande systeem te behouden. De bewindslieden kwamen aan deze wens enigzins tegemoet door te bepalen, dat over de benoeming van een aantal leden in het COTG overleg met betrokken organisaties plaats dient te vinden. Verondersteld mag worden dat deze leden het vertrouwen genieten van die organisaties. Daamaast zijn belangenorganisaties via de zogenaamde Kamers vertegenwoordigd. De wettelijke bepaling dat de Minister Kamers bij het COTG instelt, kwam pas tot stand na een uitgebreide inspraakronde die volgde op het indienen van het wetsontwerpWtg (Lapre, 1980). In tabel 3.6 wordt de samenstelling van Kamer V weergegewen.

Tabel 3.6: Samenstelling Kamer V 1986-1992

voorzitter (vanuit het COTG)

secretaris (vanuit het bureau van het COTG)

Landelijke Hussartsen Vereniging

2 leden

Landelijke Specialisten Vereniging

2 leden

Koninklijke Nederlandse Maatschappij

ter bevordering der Pharmacie

2 leden

Nederlandse Maatschappij tot bevordering

der Tandheelkunde

Kontaktkommissie Publiekrechtelijke

2 leden

Ziektekostenregelingen voor ambtenaren

Kontaktorgaan Landelijke Organisaties van

Ziektekostenverzekeraars

2 leden

Vereniging van Nederlandse Zorgverzekeraars

5 leden

De overheid dient richtlijnen goed te keuren. Deze taak ligt in handen van de Minister van Volksgezondheid, Welzijn en Sport (VWS, voorheen Welzijn, Volksgezondheid en Cultum (WVC) na overleg met Economische Zaken on Sociale Zaken en Werkgelegenheid. Een ander belangrijk element van het wettelijk systeem is de bevoegdheid voor de overheid om aurwijzingen aan het COTG te geven.

Tenslotte staat in de Wtg het College van Beroep voor thet Bedrijfileven (CBB) genoemd. Tot 1 juli 1992 kon darir beroep worden ingesteld zonder zich ecrst te wenden tot het COTG. In verband met de verwantschap met prijzen in het bedrijfsleven achtte de owerheid het verstandig deze beroepsinstantie in de wet op te nemen. 


\subsubsection{Veranderingen door de Wtg?}

Betekende de invoering van de Wtg dat grote veranderingen optraden? Hoewel deze studie kenris moet leveren om deze vraag goed te kunnen beantwoorden, zijn enige inleddende opmerkingen op basis van bestaande literatuur mogelijk. Ondanks de handhaving van het principe van onderhandelingen tussen de organisaties van medisch specialisten, ziekenfondsen en ziektekostenverzekeraars werd de strategische numte voor de onderhandelaars in toenemende mate bepaald door politieke overwegingen. Binnen deze politieke ovenwegingen werden de tarieven instrumenteel opgevat. $Z_{i j}$ dienden als tussendoel om werder gelegen doelstellingen te verwerkeliken. In de eerste helft van de jaren tachtig domineerde het inkomensbeleid, zoals dat door het ministerie van Sociale Zaken werd geformuleerd. Met behulp van speciaal daarvoor ontworpen wetten (Tijdelijke wet inkomens vrije beroepsbeoefenaren, later vervangen door de Wet inkomens vrije beroepsbeoefenaren) moesten onderhandelingen met de Wetenschappelijke Verenigingen van medisch specialisten plaatsvinden. Tijdens deze onderhandelingen, voorgezeten door de minister van Sociale Zaken, werden afspraken gemaakt over een redelijk inkomen. Als dat redelijk inkomen afweek van het norminkomen, moest het verschil worden weggewerkt door middel van tariefsveranderingen (Van der Reijden 1987). Later leidde de politielke wens tot de beheersing van de kosten wan de gezondheidszorg onafwendbaar tot grote beleidsmatige aandacht bij de overheid voor de tarieven voor medische beroepsbeoefenaren. Onafwendbaar omdat, ondanks de afwezigheid van evaluaties die effectiviteit bewijzen, de tarieven van artsen een 'natural target' bljjken te vormen voor overheden die de kosten van de gezondheidszorg te hoog vinden (Gabel en Rice 1987). Deze 'politieke druk' heef geleid tot een negatieve tendens in de ontwikkeling van de tarieven. Tenwijl de ziekenfondstarieven in de periode 1976-1980 nog een algemene stijging van 13.2 procent kenden, daalden zij over de periode 1980-1986 met 11.7 procent (Kirkman-Liff, 1989:475). Ook in de jaren na 1986 heeft zich een tariefdaling voorgedaan (zie tabel 3.7 ). 30

Tabel 3.7: Jaarlijkse veranderingen wan de tarieven voor medisch specialisten 1987-1995 in percentages

\begin{tabular}{|l|c|c|c|c|c|c|c|c|c|}
\hline \multicolumn{1}{|c|}{} & 1987 & 1988 & 1989 & 1990 & 1991 & 1992 & 1993 & 1994 & 1995 \\
\hline $\begin{array}{l}\text { ziekenfonds- } \\
\text { tarieven }\end{array}$ & 0.1 & 0.0 & -3.0 & 0.0 & -1.3 & -3.0 & -10.5 & -0.2 & +4.8 \\
\hline $\begin{array}{l}\text { particuliere } \\
\text { tarieven }\end{array}$ & 6.5 & 1.3 & +6.1 & -0.6 & -0.6 & -2.9 & -11.8 & -1.0 & -11.8 \\
\hline
\end{tabular}

Brom: Jaarverslagen COTG 1988-1995

De tarieven woor medisch specialisten speclden een belangrijke rol in de politieke discussies over kostenbezuinigingen in de gezondheidszorg maar een stelsel wan richtijnen kwam niet tot stand. Een inhoudelike onderbouwing van de tarieven van medisch specialisten bleef uit, beslissingen hielden slechts aanpassingen van historisch vastgelegde tarieven in. De tarieven zoals die door de LSV en ziekenfondsen in de maoorlogse onderhandelingen waren overeengekomen vornden het

30 Hoewel de gegevens van tabel 3.2, tabel 3.7 en Kirkman Liff niet geheel vergelijkbaar zijm, is het duidelijk dat de uitkomsten van het collectieve owerleg in de jaren tachtig scherp contrasteren met die wan voorgaande decennia. Terwijl de zogenaamde trendmatige aanpassingen tot in de Jaren zeventig leiddem tot een forse tariefstiging, is er in de laatste tien jaar sprake yan cen forse tarjefdaling. 
uitgangspunt bij de invoering wan de Wtg. Zij werden sindsdien wel generiek veranderd - dus een verlaging of verhoging voor alle specialisten of voor en bepaald specialisme - maar van onderhandelingen over de inhoudelike rechtvaardiging en daarop gebaseerde veranderingen was nauwelijks sprake. Hetzelfde gold voor de particuliere tarieven. De richtijnen van de LSV werden gelegaliseerd door ze op te nemen in de officiele tariefvoorschriften. Soms, als het overleg over tarieven overgelaten werd aan de ziekenfondsen en specialisten zelf, zoals bij de hoogte van de praktjkkosten, kreeg de onderbouwing ervan meer aandacht. Het overleg over tarieven werd echter met name beoordeeld op de effecten ervan op andere doelstellingen. Daardoor hebben tarieven een politiek karakter gekregen. Dat dit op gespannen voet kan staan met de wens on de hoogte van tarieven rationeel te onderbouwen, moge duidelijk zijn. Het COTG heeft dan ook tegen het politieke karakter van tarieven geprotesteerd (Algemene Rekenkamer 1995).

De politisering betekende in ieder geval een toename van het aantal tariefbepalers. Van de autonomie van de arts bij de vaststelling van tarieven is hoegenamd niets overgebleven. Ook de tarieven voor particuliere betalingen zijn niet meer beinvloedbaar door de individuele arts. ${ }^{31}$ Bovendien werd binmen de onderhandelingsarena de positie van de medisch specialist langzamerhand minder sterk. Er heef zich in de decennia na de Tweede Wereldoorlog een proces wan concentratie binnen de ziekenfondssector woorgedaan. ${ }^{32}$ Dit proces heeft er uiteindelijk toe gelleid dat de medisch specialisten zich sinds de late jaren zeventig geconfronteerd zagen met éen vertegenwoordigende ziekenfondsorganisatie (Vereniging van Nederlandse Ziekenfondsen, $\mathrm{VNZ}$, in 1992 omgedoopd in de Vereniging wan Nederlandse Zorgverzekeraars). Een proces van convergentie heef er zelfs toe geleid, dat met ingang van 1995 met éen organisatie die zowel ziekenfondsen als particuliere ziektekostenverzekeraars vertegenwoordigt (Zorgverzekeraars Nederland, $Z \mathrm{~N}$ ) moet worden onderhandeld. 33 Het effect van deze machtsconcentratie werd

31 Jets anders is uiteraard het genereren wan inkomsten. De toename in de kostenstijging van medisch specialistische hulp die na 1989 optrad, wordt geweten aan onder meer vergaande aanpassingen van het declaratiegedrag van artsen. Dit heeft echter niets te maken met tarieven; dit zijn vaststaande grootheden woor de individuele arts, zowel voor verrichtingen bij ziekenfondspatiënten als particulier betalende patiëntern.

32 Het proces van concentratie heeft tenminste drie dimensies. Ten eerste name het aantal ziekenfondsen enorm af. Terwijl net voor WOII sprake was van ongeveer 650 ziekenfondsen, telt het laatste Financieel Overzicht Zorg nog maar 25 ziekenfondsen. Ten tweede nam het aantal vertegenwoordigende organisaties door samengaan af. In 1962 was sprake wan de Federatie van door Verzekerden en Medewerkers bestuurde Ziekenfondsen, de Organisatie wan Algemene Ziekenfondsen, de Centrale Bond van Onderling beheerde Ziekenfondsen, het Overleg van Ondememingszickenfondsen, de Nederlandse Bond wan Ziekenfondsen (deze vier vormden het Gezamenlijk Overleg van Ziekenfondsorganisaties), de Bond van Rooms-Katholieke Ziekenfondsorganisaties, en de Stichting Autonome Ziekenfondsen (Godefroi 1963: 100). Na 1977 werden de ziekenfondsen slechts door één organisatie vertegenwoordigd in de centrale besprekingen: de Vereniging van Nederlandse Ziekenfondsen (VNZ), die in 1995 samengegaan is met de KLOZ in de Zorgverzekeraars Nederland (ZN). Ten derde is er sprake van een concentratie van macht. Het belang van het nationaal owerleg tussen vertegenwoordigende organisaties nam toe ten koste van het traditionele averleg.

33 Nog bedreigender voor artsen dan een invloedriyke overheid of een krachtige ziekenfondsorganisatie is 'monopsony'. Monopsony is de situatie waran er maar één betaler voor de gezond. heidszorg is, zoals in Groot-Britannie en Canada de overheid. "The position of doctors is strengthened if they can sell their services not to a single buyer, but to many buyers." (Immergut 1992: 35). Met het ontstan van éen-betaler-systemen verdwijmt de mogelijkheid voor de arts on een strategie van Divide et Impera toe te passen, een strategie die met name in de Verenigde Staten bijzonder effectief is gebleken (Reinhardt 1987). 
versterkt door een veranderende houding van de ziekenfondsen. Tot in de jaren zeventig stonden zij tariefsverhogingen toe als dit hun werzekerden in de vom van meer en betere zorg ten goede kwam. In de jaren tachtig ontwikkelden de georganiseerde ziekenfondsen strategieèn on de groei wan tarieven en de omzet van medisch specialisten bimen de perken te houden. Van de globale gelijkgerichtheid van doelstellingen wan ziekenfondsen en artsen; kenmerkend voor de periode van zelfregulering, was geen sprake meer. De wele conflicten die de onderhandelingen in de jaren tachtig kenmerkten, konden niet meer onderling geregeld worden. Juridische procedures bepaalden in toenemende mate de loop van besluitvorming over tarieven.

Deze veranderingen in de machtspositie bimen de onderhandelingsarena werden nog versterkt door interne verdeeldheid bij de medisch specialisten. Daar waar de belangenbehartiging van ziektekostenverzekeraars inklonk, desintegreerde de LSV. Door de overstap van ontevreden medisch specialisten naar alternatieve organisaties als de Nederlandse Specialisten Federatie, kreeg de voorheen zo machtige LSV concurrentie bij de belangenbehartiging. In 1997 werenigden de specialisten zich weliswaar weer in éen organisaties, de Orde van Medisch Specialisten, maar niet zonder het verschil tussen de 'bloedgroepen' (vrijgevestigde versus in loondienst werkende artsen) door middel van de instelling wan zogenamde Kamers te institutionaliseren.

\subsection{Een terugblikkende analyse}

De ontwikkeling van de instituties voor tariefvorming voor medisch specialisten in Nederland sinds 1900 zou ik willen samenvatten aan de hand van vier aspecten. Deze vier aspecten zijn achtereenvolgens: wie neemt de besluiten over tarieven, wat wordt besloten, hoe worden de besluiten genomen en waar worden zij genomen? Het warom van de ontwikkelingen komt aan de orde in de paragraaf waarin het pad gereconstrueerd wordt.

\section{Wie?}

In Nederland heeft de individuele arts elke zeggenschap over de prijs voor zijn diensten ver loren. Dit verlies is kenmerkend voor landen waarin een sociaal zicktekostenverzekeringsstelsel werd ingevoerd (Stone 1980). Voor de omvangrijke particuliere sector in de eerste decennia van deze eeuw was de arts in staat door middel van tariefdiscriminatie zelistandig gedifferentieerde tarieven vast te stellen. In deze tijd vomde een ziekenfondspatient, waarwoor een vast bedrag per jadr gold, vooral een additionele inkomstenbron. Voor een aantal artsen bood de ziekenfondspraktijk de broodnodige economische zeketheid omdat niet elke arts door het overatubod van antsen en schaarste aan (welgestelde) patienten een volwaardige particuliere praktijk had. De medisch specialist verkeerde evenwel in een moeilijke positie. Zijn aandeel in de medische zorg was aanwankelijk nog gering. Voor patienten was het dus niet aantrekkelijk om zich tegen medisch specialistische kosten te verzekeren. Ziekenfondsen en verzekeringsmaatschappijen boden een dergelijke verzekering nog miet op grote schaal asm. Bovendien bevonden de medisch specialisten zich in een concurrentiepositie met vooral de husartsen, in die tijd een machtige groepering binnen de medische beroepsgroep. De honorering verliep in de zieken fondssector dan ook gedeeltelik via de specialistenpot die in feite een worm wan budgettering inhield (Japenga en Van der Velden 1992). Uiteindelijk zou de medisch specialist onderdeel worden van én belangenbehartigende organisatie. Dit makkte de medische stand tot een machtige politieke actor, mat het betekende ook dat de medisch specialist wolledig werd geincorporeerd in het bestaande neocorporatistische beleidssysteem met zijn overheersende ruillogica.

De witkomst wan de politieke strijd rond de invoering van een verplichte ziekenfondsverzekering leek in het voordeel van de medische professie. Gevolg was echter wal dat de positie van ziekenfondsen sterk verbeterde. Vertegenwoordigende organisaties van medisch 
specialisten th ziekenfondsen moesten proberen in collectieve onderhandelingen een tarief af te spreken. De economische afhankelijkheid wan artsen ten opzichte van de ziekenfondsen was gegroeid. De economische groei bood evenwel ruimte voor gelikgerichte doelstellingen waardoor het materiele effect wan het autonomieverlies voor de artsen niet groot was.

De centrale onderhandelingen over de medisch specialistische zorg strekten zich tot 1982 niet uit tot de particuliere verzekeraars. Hoewel op regional niveau richtlinadviezen werden gegeven, blewef de medisch specialist vrij in het bepalen van zijn tarief hetgeen er toe leidde dat een particulier tarief vele malen hoger kon zijn dan een ziekenfondstarief voor dezelfde verrichting Maar in de jaren zeventig en tachtig rakten ook de particuliere verzekeraars betrokken bij de collectieve onderhandelingen. Bovendien verdween het private karakter van de tariefbepalng; overheden en onafhankelike instanties als het COTG deder hun intrede. Dit betekende wiet alleen en politisering van de besluitvorming over tarieven maar ook een toename van het atntal betrokkenen. Deze betrokkenheid was niet toevallig maar wettelijk gereguleerd. Besluiten wroegen steeds meer de instermming van vele partijen. Tariefvoming voor medisch specialister is steeds meer een collectieve ondememing geworden, op nationall niveau, waarbij interdependenties steeds groter zijn geworden. ${ }^{34}$

\section{Wat?}

Hoewel de ziekenfondsbetaling woor veel specialisten in de eerste decenmia van deze eeuw nawwelijks de moeite waard was, kent een vrijgevestigde medisch specialist sinds jaar en dag twee soorten van tarieven: en tarief woor de betaling wan het ziekenfonds aan de arts en een tarief voor de particulier verzekerde patiënt. Tot aan de invoering van de Wtg in 1982 was de totstandkoming van beide tarieven volledig gescheiden en onafhankelijk waardoor zij in grote mate uiteenliepen. Pas in 1997 werd een einde gemaakt aan de verschillen, ondanks de reeds lang bestaande alandacht in het nationale overleg voor de zogenaamde toegroei van particuliere en ziekenfondstarieven. Maar ook binnen beide sectoren konden tarieven onderling sterk verschillen. Een tarief per verrichting week af van de betaling uit een specialistenpot of een betaling per verwijskaart. Amsterdamse tarieven woor particuliere patiënten weken af van Friese tatieven. De besluitvormingsstructuur valn de Wtg onderscheidt zich wan vroegere structuren door de onderhandelingen over een uniform tarief voor geheel Nederland.

De hoogte van tarieven is uiteraard van belang, maar volgens Marmor en Thomas kunnen andere aspecten van de betaling aan artsen eveneens discussie oproepen. Zij onderscheiden de methode van betaling (per persoon, per verrichting of per tijdseenheid), over wie moet betalen (de overheid, een verzekeraar of de patiënt zelf), of over de differentiatie van betaling onder artsen (1972: 428). Ik zou daar nog de vormgeving van de besluitvorming over de hoogte van betaling aan toe willen voegen. Deze aspecten zijn echter onderwerp van meta-besluitvoming. Meta-besluitvoming kan plats vinden op een ander niveau dan de besluitvorming over de hoogte wath het tarief. Zo ontwierp de NMG honorariumstructuren voor de eigen Maatschappijfondsen (bijvoorbeeld in de vom van modelcontracten), maar vonden de tariefafspraken tussen

34 Matu anders dan bijvoorbeeld in de VS zijn vele andere aspecten van de beroepsuitoefening dan de honorering buiten de collectieve besprekingen gehouden. Gedurende lange tijd bestonden de medewerkerscontracten tussen ziekenfondsen en medisch specialisten in Nederland wrijwel alleen uit alspraken over de hoogte van tarieven (Commissie Becht 1978). De begrippen van Freidson (1970: 25) toepassend, heeft de Nederlandse arts zijn technische autonomie grotendeels behouden, maat heeh hij tevens grote delen van zijn economische autonomie moeten inleveren. Met deze ruil werd de medische professie overal in de Westerse wereld geconfronteerd, met als gevolg de paradoxale situatie dat daar waar de individuele arts zijn economische autonomie heeft vertoren, de professionele autonomie van de medicus het grootst is gebleven (Reinhardt 1986). 
fonds en arts decentraal plaats. Ook was de plaatselijke specialistempot een uitwloeisel van tegenstellingen tussen specialisten en huisartsen die op een hoger niveau moesten worder gepacificeerd. Besluitvomming en meta-besluitvorming kumen echter ook samenvallen zoals bij de ontwikkeling van een eigen politiek door onafhankelijke fondsen.

Nadat in de jaren na de Tweede Wereldoorlog enkele belangrike beslissingen waren genomen, speelde de discussie over de betaling van medisch specialisten zich af binnen de besloten context van vertegenwoordigende organisaties van ziekenfondsen, de LSV en de Ziekenfondsraad. De nadruk lag op de hoogte van de betaling, de andere aspecten . zoals contracten die gebaseerd waren op een verrichtingentarief - waren min of meer geregeld. Binnen het kader van geinstitutionaliseerde regels overlegden belangenorganisaties over de verdeling van geld. Met de voorbereiding en invoering van de Wtg kreeg de vormgeving van de beshuitvoming over tarieven weer veel aandacht, maar fundamentele vaagtekens werden nog niet bij de betalingsrelatie gezet. Als gevolg wan de neocorporatistische beleidsstructuur vond de bestuitvorming over tarieven voor medisch specialisten en de meta-besluitvorming op hetzelfde niveau plaats.

Pas in de late jaren tachtig en vroege jaren negentig verschenen rapporten die ook aandacht vroegen voor de methode van betaling en voor de vraag wie eigenlijk zou moeten betalen. $D e$ commissie Modemisering curatieve zorg (1994) ging ver door aan te bevelen de betaling vam medisch specialisten over te laten aan ziekenhuizen die daarbij kunnen uitgaan van een basisinkomen. Werkelijk grote invloed hebben de regionale regelingen tussen ziekenhuizen, verzekeraars en medisch specialisten die sinds 1994 overal in Nederland van kracht zijn. In deze regelingen is vastgelegd dat de inkomsten van medisch specialisten jaarlijks gebudgetteerd worden. Deze initiatieven zijn echter niet gepaard gegaan met veranderingen van de regels voor tariefvoming. Declaraties vinden nog steeds plaats op basis van tariefovereenkomsten die tot stand dienen te komen aan de hand van de regels van de Wtg.

\section{Hoe?}

Het is gebleken dat de regels voor besluitvorming over tarieven zijn veranderd. Gedurende lange tijd bestonden voor de ziekenfondssector noch voor de particuliere sector wettelijke voorschriften, maar beslisregels ontwikkelden zich uiteraard wel. De vele ziekenfondsen hadden vaak gemeen dat zij per jaar een vast bedrag uibetaalden, maar overleg daarover gebeurde op regionaal dan wel plaatselijk niveau. Door de invoering van het Ziekenfondsenbesluit en de Ziekenfondsraad (1947) werd deze besluitvorming gecentraliseerd en dus geuniformeerd. Daamee was echter nog geen sprake van doorzichtigheid; duidelijke criteria ten behoeve van tariefbesluiten voor artsen ontbraken, constateerde de commissie Becht nog in 1976 . Ook bij de particuliere tarieven was sprake wan een grote heterogeniteit, alhoewel de algemene beslisregel duidelijker was dan bij de totstandkoming van ziekenfondstarieven. Bij de berekening van het particulier tarief liet de daarin autonome arts zich vooral leiclen door de welstand van de patient. Die welstand liet zich aflezen aan het inkomen en later aan de verplegingsklasse warvoor de particulier patünt zich had verzekerd. De grote varietteit van beslisregels verdween gedurende deze eeuw. De tariefvoming raakte steeds meer georganiseerd. In de ziekenfondssector streefde men naar zogenaamde modelovereenkomsten, en de LSV formuleerde nationale richtlijnen yoor de particuliere betalingen. Een onvermijdelijk gevolg daarvan was dat de besluitvorming gekenmerkt werd door juridisering. Het Ziekenfondsenbesluit, de Ziekenfondswet, de Wtg maar ook het opnemen van de particuliere richtlijnen in de prijzenbeschikkingen door het ministerie van Economische Zaken tonen dit aan. In toenemende mate was sprake van wettelijke regulering, toegespitst op tariefvoming in de gezondheidszorg. Dit heeft enkele belangrijke gevolgen gehad. 
Tabel 3.8: De ontwikkeling wan de institutes woor tariefvorming voor medisch specialistische hulp in Nederland sinds 1900 (exclusief de betaling wan (poli)kinische hulp in ziekenhuzen en collectieve verzekeraars voor WOH)

\begin{tabular}{|c|c|c|c|}
\hline & wile & hoe & war \\
\hline \multicolumn{4}{|c|}{ Wat de hoogte var particullere tarieven } \\
\hline $\begin{array}{l}1900 \\
1940\end{array}$ & de arrits & $\begin{array}{l}\text { tariefdiscrininate aam de band } \\
\text { van welstand van patient } \\
\text { (tnkomen) eventueel bimer } \\
\text { grenzer gesteld door } \\
\text { specialistenverenigingen }\end{array}$ & $\begin{array}{l}\text { in lokale } \\
\text { speciallisten werenigingen on } \\
\text { in de artsenpraktik }\end{array}$ \\
\hline $\begin{array}{l}1945= \\
170\end{array}$ & de arts & 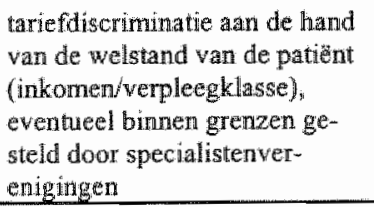 & $\begin{array}{l}\text { in lokale } \\
\text { specialistenverenigingen en } \\
\text { in de artsenpraktgk }\end{array}$ \\
\hline $\begin{array}{l}1970 \\
1982\end{array}$ & $\begin{array}{l}\text { de arts/de LSW/wetenschap- } \\
\text { pelinke werenigingen }\end{array}$ & $\begin{array}{l}\text { tariefdiscriminatie volgens de } \\
\text { richtijnen var de LSV: rede- } \\
\text { lijkheid en billikhueid }\end{array}$ & $\begin{array}{l}\text { in de antsenpraktijk en bin- } \\
\text { nen de J.SV }\end{array}$ \\
\hline $\begin{array}{l}1970 \\
1982 \\
\end{array}$ & $\begin{array}{l}\text { minister van Heonomisc hie } \\
\text { Zaken }\end{array}$ & $\begin{array}{l}\text { volgens wettelijke procedur } \\
\text { (Prijzenbeschikkingen). }\end{array}$ & de overheid \\
\hline $\begin{array}{l}1982 \\
1992\end{array}$ & $\begin{array}{l}\text { vertegenwoordigende organi- } \\
\text { saties van ziefenfondsen, } \\
\text { particuliere verzekeraars en } \\
\text { overheid, cotri }\end{array}$ & $\begin{array}{l}\text { volgens wettelike procedure } \\
\text { (Wet tarieven } \\
\text { gezondlyeidszorg) }\end{array}$ & $\begin{array}{l}\text { in landelijk overleg tussen } \\
\text { vertegenwoordigende } \\
\text { organisties }\end{array}$ \\
\hline \multicolumn{4}{|c|}{ Wat: de hooge van het zickenfondstarief } \\
\hline $\begin{array}{l}1900 \\
1940\end{array}$ & zieken fondsen en artsen & $\begin{array}{l}\text { per verwijskart; uit de lokale } \\
\text { "specialistenpot', op basis wan } \\
\text { specialisme en aantal ver- } \\
\text { richtingen }\end{array}$ & $\begin{array}{l}\text { in platselijk overleg tussien } \\
\text { fondsen en artsen }\end{array}$ \\
\hline $\begin{array}{l}1945 \\
1982\end{array}$ & $\begin{array}{l}\text { vertegenwoordigende organ- } \\
\text { waties vam specialisten en zie- } \\
\text { kenfondsem de Ziekenfoncs- } \\
\text { raad }\end{array}$ & $\begin{array}{l}\text { volgens wettelijke prowedures } \\
\text { onderhandelen over criewen } \\
\text { per vertichting, trendmatide } \\
\text { danpassingen (Ziekenfondsen- } \\
\text { besluit (1941), Ziekenfondswel } \\
\text { (1966) }\end{array}$ & $\begin{array}{l}\text { in landelik overleg nussen } \\
\text { vertegerwoondigende } \\
\text { organisaties }\end{array}$ \\
\hline $\begin{array}{l}1982 \\
1992\end{array}$ & 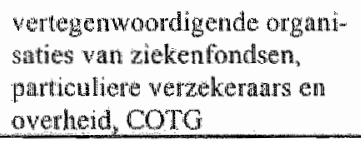 & $\begin{array}{l}\text { wolgens wetelijke procedure } \\
\text { (Wet tarieven } \\
\text { gezondheidseorg) }\end{array}$ & $\begin{array}{l}\text { in landelik owerleg tussen } \\
\text { vertegenwoordigemde } \\
\text { organisaties }\end{array}$ \\
\hline
\end{tabular}

Ten eerste veranderde de rol van de betrokkenen. Zij werden ingeschakeld bij de implementatie van overheidsbeleid. De besluitworming over tarieven werd mede afhankelijk gemaakt van de wens of en hoe ziekenfondsen, medisch specialisten, en later de particuliere verzekeraars wensten mee te werken aan overheidsbeleid. Met name de ontwikkeling van ziekenfondsen is illustratief. Opgekomen vanuit de noodzaak om voor minvermogenden de mogelijkheid te scheppen zich te verzekeren tegen medische zorg, veranderden de ziekenfondsen na de invoering van het Ziekentondsenbesluit in uitvoeringsorganen. Een enkele teleurgestelde beoordelaar heeft opgemerkt dat hierdoor de ziekenfondsen de mogelijkheid werd ontmomen zich te ontwikkelen 
tot winstmakende en competitieve ziektekostenverzekeringen (Van der Wielen, 1961: 17). Ten weede betekende de wettelijke specificatie van rollen en procedures dat de beshitworming kon plats gaan vinden door juridische conflictoplossing. Het waren net meer alleen de traditionele onderhandelaars die verschillen van mening konden oplossen, maar de interventie van een derde werd mogelijk, op basis van juridische overwegingen.

\section{Waar?}

De locus van besluitvorming over tarieven voor medisch specialisten is verschoven van de artsenpraktijk en het plaatselijk overleg naar het centraal national niveau, passend binnen de neocorporatistische cultuur in Nederland. Organisaties met een monopolie op het vertegenwoordigen wan een functioneel belang overleggen met elkaar en met de overheid over velerlei beleidsthema's binnen een specifiek beleidsterrein. De structuur voor de onderhandelingen voor ziekenfondstarieven, ontstaan na de Tweede Wereldoorlog, was een compromis tussen het traditioneel neocorporatisme in de sector wan de sociale zekerheid (de triparlite bestuurstructuur van overheid, werkgevers en werknemers) en de wens van ziekenfondsen en artsen om betrokken te zijn bij de uitvoering van de ziekenfondswetgeving (Lieverdink, Van der Made en Van Merode 1995: 4-5). Door de invoering van de Wtg zijn de particuliere verzekeraars door middel van hun wertegenwoordigende organisatie ook wettelijk betrokken gerakk bij de nationale onderlandelingen. Er is een breed overleg- en onderhandelingsplatform ontstaan. De verschuiving van de locus heeft zich vervolgens gematerialiseerd in omvangrijke, voor alle specialisten geldende en nationaal gedistributeerde tariefboeken waarvan het afwijken als een economisch delict wordt beschouwd.

\subsection{Op zoek naar het pad der ontwikkeling}

Ten behoeve van de reconstructie van het pad der ontwikkeling verbindt de onderzoeker keuzen en institutionele structuren aan elkaar om aan te kunnen geven waarom de ontwikkelingen liepen zoals zij liepen en niet anders. Bij de reconstructie van het pad van de ontwikkeling van de instituties voor de besluitvorming over tarieven voor medisch specialisten kan worden voortgebouwd op bestaande theorievorming. Ten eerste is de ontwikkeling van de besluitvorming ower tarieven voor medisch specialisten een deelaspect van de collectivisering wan zorgarrangementen. De kenmerken van deze collectivisering hebben uitgebreide sociologische en geschiedkundige aandacht gekregen (De Swaan 1990, Van der Velden 1993). Ten tweede wijzen comparatieve studies van de ontwikkeling van financieringssystemen in de gezondheidszorg uit dat het proces van collectivisering vain de betaling van artsen geleidelijk is verlopen (Glaser $1970,1989 \mathrm{a}, 1989 \mathrm{~b}, 1990$ ).

De Swaan beschrijft het proces van collectivisering van de gezondheidszorg en onderscheidt daarbij drie dimensies. Ten eerste nam de schaal van de zorg toe: zij werd van toepassing op Nederland als geheel. Ten tweede $\mathrm{kreeg}$ de zorg een collectief karakter. Formele regelingen gingen bepalen wie op welke zorg recht heef. Individuele, unicke kenmerken deden niet meer terzake. De derde dimensie van het collectiviseringproces onvat het door de overheid op zich nemen van de taak toe te zien op de naleving van de formele regelingen en het creeren van een uitwoerend bureaucratisch apparaat (1990:17).

Met de collectivisering is de besluitvorming over de tarieven voor de zorg meeveranderd. Afspraken over tarieven vonden in het begin van de eeuw nog plaats tussen de arts en de individuele patiënt. Het uiteindelijke tarief werd bepaald door min of meer toevallige omstandigheden. De te betalen prijs voor zorg hing af van persoonlijke karakteristieken, maar ook wan geografische kenmerken. Het maakte veel uit of men in de stad of op het platteland naar de dokter ging. Met de opkomst van het ziekenfonds werd de invloed van persoonlijke 
kenmerken van de patient al aamerkeljk beperkt. Het stelsel van collectieve onderhandelingen en de daraan opgehangen implementatiestructur heef de tariefbepaling total gecollectiviseerd. De tanefafspraken op national niveau zijn nu van toepassing op alle betalingsrelatjes in de gezondheidszorg. Zowel de ziekenfondspatiënt, de particulier werzekerde als de ambtenaar betalen de prijs die national bepaald wordt. Zelfs cen hedendaagse privékliniek, die $x i j n$ bestaan dankt aan lacunes in wetgeving, is wettelijk verplicht de officiele COTGtarieven te hanteren.

De tariefvoming is eveneens in toenemende mate een zaak van de overheid geworden. Het ingewikkelde mozarek van betalingsrelaties van voor de Tweede Wereldoorlog werd tijdens de oorlog herordend en kwam reeds in 1949 onder toezicht van een publiekrechtelijk toezichtsorgaan, de Ziekenfondsraad. Deze Ziekenfondsraad was echter een orgaan dat paste in de periode wan zelfregulering. Bovendien had de overheid weinig bevoegdheden tot interventie in de tariefonderhandelingen. Pas met het oprichten van het Centraal Orgaan Tarieven Gezondheidszorg (1982) en de bepalingen ten aanzien van aanwijzingen en richtlijnen in de Wtg kwan de tariefvorming voor medisch specialisten onder controle van de overheid. Met name voor de particuliere tarieven betekende de Wtg een breuk met het werleden waarin artsen weel vrijheid kenden bij het berekenen van hun prijs. Abrupt kwam de overheidsbemoeienis met de particuliere sector evenwel niet tot stand. De totstandkoming van particuliere tarieven was al gedeeltelijk gecollectiviseerd omdat de interne LSV-richtlijnen in de sinds 1970 verschujnende prijzenbeschikkingen van het ministerie van Economische Zaken waren "gelegaliseerd".

Uit de beschrijving van Glaser volgt de algemene conclusie dat veranderingen in de betaling van artsen bepaall werden door reeds langer bestaande praktijken, en dat de invoering. van een wettelijke verzekering geen revolutionaire veranderingen teweeg bracht. Glaser verbindt de ontwilkkeling van de besluitvorming over de betaling aan artsen aan de instelling van een verplichte socialle ziektekostenverzekering.

"The adoprion of national healh insurance or a nalional healih service makes inevitable certain changes in the working conditions and economic positions of doctors. Money comes avallable to pay for patients who othewise might have been treated free or not at all. For the remaining patients, the sowrce of the payments changes from the individual to an organization. As a condition for collecting payments, the doctor must accept the financial procedures of the third party; "(1970: 98)

Meestal ging deze ontwikkeling geleidelijk omdat de overheden moeilijkheden met de artsen en de ziekenfondsen wilden vermijden en oude praktijken handhaafden (Glaser, 1970: 98). De ontwikkeling van tarieven was meestal al door de medische stand voorbereid (Glaser, 1.970: 98). Betalingssystemen bleven over het algemeen dezelfde. De heersende betalingssystemen werden zelfs nationaal verplicht ondat een verplichte ziektekostenverzekering gestandaardiseerde nationale administratieve instituties vereiste (Glaser, 1970: 100). Daanaast leidde het invoeren van de wettelijk verplichte ziektekostenverzekering weliswaar tot cen grotere ziekenfondspopulatie, een wettelijk afdwingbare premiebetaling en minimum eisen aan administratieve procedures, mar de uitvoering werd in handen gegeven van reeds lang bestaande ziekenfondsen.

De ontwikkelingen in Nederland passen in het patroon dat door Glaser beschreven is. In de periode 1900-1940 werd de kiem gelegd van het systeem dat na 1945 tot volle wasdom zou komen. In deze periode werden de keuzen gemaakt die uiteindelijk leidden tot een pad. Om de woorden van Wilsford (1994) te gebruken, de toen gemaakte keuzen in de context van bestande praktijken resulteerden in instituties die de kaders gingen vormen voor de ontwikkeling van de besluitvonming over tarieven. Als onderdeel van sociale wetgeving waren er veel initiatieven om tot een wettelijke ziektekostenregeling te komen. Ondertussen werden in de nog decentrale onderhandelingen tussen artsen en ziekenfondsen belangrijke inhoudelijke keuzen gemaakt. De organisaties wan artsen en ziekenfondsen hielden zich bezig met beleidsmatige keuzen. De eerste 
aanzetten tol nationale collectieve onderhandelingen werden gegeven. Er was sprake van: tendensen om landelijke afspraken over arbeidswoorwarden te maken. De grote inefficientie wan de versplinterde ziekenfondssector (uiteindelijk zouden de kleine fondsen de toename van kosten toch niet hebben kumen opbrengen), de toenemende mate var organisatie, niet alleen in de gezondheidszorg maar ook van de arbeidersbeweging die zich sterk interesseerde voor sociale verzekeringen tegen ziektekosten, de strategische keuzen van de NMG, de dreigende regulering door de overheid, de opkomst van een verzuilde maatschappij waren factoren die uiteindelijk een nationaal overleg onvermijdelijk maakten. Het Ziekenfondsenbesluit heeft dit slechis versneld.

De vormgeving van de betaling van medisch specialisten liet evenwel op zich wachten omdat eerst een machtsstrijd binnen de medische professie moest worden beslecht. De manier van betaling was in de naoorlogse jaren de inzet van de onderhandelingen tussen de medisch specialisten en de ziekenfondsen. De uitkomst van deze onderhandelingen - een betaling per verriching - had als gevolg dat sindsdien de betaling van medisch specialisten fundamenteel verschilt van de betaling van de huisartsen. Ook hier is echter meer sprake van continuiteit dan van plotse veranderingen. De relatie tussen zieken fondsen en artsen was voornamelijk een relatie geweest tussen ziekenfondsen en huisartsen. De betaling per verrichting overheersite van oudsher bij de particuliere betalingen en werd door een steeds machtiger wordende groep wan medisch specialisten ook aan de ziekenfondsen opgedrongen.

Er werden tevens een aantal scheidslijnen vastgesteld. Zoals Schut (1995: 132) terecht stellt: ontstond met het instemmen net de loongrens en het afschermen van een gedeelte van de bevolking die hogere bedragen voor zorg moesten betalen een scheiding tussen mensen die zich konden verzekeren bij een ziekenfonds en mensen die particulier moesten betalen. De particuliere praktijk bleef bestaan, met heel eigen tariefbepalingen. Het abonnementensysteen. woor huisartsen dat al lang bestond, kwam niet ter discussie te staan. Binnen de geonganiseerde medische beroepsgroep zouden de medisch specialisten voet aan de grond krijgen en laten de LSV vormen, waardoor de besprekingen over tarieven gevoerd werden door verschillende soorten artsen. Van directe confrontaties tussen de belangen van specialisten en huisartsen was hierdoor geen sprake meer.

$\mathrm{Na}$ de strubbelingen in het eerste decennium na de oorlog trad een rust in. Er veranderde weinig. De economische toestand en de institutionele regels boden alle mogelijkheden tot een ongebreidelde groei van de gezondheidszorg en uitgebreid zelfbeheer. Toch ontkwamen de medisch specialisten niet aan het afleggen van verantwoording over de hoogte van de particuliere tarieven. De samenleving kon echter nog tevreden worden gesteld met een interne regeling van de LSV. Pas in de jaren zeventig vonden weer uitgebreide discussies plaats over de besluitworming over tarieven. Door de invoering van de Wtg veranderde weliswaar de bestuitwor mingsstructuur, maar de bestaande tarieven, hun structum en de manier van betaling werden gelegaliseerd. In dit opzicht betekende de Wtg meer een continuering van bestaande praktijken dan een breuk met het verleden, mede omdat tijdens de implementatie van deze wet de historische tarieven nauwelijks ter discussie werden gesteld. Het belangrijkste van de Wtg was dat de overheid een belangrijke wettelijk omschreven rol in de besluitvorming over larieven in de gezondheidszorg kreeg.

De organisatie van de betaling van medisch specialisten was de tijdelijke uilkonst van de interacties ussen ziekenfondsen, artsen, de overheid, werknemers, werkgevers en particuliere ziektekostenverzekeraars. De ontwikkeling van deze organisaties was geleidelijk omdat de anderen de intiatieven en praktijken wan de medische professie overnamen. De NMG heefi door zijn strategie om zelf ziekenfondsen en tariefstructuren te ontwikkelen in belangrijke mate de ontwikkeling van de beslluitworming over tarieven bepaald. Het uiteindelijke effect dat tarieven niet meer door de artsen zelr kunnen worden vastgesteld, is een tegengestelld effect van de pogingen van de georganiseerde artsen om de financièle ontwikkelingen bestuurlijk te 
beheersen. 35 De paradox is dat de oorzaken van het verlies van de financiele autonomie van de medisch specialist voor een belangrijk deel te herleiden zijn tot beleidskeuzen van zign bellangenorganisatie. Artgen wisten vaak voordelen op de korte termijn te behalen, maar zij repen tevens door bepalde keuzen een structur in het leven, warn niet altijd ten gumste van artsen machtsverhoudingen fundamented veranderden. Bimen de institutionele theorie zou men spreken van verkeerde keuzen (wrong choices) (Thelen en Stemmo, 1992: 21). Dat de uiteindelijke gevolgen tegengesteld kumnen zijn aan de geuite belangen, heeft alles te maken met de context watin zij gepercipieerd werden. Nationale uniforme tarieven zijn het gevolg van de wens van de belangenorganisaties - ook van de $\mathrm{NMG}$ - om de ontwikkelingen in de financiering wan de gezondheidszorg te beheersen. De daarbij gemakkte keuzen hebben vervolgens een besluit vormingsstructuur over tarieven gegenereerd.

Het pad van de collectivisering kan echter niet alleen verklaard worden door te verwijen natar de uitkomsten van de interacties in de constellaties van actoren. De maatschappelijke en sociaal-economische omstandigheden hebben grote invloed gehad. In de periode voor de Tweede Wereldoorlog werd de sociale strijd gevoerd. Allerlei social-economische zaken vroegen om een oplossing. De ontwikkeling van cen sociale ziektekosterverzekering en de opkomst van het ziekenfonds makten deel uit van de manier waarop de maatschappij reageerde op de individuele en collectieve sociaal-economische gevolgen van ziekte. Een andere belangrijke factor was uiteraard de economische conjunctuur. Hoe financiële beperkingen leidden tot bepaalde constructies liet de regeling rondom de specialistenpotten zien. De economische groei in de jaren zestig maakte daarentegen onderhandelingsresultaten mogelijk die tot op de dag vandaag de tariefstructuur voor medisch specialisten bepalen. Op zijn beurt heeft de sinds de jaren tachtig overheersende politieke wil om de groei van de kosten van de gezondheidszorg te beteugelen weliswaar geleid tot een neergaande tendens in de hoogte van tarieven, maar nog niet tot een andere besluitwormingsstructuur.

De inwloed van de artsen op de ziekenfondssector is heel groot geweest. In feite was de groep van de Maatschmpij ziekenfondsern de belangrijkste en omvangrijkste. In 1962 waren 48 van de 115 ziekenfondsen in Nederland voormalig Maatschappij-fonds, en was bijna 45 procent van de ziekenfondsverzekerden bij een voormalig Matschappij-fonds verzekerd (Godefroi, 1963: 100). Ook werd in 1956 nog de fusie van de drie grootste organisaties van ziekenfondsen verhinderd door de $\mathrm{NMG}$ die daarvoor de arts-bestursleden van de ziekenfondsen had beinvloed (Godefroi, 1963: 101). De positie van de Maatschappij-ziekenfondsen was van oudsher veel sterker dan die van ander fondsen. Zij hadden meer leden (gemiddeld drie keer zo veel als andere), en er was slechts éch fonds per afdeling van de Matschappij, hetgeen versnippering tegenging (Godefroi, 1963: 30). Het was ook de NMIG die probeerde door het opstellen van modelcontracten te voorkomen dat individuele artsen in onderhandelingen met beter georganiseerde ziekenfondsen het 


\section{Besluitvorming over tarieven voor medisch specialisten tussen 1986-1992: het verloop}

\subsection{Inleiding}

In dit hoofdstuk wordt de totstandkoming van de tariefbesluiten chronologisch weergegeven. Bij het opstellen van deze chronologie van de besluitvoming hebben de volgende vragen centraal gestaan. Welke gebeurtenissen vonden plaats? Welke interacties waren daarbij van belang? Wie waren de deelnemende actoren? En wat waren de overwegingen van deze actoren? De doelstelling is slechts een beschrijving te geven. Verdere analyse vindt in de volgende hoofdstukken plaats.

In de volgende paragrafen komen achtereenvolgens aan de orde de totstandkoming van de besluiten over de vergoeding voor praktijkosten, de reshuffling en de tweeslag. Een korte introducerende paragraaf gaat aan elke beschrijwing van deze beshuiten vooraf. Bovendien krijgt het Vijfopartijen Akkoord aandacht in de derde paragraaf omdat dit de context vormt voor de besluiten over de tweeslag en de reshuffling.

\subsection{De praktijkkosten}

\subsubsection{Een kort overzicht}

Zoals in het derde hoofdstuk al werd aangegeven bestaan tarieven voor medisch specialisten in Nederland gllobal gezien uit twee elementen: een inkomensgedeelte en een praktijkkostengedeelte. Bij de invoering van de Wtg in 1982 en de aanvang van de werkzaamheden van het COTG ontbreekt echter inzicht in de kosten die medisch specialisten maken. Met de verzameling van kostengegevens moet nog worden begonnen, en het COTG meent dat als gevolg daarvan het enige tijd zal duren voordat richtlijnen tot stand komen. ${ }^{.}$

Waarschijnlijk nog veel later dan men had kunnen bevroeden, komt de voorspelling van het COTG uit. Pas in 1988 komen ten behoeve wan de tarieven voor medisch specialisten richtlijnen ten aanzien van de praktijkkostenvergoeding voor medisch specialisten, werkzaam in ziekenhuizen, tot stand. Deze richtijinen bevatten de bedragen per kostencomponent die in tarieven dienen te worden verwerkt (tabel 4.1 ). 
Het besluitvormingsproces doorloopt de volgende fasen. In 1986 gooit de VNZ de knuppel in het hoenderhok door publiekelijk aan te geven dat de zickenfondsen er naar zullen streven de betaling van medisch specialisten vanuit het budget van het ziekenhuis te laten verlopen. Gaandeweg moet de VNZ de doelstellingen bijstellen en ontspint zich een discussie over de hoogte van de vergoedingen woor praktijkkosten. Onderhandelingen tussen de ziekenfondsen, verzekeraars en artsen leveren niets op. Het draait uit op een heftige discussie over richtijnen binnen het COTG, die eendwidig leiden tot een door het COTG vast te stellen tarief. Om een discussie over de vergoeding voor praktikkosten mogelijk te maken, neemt het COTG ten eerste hef principe-besluit dat elk tarief uit een inkomens - en een kostendeel bestaat. Het tarief wordt als het ware gesplitst. Vervolgens is er, na met name initiatieven van de VNZ, sprake van een onderscheid wussen kosten die de specialist maakt en die dan ook vergoed zouden moeten worden, en kosten die voor rekening van het zjekenhuis komen. De kosten die de specialist zelf makt, worden door het COTG-secretariaat beroepskosten genoemd, en de kosten in het ziekenhuis de praktijkkosten. Onder de beroepskosten vallen de componenten 1 tot en met 7 . Component 8, die voomamelik bestaat uit secretariele ondersteuning, zou volgens het secretariaat van het COTG, de ziekenfondsen en de particuliere ziektekostenverzekeraars niet aan de medisch specialist moeten worden vergoed, maar voor rekening van het ziekenhuis moeten komen. Het gevolg zou een maximale kostenvergoeding van $f 35.000$,- per jaar per specialist zijn. Uiteindelijk zal het bestuur van het COTG dit standpunt niet overnemen, zoals blijkt wit tabel 4 .1. Het bestum bepaalt dat $f 65.000$, per jaar een redeljjke vergoeding is.

\section{Tabel 4.1: De opbouw van de kostenvergoeding, richtijnen W/5600/2.1.1/1 an $\mathrm{V} / 5600 / 2.2 .1 / 1$}

1. Huisvesting

2. Algemene kosten

3. Oriêntering

4. Administratiekosten

5. Vervoer

6. Interest

7. Diversen

8. Verslaggeving en praktijkorganisanie

- personeel

- overhead
4.145,-

4.300

9.200 ,

$10.000^{-}$

4.067 .

3.117,

171,

23.760

6.240 , -

Totaal

$65.000_{4}$

De vergoedingen die in de richtlijnen van 1988 staan vermeld zijn de uitkomst van een nomatieve bepaling. Er is bekeken wat per kostenpost een redelijke wergoeding zou zijn. Dat hierbij de meningen ver uiteen lopen, valt te verwachten. Vooral de LSV verzet zich hevig, hetgeen goed te begrijpen is ondat de werkelijke kostenvergoeding op dat moment naar alle waarschijulijkheid meet dan het tweevoudige van de normatieve kostenvergoeding bedragt. Dit forse verschil is reden voor het COTG de tarieven geleidelijk aan te passen. De laatste aanpassing zou op 1 januari 1991 moeten plaatsvinden.

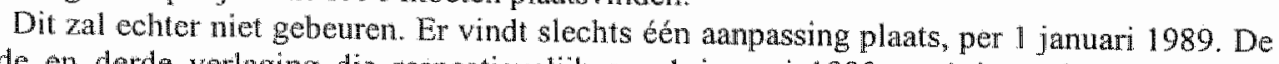
tweede en derde verlaging die respectievelijk per 1 januari 1990 en 1 januari 1991 zouden ingaan, worden in de ijskast gezet als vijf organisaties, waaronder de LSV en de VNZ, in 1989 een Raamovereenkomst ondertekenen., warvan de resulterende tariefveranderingen de verlaging van de vergoeding van kosten moeten vervangen. De overheid stemt hiermee in. 


\section{Onderhandelingen na de beleidsnota}

Hoewell reeds eerder tussen de VNZ en LSV tijdens onderhandelingen de vergoeding van de praktikkosten ter sprake is gekomen, wordt in het algemeen het startpunt van het besluitvormingsproces rondom de praktijkkosten gelegd bij het verschinen van het beleidsplan van de VNZ van maart 1986 en de daaropvolgende publicatie in het blad 'Inzet", dat uitkomt in april 1986. Het beleidsplan bereikt de LSV op 7 maart. De ambtenaren van WVC schriven aan hun staatssecretaris:

"Sinds woensdag is het conflict tussen de VNZ en LSV weer actweel. De LSW heef de onderhandelingen over de hoogte en structum van de praktikkosten afgebroken. Achtergrond. de VNZ-belerdsmota in het VNZ blad "Inzet" mP 4/1986. In reactie zeg! de LSV de overeenkomsten tussen ziekenfondsen en specialisten op per 1-6-86. Gevolg: per 1-7-87 is er geen contractuele nelatie NNZ LSW meer."2

De secretaris van de $\mathrm{VNZ}$ vat één en ander als volgt samen.

"Er is al enige jaren onvrede over wat de ziekenfondser bereiken op het gebied van de specialistenhonorering. Daarop volgde een beleidsnotitie wan de $V N Z$ aan de LSV. de specialisten zeggen de overeenkomsten op en de LSV krigi wan de specialisten een machtiging om de overeenkomst op te zeggen. De LSW wenste niet te praten over de beleidsnotitie. Dit resulteerde in bestuurlik overleg LSV-VNZ."3

En ook binnen de LSV wordt het verschijnen van het beleidsplan als het begin van een verstoorde relatie met de ziekenfondsen aangeduid.

"Het bestumplijk overleg (in het kader van het Wize Mannen-overleg, hl) met de VNZ op 19 december gaat niet door, alsnog op 22 of 23 december. Ik herinner u an de achtergronden. Belangrijk moment was het publiceren door de VNZ van het beleidsplan waarin geen relatie meer bestond tussen specialist en ziekenfonds. Fooral daarom werd per 1-7-87 het medewerkerscontract collectief opgezegd met de bedoeling de zaak te restaureren." 4

In Inzet geven de secretarissen Huffmeijer en Blanken van de VNZ aan welke doelstellingen hun organisatie in de relatie met de LSV in de komende jaren voorop zal stellen. Zij tonen allereerst thun ontevredenheid met de bestaande situatie. De honoreringsstructuur is er de oorzaak wan dat artsen meer verrichtingen doen dan gewenst is. Bovendien sluit de honoreringstructuur voor artsen niet aan bij het in 1983 ingevoerde budgetsysteem voor ziekenhwizen. Tenslotte blijken de onderhandelingen tussen de ziekenfondsen en de medisch specialisten in de afgelopen jaren niet tot resultaten te hebben geleid. De VNZ stoort zich aan wat zij de invloed van politiek-matschappelijke ontwikkelingen noemt. Daaronder wordt zowel het inkomensoverleg als de bilaterale afspraken tussen de overheid en de LSV verstan. ${ }^{5}$ Tot aan 1986 was het overleg over tarieven in feite een afgeleide van het inkomensoverleg tussen de LSV en de overheid. Afspraken over inkomens zouden moeten leiden tot tariefaanpassingen. Deze afspraken waren 20 nauwkeurig dat woor een eigen inbreng vas de zickenfondsen en zorgverzekeraars weinig ruimte meer overbleef (Baajens 1988, Scholten 1994). In de nieuwe benadering van de VNZ zijn de belangrijkste uitgangspunten dat de medisch specialistische hulp opgenomen moet worden in het ziekenhuisbudget en dat de relatie tussen productie en inkomen van medisch specialisten moet worden verbroken. Het korte termijnbeleid van de VNZ zal

2 WVC, memorandum; 27 februari 1987

3 DB VNZ, 26 november 1986

4 CB LSV, 18 december 1986

$5 \mathrm{VNZ}$, notitic Honorering medisch-specialistische hulp, 2 december 1986 
gericht zin op en betaling van de medisch specialist via het ziekenhuis, een nieuwe modelovereenkonst en en oplossing voor de goodwillproblematiek. Pas als laatste noemen de twee sectetarissen de in hun ogen veel te hoge vergoedingen voor praktjjkkosten. Die vergoedingen
"...(z)in veel le hoog en niet meer in werhouding wet de werkelike praktikkosten.
De meeste spectalisten zijn werkaam in ziekenhwizen en maken gebruik van de apparatur die in bezit is van het ziekenhus. De $\mathbb{V N Z}$ zal ook hier op korte termijn voorstellen doen." 6

Een verlaging van de vergoeding voor de praktijkkosten is dus niet de eerste prioriteit van de WNZ als de secretarissen van zich doen spreken. Pas later, in 1987, beperken de onderhandelaars zich tol de praktijkkosten. Het is ook niet het voorstel van de VNZ ten aanzien wan de praktijkkosten dat bij de LSV de meeste ophef veroorzalakt. Het voorstel de betaling voor medisch specialistische hulp onder te brengen bij het budget van het ziekenhuis waarin do specialist zijn werkzamheden verricht, geeft veel meer reden tot felle reacties. Vertegenwoordigers van de medische professie spreken de verwachting uit dat de beleidswoomemens van de VNZ er toe leiden. dat de verantwoordelijkheid voor het medische handelen in handen wordt gelegd van de ziekenhuisdirecties, dat er enkele honderden miljoenen guldens op de specialistische zorg bezuinigd zullen worden en dat het aantal specialisten zal verminderen. 7 Omdat de beleidsnotitie zo nadrukkelijk in het teken sitaat van het onderbrengen van de artsen in het ziekenhuisbudget is de LSV in 1986 absolunt niet bereid met de VNZ te over de gedane voorstellen te onderhandelen. De beleidsnotitie is voor de LSV tevens reden in mei te beshssen dat zij namens individuele medisch specialisten de medewerkerscontracten met ziekenfondsen zal opzeggen. In juli heeft al tachtig procent van haar leden de LSV daartoe gemachtigd. Daarmee creêent de LSV een probleem in de relatie met de VNZ dat de komende jaren een prominente rol zal spelen. De VNZ hecht namelijk zeer aan het herstel van het naturastelsel. In een medewerkerscontract is onder andere de rechtstreekse betaling van ziekenfondsen aan artsen geregeld. Gevolg van het opzeggen van een medewerkerscontract is dat de patiënt zelf zijn rekening moet betalen. Voor ziekenfondsen betekent het een toename van administratieve werkzaamheden; zij moeten inmers alle individuele rekeningen van patiënten gaan verwerken in plaats van een maand- of kwartaaloverzicht per medisch specialist.

Het is overigens niet alleen de VNZ die de LSV onwelgevallige voorstellen doet. De LSV meent in 1986 een algemene trend in de houding van de organisaties uit haar omgeving te bespeuren. Veel van die organisaties zouden in toenemende mate voorstander zijn van cen betaling van de medisch specialist door het ziekenhuis vanuit het budget.

"De pamacee die men meent gewonden te hebben in het kader van de bezuinigingen die de Regering wil doorweren, likt voor vele organisaties, politici etc te zijn de specialist in het ziekenhusbudget op te nemen"."

6 Inzet, nr. 4,1986, p. 6

7 Merkelbach (secretaris LSV), Medisch Contact, 1986, p. 780

8 CB LSV, 10 juli 1986. Contracten tussen medisch specialusten en ziekenfondsen worden individueel gesloten. Om dergelijke contracten op te zeggen heeft de LSV een machtiging van elk individueel lid nodig.

9 CB LSV, verslag werkbijeenkomst, 8 november 1986. In het CB LSV op 21 augustus 1986 wordt gezegd dat "in het overleg met de VNZ gesteld is dat er allerlei organisaties steeds weer 'prikkend' op de LSV afkomen". Hoe resel is deze vrees van de LSV voor het ziekenluuisbudget? De staatssecretaris van Volksgezondheid, Dees, streeft in ieder geval niet naar afschaffing van het vrije ondememersehap van de medisch specialist. Bevordering van het dienstverband van artsen ziet hij als een teveel bereden stokpaardie, warvan het kostenbesparend effect betwijfeld kan worden (Inzet, nr. 7/8, 1986, p. 8). 
De ongerustheid bij de LSV leidt tot en inteme strategiebepaling, net als uitkonst dat de nadruk zal liggen op een zakelijke in plaats van een ideologische verdediging van de wrije vestiging. Ook proberen de artsen de mening van anderen te beitnvloeden door hen te wijzen op de nadelen van een dienstverband. Zo stelt de LSV een memorandum in februari 1987 op dat onder andere an de Vaste Commissie voor de Volksgezondheid in de Tweede Kamer wordt gestuurd. De LSV laat duidelijk weten geen enkel voordeel te zien in het voorstel om de specialistische hulp uit het ziekenhuisbudget te laten betalen. 10

De VNZ komt medio 1986 tot de conciusie dat bestuarlijk overleg nodig is als middel om de onderhandelingen weer op gang te krigen. / On het bestuurlijk overleg voor te bereiden, stellen beide organisaties een Commissie van Wijze Mannen in. ${ }^{12} \mathrm{Na}$ vijf maanden vergaderen moeten de Wijze Mannen in november conchuderen, dat een eensluidend advies over de honorering en de praktijkkosten onmogelyk is omdat de meningen teveel uiteenlopen. 13 Bovendien blikkt dat de LSV slechts wil gaan onderhandelen als er niet meer gesproken wordt over het onderbrengen wan de specialistische hulp in het ziekenhuisbudget. Zij lat dil aan de VNZ in het eerste bestuurlijk overleg op 27 november weten. ${ }^{14}$

De vertegenwoordigers van de VNZ realiseren zich, dat het niet halbatar is om op korte temijn werkeligk te onderhandelen met de LSV over de voornaamste eisen uit de beleidsnotitie van maart. Zij nemen hun toevlucht tot een incrementele aanpak door de nadruk te leggen op éen van de minder belangrijke agendapunten, de vergoeding voor de praktijkkosten. 15 Zij doen het voorstel honderd procent degressie toe te passen op de inkomsten vain artsen boven het ziekenfondsdeel van de normomzet, dat vermeerderd wordt met wintig procent. De LSV weigert het voorstel te aanvaarden; zij wil een degressieregeling die slechts weinig afwijkt van de bestaande regelingen. Bovendien willen de specialisten overeenstemming bereiken over de nornen die bepalen hoe hoog een kostenvergoeding moet zijn. De oude degressiepercentages, waarnaar het voorstel van de LSV verwijst, liggen veel lager dan in het nieuwe voorstel van de VNZ. Het advies van het bureau van de VNZ aan het Algemeen Bestuur over het voorstel van de LSV is dan ook ondubbelzinnig negatief. 16 De VNZ steli vervolgens voor de vergoeding voor praktijkkosten wit het normale tarief te halen, en zich daabij te baseren op de gehanteerde

10 Memorandum LSV, Medisch Contact, 1987, nt.10, p.295-296

11 DB VNZ, 11 juni 1986

12. In de commissie van Wijze Mannen zitten de heren Leers en Huffmejer namens de VNZ, en de heren Heckman en Willems namens de LSV. De commissie word: sonns ook het zogenaande Heide-overlegr genoemd. CB LSV, 18 decenber 1986

13. Commissie van Wijze Mannen, notitie Resultaten overleg besturen VNZ-LSV t.a.*. tussen VNZ en L.SV ontstane geschilpunten, november 1986

1.4 CB LSV, 18 december 1986

$15 \mathrm{VNZ}$, nottie Honorering medisch-specialistische hulp wan 2 december 1986: "In het overleg van de commissie van Wijze Mannen is gebleken dat de LSV principieel tegenstander is van het leiden van de declaratiestroom via het ziekenhuis. Dit zou een verkapte loondienst irihouden. Onze voorgestelde honoreringsstructuur (de specialist in het ziekenhuisbudget, hil) kan dus niet wia het harnoniemodel worden gerealiseerd. Om toch een eerste aanzet te doen, stellen wij voor de praktijkkosten uit de tarieven te elimineren. De praktijkkosten kunnen via een maandelijkse vergoeding aan de specialist worden betaald."

16 WNZ, notitie Reactie op LSV-voorstel degressief systeem, 16 december 1986 
veitgoedungen in plaats van een normatieve bepaling 17 Hierover word in 1986 geen overeensterming bereik.

De discussie over de hoogte van de vergoeding voor praktijkkosten begint dus tussen de LSV en de VNZ. Dat wil niet zeggen dat in het overleg met de particuliere verzekeraars de kwestie niet an de orde komt. Op 23 september 1986 stelt de LSV aan het KLOZ normatieve kostenpakketten voor om te kunnen beslutten over nieuwe tarieven. De vertegenwoordigers van het KLOZ vinden de nomen van de LSV aan de hoge kant. ${ }^{18}$ In overleg met de KPZ wordt besloten het overleg samen met de VNZ te voeren als de LSV streef naar tarieven die zijn gebaseerd op nieuwe kostenbudgetten. 19 Ook ten aanzien van de vergoeding voor praktijkkosten in de particuliere tarieven vindt in 1986 dus geen besluitvorming plaats.

In de laatste weken van 1986 en de eerste maanden van 1987 word het VNZ en LSV duidelijk dat de standpunten sterk uiteenlopen. De onderhandelaars van de VNZ spreken in januari 1987 van een patstelling, en de onderhandelaar wan de LSV ziet op korte termijn geen overeenstemming tot stand komen. De LSV acht $f 135.000$,- redelijk, makr de VNZ vindt f 52.000 ,- voldoende ${ }^{20}$ Later zal de VNZ, in een persbericht, stellen dat de VNZ I 50.000,- per jaar het maximum vindt, en de LSV P 131.000,--21 De LSV heeft geen haast en wil "de deur naar de VNZ open houden' en de gesprekken over een normatief kostempakket voortzetten. ${ }^{22}$ De bedoelingen van de WNZ zijn echter heel anders. Het bestuur van de VNZ besluit 1 maart als absolute tijdgrens te hanteren. Mocht dan geen overeenstemming bestaan, dan zal een eenzijdig verzoek aan het COTG worden verstuurd. Dat het COTG naar alle waarschijnlijkheid met de voorstellen van de VNZ zal instemmen, maakt deze strategie aantrekkelijk. ${ }^{23}$

\section{Van onderhandelingen naar het COTG-circuit}

Na vruchteloze gesprekken in de maanden januari en februari van 1987 , breekt de VNZ de onderhandellingen met de LSV af. Volgens haar valt geen overeenstemming met de LSV te bereiken over een redelijke honoreringsstructuur. ${ }^{24}$ Begin maart doet de $\mathrm{VNZ}$ een eenzijdig voorstel aan het COTG, dat door de LSV eerder in de onderhandelingen van de hand werd gewezen. De VNZ vraagt het COTG of het realiseerbaar is een degressief systeem voor de totale ziekenfondsomzet met een degressiepercentage van 100procent in te voeren. Als dit niet mogelijk zou zijn, dan stelt de VNZ voor de tarieven voor medisch specialisten op te splitsen in een honorarium-en een kostendeel, en vervolgens de praktijkkosten uit het tarief te halen.25 De strategie van de VNZ is er op gericht door een splitsing van het tarief in een inkomensdeel en een

17 Het voorstel van de VNZ suggereert wellicht dat duidelijkheid zou bestaan over welk deel wan een tarief bestemd is voor de praktijkkosten. Dit is echter niet zo. Men hanteert slechts de vage aanname dat de arts slechts een derde van de praktijkostenvergoeding ook voor onkosten gebruikt. De rest is gewoon extra inkomen. Volgens de VMV wordt gemiddeld f $135.000,-$ per jaar an praktijkkosten uitgekeerd. Daarwan kan ongeveer f 35.000 ; aan de specialist betald worden, om de kosten van vervoer, communicatie, administratie en scholing te bekostigen, en de rest aan het ziekenhuis on de kosten die artsen maken te kunnen betalen (WNZ, notitie Honorering medisch-specialistische hulp, 2 december $1986 \%$.

18 Verslag overleg LSV-KLOZ/KPZ, 23 september 1986

19 Verslag vooroverleg KLOZ/KPZ, 23 september 1986

$20 \mathrm{DB}$ VNZ, 14 jamuari $1987, \mathrm{CB} \mathrm{LSV}, 12$ februari 1987

21 Persbericht VNZ, 26 febmari 1987

22 CB LSV, 29 januari 1987

23 De onderthandelarir wan de VNZ beklemtoont in werschillende DB-wergaderingen dat het COTG naar werluidt "op de lijn van de VNZ zou zitten'. DB VNZ, 14 januari 1987/DB VNZ, 11 februari 1987

24 Persbericht VNZ, 26 februari 1987

25 Brief VNZ aan COTG 4 maart 1987 
kostendeel een verlaging van ve vergoeding voor de praktijkkosten tot $f 50.000,-$ per juar te bewerkstelligen.

De $V N Z$ neemt deze stappen in overleg met het secretariaat van het COTG.26 Het bestuur wan het COTG stemt op 16 maart in met het principe van een splitsing van het tarief. Het besluit wan het COTG is het resultaat van een meer actiewe opstelling van het COTO. In vergelijking met andere sectoren is de onderbouwing van de tarieven voor medisch specialisten nawweliks van de grond gekomen. In de tweede helft van de jaren tachtig is deze situatie reden voor het COTG zelf richtlinen te gaam ontwikkelen. Deze plannen krijgen een krachtige impuls door de woorstellen wan de WNZ.

AI met al ziet de LSV zich geconfronteerd met een aantal initiatieven van verschillende kanten. De LSV heef een geschil met de VNZ over het beleidsplan, over de contracteerphicht en over de waag of de specialist in het ziekenhuisbudget moet. Het COTG wil de praktikkosten afsplitsen van het larief. Daarnaast heeft de overheid wensen. De staatssecretaris van WVC, Dees (VVD), wil dat het COJG werk maakt van een korting van 40 miljoen gulden op uitgaven aan praktijkkosten voor medisch specialisten. Hij heeft in januari 1987 aan het COTG gevraagd om de verlaging van de praktijkkosten ter hand te nemen omdat de Tweede Kamer per motie heeft besloten tot een bezuiniging van veertig miljoen op de praktijkkosten van medisch specialisten. ${ }^{27}$ Hierdoor wordt de rol wan een actiefCOTG nog groter. Het Centraal Bestuur van de LSV besluit am voor elk van deze onderwerpen 'te gaan liggen'. 28 De LSV protesteert hewig bij het COTG. Gewezen wordt op de structurele onderbetaling door de ziekenfondsen waardoor subsidiering door de particuliere sector via hogere tariewen optreedt, op de Wtg die een splitsing van het tarief niet toestaat, en op de onzinnigheid yan honderd procent degressie. De medisch specialisten willen een hoorzitting bij het COTG. ${ }^{29}$ Tevens will de LSV in gesprek komen met de overheid.

Ook het KLOZ benadert de LSV om van gedachten te wisselen over het probleem van de praktijkkosten. In eerste instantie heeft het $\mathrm{KLOZ}$ een afwachtende houding. Men beseft wel dat het conflict tussen de VNZ en de LSV gevolgen zal hebben voor de particuliere sector, maxar het is niet duidelijk wat er precies zal gebeuren. ${ }^{30} \mathrm{De}$ principe-uitspraak van het COTG ten anzien van de splitsing van tarieven dwingt het KLOZ tot een standpuntname. Binnen het KJ,OZ worden wel de voordelen gezien van een meer gestmuctureerde benadering van de praktijkkosten, maar men vindt tevens dat bij de anderen te weinig oog is voor de uitvoeringsproblemen voor particuliere verzekeraars. Het KLOZ besluit zich te scharen achter de VNZ ien de uitspraak van het COTG, zonder evenwel vergaande conclusies voor de particuliere sector te willen trekken. ${ }^{1}$ Ook $2 a 1$ afstemming met de VNZ moeten plaatsvinden. ${ }^{32}$

In de eerste vier maanden van 1987 worden aldus de condities geschapen voor de bespreking van de richtlijnen voor de splitsing van het tarief in kamer $V$ waar de vertegenwoordigers van KLOZ, LSV en VNZ elkaar weer treffen. Die condities zijn dat het COTG heeft besloten tot een splitsing vam het tarief in een inkomensdeel en een kostendeel, dal de $V \mathrm{NZ}$ hiertoe de aanzet heef gegeven en deze splitsing ook in richtlijnen wil vastleggen, en dat de

26 DB VNZ, 11 maart 1987

27 Brief Dees aan COTG, 28 januari 1987 . Het verzoek van de staatssectetaris word in materièle zin wel (als onderded van de tariefbesluiten van 1988) maar op deze wijze en op basis wan de brief niet uitgevoerd omdat het COTG zelf al bezig is met een kostenverlaging. Bowendien vindt een meerderheid in Kamer $V$ dat de overtheid het verzoek in de vorm van een formele aanwijzing had moeten gieten.

$28 \quad$ CB LSV 19 maart 1987

29 Brief LSV aan COTG, 17 maart 1987

$30 \mathrm{KLOZ}$, notitie Betreft: medisch specialisten, 26 februari 1987

31 KLOZ, notitie, 14 aprill 1987

32 Bestuur KLOZ, 6 april 1987. 
purticuliere verzekeraus zich enigszins aarzelend hebben geschaard achter het voorstel van de VNZ. De LSV is het eens met de splitsing var het tarief noch met een verlaging van de vergoeding voor praktijkkosten in de omvang die de VNZ voorstelt.

De besprekingen in Kaner $V$ leveren geen overeenstemming op. In de vergadering op 28 april komt een verdeeld advies tot stand. De Kamer besluit, tegen de zin wan de LSV, tot een tarief dat bestaat wit twe componenten: een inkomens- en en kostencomponent. De verhouding zal 60:40 zijn, en over de hoogte van de kostencomponent zal in het COTG gediscussieerd worden. ${ }^{3}$ Ook de hoorziting bij het COTG, op verzoek van de LSV gehouden, brengt de partijen niet nader tot elkaar; de oude stamipunten worden slechts herhaald. ${ }^{34}$ Wel heeft zich tifdens de discussies een nieuwe kwestie aangediend. De VNZ is zich af gaan vragen of het mogelijk zou zijn om de praktijkkosten te gaan verdelen in de kosten die het ziekenhuis makk voor de specialist (en die dus aan het ziekenhuis uitbetaald zouden moeten worden) en de kosten die de specialist zelf makt. Deze laatste kosten zouden aan de specialist zelf kunnen worden uitbetaald. Als een dergelijk onderscheid zou worden gehanteerd, zijn de gevolgen voor het tarief voor de medisch specialist duidelijk. Het tarief zal fors dalen. Over de mogelijkheden van deze opdeling van de praktijkkosten, alsmede over de hoogte wan het kostenpakket, zullen de VNZ en het secretariaat van het COTG contact met elkaar onderhouden. ${ }^{35}$

\section{Nieuwe onderhandelingen, maar met een bemiddelaar}

Eind mei gaan de onderhandelaars van de VNZ er vanuit dat de besluitvorming bij het COTG over de verlaging van de praktijkkostenvergoeding nog maar weinig tijd zal vergen en laten dit ook weten in een bestuursvergadering van de VNZ. Hun voorstellen, in te dienen bij het COTG, zijn al bijna klar, en de onderhandelaars zijn ervan overtuigd dat het secretariat van het COTG in zal stemmen met een aantal uitgangspunten van de VNZ. ${ }^{36}$ Dat in één en dezelfde vergadering wordt aangekondigd dat de VNZ overleg zal voeren met het secretariat van het COTG over een deling var de praktijkkostenvergoeding en dat de voorstellen daartoe al klaar liggen, duidt erop dat in de maanden april en mei tussen VNZ en COTG uitgebreid is gesproken over de mogelijke vorm en inhoud wan een voorstel tot verlaging van de praktjkkostenvergoeding.

Maar alles zal anders lopen dan de onderhandelaars van de VNZ denken. Wel dient de VNZ nog op 9 juni een eenzijdig voorstel in bij het COTG de richtlijnen voor medisch specialistische hulp te wijzigen, met als uiteindelijk doel de tarieven aan te passen op basis van een normering van de praktijkkosten. ${ }^{37}$ Mar naast het zogenaamde 'COTG-circuit' ontstaat een andere besluitvormingsarena. In de laatste weken van mei en de eerste weken van juni 1987 vindt informeel overleg plats tussen de VNZ en de LSV.38 In deze gesprekken staan twee onderwerpen central. Ten eerste het tekenen van een modelovereenkomst en ten tweede do vergoeding voor praktijkkosten. De LSV Iat weten dat de specialisten bereid zijn te praten over de ondertekening van de door de Ziekenfondsraad opgestelde modelovereenkomst, maar dat van het gedeeltelijk uitbetalten van praktijkkosten aan het ziekenhuis geen sprake kan zijn. De

\section{DB VNZ, 27 mei 1987}

Verslag hoorziting COTG nr. 70, 22 mei 1987

DB VNZ, 27 mei 1987. De VNZ vindt dat bijwoorbeeld de kosten van een studeerkamer of de auto wel and de medisch specialist moeten worden wergoed, maar niet de kosten in thet ziekenhuis. DB VNZ, 27 meil 1987

Brief VNZ aan COTG, 9 juni 1987

De exrste anzet word gegeven door Van der Griend (directeur Ziekenfonds Spaarneland), die in gespek is gekomen met een medisch specialist die lid is van het DB van thet ziekenfonds, en Blanken, onderhandelaar van de VNZ. Het contact met o.a. Houwing, voorzitter van de onderhandelingsdelegatie van de LSV, is snel gelegd; deze woont in het werkgebied van Zickenfonds Spaarneland. Bron: Van der Griend in DB VNZ, 10 juni 1987 
besluitwoming hierover buj het COTG zou dan ook stopgezet moeten worden ${ }^{39}$ De LSV is bijzonder bevreesd woor deze besluitworming, die zij als een "autonoom gebeuren" typeert.40 Wel wil de LSV door middel van een enquete onder medisch specialisten de hoogte van het kostenbedrag vaststellen. De VNZ beshuit in juni, dat er wel gepratat kan worden over de modelovereenkomst en ook over de praktijkkostenvergoeding, maar dat niet gevraagd zal worden aan het COTG de procedures te stoppen die door de éenzijdige verzoeken van de $\mathrm{VNZ}$ in gang zijn gezet. 41 Hoewel het CB van de LSV midden juni van de eigen bemiddelaars te horen krijgt dat de VNZ de intentie heeft het COTG te vragen de behandeling van haar verzoeken aan te houden, is de VNZ in brieven aan het KLOZ en de ziekenhuizen duidelijk: het is aan het COTG een uitspraak te doen over de hoogte van de praktijkkosten. ${ }^{42}$

De VNZ slaagt er in eerste instantie dus in twee gescheiden circuits in stand te houden - de besluitvorming in het COTG en het overleg met de LSV - maar raakt onder zware druk als de staatssecretaris van Volksgezondheid zich gaat bemoeien met het conflict. De overheid vindt het ontbreken van contracten tussen medisch specialisten en ziekenfondsen zorgwekkend. ${ }^{43}$ In juli intervenieert de staatssecretaris als de eerste besprekingen in mei en jwi niet tot overeenstemming leiden. Er wordt een bemiddelaar aangesteli, de heer Lamers, een voomalig topambtenaar van het ministerie van SZW. Ook hij komt in zijn eerste inventariserende gesprekken tot de conclusie dat de standpunten van de beide partijen met betrekking tot een vergoeding voor praktijkkosten ver uiteenlopen. In de laatste week van jull verklaren zowel de WNZ als de LSV zich bereid deel te nemen aan besprekingen, die zich onder meer zouden moeten richten op nompraktijkkosten, een accountantsonderzoek en een bindend advies aan het COTG op basis van het accountantsonderzoek, dat eerdere eenzijdige voorstellen zou moeten vervangen. ${ }^{4}$ Wel laat de VNZ aan Dees weten dat de ziekenfondsen geen eindeloos geduld hebben en graag zouden zien dat de besluitworming over de praktijkkosten per 1 januari 1988 is afferond. 45 Maar net als een half jaar eerder heeft de LSV geen haast. De medisch specialisten hebben tijd nodig om intern een standpunt te kummen formuleren. Ook vom de beniddeling door Lamers een goede gelegenheid de besluitvorming binnen het COTG op te houden. ${ }^{46}$

En dus begint Lamers zijn bemiddelingspoging met twee partijen die in totaal verschillende uitgangssituaties verkeren. De VNZ will zo snel mogelijk en zo veel mogelijk op basis wan bestaande gegevens de vergoeding voor de praktijkkosten drastisch verlagen, de LSV heeft daarentegen geen haast, wil een normatieve bepaling van de praktijkkosten en ziet niets in een verlaging van de vergoedingen. Wederom wordt het overbruggen van de inhoudelijke tegenstellingen zeer bemoeilijkt door het verschil van mening over de toegestane tijdsduur van

$39 \quad \mathrm{DB} V N Z 10$ juni 1987

40 CB LSW 18 juni 1987

41 DB VNZ, 10 juni 1987

42 CB LSV, 18 juni 1987/Brief VNZ an KLOZ, 29 juni $1987 /$ Brief VNZ aan besturen en directies algemene en categoriale ziekenhuizen, 29 juni 1987

43. Naast de ziekenhuizen zijn het uiteraard de consumenten/patienten die nadeel ondervinden van het conflict tussen de artsen en de ziekenfondsen. Niet alleen door de acties van de medische specialisten, maar ook door het opzeggen van de overeenkomsten. Dit is én van de belangrijkste redenen voor staatssecretaris Dees om in 1987 aan te dringen op nieuw overleg tussen de LSV en de VNZ (verslag gesprek WVC-LSV, 18 juli 1987 ).

44 Rapportage Lamers aan staatssecretaris WVC, 20 juli 1987 . Nog steeds vindt de LSV dat $f$ $130.000^{-}$- een juiste vergoeding is, terwijl de VNZ blijft vasthouden aan $f 50.000^{-}$-

45 Brief VNZ aan Dees, 29 juli 1987

$46 \mathrm{LSV}$, notitie aan CB, $27 \mathrm{juli} 1987 /$ notitic aan $\mathrm{DSB}_{n} 4$ augustus 1987 
de onderhandelingen. 47 Toch worden de partien het eens over de wenselijkheid van een bindend accountantsadvies over de hoogte van de praktikkosten, en over I januari 1988 als materièle ingangsdatum var nieuwe tarieven. Daarnast vaagt de VNZ aan het COTG de behandeling van de verzoeken tot aanpassing van de richtlinen voor praktijkkostenvergoedingen op te schorten. ${ }^{48}$ Het herstel wan de medewerkerstelatie is de VNZ wel een concessie waard. Bovendien wordt de kwestle van de betaling van en gedeelte van de praktikkostenvergoeding aan het ziekenhuis varn de agenda gehaald, en de splitsing in twee afzonderlijke tarieven blijkt voor de VNZ evenmin een halszaak te zijn. Vooruitopend op de uitkomsten van het accountantsonderzoek will de VNZ echter wel de tarieven verlagen, mede gezien de verwachte duur van het onderzoek van ongeveer anderhalf jaar. Als voorlopige oplossing is de VNZ uiteindelik bereid accoord te gaan met een jaarlijkse betaling van f 80.000, . De LSV wil daarentegen de tarieven met terugwerkende kracht ampassen, na het bekend worden wan de bevindingen van de accountants. Ook voelt de LSV nog weing voor het tekenen van de modelovereenkomst. De tegenstellingen kunnen niet uit de wereld worden geholpen, zelfs niet als Lamers emmee dreigt dat "de politiek" besluiten buiten de zickenfondsen en specialisten om zal nemen. Uiteindelijk valt in de bijeenkomst van 1 december het doek voor de bemiddeling door Lamers; de VNZ deelt mee de bemiddeling als beeindigd te beschouwen. 49 Vrij snel daarna vragt de VNZ het COTG de behandeling van de verzoeken te hervatten. 50

Tijdens de bemiddeling van drie maanden stokt de besluitvonning bij het COTG in formele zin. Omdat zij wel bij deze formele besiuitworming maar niet bij het informele overleg tussen ziekenfondsen en specialisten onder leiding van Lamers betrokken zijn, raken de particuliene ziektekostenverzekeraars buiten gesloten. De VNZ en de LSV monopoliseren de onderhandelingen waartegen het $\mathrm{KLOZ}$ in opstand komk. De particuliere verzekeraars dreigen de onderhandelende partijen dat zij zelf eenzijdige voorstellen aan het COTG zullen doen als zij niet bij het overleg betrokken worden. 51 Het antwoord van de VNZ is echter duidelijk. De ziekenfondsen willen niet dat het KLOZ een tweede gespreks- en onderhandelingspartner voor de LSV wordt. 52

\section{Opnieuw het COTG}

Na het mislukken van het Lamers-overleg belandt de kwestie van de praktijkkosten weer bij het COTG ondat de VNZ het COTG vraagt de eerdere verzoeken te gaan behandelen. Maar een actieve rol van het COTG wordt ook sterk ondersteund door de overheid nu WVC al het vertrouwen in het onderlinge overleg verloren heeft. Evenmin als de ziekenfondsen heeft het departement veel tijd. Er is sprake van politieke druk omdat WVC zijn bijdrage aan de

47 Zo meent de voorzitter van de LSV dat het overleg onder leiding van Lamers nodeloos vroeg wordt afgebroken onder druk van de achterban van de VNZ die persé voor 1 januari 1988 een resultant wil zien. "Inhoudelijk waren we het wel eens, maar als de andere partij zegt luister eens: dat traject is prachig, maar ik wens een voorschot te nemen op het pad dat we gezamenlijk hebben witgezet.... Maar ja, dat was duidelijk wan de VNZ gewoon politiek ten opzichte van de achterban. Ze zall immers met die vermaledijde vergadering van 10 december (algemene lledenvergadering wan de $\mathrm{VNZ}, \mathrm{h})$, die als een bom boven de onderhandelingstafel hing. Toen is gezegd, met de natte vinger: er moet een voorschot genomen worden van tien procent. Toen hebben wij dus nee gezegd." (Plasmans, Inzet, 1988, nr. 4) Ook bimnen het CB wan de LSV wordt herhaaldelijk vastgesteld dat de VNZ veel meer dan de LSV denkt in 'termijnen' (CB LSV, 3 december 1987).

48 Brief VNZ aan COTG, 29 september 1987

49 Rapport inzake bemiddeling LSV-VNZ, 7 december 1987

so Brief VNZ an COTG, 11 december 1987

51 Brieven KLOZ aan VNZ en LSV, 13 oktober 1987

52 Bricf VNZ aan KLOZ, 26 oktober 1987 
bezuinigingen moet leveren. Op het departement spreekt men van een 'problematiek' van meer dan weehonderd miljoen gulden in de medisch specialistische sector. Bovendien ligt er nog steeds een onuitgevoerde motie veertig miljoen op de praktijkkosten te bezuinigen. Om tot besparingen te kunnen komen maakt WVC "schoon schip"; niet langer wordt vertrouwd op het degressieve tarievenstelsel.53 Dit stelsel, warin tarieven lager worden boven een bepaalde omzetgrens, had lange tijd de voorkeur omdat de weerstand hiertegen wan de LSV minder was dan tegen algemene tariefverlagingen. In 1988 is het vertrouwen in de degressie verdwenen omdat de effecten van het degressief tariefstelsel erg tegenvallen. Voor de particuliere tarieven blijk het zelfs onuitvoerbaar te zijn. In juni 1988 rekenen zijn ambtenaren het Dees allemal nog eens woor. Het beleid van degressieve tarieven is zo ineffectief dat WVC ongeveer 1370 miljoen onder de doelstelling zit. Voor een oplossing voor het structurele gedeelte van deze f 370 miljoen. (f 225 miljoen) acht WVC de verlaging van de praktijkkostenvergoeding een geschikt middel, hoewel dan slechts sprake zou zijn van een bezuiniging van f 165 miljoen 54 In de verlaging van de vergoeding voor praktijkkosten ziet de overheid wel een mogelijkheid on temminste een deel. van de bezuinigingen to stand te brengen. Het duidelijkst over de verandering van beleid is Dees in een brief aan het KLOZ warin hij desgewragd toegeeft '...dat ik inderdaad geconcludeerd heb dat de degressie binnen de particuliere sector niet van de grond zal komen. Daarom heb ik besloten de hiennee verbonden structurele takstelling op een andere wijze te effectueren. Hiertoe heb ik een relatie gelegd met de te verwachten verlaging wan de praktijkkosten.' 55 Tenslotte vindt men bij WVC dat het COTG zijn tak moet kunnen vervullen, eventueel geholpen door een aamwijzing. In infonmele gesprekken laat de staatssecretaris ook aan de LSV weten dat wat hem betreft de besluitvoming vanaf nu binnen het COTG verloopt. ${ }^{56}$

Daarmee is de arena weer verschoven in een richting die door de LSV als bijzonder bedreigend wordt ervaren. ${ }^{57}$ De eerste stap van het COTG is een gerichte adviesaanvraag aan Kamer $\mathrm{V}$ ten behoeve van het opstellen wan richtlijnen ten aanzien van het kostenbestanddeel van de tarieven. De leden van $K$ amer $V$ wordt gevragd advies te geven over richtlijnen voor 8 kostencategorieèn. Omdlat het COTG verwacht dat de besprekingen moeizam zullen verlopen, wordt voorgesteld dat de Kamer zich een tijdslimiet oplegt. Ook zou kunnen worden overwogen de weranderingen in de tarieven gefaseerd te laten verlopen als de tariefveranderingen groot zouden zijn. 58 De behandeling van de adviesaanvraag in Kamer V leidt, zoals verwacht, niet tot

53 Reeds in een eerste reactie op het rapport van Lamers geeft WVC and dat het roer drastisch om moet (Voorlopige reactie van Staatssecretaris van WVC op rapport Lamers, december 1987). En in een brief aan de Tweede Kamer wit Dees zijn teleurstelling over het mislukken wan het overleg onder leiding van Latmers. Hij legt daarbij de zwarte piet bij de LSV, ondat ook de uitwoering van het Generaal Akkoord is spakkelopen (Brief Dees aan Tweede Kamer, 14 januari 1988).

54. WVC, notitie aan staatssecretaris t.b.v. overleg LSV, 22 juni 1988

55 Brief WVC aan KLOZ, 6 april 1988. De beleidswijziging van Dees vali overigens niet in goede aarde bij het KLOZ. Daar vindt men dat het niet innen van de degressie een niet verdiend 'douceurtje'voor de specialisten is. Bovendien vindt men dat de opbrengst van de praktijkkostenmaatregelen in de tokkomsd zal worden genoten, en dus niets the maken heeft met de degressicopbrengst van het verleden (KLOZ, notitie Betreft: afloop bemiddeling Lamers conflict. VNZ en LSV, 11 maart 1988

56 CB LSV, 17 december 1987

57 CB LSV, 17 decenber $1987 / \mathrm{cb} \mathrm{LSV}, 18$ januari 1988

58 CoTG, nota 88-16. De kostencategorieën zijn: 1. huisvesting, 2. autokosten, 3. administratieve kosten, 4. nascholing, congressen en vakliteratuur, 5. algenene kosten, 6. divergen, 7. interest, 8. kosten verslaggeving. Overigens makt het COTG in de advicsaanvraag de opmerking dat het wellicht beter is te spreken wan beroepskosten, zijnde de kosten die buten het ziekenhuis worden gemaakt en die ten laste komen van de medische specialist zelf. Andere kosten, samenhangend met het woeren van een praktijk in een ziekenhuis, zouden praktijkkosten genoemd moeten 
een eensgezind standpunt. Na verschillende bijeenkomsten komt een verdeeld advies tot stand. De verzekeraars zijn het eens met de benadering van het COTG, de LSV stelt vraggtekens bij de beleidsuitgangspunten van het COTG. De LSV vind dat nieuwe tarieven alleen tot stand kunnem komen als alle onderdelen van het tarief bekeken worden (dus ook het nominkomen en de normprakdijk) terwijl de anderen van mening zijn dat tarieven aangepast kunnen worden op basis van veranderingen van slechts een enkele component. Verder kan de LSV zich niet veremigen met het gebruik van gegevens uit 1977. Bovendien moet volgens de specialisten bij de praktijkkostem een onderscheid tussen specialismen gehanteerd worden. Tenslotte zijn er forse: verschillen van menirg over de hoogte van de kostenposten. 59

De medisch specialisten en de verzekeraars kunnen het over geen enkele kostenpost eens worden. De voorstellen van de verzekeraars en het secretariaat van het COTG komen daarentegen grotendeels overeen. Dit is het resultaat van onderlinge afstemming. De activiteiten van de verzekeraars en het secretariaat worden onderling gecoördineerd. Zo spreken het KLOZ en de $\mathrm{V} N \mathrm{Z}$ al in maart af zoveel mogelijk 'op éen lijn te blijven met het COTG-secretariaat".60

\section{Tabel 4.2. Standpunten in met 1988}

\begin{tabular}{|c|c|c|c|}
\hline Kostempost & $\mathrm{LSV}$ & VNZIKLOZ & COTG \\
\hline Huisvesting & 6.444 & 4.145 & a \\
\hline Algemeen & 4.913 & 4.300 & 4.300 \\
\hline Oriëntering & 11.987 & 7.200 & 7.200 \\
\hline Administratie & 37.170 & 5.500 & 10.000 \\
\hline Vervoet & 14.173 & 3.358 & 4.067 \\
\hline \multirow[t]{3}{*}{ Interest } & 7.011 & 0.193 & 2.200 \\
\hline & & VNZ: 1.844 & \\
\hline & & KLOZ: 1.006 & \\
\hline Interest goodwill & 12.158 & - & - \\
\hline Diversen & 7.000 & 0.500 & 0.500 \\
\hline Verslaggeving & 37.475 & - & - \\
\hline \multirow[t]{2}{*}{ Totaal } & 138.331 & VNZ: 27.040 & 28.267 \\
\hline & & KLOZ: 26.202 & \\
\hline
\end{tabular}

Brom: COTG V 88.11

Het verschil tussen de voorstellen wan de "coalitie" en de LSV lijkt haast onoverbrugbaar nu ook de VNZ het standpunt aanzienlijk heeft verscherpt. In plaats van een totaal van $\mathrm{f} 50.000$,zoals eerder in de onderlinge onderhandelingen werd geboden of $f$ 80.000,- tijdens de bemiddeling door Lamers) is de VNZ nu van mening dat $\mathrm{f} 27.000$, voldoende is. Belangrijks oorzak van deze anpassing van het standpunt is, dat tijdens de discussies in kamer V de VNZ heef ingestemd met het voorstel van het COTG-secretariaat onderscheid te maken tussen beroepskosten en praktijkkosten. Tot de beroepskosten behoren alle kosten die de specialist

worder.

59 CoTG V 88-11, Richtijnadviezen Kamer V praktijkkostenbestanddelen in tarieven medisch specialisten (zitekenfonds en particulier)

$60 \mathrm{KLOZ}$, notitie Betreft: vaststelling praktijkkostenpakket medisch speciallisten. Overleg COTG Kamer V. 11 maart 1988 
buiten het ziekenhuis maakt en administratieve werkzaamheden die bestaan uit de financiele administratie en facturering. De praktijkkosten zijn die kosten die gemaakt worden in het ziekenhuis zoals bijvoorbeeld de personeelskosten van een secretaresse die zich deels bezig houdt met verslaggeving die tot nog toe voor rekening kwam van de specialist. Verslaggeving betreft het geven van verslag aan huisartsen en medebehandelaars. Dit zijn volgens het secretariaat van het COTG kosten van registratie van gegevens met betrekking tot de medische behandeling, die niet tot de beroepskosten van een arts behoren. Praktijkkosten zouden wolgens het secretariaat van het COTG, en dus ook volgens de verzekeraars, aan de ziekenhuizen in de vorm van een budgetverhoging moeten worden vergoed. De verharding van het standpunt van de $\mathrm{VNZ}$, en daarmee de verscherping van het conflict met de medisch specialisten, is dus toe te schrijven aan de initiatieven van het COTG. Overigens past het voorstel om de vergoeding voor praktijkkosten onder te brengen in het ziekenhuisbudget zeer goed in de beleidsvoornemens die de VNZ begin 1986 publiceerde. Op deze suggestie reageren de ziekenhuizen overigens heel terughoudend. De Sectie Ziekenhuizen van de Nationale Ziekenhuisraad laat aan het COTG weten dat van betaling van praktijkkosten aan ziekenhuizen pas sprake kan zijn als specialisten, ziekenhuizen en het COTG het eens zijn geworden over om welke kosten het gaat. De ziekenhuizen zijn bezorgd over het ontstaan van conflicten tussen specialisten en directies bij het gebruik maken van ziekenhuisvoorzieningen. ${ }^{61} \mathrm{De} \mathrm{NZr}$ probeert deze dreiging te bestrijden door eerst de betrokkenen op te roepen tot een oplossing te komen en daarna, in samenwerking met de Landelijke Patiënten/Consumenten Platform (LPCP), in een gerechtelijke procedure de acties onrechtmatig te laten verklaren.

De LSV omschrijft de uitkomsten van het overleg in Kamer V als 'zeer minimaliserend'. Als de vergoeding voor praktijkkosten inderdaad verminderd zou worden tot ongeveer $f 26.000,-$, dan zouden de tarieven volgens eigen berekeningen met ongeveer 28 procent dalen. 62 Om dit te voorkomen richten de specialisten hun aandacht op de discussie in Kamer $V$ die zij willen beïnvloeden door zelf voorstellen bij het COTG in te dienen. Daarnaast stelt de LSV het bestuur van het COTG en het departement van WVC op de hoogte van hun bezwaren tegen de gang van zaken. Het zijn de bezwaren die al in Kamer V naar voren worden gebracht: er worden verouderde gegevens gebruikt (gegevens van de zogenaande commissie Van Mansvelt uit 1977 die geëxtrapoleerd worden), een verlaging van het kostendeel van een specialistentarief mag niet omdat het tarief in zijn geheel moet worden bekeken, het COTG maakt ten onrechte onderscheid tussen kosten binnen en buiten het ziekenhuis en gaat zijn boekje te buiten door voor te stellen dat een gedeelte van de kostenwergoeding aan het ziekenhuis moet worden betaald, en de uitkomsten van een enquête onder medisch specialisten over praktijkkosten zijn onmisbaar voor een besluit over een normatief kostenpakket. WVC zou een 'correctie' moeten uitvoeren ${ }^{63}$ In een reactie laat Dees echter weten dat hij het beleid van het COTG steunt en dat hij geen enkele aanleiding ziet om een correctie uit te voeren. ${ }^{64}$ Met de besluitvormende vergadering van het

61 Brief $\mathrm{NZr}$ (Sectic Ziekenhuizen) aan $\mathrm{COTO}_{3} 7$ juni 1988. Een treffend voorbeeld van de gevolgen van specialistenbeleid voor ziekenhuizen vormt de introductie van de eigen bijdrage van $f 25$, woor een eerste bezoek aan een specialist ("specialistengeeltje"). Het Academisch Medisch Centrum in Amsterdam rekent voor dat deze maatregel in zijn geval 1 miljoen gulden moet opbrengen maar omdiat, naar verwachting, de helft van de patiënten de rekening niet zal betalen en ongeveer f 500.000, nodig is voor administratie- en inningskosten zal het ziekenhuis op een verlies van 1 miljoen moeter rekenen (De Volkskrant, 1 februari 1988).

62 LSV, notitie Consequenties van het COTG woorstel inzake nieuw kostenpakket, 3 maart 1988

63 Brief LSV aan Dees, 14 april 1988/Brief LSV aan COTG, 7 juni 1988

64 Brief Dees aan LSV, 9 mei 1988 
bestuur van he COTG op 20 juni in het wooruitzicht doet de LSV op 14 juni een beroep op liet COTGmestuur niet in te stemmen met het voorstel wan het secretariaat. 65

Het bestuur van het COTG kiest voor een compromis. Het stelt op 20 jun richtlijnen vast die inhouden dat de kostenvergoeding $f 65.000$,- per jaar zal bedragen. Volgens het COTG moeten de zogenoemde beroepskosten worden vergoed alsook de kosten van een halve administratieve kracht ten behoeve van de werslaggeving. Met andere woorden, de secretariele ondersteuning blijt in het kostenpakket wan de medisch specialist. De wens van de $\mathrm{NZ}$ r deze kosten niet onder te brengen in het ziekenhusbudget speelde een rol voor het COTG. Ook zou door de overheid op basis van de kostenbesparing een bedrag kunnen worden gereserveerd voor de afkoop van de goodwill. Het resultaat zal een gemiddelde tariefdaling van 12 procemt zijn. ${ }^{66}$ In verband met deze consequenties zal het COTG aan Kamer $V$ vragen om een gefaseerde witwoering te bedenken. Eind juni vraagt het COTG de staatssecretaris deze richilinen goed te ketren. Het COTG laat daarbij weten dat het gaat om een verlaging van $f$ 42.000, - per individuele specialist, en dat op macroniveau een besparing van $\mathrm{f} 230$ miljoen bereikt zal worden als het besluit geheel wordt uitgevoerd. De verlaging zou moeten ingaan op 1 januari 1989 , naar eerst dient het COTG eeth besluit te nemen over de vertaling van de richtlijnen in nieuwe tarieven. Er zou sprake moeten zijn van een gefaseerde verlaging. 67

Nog voordat de statssecretaris zujn goedkeuring kan hechten aan de richtlinen, laat de LSV weten dat hij zal worten gehouden aan de afspraken van het Generaal Akkoord wit 1984 tussen overheid en LSV. Eerder al hebben WVC, SZW en EZ aan de LSV laten weten dat zij, in overeenstemming met de beleidsvoomemens die de staatssecretaris in januari uitte, op korte temijn het Generaal Akkoord zullen opzeggen. De doelstellirigen zijn slechts gedeeltelijk gehaald, met name door de opstelling van de LSV.68 De LSV spant daarop een rechtszaak aan tegen de drie betrokken mirnisteries. De voorgenomen richtlijnen en hun goedkeuring zijn volgens de LSV in strijd met het Generaal Akkoord. De LSV benadrukt in 1988 werschillende malen publiekelijk dat de initiatieven tot het reduceren van tarieven op gespannen woet staan met de afspraken van het Generaal Akkoord. Al in februari 1988 schrijft de voorzitter:

"Fen ingreep in de farieven zou met andere woorden niet alleen onredelijk, maar voonal ook ondoelmatig zijn. Onredelijk, omdat de waststelling wan de tarieven dient te geschieden volgens de afspraken in het Generaal Akkoord. zowel ten aanzien van het kostendeel als ten aanzien van het honorariumdeel." (Medisch Contact. 11r.5, p. 43)

\section{Brief LSV aan COTG, 14 juni 1988}

66 Persbericht COTG, 20 juni 1988. De LSW noemt het besluit het gevolg van een 'globale' benadering van de voorzitter van het COTG. Het ging erom of thet totaal (f $65.000_{,}$) acceptabel was, waarbij de voorzitter vond dai de bedragen van de LSV sterk overtrokken waren, maar ook dat het secretariaat van het COTG wel erg 'in de min was gaan zitten' (CB LSV, 20 juni 1988). 
1. Huisvesting

2. Algemene kosten

3. Oriëntering

4. Administratiekosten

5. Vervoer

6. Interest

7. Diversen

8. Verslaggeving en praktijkorganisatie

- personeel

- overhead
4.145,

4.300,

9.200 ,-

10.000

$4.067,-$

$3.117,-$

$171,-$

$23.760,-$

$6.240,-$

Totaal

$65.000,-$

Woorden van gelijke strekking komen uit zijn pen in april 1988:

"Voor de goede orde: de LSV is van haar kant voor zover mogelijk de in het Generaal Akkoord gemaakte afspraken nagekomen en zal dit ook blijven doen. Wij blijven derhalve bereid, zoals wij de minister ook hebben laten weten. tot een onderzoek dat op evenwichige wijze aandacht besteed aan zowel inkomen als kosten, alsook aan de werkbelasting. En...als die gegevens voophanden zijn en zij zouden tot een tariefverlaging aanleiding geven, dan zal dat alsdan ook gebeuren. want afspraak is mu eenmaal afspraak. Maar zolang dergelijke gegevens niet voorhanden zijn, zal iedere tariefverlaging of poging daartoe op verzet kumen rekenen..." (Medisch Contact (nr. 16, p. 43)

De ministeries worden op 16 juni gedagvaard, nog voor de besluitvorming door het COTG. ${ }^{69}$ De Arrondissementsrechtbank in Den Haag bepaalt vervolgens dat de overheid de richtlijnen niet mag goedkeuren zolang het Generaal Akkoord niet is opgezegd. De overheid is wel gerechtigd het Akkoord op te zeggen, maar daarvoor dient eerst nog overleg met de LSV plaats te vinden. De bewindslieden en de LSV overleggen ook, onder protest van de ziekenfondsen en de ziektekostenverzekeraars. Zij vrezen dat oude tijden herleven en dat een nieuw Generaal Akkoord gesmeed zou kunnen worden. Dergelijke "pacten' zijn in strijd met de Wtg. Zij verzoeken de staatssecretaris de LSV te verwijzen naar de procedures van de Wtg en Wivb. Ook waarschuwen $\mathrm{VNZ}, \mathrm{KLOZ}$ en $\mathrm{KPZ}$ de staatssecretaris voor suggesties van de LSV tot oplossing van de honoreringsproblemen, die "theoretisch mool maar praktisch onuitvoerbaar" zijn. Dit overleg levert echter niets op, waarna op 13 juli de overheid het Generaal Akkoord opzegt. ${ }^{70}$

Op dit moment ligt de weg open voor de statssecretaris van WVC de richtlijnen goed te keuren. De richtlijnen zijn op verzoek van betrokken partijen zelr tot stand gekomen, de besluitvorming, waar de LSV bij betrokken was, verliep zeer zorgvuldig en bovendien passen zij bij de bezuinigingsdoelstellingen, argumenteert WVC.71 De LSV blift echter proberen de besluitvorming door de staatssecretaris te beilnvloeden. De specialisten schrijven verschillende brieven met argumenten om de richtlijnen niet goed te keuren. Daarbij verwijst de LSV naar

69 Dagvaarding, 16 jum 1988 .

70 Brief VNZ, KLOZ, KPZ aan de minister-president, minister wan $\mathrm{SZW}$, en de staatssecretarissen van EZ en WVC, 18 jun $1988 / B r i e f$ VNZ aan de minister-president, de minister van SZW en de staatssecretarissen van EZ en WVC, 1 juli 1988

71 WVC, notitie Positie staatissecretaris WVC goedkeuring COTG richtlinen praktijkikosten medisch specialisten, 15 juli 1988 
onderzoken door het bureau KPMG die aantonen dat voor intermisten en chirurgen de werkelijke praktjkkosten respectievelijk f 114.200 en f 132.500 bedragen. Daamaast is een uniform kostenpakket voot alle speciallismen onrechtvaardig en is een halve secretaresse te weinig voor het vele administratieve werk ${ }^{72}$ De staatssecretaris geef echter niet toe. Als de LSV nieuwe gegevens heef, moeten deze maar in het COTG bediscussieerd worden, en met de onderhandelingspartners. Bovendien geef Dees eind augustus aan dat een besluit van hom ansstaande is. 73

\section{De overheid geeft ruimte aan nueuw overleg: het Dekker-overleg als prelude}

En dus Hijken in augustus 1988 alle posities vast te staan. Het COTG heeft zich uitgesproken, VNZ, KLOZ on KPZ hebben hun tevredenheid daarover getoond, de statssecretaris zal op korte termijn de richtlinen goedkeuren en de rechter heeft de bezwaren tegen de richtlijnen en hun goedkeuring afgewezen. De ISV ziet geen kans haar argumenten door anderen te laten overnemen. Alles wijst op een definitieve afronding wan de besluitvorming over de praktikkostenvergoeding voor medisch specialisten. Maar in de labste week van juli hebben enkele informele gesprekken platsgevonden. Zo hebben de voorzitter en de ondervoorzitter van de LSV met Dekker gesproken. Dekker, voormalig topman van Philips, zat de commissie voor die in februari 1987 een invloedrijk structumrrapport over de gezondheidszorg publiceerde. Afgesproken is dat Dekker nader gedocumenteerd zal worden. Ook hebben informele gesprekken met de voorzitter van de VNZ plaatsgevonden, onder meer over een normatief kostenpakket. ${ }^{74}$ Deze gesprekken monden uit in een gesprek op 31 augustus tussen KLOZ, VNZ, NZr en LSV onder leiding van Dekker. Dekker laat aan Dees weten dat er sprake is van
"... (g)rote zorg van betrokkenen over zich toespitsende verhoudingen en de schade aan de huidige en toekomstige gezondheidszorg. Er is een grote bereidheid bij betrokkenen om praktische plannen wit te werken, passend in het rapport-Dekker. voor concrete resulicaten." 75

Wel is van belang de huidige situatie voor 4 weken te 'bevriezen".76 Met andere woorden, de formele procedure ten aanzien van de goedkeuring van de richtlijnen dient met minimal een maand te worden verlengd. Dees laat weten dat het overleg deze tijd wordt gegund, maar ook dat WVC de aanstaande goedkeuring van de richtijnen van 20 juni slechts zal heroverwegen als het alternatieve voorstel van het Dekker-overleg de goedkeuring krijgt van het COTG. ${ }^{7}$. Dees laat aan het CO'TG weten dat het Kabinet heeft besloten de situatie vier weken te 'bevriezen', in afwachting van de resultaten die Dekker boekt. 78 De randvoorwaarden van WVC en VNZ $21 j n$ echter streng. Voor WVC mogen de eventuele afspraken niet leiden tot hogere praktijkkosten dan de richthijen van het COTG aangeven. De marges moeten gevonden worden in een fasering van de verlaging van de tarieven. ${ }^{79}$ Voor de VNZ zijn de richlijnen zelfs onbespreekbaar; de enige concessie zou een fasering van de uitvoering van de richtlijnen kunnen zijn, teneinde de "pijn" van de specialisten te verzachten. Eigenlijk, zo vindt het bureau van de VNZ, zijn er voor de $V N Z$ geen goede redenen mee te doen met het overleg. De rol van de $N Z$ is onduidelijk, de eensgezindheid met het KLOZ kan gevaar garn lopen, de tijd is zeer beperkt, en bovendien is in het verleden gebleken dat er' interne" spanningen bestaan. De enige reden tot deelname zou zijn

Brieven LSV aan Dees, 14 juli, 28 juli en 16 augustus 1988

Brief Dees aan LSV, 25 augustus 1988

CB LSV, 18 augustus 1988

Telex Dekker aan Dees, 31 augustus 1988

Telex Dekker aan Dees, 31 augustus 1988

79 WVC, nota Vrijgevestigde medische speciatisten (Dekker-marges), 8 september 1988 
het herstel van de contractuele relatie tussen specialisten en ziekenfondsen af te dwingen. 80 De LSV ziet meer voordelen in het overleg (men wil de COTG-besluitvorming een halt toeroepen), hoewel ook de specialisten beseffen dat een alternatief voor het richtlijnenbesluit van 20 juni de goedkeuring behoeft zowel van het COTG als van verschillende ministeries. ${ }^{81}$

$\mathbb{N a}$ besprekingen in de maand september wordt witeindelijk een concept-convenant ontworpen. De belangrijkste elementen zijn een uurtarief voor medisch specialisten wan f 200 ,en een herstel van de contractuele relatie tussen ziekenfondsen en specialisten. Op 29 september moet Dekker echter aan de partijen laten weten dat het VNZ-bestuur het concept-convenant afwijst. Het KLOZ haakt reeds eerder af omdat het terugbrengen van de verschillen tussen tarieven voor particulier verzekerde patiënten en ziekenfondspatiënten niet geregeld kon worden. ${ }^{82}$ Dekker concludeert vervolgens dat het geen zin heeft het overleg voort te zetten. 83

Onmiddellijk krijgt de staatssecretaris van WVC van zijn ambtenaren te horen dat niets meer het goedkeuren wan de richtlijnen verhindert. ${ }^{84}$ Op 5 oktober is er nog een latste bestnurlijk overleg tussen enkele bewindslieden en de LSV. Nogmaals geeft Dees aan dat naar zijn mening de besluitvorming over de vergoeding voor praktijkkosten zorgvuldig is verlopen, dat het COTG de plek is waar gediscussieerd moet worden en dat er sprake was van een 'bottomup proces' waarin ieder heeft geparticipeerd. Noch hij noch de minister wan SZW (De Koning), betrokken bij het overleg vanwege besluiten over het normatieve inkomen van de artsen, is bereid te onderhandelen met de specialisten. ${ }^{85}$ Op 6 oktober keuren de bewindslieden de richtijinen van het COTG goed, waana de dag daama de Tweede Kamer wordt ingelicht. Besloten is aan het COTG mee te delen dat de praktijkkosten op 1 januari 1990 gemiddeld $f$ 80.000 moeten zijn, zodat sprake is van een geleidelijke verlaging wan de vergoeding voor praktijkkosten. ${ }^{86}$ Hoewel de LSV het bestuur van het COTG probeert te beïnvloeden door te wijzen op de willekeurige en onaanvaardbare resultaten van de voorstellen van het secretariaat van het COTG, besluit het op 17 oktober toch tot richtlijnen voor tariefmutaties, die een verlaging van de tarieven voor medisch specialisten op basis van de reeds goedgekeurde

80 VNZ, notitie Overleg LSV/NZr/VNZKKLOZ, 6 september 1988

$81 \quad$ CB LSV, 13 september 1988

82 KLOZ, verslag voortgang overeenkomst LSV-VNZ-KLOZ-NZI sinds 14-9-88

83 Telefax Dekker aan Dees, 30 september 1988. De betrokken partijen zijn het er over eens dat de VNZ zich niet zeer constructief heeft opgesteld. De LSW wijt de late afwijzing van het conceptconvenant door het VNZ bestuur aan interne tegenstellingen bij de VNZ. Het KLOZ verwijt de ziekenfondsen een "conserwerende houding omdat zij zich alleen zouden hebben willegy richten op het ondertekenen van een modelowereenkomst. Andere zaken, zoals de verschillen tussen ziekenfonds- en particuliere tariewen, waren onbespreekban (KLOZ, Verslag voortgang overeenkomst LSV-VNZ-KLOZ-NZr sinds 14-9-88). Ook Dekker heeft zich verkeken op de bereidwilligheid van de $V N Z$; in zijn fax aan Dees geeft hij aan dat de afwijzing door de VNZ geheel onverwach kwarm.

84 WVC, notitie LSW/VNZ/KL.OZ/NZT onderhandelingen onder leiding van W. Dekker, 29 september 1988

85 Brief SZW aan LSV (concept-verslag B.O. dd 5 oktober 1988), 24 oktober 1988

86 Brief WVC/SZW aan COTG, 7 oktober 1988/Persbericht WVC, 6 oktober $1988 /$ Handelingen Tweede Kamer, 1988-1989, 16507, nr. 70. Gelijktijdig met het besluit over de praktijkkosten neemt het kabinet een besluit over het norminkomen voor specialisten. Uit interne stukken van de ministeries blijkt dat in interdepartementaal overleg is besloten voorrang te geven aan hef besluit over de praktijkkosten, en zich soepel op te stellen bij het vaststellen wan het normatieve inkomen. Dit om de "pijn' bij de artsen enigszins te verzachten. Ook is de soepelheid van $\$ Z$ W ie werklaren uit de tanende aandacht die bij $\$ Z W$ voor inkomensbeleid voor medisch specialisten bestat. 
richtlinen betekenen. 87 In novembet keurt WVC de richtlinen goed warm vast is komen te liggen dat op 1 januari 1989 de praktijkkosten tot 100.000 - zullen worden verlaagd, op 1 januari 1990 tot f 80.000 ,-, wama op 1 januari 1991 het niveau van $(65.000,-$ moet zijn bereik4.88 Ook bij deze goedkeuring negeert de overheid de bezwaren van de LSV die haar nogmaals bereikt hebben. 9 Protesten van de specialisten bij andere instanties hebben eveneens geen invloed. 90 Eind nowember stelt het COTG overeenkomstig de richtijmen tarieven vast. 91

\subsection{Het Vijf-partijen Overleg}

\subsubsection{Inleiding}

De uiteindelijke besluitvorming over de praktijkkosten geeft aan dat de LSV haar belangen eind 1988 niet meer effectief kan behartigen. Desalniettemin kan het COTO geen uitvoering geven aan de kostenrichtlijnen voor 1990 en 1991 omdat vijf organisaties (KLOZ, KPZ. VNZ, LSV, NZr) daarwor in de plats andere tariefvoorstellen doen op basis van het zogenoemde $V$ ijfpartijen Akkoord (VPA) van december 1989. Daaraan is lang overleg voorafgegaan onder leiding van voormalig minister Van Aardenne. Door het VPA wordt een ruil mogelijk: WVC is bereid zijn goedkeuring te hechten aan de voorstellen van de vijf organisaties omdat de beloofde financiele opbrengst de verwachte gevolgen van de kostenrichtlijnen evenaart. Bovendien houdt het VPA tevens herstel wan de bestuurlijke rust woor enkele jaren in. Ook dit is zeer wenselijk voor WVC met het oog op de herstructurering van de zorg.

Her VPO is de organisatorische context warbinnen de afspraken over de tweeslag en de reshuffling tot stand komen. Bovendien komen binnen het VPO de organisaties tot het besluit het COTG te wragen de uitvoering van de kostenrichtlijnen stop te zetten. Daarom zal in deze paragraaf een korte beschrijving volgen. Het belangrijkste onderdeel van het VPA is evenwel het macrobudget voor medisch specialistische zorg dat voor drie jaren zal gelden. Het macrobudget is de voomaamste reden voor de overheid om, ondanks twijfel over de juridische mogelijkheden van verschillende onderdelen, het VPA toch vertrouwen te schenken.

Het maken van onderlinge afspraken is éen ding, de tarieftechnische uitvoering iets anders. Ten behoeve van een juiste uitwoering is de betrokkenheid van het COTG bij de vormgeving van de definitieve tariefbesluiten onmisbaar. Het COTG blijkt andere criteriat te hanteren dan de onderhandelaars, hetgeen leidt tot een soms langdurig proces van afstemming. Deze en andert factoren hebben tot een forse vertiaging bij de uitvoening wan het VPA geleid. Veel van de

87 Brtef LSV an COTG, 10 oktober 1988. Het COTG moel richthinen opstellen om er voor te zorgen dat de hoogte wan $\mathrm{f} 65,000$, in de tarieven verwerkt kan worden. Daarnaast moet uiteraard de fasering in richtlignen wast komen te liggen.

88 Briaf WVC aan COTG, Besluit goedkeuring richlijnen inzake medisehe specialisten, 10 novermber 1988

89 Brief LSV aan WVC, 3 november 1988

9020 makk de LSV aan de leden van de Eerste en Tweede Kamer haar bezwaren kenbaar (briel 3 november 1988), protesteert $\mathrm{zij}$ in de door haar aangewragde hoorzitting bij het COTG (COTG. verslag hoorzitting 3 november 1988 ) en heef zij reeds eerder bij het Haagse Gerechtshof beroep aangespannen tegen de uitspraak van de Arrondissementsrechbank. Het Hagse Gereehtshof doet echter de uitspraak dat alle vorderingen wan de LSV zijn afgewezen (Uitspraak Haagse Gerechtshof, 17 november 1988 ).

91 Overigens gaan de particuliere tarieven per 1 januari met 6 procent omboog omdat de verlaging van de kostenvergoeding meer dan gecompenseerd wordt door andere tariefbesluiten van her COTG. Persbericht, 19 oktober 1988 
afspraken moeten nog worden gerealisecrd als de looptijd vatn het Akkoord formeel geeindigd is. 92 Het grootste knelpunt betreft de tariefsverlagingen die nodig zijn als gevolg vari forse stijging wan de uitgaven woor medisch specialistische hulp na 1989. In het Financieel Owerzicht Zorg 1994 wordt gesproken van een overschrijding van 463 miljoen gulden in 1992. Daarmee 2 inn de totale uitgaven voor medisch specialistische zorg sinds 1989 met 16,8 procent (inclusief psychiaters met 20,7 procent) gestegen. ${ }^{93}$ De overschrijding in $1990 \mathrm{kan}$ nog door een algemene tariefsverlaging worden gevolgd, alhoewel deze pas tot stand komt na langdurig overleg warin ook het ministerie van WVC nadrukkelijk participeert. Het blikt evenwel niet mogelijk de overschrijdingen in de jaren 1991 en 1992 door tariefsverlagingen te compenseren omdat men het in het Vijf-partijen Overleg niet eens kan worden. De door de overheid eenzijdig afgekondigde tariefsverlagingen die daarop volgen brengen weliswaar besparingen tot stand, maar herstellen eveneens de kille bestuurlijke betrekkingen van voor het VPA.

\subsubsection{Geleide onderhandelingen en een incomplete ruil}

In het begin van 1989 beschrijft de woorzitter van de LSV de situatie bijzonder treffend.

"De LSY heeft het in 1988, als het gaat om de relaties met andere groeperingen binnen het maatschappelik verkeer niet gemakkelik gehad. De overheid wilde af wan een owereenkomst en wilde eigenlijk niet meer echi overleggen. De rechter gaf een sterth negatief oordeel over de zondagsdienstem als actiemiddel en legde ons eigenlijh aan de ketting. De Nationale Ziekenhuisraad ging samen met het Landelijk Patienten/Cièntemplatform naar de rechter om de acties te verbieden. Met de ziekenfondsen waren we officieel niet neer on speaking terms. De media waven in hun commentaren miet op onze hand. "igt

Deze situatie die in ander onderzoek al eens betiteld werd met de tern 'omsingeling" (Scholten 1995) lijkt een rimpelloze uitwoering van de maatregelen ten anzien van de praktijkkostenvergoeding te bevorderen. ${ }^{95}$ Het ontbreekt de LSV immers aan elk middel om de witvoering tegen te houden. Maar de bredere context van de besluitworming over tarieven is niet statisch. De overheid wil in navolging van het rapport van de commissie Dekker hervomingen in de gezondheidszorg doorvoeren. ${ }^{96}$ Een verstoorde relatie thet de medisch specialisten is daarbij een hinderlijke sta in de weg. ${ }^{97}$ Ook blijkt dat de conflicten tussen de verzekeraars, artsen en

92 Financieel Overzicht Zorg 1993, Tweede Kamer, vergaderjaar 1992-1993, 22808, nrs. 1-2, pag. 288

93 Financieel Overzicht Zorg 1994, Tweede Kamer, vergaderjaar 1993-1994, 23407, nrs. 1-2, pag. $43 / 47$

94. Medisch Contact, 1989 , nr. 6

95 Terugkijkend op 1988 constateert de voorzitter wan de LSV in 1992: "De basis wan het Vijpartijen Akkoord vormde destijds een wurgsituatie ten aanzien van de specialisteninkomens. We werkeerden toen politiek en maatschappelijk in een isolement en waren totaal machteloos". In: Medisch Contact, 1992, nr. 29/30, p. 47

96 Commissie Structure en Financiering Gezondheidszorg, Bereidheid lot verandering, maart 1987

9720 wordt een eerste overlegronde over 'Verandering verzekerd", de cerste beleidsnota warin het advies van de commissie-Dekker stond uitgewerki, door de LSV geboycot omdat WVC in 1988 aankondigde het Generaal Akkoord op te willen zeggen. Dagrbij onderwind we belangenorganisatie steun van de Landelijke Huisartsen Vereniging en de KNMG (Plasmans, voorzitter LSV, Medisch Contact, 1988, nr. 26, p. 804). Later zou de LSV nog dujdelijker stellen dat elke herstructurering wan de gezondheidszorg het zou moeten doen zonder medewerking van de LSV (NRC, 15 oktober 1988 .) 
owerheid een "spillower" hebben. Volgens de NZr maakt de doorwerking van de verstoorde verhoudingen in de dagelijkse praktijk van hei ziekenhuis pacificatie nodig. ${ }^{98}$ Bovendien vormt het rapport van de commissie Dekker een uiting van ook in overheidskringen veranderende inzichten in de structuru yan de financiering van de gezondheidszorg. Centrale beheersing wordt in toenemende mate afgezworen en steeds nadrukkelijker worden 'marktachtige' structuren als mogelike oplossing genoemd 99 Ook op de afdelingen van WVC, belast met het specialistenbeleid, probeert men een strategie te bedenken warin effectieve maatregelen woor kostenbeheersing in de medisch specialistische sector gepaard gaan met minder overheidsbemoeienis. Dat de owerheid bij de besluitworming over tarieven een meer afstandelijke rol prefereert en aan de naatschappelijke organisaties verantwoordelijkheden toeschrift, wordt ook door de belangenorganisaties in het begin van 1989 zo ervaren. ${ }^{100} \mathrm{De}$ opstelling van de overheid biedt dus weer ruinte woor overleg, op basis van zowel strategische ais inhoudelijke overwegingen.

Met het besluit van het COTG tot een gefaseerde verlaging is het verhaal van de vergoeding voor praktijkkosten dus niet afgelopen. Verdere verlagingen van de vergoeding worden ingehaald door het Vijf-partijen Akkoord (VPA), ook wel de Raamovereenkomst genoemd. Het VPO is het gevolg van nieuwe besprekingen die worden opgestart als in november, na het mislukken wan het overleg onder leiding van Dekker, maar nog voor de goedkeuring van de richtlinen van het COTG het CDA hernieuwd owerleg tussen specialisten, verzekeraars en overheid tot stand will laten komen. 101 Het kabinet heeft daar wel oren naar omdat de heersende situatie warin mauwelijks nog wond gesproken tussen de overheid en de medisch specialisten, geen mogelijkheden biedt woor de implementatie van de adviezen wan de corimissie-Dekker, waaraan de overheid een hoge prioriteit geeft. 102 Nog voordat het kamerlid Lansink (CDA) op 24 november de wens van zijn fractie met een motie kracht bijzet, vindt overleg tussen Dees en de verzekeraars (VNZ, KLOZ en KPZ) plaats, waarbij aan de werzekeraars gevraagd wordt, of zij bereid zijn tot nieuw overleg. 103 In verschillende contacten tussen ambtenaren, politici en de LSV wordt vervolgens de bereidwilligheid van de medisch specialisten onderzocht 104

De bestuurders van de LSV vinden de plotse verandering van standpunt bij het CDA weliswaar opmerkelijk maan denken dat nieuw overleg de specialisten ten goede kan komen. Wel

98 Brief NZr aan De Koning (SZW) en Dees (WVC), 28 oktober 1988. De toenemende bemoeienis van de NZr met de tariefwoming moet dus verklaard worden uit defensieve overwegingen. De ziekenhuizen bewaken de gevolgen van de besluitvorming voor het functioneren van ziekenhuizen.

99 Zie bijvoorbeeld de toesprak van de statssecretaris Dees bij de installatie van de cie-Dekker op 25 augustus 1986

100 DB VNZ, 11 januari 1989

101 Het voorstel van thet CDA stuit wel op hevig verzet van de Pwd A. De bereidwillige houding die de statssecretaris van WVC en de minister van SZW al tijdens het overleg tonen, levert hen het verwit op dat zij "weer gaan schuiven." Verslag Mondeling overleg Vaste Commissies voor: Sociale Zaken en Werkgelegenheid en woor de Volksgezondheid met de Minister van Sociale Zaken en Werkgeleggenheid, 3 november 1988.

102 Of zoals WVC in een brief an de Ministerrazd zal opmerken, "Het Kabinet ging daarop in in de wetenschap dat het met onwillige honden slecht hazen vangen is." $B$ rief WVC aan de MP/MR, 12 Januari 1900

103 Brief VNZ, KLOZ en KPZ aan Dees, 18 november 1989

104. CB LSV, 15 december 1988. In het bestwur wan de LSV wordt melding gemaakt wan ambtelijk vooroverleg geinitieet door het kamerlid Lansink (CDA), alsook wan telefonisch contact tussen staatssecretaris Dess en Plasmans, de voorzitter van de LSV. De LSV wordt eveneens rechtstreeks door ambtelijk WBV benaderd. Brief LSV aan WVC, 18 november 1989 
dient de overheid aan te geven dat de resultaten van neuw overleg in de plats kunnen komen van de maatregelen ten amzien van de praktijkkosten. 105 De voomaamste drijfveer voor de LSV deel te nenten aan het overleg is de mogelijkeid de uitkomsten in de plaats te laten komen wan de gefaseerde verlaging van de vergoeding wan de praktikkosten. 106 Dai is de overheid voorshands miet van plan. De uitvoering van de tariefbesluiten dient gewoon plaats te vinden: Van een toezegging minder te hoeven bezuinigen is ook geen sprake. Wel is de overheid benieuwd of de partijen onderling tot cen goed alternatief kunnen komen. 107

Het begin van het VPO heeft nogal wat voeten in de aarde omdat de organisaties de overheid naw betrokken willen zien. Voor de VNZ is een formele betrokkenheid van de overheid zelfs een absolute voorwaarde voor participatie. 108 Voor bestuurders in het DB is het een voorwaarde voor zinvol overleg; ook word zo voorkomen dat de partijen te genakkelijk de schuld in de schoenen kan worden geschoven, indien het overleg mislukt. 109 Bovendien heeft de overheid zelf het nieuwe overleg in het leven geroepen. Maar de overheid geeft an dat zij liever op afstand blijft. 10 De inwloed van de ideeen van de commissie-Dekker wordt merkbaar in de beleidsopvattingen van WVC, De overheid dient terug te treden, om ruimte te geven aan oplossingen van de partijen zelf. Bovendien wil het ministerie wan SZW Zich steeds minder bemoeien met de inkomensniveaus van de medisch specialisten." Dees vraagt reeds in december Van Aardenne, voomalig minister van Economische Zaken, na samenspraak met alle betrokkenen voorzitter te worden, maar dit kan de VNZ niet weerhouden te blijven protesteren tegen de afwezigheid van de overheid. In februari blijkt dat de andere partijen niet bereid zijn hier een absolute voorwaarde van te maken. De VNZ zal zich tevreden moeten stellen met een regeling waarin staat, dat de voorzitter van het VPO de politiek verantwoordelijken regelmatig op de hoogte zal stellen. 112

De fracties van PvdA, CDA en D'66 in de Tweede Kamer zijn niet zo tevreden met deze procedurele afspraken, met name omdat zij niet overeenkomen met de beloften die gedaan werden in het overleg wan 3 november waarin het CDA aandrong op nieuw overleg. De PwdA constateert dat geen enkel bewindslid betrokken is bij de besprekingen. Aangezien er ook geen aanwijzing is gegeven, vragen de sociaalmdemocraten zich af of er wel op tijd besluilen tot stand komen die tot bezuinigingen zullen leiden. Lansink (CDA) mokt ook over de afwezigheid van inspirerende bewindslieden en zegt dat het lijkt alsof er sprake is wan een 'veredelde uitschuifoperatie'. De Minister van SZW laat daarop weten dat hij informeel heeft vemomen dat er voortgang is, en dat het de wens was van de partijen zelf om zelf de bewindslieden in te lichten, zonder directe betrokkenheid. Verder belooft hij de Tweede Kamer rond juni in te lichten

105 CB LSV, 15 november 1988

$106 \mathrm{CB} \mathrm{LSV}, 30$ mei 1989

107 Brief minister wan SZW aan Tweede Kamer, 13 december 1988

108 Directeurenoverleg, 11 januari 1989

109 DB VNZ, 11 januari 1989

110 Brief Dees aan Van Aardenne, 16 januari 1989

111 WVC, Eerste aanzet tot een strategienotitie ten aanzien van het specialistenbeleid, 29 juni 1989

112 Directeurenoverleg $\mathrm{VNZ}, 8$ februari 1989 
over de resultaten van het overleg. 13 Daamee hebben politici grenzen aan de duur van de onderhandelingen gesteld. 114

In de eerste maanden van 1989 word een agenda opgesteld. Men streef naar een overeenkomst voor I juli. In veelal bilaterale gesprekken met Van Aardenne wordt elke partij in de gelegentieid gesteld de eigen wensen in te brengen. De doelstellingen van de betrokkenen lopen nogal uiteen. Het streven van de LSV is gericht op een uitrull: de zogenamde "7 oktober matregelen' moeten verwallen als het VPO met resultaten komt. In gesprekken met Van Aardenue blijkt dait de LSV tevens wil praten over een uurloon, een herijking van de huidige tarifering, een herstructurering van tarieven en maatregelen ter bevordering van de doelmatigheid. De besprekingen dienen plaats te vinden tussen bestururijke en ambtelike vertegeitwoordigers onder leiding van en onafhankelijke voorzitter van hoge bestuurlijke kwaliteit.15 Onder en herstructurering valt volgens het bestuur van de LSV een reshuffing van tarieven. 116 De warzekeraars zijn bereid tot nieuw overleg, maar noch de ziekenfondsen nocly de particuliere verzekeraars zijn bereid de besluitworming over de praktijkkosten opnieuw ter discussie te stellen. De particuliere verzekeraars is het te doen om volumebeheersing en en evenwichtiger tarievenstelsel. Meer evenwicht zou met name bereikt worden als de verschillen ussen de ziekenfondstarieven en de particuliere tarieven werkleind worden. 117 Vooralsnog zal het overleg over de 'toegroeit wan tarieven bilateral, dat wil zeggen tussen VNZ en KLOZ (en KPZ) plaatsvinden. 118 Bij de ziekenfondsen staat vooralsnog het herstel van de contractuele relatie voorop, maar bovendien moet een substantiele bezuiniging tot stand worden gebracht. 19

Een substantiele besparing op de kosten van medisch specialistische zorg kan worden bereikt door afspraken te maken over tariefverlagingen mar ook door middel van een budgettering van de uitgaven aan medisch specialistische hulp. De budgettering komt aan de orde omdat de verzekeraars en ziekenfondsen sterk hechten aan volumebeheersing. ${ }^{20}$ Het beheersen van het volume staat voorop omdat ook de ziekenfondsen en de verzekeraars beseffen: dal een verlaging van tarieven gecompenseerd kan worden door een toename van het aantal verrichtingen door de medisch specialisten. De voorgenomen verdere tariefverlagingen als

113. Mondeling overleg Vaste Commissies voor Sociale Zaken en Werkgelegenheid en voor de Volksgezondheid met de Minister van Sociale Zaken en Werkgelegenheld, 16 maart 1989, Tweede Kamer, vergaderjaar 1988 1989, 16507, nr. 78

Is de Minister wel helemal cerlik geweest of heeft hij poltiek wenselije antwoorden gegeven? In ieder gewal is het zo dat de bij het overleg betrokken organisaties rond maart zelf weinig voortgang opmerken. In de vergadering van 16 maart typeert het CB van de LSV de gesprekken als "aftastend, luisterend, inventariserend en te zien als een ouverture voor de plenaire besprekingen". De andere betrokkenen spreken in soortgelijke termen. En het is in ieder geval helemaal niet zo dat het de organisaties zijn die aandringen op een meer afstandige houding van de overheid.

114 Het effect word duidelijk in juni waan het VPO onder 2 ware dnuk komt en waarin uiteindelijk de basis gelegd wordt voor de Raamovereenkomst die in december ondertekend kan worden.

115 Brief LSV aan WVC. 18 november 1988

116 CQ LSV, 15 december 1988. Wederom blikt dat de termen van onderhandelaars gedurende de onderhandelingen zelf worden ingevuld. Een term als herstructurering van tarieven kan veel betekenen, maar krijgt pas betekenis als concreet wordt aangegeven wat men daamee bedoeld.

$117 \mathrm{KLOZ}$, noitie Nieuwe overlegronde medische specialisten aan de KLOZ/KPZ-leden van de onderhandelingsdelegatie met de LSV, 16 november 1988

$118 \mathrm{VPO}$, verslag Iste plenaire VPO, 15 februari 1989

119 VNZ, notitie, 17 mei 1989

$120 \mathrm{KLOZ}$, notitio an de KLOZ/KPZ-leden van de onderhandelingsdelegatie, 16 nowember 1988 
gevolg wan de besluitvorming over de praktijkkostenvergoeding worden gezien ais krachtig nillmiddel. 121

De uitgebreide agenda die tot stand komt na de eerste besprekingen kent als voomaamste punten volumebeheersing van medisch specialistische hulp, herstructurering van tarieven, invoering van een adequaat informatiesysteem, en te sluiten overeenkomsten. ${ }^{22}$ Duidelijk wordt dat het uiteindelijke resultaat het karakter van een 'package deal' zal hebben. Een eerste indicatie over hoe een dergelijke 'package deal' aruit zal komen te zien, vormt het voorstel van Van Aardenne, dat hij in juni formuleert. Aan de eis van de verzekeraars en de ziekenfondsen is tegemoet gekomen; de voorzitter van het VPO stelt voor de omzet van de medisch specialistische hulp voor drie jaar gelijk te houden. Daarmee zou honderd miljoen gulden te bezuinigen zijn. In ruil daarvoor zal het besluit ower de praktijkkostenvergoeding niet verder worden uitgevoerd. Ook stelt Van Aardenme een 'reshuffling' van tarieven woor alsmede een tweeslag. 23 Met name het COTG brengt het probleem van de juridische haalbaarheid ter sprake in een afwijzende reactie op de voorstellen wan het VPO. 124 Ook een meerderheid in de Tweede Kamer geeft blijk van weinig vertrouwen in cen goede alloop. Met een kabinetsformatie in het vooruitzicht pleiten de woordvoerders van het CDA en de PvdA voor definitieve afspraken in september. Als Van Aardenne er voor die tijd niet in slaagt aan zijn opdracht te voldoen, zal aan de statssecretaris gevraagd worden maatregelen op te leggen. 125

De politieke druk heeft het beoogde effect. In het VPO geeft Van Aardenne aan dat het overleg de tijdslimiet heeft overschreden. De verzekeraars dringen er vervolgens op aan dat er een brief wordt versturd aan de achterban van alle partijen om deze op de hoogte te stellen van de woortgang, en on aan te geven dat er geen reden is om het overleg af te breken. Ook willen de verzekeraars, dat de brief verstuurd wordt aan staatssecretaris Dees en ministen De Koning omdat hun medewerking aan en instemming met de ingeslagen. weg van groot belang wordt geacht, 26 De ziekenfondsen voegen daaraan toe, dat het gezien de politieke druk op de bewindslieden verstancig is on aan te geven, dat een overeenkomst op 1 juli niet haalbaar is. De specialisten vrezen evenwel een verstoring van de voortgang door het versturen van de brief omdat de onderhandelaars op een tegenstribbelende achterban kunnen stuiten. De verzekeraars zien daarop af wan een rapportage aan de achterban, in augustus zal een protocol aan de achterbannen worden voorgelegd. Wel besluit Van Aardeme tot een brief aan de overheid. Hij heeft het kabinet in juni nog heeft laten weten, dat het overleg zou kunnen worden afgerond voor 1 juli. De voorwarde is dat de vijf partijen het eens kunnen worden over de brief. ${ }^{27}$ Op 21 juli stuurt Van Aardenne het verslag van de voortgang van thet VPO naar de ministeries van WVC en SZW. Hij kondigt aan dat er 'overeenstemming op hoofdlijnen' is. 128

Na dit tussentijdse resultaat heeft de overheid voldoende reden tot vertrouwen in een verder verloop wan de besprekingen in het VPO. WVC reageert dan ook welwillend, hoewel de tijdslimiet van $\mathbb{1}$ juli niet gehaald is en er iwifel bestaat over de juridische haalbarheid van verschillende onderdelen. 129 De 'overeenstemming op hoofdlinen" en de welwillende veactie van staatssecretaris Dees geeft de deelnemers aan het VPO de ruimte on de vaak nog onduidelijke afspraken te preciseren.

\section{DB VNZ, 17 mei 1989}

122 Brief van Van Aardenne aan De Koning, 18 april 1989

123 Brief van Van Aardenne aan deelnemers VPO, 13 juni 1989

124 COTG, nothe, 19 juni 1989

125 de Volkskrant. "Politiek dreigt specialisten met dwang", 20 juni 1989

$126 \mathrm{VPO}$, verslag $10 \mathrm{de}$ plenaire vergadering, 16 jun 1989

$127 \mathrm{VPO}$, verslag 10 de plenaire vergadering, 16 juni 1989

128 Brief Van Aardene aan SZW en WVC, 21 juli 1989

129 Brief WVC (Dees), SZW (De Koning) en EZ (De Korte) aan Wan Aardeme, 8 september 1989 
De LSV kan in september aan de achterban bekend maken dat de voomaamste doelstelling bereikt is. De dreiging van verdere tariefverlagingen als gevolg van de besluitworming over de praktjkkostenvergoeding is weggenomen. De belangenorganisatie verzekert haar leden dat een tariefdaling weliswaar theoretisch mogelijk zal zijn, maar dat de verwachting is dat de tarieven voor de komende drie jaren gelijk zullen blijven. 30 De leden tonen zich in de Ledervergadering bereid tot goedkeuring van het onderhandelingsresultaat hoewel met name de tweeslag en de gevaren wan het macrobudget woor de professionele autonomie voldoende reden zijn voor harde discussies. De zickenfondsen zijn ook tevreden met het bereikte resultaat. Tegenover het niet doorgaan van de verdere verlaging van de kostervergoeding stat het einde van de open eindefinanciering van medisch specialisten. Dat ook de degressieoporengsten van de jaren tachtig moeten worden weggegeven word gelaten geaccepteerd. De inning van de degressie was toch al onhaalbaar geworden. 131 ook het KLOZ stemt in met deze ruil. Athankelik van de juridische uitwerking gaat het $\mathrm{KLOZ}$ accoord met de voorstellen van Van Aardenne met als argument dat de overeenstemming zal leiden to meer doorzichtige tarieven. 132

Zoals al eerder werd opgemerkt, staat de tevredenheid bij de deelnemers aan het VPO en hef ministerie van WVC in schril contrast met de kritische houding van het COTG. Het COTG houdt wast aan de eigen onafhankelijke positie en geeft verschillende keren aan dat op basis van een juiste interpretatie van de bestaande wetgeving bij de uitvoering van de afspraken van het VPA grote vraagtekens moeten worden gesteld. 33 Het overleg met het secretariaat van het COTG komt in de maanden na september weliswaar op gang maar niet zelden leidt dit tot twijfel bij de participanten. De vertaling van de afspraken van de onderhandelaars in tariefbeslissingen door het COTG zal een moeizaam proces blijken te zijn.

De zelfstandige houding van het COTG baart met name de LSV grote zorgen. De onderhandelaars in het VPO mogen dan wel overeengekomen zijn dat de verlaging van de kostenvergoeding niet doorgaal, maar de uitwoering van deze afspraak vereist nog één en ander. Ten eerste moet voorkomen worden dat het COTG de richtlijnen van 1988 alsnog witvoert, en ten tweede moet bereikt worden dat het COTG de richtlijnen intrekt. Geheel in overeenstemming met zijn taakopvatting neemt het secretariaat van het COTG geen afwachtende houding aan. Men bereidt in de laatste maanden van 1989 de tweede verlaging van 1 januari 1990 voor. In gesprekken met Van Aardenne makt Dees duidelijk dat van de overheid geen activiteiten te verwachten zijn teneinde deze besluitwonming tegen te gaan. De deelnemers aan het VPO zullen zelf na definitieve overeenstemming aan het COTG moeten verzoeken de besluitvorming op te schorten. ${ }^{134}$ De ambtenaren van WVC zien weinig in een actieve opstelling. Een ongewenste betrokkenheid van WVC zou optreden als de overheid door bijvoorbeeld een aanwijzing de verlaging van de kostenvergoeding lat uitstellen. Zelfs enige vertaging van de invoering van de te sluiten overeenkomst is acceptabel, mits de daardoor uitblijvende besparingen later alsnog tot. stand komen. 135

De Raamovereenkomst die in december 1989 tot stand komt, stemt het KLOZ en de VNZ tevreden. Zij strepen de voors en tegens van de Raanovereenkomst en de besluitvorming over de

130 Spechalistenbrief, september 1989

131 DB VNZ, 9 augustus $1989 / \mathrm{AB}$ VNZ 23 augustus 1989

132 KLOZ, notitie Betreft: VPO, 24 jull 1989/Brief K.PZ, KLOZ en VNZ aan Wan Aardenne, 31 augustus 1989

133 COTG, notitie Het Van Aardenne overleg en de WTG, 5 juli 1989/COTG, notitie Mogelijkheden en onmogeligheden t.a.v. vrije beroepsbeoefenaren, 14 juli 1989/COTG, Verslag overleg wertegenwoordigers $\mathrm{LSV}, \mathrm{NZr}$, VNZ, KLOZ, KPZ en het COTG-secretariat dd 25 juli 1989,3 augustus 1989

134 VPO, versiag plenaire vergadering, 24 oktober 1989

$135 W$, ambtelijk advies aan de staatssecretaris, 4 oktober 1989 
praktijkkositenvergoeding tegen elkar af en komen tot de conclusie dat zij winst kunnen boeken. ${ }^{36}$ De nuil met de verlaging van de kostenvergoeding kan plaats winden. In artikel 9 van de Raamovereenkomst staat dan ook dat de organisaties alles zullen doen "wat in hun vermogen ligt teneinde te bereiken dat de wit de richtlijhen (de kostenrichtijnen (HL) (...) voortvloeiende tariefsverlagingen niet worden doorgevoerd." De WNZ en het KLOZ stemmen er uiteindelijk mee in het COTG te vragen de uitvoening van het kostenbesluit voor 1990 en 1991 wit te stellen: waartoe het COTG in zijn vergadering van 18 december 1989 besluit.

De verlaging van de tarieven per 1 januari 1990 gaat dus in veder geval niet door, maar het COTG zal de richtlijnen voor de vergoeding voor praktikkosten niet intrekken. Het antwoord van de overheid op de 'overeenstemming op hoofdijnen' is wat dat betreft al een woorbode. De bewindslieden geven aan, dat het beleid ten aanzien van de kostenvergoeding pas als vervangen wordt beschouwd zodra het COTG nieuwe richllinen heeft opgesteld en zodra deze goedgekeurd zinn door de overheid. Van intrekken van de oude richtijnen is geen sprake. "Het huidige instrumentarium zal zodra de nieuwe situatie is ingetreden nog slechts benut worden indien de beoogde effecten in gevaar (dreigen te) komen."137 De verzekeraars, de ziekenfondsen an WVC zun bevreesd voor een situatie waarin het VPA een mislukking wordt terwijl de richt lijnen van 1988 niet meer bestaan. Volgens de verzekeraars en ziekenfondsen volstaan ten belnoeve wan de uitvoering van de overeenkomst veranderingen in de fasering en kunnen de oude richtlijnen gehandhaafd blijwen. 138 De wensen van de LSV zijn ook voor WVC geen reden van mening te veranderen. In het regelmatige overleg laten de ambtenaren aan de LSV weten, dat "de oude schoenen niet weg worden gedaan voor er goede nieuwe zijn." 139 Het secretariat van het COTG is het met het Akkoord in zijn geheel niet eens en wil de richtlijnen in stand houden om na afloop van de owereenkomst (na 1992) verder beleid te kunnen voeren. 10 . Het secretariaat prefereert een situatie, waarin de kostenrichtlijnen "boven de markt blijwen hangen" en warin de geplande verlagingen van de vergoedingen voor de praktijkkosten per 1 januari 1990 en 1 januari 1991 verschoven worden naar 1 januari 1993 . Voor de voorstellen van de Raamovereenkomst zouden aanvullende richtlijnen moeten worden opgesteld. 141

Tegen een coalitie van COTG, WVC, VNZ en KLOZ is de LSV niet opgewassen. In januari beslist het COTG dat de oude richtlijnen blijven bestaan. Daardoor is het streven van de LSV slechts gedeeltelijk vervuld; de maatregelen om de vergoedingen woor praktijkkosten door te voeren zijn weliswaar uitgesteld, maar de richtlijnen waarop deze maatregelen gebaseerd zijn kunnen ma 1992 of als het VPA woortijdig strandt weer worden 'geactiveerd'. De LSV heeft daarin te berusten, in het besef dat op zijn minst voorlopig geen berichten over algemene tariefverlagingen de achterban bereiken.

$136 \mathrm{KLOZ}$, notitie Betreft: VPO, 30 oktober 1989

137 Brief WVC (Dees), SZW (De Koning) en EZ (De Korte) aan Van Aardenne, 8 september 1989

$138 \mathrm{VPO}$, verslag plenaire vergadering, 22 november 1990

139 WVC, nota Medisch specialisten, 6 december 1989. Elders noem WVC dit de automatische piloot'. Daaronder word verstaan dal de richtijnen over de kostenvergoeding onmiddellijk weer kunnen gaan gelden als de uitwoering van de Ramovereenkomst daar reden toe zou geven. WVC, nota, 18 december 1989

140 COTG, nota 90-02, 19 januari 1990. Het secretariaat stelt: "Per I januari 1993 houdt de wereld en de WTG niet op. Derhalve dient er per 1 januari 1993 krachtens de WTG een kostenrichtijn te zijn voor de trendmatige aaripassing van het kostenbestanddeel in de tartieven."

141 Fax COTG-sectetariaat aan WVC, 4 december 1989 


\subsection{De dans met de inkomensverschillen: de reshuffling}

\subsubsection{Een kort overzicht}

Aan een precies en gedocumenteerd inzicht in de inkomsten wan medisch specialisten heeft het vrifwel altijd ontbroken. Weliswaar vonden in de eerste helft van de jaren tachtig discussies plaats tussen de overheid en Wetenschappelijke Verenigingen over de verlaging van inkomens, maar deze hadden en onderhandelingskarakter. Het werkelijke niveaw van de inkomsten bleef verborgen. In de vorige paragraf is verscheidene keren gebleken dat de onderhandelaars het niet eens zijn over de omzetgegevens van artsen. Daaron moet bij de besluitvoming tot in de jaren negentig teruggevallen worden op uitkomsten van onderzoek uit de jaren zeventig. In de jaren tachtig zijn wel onderzoken naar de inkomsten van medisch specialistern gedaan, maar juridische procedures hebben gebruik van de uitkomsten in de formele besluitvorming voorkomen. 142

Ondanks dit gebrek aan formele gegevens is in de jaren tachtig het vermoeden algemeen aanwezig, dat or tussen specialismen aanzienlijke inkomstenverschillen zijn. Dat dit vermoeden gegrond is, blijkt uit de gegevens die opgenomen zijn in het Definitief Eindrapport Medisch Specialisten van de accountants van Van Dien en co (1988). Volgens dit rapport hebben artsen wetkzam in de revalidatie (f 86.000 ), allergologie (f 98.000), psychiatrie (f 123.000) en reumatologie (f 148.000) een aanmerkelijk lager gemiddeld inkomen dan de artsen die werkzaam zum in de radiodiagnostiek (f 352.000 ), radiologie (f 361.000 ), radiotherapie (f 366.000 ) en medische microbiologie (f 380.000 ). 143

Volgens de algemene opinie lopen de werschillen wit de hand. Het LSV-besturur maakt zich in 1988 dermate zorgen over de witeenlopende inkomsten, dat men het probleem op de agenda van de ledenvergadering plaatst. Het bestuur stelt vast, dat artsen gespecialiseerd in de radiodiagnostiek, radiotherapie, cardiologie, medische microbiologie, pathologische anatomie en cardiochirurgie anmerkelijk hogere omzetten zouden hebben dan zij die werkzaam zijn als

142 Belangrijke rapporter zijn het Interimrapport van de Commissie Structuur Honorering Medische Specialisten (Commissie Van Mansvelt) met gegevens over omzetten en kosten in 1977 , gepubliceerd in 1980, en het rapport van de zogenaamde Rekenmeesters (Frielink en Van der Smeede), uitgebracht in 1981 , warin de gegevens van 1977 worden geactualiseerd. Een ander informatieve bron voor beleidsmakers en onderhandelaars had een enquête kunnen zijn die het COTG instelde nar aanleiding van het General Akkoord (de zgn. Van Dien-enquête die resulteerde in het Definitief Eindrapport Structuurenquête Medisch Specialisten) maar gebruik van de uitkomsten is door de rechter in 1988 verboden.

143 Het gnat hier om gemiddelde inkomens, niet on de gemiddelde omzetten, die uiteraard veel hoger liggen omdat daar ook de praktijkkosten nog in zitten (De Tijd, 21 oktober 1988 ).

In 1997 werden omzetgegevens bekend per erkende specialistenplats per specialisme. Ondat er per specialistenplats verschillende specialisten werkzaam kumen zijn, en omdiat ook agio"s en agnio's omzet genereren, is het nauweligk mogelijk conclusies te trekken ten aanzien van de inkomsten van individuele medisch specialisten. Hierdoor zijn deze gegevens ook onvergelijkbaar zijn met de Van Dien gegevens. Wel geven zij aan dat er nog steeds sprake is van inkomstendifferentiatie. Zo is de geniddelde omzet per fte reumatologie in 1995 P 264.190 , per fte revalidatiegeneeskunde f 181.466 , per te medische microbiologie $f 787.047$ en per fte cardiologie † 522.466 . Bovendien is het zo dat binnen é̉n specialisme de omzet per fte tussen ziekenluuizen sterk kan verschillen (H. Van Vliet (COTG), Macro-en mesogegevens over de kosten medisch specialistische hulp voor het jaar 1995 op basis van de lokale initiatieven, voordracht, 30 januari 1997) 
kindergeneeskundige, reumatoloog, allergoloog, psychiater of revilidatiearts. 4 Het $\mathrm{CB}$ van de LSV laat in de ledenvergadering in november 1988 weten, dat gestreefd zal moeten worden naar meer solidariteit en dat "...(d)e solidariteit bimen de specialistengroep vertald moet worden in een zekere reshuffing van hoog naar laag en wat minder in de middenmoot." Het CB wijst erop "...(d)at degenen die jarenlang ten opzichte van anderen te weinig hebben verdiend en die toch zeer solidair zijn geweest (...) tegemoet gekomen moeten worden."145 Het bestuur wil de mening horen over een tariefverlaging met twee procent voor de zes bovengenoemde meerverdieners om zo een tariefstijging van vijf procent voor de kundergeneeskundigen en tien procent voor de overige minderverdieners mogelik te maken. Alle overige specialismen zouden met een zeer geringe verlaging moeten instemmen. ${ }^{146}$ De ledenvergadering is het er niet mee eens. Vertegenwoordigers van de meer verdienende specialismen laten weten, dat er sprake is van een slechte timing en dat de onderbouwing nog onvolledig is. De minder verdienende specialisten menen daarentegen, dat er nodig iets moet gebeuren en dat het voorstel van het bestuur nog niet wer genoeg gaat. 147

Het bestuur van de LSV stoot dus zijn hoofd als geprobeerd wordt een verkleiming van de inkomensverschillen tot stand te brengen. Desalniettemin komt in het VPO al snel een manier aan de orde waarop de onzetverschillen tussen specialismen verkleind zouden kunnen worden. Dit wordt de reshuffling genoemd overeenkomstig de terminologie van het bestuurlijk voorstel van de LSV in de ledenvergadering van oktober 1988. De reshuffling behelst een verlaging van de tarieven voor de bovenverdieners en een werhoging van de tarieven voor de onderverdieners. De reshuffling zall uiteindelijk als artikel 6 in de Raamovereenkomst van december 1989 opgenomen worden. In het artikel staat tevens, dat de reshuffling gefaseerd zal worden aitgevoerd vanwege de omvang van de anpassingen van de tarieven. In 1992 moet de latste aanpassing plats vinden.

De afspraak omzetwerschillen te verklemen laat zich echter moeilijk uitvoeren. Het zal tot clecember 1990 duren voordat duidelijkheid bestaat over een manier om op basis van het artikel 6 op een juridisch verantwoorde manier tariefoesluiten te nemen. Uiteindelijk zal dit gebeuren door een onderdeel van de tariefformule te veranderen. In technische zin bestaat een tarief voor medisch specialisten uit twee componenten: een inkomenscomponent en een kostencomponent. Tarieven bestaan dus voor een deel uit een vergoeding die als inkomen wordt bestempeld en voor een deel uit een vergoeding voor de kosten die een specialist makt. 48 Daamaast is en een werkbelasting (workload). Het tarief woor een bepaalde verrichting kan worden bepaald door de (nomatieve) kosten en het (nomatieve) inkomen te delen door de (normatieve) werkbelasting.

$144 \mathrm{CB}$ LSV, 15 november 1988/LSV, toelichting op punt 9. van de agenda wan de Ledenvergadering. van 24 november 1988

145 Nowlen Ledenvergadering LSV, 24 nowember 1988

$146 \mathrm{LSV}$, toelichting op punt 9. wan de agenda van de Ledenvergadering van 24 nowember 1988

147 Notulen Ledenvergadering LSV, 24 novernber 1988

148 Maar ook de overeenstemming over welke kosten een specialist maakt, is mcer een onderhandelingsuitkomst dan een gegeven. In 1988 worden, aan het einde var de praktikkostenbesluitvorming, de volgende kostenposten onderscheiden: huisvesting, algemene kosten (telefoon, werzekeringen, werkkleding), orientering (nascholing, congressen, literatuur, contributies), administratickosten (accountantskosten, facturering), verwoer, interest, diversen an verslaggeving en praktijkorganisatie (personeel en overhexd). Brief van het COTG aan de Staatssecretaris van, Welzijn, Volksgezondheid en Cultuur (richtlijnen kostenvergoeding medische specialisten (ziekenfonds en particulier), 29 juni 1988 . Zie ook paragraaf 4.1 
De tariefformule is een technisch instrument van het COTG teneinde tarieven te onderbouwen. Bij de onderhandelingen tussen de vertegenwoordigende organisaties speelt de tariefformule geen rol. Zij komen veelal door middel van onderhandelingen tot bepaalde afspraken die zouden moeten resulteren in tariefaanpassingen door het COTG. In deze zin is de tariefformule een vertaalmiddel: de uitkomsten van de onderhandelingen tussen ziekenfondsen, verzekeraars en artsen kumnen met behulp van de formule vertaald worden in technisch juiste tariefbesluiten van het COTG.

De discussie zal zich in 1990 toespitsen op onder meer de vraag of het aanpassen van omzetten door middel van tariefveranderingen inkomensbeleid inhoudt. In formele zin is er van inkomensbeleid sprake, alls tarieven worden veranderd op basis van overwegingen ten aanzien van de I in de tariefformule. Als dit het geval is, dient de overheid een aanwijzing aan het COTG te geven en wel op basis van artikel 15 van de Wtg. Er zijn tot aan 1992 twee soorten aanwijzingen. ${ }^{149}$ Aanwijzingen gebaseerd op artikel 14 van de Wtg vereisen overleg tussen de overheid en COTG. Aan aanwijzingen die gebaseerd zijn op artikel 15 van de Wtg kleven voor de overheid meer verplichtingen. Zij kunnen namelijk alleen worden gegeven na overleg met de LSV hetgeen vaak moeizame discussies over toelaatbare inkomens van medisch specialisten inhoudt.

Overleg over inkomens vond in de jaren tachtig uitgebreid plaats op grond van de toen geldende inkomenswetgeving. Het overleg tussen de overheid en de beroepsgroepen over inkomens werd omschreven in de Tijdelijke wet normering inkomens vrije beroepsbeoefenaars (Twn, 1981-1987) en Wet inkomens vrije beroepsbeoefenaren (Wivb, 1987-1992). De Wivb verving de Twm. Tot 1986 heeft de overheid een intensief inkomensbeleid gevoerd, ook ten aanzien van de medisch specialisten. Tot die tijd was dan ook sprake van een gecombineerd prijs- en inkomensbeleid. In het overleg in het kader van de inkomenswetgeving dienden de overheid en de beroepsgroepen tot afspraken te komen over de hoogte van het inkomen van een specialist. Dit niveau moest worden vertaald in tarieven. Men sprak dan ook over het overleg over inkomens als 'normatief voorportaal'. Na 1986 neemt het belang van het inkomensoverleg in rap tempo af, mede omdat de minister van $\mathrm{SZW}$ dit niet meer prioriteert.

Hoewel het inkomensbelejd dus minder belangrijk wordt, kampen de organisaties door het voortbestaan van de Wivb nog well met het probleem hoe de reshuffling kan worden uitgevoerd zonder dat het als een inkomenspolitieke maatregel kan worden bestempeld. De overheid wil namelijk geen aanwijzing geven en de dreiging met juridische processen van ontevreden specialisten vereist juridisch waterdichte tariefveranderingen. De uiteindelijke oplossing zal door het COTG worden aangedragen. Door op basis van complexe berekeningen de werkbelasting in de tariefformule te veranderen is het mogelijk tarieven aan te passen zonder dat sprake is van inkomensbesluiten. De I in de tariefformule wordt immers niet aangepast. De meegaandheid van het COTG verontrust de deelnemers aan het VPO, maar er rest hen weinig anders de voorgestelde weg in te slaan. De reshuffling wordt tenslotte geheel uitgevoerd ondanks juridische procedures van ontevreden artsen. De besluitvorming wordt door de rechter als rechtmatig beoordeeld.

149. Met de wijziging van de Wtg op 1 januari 1992 is er nog maar één soort aanwijzing (ex artikel 14). Een anwijzing op basis van artikel 15 is niet meer mogelijk. 


\subsubsection{De reshuffing}

\section{Naar de "trouvaille van Van Aardenne"}

In april 1989 komt de reshuffling in het VPO ter sprake. Bij de uitwisseling van notities heeft de LSV de bereidheid getoond de omzetverschilen tussen de specialismen te verthleinen." 150 zoals in de inleiding beschreven werd, is al eerder binnen de LSV gesproken over de verschillen in omzet tussen de specialismen. Gesprekken met bovenverdieners verloperi echter dusdanig, dat het bestuur van de LSV zich gedwongen ziet concrete voorstellen uit te stellen. 151 Bij het bepalen van de onderwerpen die de LSV wil inbrengen in het nieuwe overleg in december 1988 wordt de reshuffing een doelstelling. 152

Van Aardenne laat in het VPO weten dat een aantal specialismen de spil vomen; $z i j$ hebben omzetten waarbij het verschil tussen de hoogste en de laagste omzet niet meer dan ongeveer f 50.000 - bedraagt. Alle specialismen zouden binnen deze band moeten worden gebracht. In geval van tariefmutaties van twintig procent zou een gefaseerde verlaging plaats moet vinden, maar langer dan drie of vier jaar mag liet niet duren. De andere partijen rageren lauw. Veel is nog onduidelijk; bovendien vinden de verzekeraars en ziekenfondsen het eigerilijk lets dat alleen de LSV aangaat. Zij zien het als een interne kwestie, bedoeld om de stabiliteit onder de leden te bewerkstelligen. Zij geven aan de reshuffing een 'technische' kwestie te vinden. De LSV wordt dan ook gevraagd met een meer uitgewerkt voorstel te komen. De LSV is wel bereid de voorstellen uit te werken, maar wil dat de voorstellen worden opgenomen in het geheel wan uitkomsten van overleg. Een regeling van de reshuffing zal onderdeel moeten zijn van de "package-deal". Van Aardenne komt daarop de LSV tegemoet en zagt toe dat hij als bemiddelaar zorg zou kumen dragen voor de schriftelike weergave wan de reshufflingvoorstellen. 153

Maar de formulering van een precies reshufflingvoorstel laat op zich wachten. Aan de reshuffling moet ook binnen de LSV veel aandacht geschonken worden nu Van Aardenne een voorstel wil. 154 Bovendien vragen andere kwesties de aandacht van de deelnemers an het VPO. Veel tijd besteden de onderhandelaars aan de kwestie van het macrobudget. Tijdens de onderhandelingen wordt duidelijk dat de VNZ een structurele bezuiniging wil. In juni spreekt het VPO af de uitgaven voor drie jaar te bevriezen wardoor de ziekenfondsen tevreden kunnen worden gesteld. In nul daarvoor moeten de zogenaamde 7 oktober maatregelen wan tafel, die een verlaging van de kostenvergoeding in 3 jaar inhouden. De bestuurders van de LSV noemen het de 'trouvaille van Van Aardenne' 155

Een ander onderdeel van de trouvaille van Van Aardenne is, dat ongerechtvaardigde afwijkingen tussen inkomensniveaus van specialisten wermeden moeten worden (de reshumling). Het is de ziekenfondsen echter nog steeds niet duidelijk wat de LSV nu precies wil. De LSVvertegenwoordiger herinnert de ziekenfondsen aan de afspraak dat een voorstel de vergadering zou bereiken via de voorzitter. Wederom geef Van Aardenne aan dat in bilateral overleg (tussen hem en de LSV) een voorstel zal worden ontwikkeld, dat vervolgens aun het gehele VPO zal worden voorgelegd. 150

$150 \mathrm{VPO}$, versiag $2 \mathrm{e}$ plenaire vergadering, 13 april 1989

151 CB LSV, 15 november 1988

152 CB LSV, 15 december 1988

153. VPO, verslag 2 de plenaire bijeenkomst, 13 april 1989. Van Aardenne zal formeel het voorstel doen, maar de LSV mag het echte werk doen. KLOZ, Vooroverleg KLOZ/KPZ, 12 juni 1989

154 CB LSV, 30 mei 1989

155 CB LSV, 15 juni 1989

156 VPO, verslag 8 ste plenaire bijeenkomst, 13 juni 1989 


\section{Naar cen akkoord en cen sprong in het duister}

Hoewel Van Aardenne geen concree voorstel voor een reshuffing in juni kan aanbieden, is de reactie op het departement van WVC vooralsnog positief. De voomamste doelstelling van de overheid is de groei van de uitgaven aan gezondheidszorg te verkleinen. Een nivellering van de inkomensverschillen van artsen is geen nevendoelstelling en ook geen randvoorwarde. Bij WVC is de reshuffling "van belang", maar de ambtenaren denken ook dat de witwoering voor WVC envoudiger zal verlopen als de Wiwb niet meer geldig is. Door deze wet is de overheid wettelijk verplicht tot bepaalde initiatieven in geval van inkomenspolitieke besluiten. 15 ? Het gematigde optimisme van WVC word niet gedeeld door het COTG. Integendeel het sectetariaat reageert bijzonder geimiteerd. Gewezen wordt op de eigen rol en de grenzen die de Wtg stelt aan de uitkomsten van het Viff-partijen Overleg. Verwijtend stelt het, dat het doel van de reshufning wanzelf wordt gerealiseerd als het COTG van de overheid eindelijk de rumte krijgt met behulp wan de verzekerars adequate tarieven vast te stellen. Reshuffling is in het ogen wan het COTG het wanzelfsprekende gevolg van het tot stand brengen van goede tarieven. Ook geeft het secretariaat aan, dat de mening dat alles nogelijk is binnen de Wtg als er maar overeenstemming bestaat tusser de partijen onjust is. Het COTG heeft een eigen verantwoordelijkheid voor wat wel of niet bimen de Wtg past. Een oordeel daarover komt onafhankelijk van de overheid of de partijen tot stand. Zo ook het oordeel over het reshufflingvoorstel. De reshuffing zoals voorgesteld - "macrobedragen bij het ene specialisme eraf en bij het andere erbij" - past niet in het beeld van een adequate tariefopbouw. Bovendien zijn er gegevens in het spel waarvan het gebruik eerder door de rechter werboden werd. 158 Een juridisch houdbare manier om de reshuffing te regelen is volgens het COTG een verandering van én of enkele elementen van de tariefformule. Het tarief voor een bepaalde verrichting kan worden bepaald als men het inkomen (I), opgeteld met de kostenvergoeding (K), deelt door de werkbelasting (W), vermenigvuldigd met de tijdsbesteding per werrichting (Pi). De te veranderen elementen zijn de kostenvergoeding, de werkbelasting of de tijdsbesteding, matr zeker niet het inkomen. De reshuffling in het woorstel wan het VPO is wel macro-neutraal maar niet inkomens-neutraal. ${ }^{59}$ Met andere woorden de totale kosten van medisch specialistische hulp veranderen door de reshuffling niet mar de inkomenscomponent van het tarief wel.

Do twijfels over de juridische mogelijkheden voor de reshuffling bereiken het overleg tussen de vijf organisaties. De VNZ wijst op de mogelijke strijdigheid tussen de reshuffling en de Wtg. Van Aardenne geeft aan medewerking van de overheid te verwachten als een inkomenspolitieke aanwijzing nodig mocht zijn. Ook zal hij gaan praten met het COTG. ${ }^{60} \mathrm{Van}$ de voorzitter van het COTG verneemt Van Aardenne, dat het COTG bij de uitwoering van de reshuffling een arwwijzing var de overheid zal moeten ontwangen omdat de reshuflling inkomonsbeleid is. Het VPO weet eind juni war het aan toe is. De reshuffling vereist een goede onderbowwing omdat de overheid een juridisch betrouwbare aanwijzing an het COTG moet geven. 161

De conclusie dat het voorstel tot de reshuffling inkomensaanwijzingen wan medisch specialisten noodzakelijk makt, is onwelkom bij de overheid. Dit betekent immers dat $z$ ij wederom betrokken raakt en direct overleg zal moeten voeren met de LSV. Aan deze bezwaren heeft de voorzitter van het VPO geen boodschap. Op 18 jull stuurt Van Aardenne aan de leden

157 WVC, nota Yan Aardeme-overleg, 4 jull 1989

158 Het betreft de zogenaande Van Dien-gegevens.

159 COTG, notitie n.a.v. de balans van 13 juni 1989, 19 jun 1989/COTG, notitie Fet Van Aardenno overleg en de WTG, 5 juli 1989

$160 \mathrm{VPO}$, werslig plenaire vergadering, 15 juni 1989

$161 \mathrm{VPO}$, werslag $\$ 2$ de plentire vergadering 
van het VPO een voorstel voor de reshuffing. Het voorstel bevat de tariefsveranderingen die in tabel 4.4 zin weergegeven.

Onder voorwaarde dat het volume van de medisch specialistische hulp niet stijgt, verwacht Van Aardenne een daling van de kosten van deze hulp. In 1990 zou het gaan on ongeveer 4 mifjoen, in 1991 om 14 miljoen en in 1992 om ongeveer 34 miljoen. 162 Dat de reshufling een besparing tot gevolg heef, is een nieuw element in de discussie. Eerder was aangegeven dat alles 'budget-neutral' zou verlopen waardoor de macrokosten niet zouden stigen of dalen. Voor de opbrengst is meteen een bestemming bedacht. Met het geld kunmen meer specialisten instromen. 163

Al deze specificaties van het reshufflingsvoorste], staan niet in het voortgangsverslag, dat Van Aardenne op 21 juli naar de ministeries wan WVC en SZW stuurt. Van Aardenne stelt onder meer dat maatregelen nodig zijn om de omzet-en inkomensverschillen tussen de specialismen te verkleinen aangezien de verlaging wan de kostenvergoeding niet doorgaat. Hij noemt het principe van de reshuffing en beloofl dat voor 1 september nadere gegevens beschikbatar zullen zijn. Van Aardenme doet tevens een beroep op de overheid. Volgens hem zal ook de overheid één en ander toî stand moeten brengen. Daarbij verwijst hij naar het geven van aanwijzingen en naar do manier waarop omgegaan zal worden met de Wivb. ${ }^{164}$ Tegelijk wordt in het VPO een "protocol" ontworpen. In augustus en september zullen de patijen het reshufflingswoorstel nader onderbouwen en aan de achterban voorleggen. Begin oktober zou het VPO het voorstel moeten goedkeuren, waarna in november het COTG om goedkeuring gevraagd zal worden. De datum van invoering stellen de partijen op januari 1990.165

Ambtelijk WVC noemt het wegwerken van de inkomensverschillen bij de medisch specialisten een 'belangrijk punt met grote politieke relevantie.' Maar WVC constateert tevens, dat de voorstellen nog vaag zinn. Precieze voorstellen zijn voor WVC voorwarde on te praten over afschaffing van de Wiwb. Met bezorgdheid wordt verwezen naar de inkomensmutaties. WVC vreest allerlei vertragende procedures. 160 Ondanks de bezwaren verdedigt Dees het voorstel van Van Aardenne in het kabinet, waarna in het begin van september het VPO te horen krijgt dat het kabinet in principe instemt met het verslag van Van Aardenne en het overleg groen licht geef. De reshuffling omschrijven de bewindslieden als zeer gewenst uht het oogpunt van inkomenspolitieke overwegingen en bevordering van evenwichtige tarieven. Wel wordt het de bewindslieden nog onbekende reshufflingsvoorstel afgewacht. 167

Zo ontstaat een situatie waarin de vijf organisaties het onderling exns zijn over de vormgeving van de reshuffling. Deze had weinig discussie gevergd en wan onderhandelingen was ook nauwelijks sprake. De LSV is afhankelijk van de medewerking van anderen die het voorstel wel van belang vinden - "het terugdringen van zeer hoge inkomens is in bet belang wan alle partijen" zegt de onderhandelaar van de VNZ168 - maar andere prioriteiten hebben. De ziekenfondsen blijven vooral wasthouden aan hun doelstellingen die zij reeds aan het begin van het overleg formuleerden: er moet "wolumebeheersing" tot stand komen en de specialisten moeten weer cen medewerkerscontract met de ziekenfondsen ondertekenen. ${ }^{169}$ Ook de particuliere verzekeraars hechten aan 'volumebeheersing', maar vooral aan veranderingen in

162 Brief Van Aardenne aan leden wan let VPO, 18 juli 1989

$163 \mathrm{KLOZ}$, notitie aan DB, 24 juli 1989

164. Brief Van Aardenne aan SZW en WVC, 21 juli 1989

165 VPO, notitie Concept draaboek "protocol", 21 juli 1989

166 WVC, nota VPO/m.s., 3 augustus 1989

167 Brief WVC/SZW/EZ aan VPO, 9 september 1989

$168 \mathrm{DB}$ VNZ, 9 augustus 1989

169 VNZ, Notitie aan het DB, 17 mei 1989 
tarieven teneinde de verschillen tussen particuliere en ziekenfondstarieven te verkleinen. ${ }^{70}$ Het is te danken aan het uitgangspunt dat ook de reshuffling deel uitmaakt van het totale pakket van overeen te komen besluiten, dat de verzekeraars en ziekenfondsen betrokken bliven. Daamaast vergt de juridische discussie de aandacht van de anderen. De reshuffling mag dan vooral van belang zijn woor de LSV zelf, de juridische uitwerking is een zaak van allen. Men will geen accoord dat later nog moet worden uitgewerkt, maar een overeenkomst waarvan de uitvoering juridisch zoveel mogelijk veilig is gesteld. Hoewel de LSV in het recente verleden regelmatig een beroep op de rechter heeft deed om tariefbesluiten tegen te gaan, geldt het wantrouwen haar mu niet. Met de LSV als actieve deelnemer zal het VPO ervoor moeten zorgen dat individuele specialisten de collectieve afspraken juridisch niet kunnen aanvechten. ${ }^{171}$

Tabel 4. Hel reshuflingsvoorstel wan juli 1989

specialismen met tariefverlagingen

specialismen met tariefverhogingen.

\begin{tabular}{llll}
\hline cardio-chirturgie & $3 \times 10 \%$ & kindergeneeskunde & $1 \times 10 \%$ \\
cardiologie & $2 \times 5 \%$ & maag-darm geneeskunde & $1 \times 10 \%$ \\
& $1 \times 2,5 \%$ & psychiatrie & $2 \times 12,5 \%$ \\
cardio-anaesthesie & $3 \times 5 \%$ & allergologie & $2 \times 12,5 \%$ \\
radio-diagnostiek & $3 \times 5 \%$ & reumatologie & $2 \times 12,5 \%$ \\
medische microbiologie & $3 \times 5 \%$ & revalidatie & $2 \times 12,5 \%$ \\
pathologische anatomie & $3 \times 5 \%$ & & \\
\hline
\end{tabular}

De overheid omamt het voorstel , maar is bevreesd voor de verplichtingen die ontstaan als vast komt te staan dat het reshufflingsvoorstel inkomenspolitiek is. Het geven van aanwijzingen zien met name de verzekeraars en de ziekenfondsen echter als belangrijkste middel om een effectieve regeling af te spreken. ${ }^{172}$ Het secretariaat wan het COTG speelt de rol van de duivel. Volgens het COTG maken het gebruik van door de rechter verboden bronnen en het inkomensbeleidsmatige karakter van de reshuffling de juridische houdbaarheid van het voorstel zeer twijfelachtig. Gaan sleutelen aan enkele elementen van de tariefformule zou een oplossing kunnen zijn. Overigens vindt de secretaris van Kamer $V$ de suggestie twijfelachtig, dat de reshuffling een besparing oplevert. Volgens hem kost de reshuffing zelfs geld. ${ }^{73}$

Na september 1989 is er sprake van een parallel verloop van ontwikkelingen. Tussen de voorzitter van het VPO en de overheid worden gesprekken gevoerd over de houding van de bewindslieden ten opzichte van het overleg, tussen het VPO en het COTG wordt overlegd over de vormgeving van de afspraken en de onderhandelaars lichten de achterbannen in over de uitkomsten van de onderhandelingen.

$\mathrm{Er}$ is in het VPO nauwelijks onenigheid over het meer in overeenstemming brengen van de inkonens van medisch specialisten op de manier van Van Aardenne, maar de reshuffling is moeilijk it overeenstemming te brengen met de eisen van het COTG. Het leidt tot veel onzekerheid over de relatie met de bestaande wettelijke voorschriften. De onzekerheid wordt voortdurend aangewakkerd door de waarschwingen van het secretariaat van het COTG,

170 KLOZ, Notitie t.b.v. overleg met Van Aardenne, 5 juni 1989

$171 \mathrm{AB}$ VNZ, 25 oktober 1989

172 Verslag 20ste Plenaire vergadering VPO, 13 september 1989

173 COTG, notitie Het Van Aardenne-overleg en de WTG (m.s.), 10 juli 1989 
waarvan het niet voor iedereen duidelik is of er gesproken wordt op basis wan de wet of op basis van eigen opvattingen. ${ }^{174}$ De juridische onzekerheden zijn reden voor veelwuldig overleg tussen VPO, COTG en WVC. Het COTG stelt zich op het standpunt dat men slechts dan kan meewerken als naar het eigen oordeel de juridische houdbatrheid is gegarandeerd. Bij het opstellen van dat oordeel is het COTG zelfstandig; het COTG maakt geen deel wit van het VPO en is niet gebonden aan de witkomsten. 175 Ook aan de overheid wordt de positie van het COTG duidelijk gemaakt. De medewerking van het COTG is afhankelijk van het oordeel wan het COTG over de witwerking van de verschillende onderdelen. Ook volt het COTG zich geen partij van het VPO, en behoudt dus het recht een andere koers te gaan varen. Ten aanzien van de reshuffing is een aanwijzing op grond van een Wivb-besluit noodzakelijk. Dit geldt zolang de Wivb geldig is. Echter, ondat inzicht in de feitelijke inkomens van medisch specialisten ontbreekt, zal elk inkomensbesluit met succes aanvechtbaar zijn. Om het VPO juridisch houdbaar te laten zijn, is dus het vervallen van de Wivb noodzakelijk. 176 In het overleg laat het COTG-secretariat in eerste instantie weten, dat een aanwijzing van de overheid nodig is. 177 Bovendien blijkt dat de overheid niet alleen een actieve participatie afhoudt, maar tevens als uitkomst van juridische procedures vreest dat alleen de verhogingen van tarieven in stand blijven en de verlagingen worden verboden. 178 Maar in de bouding wan het COTG treedt na verloop van tijd enige verandering op. Wel geeft het secretariaat op 19 september nog aan dat de reshuffling éen van de moeilijkste problemen is, maar in deze bespreking is eveneens gesproken over een manier waarop het COTG en de partijen gezamenlijk tot een redelijke onderbouwing zouden kunnen komen. 179 Hoe die onderbouwing er uit zou moeten zien en waarop deze gebaseerd zou moeten zijn, is overigens nog onduidelijk. 180 Bovendien geeft Van Aardenne in het begin van oktober aan dat de voorzitter van het COTG heeft laten weten alle medewerking te willen verlenen aan de oplossing van het specialistenconflict.181 In het technische overleg wordt vervolgens gesproken over een onderbouwing van de percentages uit het voorstel van Van Aardenne. 182 Kennelijk is een aanwijzing voor het COTG-secretariaat niet meer noodzakelijk. Maar een expliciete onderbouwing van de mutatiepercentages komt desondanks niet tot stand. 183

De LSV maakt ondertussen tot tevredenheid van de anderen werk van de verdediging van de afspraken bij de achterban. $184 \mathrm{Na}$ de tussentijdse voorstellen van Van Aardenne heeft de LSV de percentages van de tariefsveranderingen al aan de Wetenschappelijke Verenigingen voorgelegd. Als er specialisten zijn die op grond van gegevens aan kunnen tonen dat de reshufflingspercentages onjuist zijn, dan zal de LSV dit weer in het VPO ter sprake brengen.

$174 V N Z$, notitie aan interne specialisten overleg, 2 oktober 1989

175 COTG, agendanotitie aan LSV, VNZ, KLOZ, KPZ en NZr, 12 september 1989. IJlustratief woor de afstandelijke houding wan het COTG zijn de opmerkingen in een notitie ten behoeve van het Technisch Overleg VPO (TOVPO), Uitdrukkelijk wordt gesteld dat de inbreng van het COIGsecretariat technisch is en dat er geen beleidsmatige binding bestat. COTG, notitie t.b.v. het Technische Overleg VPO (TOVPO), 3 oktober 1989

176 Concept van secretariaat COTG aan WVC (fax), 22 augustus 1989

177 COTG, Verslag overleg LSV, NZT, WNZ, KLOZ, KPZ, COTG-secretariat op 25 juli 1989,3 augustus 1989

178 Brief WVC/SZW/EZ aan VPO, 8 september 1989

179 Verslag 20 ste Plenaire vergadering VPO, 20 september 1989

180. VNZ, notitie aan het interne specialisten overleg, 2 oktober 1989

181 Verslag 22ste Plenaire vergadering VPO, 5 oktober 1989

182 COTG, Verslag van het TOVPO, 25 september 1989

183 Fax COTG-secretariat an WVC, 15 november 1989

184 Zie: Specialistenbrief, 6 september 1989/Medisch Contact 
Ontewreden groepert van specialisten zijn daartoe niet in staat ${ }^{185}$ Alleen de radio-therapeuten slagein daarin wardoor zij met langer deel uimaken wan de groep vedverdieners. Voortgang is ook hard nodig. Volgens de procedureplanning wan het COTG hadden richtijnvoorstellen al op 28 angustus bij het COTG moeten zijn ingediend. ${ }^{186}$ Bovendien heef WVC haast. In januari staat onder meer het financieel Overzicht Zorg op de agenda van de Tweede Kamer. De voorziter van het VPO maant de onderhandelaars to: haast; uiterlik 1 december noeten de voorstellen bij het COTG zijn neergelegd. ${ }^{187}$ Deze datum wordt evenmin gehaald. Het duurt tot 11 december voordat er een complete overeenkomst is. De reshuffling wordt heel pragmatisch onderbouwd. Op basis van een totaal aan beschikbare gegevens wordt het voorstel verdedigbaar geacht. ${ }^{188}$

Nog voordat met het COTG overeenstemming over de onderbouwing wordt bereikt is in concepten van de Ramoverenkomst artikel 6 opgenomen. In artikel 6 staan de percentages Warmee de tarieven voor verschillende specialismen zullen veranderen. ${ }^{189} \mathrm{Zij}$ wijken niet af van het voorstel van Van Aardenne in jull. Ook in de definitieve tekst staan de bekende percentages. Noch de vele discussies met het COTG noch de discussies tussen het bestuur van de LSV en de achterban hebben de percentages veranderd, die ongeveer al een half jaar oud zijn. Als technische oplossing geldt dat de tarieflomule wordt toegepast zonder evenwell de K (de kosten) of de I (het inkomen) aan te passen. 190

Hoewel wrijwel iedereen het grote belang ervan heeft aangegeven wordt het reshufflingsvoorstel dus niet versterkt door een expliciete onderbouwing. Ook de verwachting van velen dat de owerheid een aanwijzing zou moeten sturen an het COTG kornt niet uit. De waarschuwing van het COTG dat de Wivb een aanwijzing aan het COTG impliceert teneinde de reshuffling te kumnen witvoeren, weerhoudt WVC er niet van in de technische gesprekken gedurende de laatste maanden wan 1989 het standpunt in te nemen dat zij niet van plan is bij het kabinet aan te dringen op intrekking van de Wivb en dat zij niet van plan is een aanwijzing aan het COTG te sturen. De verantwoordelijkheid ligt geheel en al bij het COTG en de partijen. WVC wil al langer directe betrokkenheid bij de besluitworming over tarieven voor medisch specialisten voorkomen. Bovendien voelt WVC er niets voor om de richtlijnen van het COTG voor de vergoedingen voor de praktjkkosten te laten vervallen. Hierdoor is het voor WVC mogelijk de onderhandelende partijen onder druk te zetten, maar ook het oude praktijkkostenbeleid te hervatten op het moment dat het VPO alsnog mislukt. ${ }^{19} 1$

De staatssecretaris van WVC mag van zijn ambtenaren in het overleg met Van Aardenne vlak na de totstandkoming van de Ramovereenkomst dan ook niet toegeven aan de wens van de LSV tot opheffing van de bestaande richtlijnen en wettelijke regels. De heersende bevoegdhedenverdelingen en financiële doelstellingen van de overheid vormen de criteria warmee de overheid de overeenkomst beoordeelt. 192 Dat de juridische houdbaatheid van het voorstel de tarieven voor" medisch specialisten te 'reshufflen' niet vaststaat, is voor de staatssecretaris geen beletsel de voorzitter van het VPO te complimenteren met het bereikte resultaat, hoewel de overheid dit toch nadrukkelijk aan de orde stelde in haar reactie in september op het tussentijdse verslag van $V_{\text {ar }}$ Aardenne. De overheid heef volgens zichzelf geen andere keure. De verschillende betrokken ministeries beseffen dat de overeenkomst op een aantal

185 Verslag 25 ste Plendire vergadering VPO, 2 november 1989

186 Brief COTG aan LSV, VNZ, KLOZ, KPZ en NZr, 31 juli 1989

187 Verslag 22 ste Plenaire vergadering VPO, 5 oktober 1989

188 VNZ, notitie Voorlopige resultaten werkgroepen in het kader van het VPO, 3 november 1989

189 Concept Raamovereenkomst VPO, 9 november $1989 / 13$ november 1989

190) Fax COTG-secretariat an WVC, 4 december 1989

191 WVC, nota aan staatssecretaris, 18 decemben 1989

192 WVC, nota aan statssecretaris, 18 december 1989 
punten juridisch kwetsbaar is. Zij weten ook dat individuele specialisten via de Witg juridisehe procedures zullen anspannen waardoor aan de poten van de overeenkomst kan worden gezaagd. Maar er wordt op vertrouwd dat de betrokken partijen veel waarde hechten aan het Akkoord. Bovendien heef de overheid geen alternatief voor instemming; het kabinet heef immers ermee ingestemd dat de partijen zelf oplossingen zouden zoeken en heeft tevens zijn goedkeuring gehecht aan het voorlopige accoord in het tussentijdse verslag wan Van Aardenne 193 Zeker op een aantal punten lijkt de overeenkomst een sprong in het duister. Hoe duister moet WVC al snel dudelijk zjn. Als in februari de Landsadwocaat om advies wordt gevraagd zegt deze ten aanzien van artikel 6 , dat de rechter een beslissing van het COTG on uitvoering te geven aan artikel 6 met aan zekerheid grenzende waarschinlijkheid onrechtmatig en onverbindend zal verklaren als niet een aanvaardbaar inkomensniveau en cen daarop aansluitende aanwijzing in het kader van artikel 15 Wtg opgesteld worden. 194

\section{De uitwerking met een tegenstribbelend COTG}

Onder tijdsdruk en in de wetenschap dat WVC niet popelt on aan het COTG een aanwiging te geven, dienen de organisaties zich te zetten aan het maken van richtlijnen. Zoals reeds eerder beschreven stuiten zij daarbij op het COTG. Voor het COTG is het onacceptabel dat de bestaande kostenrichtlijnen die na veel moeite tot stand zijn gekomen ingetrokken worden. Het secretariaat prefereent een situatie waarin de kostenrichtlinen 'boven de markt blijven hangen', en waarin de geplande verlagingen wan de vergoedingen voor de praktijkkosten per 1 januari 1990 en 1 januari 1991 verschoven worden naar 1 januari 1993. Voor de voorstellen van de Raamovereenkomst zouden aanvullende richtlinen moeten worden opgesteld, 195 Het secretariaat. koppelt de uitwoering van het Akkoord los wan het vervallen van bestaande richtlinen. Als de organisaties, verenigd in het $\mathrm{VPO}$, hun voorstellen willen verwezenlijken moeten zij maau komen met nieuwe richtlijnvoorstellen die vervolgens door het COTG beoordeeld zullen worden. 196.

Het vasthouden an de bestaande richtlijnen is echter stechts voor de LSV een straikelblok. Anderen onderschrijven het standpunt van het COTG. In januari 1990 trapt het secretariaat de andere organisaties wel echt op de staart. Ter voorbereiding van de vergadering van het bestuur van het COTG in januari schrijft het secretariat het concept van nota 90-02. Het secretariaat constateert dat er weliswaar een aantal goede zaken zijn, maar dat bijstellingen nodig zijn ten behoeve van de juridische houdbaarheid en uitvoerbaarheid. Zelfs bijgesteld kan echter geen enkele garantie worden gegeven voor de juridische houdbaarheid. Ten aanzien van de reshuffling merkt het secretariat op dat de mutatiepercentages niet onderbouwd zijn. Tenslotte moeten de bestaande richtlinen gehandhaafd worden. Eén van de argumenten is dat het VPA niet meer is

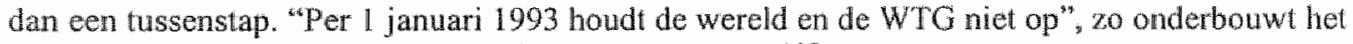
COTG-secretariaat de wens de richtlijnen te handhaven. 197

De nota is voor de deelnemers aan het VPO reden bij WVC te klagen over de houding van het COTG en de gevaren daarvan voor de realisatic van de afspraken. 198 De meuwe staatssecretaris Simons prat vervolgens verschillende keren met voorzitter Elsen wan het COTG

193 WVC, notitie an de staatssecretaris, 12 januari 1990. Overigens blikt het departement van Financièn het meest wantrouwend en wil in de officiele reactie opgenomen zien dat her huidige kostenbeleid automatisch weer in werking treed als het VPA niet blijkt te werken. Dit wordt bekend onder de naam 'automatische piloot'. WVC as daartoe echter niet bereid. Brier WVC aan de MP/MR, 12 januari 1990

194 Advies landsadvocat, 7 februar 1990

195 Fax COTG-secretariaat an WVC, 4 december 1989

196 BriefCOTG aan VNZ, KLOZ, LSV, KPZ, NZr, 20 maart 1990

197 COTG, nota 90-02, versie dd 19 januari 1990 en versie dd 24 januari 1990

198 Memo WVC aan de staatssecretaris, 22 januari 1990 
over de positie van het COTG. Hoewel WVC erkent dat het COTG een zelfstandige functie heeft, vinden de ambtenaren dat het secretariaat van het COTG teveel let op de problemen en minder op de mogelijkheden tot realisatie. Deze houding wordt gerelateerd aan de eigen mening van het COTG en de teleurstelling over het dreigende lot van de kostenrichtlijnen. 199

De interventie van de staatssecretaris draagt weinig bij tot een spoedige realisering van de reshuffling. Deze dient per 1 juli 1990 aan te vangen. Dan moeten immers volgens de Raamovereenkonst de eerste verlagingen en verhogingen van tarieven plaatsvinden. Het uitblijven van verlagingen wormt op zich geen probleem; het uitstellen van beloofde verhogingen van tarieven daarentegen is met name voor de LSV moeilijk verdedigbaar bij de 'onderverdieners', 200 Nog steeds spelen de twee centrale problemen. Hoe kunnen de percentages van artikel 6 onderbouwd worden opdat houdbare richtlijnen door het COTG opgesteld kunnen worden? En hoe kan het voorstel tot nieuwe richtlijnen worden vormgegeven zonder dat het strijdig is met de bepalingen in de Wtg en de Wivb?

Het VPO probeert in de gesprekken met de overheid en het COTG duidelijkheid te krijgen, maar vraagt aok aan anderen advies. Advocaten en juristen worden ingeschakeld, maar alle informatie lijkt de betrokkenen alleen maar meer in verwarring te brengen.201 Nader overleg tussen partijen, overheid en COTG blijft nodig. Het wordt onmogelijk om een COTG-besluit voor 1 juli tot stand te brengen.202 Er komt pas schot in de zaak op het moment dat het College voor Beroep woor het Bedrijfsleven (CBB) de tweeslag verbiedt. De vitspraak zaait twijfel in het VPO over de goede afloop, maar Van Aardenne laat de buitenwereld vrij snel weten dat het Akkoord uitgevoerd zal moeten worden zoals het is overeengekomen. ${ }^{203}$ Wel doet het oordeel van het CBB de betrokkenen in nog sterkere mate beseffen hoe nodig het is dat alle afspraken juridisch mogelijk zijn. 204 De deelnemers aan het VPO (of meer precies het Klein-VPO (KVPO) dat de technische uitvoering van de Raamovereenkomst verzorgt) krijgen informeel van de overheid te horen, dat zij maar moeten aangeven wat van WVC wordt verwacht om het VPA uit te kunnen voeren. ${ }^{205}$ Daarop aansluitend besluiten de vijf organisaties de overheid zo snel mogelijk te vragen de Wivb af te schaffen. 206 De partijen laten Simons weten dat het externe juridische advies hen heeft geleerd dat de realisering van het VPO niet mogelijk is zonder verandering van het wettelijke stelsel. De deelnemers aan het overleg hebben het onderscheid tussen kosten en inkomen laten varen en zijn van mening dat inkomenspolitieke doelstellingen achterhaald zijn. Gegevens van de partijen tonen aan dat er geen goed evenwicht is tussen de verschillende specialismen als het gaat om de relatie tussen de werkbelasting en de gemaakte omzet. De gegevens rechtvaardigen de veranderingen van tarieven zoals zij vermeld staan in de Raamovereenkomst. Het probleem is dat er met het voortbestaan van de Wivb een procedure is die bepaalt hoe besluiten over inkomensbeleid tot stand dienen te komen. De enige oplossing is

199 WVC, Ambtelijk advies an de staatssecretaris, 23 januari 1990. Door DGVgz wordt opgemerkt: "Beter de ene richtlijn wan het COTG in de hand dan de vele van het VPO in de lucht, zall Elsen aangeven." WVC heet het concept van nota 90-02 op 22 januari informecl ontvangen.

200 Zie bijvoorbeeld de oproep aan de kinderartsen geduld te bewaren door de voorzitter (Medisch Contact, 1990, nr. $27-28$, p. 45).

201 Zo vingen de LSV, VNZ, KLOZ en KPZ op 24 april aan Buruma en Maris om advies over de realisatie van de artikelen 2, 3, 6 en 9 van de Raamowereenkomst. Brief LSV aan Buruma en Maris, 24 april 1990

202 COTG, notitie Stand wan zaken effectuering tariefmaatregelen medische specialisten zoals vermeld in het Vijf Partijen Akkoord (VPA), 23 april 1990

203 Communique Van Aardenne, 11 juni 1990

204 CB LSV, 12 jull 1990

205 Verslag vergadering KVPO, 20 juni 1990 / verslag vergadering $\mathrm{KVPO}, 12$ juli 1.990

206 Verslag wergadering $\mathrm{KVPO}, 27$ juni 1990 
dat de Wivb wordt afgeschaf, en dat de Wig op onderdelen moet worden aangepast. 20 zal arthel 15 moeten verdwijnem omdat dit artikel de overheid verplicht aanwizingen aan het COTG te geven in geval van inkomenspolitieke besluten. 207

Al eerder is door de LSV de noodklok geluid over de realisatie van de afspraken wan het VPO die gevaar loopt door juridische obstakels en gebrek aan medewerking door het COTG. WVC wordi gevraagd deel te nemen aan een "reddingsoperatie". ${ }^{208}$ Maar midden juni is ambtelijk WVC echter helemaal niet zo enthousiast over een actieve opstelling van de overheid. Bovendien betwijelt men op het departement het nut van het intrekken wan de Wivb. Volgens de ambtenaren heeft de uitspraak van het CBB duidelijk gemaakt dat de afspraken juridisch niet goed in elkaar steken. De reshuffling is inhoudelijk geen goede afspraak en daardoor juridisch niet uitvoerbaar. De intrekking van de Wivb zal daar miets aan veranderen. Overigens is het intrekken van de Wivb geen probleem, mar het is politiek gezien geen goed moment omdat het in verband zal worden gebracht met de moeilijkheden met het VPA. Kortom, WVC wil op dat moment niet meer overheidsbemoeienis. 209 Voor het owerleg in juli mag Simons dan ook niet toegeven aan de wensen van de deelnemers aan het VPO. Watswijzigingen op basis van een tijdelijk accoord worden hem afgeraden. Simons moet laten weten dat de wijf organisaties maar moeten zoeken naar oplossingen binnen de bestaande wettelijke kaders. Wel kan worden aangegeven dat de intrekking van de Wivb wordt overwogen. Een aanwijzing is evenwel helemaal wit den boze; daarmee zou de overheid "zich kwetsbaar maken omdat het dan de overheid is die moet bewijzen dat de inhoud juist is." 210

De probleemdefinities blijken in de loop van 1990 niet meer overeen te komen. Terwijl de wijf partijen het standpunt aanhouden dat het voortbestan van de Wivb een obstakel is voor de uivoering van het VPA, huldigt WVC de opvatting dat verandering van de wettelijke kaders weinig verandert. De vraag rijst waarom het VPO daaraan vasthoud. Een verklaring van WVC is dat de LSV ten allen tijde zou willen voorkomen dat een onderdeel van het VPA als een inkomensmaatregel bekend wordt. 11 Een andere vraag is waaron WVC de relevantie van het argument van het VPO zo laag inschat terwijl de Landsadvocaat in februari nog zo duidelijk was.

Intussen zijn ook voorstellen bij het COTG ingediend on richtijnen op te stellen met als doel de mutaties in tarieven als aangegeven in artikel 6 van de Ramovereenkonst. In het VPO is er in juni voor gekozen door middel van voorstellen aan het COTG duidelijkheid te krijgen over de juridische haalbaarheid, hoewel de particuliere verzekeraars het beter vinden eerst in gesprekken met het departement van WVC duidelijkheid te krijgen.212 Dit gebeurt in de vorm van een concept-brief omdat de formete richtlijwwoorstellen pas ingediend kunnen worden als de Wivb is ingetrokken. De indieners streven naar nieuwe, geldige tarieven per 1 oktober. ${ }^{213}$ Matar ook 1 oktober is nar de mening van het COTG niet haslbaar. Zelfs 1 januari 1991 is

207 Brief VNZ aan de staatssecretaris, 28 juni 1990

208 Brief LSV alan de staatssecretaris, 11 juri 1990

209 WVC, Notitie aan de statssecretaris, 18 juni 1990

210 WVC, notitte aan de staatssecretaris, 11 juli 1990 . WVC doet er alles aan om niet betrokken te raken bij de uitwoering van het VPA. SZW heeft in juni 1990 al reeds besloten dai de Wivb niet meer levensvatbaar is. Alleen $\mathrm{EZ}$ werkt nog tegen. Bovendien heeft WVC een dubbele houding. Van de partijen wordt geẻist dat zij zich houden aan de bestaande wet- en regelgeving mar zelf wenst zij haar bevoegdheden ex Wivb en Wtg niet worm te geven.

211 WVC, notitie aan de staatssecretaris, 11 juli 1990

212 VPO, verslag plenaire vergadering, 25 juni 1990

213 Brief LSV, mede namens VNZ, KPZ en KLOZ, aan COTG, 23 juli 1990. Net als bij de richtlinnen wan de praktijkkosten, komen richtijnen en tariefwijzigingen overeen. 
twijfelachtig omdat, zo schnjft het secretariaat, de Wivb nog lang niet ingetrokken is en de omzetting van de verzoeken in richtlinnen nog 4 maanden zal vergen. 214

\section{De ommezwali van het COTG}

Eind augtstus stat thet water met name de LSV tot aan de lippen. De uitvoering van enkele juist woor de specialisten belangrijke elementen vam het VPO loopt aanzienlijke vertraging op. Binnen de LSV wordt reeds gesproken van een impasse. Men woelt een gebrek aan medewerking door de overheid, door het COTG dat zelfs tegenwerkt en ook door andere VPO-deelnemers. Niet iedere deelnemer blijkt het belang dat de $L S V$ an de reshuffing hecht te delen. $215 \mathrm{De}$ vertraging van de invoering van de reshuffing geeft tevens problemen met de achterban. De kinderartsen, psychiaters en reumatologen maken bezwar tegen het uitstel van de verhoging van huin tarieven. 216

De wens van de LSV zo snel mogelijk de reshuffling in te voeren, leidt in het VPO to de discussie omtrent de koppeling met herijking binnen specialismen en de herstructurering van de tarieven. Met name de verzekeraars zien thet woorstel tot de reshuffing als een onderdeel van een pakket aan voorstellen waarin ook de herstructurering en herijking binnen de specialismen geregeld worden. Deze beide onderwerpen nemen echter nogal wat tijd in beslag ondat de benodigde gegevens niet woorhanden zijn. 217 Ten behoeve van een snelle afhandeling wordt mede onder druk van de voorzitter van het VPO aan het COTG een overeenkonst voorgelegd, waarin weliswaar alle drie onderdelen zijn verwerkt, maar waarin alleen voor de reshuffing uitdrukkelijk word gevraggd om invoering per 1 januari 1991 . De weede en derde fase zouden moeten ingaan op respectievelijk 1 juli 1991 en 1 juli 1992. Het COTG wordt gevraagd de overeenkomst pas arn de orde te stellen als het kabinet het voomemen tot afschaffing van de Wivb kenbaar heeft gemaakt. ${ }^{1 / 8}$ Nog steeds windt het secretariaat van het COTG dat het COTG moet wachten op de daadwerkelijke intrekking van de Wivb. Ook stelt het wederom dat hel twijfelachtig is of deze intrekking de juridische houdbaarheid vergroot. Bovendien bevat de overeenkomst van het VPO naar de mening van het secretariat wel veel cijfermatige modellen, maar nawweliks beleidsmatige en juridische onderbouwing. Voorstellen tot richtlijnadviezen zullen wellicht binnen afzienbare tijd klaar zijn, maar 1 januari zal niet gehaald worden. 219

Maar 1 januari 1991 wordt toch gehaald. In de tweede helft van november verandert het standpunt van het secretariaat van het COTG. Op basis van bestururijk-strategische overwegingen wordt besloten het maatschappelijk belang te onderkennen en een minder starre houding in te nemen. Tot dan toe hamerde het secretariaat op juridisch houdbare richthinen die de oude richtlijnen zouden moeten wervangen. Op 15 nowember wordi in een informeel gesprek van de LSV met de voorzitter en de algemeen secretaris van het COTO plots verkondigd dat misuwe vichtijnen niet meer nodig zijn, en dat toetsing van de voorstellen aan de bestaande richtijnen volstat. De vertegenwoordigers wan het COTG maken onomwonden duidelijk dat de richtijnwoorstellen zoals zij zijn ingediend niel op steun hoeven te rekenen.20 Na een jaar durende discussie is het kortom niet langer nodig dat voor juridisch houdbare tariefveranderingen goed onderbouwde richlijnvoorstellen worden ingediend, die impasbaar zijn in de Wig en Wivb.

214 Brief COTG an LSV, 31 juli 1990

215 CB LSV, 23 augustus 1990

216 VPO, verslag plenaire vergadering, 6 september 1990

217 De herstructurering en herijking zullen later slechts gedeeltelijk worden witgevoerd (Financieel Overzicht Zorg 1993, Tweede Kamer, wergaderjaar 1992-1993, 22808, nrs. 1-2, pag. 288)

218 Brief LSV, VNZ, KLOZ en KPZ aan COTG, I oktober 1990

219 CoTG, notitie Stand van zaken tarieven medisch specialisten, 14 november 1990

$220 \mathrm{VPO}$, verslag plenaire vergadering, 29 november $1990 / \mathrm{CB}$ LSV, 29 november 1990 
De twijfel over de juridisch houdbaarheid word door de plotse verandering in het standpunt van het secretariat van het COTG bij sommigen alleen mar groter. Het COTG trekt inmers zijn handen af van de juridische beoordeling en legt de verantwoordelijkheid byj de indieners van het voorstel. 221 Het secretariat van het $\mathrm{COTG}$ stelt expliciet begin december: dat het ervan uitgaat dat de partijen zelf overtuigd zijn van de juridische houdbarareid van de onderbouwing van de veranderingen in tarieven ten behoeve van neer evenwichtige omzetter. Ook ten aanzien van de gebruikte bromen wenst het COTG niet werantwoordelijk gesteld te worden. Het is wel van mening dat de reshuffing een goede stap is in de richting van meer evenwichtige tarieven, en ook dat de voorstellen niet strijdig zijn met de bestaande richtlinen 222 De vrees voor het juridisch oordeel weerhoudt de deelnemers an het VPO er niet wan gebruk te maken van de mogelijkheid die het COTG aangeeft. Er is simpelweg geen altematief voor een spoedige afronding, houdt de LSV het VPO voor ${ }^{223}$ De LSV ziet met deze door het COTG aangeboden oplossing een belangrijke doelstelling - de oude richtlijnen voor de verlaging van de praktijkkosten moeten verdwijnen - als sneeuw voor de zon verdwijnen, maar de onderhandelaars van de LSV in het VPO spreken hun vertrouwen uit in de ziekenfondsen en verzekeraars. 224 Bovendien blijkt de LSV wederom veel belang te hechten aan een zo spoedig mogelijk invoering van de reshuffling. Door het voorstel van het COTG is er tijdwinst. Het blijven bestaan wan de oude richtijnen wordt nog slechts beschouwd als een risico, dat men eigeniijk een jaar geleden ook al had ingecalculeerd. 225

In december vragen de verzekeraars, zickenfondsen en medisch specialisten gezamenlijk aar het COTG de eerste fase van de herijking van de tarieven tussen specialismen per 1 januari 1991 in te laten gaan. Het woorstel is in tabel 4.5 weergegeven. ${ }^{226}$ De organisaties hebben deze percentages kunnen berekenen door eerst de totale onzet per specialist in 1989 vast te stellen en deze te relateren aan een relatieve werkbelasting (zie tabel 4.6 ). Voor het vaststellen van de relatieve werkbelasting zijn ook verschillende bronnen gebruikt 227

221 KLOZ, notitie Voortgang VPO, 26 november 1990

222 COTG, Nota 90-82-e1, 12 december 1990. Het COTG presenteert deze "november-oplossing" als redelijk vanzelfsprekend in het jaarwerslag over 1990. In het jaarverslag geeft het corG aan dat er niets verandert in de teller in de tarieffomule en dat er dus sprake is wan noch inkomens- noch kostenbeleid. Alleen de noemer, de W (workload) verandert. Er wordt niets wermeld over de bijna een jaar durende discussie over de juridische aspecten en de richtijnproblenatiek. Sterker nog, het COTG herhalt het standpunt dat zij in 1991 ten behoeve vart de reallisatie wan andere onderdelen wan het Vijf-partijen Akkoord met belangstelling nieuwe richtlijnvoorstellen afwacht, waarna beslist kan worden of de bestaande richtijinen gewijzigd dan wel vervangen kunnen worden (Jaarverslag Coro 1990:26-27).

$223 \mathrm{VPO}$, verslag plenaire vergadering, 29 november 1990

224 VPO, verslag plenaire vergadering, 29 november 1990

$225 \mathrm{CB}$ LSV, 29 nowember 1990

226 Brief KLOZ/KPZ/LSW/VNZ aan COTG, 5 december 1990

227 Bijlage 4 bij Bijlage 1 bij COTG 90-82. Voor het vaststellen van de omzet per specialist is gebruik gemaakt van CBSH-, LISZ- en Van Dien-gegevens, terwijl de relatieve werkbelasting gebaseerd is op enquêtes van Van Dien\&Co, Van Mansvelt, het NZI, de Rijksuniversiteit Limburg; en 'de erwaring en waarmeming van partijen' (sic). 


\begin{tabular}{lccc}
\hline & $1-1-91$ & $1-7-91$ & $1-1-92$ \\
\hline cardio-pulmonale chirurgie & -10 & -10 & -10 \\
cardiologie & -5 & -5 & $-2,5$ \\
cardio anaesthesie & -5 & -5 & -5 \\
radiodiagnostiek & -5 & -5 & -5 \\
medische microbiologie & -5 & -5 & -5 \\
kindergeneeskunde & +10 & 0 & 0 \\
gastro enterologie & +10 & 0 & 0 \\
psychiatrie & $+12,5$ & $+12,5$ & 0 \\
allergologie & $+12,5$ & $+12,5$ & 0 \\
reumatologie & $+12,5$ & $+12,5$ & 0 \\
revalidatie & $+12,5$ & $+12,5$ & 0 \\
\hline
\end{tabular}

Zoals na het eerdere overleg in november te verwachten valt, reageert het secretariaat van het COTG welwillend. De voorstellen zijn een goede stap in de richting van adequaat onderbouwde tarieven. Bovendien zijn de voorstellen niet strijdig met de bestaande richtlijnen. Omdat niets verandent in de teller van de tariefformule is er geen sprake wan inkomensbeleid ${ }^{228}$ Het COTG besluit op 18 december 1990 om overeenkomstig de voorstellen van de partijen de tarieven aan te passen per 1 januari 1991 .

Het besluit van het COTG wordt door achthonderd medisch specialisten en de beide Nederlandse Verenigingen voor Anesthesiologie en Cardiologie aangevochten bij het CBB. Zij willen het besluit van het COTG schorsen in afwachting van een uitspraak in een bodemprocedure en vragen om een voorlopige voorziening. De voorzitter van het CBB wijst het verzoek op 20 februari af. Hij vindt dat er geen sprake is van inkomensbeleid omdat het aanvaardbaar inkomensniveau niet wordt gewijzigd. Ook hebben de verzoekers naar zijn mening niet kunuen aantonen, dat het aanvaardbaar inkomensniveau door de reshuffling niet meer gehaald kan worden. Tenslotte wordt wolgens het CBB de everwwichtigheid van tarieven bevorderd.229 Uiteindelijk bljkt dus het woorstel dat door het COTG als juridisch onhoudbaar werd omschreven en van het begin af aan als éen van de juridisch meest kwetsbare onderdelen werd gezien, de junidische proef met verve te doorstaan door de technische onderbouwing in de laatste maanden van 1990. Door het juridische oordeel is de weg vrij voor de verdere afhandeling van de reshuffing. Op 27 mei 1991 besluit het COTG na een verzoek van de partijen tot uitvoering van de tweede stap van de reshuffling op 1 juli 1991 . In 1992 vindt de voltooing van de reshuffing conform de plannen van december 1990 plats. Op 18 mei besluit het COTG eveneens na een varzoek van partijen dat ook de derde stap uitgewoerd moet worden. Deze stap bestat wit alleen verlagingen. 


\begin{tabular}{lcc} 
cardio-pulmonale chirurgie & 831.883 & 135 \\
cardiologie & 382.575 & 120 \\
cardio anaesthesie & 288.834 & 120 \\
radiodiagnostiek & 480.446 & 100 \\
medische microbiologie & 401.206 & 100 \\
kindergeneeskunde & & \\
gastro enterologie & 234.324 & 110 \\
psychiatrie & 260.966 & 120 \\
allergologie & 149.534 & 120 \\
reumatologie & 207.558 & 100 \\
revalidatie* & 222.692 & 110 \\
\hline
\end{tabular}

Bron: Bijlage 4 bij Bijlage $\mathbb{1}$ bij COTG $90-82$

* De indieners van het voorstel geven aan dat de gebruikte informatie geen feitelijk inzicht geeft in de omzet van een revalidatiearts. Naar hun mening, moet deze ver onder het genoemde geldbedrag liggen.

\subsection{Straf voor onwillige specialisten: de tweeslag}

\subsubsection{Een kort overaicht}

Zoals al in het eerste hoofdstuk werd aangegeven, bestaat in principe voor elke medische verrichting éen tarief. Weliswaar was het tarief voor de particulier verzekerden tot aan 1997 veel hoger dan dat voor ziekenfondsverzekerden, maar dit was verklaarbaar vanuit de historische ontwikkeling van de voorheen gescheiden manieren van financiering van de zorg en niet door een dubbele omschrijving van verrichtingen in een tariefbesluit van het COTG. De in de volgende paragraaf beschreven activiteiten van de organisaties van ziekenfondsen, verzekeraars en specialisten hebben als doel voor elke verrichting van een medisch specialist twee tarieven in het leven te roepen.

In de loop van het Vijf-partijen Overleg ontstaat bij de onderhandelaars het idee een prikkel voor medisch specialisten te bedenken, die hen zou kunnen aanzetten tot het tekenen van een overeenkomst die gebaseerd is op de nationale afspraken tussen de VPO-organisaties. Uiteindelijk zullen de partijen het eens worden over een zogenaamde tweeslag: voor elke medische verrichting konen twee tarieven, zowel in de ziekenfondssector als in de particuliere sector. Als de arts een overeenkomst met een ziekenfonds of een particuliere verzekeraar tekent en alle verplichte activiteiten in de nieuwe overeenkomst uitvoert, heef hij recht op een volledige betaling. Als hij echter nataat een overeenkomst te tekenen of weigert de verplichtingen na te komen, kan hem een 90 procent tarief worden uitbetaald.

De grote moeilikheid is hoe voor én en dezelfde medische verrichting twee tarieven kunnen bestaan. In overleg met het COTG besluiten de onderhandelaars in het VPO verschillen in de zogenaamde werkbelasting aan te voeren als rechtvaardiging voor het tariefverschil. Een arts die wel een overeenkomst tekent $z a l$ meer niet-patiëntgebonden activiteiten (bijwoorbeeld managenentparticipatie) moeten verrichten dan een arts zonder overeenkomst. In snel tempo leidt deze onderbouwing tot een nieuwe richtlin in maart 1990 als basis voor een tweeslag in tarieven. De juridische houdbaarheid van de richtlijn blijkt echter flinterdun te zijn als 
individuele medisch specialisten de richtijn en het tariefbesluit van het COTG bij het CBB aanvechten. In juni schorst de voorzitter van het CBB de tariefbeschikking die er daarmee voor zorgt dat de ecrste proef op de juridische houdbaarheid van de Raamovereenkomst een negatieve uitkomst heef. Lang treurt het VPO cchter niet. De medisch specialisten tekenen in de eerste helf van 1990 massaal overeenkonsten, onder de indruk van de financiele gevolgen wan hei verllenen van contractloze zorg.

\subsubsection{De tweeslag}

\section{Van bonus tot tweeslag}

In vergelijking met de besluitvorming over de vergoeding voor praktijkkosten en de reshuffling komt een tariefbeschikking met daarin de tweeslag in tarieven snel tot stand. Het is echter niet precies aan te gewen wanneer binnen het VPO de tweeslag woor het eerst ter sprake komt. Een voorstel om twee tarieven te gaan hanteren makt geen onderdeel wit van de inventarisatie van knelpunten die in de eerste maanden van 1989 plaats vindt en de daaruit resulterende onderhandelingsagenda. Het voorstel tot en tweeslag in tarieven komt tijdens de besprekingen gelleidelijk ter tafel, als gevolg van het idee wan de VNZ specialisten die de overeenkomst witwoeren te belonen met een geldbedrag. Er is kennelijk twijfel bij de ziekenfondsen over de mogelijkeden wan de LSW de eigen leden te disciplineren. Al eerder heef het KLOZ gedachten ontwikkelt over prikkels om zich van de medewerking van individuele specialisten bij de uivoering wan nationale afspraken te verzkeren. Een macrobudget waarbij aan de gehele medisch specialistische hulp een uitgavengrens wordt gesteld en tarieven worden verlaagd als deze grens wordt overschreden, zou volgens de vertegenwoordigers van de particuliere verzekeraars niet werken vanwege het optreden van het 'prisoners' dilemma"; als iedere specialist minder verrichtingen zou gaan doen heeft iedereen voordeel, maar als enkele specialisten meer verrichtingen doen hebben zij op de korte termijn voordeel terwijl het lagere tarief pas veel later volgt. Daarvoor in de plaats achten zij de effectiviteit van een budgettering van de medisch specialistische hulp op ziekenhuisniveau groter. 230

De tweeslag mag dan wel geleidelijk ter tafel komen, de onderhandelaars zijn het reeds tijdig eens over het principe van verschil van betaling tussen specialisten als prikkel mee te werken aan de uitvoering van afspraken. Het is eigenlijk én van de eerste onderdelen van het latere accoord waarover overeenstemming bestaat. Andere meer gevoelige zaken worden vooruitgeschoven. In de eerste maanden worden nog geen forse knopen doorgehakt. De particuliene verzekeraars vinden zelfs dat 'om de echt moeilike punten wordt heen gedratid', waaronder de eis van de LSV om de verlaging wan de kostenvergoeding terug te draaien.23\% Dí geldt dus niet voot de tweeslag; al in de eerste week van mei kan besloten worden tot de invoering van een "tweeslag in tarieven'. Er moeten twee tarieven voor én en deze]fde vorichting komen. Een specialist krijgt een hoog tarief, als hij bereid is een contract af te sluiten warin hij zich onder meer verplicht mee te werken aan de te sluiten overeenkomst. Een arts die dat weiger, krijgt slechts een laag tarief uitbetaald. Dit kan op twee manieren worden uitgevoerd. Het COTG zou een (laag) tarief kunnen vaststellen waama de verzekeraars bijpassen als de medisch specialist de overeenkomst nakomt. Het altematief is dat het COTG twee tarieven vaststelt: een laag tarief woor de specialist die zich niet wenst te houden an de overeenkomst en

230 Notitie KLOZ, KPZ, en VNZ aan Van Aardenne, 8 maart 1989

231 Verslag wooroverleg KLOZ/KPZ, 25 mei 1989 
een hoog tarief voor de medisch specialist die dat wel doet. Over het verschil tussen het hoge an het lage tarief bestaat geen verschil wan mening. Dit moet tien procent $21 j n{ }^{232}$

De uitkering van een bonus mag naar de mening van de VNZ niet onvoorwaardalijk gebeuren. Er dienen voldoende overeenkomsten door de artsen worden ondertekend zodat het Restitutiebesluit kan worden ingetrokken. Hiermee wordt tevens aangegeven, wat de primaire doelstelling van de WNZ is. Door middel van een bonus wordt de herinvoering van het naturastelsel waarschijnlijker. Deze herinvoering stat bij de VNZ bovenaan de verlanglijst, samen met de beheersing van de uitgaven van die medisch specialisten. De VNZ wil voor het belonen van specialisten het geld gebruiken war zij nog recht op heef op basis van do degressiesystematiek. Door de ziekenfondsen wordt dit voor de periode 1983-1989 op 175 a 185 miljoen gulden geschat. In 1990 zou daarvan maximaal 45 miljoen gulden aangewend kumen worden als bonus voor bereidwillige specialisten, waarna in 1991 nogmaals een geldbedrag ter beschikking kan worden gesteld. 233

Ook de particuliere verzekeraars zijn genegen de bereidwilligheid van artsen mee te werken aan de uitvoering van een overeenkonst te belonen. In tegenstelling tof de ziekenfondsen is bij hen niet sprake van een dubbel belang. In de particuliere verzekeringssector is immers nooit gewerkt met contracten tussen verzekeraars en artsen. Het herstel van het naturastelsel is woor hen dan ook niet van belang. Aan twee tarieven per verrichting zitten zelfs nadelen vast. Een dubbel tarief betekent naar de mening van het $K L O Z$ voor particuliere verzekeraars een administratieve belasting. Bovendien is voor een beloning van artsen fondsvorming nodig. Deze fondsvorming vormt eveneens een extra belasting. 234 Het gat de particuliere verzekeraars slechts om een regeling die de realisatie van de afspraken waarschijnlijker zal maken. 235

Met de vaststelling in mei dat er twee verschillende tarieven dienen te komen, rijst de vraag hoe dit geregeld zou moeten worden. Terwijl VNZ en KLOZ in eerste instantie denken aan een extra geldbedrag voor coöperatieve specialisten (een bonus) komt Van Aardenne midden juni met het voorstel tot een 'penalty-tarief'. In plaats van een beloning dient er een tarief te komen dat niet-coöperatieve artsen straft. 336 Het voorstel maakt onderdeel uiit van de 'trouvaille' van Van Aardenne, zoals de LSV het noemt. Naast de tweeslag stel Van Aardenne voor de omzet voor medisch specialisten voor drie jaar vast te stellen en maatregelen om de praktijkkostenvergoeding niet uit te voeren. ${ }^{237}$

Zoals al bij de beschrijwing, van de besluitvorming over de reshuffling aan de orde kwam, blijkt het secretariaat van het COTG in juni 1989 niet gecharmeerd te zijn van deze tussentijdse nitkomsten van het VPO. Het COTG beroept zich op de eigen verantwoordelijkheid voor wai wel en wat niet binnen de Wtg past, welke mening de overheid dan wel de partijen aok mogen hebben. Ook ten aanzien van de tweeslag is het secretariaat zeer terughoudend. Het secretariaat werzet zich tegen de mening dat de Wtg alles toelaat als de onderhandelaars het maar eens zijn. Er wordt dan ook geconcludeerd dat een tien procent bonus of tien procent malus niet past in de gedachten die het COTG heeft over goed onderbouwde tarieven. 238

Het ministerie van. WVC daarentegen vindt de uitkomsten redelijk, maar zet evenals bij de reshuffing vraagtekens bij de juridische houdbaarheid van de tweeslag. Uit informatie van de Landsadvocaat weten de ambtenaren dat twee tarieven alleen mogelik zijn als het verschil

$232 \mathrm{VPO}$, verslag plenaire vergadering, 7 mei 1989

233 Brief VNZ aan Van Aardenne, Voorstel met betrekking tot de onzet- en tariefontwikkeling. 2 juni 1989

$234 \mathrm{KLOZ}$, notitie aan het DB, betreffende het Van Aardenme-overleg, 26 juni 1989

$235 \mathrm{KLOZ}$, notitie Tariefuivo's wan medische specialisten, 5 juni 1989

$236 \mathrm{VPO}$, verslag plenaire vergadering, 3 juni 1989

237 CB LSV. 15 juni 1989

238 COTG, Notitie n.a.w. voorstel Van Aardenne de 13 juni 1989, 19 juni 1989 
gerechtvaardigd word door handelingen die de arts verricht naast de medische handelingen. De niet-medische activiteiten moeten een verschil van tien procent mogelijk maken. De Landsadvocaat denkt aan bijscholing, samenwerking, verantwoording en overleg. Op het departenent komt men tot de conclusie dat een tweeslagregeling juridisch haalbaar is, maar de noodzakelijk geachte creativiteit moet vooral gezocht worden bij het COTG. Of het COTG wil meewerken is niet duidelijk. Een aanwijzing van de overheid is ook weinig anlokkelijk omdat "de overheid zich dan erg kwetsbaar maakt." 239

Ondanks de juridische twijfels en onduidelikheden maakt de tweeslag onderdeel wit van het geheel van maatregelen in juli (de overeenstemming in hoofdlinen). ${ }^{240}$ Een tariefsverzoek ten behoeve van een tweeslag in tarieven zou volgens het draaboek van het VPO reeds in oktober bij het COTG kumnen liggen. In juli en augustus zou tussen de vijf organisaties, het COTG en de overheid overleg moeten plaatswinden over de technische uitwerking en de juridische houdbaarheid. ${ }^{24}$ Het ontbreken van duidelijkheid weerhoudt WVC er nog steeds niet van uit te blijwen spreken dat wee tarieven naast elkaar kunnen bestaan, als er maar verschillen te formuleren zijn tussen de prestaties van de medisch specialist waarwoor de tarieven worden uitbetaald. 242 Deze optie schijnt de kans op medewerking van het COTG te vergroten. Een bonus of malus regeling mag dan in het kader van de Wtg niet haalbaar zijn, het secretariaat van het COTG is wel van mening dat "met enige creativiteit er in het algemeen wel enige kostenverschillen te formuleren zijn".243

Naast een formulering die past in de Wtg en een inhoudelijke rechtvaardiging van het tariefverschil van tien procent speelt de contractuele vormgeving een belangrijke rol. Als in juni Van Aardenne zijn tweeslagvoorstel doet, gaat hij er van nit dat er slechts een tarief komt dat 90 procent van het oude COTG-tarief bedragt, waarna specialisten meer geld krijgen op basis van een privaatrechtelijke overeenkomst met ziekenfondsen. Deze vormgeving wordt door de ziekenfondsen ondersteind: slechts één tarief en een bijbetaling van tien procent als de specialist de verplichtingen van een privaatrechtelijke overeenkomst nakomt. ${ }^{244}$ Door de betaling van de bonus in de contracten zo te regelen, verkrijgen de verzekeraars meer controle op de werkzaamheden van de specialist. De verplichtingen van de arts zullen namelijk betrekking hebben op bepaalde administratieve vereisten en het onderwerpen aan controle.245 Maar in de besprekingen in het VPO blijkt deze tweeslagregeling niet acceptabel te zijn voor de LSV. De specialisten vinden dat elke specialist die een overeenkomst tekent, recht heeft op het COTGtarief van honderd procent. Slechts aan specialisten die niet tekenen mag negentig procent van het tarief worden uitbetaald. $24 \%$ De voorzitter van het VPO erkent even later dat zijn voorstel niet door iedereen wordt gedragen. 247 Hoewel de onenigheid hierover nog even voortduurt, wordt duidelijk dat de VNZ geen halszaak van zijn bonus-gedachte maakt. De ziekenfondsen beseffen

239 WV , memorandum nat aanleiding van overleg Van Aardenne, Sluimers, Uittenbogaard, Van Nederveen op 17 juli 1989,18 juli 1989

240 Brief Van Aardenne aan Dees, 21 juli 1989

$241 \mathrm{VPO}$, notitie Concept draaboek "protocol" wan het VPO, 21 juli 1989

242 WVC, an de staatssecretaris (eerste voorlopige reactie op het verslag wan het VPO), 3 augustus 1989

243 COTG, notitie Mogelikheden en onmogelijkheden ten aanzien wan wrije beroepsbeoefenaren, 14 juli 1989

244 VNZ, Reactie op het concept-protocol, 26 juni 1989

245 COTG, notitie Mogelijkheden en onmogelijkheden ten aanzien van vrije beroepsbeoefenaren, 14 juli 1989

$246 \mathrm{VPO}$, verslag plenaire vergadering, 13 jumi 1989

$247 \quad \mathrm{VPO}$, verslag plenaire vergadering, 15 juni 1989 
dal het voorstel onacceptabel is woor de LSV en bekijken de voorstellen die Van Aardenne in het verdere verloop wan het VPO doet 248

Een andere complicatie wordt veroorzaakt door het stelsel van contracten in de ziekenfondssector. De betalingsrelatie tussen een ziekenfonds en een arts is gebaseerd op een overeenkomst. Als gevolg van de onenigheid omtrent de praktijkkostenvergoeding zijn alle contracten evenwel opgezegd en heeft de overheid in 1987 het Restitutiebesluit afgekondigd. De VNZ streeft er naar hel naturastelsel te herintroduceren. In het naturastelsel heef een arts zonder een contract dat gebaseerd is op de nieuwe centrale overeenkomst geen recht op een vergoeding wan een ziekenfonds voor de behandeling van een ziekenfondspatient. De keuze van een arts gaat bij de behandeling van ziekenfondsverzekerden in feite dus niet meer tussen honderd en negentig maar ussen honderd en nul procent. WVC concludeert dat het intrekken van het Restitutiebesinit de druk op medisch specialisten de modelovereenkomst te tekenen flink zal laten toenemen. ${ }^{249}$ De LSV realiseert zich het gevaar en maakt dan ook binnen het VPO bezwaar tegen het intrekken van het Restitutiebesluit. Van Aardenne stelt zich echter hard op. Als de ledenvergadering van de LSV het voorstel goedkeurt, mag van de specialisten worden verwacht dat zij hun medewerking verlenen. Een specialist die niet tekent, zal de consequenties moeten aanvaarden en alleen nog maar particulier verzekerden kunnen helpen.250 Maar zo eenvoudig is het niet. Wat bijvoorbeeld te doen als alle artsen van een bepaald specialisme weigeren een overeenkomst te tekenen? Dan zal deze hulp dus niet aan ziekenfondsverzekerden kunnen worden verstrekt. Ook dit aspect laat zich niet snel oplossen en blijft een rol spelen bij de verdere besprekingen. 251 Daarbij speelt dat een besluit omtrent het intrekken van het Restitutiebesluit niet tot de bevoegdheden van het VPO behoort. Het is slechts de Minister die daartoe kan besluiten na advies van de Ziekenfondsraad.

\section{Het zit ' $\mathrm{m}$ in de werkbelasting}

Er zitten dus nog volop haken en ogen aam de tweeslag als de betrokkenen de voorstellen uit juli willen gaan uitwerken. De vertegenwoordigers van de vijf partijen proberen het secretariaat van het COTG in besprekingen over de uitvoering van de maatregelen ervan te overtuigen dat er twee tarieven moeten komen. Maar het secretariaat maakt hen meteen duidelijk dat zij dit op een met de Wig strijdige manier willen doen. De bepaling dat er een tarief komt voor medisch specialisten die meewerken, en een tarief voor artsen die niet meedoen met de overeenkomst, is volledig onvoldoende. Evenals de ambtenaren van WVC stelt het COTG dat er een andere en betere onderbouwing van het tariefverschil van tien procent moet komen. 252

Het wordt al snel duidelijk dat gezocht zal moeten worden naar inhoudelijke argumenten die rechtvaardigen waarom de ene specialist meer zal krijgen dan de ander. De handeling van de specialist die met 100 procent wordt beloond zal substantieel moeten verschillen van de handeling die slechts met 90 procent wordt beloond. Het is deze oplossing die met name door de overheid wordt aangehangen en warbij een actieve rol van het COTG is vereist.253 De strafkorting uit het voorstel van het VPO is wellicht haalbaar als er een aanwijzing komt van de overheid. 254 Deze manier is echter voor de overheid onacceptabel. De betrokkenheid van de overheid bij de totstandkoming van tarieven moet zoveel mogelijk worden beperkt. Deze

248 DB VNZ, 9 augustus 1989

249 WVC, notitie Een eerste voorlopige reactie op het verslag van het VPO op de brief van 21 jullijl., 3 augustus 1989).

$250 \quad \mathrm{VPO}$, verslag plenaire vergadering, 7 juli 1989

$251 \mathrm{VPO}$, verslag plenaire vergadering 20 september 1989

252 COTG, Verslag overleg vertegenwoordigers van LSV, NZr, VNZ, KLOZ, KPZ en het COTG. secretariaat op 25 juli 1989,3 augustus 1989

253 WVC, brief aan de voorzitier van het COTG, 11 september 1989

254 COTG, brief aan LSV, VNZ, KLOZ, KPZ en NZr, 12 september 1989 
houding van de overheid kan op weinig waardering rekenen van de leden van het VPO. Ook in de reactie van de overheid op de principe-overeenkomst vanj jul menen zij een passieve houding van WVC te herkennen. Met name war het gaat om kwesties als de tweeslag die alleen op te lossen zijn met behulp van de overheid en het COTG, zouden de onderhandelaars graag zien dat de overheid een grotere rol gaat spelen. Zij vrezen ook dat de houding van het COTG niet bijdragt tot meer participatie door het ministerie. 255

Het COTG is zich bewust van de druk om medewerking te verlenen aan het omzetten van het weeslagvoorstel in een juridisch houdbare tariefbeschikking. Maar deze medewerking is afhankelijk van het oordeel van het COTG over de uitwerking van het voorstel. Keer op keer bemadrukt het COTG dat het geen deel uitmakt van het VPO en dat het niet gebonden is aan de owereenkomst. En de manier waarop het VPO de tweeslag wil regelen, is een belemmering voor het COTG tot medewerking.256 Zolang de partijen het tweede, hogere tarief blijven definiëren als een stimulans voor specialisten mee te werken aan de uitwoering van het VPA. likt een aanwijzing van de overheid noodzakelik. 257 De enige mogelijkheid lijkt een serieuze discussie over de substantièle verschillen. De medische handeling op zich kan het verschil niet werklaren. en dus komen alleen de niet-patiëntgebonden activiteiten in aanmerking. De LSV presenteert deze maatregel zo aan de eigen Jeden. In de Specialistenbrief wordt uitgelegd dat er een tarief van 90 procent zall komen voor specialisten zonder overeenkomst. Via de overeenkomst wordt aan verzekeraars gegarandeerd, dat ook de niet-patientgebonden activiteiten door de specialist worden verricht, 258

Eind september blijkt dan toch consensus mogelijk over de onderbouwing van de tweeslag. In overleg komt naar woren dat het COTG geen principièle bezwaren heeft tegen "een breder geheel van prestaties" als onderbouwing van de tweeslag. ${ }^{259}$ Op 18 oktober komen de vertegenwoordigers van de ziekenfondsen, verzekeraars, specialisten en het COTG er uit. $\mathrm{Na}$ verschillende technische overlegbijeenkomsten neent men zich voor de tweeslag te gaan baseren op verschillen in werkbelasting. 260 Teneinde het tweeslagvoorstel door het COTG geaccepteerd te krijgen zijn de deelnemers aan het VPO bereid zich aan te passen aan de wensen van het COTG. In de werkgroep owereenkomsten - een van de werkgroepen die zijn ingesteld om de afspraken wit juli nader uit te werken - staat de formule van het COTG centraal. Naar de mening van de deelnemers vormt deze het toetsingskader van het COTG. Aangezien een overeenkomst plichten voor de specialist inhoudt, moet de tweeslag betrekking hebben op de werkbelasting, ofwel de $W$ in de tariefformule.

tarief $\mathrm{i}(\mathrm{li})=\operatorname{mkomen}(\mathrm{D})+\operatorname{kosten}(\mathrm{K}) \times$ aantal prestatie eenheden $(\mathrm{P})$ werkbelasting $(W)^{26}$

Om de taricfafspraken van het WPO in een woor het COTG acceptabele worm te gieten, zal aan de W in de tarieffomule gesleuteld moeten worden. 202 In de concept-raamovereenkomst stat in

255 Plenaire VPO vergadering, 13 september 1989

256 COTG, brief aan LSV, VNZ, KLOZ, KPZ en NZr, 12 september 1989

257 COTG, intern versiag, 25 september $1989 /$ COTG, werslag van het TOVPO dd 25 september 1989

258 Specialistenbrief nir. 6 , september 1989

$259 \mathrm{VPO}$, verslag plenaire vergadering, 20 september 1989

260 Concept-brief VNZ aan VPO/KLOZ, COTG, en LSW, 31 oktober 1989

261 VNZ, notitie Irpassing van WPO-afspraken in WTG, november 1989

262 Concept-brief VNZ aan VPOKKLOZ, COTG en LSV, 31 oktober 1989 
artikel 8 dat voor medisch specialistem die overeenkomsten hebben afgesloten hogere tarieven zullen gelden gelet op de uit deze overeenkomsten voortvloeiende substantielle verzwaring. ${ }^{263}$

Daarmee lijkt de tweeslag in een voor iedereen acceptabele formulering in de Raamovereenkomst opgenomen te kunnen worden. Hoewel de exacte onderbouwing nog voer woor discussie vormt, is er overeenstemming over de substantiele verzwaring van de werklast wan de medisch specialist als gevolg van ondertekening van de in het VPA opgenomen medewerkersbijeenkomst. Men is het tewens eens over de gevolgen voor de betahing als hij de overeenkomst niet tekent. Toch is er nog geen consensus over alle zaken. Zoals eerder aangegeven is het in de ziekenfondssector niet mogelik een arts zonder contract te betalen, ondat bij afwezigheid van een restitutiebeshit de betaling door een ziekentonds een overeenkomst vereist. In de medewerkersbijeenkomsten wordt de afspraak over een differentiatie van betalingen evenwel wel verwerkt in de vorm van een sanctie. De vraag is, hoe in een medlewerkersovereenkomst moet worden vastgelegd op welke manier besloten kan worden een specialist die zijn verplichtingen niet nakomt slechts negentig procent van het tarief uit te betalen. 264 Het standpunt wan Van Aardenne Iuidt dat specialisten die een overeenkomst niet tekenen sowieso slechts negentig procent krijgen. Artsen die wel tekenen maar vervolgens hun verplichtingen niet nakomen, kunnen negentig procent uitbetaald krijgen als het ziekenfonds daartoe beslluit. Een beroepsmogelijkheid voor de arts wordt ingesteld 265 Begin november spitst de discussie zich toe als onder tijdsdruk de onderhandelaars de precieze tekst van de modelovereenkomst specialist-ziekenfonds moeten gaan opstellen.266 Volgens de VNZ moet het ziekenfonds in staat zijn negentig procent van het tarief uit te betalen als de arts zijn verplichtingen uit de owereenkomst niet nakomt. Daarnaast moet het mogelijk zijn de overeenkomst in zijn geheel op te zeggen in geval van wanprestaties. 267 De LSV daarentegen windt dat het ziekenfonds bij wanprestaties kan besluiten tot een negentig procent tarief 268 Deze kwestie zal uiteindelijk ook worden opgelost. De ziekenfondsen en de specialisten kummen beide leven met de bepaling dat een arts die de verplichtingen van de overeenkomst niet nakomt gestraft kan worden met een betaling die tien procent lager is dan het fomele tarief. Voor het niet nakomen van andere verplichtingen moet een procedure worden ontworpen, waarin een onafhankelijk orgaan een uitspraak moet doen. Dit zal zo worden opgenomen in de tekst van de owereenkomst tussen de medisch specialist en het ziekenfonds. ${ }^{269}$ De consequentie hiervan is, dat elke specialist die een medewerkersovereenkomst met een ziekenfonds tekent nog slechts recht heeft op negentig procent als de algemene Raamovereenkomst verbroken wordt. 270 De VNZ legt dan ook een relatie tussen de uitvoering van het VPA en de tweeslag. Mocht én en ander scheef lopen tijdens de looptijd van het Akkoord, dan zijn de ziekenfondsen in staat door de tweeslag cen besparing van tien procent te behalen. 271

263 Concept Raanovereenkomst VPO, 9 november $1989 / 13$ nowember 1989

264 Voor alle duidelijkheid: het gaat hier om een discussie over de civielrechtelijke vormgeving van de betaling van twee verschillende tarieven terwijl de voorgaande discussie betrekking heeft op de wormgeving van tarieven ex Wtg.

265 CB LSV, 9 november 1989

266 Het gaat hier om de formulering vara artikel 16 , lid 5 van de modelovereenkonst specialistziekenfonds

267 VNZ, notitie Aanpassingen VNZ op LSV concept-modelovereenkomst speciallist-zickenfondis, 27 november 1989

268 CB LSV, 9 november 1989

269 Plenane VPO wergadering, 4 december 1989

$270 \mathrm{DB} V \mathrm{NZ}, 29$ nowember 1989

$271 \mathrm{AB}$ VNZ, 29 november 1989 
Een andere onzekerheid betreft het intrekken van het Restitutiebesluit na ondertekening van de overeenkomst. 272 De onderhandelaars rest niets anders dan de reactie van de individuele medisch specialisten af te wachten. Alles valt of staat met de bereidwilligheid wan artsen de hen aangeboden overeenkomst te tekenen. Te weing overeenkomsten kan een reden zajn na ondertekening het VPA alsnog op te zeggen. 273 Als er voldoende contracten worden afgesloten in de eerste maand van 1990, dan kan het naturastelsel weer worden in gevoerd en geldt alleen voor de particuliere sector cen tweeslag in tarieven. 274

Uiteindelijk zal in de Ramovereenkomst de volgende tekst staan vermeld.

"Art. \&. Het tarief zoals wastgesteld overeenkomstig het bepaalde in de overige artikelen in dit hoofdstuk. is gebaseerd op een geheel van prestaties warnan witdrukkelijk ook deel uitmaken de niet-patiëntgebonden activiteiten, onder meer gericht op doetmatigheid en kwaliteit. De specialist dient middels de overeenkomst met het ziekenfonds en de particuliere verzekeraars, als bedoeld in artikel 15 , de garantie he bieden deze miet patiëntgebonden activiteiten op zich te nemen, wil hij gerechtigd zijn het tarief zoals omschreven in de eerste volzin van dit artikel, te declareren. Voor die gevallen wartin de specialist wiet bereid is deze verplichtingen door middel van die overeenkowst op zich te nemen is een 10 procent lager tarief voorien."

Deze formulering is naar de volle tevredenheid van de LSV.275 Modellen van overeenkomsten zijn opgenomen in de bijlagen bij het VPA. Tevens is overeengekomen de tweeslag per 1 februari 1990 in te voeren.

\section{Een trage realisatie met bovendien een slecht resultaat}

Zoals al eerder door mij werd aangegeven toont WVC zich verheugd over de totstandkoming van de overeenkomst in december. Hoewel dit een half jaar langer duurde dan de overheid zich had voorgesteld stemt zij in met de afspraken van de vijf partijen. Niet alleen is er inhoudelijke instemming met alle onderdelen, ook wordt door het ministerie veel waarde gehecht aan het herstel van de onderlinge verhoudingen. Ten aanzien van de tweeslag is er in de formele reactie enige terughoudendheid. Er dient nog één en ander plaats te vinden in zowel het COTG alls de Ziekenfondsraad (daar moeten immers de overeenkomsten goedgekeurd worden, hl). Ook hecht de overheid aan een spoedige invoering. 276 Op het departement zelf bestaat meer twijfel bij de juridische houdbaarheid dan uit de brief aan Van Aardemne spreekt. De ambtenaren laten aan de staatssecretaris weten dat de rechter bij de tweeslag in tarieven wel vraagtekens zal zetten. De extra verplichtingen zijn immers niet nieuw. 277 Deze juridische onzekerheid wordt echter als onvermijdelijk geaccepteerd. WVC is zich ervan bewust dat er problemen zijn die wachten op een oplossing, maar het risico dat onderdelen van de overeenkomst juridisch spaak lopen moet genomen worden omdat er geen altematief voor de Raamovereenkomst is. ${ }^{278}$

De verantwoording van de onderhandelingsresultaten door de belangenorganisaties vindt plaats in december zodat in de verschillende ledenvergaderingen in januari 1990 de achterbannen

272 Plenaire VPO vergadering, 7 nowember 1989

273 KLOZ, Verslag LSV-vooroverleg, 16 november 1989

274 In het geval dat alle artsen van een specialisme niet tekenen, zal voor dat specifieke specialisme een restitutiebesluit gaan gelden, waarbij de ziekenfondsen nog slechts negentig procent hoeven te betalen. Bij de onderhandelaars bestaat de wrees dat met name de thoraxchirurgen als groep zullen weigeren de overeenkomst de gehoorzamen.

275 CB LSV, 13 december 1989

276 WVC, brief aan Van Aardenne, 19 januari 1990

277 WVC, nota t.b.V de staatssecretaris, 18 december 1989

278 WVC, notitie aan de staatssecretaris, 12 januari 1990 
hun goedkeuring kunnen hechten aan de Raamovereenkomst. De tweeslag zorgt bij de verzekeraars voor weinig problemen. Voor de ziekenfondsen wormt de mogelijkheid een lager tarief te betalen een goede compensatiemogelijkheid als onverwijld de overeenkomst onuitwoerbaar mag blijken. ${ }^{279}$. Bij de medisch specialisten bestat daarentegen forse oppositie: Op locatiebijeenkomsten laten indwiduele specialisten duidelijk weten grote bezwaren te hebben tegen de voorgestelde tweeslagregeling. 280 Al na de overeenstemming op hoofdilinen in julth 1989 komt in tal van onmoetingen tussen vertegenwoordigers van de LSV en medisch specialisten maar voren, dat met name de tweeslag woor veel specialisten een moeilijk te verteren uitkomst van het centrale overleg is. ${ }^{28}$ Ook in de Ledenvergadering van de LSV op 21 september waarin het principe-akkoord wordt aanvaard, is de tweeslag onderwerp van kritiek, 282 Het is dus miet verwonderlik dat de LSV de tweeslag presenteert als én van de minpunten van het Vijf-partijen Akkoord. 283. In de beraadslagingen in het bestuur van de LSV wordt tevens aan de orde gesteld dat sommige specialisten de LSV het verwijt maken dat de keuze tussen honderd en nul procent hen niet eerder duidelijk gemaakt is. Het bestuur verwerpt deze kritiek echter; eén en ander zou al veel eerder in de Ledenvergadering aan de orde zijn gesteld.284

De weerstanden tegen onderdelen van het VPA bij medisch specialisten weethouden hen niet de overeenkomst te tekenen. Een weigering zou desastreuze financiele consequenties kunnen hebben. Gegevens van de VNZ uit februari wijzen uit dat meer dan zeventig procent van de specialisten de nieuwe overeenkomst heeft getekend. Dit pereentage ligt een maand later al. op tachtig procent 285 Daarmee is de kans dat ziekenfondsen geen zorg kunnen aanbieden omdat geen contracten zijn afgesloten zeer klein geworden en is de weg vrij woor het intrekken van het Restitutiebesluit. Al in februari vraagt de staatssecretaris van WVC aan de Ziekenfondsraad te onderzoeken, of er al zoveel overeenkomsten zijn afgesloten dat hij de Restitutieregeling kan intrekken.286 in juni komt de Ziekenfondsraad tot de conclusie, dat een overgrote meerderheid wan de specialisten een overeenkomst heeft getekend en dat het Restitutiebesluit ingetrokken kan worden. 287

De medisch specialisten anticiperen met het tekenen van overeenkomsten op de daadwerkelijke invoering van de tweeslag. Want het is duidelijk dat, hoewel de Raamowereenkomst getekend wordt en de overheid een spoedige invoering waardeert, de tweeslag niet

279

280

28120 vindt de hoofdredacteur van Medisch Contact het principe-akkoord een goede zaak en roept hij de op 21 september bijeenkomende Ledenvergadering op het te steunen, maar noemt hij de tweeslag 'curieus' (Medisch Contact, 1989, nr. 37, p. 1163).

282 Medisch Contact, 1989, nr. 50, p. 1643

283 Medisch Contact, 1989, nr. 50, p. 1643

$284 \mathrm{CB} \mathrm{LSV}, 11$ januari 1990

285 Inzet, $1990, \pi+2$, p. 1 . Het percentage van tachig wordt genoemd door het ziekenfonds $\mathrm{ANOZ}$ tijdens de zitting wan de Rechtbank te Utrecht op 27 maarl 1990 (Tijdschrift voor Gezondheidsrecht, juni 1990 , p. 297). Dat inhoudelijke instemming met de Rasmovereenkomst veelal ontbreekt word geillustreerd door de tekst die velie specialisten laten toevoegen an lhet doot hen ondertekende contract. In die tekst stat onder meer: "Bowengenoemde specialist hecht er waarde aan om, hier en nu, nog eens duidelijk te stellen dat de ondertekening van deze overeenkomst niet in die wriheid platsvind wasin volgens de Wet het tekenen wan overeenkomsten tussen partijen dient plaats te vinden, maar hem wordt opgedrongen als ultiem gevolg van het V.P.A., daar een niet-ondertekenen wan de litigieuze overeenkomst, in samenhang met het intrekken wan het Restitutiebesluit hem maatschappelijk en financieel volledig ten gronde zall richten." (Inzet, 1990, nr. 4, p. 6)

286 Brief van de staatssecretaris aan de Ziekenfondsraad, 14 februari 1990

287 Ziekenfondsrad, Adwies aan de statssecretaris wan WVC, juni 1990 
op I februari 1990 ingevoerd kan worden $28 \%$ Een tariefbesluit over de tweeslag vergt namelijk nogal wat fomele stappen. Gedurende 1989 gaan alle betrokkenen ervan uit dat voor de weeslag newwe richllinen moeten worden ontworpen.28\%. Als gevolg hierwan zall cerst een richtlinvoorstel moeten worden ontworpen, door partien dan wel door het COTG, waama na een adwiesronde in Kamer $V$ het besturur van het COTG zich kan uitspreken over de richtlin. De richtijn dient vervolgens goedgekeurd te worden doot de staatssecretaris, waama het bestuur van het COTG de op de tichtijn gebaseerde tarieven kan goedkeuren. Gezien de fomele procedure is het niet verwonderlijk dat het COTG al in juli 1989 bij het ontwerpen van een protocol voor de uitwerking van de overeenstemming op hoofdlijnen heef aangegeven, dat voorstellen voot richtlinwijzigingen eind augustus moeten worden ingediend teneinde per 1 januari tot nieuwe tarieven te kunnen besluiter. 290

Ook in janwari van 1990 houdt het COTG-secretariat vast aan de formele procedure. Ten eerste zal het COTG zich moeten uitspreken ower de Raamowereenkomst en over de gevolgen voor de bestaande richtlijnen over de praktijkkostenvergoeding. Bovendien is het niet mogelijk om in éen en dezelfde vergadering zowell de richtlinen als de tariefbesluiten te behandelen. 291 Gewolg is dat de tweeslag niet voor 1 maart 1990 ingevoerd zal kunnen worden.

Een spoedige uitwoering van de afspraken likt helemaal onmogelijk te worden als het COTG in nota 90-02 in het geheel niet gelukkig zegt te zijn met het resultaat wan het VPO. Bovendien is het door het ontbreken van voldoende onderbouwde tariefvoorstellen niet mogelijk al in januari uitwoering te geven aan de Ramovereenkomst. De enige kwestie die in de bestuursvergadering aan de orde gesteld kan worden is of de gefaseerde uitvoering van de verlaging van de praktijkkosten door kan gaan. Het voorstel tot een tweeslag in tarieven krijgt evenwel een mild oordeel. Het voorstel is naar de mening van het secretariaat niet in tegenspraak met het COTG-beleid, maar dient evenals andere voorstellen nog wel beter onderbouwd te worden. 292

Op 31 januari sturen de VPO-organisaties aan het COTG een tariefverzoek met daarin de weeslag. Ook sturen zil twee conceptrichtlijnen. 293 Het milde oordeel ower de tweeslag voorkont niet dat het COTG met de partijen enstig van mening verschilt over hun richtlijnvoorstellen. Mede op basis van advies van de Landsadvocaat stelt het secretariaat voor twee tarieven voor één medische prestatie in te stelien en de geldigheidsduur van de richlijnen onbepaald te laten zijn. Bovendien moet de tariefdifferentiatie gekoppeld worden aan een overeenkomst tussen verzekeraar en arts. In de richtlijn van de VPO-deelnemers wordt gesproken van wee prestaties en twee tarieven en een geldigheidsduur die overeenkomt met die van de Raamovereenkomst. ${ }^{294}$ Kamer $V$ komt vervolgens tot een unaniem advies over de eigen richtijnvoorstellen. ${ }^{295}$ Maar het unanieme advies wordt nief overgenomen door het secretariaat

288 Buiten beschouwing blijft hier de procedure voor de goedkeuring van de modelovereenkomst warwoor de Ziekenfondsrad werantwoordelijk is. De Ziekenfondsraad keurt de modelovereenkomst, op een klein onderdeel na, op 25 jantari 1990 goed. Deze beslissing zal door medisch specialisten bij de Kroon worden angevochten.

289 VPO, vers'ag plenaire vergadering, 22 novenber 1989

290 COTG, Concept draaboek "protocol" VPO, gestumrd aan LSV, VNZ, KLOZ, KPZ en NZr, 31 juli 1989

291 COTG, brief aan KLOZ, 5 januari 1990

292 COTG, nota 90-02, 19 januari 1990

293 Brief LSV, KLOZ en KPZ aan COTG, 31 januari 1990 brief LSV, mede namens KLOZ, KPZ en WNZ aan COTG, 31 januari 1990)

294 Brieven Landsadvocat, aan COTG, 1 februari 1990/2 februari 1990/COTG, notitie, 14 februar: 1990

295 CoTG, verslag Kamer V-vergadering, 6 februari 1990 
als het de richtijnvoorstellen voor de tweeslag aan het bestwur wan het COTG voorlegt. Dit is reden voor de deelnemers an het VPO om het bestuur van het COTG rechtstreeks aan te schrijven om er op te wijzen dat de richtijn waarover Kamer V positief heeft geadviseerd goedgekeurd zou moeten worden. De uitvoerbaarheid van VPA zou gevaar kunnen lopen als in het advies wijzigingen worden aangebracht. ${ }^{206}$

Het bestuur van het COTG volgt echter het eigen secretariaat. Op 19 februari stelt het COTG richtlijnen wast zoals zij door het secretariaat zijn ontworpen. Artsen die een overeenkomst met een verzekeraar sluiten, dienen vijf niet-patiëntgebonden activiteiten uit te voeren als $z \mathrm{ij}$ het hogere tarief in rekening willen brengen. De richtlijnen worden hast per ommegaand goedgekeurd.297 Op 19 maart stelt het COTG de weeslagtarieven vast. De tariefverzoeken wan verzekeraars, ziekenfondsen en specialisten van 31 januari worden afgewezen omdat zij in strijd zijn met de door het COTG zelf ontworpen richtijnen. De nieuwe tarieven zullen gaan gelden per 1 aprill 1990.298 Hiemee is de tweeslag de eerste afspraak wan het Vijf-partijen Overleg die daadwerkelijk wordt uitgevoerd.

De tariefbeslissing van het COTG wordt echter een dankbaar object voor juridische procedures. Al in maart betwisten vier specialisten het recht van het ziekenfonds ANOZ artsen negentig procent van het tarief te betalen als zij geen overeenkomst hebben. De Rechtbank te Utrecht geeft then geen gelijk omdat de Raamovereenkomst en de daarbij behorende bijlagen (met daarin de modelovereenkomst) rechtsgeldig zijn. Op 5 juni dient vervolgens het CBB witspraak te doen in de procedure die onder andere cardiochirurgen hebben aangespannen. De protesterende specialisten vechten de tweeslagrichtijn van 13 maart aan omdat zij vinden dat de tweeslag in feite een strafkorting van tien procent is, bedoeld om medisch specialisten te dwingen mee te werken aan de uitvoering van de Raamovereenkomst. Zij worden un hun gelijk gesteld. Gezien het feit dat het COTG al langer niet-patientgebonden activiteiten in tarieven werrekent, lijkt het in de ogen van het CBB inderdaad zo te zijn dat de tweeslag bedoeld is de specialisten te dwingen mee te werken. Daardoor heeft het COTG op een onjuiste manier gebruik gemaakt van zijn bevoegdheden. De tweeslag-richtlijn wordt geschorst. 299

Deze forse tegenslag is reden voor discussie in het VPO. De gevolgen voor de deelnemers zijn verschillend. De particuliere verzekeraars hebben geen sanctiemogelijkheid mee, de specialisten zonder overeenkomst hebben weer recht op een tarief van honderd procent, en de zich tegen de LSV verzettende artsen hebben een flinke steun in de rug gekregen, ${ }^{300}$ Bovendien moet nog maar worden afgewacht welke gevolgen deze uitspraak heef voor de medewerking van het COTG. Ondanks deze consequenties weigeren alle betrokkenen het Alkkoord op te zeggen. Daar is volgens de LSV weinig reden toe. Er zijn immers al massaal overeenkomsten

296 Brier LSV, mede namers KLOZ, KPZ, NZT, en VNZ, aan Bestuur COTG, 14 februari 1990

297 De activiteiter waar het om gaat zijn:

- het verlenen wan medewerking atan de budgettering van de ziekenhuzen;

- het plegen van overleg over de extramurale praktijkvoering;

- de bevordering en bewaking van de doelmatigheid en de kwaliteil van de geleverde medische prestaties;

- het verlener van de medewerking aan de controle door de medisch adviseur wan de particuliere verzekeraar:

- het verlenen van medewerking an de gegevenswerzameling.

Brief COTG aan WVC, 22 februar 1990/Brief WVC aan COTG, 13 maan 1990

298 Niet alleen de tweeslag wordt verwerkt in de niewwe tarieven per 1 april 1990. Ook word een tijdelijke toeslag op de particuliere tarieven ingetrokken.

299. Uitspraak CBB, 5 juni 1990. De tariefbeschikking zal in 1992 worden vernietigd.

300 KLOZ, nottie stand van zaken VPO-accoord, juni $1990 / \mathrm{VNZ}$, notitie Consequenties van de uitspraak van het CBB inzake de Iweeslag voor medische specialisten, 7 juni 1990 
gesloten 301 Tot het opzeggen van contracten door medisch specialisten le dit de uitspraak evermin. 302 Veeleer heeft de uitspraak tot gevolg dat de deelnemers aan het VPO nog meer dan voorheen afspreken, de overheid er op te wijzen dat een succesvolle uitvoering van het VPA staat: of valt mel aanpassingen in de wettelijke kaders. De druk op de overheid zal moeten worden verhoogd. 303 Deze afspraak heeft gevolgen voor met name de uitvoering van de reshuffling. Ook bij deze implementatie spelen immers de fomele wettelijke bepalingen een grote rol. WVC trekt zich echter weinig aan van deze druk. Op het departement neemt men het standpunt in, daf. de goedkeuning wan het Akkoord plaats vond onder de nadrukkelijke voorwaarde dat de partijen zelf de juridische houdbaarheid moesten kunnen verzorgen. Bovendien heeft de uitspraak voor het macrobudget als belangrijkste afspraak nauwelijks gevolgen. 304

301 VPO, verslag plenaire vergadering, 11 juni 1990

302 Voorzitter L.SV, Medisch Contaot, nr. $27 / 28,6$ jull 1990, p. 45

$303 \mathrm{VPO}$, verslag plenaire vergadering, 11 juni 1990. Typerend voor de frustatie over de beperkingen die de wetgeving aan de onderhandelaars oplegt, zijn de woorden wan Limborgh in een vergadering van het KLOZ-bestuur. "ledere afsprak buiten gebaande paden wordt afgeschoten. Er kan miets worden veranderd als de werten niet worden gewijzigd." CB KLOZ, 11 juni 1990

304 WVC, meno, 8 jun 1990/WVC, notitie aan de statssecretaris, 18 juni 1990 


\section{Patronen van participatie ${ }^{1}$}

\subsection{Inleiding}

Zoals in het eerste hoofdstuk werd aangegeven zijn actoren en constellaties van actoren belangrijke onderdelen van het actorgerichte institutionalisme. Eén van de deelvragen van dit onderzoek betreft dan ook de participatie van organisaties en personen in processen van beshutvorming ten aanzien van tarieven voor medisch specialisten. Deze participatic zal worden onderzocht door de gebeurtenissen die plaats vinden tijdens de besluitvorming in relatie te brengen met daarin participerende actoren. Dit resulteert in een gebeurtenis-actor matrix. Door deze aanpak is het mogelijk om de temporele orde van de participatie van actoren in de besluitvorming over tarieven te verduidelijken en blijft de analyse niet beperkt tot een statische opsomming van betrokken actoren. Vervolgens is het mogelijk om met behulp wan clusteranalyse de participatie van groepen van actoren bij reeksen van gebeurtenissen vast te stellen. Door middel van tijdreeksanalyse wordt getracht aan te tonen dat deelname aan een bepaalde gebeurtenis verklaarbaar is vanuit deelname aan eerdere gebeurtenissen. Beide methoden maken het mogelijk te komen tot uitspraken over patronen van participatie. Bij deze methodische aanpak wordt uitgegaan van besluitvorming als een sequentie van gebeurtenissen, hetgeen ook in andere procesgerichte onderzoeken van besluitvorming is gedaan (Laumann en Knoke 1987, Immergut 1992, Teisman 1992).

Het aldus gekwantificeerde overzicht wan participatie en participatiepatronen dient te worden onderbouwd met een toelichting over de relatie met het formele institutionele kader. Door het actorgerichte institutionalisme wordt immers een relatie gelegd tussen de formele regels voor participatie en de werkelijke deelname. In dit hoofdstuk zal blijken dat de formele regels slechts een gedeeltelijke verklaring bieden voor participatie van groepen van actoren. Andere factoren speelden eveneens een belangrijke rol.

De opbouw van dit hoofdstuk is als volgt. Allercerst komen de uigangspunten van de analyse aan de orde. Voor het grootste deel zijn deze al beschreven in het tweede hoofdstuk. In de derde paragraaf wordt de deelname aan de besluitvorming over tarieven voor medisch specialisten geanalyseerd. Eerst zal een actor-gebeurtenis matrix worden opgesteld, verwolgens zullen de resultaten van de clusteranalyse aan de orde komen, waarna een tijdreeksanalyse wordt uitgevoerd. In de laatste paragraaf is aungegeven in hoeverre de werkelijke participatie

1. De auteur dankt Frits van Merade voor zijn inbreng bij dit hoofdstuk. Het hoofdstuk is in een andere versie werschenen in Beleidswetenschap (Lieverdink en Van Merode, 1997). 
overeenkwam met de regels van de wet. Bovendien geef ik daarin aan welke andere factoren verantwoordelijk waren voor de deelname aan de besluitvorming.

\subsection{Methodollogie}

Hoewel moderne besturskundigen aangeven dat de traditionele institutionele structuren van beshitwoming aftrokkelen, wordt in de institutionele benadering van besluitvorming gesteld dat formele kaders invloed hebben op de daarbimnen plaatsvindende besluitworming (March en Olsen 1994/1996, Immergut 1992). De deelname aan besluitvorming zou dan ook beinvloed moetern worden door de formele regeling van de mogelijkheden tot participatie. De deelname aan de besluitworming ower tarieven voor medisch specialisten tussen 1986 en 1992 was in sterke mate formeel geregeld. Alleen representatieve organisaties mochten deelnemen aan de onderhandelingen over tarieven. Ook stond vast welke ministeries goedkeuring konden verlenen aan richllinwoorstellen wan bet COTG, alsmede welke ministeries aanwizingen aan het COTG mochten geven. Daamaast was het COTG bevoegd tarieven vast te stellen. Tegen beslissingen wan het COTG kon beroep worden ingesteld bij het College van Beroep voor het Bedrijfsleven.

De vraag luidt in hoeverre de werkelijke participatie overeenkwam met deze fomele woorschriften. Voor de beantwoording van deze vaag moeten de formele regels duidelik zijn. Vervolgens moeten drie kenmerken van paricipatie empinisch worden onderzocht. Ten eerste moet duidelijk worden welke actoren deelnamen en of daarin veranderingen optraden. Ten tweede moeten patronen van deelname worden vastgesteld. Ten derde dienen veranderingen in patronen worden onderzocht.

Hoewel beleidswetenschappers bij de analyse van het object van studie wak spreken in termen van processen, zijn ze over het algemeen theoretisch, methodologisch en zeker methodisch niet erg helder. Er is geen algemeen geaccepteerde methodiek om bijwoorbeeld het verloop van bestuitwormingsprocessen te kumen bestuderen, hoewel verschillende onderzoekers daartoe wel aanzetten hebben gegeven (zie bijwoorbeeld Teisman 1992). Ik zal de besiluitvoming over tarieven voor medisch specialisten conceptualiseren als een proces waarin het besluit over een tarief het uiteindelijke resultaat is van een reeks van gebeurtenissen, die op de én of andere manier met elkaar in verband staan. Omdat dit betrekkelijk weinig is gedaan, zal naast de witkomsten van de analyse beschreven worden welke methodische stappen zijn gezet.

Bij de selectie van de gebeurtenissen zijn enkele criteria gehanteerd. Deze zijn al in hoofdstuk twee aan de orde gekomen, thier worden ze slechts kort aangeduid. Ten eerste is de gehele verzameling van gebeurtenissen inhoudelijk homogeen hetgeen wil zeggen dat zij betrekking hebben op de lotstandkonning van de geselecteerde tariefbeslutiten. Ten behoeve van het opsporen van patronen zijn alle tariefbesluiten samengenomen en is een verzameling van gebeurtenissen samengesteld, die betrekking heeft op alle bestudeerde tariefbeshiten. Ik maak in dit hooldstuk dus geen onderscheid tussen de tariefbeshiten. Wel is er woor gezorgd dat de juiste tijdsvolgonde gehandhafd bleef. Ten tweede waren de gebeurtenissen volgens de direct betrokkenen onderdeel van de totstandkoming van de tariefbesluiten. Ten derde galat het alleen om gebeurtenissen die plaatsvonden op het niveau van de relaties tussen organisaties. Gebeurtenissen binnen de organisaties worden dus niet in de analyse betrokken. Tenslotte is bij de selectie van gebeurtenissen niet uitgegaan van padafhankelijkheid. Dat wil zeggen dat niet slechts die gebeurtenissen zijn gekozen die het verdere verloop van de besluitvorming bepaalden. Ook gebeurtenissen die ogenschijnlijk zonder gevolgen zijn, geven informatie over de participatie van acloren, hun handelingstheorieën en soorten van interactie. 


\subsection{De participatie in de besluitworming over tarieven}

In totaal was bij de tariefbesluiten sprake van 443 gebeurtenissen. Elk wan deze gebeurtenissen valt te beschouwen als een casus die door middel van een aantal variabelen beschreven kan worden. Eén van die variabelen betreft het wel of niet deelnemen van een bepaalde actor. Als elke gebeurtenis met behulp van deze variabele wordt getypeerd, ontstaat een beeld van de participatie per gebeurtenis en van het verloop van de participatie per actor over de 443 gebeurtenissen.

Deze relaties kunnen in een actor-gebeurtenis matrix worden gevisualiseerd (figuur 5.1 ). De matrix toont aan dat meer dan twintig actoren deelnamen in een bepaalde gebeurtenis of verschillende gebenrtenissen die plaats vonden gedurende de besluitvorming over tarieven voor medisch specialisten tussen 1986 en 1992.

Figum 5.1: De actor-gebeurtenismatrix

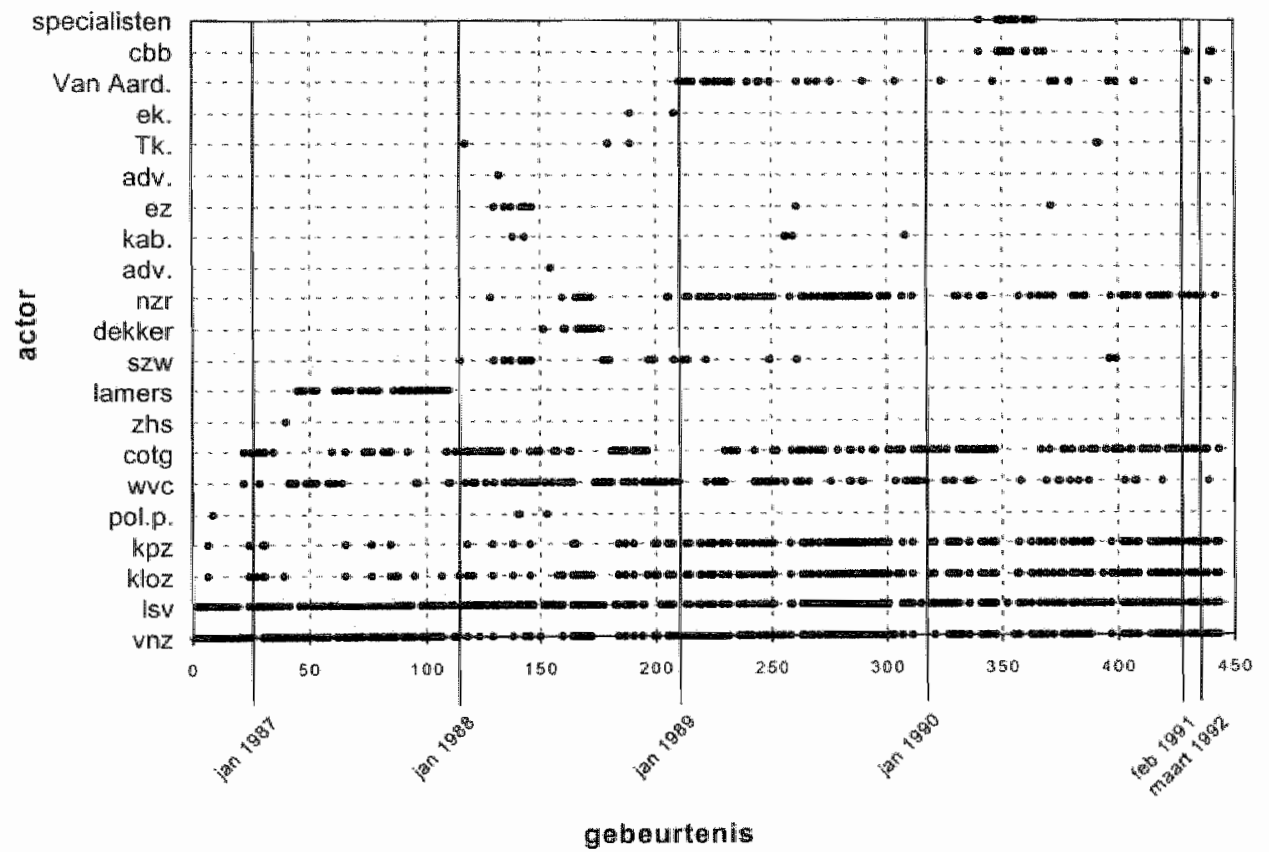

De deelnemende actoren kunnen gegroepeerd worden in (de afkortingen verwijzen naat de codering in figuur 5.1):

1. De belangenorganisaties van ziekenfondsen (VNZ), ziektekostenverzekeraars (KLOZ/KPZ), medisch specialisten (LSV) en ziekenhuizen (NZr)

2. De ministeries wan. WVC, Sociale Zaken en Werkgelegenheid (SZW) enEconomische Zaken (EZ)

3. Individuele intermediairen (Lamers, Dekker, Van Aardenne)

4. Het COTG

5. Juridische instanties, voomamelijk het CBB 
6. Politici, zowel van het kabinet als van het parlement (politieke partijen (pol.p)., het kabinet (kab.), Tweede Kamer (Tk), Eerste Kamer (Ek)

7. Individuele actoren uit de gezondheidszorg (ziekenhuizen (ZHS), specialisten)

8. Adviseurs (adv.)

De matrix geeff aan dat zeven institutionele actoren (organisaties) aanzienlijk meer participeerden dan de anderen. Dit zijn de belangenorganisaties, het ministerie van WVC en het COTG. Met andere woorden, als de mate waarin organisaties participeerden in gebeurtenissen tijdens de besluatvorming over tarieven voor medisch specialisten als indicator voor de participatie wordt beschouwd, kunnen we spreken van een aantal kernactoren: VNZ, KLOZ/KPZ, LSV, NZr, COTG en WVC. Naast deze organisaties kunnen we andere actoren onderscheiden die zo nu en dan aanhaken (adviseurs, juridische instanties, bemiddelaars). Uit de actor-gebeurtenismatrix blijkt dat alle organisaties die in de Wtg genoemd werden participeerden in de besluitvorming. Dit betreft het COTG, WVC, de VNZ, de LSV, het KLOZ, en de KPZ. Bovendien speelde het CBB een rol. Daarnaast zijn er evenwel actoren die men niet zou verwachten. Dit geldt bijvoorbeeld voor de bemiddelaars en de NZr. Verder valt de grote mate van variatie door de jaren heen op. Noch de groep van kernactoren noch de groep van tijdelijk "aanhakende" actoren was onveranderlijk. Bovendien was de betrokkenheid van sommige actoren onregelmatig. In het begin van 1986 bleef de participatie in de besluitworming over tarieven hoofdzakelijk beperkt tot twee actoren: de representatieve organisaties van ziekenfondsen en medisch specialisten. Daarna breidde het aantal participanten zich uit. KLOZ, KPZ, WVC en $\mathrm{NZr}$ meldden zich nadrukkelijk in het overleg. Later werd de bemoeienis van zowel WVC als $\mathrm{NZr}$ kleiner nadat het VPO begonnen was met de implementatie van het VPA (in december 1989, vanaf ongeveer gebeurtenis 300). Tenslotte blijkt uit de matrix de roll van de bemiddelaars. Lamers is zichtbaar met name tussen gebeurtenissen 50 en 100. Het voorzitterschap van Van Aardenne bij het VPO had plaats vanaf gebeurtenis 210 .

\subsection{Patronen van participatie}

De bovenstaande analyse levert enkele belangrijke conclusies op, maar deze blijven beperkt tot de participatie per afzonderlijke actor. De actor-gebeurtenismatrix geeft een eerste overzicht van de participatie van actoren. Het is echter moeilijk patronen van participatie vast te stellen. Weliswaar kon al uit de kwalitatieve beschrijving van de besluitvorming (zie het vierde hoofdstuk) opgemaakt worden dat een breed overleg tot stand gekomen was, maar deze bevinding kan niet met de actor-gebeurtenismatrix worden onderbouwd.

Voor het vaststellen van patronen van participatie heb ik gebruik gemaakt van clusteranalyse. De werkwijze was als volgt. Een patroon geeft aan dat twee of meer gebeurtenissen op elkaar leken. Gebeurtenissen leken op elkaar als daarin dezelfde actoren participeerden. Op basis van deze gelijkenis werden gebeurtenissen geclassificeerd. Gebeurtenissen die op elkaar leken, werden tot dezelfde klasse (of: cluster) gerekend, zij die niet op elkaar leken werden tot verschillende klassen gerekend. De vraag die in dit hoofdstuk gesteld wordt, is of er systematische combinaties van actoren voorkwamen en, voor zover dat het geval was, of een verband bestond tussen het voorkomen van bepaalde combinaties van actoren aan de ene kant, en de periode en/of het soort gebeurtenis aan de andere kant. Om dit verband vast te kunnen stellen diende het al dan niet participeren van een actor in een bepaalde gebeurtenis het criterium te zijn op basis waarvan gebeurtenissen zouden worden gegroepeerd. Doordat de gelijkheid van gebeurtenissen niet absoluut was, diende een afkappunt te worden vastgesteld. Dit afkappunt bepaalde wanneer een bepaalde gebeurtenis nog wel tot een bepaalde klasse hoorde en wanneer niet meer. Het afkappunt werd in belangrijke mate bepaald door het aantal gehanteerde klassen. 


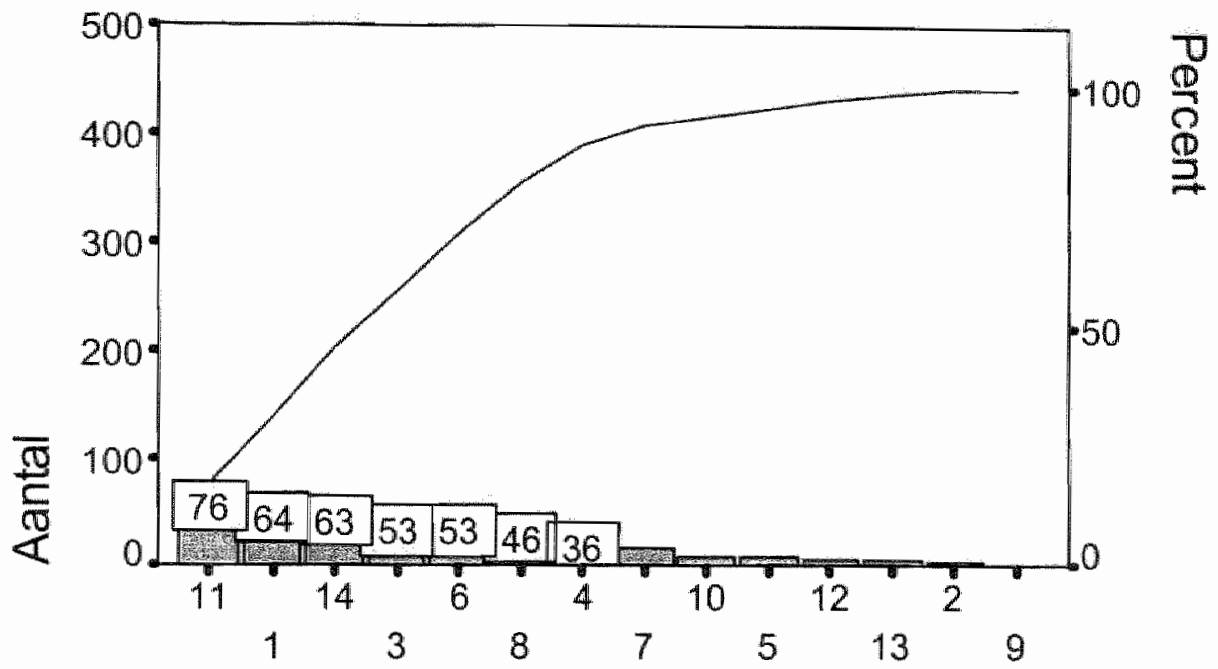

\section{Cluster code}

Als mij een bepaalde typologie ter beschikking had gestaan waarin groepen wan gebeurtenissen worden onderscheiden, zou het aantal klassen in de clusteranalyse gelijk zijn geweest an het aantal groepen van de typologie. Voor de analyse van participatiepatronen bij de besluitvorming over tarieven voor medisch specialisten bestaan echter geen bruikbare theoretische modellen, zodat ik terug moest vallen op een inductieve analyse. Daarbij was ik geïnteresseerd in de vraag hoe door classificatie datareductie kon worden bereikt. Ik probeerde dus het aantal klassen zoveel mogelijk te reduceren. Een afweging moest worden gemaakt tussen de mate van datareductie en de hoeveelheid informatie die hierdoor verloren ging. Een absoluut criterium viel moeilijk te geven, een Pareto-diagram was wel behulpzaam. Op basis van het Pareto-diagram (figuur 5.2) kon worden geconcludeerd dat het toevoegen van meer dan zeven klassen relatief gezien slechts een gering effect had. De zeven klassen omvatten ongeveer 90 procent van de gebeurtenissen en hebben de volgende samenstelling (tabel 5.1) (zie de appendix voor een beschrijving van de cluster analyse). 


\begin{tabular}{clc}
\hline Klasse & Actoren & Aantal gebeurtenissen \\
\hline 1 & LSV, diverse anderen & 64 \\
3 & VNZ, diverse anderen & 53 \\
4 & VNZ, LSV & 36 \\
6 & WVC, diverse anderen & 53 \\
8 & VNZ, LSV, KLOZ, KPZ, COTG & 46 \\
11 & LSV, VNZ, NZr, KPZ, KLOZ & 76 \\
14 & COTG, diverse anderen & 63 \\
\hline
\end{tabular}

\begin{abstract}
* Dit lijken elkaar niet-uitsluitende klassen van actoren te zijn. Woor een juiste interpretatie wan de indeling van Klassen dient echter het begrip patroon (de participatie wan combinaties van actoren) centraal te staran. Met dit begrip wordt hier aangegeven dat het meedoen van een bepaalde actor aan een bepaald owerleg weliswar afhankelijk is van het meedoen van bepaalde andere actoren, maar deze afhankelijkheid is nitet lineair bepaald. De combinatie van actoren is op zichzelf een verklarende variabele. Wat is hiervan de consequentie? Stel we willen verklaren in welke mate de aanwezigheid van de LSV in een gebeurtenis de aanwezigheid van de VNZ bepaalt. Indien dit werband lineair zou zijn, dan zou het gewicht dat aan de aanwezigheid wan de LSV wordit toegekend ter werklaring van de aanwezigheid wan de $V M Z$ bij iedere gebeurtenis gelijk zijn. In bet riet-lineaire model word echter rekening gehouden met het gegeven dat de aanwezigheid van de LSV in wisselende combinaties kan plaatsvinden en afhankelijk van de combinatie wordt aan de aanwezigheid van de LSV een bepaald gewicht toegekend. Hier is clusieranalyse gebruikt teneinde de meest significante combinaties van actoren op te sporen.
\end{abstract}

Bij de bovenstaande clusteranalyse was het doel tot klassen van gebeurtenissen te komen die gekarakteriseerd werden door de participatie van groepen wan actoren. Dit is een statische analyse omdat de tijd geen rol speelt. De conclusie kan slechts luiden dat groepen van gebeurtenissen gekenmerkt werden door de participatie van een bepaalde groep van actoren. Hierdoor is inzicht in patronen verkregen. Door echter weer de sequentie van gebeurtenissen te hanteren werd het mogelijk de uitkomsten van de clusteranalyse te dynamiseren. De verkregen klassen van gebeurtenissen konden op een tijdsas worden geplaatst, waardoor de veranderingen in de patronen van participatie zichtbaar werden. In figuur 5.3 zijn de klassen afgezet tegen de gebeurtenissen waarbij hun tijdsvolgorde wordt gehandhaafd.

De belangrijkste conclusies naar alanleiding wan de clusteranalyse luiden als volgt. Ten eerste zijn er zeven klassen die een hoge frequentie hebben: klasse $\mathbb{1}$ (bilateraall contact LSVwisselende actoren), klasse 3 (bilateraal contact VNZ-wisselende actoren), klasse 4 (LSV-VNZ), Klasse 6 (bilateraal contact WVC-wisselende actoren), klasse 8 (COTG-VNZ-KLOZ-KPZ-LSV), Klasse 11 (Vijl-partijen Overleg: VNZ-KLOZ-KPZ-LSV-NZr) en klasse 14 (COTG-wisselende actoren). Enkele klassen springen in het oog omdat zij over de gehele periode 1986 - 1992 min of neer regehnatig aanwezig waren. Dit zijn met name die klassen die bestaan uit éen centrale actor en wisselende partners $(14,6$, en 3). De centralle actor in klasse 14 is het COTG, in klasse 6 WVC. Vooral de regelmatige betrokkenheid van het COTG hoeft geen verbazing te wekken. Geen enkel tariebeshit kwam immers tot stand zonder de bemoeienis wan het COTG. Wel is de regelmatige aanwezigheid van klasse 3 opvallend. De centrale actor in klasse 3 is de VNZ, die kemnalijk ook na de installatie van het Vijf-partijen Overleg (ongeveer gebeurtenis 200) nog andere bilaterale relaties onderhield. Bovendien is de afwezigheid wan het KLOZ, en met deze organisatie ook de $\mathrm{K} \mathrm{PZ}$, als deelnemer in een bilaterale overleg opvallend. 


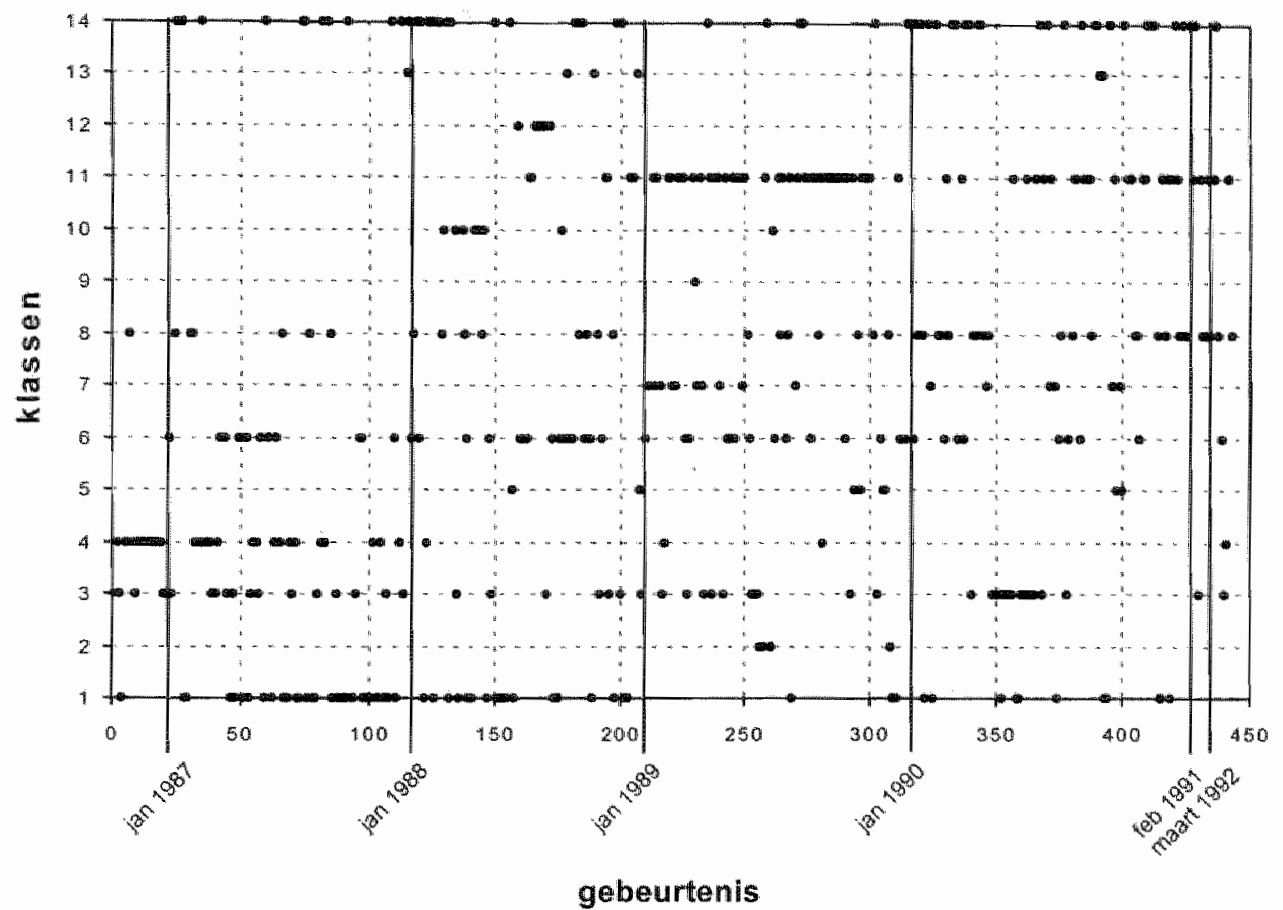

Interessanter dan de continue aanwezigheid van de bovenstaande klassen is de ontwikkeling van klassen $1,4,8$ en 11 . Klasse 1 bestaat uit de LSV en wisselende actoren (bilateraal) en klasse 4 uit de LSV en de VNZ. Gebeurtenissen werden na verloop van tijd steeds minder gekenmerkt door bilateraal contact tussen de LSV en een andere actor. Daarvoor in de plaats kwam het brede forum in het kader van het VPO (klasse 11) en de contacten tussen het COTG en de $\mathbb{L S V}, \mathrm{VNZ}, \mathrm{KPZ}$ en het KLOZ (klasse 8). Het ontstaan van het multilaterale overleg wordt dus door de clusteranalyse aangetoond. Het patroon van participatie waarin sprake is van bilaterale interactie tusser ziekenfondsen en specialisten verdween na verloop van tijd. We kunnen hier spreken van een historische breuk omdat dit onderlinge overleg vanaf de Tweede Wereldoorlog de totstandkoming van tarieven voor medisch specialisten domineerde.

\subsection{De participatie op basis van formele regels en de noodzaak van additionele verklaringen}

Uit de actor-gebeurtenismatrix (figuur 5.1) valt af te lezen, dat de actoren die in de Wtg genoemd worden aan de besluitvorming deelnamen (LSV, KLOZ, VNZ, KPZ, COTG, WVC, CBB). Tevens is naar voren gekomen dat ook actoren participeerden die niet wettelijk waren aangewezen (NZr, bemiddelaars). Bovendien is duidelijk geworden dat er variatie in de participatie van actoren was. Waar bijwoorbeeld de VNZ al vanaf het begin participeerde, sloot 
het KLOZ zich pas later aan, ondanks de wettelike verplichting om ook woor de particuliere medisch specialistische zorg tarieven tot stand te laten komen. Uit de clusteranalyse is met name naar voren gekomen dat bilateraal overleg plaats moest maken voor overleg waarbij vijf organisaties tegelijk waren betrokken.

Uit de vergelijking van de uitkomsten van de participatie van actoren met de voorschriften in de Wtg wordt duidelijk dat additionele verklaringen voor deze participatie nodig zijn. Het formele wettelijke kader heeft verklaringskracht waar het gaat om het optreden van de vertegenwoordigende organisaties die wettelijk representatief zijn verklaard, instanties die formele beslissingsmacht hebben, en het CBB als juridische instantie. Maar de verklaringskracht van het formele kader schiet tekort ten amzien van de dynamiek van de participatie. Het is niet mogelijk veranderingen in de participatie toe te schrijven aan veranderingen in het formele wettelijke kader, omdat hiervan geen sprake was. Het antwoord ontbreekt op de vraag waarom. actoren op een specifiek moment en in een bepaalde constellatie met andere actoren hun opwachting maakten. Waarom, bijwoorbeeld, wond in de jaren 1986 en 1987 onderling overleg tussen de VNZ en de LSV plaats terwijl toch ook KLOZ en KPZ formeel een rol bij de onderhandelingen hadden? Bowendien blijft onduidelijk waarom actoren optraden die niet door de Wtg genoend werden. Waarom traden bijwoorbeeld de bemiddelaars op de voorgrond, spelers warin de Wig niet voorzag? En waarom kregen de ziekenhuizen geleidelijk aan een erkende plek aan de onderhandelingstafel? Er zal dus bij de verklaring van de gevonden patronen onderscheid gemaakt moeten worden tussen de verklaring van de statische aspecten door het formele institutionele kader en van de dynamiek door andere factoren. Meer precies gaat het daarbij on de rol van strategische overwegingen, het onvermogen tot informele coördinatie en het optreden van externe effecten.

\section{De invloed van het formele institutionele kader}

Het formele wettelijke institutionele kader had op drie manieren grote invloed op de participatie bij de besluitworming over tarieven voor medisch specialisten. Ten eerste bepaalden formele regels voor een belangrijk deel wie mocht deememen. Ten tweede werd sommigen het recht van participatie onthouden. Ten derde maakte de Wtg als jumidische structuur de organisaties afhankelijk van actoren met juridische expertise die bij tijd en wijle betrokken raakten.

De formele regels legden in belangrijke mate de grenzen van het netwerk vast.. Dit gebeurde met name door het toewijzen van bevoegdheden aan actoren. Hierdoor werd het onvermijdelijk dat bepaalde organisaties op een gegeven moment een rol speelden bij de besluitvorming. De voorbeelden liggen woor de hand. Tariefbesluiten kwamen niet tot stand zonder de goedkeuring van het COTG. Bij de ontwikkeling van richtlijnen was een adwies van Kaner V verplicht. WVC had een belangrijke rol bij de totstandkoming van richtlijnen die door de overheid goedgekeurd moesten worden. Constellaties van actoren waarvan WVC en COTG deel uitmakten kwamen gedurende de gehele periode 1986-1992 regelmatig voor. Illustratief is eveneens de bepaling in de Wtg dat tarieven in overleg tussen representatieve organisaties tot stand dienen te komen. Hierdoor maakten organisaties als de LSV, KLOZ/KPZ, en de VNZ veelal van het begin af aan deel uit wan het besluitwormingsproces. Het CBB $\mathrm{kwam}$ in het spel zodra beroep werd angetekend tegen de besluiten van het COTG.

De formele bepalingen gaven rechten aan bepaalde actoren, maar anderen werden buitengesloten. Er waren actoren die ondanks hun wens daartoe, niet in staat waren zich in formele zin direct te bemoeien met de totstandkoming van tarieven. Dit gold in het bijzonder medisch specialisten die naast de LSV deel zouden willen nemen. Hen stond slechts de beroepsmogelijkheid bij het CBB ter beschikking waardoor zij niet tijdens maar alleen na de formele beslwitvorming invloed konden uitoefenen. Zich organiseren hielp weinig. Nieuwe organisaties van specialisten die representativiteit claimden, werden buiten de deur gehouden. 
Behalve als structuur waarin bevoegdheden werden verdeeld speelden de formele regels een rol door middel van de structurering van interacties. Varwege de formele procedures inclusief juridische beroepsmogelijkheden waren de interacterende actoren gedwongen zich bewust te zijn van de juridische mogelijkheden en onmogelijkheden van hum voorstellen en acties. Dit bracht afhankelijkheid met zich mee ten opzichte van actoren die uit hoofde van hun formele rol bevoegd waren tarief- en richtlijnvoorstellen te beoordelen (respectievelijk het COTG en WVC) en van actoren die juridisch advies konden geven (advocaten, soms ook WVC en COTG).

\section{De rol van strategische overwegingen}

Tijdens de besluitvorming over tarieven tussen 1986 en 1992 is gebleken dat de Wtg vooral een instrumentele betekenis had voor actoren. De mate waarin bepalingen gevolgd werden, was in grote mate afhankelijk van de strategieën die de organisaties ontwikkelden. Elders heb ik dit, in navolging van Jon Elster, 'juridisch opportunisme' genoemd; het nastreven van eigen belang door middel van het gebruik van de mogelijkheden die de wetgeving biedt (Lieverdink en Maarse 1995). WVC is daarin wellicht nog het duidelijkst. Waar het departement in de eerste helft van de jaren tachtig direct betrokken was bij de besluitvorming over tarieven koos het in de tweede helft voor meer distantie. Dit betekende onder meer dat WVC niet participeerde in het VPO. Daarnaast weigerde WVC de implementatie van het VPA te vereenvoudigen door aanwijzingen af te geven, hetgeen indruiste tegen de wens van de onderhandelende organisaties.

Ook het COTG ging op een wisselende manier om met de mogelijkheden die de wet bood. Tijdens de totstandkoming van besluiten over de praktijkkosten was het orgaan zeer actief en ontwikkelde het een beleid om de vergoeding aan artsen drastisch te verlagen. Ten tijde van het Vijf-partijen Overleg nam het COTG een veel meer afwachtende houding aan en liet het de formulering van tariefvoorstellen over aan de onderhandelaars. Naast WVC en het COTG waren ook de verzekeraars, ziekenfondsen en specialisten zich bewust van cle mogelijkheden die de bestaande wet hen bood. Illustratief zijn de juridische procedures die de LSV aanspande om de formele besluitvorming te beïnvloeden op de momenten dat haar rol daarin was uitgespeeld. Daarnaast gebruikte de VNZ de mogelijkheid om éénzijdige tariefvoorstellen aan het COTG te doen teneinde tijdrovende gesprekken met de LSV te vermijden.

\section{Het tekort schieten van het onderlinge overleg bij contlictsituaties}

De centrale organisaties bleken tot aan het VPO niet in staat de conflicten door middel van onderling overleg bij te leggen. In de literatuur over conflictoplossing wordt gesproken over de zogenaande 'derde partij" die nodig is als een onderling compromis niet meer mogelijk is. Meestal bestaat de derde partij uit een rechter of een bemiddelaar. Volgens Eckhoff (1966) komt onder vijf omstandigheden de derde partij in het spel. Er dienen tegengestelde belangen te zijn warbij een compromis onmogelijk is vanwege de 'ondeelbaarheid' van het onderwerp van onenigheid. Ondeelbaarheid treedt bijvoorbeeld op als twee mensen moeten beslissen wie van then als eerste door een deur mag. Bovendien dienen de antagonisten belang te hebben bij een oplossing. Verder kan overeenstemming over de relevante normen en regels ontbreken. Men is het bijwoorbeeld niet alleen oneens over het onderwerp, maar ook over de procedures waardoor een gezaghebbende buitenstaander (de rechter) hierover uitsluitsel moet geven. Tenslotte wordt een derde partij waarschijnlijker als deze belang heeft bij de oplossing van het conflict en als het conflict leidt tot negatieve gevolgen voor de omgeving (negatieve externe effecten). In tabel 5.2 staat aangegeven in hoeverre de vijf condities bij de onderzochte gevallen aanwezig waren. 
Tabel 5.2: De condities voor de derde partij in de castïstiek

\begin{tabular}{|l|c|c|c|}
\hline $\begin{array}{l}\text { Theoretische voorwaarden optreden derde } \\
\text { partij }\end{array}$ & praktijkkosten & tweeslag & reshuffling \\
\hline Het probleem is ondeelbaar & + & - & - \\
\hline De partijen hebben belang bij oplossing & ++ & + & + \\
\hline $\begin{array}{l}\text { Er is geen overeenstemming over normen } \\
\text { en regels }\end{array}$ & + & - & - \\
\hline Derde partij heeft belang bij oplossing & + & + & + \\
\hline Er zijn negatieve externe effecten & + & + & + \\
\hline
\end{tabular}

Uitleg: cen theeft aan dai de theoretische woorwaarde voor hell optrenten van de derde partij bij de casus aanwezig was. Zo was er bij de praktijkkosten inderdaad geen overeenstemming over normen en regels, maar ontbrak deze voorwaarde bij de tweeslag en de reshuffling.

De condities voor het optreden van een derde partij waren het meest volledig aanwezig bij het conflict over praktijkkosten. De woorstellen van beide kanten (de coalitie versus de LSV) weken gedurende het gehele beshitvormingsproces niet alleen sterk van elkaar af, de partijen verschilden tevens van mening over de normen en regels die gehanteerd moesten worden. De normatieve aanpak van de coalitie van VNZ, KLOZ en COTG botste met de nadruk van de LSW op de feitelijke situatie, terwijl ook het opdelen van het tarief tot felle discussies leidde. Bovenal veroorzaakte de ondeelbaarheid wan het probleem van de praktijkkosten een patstelling. Er was nauwelijks compensatie mogelijk voor het eventuele verlies van éen van de betrokkenen. Alleen de voorwaarde dat alle partijen belang hebben bij een oplossing was slechts gedeeltelijk aanwezig. De LSV wenste immers een besluit zo lang mogelijk uit te stellen. Pas toen duidelijk werd dat een besluit ook zonder de inbreng van de medisch specialisten mogelijk was, werd een oplossing voor de LSV meer urgent.

Bij de besluitvorming over de tweeslag en de reshuffling ontbraken twee noodzakelijke voorwaarden voor het optreden van en dende partij. Ten eerste vormden de kwesties geen ondeelbatr probleem ondat de oplossing als onderdeel van een geheel van afspraken aanvaardbaar was voor iedereen. Ten tweede bestond geen verschil van mening over normen en regels. De percentages van zowel de tweeslag als de reshuffling leverden nauwelijks discussie op, en bij de manier van verwerking in de tarieven waren de onderhandelatars het erover eens dat een juridisch waterdichte vorm gekozen moest worden. Dat bij de tweeslag en de reshuffling toch derde partijen optraten, was an twee factoren te danken. Ten eerste moest een bemiddelatar (Van Aardenne) de verhoudingen verbeteren om tariefonderhandelingen weer mogelijk te maken. Ten tweede speelde de rechter een rol als gevolg van het optreden van negaticve exteme effecten. Zowel de tweeslag als de reshufling hadden grote gevolgen voor groepen medisch specialisten die zich niet meer vertegenwoordigd achtten door de LSV.

Bemiddeling leidde niet alleen tot de bemoeienis van individuele internediairs (Lamers, Dekker, Van Aardenne) maar ook indirect van politici. De bemiddelaars dienden immers regelmatig over de voonutgang te rapporteren aan de politiek verantwoordelijke bewindsman. Deze bewindsman werd op zijn beurt weer gecontroleerd door een parlement dat de medisch specialistische zorg al geruime tijd als éen van de probleemgebieden van de kostenbeheersing in de gezondheidszorg had gedefinieerd. Aan de onderhandelingen konden zo politieke grenzen gesteld worden, die steeds nauwkeuriger werden. Lamers kende nog een behoorlijke autonomie 
bij zijn bemideling, maar aan Van Aardene werden strenge randvoorwaarden en tijdslimieten gesteld.

\section{Externe fectem}

Organisaties die afspraken makkten over tarieven waren vak niet in staat on de gevolgen van hum besluiten - of van het uiblijven daarvan - voor andere niet in het overleg betrokken partijen te beheersen. Deze gevolgen konden te maken hebben met tarieven, maar het ging vak ook om andere zaken. Dit is wat ik versta onder de externe effecten van de besluitvorming die wak megatief waren. De controle op het overleg was niot zo sterk ontwikkeld dat voorkomen kon worden dat tariefvoorstellen en -besluiten met negatieve externe affecten tot stand kwamen. De volgende vijf exteme effecten kumen worden onderscheiden.

\section{a. De gevolgen van tariefafspraken in de ziekenfondssector voor de particuliere sector}

Externe effecten traden op, toen specialisten en ziekenfondsen in 1986 probeerden de vergoeding voor de praktijkkosten onderling te bepalen. Door het COTG werd hun al snel duidelijk gemakt dat een onderlinge overeenkomst gevolgen zou bebben voor de particuliere sector, omdat het COTG geen gescheiden regelingen toestond. Ook lieten de particuliere verzekeraars weten met te willen dat over hun belangen besloten werd zonder bij het overleg betrokken te zijn geweest. Toen later in 1988 nieuw overleg van start ging, kozen de organisaties voor een zo breed mogelijke vertegenwoordiging van belangen. Het bleek dat besluiten over tarieven niet langer in van elkaar gescheiden groepen van actoren (in mijn casus: LSV/VNZ ws LSV/KLOZ/KPZ) tot stand konden komen, hetgeen tot aan de introductie van de Wtg de praktijk was.

\section{b. De gevolgen voor de politieke discussie over de uitgaven aan medisch specialistische zorg}

De financiële voorwaarden waaraan de uitkomsten van het overleg over de tarieven moesten woldoen, werden niet door de onderhandelende partijen maar door anderen bepaald. Het ministerie van WVC had daarin een belangrijke stem mat bezat geen autonomie. De staatssecretanis van WVC moest binnen het Kabinet overleg voeren over hoeveel geld elk jaar beschikbaar zou zijn voor de diverse sectoren in de gezondheidszorg. Door het verschil te berekenen tussen de te verwachten uitgaven en thet beschikbare budget, werd het voor WVC duidelijk hoeveel geld bespaard zou moeten worden. Aan deze afweging dankte het Financièle Overzicht Zorg (FOZ, voorheen FOGM/FOG) zijn belangrijke functie. In dit jaarlijkse overzicht vertaalde WVC de opgedrongen budgetkortingen in matregelen.

Voor de medisch specialistische zorg zag WV het meest in veranderingen van tareven. Van de uitkomsten van de tariefonderhandelingen werd de bijdrage aan het bereiken wan de doelstellingen van WVC berekend. Als deze bijdrage naar tevredenheid was, legitmeerden de tariefonderhandeingen het beleid van de statssecretaris van WVC. Als de bijdrage tekort schoot, moest verantwoording afgelegd worden aan externe actoren. Dit betekende dat er noojt absolute grenzen gesteld konden worden aan de onderhandelende organisatics. Of WVC instende met de resultaten van het onderlinge overleg, was een gevolg van een strategisch oordeel waarvan de politieke verdedigbaarheid, de te werwachter opbrengst alsook de gevolgen woor de verhoudingen met het "veld" belangrijke onderdelen waren.

De gerichtheid op de financiéle effecten domineerde bij politici. Leden wan de Tweede Kamer hielden de verantwoordelijke bewindsman aan zijn beloften die in met name het $F O Z$ stonden vermeld, en leden van het Kabinet hielden de staatssecretaris aan zjjn budgetafspraken. Op de momenten dat de staatssecretaris moest melden dat de onderhandelingen in het slop gerakt waren, werden deze "toezichthouders" gewekt. Met andere woorden, door het onwermogen van de onderhandelende partijen om in de jaren tachtig tot tijdige afspraken te komen over tariefverlagingen, riepen zij de bemoeienis op van actoren die toezagen op de effecten op de 
uitgaven aan de sector. Deze bemoeienis verhoogde de druk op het overleg maar de bemiddelaars gebruikten deze druk om de onderhandelaars tot spoed te manen. De onderhandelaars konden er gelegenheidsargumenten aam ontlenen. Zo probeerde de VNZ tijdens de bemiddeling door Lamers de LSV er van te overtuigen dat een verlaging van de tarieven met 10 procent cen noodzakelijke 'handreiking' aan de politiek zou zijn. Pas met het VPA slaagden de organisaties erin om de politici tevreden te stellen.

\section{c. De gevolgen voor ander overleg}

In 1987 verscheen het rapport-Dekker dat de aanzet zou zijn voor drastische veranderingen in het beleid wan WVC. On dit beleid uit te voeren was overleg met alle betrokkenen nodig. Dit overleg kwam echter moeilijk op gang. De medisch specialisten wensten de dreigende voornemens van de overheid ten aanzien van de tarieven niet los te zien van de medewerking aan het nieuwe overheidsbeleid. Deze obstructie leidde tot cen reactie van actoren die baat hadden bij het nituwe algemene overleg. De $\mathrm{NZr}$ drong er bij WVC op aan de tegenstellingen zo snel mogelijk weg te nemen en leden van de Tweede Kamer maanden de staatssecretaris van WVC in de herfst van 1988 het doodgelopen overleg nieuw leven in te blazen. Deze reacties hebben de besluitworming over tarieven beinvloed want zij versnelden de totstandkoming van het VPA.

We zien dus dat door twee externe effecten - de invloed van het tariefoverleg op de uitgaven aan de gezondheidszorg en de gevolgen voor de herstructurering van de gezondheids2org - politieke actoren zich gingen bemoeien met het overlleg. Dit vertaalde zich nauwelijks in directe participatie (zie paragraaf 5.3), maar leidde wel tot politieke druk via WVC en de bemiddelaars. Tegelijk leerde de overheid haar grenzen kennen doordat de medisch specialisten lieten weten dat hun participatie in het door WVC als zeer belangrijk gedefinieerde overleg over de uitvoering van de plannen van 'Dekker' gevaar liep als het tariefoverleg niet veranderde.

\section{d. De gevolgen voor de relatie tussen zieken buizen en specialisten}

Sinds 1983 kent Nederland een budgetsysteem voor ziekenhuizen. De uitgaven voor medisch specialisten zijn daarin niet verwerkt. Het overleg over de betaling van medisch specialisten en de onderhandelingen over de jaarlijkse budgetten voor ziekenhuizen hebben zich altijd, zowel inhoudelijk als institutioneel, gescheiden voltrokken. Dit leverde lange tijd niet veel problemen op, maar de ziekenhwizen zagen zich genoodzaakt het overleg over de tarieven voor medisch specialisten te beinvloeden toen door de initiatieven van de VNZ het mogelijk dreigde te worden dat sommige betalingen aan de specialist wanuit het ziekenhuisbudget plaats zouden gaan vinden. De $N Z \mathrm{r}$ vreesde een verstoring van de relaties in de ziekenhuizen zelf en verzocht het COTG dan ook met klen dit te voorkomen. In hoeverre het bestuur van het COTG hierdoor beinvloed werd, is niet duidelijk. Wel was het zo dat het COTG in de richtlinen de LSV juist op de kostenposten verslaggeving en administratie die naar de mening van de VNZ en het secretariat van het COTG in het budget van het ziekenhuis opgenomen hadden moeten worden, in belangrijke mate tegemoet kwam.

\section{e. De gevolgen voor medïsch specialisten}

Negatieve exteme effecten met een bijzonder karakter traden op bij de tweeslag en de resilufhing. Zolang een belangenorganisatie in staat is besiluiten namens de gehele achterban te nemen, zullen de gevolgen niet als een extern effect benoemd kunnen worden. Bij de LSV was echter sprake van toenemende ongehoorzaamheid van delen van de achterban die er toe leidde, dat groepen van specialisten formeel verklaarden dat de LSV hen niet meer representeerde. Daamee platsten zij zich buiten het netwerk van onderhandelaars en percipieerden zij de genomen besluiten als overeenkomsten die hen in hun belang troffen zonder betrokken te zijn geweest bij de besluitvorming. Bij de uitvoering van de besluiten over de tweeslag moesten ze door hen ongewenste contracten ondertekenen, en als gevolg van de reshuffling dalden de 
tarieven voor bepaalde specialismen aamzienlijk. Voor ontevreden specialisten stond slechts de juridische procedure nog open om de tariefbestuiten aan te vechten.

\subsection{Conclusies}

In dit hoofdstuk stond de deelname van actoren aan processen van besluitvorming over tarieven voor medisch specialisten centraal. Onderzocht is welke actoren participeerden en of er sprake was van patronen van participaties. Tevens ben ik nagegaan of bij de participatie de regels van de Wtg werden gevolgd en of andere factoren inzicht konden geven in de participatie en haar patronen.

Door tariefbesluiten op te vatten als de uitkomst van een reeks van gebeurtenissen kon de participatie per actor dynamisch worden onderzocht. De uitkomsten hiervan konden worden weergegeven in een actor-gebeurtenismatrix. Uit deze matrix theb $\mathrm{ik}$ afgelezen dat van een groep van kernactoren sprake was. Deze groep bestond uit VNZ, KLOZ/KPZ, LSV, NZr, COTG, en WVC. Deze groep was evenwel niet onveranderlijk. In het begin (1986/1987) domineerden VNZ en LSV nog, later breidde het aantal deelnemers zich uit. Bovendien haakten sommige deelnemers tijdelijk aan. Uit de analyse van patronen van participatie is gebleken dat deze uitbreiding gepaard ging met een overgang van bilateraal overleg naar multilateraal overleg. Het Vijf-partijen Overleg (VPO) dat vanaf 1989 functioneerde was hiervoor illustratief.

De participatie werd gedeeltelijk bepaald door het formele institutionele kader. De formele regels stelden in belangrijke mate grenzen aan het netwerk van acioren hetgeen tot gevolg had dal sommige actoren niet werden toegelaten tot het proces van besluitvorming. Voor het verkrijgen van inzicht in de achtergronden van de veranderingen in de participatie is een verwijzing naar het formele kader ontoereikend. Voor de verandering in de participatie waren andere factoren verantwoordelijk. Ten eerste bleek deelname door actoren af te hangen van hun strategische overwegingen. Ten tweede riep het tekort schieten van het onderlinge overleg de deelname van derde partijen op. Tenslotte zorgde het optreden van externe effecten ervoor dat actoren belang zagen in deelname aan het besluitvormingsproces. 


\section{Appendix}

Het verschil of de afstand tussen gebeurtenissen is bepaald volgens de methode van Gekwadrateerde Euclidische Afstanden. Bij deze methode wordt van ieder paar van gebeurtenissen van iedere variabele het verschil bepaald en vervolgens wordt dit verschil gekwadrateerd. De afstand tussen twee casussen wordt bepaald door de verschillen van alle in de analyse betrokken variabelen te sommeren. De functie "afstand" om deze verschillen te berekenen zilet als wolgt uit:

$$
\text { afstand }\left(e_{i}, e_{j}\right)=\sum_{\alpha \in A}\left(a_{j}-a_{j}\right)^{2}, e_{i} \in E, e_{j} \in E_{v} i \neq j
$$

Waarbij afstand $\left(e_{p} e_{j}\right)$ het verschil is tussen twee gebeurtenissen. $E$ is de verzameling van alle gebeurtenissen.

$A$ is de verzameling van variabelen (al of niet deelname van een actor $a$ ).

Als methode om clusters (of: klassen) te vormen is gekozen voor de Average Linkage Between Groups Method. In deze methode wordt de afstand tussen clusters bepaald per twee clusters tussen alle mogelijke paren van casussen die in deze twee clusters voorkomen, de afstand te bepalten en vervolgens de gemiddelde afstand te bepalen. Die clusters worden vervolgens bepaald warbij de afstand tussen de clusters maximaal is. Het model van deze methode is als volgt.

$$
\operatorname{Max}: \frac{\sum_{i \in C_{k}} \sum_{j \in C_{i}} A f \text { stand }\left(e_{p} e_{j}\right)}{\left|C_{k}\right| *\left|C_{j}\right|}
$$

Onder de volgende voorwaarden:

$$
\begin{gathered}
C_{i}, C_{2}, \ldots, C_{x}=E \\
\bigcup_{i=1}^{x} C_{1}|=| E|\wedge| \bigcap_{i=1}^{x} C_{i} \mid=0
\end{gathered}
$$

Waarbij de variabelen $C$ in (3) deelverzamelingen betreffen uit de totale verzameling van gebeurtenissen $E . C$ is de verzameling van gebeurtenissen behorende bij een bepaald cluster $x$ is het aantal clusters clat wordt vastgesteld. Voorwaarde (4) bereikt dat iedere gebeurtenis deel uitmaakt van precies één cluster. Doelstellingsfunctie (2) bewerkt dat de afstand tussen de verschillende clusters wordt gemaximeerd. 


\section{De handelingstheorieën en hun logica}

\subsection{Inleiding}

De doelstelling van dit hoofdstuk is meervoudig. Ten eerste zal ik de handelingstheorieën van de betrokken actoren bespreken. In het vorige hoofdstuk is duidelijk geworden dat ik mij daarbij kan beperken tot de VNZ, KLOZ/KPZ, LSV, COTG en WVC.' Ook de mate waarin zij met elkaar overeenkwamen of van elkaar afweken, komt aan de orde. Een vergelijking van handelingstheorieèn is van belang omdat daarmee begrijpelijk gemaakt kan worden waarom bepaalde interacties optraden. Zoals reeds eerder aangegeven zijn van een handelingstheorie vooral de situatieschets, handelingsopties en strategieën wan belang. Daarnaast moet in dit hoofdstuk de relatie tussen de institutionele context en de handelingstheorieën duidelijk worden. Daarvoor is inzicht in de logica van de handelingstheorieën nodig.

In de volgende paragrafen komen per casus de handelingstheorieën van de participerende actoren aan de orde. Deze zullen uitgebreid beschreven worden hetgeen echter niet altijd zal kunnen voorkomen dat de lezer terug wil gaan naar het vierde hoofdstuk om de handelingstheorieèn weer te kunnen plaatsen in de complexe situaties. Dat ook in dit hoofdstuk de chronologie een belangrijk ordenend principe is, zal de lezer evenwel daarbij van hulp zijn. De uitgebreide beschrijving van de handelingstheorieën wordt per casus afgesloten met een samenvattende tabel. Daarin staat voor elke actor de handelingstheorie ingevuld. Daarna krijgen de verschillen en overeenkomsten aandacht door middel van een vergelijking. Tenslotte schets ik de logica van de handelingstheorieèn en de institutionele invloed.

\subsection{De praktijkkosten}

\section{VNZ}

Het initiatief tot een verlaging van de vergoeding van praktijkkosten kwam van de VNZ. Hel ondoelmatig verloop van de besprekingen met de LSV over tarieven noople tot een actiever beleid. Al langer was binnen de VNZ sprake van irritatie over het tarievenoverleg. De inkomenspolitiek van de overheid had de VNZ buiten spel gezet. Bovendien vonden verschillende ziekenfondsen dat er als gevolg wan weinig gefundeerde tarieven ongerecht-

In veel gevallen trad het $K L O Z$ op als vertegenwoordiger van de $K P Z$. Daarom zal ik in bet verwolg geen aparte aandacht meer schenken aan de $\mathrm{KPZ}$. 
vardigde inkomstenverschillen tussen specialismen waren ontstaan. Orndat de ziekenfondsen formeel geen zeggenschap hadden over de inkomens van medisch specialisten, richtte de VNZ de aandacht op de wel beinvloedbare tariefonderdelen. Het resultaat was de beleidsnota van maart 1986 waarin de VNZ onder andere streefde naar betaling wan de medisch specialist unt het ziekenhuisbudget. Ook zou de vergoeding voor praktijkkosten verlaagd moeten worden want die was veel te hoog. De VNZ wist zich in dat oordeel gesteund door de ambtenaren van WVC en het secretariat van het COTG. ${ }^{2}$ Toch waren er iwiffels ower een harde confrontatie met de LSV. Gesprekken met bestuursleden en politici van PWdA en CDA hadden namelijk geleerd dat de overheid waarschijnlijk niet zou optreden als er een conflict wissen de ziekenfondsen en de specialisten aitbrak. Politici waren slechts geinteresseerd in het realiseren van bezuinigingen. ${ }^{3}$ Bowendien zag de VNZ het KLOZ niet als een betrowwbare bondgenoot. De VNZ vreesde dat het KLOZ andere belangen had dan de VNZ en bereid was tot meer concessies aan de LSV. De wens wan het $K \mathrm{KLOZ}$ om tot gelijkschakeling van tarieven te komen (hetgeen hogere ziekenfondstarieven zou betekenen) werd als een bedreiging van de strategie van de VNZ gezien. Gedurende lange tijd. was de VNZ dan ook niet bereid de dialoog met de LSV open te stellen voor het KLOZ. Wel vroeg de VNZ steun van het KLOZ bij de verzoeken aan het COTG.

Het felle protest van de LSV dwong de WNZ de doelstellingen bij te stellen. In plaats van de honorering van de arts in het budget van het ziekenhuis op te nemen, zouden alleen de praktikkosten aan het ziekentuis betald moeten worden. Het ziekenhuis zou vervolgens de kosten van de specialist moeten vergoeden. In overleg met het COTG ontwikkelde de VNZ een strategie van kleine stappen. Als eerste stap suggereerde het bureau van de VNZ de vergoeding voor de praktijkkosten uit het tarief te halen en via een maandelijkse vergoeding aan de specialist te betalen. 5 De voordelen van deze splitsing van tarieven waren binnen de VNZ duidelijk. Ten eerste konden twee tarieven op verschillende wijze worden vergoed. De voorkeur ging bij de VNZ uit naar betaling aan de specialist wa het ziekenhuis. Ten tweede werd het mogelijk om het ene tarief (de kostenvergoeding) te verlagen zonder meteen het andere (het inkomensdeel) te moeten aanpassen. Daarop was het eenzijdige woorstel aan het COTG gericht. De VNZ koos voor deze formeel-juridische weg via het COTG in overleg met het secretariaat van het COTG, omdat afspraken met de LSV via onderhandelingen niet realiseerbaar werden geacht. ${ }^{7}$

Voor de VNZ ontstond echter een dilemma. Aan de ene kant wist men dat de voorstellen aan het COTG door het secretariaat in ieder geval gedeeltelijk zouden worden gesteund, en binnen enkele weken uitgewerkt konden zijn. ${ }^{8}$ Tegelijk erwoer men dat een dergelijke aanpak hei tot stand komen van "nieuwe" medewerkersovereenkomsten met de medisch specialisten danig frustreerde. Omdat de VNZ aan een nieuwe modelovereenkomst hechtte, waren nieuwe gesprekken met de LSV nodig. Daarom besloot het bestuur in juni 1987 opnieuw te gaan praten met de LSV, hoewel men tevreden terugkeek op de besluitvorming binnen het COTG waarbij een splitsing van tarieven als principe was vastgelegd. ${ }^{9}$ Het dilemma leidde tot een strategie van aanpassing. In eerste instantie hanteerde de VNZ het strategisch standpunt dat pas aan het COTG uitstel van de behandeling van de tariefvoorstellen zou worden gevraagd als er een opdracht aan

2 DB VNZ, 12 maart 1986

3 DB VNZ, 26 november 1986

$4 \quad$ DB VNZ, 14 ok tober 1987

$5 V N Z$, notitie Honorering medisch-specialistische hulp, 2 december 1986

$6 \quad V N Z$, notitie De consequenties van de tariefsplitsing voor medisch specialisten, 1 september 1987

7 Hoewel de coalitie met het COTG naar de mening van sommige bestuursleden toch wel erg snell tot stand kwam. DB VNZ, 11 maart 1987

8 DB VNZ, 25 mei 1987

9 DB VNZ, 10 jun 1987 
accourtants was gegeven en de juridische relatie zou zijn hersteld. Tijdens het overleg was de VNZ evenwel bereid tot concessies. De ziekenfondsen stemden in met opschorting van de behandeling van tariefverzoeken door het COTG. Bovendien wilden de ziekenfondsen genoegen nemen met een kostenvergoeding van $f 80.000$ - per jaar, als er een modelovereenkomst getekend werd.

Het dilemma voor de VNZ herhaalde zich in september 1988 , toen Dekker gedurende een maand bemiddelde. Net als eerder had de VNZ op de korte termijn meer voordelen te verwachten wan besluitvoming in het COTG. Toch participeerde de $V N Z$ in het overleg onder leiding van Dekker, warin geprobeerd werd een nieuwe medewerkersovereenkomst te bereiken. De VNZ was bereid daarvoor de kostenvergoeding minder drastisch te verlagen maar hierop zei de LSV nee." I

In beide gevallen keerde de VNZ terug naar het COTG, toen de LSV besioot niet in te gaan op de tegemoetkomingen. De besluitvorming vond vervolgens in het COTG plaats waarin het secretariaat, VNZ en particuliere verzekeraars één lijn trokken. De ziekenfondsen ondersteunden de benadering van het COTG-secretariaat on een onderscheid te maken tussen beroepskosten en praktijkkosten. Zij waren het er over eens dat de discussie beperkt zou moeten worden tot de beroepskosten en dat de praktijkkositen (waaronder de secretaresse) aan het ziekenhuis moesten worden betaald. De gevolgen voor de tarieven voor medisch specialisten zouden zo drastisch zijn, dat de VNZ accoord zou kunnen gaan met een hogere kostenvergoeding of met een fasering in de doorvoering. 12

De besluitvorming door het COTG werd vervolgens in de juridische procedures die de LSV aanspande, bekrachtigd. De VNZ ondersteunde de Staat in het hoger beroep van de LSV tegen de Staat bij het Haagse gerechtshof door te verzoeken als gevoegde partij toegelaten te worden. $\mathrm{Bij}$ de VNZ constateerde men dat dit effect had omdat de overwegingen van de rechter vooral op de argumenten van de VNZ waren gebaseerd. 13

\section{KLOZ}

Het KLOZ typeerde het conflict hussen de VNZ en de LSV weliswaar als iets dat zich tussen die twee organisaties afspeelde - zo hadden de particuliere verzekeraars niets te maken met de modelovereenkomst -, maar vreesde de gevolgen voor de totstandkoming van de particuliere tarieven. De scheiding tussen het inkomensdeel en het kostendeel in het tarief woor de medisch specialist was voor de particuliere verzekeraars niet zonder problemen, omdat een rechtstreekse betalingsrelatie tussen medisch specialisten en particuliere verzekeraars ontbrak. De betaling van twee tarieven vereiste dus aampassingen bij de verzekeraars. Bovendien wist men dat de ziekenhuizen de uibetaling van kosten aan medisch specialisten niet wensten. ${ }^{14}$ Het KLOZ kreeg daamaast in het overleg met de LSV te maken met de effecten van conflicten die zich elders afspeelden. De LSV toonde weinig interesse in onderhandelingen met het KLOZ, ondat de specialisten al hun aandacht moesten richten op het voorkomen van besluiten die konden leiden tot een verdere aantasting van het inkomen van de medisch specialisten. ${ }^{15}$ Toch besloot het KLOZ een algemene verlaging van de particuliere tarieven na te streven, op basis van discussies over het praktijkkostendeel. Bovendien wenste het KLOZ één en ander af te stemmon

10 VNZ, notitie Mogelijke opschorting van eenzijdige werzoeken, 1 september 1987

11. DB VNZ, 6 september $1988 / 7$ september 1988

12 VNZ, notitie Praktijkkosten, 10 juni 1988

$13 \mathrm{VNZ}$, notitie Arresten gerechtshof Den Hag. LSV contra StaatVNZ/KLOZ/KPZ (richtlijnen praktijkkosten medische specialisten), 18 november 1988

$14 \mathrm{KLOZ}$, notitie Betreft: kostenpakketten medische specialisten, 27 maart 1987/KLOZ-besturu, 6 april $1987 / \mathrm{KLOZ}$, notitie, 14 april $1987 / \mathrm{KLOZ}$, verslag wooroverleg $\mathrm{KLOZ} / \mathrm{KPZ}, 23$ april 1987

15 KLOZ/KPZ onderhandelingsdelegatie, notitie, 20 aktober 1987 
met de VNZ. Tevens werd hei COTG in zijn benadering gesteund. 16 De particuliere verzekeraars hadden namelijk geconstateerd dat de LSV onaanwaardbare bedragen in de onderlandelingea over de kostenpakketten naar voren bracht.17 Het resultaat was steun van het KLOZ voor de voorstellen die de VNZ in de loop van 1987 aan het COTG deed, hoewel op enkele kostenposten de wensen afweken. ${ }^{18}$

Ofschoon het KLOZ niet het initiatier nam tot en verlaging van de tarieven voor medisch specialisten, was de organisatie dus evenmin genegen de wensen van de LSV te honoreren. Het KLOZ stemde ook niet in met het afscheid van het degressiebeleid dat WVC in 1988 aangaf. Het KLOZ meende dat de medisch specialisten te veel geld werd kwijgescholden. ${ }^{19}$ Het KLOZ steunde wel de $V N Z$ en het COTG. Een verlaging van de vergoeding voor praktijkkosten en de daaruit volgende tariefverlaging werd aantrekkelijk geacht 20 De manier van besluitvorming in het COTG kreeg de volledige instemming van het KLOZ. Het bouwde in de ogen van de verzekeraars voort op de vootstellen van de VNZ.21 Het KLOZ zette deze strategie voort na de besluitworming door het COTG. Het $\mathrm{KJ}-\mathrm{OZ}$ (en de $\mathrm{KPZ}$ ) wolgde het voorbeeld van de $\mathrm{VNZ}$ en steunde de Staat in het hoger beroep dat de LSV bij het Haagse Gerechtshof instelde. Ook in de ogen wan het KLOZ was het opzeggen wan het Generaal Akkoord door de overheid dat door het Gerechtshof behandeld zou worden noodzakelijk. Hoewel het KLOZ het Generaal Akkoord allijd had afgekeurd, volgde men nu de VNZ om de eenheid bij de financiers te benadrukken. ${ }^{22}$

Het KLOZ scharde zich gedurende de besluitvorming aver de praktijkkosten achter de VNZ op basis van een tijdelijke overeenstemming van belangen. Toch merkte het KLOZ naarmate men meer betrokken raakte, dat de eigen belangen niet altijd even goed aan de orde kwamen. Zo verliep de bemiddeling door Dekker in september 1998 alleminst naar wens. Het KLOZ had tijdens deze bemiddeling weinig problemen met een hoger bedrag (f 80.000 ) voor de kostenvergoeding voor medisch specialisten hetgeen tegemoet kwam aan de wensen van de LSV, maar wilde in ruil daarwoor goede afspraken met de specialisten over volumebeheersing. Bovendien streefde het KLOZ naar afspraken over het naar elkaar toe laten groeien van de tarieven in de ziekenfondssector en particuliere sector. De VNZ verzette zich echter hevig. De VNZ hanteerde in de ogen van het KLOZ een conserverende strategie, vooral gericht op de medewerkersovereenkomst. 23

\section{COTG}

De medisch specialistische zorg was begin 1986 een moeilijke sector vorn het COTG. Er kwamen geen richtijnen tot stand en overeenstemming over het inkomensniveau was ver te zoeken. De systematische onderbouwing van de lariefbesluiten voor de medisch specialisten die de opstellers van de Wig woor ogen hadden ontbrak. Verbetering in deze situatie vereiste een actiever COTG-beleid. Maar een actief COTG-beleid kon alleen het kostendeel wan het tarief betreffen. Ten aanzien van het inkomensdeel was een actief beleid niet mogelijk ondat het COTG nar het oordeel van het CBB op basis van de Wtg geen inkomensbeleid mocht voeren. Het streven van het COTG naar een betere structurering van de tarieven vereiste dan ook als

$16 \mathrm{KLOZ}$, notitie Betren: kostenpakketten medische specialisten, 27 maart 1987/KLOZ-bestuur, 6 april $1987 / K \mathrm{LOZ}$, notitic, 14 april $1987 / \mathrm{KLOZ}$, verslag vooroverleg KLOZ/KPZ, 23 april 1987

17 KLOZ, werslag voorowerleg KLOZ/KPZ, 23 september 1986

18 KLOZ, notitic aan leden KLOZKKZ-onderhandelingsdelegatie, 22 juli 1987

19 Brid directeur KLOZ aan bestuw KLOZ, 8 januari 1988

20 KLOZ, notitie Betreft: nedische specialisten, 20 januari 1988

21 KLOZ, notitie aan leden KLOOZKPZ onderhandelingsdelegatie, 11 maart 1988

$22 \mathrm{KL}, O Z$, notitie Betreft: woeging KLOZ/KPZ in procedure LSV regen Staat, 29 september 1988

23 KLOZ, verslag overleg LSV, NZr, VNZ, KLOZ, 12 september 1988/KLOZ, verslag woortgang overleg LSV, VNZ, KLOZ, NZn sinds 14-9-88, eind september 1988 
eerste stap een splitsing van het tarief in een inkomensdeel en een praktijkkostendeel.24 De samew werking tussen de VNZ en het secretariat van het COTG die bij de voorbereiding van de desbetreffende COTG-beshitvorming plaats vond, latat zich door deze doelstelling verklaren.

Bij de vormgeving van de besluiten over de kostenvergoeding verwees het COTG naar de Wig en de formele procedures. Goede tarieven vereisten richtlijnen die door het COTG waren vastgesteld en door de overheid waren goedgekeurd. Bovendien was het COTG wan mening dat de VNZ meer voordeel zou hebben van eenzijdige tariefvoorstellen aan het COTG dan wan het overleg met de LSV. Het overleg tussen de belangenorganisaties werd door hel COTG weinig positief beoordeeld. De bemiddelingspogingen door Lamers (en later door Dekker) voorzagen wolgens het COTG alleen in tijdelijke oplossingen. Een voorbeeld was de afsprak tussen de VNZ en de LSV tot een enquête onder medisch specialisten om de werkelijke praktijkkosten in kaart te brengen. Dit zou in de ogen van het COTG-secretariaat niets opleveren, dat had immers het verleden wel geleerd. Alleen formele tariebesluiten van het COrG konden de medisch specialisten binden. 25

De hervatting van de besluitworming door het COTG werd gezien als een logisch vervolg op de splitsing van tarieven in 1987. De werkzaamheden van Lamers hadden slechts geleid tot een pas op de plaats. Nu diende de hoogte van de te vergoeden kosten vastgesteld te worden. Het secretariagt verscherpte de discussie doo" het onderscheid tussen beroepskosten en overige kosten te introduceren. Door een gerichte adviesaanvraag bij Kamer $W$ in te dienen, voorkwam het secretariaat een tijdrovende discussie. Uiteindelijk zouden bestuwrlijke overwegingen van het COTG er toe leiden, dat de richtlinwoorstellen van het eigen bureau niet geheel werden gevolgd. Niettemin lagen de richtlijnvoorstellen binnen enkele maanden ter goedkeuring bij de staatssecretaris en slaagde het COTG ei tot eigen tevredenheid in ten aanzien van de tarieven woor medisch specialisten richtlijnen te ontwikkelen.

\section{LSV}

De voorstellen van de VNZ in 1986 droegen bij tot het beeld van de omgeving dat de LSV in toenemende mate ontwikkelde. In dit beeld streefden actoren belangen na die tegengesteld waren aan die van de LSV.26 Om deze bedreiging het hoofd te kunnen bieden, moest de LSV met een aigen, goed onderbouwd beleidsplan komen waarin de opname van de medisch specialist in het ziekenhuisbudget werd afgezworen. 27 Daarwoor had de LSV tijd nodig. De LSV streefde niet naar een spoedig beshuit over de vergoeding voor de praktijkkosten, maar naar tegengewicht aan de "maatschappelijke tegenkrachten' die bedreigende plannen publiceerden. 28

In eerste instantie kreeg de moeilijke relatie met de VNZ veel aandacht. Tijdens het bestuurtijk overleg in 1986 werden in de ogen van het bestunr voor de LSV onacceptabele voorstellen gedaan. ${ }^{29}$ Desondanks wilde de LSV de gesprekken met de VNZ voortzetten over een nomkostempakket, vooral om te woorkomen dat witeindelijk de 'awarte piet' bij de LSW terecht kwam. Het ondertekenen van en modeloverenkomst was evenwel niet aan de orde. ${ }^{30}$

Jarverslag COTG 1987, p. 111/112

25 Secretariat COTG, notitie t.b.v. overleg Lamers-Elsen, 5 november $1987 / 11$ november 1987. In gesprekken met respondenten is de visie naar woren gekomen dat hel COTG het een misverstand vindt dat partijen het primaat binnen de Wig hebben. Volgens het COTG hebben partijen het recht tot initiatief, het COrG heef beslissingsrecht. Binnen de rumte van de richtignen hebben partijen de vrijheid on te onderhandelen.

26 CB LSV, 21 augustus 1986

27 LSV, versiag werkbijenkomst CB LSV, 8 november 1986

28 LSV, Interne notitie, 27 juli 1987

29 CB LSV, 18 december 1986

30 CB LSV, 29 januari 1987 
Vanaf maan 1987 stapelden de problemen zich echter op. Met de VNZ verschilden de specialisten wan mening ower het beleidsplan, de modelovereenkomst eri de kwestie van de specialist in het ziekenthuisbudget, met het COTG over de afsplitsing van de praktijkkosten wan het tarief, en met de staatssecretaris over de bezuiniging van 40 miljoen gulden waarover aan het COTG een brief was gestuurd. De LSV besiloot op geen van deze punten toe te geven. ${ }^{3}$ Het resultaat was dat de LSV net de VNZ, WVC en het COTG discussieerde over de bezwaren tegen de verschillende voorstellen. Met betrekking tot de besluitvorming in het COTG kwam het besturur van de LSV echter al snel tot de conclusie dat daar weinig eer viel te behalen. In de discussie over de afiplitsing van de vergoeding voor praktijkkosten ging de vertegenwoordiger van de specialisten ervan uit "overruled" te worden. ${ }^{32}$ Het was de specialisten echter duidelijk dat met name de besluitvorming in het COTG van groot belang was.

Het overleg met de VNZ bood de LSV meer mogelijkheden. De bemiddeling door Lamers gaf de LSV meer tijd. Het grote voordeel was dat de VNZ er mee instemde om in afwachting van een onderhandelingsresultat gezamenlijk an het COTG te vragen de besluitvorming over de vergoeding woor praktjkkosten woor zes matanden stil te leggen. 33 Hiermee was woor de LSV een belangrijke doelstelling van het gesprek met de VNZ behaald. De besluitvorming door het COTG was tenminste enige tijd uitgesteld. Als internediair tussen het departement en de belangenorganisaties kon Lamers aan het eind van 1987 echter niet langer accoord gaan met het untstellen van cen uitkomst. Hij dwong de LSV tot een inhoudelijke stellingname door een laatste voorstel te doen. De LSV kon daarmee niet instemmen. ${ }^{34}$ De LSV trotseerde daarmee bewust de politieke wens tot tariefkortingen. Uit contacten met politici wist de LSV dat tariefdalingen ook bij het CDA en de VVD op steun konden rekenen. 35

In tegenstelling tot de VNZ was de LSV van mening dat het overleg met de VNZ meer had kunnen opleveren. ${ }^{36}$ Tevens waren de bestuursileden van de LSV zich ervan bewust, dat het COTG de besluitvorming over de vergoeding voor praktijkkosten weer ter hand zou nemen waarop zij weinig invloed zouden kumen hebben. ${ }^{37}$ In maart was de LSV ervan doordrongen dat van de COTG-besluitworming een grote dreiging uitging. Op het bureau werd berekend dat het voorstel van het secretariaat wam het COTG, te weten f 26.000 ,-, een tariefdaling van $28 \%$ zou betekenen. Bovendien dreigde ook een splitsing van het tarief en het onderbrengen van een deel van de betaling van de specialist in het ziekenliuisbudget. 38 Als reactie leverde de LSV bij het COTG voorstellen voor een kostenpakket in als tegenwicht voor de voorstellen van de VNZ. 39

Het beleid van de andere actoren werd in 1988 voor de LSV alleen maar bedreigender. Door de nieuwe beleidslijn van 1988 had de overheid in de ogen van de LSV zijn werkelijke doelstelling prijsgegeven, namelijk hoe dan ook bezuinigingen tot stand brengen. De LSV wilde door middel van gesprekken met WVC de houding van de overheid verduidelijkt krijgen. ${ }^{40}$ Verder wond de LSV dat de overheid geen oor had voor de bezwaren van de LSV tegen de ampak van thet COTG. Het bestur herhalde de eigen visie dat de vergoeding voor de kosten niet veranderd mocht worden zonder in te gaan op de rest van het tarief. Op korte termijn dacht

CB LSV, 19 maart 1987

CB LSV, 16 april 1987

CB LSV 18 juni 1987

CB LSV, 3 december 1987

CB LSV, 3 december 1987

CB LSV. 17 december 1987

CB LSV, 17 december 1987

LSV, interne notitie, 3 maart 1988

LSV, intern memo aan DSB, maari 1988

40

CB LSV. 28 januari 1988 
de LSW het meeste baat te hebben bij het goed informeren van de overheid en politici. Bovendien moest de overheid duidelijk gemaakt worden dat zij aanstuurde op een conflict 41

Het COTG noch WVC gaf gehoor aan de wensen van de LSV. De LSV ervoer de houding: van de andere leden van Kamer $V$ als zeer ongunstig. Omdat de splitsing van het tarief (met het daaraan verbonden gevolg dat de betaling van een deel van de inkomsten wan de medisch specialist via het ziekenhuis zal verlopen, hl) in feite een ontmanteling van het vrije beroep inhield, besloot de LSV naar de rechter te stappen. ${ }^{2}$ Het bestuur wan de LSV bleef somber over het standpunt van WVC dat naar verwachting de richtlijnen op korte termijn goedkeuren.43 Bovendien verliep het overleg tussen de overheid en de LSV, bevolen door de rechter in de General AkKoord-zaak, ongunstig. Staatssecretaris Dees was niet gevoelig voor de argumenten wan de LSV. De LSV ging over tot juridische acties en het benaderen van politici om de druk op de staatssecretaris te verhogen. Als de overheid de richlijnen alsnog goedkeurde, zou de LSV fase 3 afkondigen, de 'totale oorlog'.44 Dit hield in dat de $\mathbb{L S V}$ de leden zou oproepen zondagsdiensten uit te voeren.

In deze situatie kwam de bemiddelingspoging door Dekker als geroepen. De voorkeur van de LSV ging uit naar een zo breed mogelijk platform. Het hele veld moest bij het nieuwe overleg betrokken raken. Het was volgens de specialisten duidelijk dat voor de besluitvorming over de praktijkkosten een goed alternatief geboden moest worden teneinde zowel het COTG als de overheid tevreden te stellen. 45 De uitkomst van het overleg, te weten een uurloon van $f 200,-$, werd door de LSV positief beoordeeld, hoewel men erkende dat het moeilijk te accepteren viel voor de VNZ. 46 Het Dekker-overleg zou echter tot niets leiden ondat de VNZ niet accoord ging met de uitkomst. Hiermee verviel voor de LSV de laatste mogelijkheid de overheid ervan te weerhouden de richtlijnen wan het COTG goed te keuren. Ook de juridische procedures liepen voor de LSW op niets uit.

\section{WVC}

Bij WVC constateerde men vroeg in 1987 een overeenkomst van belangen van de VNZ en de overheid. De strategie van WVC was duidelijk: laat de organisaties van ziekenfondsen en medisch specialisten zelf hun conflict uitvechten, en laat het COTG zijn wettelijke rol spelen. ${ }^{47}$ Enige maanden later was de situatie nog duidelijker. De VNZ had de daad bij het woord gevoegd met als gevolg dat het COTG had ingestemd met het principe van de splitsing van het tarief voor medisch specialisten in een kostendeel en een inkomensdeel. Nog steeds benadrukten de ambtenaren van WVC, dat de belangen van de VNZ en het ministerie overeenkwamen en dat het COTG de verantwoordelijkheid had de besluitvorming tot stand te brengen. WVC diende derhalve af te wachten hoe de besluitworming binnen het COTG in de loop van het jaar plaats zou vinden. 48

Het nieuwe overleg tussen de VNZ en de LSV wanaf het midden van 1987 was voor WVC geen reden af te wijken van de eerder gekozen strategie. De bemiddeling tussen de VNZ en de LSV diende 'op partijenniveau" plaats te vinden." Toch bemoeide WVC zich met deze bemiddeling, maar een oplossing wan het conflict over de praktijkkosten was riet de voornaamste

$41 \quad$ CB LSV, 3 maart 1988

42 CB LSV, 19 mei 1988

43. CB LSV, 20 juni 1988

44 CB LSV, 7 juli 1988

$45 \quad$ CB LSV, 13 september 1988

$46 \quad$ CB LSV. 22 september 1988

47 WVC, memorandum aan de staatssecretaris, 27 februari 1987

48 WVC, memorandin aan de staatssecretaris, 27 mei 1987

49 WVC, intern menorandum, 21 juli 1987 
zorg wan het ministerie. Een herstel van de relaties stond voorop en er moesten zo snel mogelijk weer contracten tussen specialisten en ziekenfondsen worden getekend.50 Met name de druk. vanuit de patientenorganisaties zou Dees tot een meer actieve opstelling hebben bewogen. 51

In de strategie van het departement trad geen verandering op na thet mislukken van de bemiddeling door Lamers aan het eind van 1987. Het uitblijven van besluiten van het COTG over de verlaging van de praktijkkostenvergoeding zette WVC wel aan tot haast. ${ }^{52}$ De situatieschets daarentegen onderging in de tweede helft van 1987 grote veranderingen. Nog steeds benadrukten de ambtenaren dat de wens van de VNZ om de kostenvergoeding te verlagen overeenkwam met de wens van de overheid veertig miljoen gulden te besparen op dit onderdeel van de betaling van medisch specialisten. Tegelijk erkenden de beleidsmakers dat het beleid van degressie gefaald had. ${ }^{53}$ In plaats daarvan was er het sombere beeld van een 'forse budgettaire taakstelling inzake de medisch specialistische kosten'. ${ }^{54}$ De korting op de vergoeding voor de praktijkkosten moest het gat opvullen dat door het mislukte degressiebeleid werd achtergelaten. In plaats van een additionele uitkomst van een besluitvormingsproces waarmee WVC zo weinig mogelijk te maken wilde hebben, werd de inzet van de $\mathrm{VNZ}$ de kern van het departementale financiële beleid ten aanzien van de medisch specialisten. Ondanks de schatting van het COTG dat de maatregelen ten aamzien van de praktijkkostenvergoeding slechts een bezuiniging van 165 miljoen gulden zouden opleveren - veel te weinig gezien de tekort schietende bezuinigingen -, wilde men bij WVC de besluitvorming van het COTG afwachten. 55

Het belang van de aanpassing van de kostenvergoeding nam voor WVC dus alleen maar toe, zonder evenwel te leiden tot een interventie. WVC bleef wertrouwen op de besluitworming in het COTG. De richtlijnvoorstellen van het COTG gaven WVC gelijk. Ambtelijk WVC vond uiteraard dat er geen enkele reden was deze niet goed te keuren. ${ }^{56}$ WVC volhardde in haar strategie met als gevolg dat de overheid niet langer een partner voor overleg voor de LSV vormde. De pogingen van de LSV tot overleg met de staatssecretaris waren in tegenstelling tot een jaar geleden gedoemd te mislukken. Hij bleef verwijzen naar het COTG en de andere "Wtgpartijen' waartussen een uitvoerige en zorgvuldige discussie over de richtlijnen had plaatsgevonden. ${ }^{57}$ De strategie van niet-bemoeien werd tot in de politieke top gehandhaafd, met als gevolg een toename van de afhankelijkheid van WVC van wat zich in het COTG ging afspelen.

Naast de omarming van de besluitvorming over de praktijkkosten veranderde de situatieschets van WVC nog op een ander punt. Een goede bestuurlijke relatie met de LSV met het oog op komende besprekingen ten. behoeve van de herstructurering van de gezondheidszorg was voor WVC niet langer noodzakelijk. Daarvoor in de plaats constateerde WVC dat het Generaal Akkoord niet had geleid tot de beloofde besparingen. Bovendien had volgens WVC de LSV de achterban niet in de hand. Zo had bijwoorbeeld de LSV ingestemd met enquêtering, terwijl de leden er in slaagden de resultaten juridisch te laten verbieden. 58

50 Brief Van London aan Lamers, 4 augustus 1987

$51 \quad D B V N Z, 19$ november 1987

52 WVC, Voorlopige reactie wan staalssecretaris WVC op rapport Lamers, 1987

53 WVC, notitie t.b.v. overleg met LSV, 22 juni 1988

54 WVC, Voorlopige reactie wan staatssecretaris WVC op rapport Lamers, 1987

55 WVC, notitie t.b.v. overleg met $\mathbb{L}$ SV, 22 juni 1988

56 WVC, notitie, 26 mei 1988

57 Brieven LSV aan Dees, 14 juli, 28 juli en 16 augustus 1988/brief Dees aan LSV, 25 augustus 1988

58 WVC, notitie ten behoeve varn overleg met LSV, 22 juni 1988 


\begin{tabular}{|c|c|c|c|c|}
\hline & situatieschets & handelingsopties & errecten & gelkozen strategie \\
\hline $\begin{array}{l}V \\
N \\
Z\end{array}$ & $\begin{array}{l}\text { - er moet meer worden } \\
\text { bereikt in het overleg met } \\
\text { de LSV } \\
\text { - verlaging van de } \\
\text { wergoeding woor } \\
\text { praktijkkosten en } \\
\text { verandering van de } \\
\text { honoreringsmethodiek } \\
\text { worden doelstelling } \\
\text { - herstel van de juridische } \\
\text { relatie ziekenfonds- } \\
\text { specialist is wan groot } \\
\text { belang } \\
\text { - congruentie van doelen } \\
\text { met WVC en COTG, } \\
\text { incongruentie met LSV } \\
\text { (en KLOZ) }\end{array}$ & $\begin{array}{l}\text { - de formele weg; } \\
\text { inclusief afstemning } \\
\text { met COTO } \\
\text { - zoeken vat compromis } \\
\text { met LSV }\end{array}$ & $\begin{array}{l}\text { - de fomeel-juridische } \\
\text { weg zal leiden tot forse } \\
\text { fariefverlagingen } \\
\text { - het overleg met de } \\
\text { LSV zal op korte } \\
\text { terminn weining } \\
\text { opleveren } \\
\text { - de formeel-juridische } \\
\text { weg zal leiden tot } \\
\text { conflicten en een } \\
\text { verninderimg van de } \\
\text { kans op herstel van de } \\
\text { juridische relatie }\end{array}$ & $\begin{array}{l}\text { afwisseling van de } \\
\text { fommel-jurdische weg } \\
\text { en het owerleg met de } \\
\text { LSV }\end{array}$ \\
\hline $\begin{array}{l}K \\
L \\
O \\
Z\end{array}$ & $\begin{array}{l}\text { - conflicten elders hebben } \\
\text { voor ons effectem } \\
\text { - doelcongruentie met } \\
\text { VNZ en COTG, } \\
\text { incongruentie met LSV } \\
\text { en WVC }\end{array}$ & $\begin{array}{l}\text {-tariefonderhandelin- } \\
\text { gen met de LSV } \\
\text { - ondersteunen van } \\
\text { VNZ en COTG }\end{array}$ & $\begin{array}{l}\text { - overleg met LSV leidt } \\
\text { niet snel tof resultaiat } \\
\text { vanwege problemen } \\
\text { elders } \\
\text { - de weg van de } \\
\text { VNZJCOTG leidt tot } \\
\text { aanzienlijk } \\
\text { tariefverlagingen, wel } \\
\text { met problemen voor } \\
\text { part. verzekeraars }\end{array}$ & $\begin{array}{l}\text { - ansingiten bij } \\
\text { VNZfCOTG }\end{array}$ \\
\hline $\begin{array}{l}\mathrm{C} \\
\mathrm{O} \\
\mathrm{T} \\
\mathrm{G}\end{array}$ & $\begin{array}{l}\text { - tarieven te weinig } \\
\text { onderbouwd } \\
\text { - doelcongruentie met } \\
\text { VNZ, incongruentie net } \\
\text { LSY }\end{array}$ & $\begin{array}{l}\text { - via formeel juridische, } \\
\text { rationeel-economische } \\
\text { weg (inteme CoTG } \\
\text { discussie, op basis van } \\
\text { eenziddige voorstellen) }\end{array}$ & $\begin{array}{l}\text { - leidt tot 'richtige' } \\
\text { tarieven, fors lager dan } \\
\text { de huidige }\end{array}$ & $\begin{array}{l}\text { - formeelojuridische } \\
\text { weg, met beleidsmatige } \\
\text { compensatie van de } \\
\text { LSV (fasering en } \\
\text { negeren beroepskosten) }\end{array}$ \\
\hline $\begin{array}{l}\mathrm{L} \\
\mathrm{S} \\
\mathrm{V}\end{array}$ & $\begin{array}{l}\text { - vijandige omgeving } \\
\text { (incongruentie wan } \\
\text { doetenden met alle } \\
\text { andere actoren) } \\
\text { - de LSV heef tijd nodig } \\
\text { woor het formuleren van } \\
\text { beleid }\end{array}$ & $\begin{array}{l}\text { - en wisselende mix } \\
\text { van formeel/informeel } \\
\text { overleg met de VNZ en } \\
\text { de overheid, forneel- } \\
\text { inhoudelijke } \\
\text { argumentatie met WVC } \\
\text { en het COTO, juridische } \\
\text { procedures (wan } \\
\text { hoorzitingen tot } \\
\text { gerechtshoven) en actie } \\
\text { (totale oorlog") }\end{array}$ & 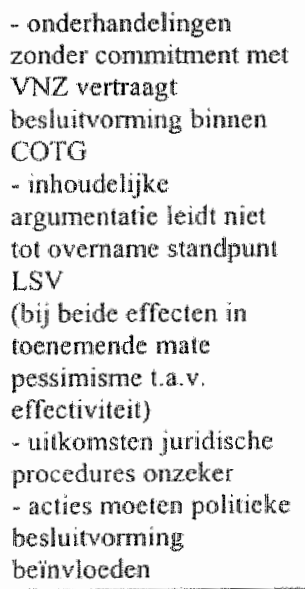 & 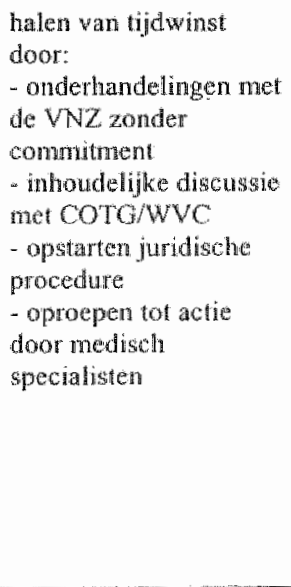 \\
\hline
\end{tabular}




\begin{tabular}{|c|c|c|c|c|}
\hline & situatieschetis & handelingsopties & ffecten & gekwzen strategie \\
\hline $\begin{array}{l}W \\
W \\
C\end{array}$ & 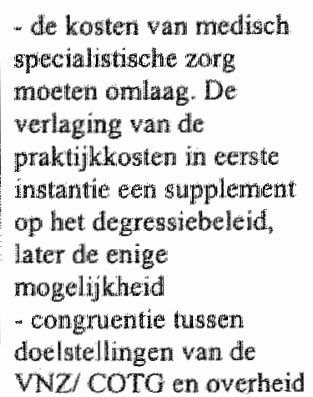 & $\begin{array}{l}\text { - dw owerheid kan actief } \\
\text { ingripen (bijy. } \\
\text { aanwijzingen., } \\
\text { woorzitten wan } \\
\text { bemiddeling) } \\
\text { - de overheid kan } \\
\text { partijen en CoTO } \\
\text { werantwoordelijkheden } \\
\text { waar laten maken }\end{array}$ & $\begin{array}{l}\text { - als de overheid zich } \\
\text { actief bemoeit raakt hij } \\
\text { betrokken bij het } \\
\text { conflict } \\
\text { - als de VNZJCOTG } \\
\text { slagen, treedt } \\
\text { kostenverlaging op }\end{array}$ & $\begin{array}{l}\text { WVC blifft op afstand } \\
\text { en laat VNZCOTG op } \\
\text { basis van de Wtg } \\
\text { beslluitvorming tot } \\
\text { stand brengen }\end{array}$ \\
\hline
\end{tabular}

Toen in augustus 1988 Dekker een laatste bemiddelingspoging ondernam, was het zaak voor WVC de financiële gevolgen in kaart te brengen. 59 Van concessies aan de LSV wilde men niets weten. Hooguit kon worden gesproken over een fasering van de invoering van de richtlijnen voor de kostenvergoeding, die overigens de realisatie van de bezuinigingen zou beînvloeden. 60 Wel werd WVC gedwongen een positie in te nemen. Aan de ene kant lonkte het perspectief van de verlaging van de kostenvergoeding, aan de andere kant beloofde de bemiddeling door Dekker concrete oplossingen woor de hoogoplopende spamingen. Als deze plannen resulteerden in hogere kostenvergoedingen werd het financiële gat evenwel alleen maar groter. 61 Toch stemde WVC in met uitstel van het bestuit teneinde de organisaties de gelegenheid te geven met eigen oplossingen te komen.

Het mislukken van het Dekker -overleg maakte de afweging tussen de COTG-richtlijnen en bemiddelingsuitkomsten woor WVC eenvoudig. Omdat er geen alternatief voor de COTGrichthijnen voorhanden was en de overheid slechts opschorting en geen afstel gedoogde, was er geen enkele reden deze niet zo snel mogelijk goed te keuren. ${ }^{62}$ Eind september stelde ambtelijk WVC dit dan ook aan haar staatssecretaris voor. De goedkeuring diende echter vergezeld te worden door enkele 'doekjes voor het bloeden': een fasering van de verlaging zoals reeds gesuggereerd door het COTG en een verlaging van het nominkomen naar een bedrag dat zo dicht mogelijk in de buurt van f 181.500 lag dat op dat moment door de overheid gehanteerd werd. 63

\subsection{De reshurning}

\section{VN2}

Hoewel de VNZ het naar elkaar toegroeien van de inkomensniveaus van de verschillende specialismen betitelde als van belang voor iedereen - de reshuffling als een maatschappelike doelstelling64 - beschouwde de belangenorganisatie de reshuffing als iets dat voomamelijk de LSV zelf aranging. Het verkleinen van inkomensverschillen was een interne zaak voor de LSV,

59 Handgeschreven conmentaar WVC bij brief Dekker an Dees, 31 augustus 1988

$60 W \mathrm{WC}$, nemorandum aan staatssecretaris, datum onbekend

61 WVC, notitie, 8 september 1988

62 WVC aan de staatssecretaris, 29 september 1988

63 WVC, memo aan de MinisteriStaatssectetaris $W V C, 29$ september 1988

64. Karakterisering van respondenten 
die woor de VNZ een vooral technische uitwerking behoefde. Hiervoor liet men het initiatief graag aan de LSV zelf, die het initiele voorstel van Van Aardenne nader vorm moest geven. Illustratief voor deze positie was de bereidheid van de VNZ in november 1989 accoord te gaan met de invoering van de reshuffling als de eigen wensen (m.n. de ondertekening van een medewerkersovereenkomst en de vaststelling van een macrobudget) op de korte termijn werden ingewilligd. De reshuffling had voor de ziekenfondsen niet de eerste prioriteit.

De VNZ deelde later, bij de uitwerking van het juni-voorstel waarin de reshuffling was opgenomen, de mening van de andere partijen dat het voorstel tot reshuffling strijdig was met de Wtg. De VNZ koos voor een goede juridische onderbouwing. Daartoe participeerde de VNZ in het overleg met het COTG en werd er bij de overheid op aangedrongen zich actief op te stellen. Als de overheid geen aanwijzingen wilde sturen, zou zij de Wivb buiten werking moeten stellen. Overigens had de VNZ zijn twijfels bij de achtergronden van de argumentaties van het COTG.

Het belang van de VNZ bij een goede juridische onderbouwing kan worden verklaard uit wwee motieven. Ten eerste was de VNZ gebaat bij een juridisch veilig gestelde uitvoering van het VPA. Men wilde geen onuitgewerkt accoord. Dit overigens meer vanwege het te verwachten 'ongehoorzame' gedrag van de achterban van de LSV dan vanwege de mogelijke reactie van de LSV, want deze organisatie werd geacht zelf te veel aan de reshuffling te hechten. ${ }^{65}$ Ten tweede vormde de reshuffing een niet af te splitsen onderdeel van het gehele pakket van overeenkomsten. Dit verplichte de deelnemers tot een gezamenlijke inzet en verdediging. Het niet doorgaan van het ene onderdeel had immers gevolgen voor het doorgaan van het andere onderdeel.

\section{KLOZ}

Evenals de VNZ hechtte het KLOZ weinig belang aan de reshuffling. Van groot belang was wel overleg over volumebeheersing en het opheffen van de onevenwichtigheden in de tariefopbouw (waaronder het verschil tussen particuliere en ziekenfondstarieven). Vooral de toegroei tussen particuliere en ziekenfondstarieven was wan groot belang. Het KLOZ had dus wel degelijk iets te bereiken in het VPO. ${ }^{66}$ Vanaf het begin van het overleg noemde het KLOZ de reshuffling én van de punten waarover weinig verschil van mening bestond maar waarmee vooral de LSV worstelde. ${ }^{67}$ Toen later in het VPO aan de reshuffling een bepaalde financielle opbrengst werd verbonden raakte het KLOZ meer geïnteresseerd, maar een prioriteit werd de reshuffing niet.

Evenals de VNZ participeerde het KLOZ in het overleg met het COTG en WVC teneinde een goede juridische houdbaarheid van de reshuffing te bereiken. Door ervaring wijs geworden nam het KLOZ niet meer genoegen met een overeenkomst die nog op een technische uitwerking wachtte, De particuliere verzekeraars wilden zekerheid omtrent de technisch-juridische vormgeving. ${ }^{68}$ Bovendien bestond bij het KLOZ de overtuiging dat de juridische houdbaarheid van de reshuffling een probleem bleef zolang de Wivb bestond. Daarbij had men wel, zowel ten opzichte van het COTG als ten aanzien van de resultaten van de discussies, een ambivalente houding. Het was het KLOZ niet geheel duidelijk of het COTG de kostenrichtlijnen verdedigde of terechte juridische bezwaren aanreikte ${ }^{69}$ Bovendien had het KLOZ niet het gevoel dat de discussies juridische helderheid opleverden. Niettemin ondersteunde het KLOZ het technische overleg met het COTG en WVC en de pogingen van het VPO om de overheid te bewegen de 
Wivb in te trekken. Alle op juridische zekerheid gerichte activiteiten konden echter niet voorkomen dat, toen het CBB in 1991 de bezwaren tegen de reshuffling afwees, het KLOZ moest toegeven enigszins verbaasd te zijn over de kennelijk effectieve afstemming. ${ }^{70}$

\section{COTG}

Bij het verschijnen van het tussenrapport van Van Aardenne in juni 1989 bleek het COTG niet gecharmeerd te zijn van de voorgestelde reshuffling. De reshuffling werd gezien als een correctie op tarieven die niet nodig geweest zou zijn als het COTG de mogelijkheden zou krijgen om juiste tarieven tot stand te brengen. Dit oordeel hing naww samen met de opvatting dat het beoordelingskader voor het COTG de bestaande wettelijke regels waren en bleven, en dat het VPA slechts een tijdelijke overeenkomst vormde. De gedachte dat de brede consensus in de groep van vijf organisaties elk tariefbesluit mogelijk zou maken, werd door het secretariaat afgewezen. Deze gedachte strookte absoluut niet met zijn rolopwatting waarin de eigen verantwoordelijkheid van het COTG en een onafhankelijke oordeelsvorming op basis van de Wtg (en Wivb) centraal stonden. Dit betekende dat het COTG alle voorstellen van het VPO apart zou gaan beoordelen en deze niet zou beschouwen als onderling samenhangende onderdelen van een moeizaam opgebouwde onderhandelingsuitkomst, zoals het VPO graag wilde.

Naast deze institutionele plaatsbepaling zorgden inhoudelijke aspecten van het reshufflingsvoorstel ervoor dat het secretariaat van het COTG een afwijzende houding aannarm. Omdat het een inkomensbesluit betrof, was een aanwijzing van de overheid noodzakelijk. Aangezien er geen overeenstemming tussen de overheid en de LSV bestond over het inkomensniveau hetgeen formeel in het kader van de Wivb vereist was, kon elke inkomensaanwijzing juridisch aangevochten worden. Een oplossing was dat de Wivb niet meer zou gelden voor de medisch specialisten. Maar zelfs als de medisch specialisten niet meer onder de Wivb zouden vallen kon het COTG ten aanzien van het voorliggende voorstel geen juridische houdbaarheid garanderen.

Dit formeel juridische uitgangspunt van het COTG-secretariaat werd geleidelijk aan minder absoluut. De strategie om op basis van een eigen onafhankelijk oordeel geen deel van het VPO uit te maken, werd langzamerhand onder druk van de brede consensus in de directe omgeving verlaten. Het secretariaat participeerde actief in werkgroepen teneinde een onderbouwing van het voorstel tot stand te brengen. Het streven was het voorliggende reshufflingsvoorstel een solide juridisch fundament te geven. Het COTG wenste echter nog steeds geen garantieverklaring ten aanzien van de juridisch houdbaarheid af te geven. De Wivb bleef in de weg zitten. Daarnaast wilde men de bestaande richtlijnen die de tweede en derde fase van de verlaging wan de kostenvergoeding in werking stelden, niet wervangen.

Een nog verdere aanpassing van het COTO aan de omgeving hield in dat zelfs nieuwe richtlijnen niet meer nodig waren. Een formele toetsing aan de bestaande richtlijnen was voidoende. Tegelijk accepteerde het COTG geen enkele verantwoordelijkheid meer voor de juridische onderbouwing. Daarmee werd duidelijk dat de groeiende cooperatie van het COTG niet gebaseerd was op een toename van inhoudelijke overeenstemming over de reshuffling.

\section{LSW}

Zoals in hoofdstuk vier bleek, had de reshuffling een verleden. Het bestuur van de LSV wilde reeds in 1988 de inkomsten tussen de specialistengroepen harmoniseren door tarieven aan te passen, maar de Ledenvergadering weigerde dit te steunen. Het voorstel van Van Aardenne paste in de beleidsvisie van de LSV, maar het was veel ingrijpender dan het eerdere voorstel van het besturur van de LSV. 
Ondat het bestur van de LSV zich geen openligke eigen voorstellen ma de mislukte poging tot inkomstenhamonisatie kon permitteren, vroeg de organisatie an Van Aardenne voorstellen te doen als onderdeel van een breed pakket die vervolgens verdedigd moesten worden tegenover de achterban. Daarbij werd de LSV zich ervan bewust dat de financiers noch de overheid veel belang hechtten aan de reshuffing. Het ging de VNZ en de overheid om het macrobudget en het KLOZ vond de herstructurering van de tarieven van veel groter belang. Een ander struikelblok bij de wivoering van de reshufling was de strijdigheid met de Wivb die met name na de uitspraak in de tweeslagzaak de volle aandacht kreeg.

In 1990 ervoer de LSV steeds meer druk. De vormgeving van de reshuffing werd aan besiuiten over de herstructurering van tarieven gekoppeld. Ondat deze evenwel door een tekort aan informatie in de particuliere sector niet tot stand kwam, liep men grote achterstand ten aanzien wan het tjidschema op. Daamaast kostte het intrekken van de Wivb weel tijd en moeite. Tevens roenden de specialistische groepen zich die een verhoging van tarieven was beloofd. De LSV koos er voor zich te richten tot de staatssecretaris teneinde de intrekking wan de Wivb te bewerkstelligen. Toen in 1990 de druk nog groter werd, richtte men zijn pijlen ook op andere politici on hen duidelijk te maken dat de verwezenlijking van onderdelen van het VPA gevaar liep. Daarnaast participeerden de medisch specialisten op ambtelijk en besturrlijk niveau in het overleg met het COTG. Bovendien spande de LSV zich binnen het VPO in on de relatio met de andere organisaties in stand te houden, teneinde de reshuffing veilg te stellen. Tenslotte slaagde de LSV er in de reshuffing los te koppelen van de besprekingen over andere onderdelen van het VPO, waardoor aan het einde van 1990 een voorstel an het COTG gesturd kon worden. Daabij werd de omslag van het COTG verwelkomd, ondat de juridische duidelijkheid nu op korte termijn verkregen werd. De weigering wan het COTG de oude richtlijnen te vervangen werd geaccepteerd als een 'fait accompli'.

\section{WVC}

Vanaf het begin van het VPO was duidelijk warom de overheid het overleg toestond. En moest namelijk een voorstel door de vijf partijen worden geformuleerd dat een goed alternatief vormde voor de besluitvorming in oktober 1988. Met een goed alternatief bedoelde WVC vooral dat de afspraken bezuinigingen zouden beloven en dus eerdere besluitvorming zouden kunnen vervangen. Een nivellering van de inkomensverschillen tussen specialismen stond buj de overheid niet voorop, en was meer sprake van en 'bijproduct" 71 Er was waardering voor de doelstelling maar tevens een zekere bezorgdheid. De reshuffing leek immers een aanwijzing van de overheid nodig te maken zolang de Wiw op de medisch speciatisten van toepassing was. De procedurele eisen van de inkomenswetgeving zou het tot stand brengen van bezuinigingen fors kumen vertragen. Bovendien zou de overheid actief betrokken raken bij de tariefbesprekingen. Hoewel er dus alle reden voor WVC was de Wivb voor de medisch specialisten niet meer te laten gelden, werd ervoor gekozen de Wivb te handhaven teneinde nog enkele mogelijkhedlen achtor de hand te hebben ten behoeve var enige sturing van de inkomensontwikkeling van artsen. WVC rekte zells het bestaan van de Wivb in gesprekken mel de vertegenwoordiger van het VPO. Terwij andere departementen al afscheid van de Wivb hadden genomen, vond ambtelijk WVC het geen goed idee dit a te duidelijk door te laten schemeren in de gesprekken. Dit typeende de dubbele moraal wan WVC ten aanzien van dit punt. Door het laten voorthestaan van de Wivb kon de reshufling als em inkomenspolitieke matregel worden gezien en lag er een taak bij de overheid, maar tegelijk sclioof de overheid deze werantwoordelikheid af en legde het departement alle verantwoordelikheid bij de organisaties zelf en het COTG.

71 Of zoals een medewerker van WVC het uitdrukte: het macrobudget was voor de overheid van groot belang, de rest was een kwestie van 'laten we het uitproberen', gesprek 11 maart 1997 
WVC was door het COTG genfomeerd over de gebrekkige onderbouwing en kende dus de magere juridische houdbaarheid van het reshufflingsvoorstel: Ook was het negatieve advies van de Landsadvocaat bekend. Bij WVC was men zich bewust dat ontevreden medisch specialisten het accoord juridisch zouden aanvechten. Maar de juridische problemen van onderdelen als de reshuffling wogen niet op tegen de grote woordelen van thet macro-budget dat in het VPO werd afgesproken. Hoewel WVC op onderdelen zijn juridische reserves hield, werd het VPA wan december 1989 krachtig ondersteund.

De situatieschets en de daaraan werbonden strategie van WVC veranderden nawwelijks gedurende de besluitvorming over de reshuffing. WVC liet zich tot in 1991 niet verleiden tot het gewen van aanwijzingen. Ook werd slechts zeer aarzelend aan het VPO duidelijk gemaakt dat naar all le watarschinlijkheid de Wiwb zou worden ingetrokken. Binnen WVC twijfelde men hevig aan het positieve effect wan het opheffen wan de Wivb, zeker toen bleck dat de tweeslag niet houdbaar was. De reshuffling was inhoudelijk geen goede afspraak waaraan het wegvallen van de Wivb niets zou helpen. Wel intervenieerde de staatssecretaris op informele wijze teneinde een meer meegaande opstelling bij het COTG tot stand te brengen. De problemen die WVC weroorzaakte door niet in te gaan op de verzoeken van het VPO zich actiever op te stellen, moesten door middel wan informeel ingrijpen worden weggenomen.

\subsection{De tweeslag}

\section{VNZ}

De tweeslag in tarieven was een beslissing waarmee werd voortgebouwd op de wens van de financiers tot prikkels voor individuele specialisten zodat zij zich zouden houden aan de centrale afspraken. Het voorstel van Van Aardenne een onderscheid te maken tussen specialisten die wel en specialisten die niet meewerkten en hen overeenkomstig te betalen, viel dan ook in goede aarde bij de VNZ. Een goede beoordeling zou echter niet eenvoudig zijn omdat er de nodige juridische haken en ogen aan zaten. ${ }^{72}$

Tabel 6.2: Handelingstheorieën bij casus reshuffling

\begin{tabular}{|c|c|c|c|c|}
\hline & situatieschets & handelingsopties & effecten & gekozen strategie \\
\hline $\begin{array}{l}\mathrm{V} \\
\mathbb{N} \\
2\end{array}$ & 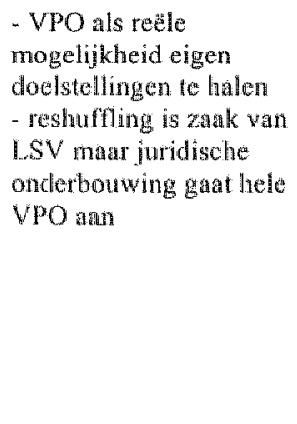 & $\begin{array}{l}\text { - initiatief bij anderen: } \\
\text { LSV levert cijfermatige } \\
\text { onderboutwing van } \\
\text { voorstellen van Wain } \\
\text { Andenne aan } \\
\text { - overleg met CoTG } \\
\text { over jurndische } \\
\text { onderbouwing } \\
\text { - druk op overtheid tb.v. } \\
\text { actieve opstelling (geven } \\
\text { van } \\
\text { annwijzing/intrekken } \\
\text { van Wivb) }\end{array}$ & 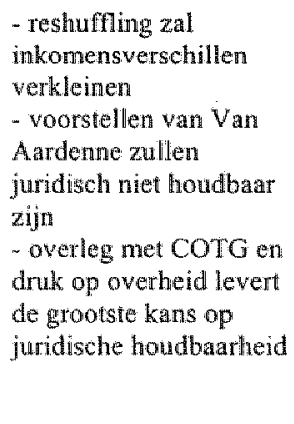 & $\begin{array}{l}\text { - raadgevingen van } \\
\text { COTG opvolgen bij het } \\
\text { vorm geven aan } \\
\text { yoorstellen wan Van } \\
\text { Aardenne }\end{array}$ \\
\hline
\end{tabular}




\begin{tabular}{|c|c|c|c|c|}
\hline & siltuaticschets & handelingsopties & effecten & gekozen strategle \\
\hline $\begin{array}{l}K \\
L \\
O \\
Z\end{array}$ & $\begin{array}{l}\text { - VPO als reele } \\
\text { mogehijheid eigen } \\
\text { doelstellingen te balen } \\
\text { - reshuming is zaak van } \\
\text { LSV maar jundische } \\
\text { onderbouwing gaat hele } \\
\text { WPO aan }\end{array}$ & $\begin{array}{l}\text { - initiatief bij anderen: } \\
\text { LSV levert cijfermatige } \\
\text { onderbouwing van } \\
\text { voorstellen van Van } \\
\text { Aardenne aan } \\
\text { - overleg met CoTG } \\
\text { over juridische } \\
\text { onderbouwing } \\
\text { - druk op overheid t.b.v. } \\
\text { actieve opstelling (gever } \\
\text { van } \\
\text { aanwijzing/intrekken } \\
\text { van Wivb) }\end{array}$ & $\begin{array}{l}\text { - reshuffling zal } \\
\text { inkonnensverschillen } \\
\text { verkleinen, met wellicht } \\
\text { een kleme financiêle } \\
\text { opbrengst } \\
\text { - voorstellen van Van } \\
\text { Aardenne zullen } \\
\text { juridisch niet houdlbarar } \\
\text { zijn } \\
\text { - overleg met CoTG en } \\
\text { druk op overheid levert } \\
\text { de grootste kans op } \\
\text { juridische houdbaarheid, } \\
\text { maar absolute zekerheid } \\
\text { is niet mogelijk }\end{array}$ & $\begin{array}{l}\text { - radgevingen van } \\
\text { CoTG opvolgen bij het } \\
\text { yorm geven aun } \\
\text { voorstellen wan Van } \\
\text { Aardenne }\end{array}$ \\
\hline $\begin{array}{l}c \\
O \\
T \\
G\end{array}$ & 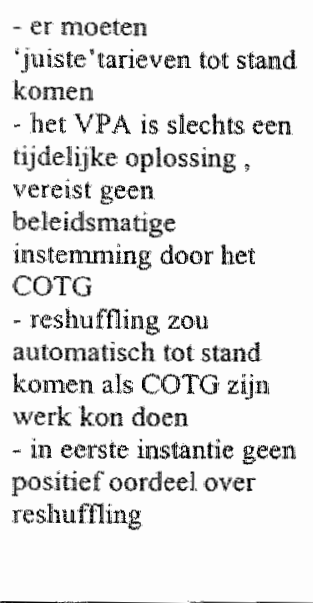 & $\begin{array}{l}\text { ween afzonderlijke } \\
\text { beoordeling van elk } \\
\text { onderdeel van het VPA } \\
\text { - voor reshuffling zijn } \\
\text { nieuwe richtlijnen } \\
\text { noodzakelijk } \\
\text { - een aanwigzing van de } \\
\text { overheid is noodizakelijk } \\
\text { - een beoordeling op } \\
\text { basis van bestaande } \\
\text { richtlijnen is mogelijk } \\
\text { - een aanwijzing van de } \\
\text { overheid is niet nodig } \\
\text { - technisch overleg over } \\
\text { vormgeving } \\
\text { reshufflingsvoorstellen } \\
\text { zonder beleidsmatige } \\
\text { instemming }\end{array}$ & $\begin{array}{l}\text { - zonder nieuwe } \\
\text { richtijnen en een } \\
\text { aanwigzing van de } \\
\text { owerheid geen juridische } \\
\text { houdbaarheid } \\
\text { - voorstellen zonder } \\
\text { aanwijzing en richtlijnen } \\
\text { zign mogelijk, maar } \\
\text { technisch overleg is geen } \\
\text { garantie voor juridische } \\
\text { houdbaarbeid }\end{array}$ & $\begin{array}{l}\text { - geleidelijke } \\
\text { aanpassing: van } \\
\text { afwijzing en } \\
\text { benadrukken van de } \\
\text { noodzank van } \\
\text { aanwijzingen en nieuta } \\
\text { nichtijnen natr } \\
\text { technisch overleg zonder } \\
\text { beleidsmatige } \\
\text { instemining }\end{array}$ \\
\hline $\begin{array}{l}\mathrm{L} \\
\mathrm{S} \\
\mathrm{V}\end{array}$ & $\begin{array}{l}\text { - het VPO als middel de } \\
\text { richtlinwoorstellen in te } \\
\text { laten trekken } \\
\text { - reshurfling is } \\
\text { belangrijk voor de LSV, } \\
\text { kan worden bereikt in } \\
\text { VPO-werband, masr } \\
\text { andere VPO-deelnemers } \\
\text { tonen minder interesse }\end{array}$ & $\begin{array}{l}\text { - zelf reshurting- } \\
\text { voorstellen doen } \\
\text { - Van Aardenne deze } \\
\text { voorstellen laten doen } \\
\text { - reshuffling als eigen } \\
\text { zaak behandelen } \\
\text { - VPO-partners erbij } \\
\text { betrekken } \\
\text { - overleg met CoTG } \\
\text { over juridische } \\
\text { onderbouxing } \\
\text { - druk op de overheid } \\
\text { t.b.v. een actieve } \\
\text { opstelling (geven van } \\
\text { aanwijzing/intrekken } \\
\text { van Wivb) }\end{array}$ & $\begin{array}{l}\text { - LSV is kwetsbaar als } \\
\text { voorstellen zelf worden } \\
\text { gedaan } \\
\text { - Van Aardenre kan } \\
\text { voorstellen onderdeel } \\
\text { laten zijn van het gehele } \\
\text { pakket } \\
\text { - betrokkenheid van } \\
\text { andere VpO-deelinemers } \\
\text { bespoedigt de reslisatie } \\
\text { - actieve opstelling } \\
\text { overheid versnelt de } \\
\text { besluivorning } \\
\text { - overleg met ConG } \\
\text { bevordert juridische } \\
\text { houdbatheid }\end{array}$ & 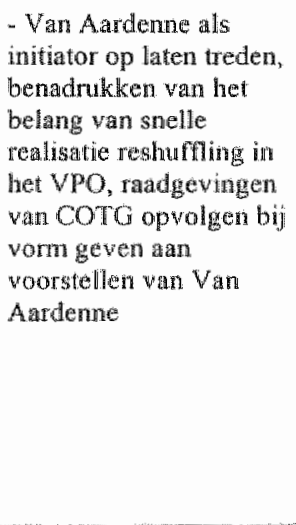 \\
\hline
\end{tabular}




\begin{tabular}{|c|c|c|c|c|}
\hline & siluatieschets & handelingsopties & efferten & gekezen strategie \\
\hline $\begin{array}{l}W \\
W \\
C\end{array}$ & $\begin{array}{l}\text { - het VPO kan een goed } \\
\text { alternatief vormen voor } \\
\text { de kostenrichthj nen van } \\
1980 \\
\text { - de reshuffling is een } \\
\text { "bijproduct" } \\
\text { - Zorg over de rol vain de } \\
\text { overheid in het } \\
\text { tarievenowerleg }\end{array}$ & $\begin{array}{l}\text { - even actieve rol woor de } \\
\text { overheid in de vorm wan } \\
\text { aamwijzingen en het } \\
\text { intrekken van de Wivb } \\
\text { - cen passieve rol: de } \\
\text { verantwoordelikheid bij } \\
\text { partijen en het CorG }\end{array}$ & $\begin{array}{l}\text { - bij een actieve rol zou } \\
\text { de overheid weer deel } \\
\text { gaan untmaken van het } \\
\text { tarievenoverieg en } \\
\text { doelwit worden van } \\
\text { juridische procedures } \\
\text { - maatregelen resulteren } \\
\text { waarschijnijic niet in } \\
\text { juridische zekerheid. } \\
\text { - bovendien vertraging } \\
\text { wan besluitworming } \\
\text { - bij een passieve rol zou } \\
\text { de overheid zich minder } \\
\text { kwetsbaar opstellen } \\
\text { wovendien met de } \\
\text { Wiwb iets achter de hand } \\
\text { in geval wan mislukken } \\
\text { het vpo }\end{array}$ & $\begin{array}{l}\text { - in formele zin geen } \\
\text { actieve rol, wel } \\
\text { informele interventie } \\
\text { t.b.v. instemming door } \\
\text { het CoTG }\end{array}$ \\
\hline
\end{tabular}

De juridische onzekerheid hield bij de VNZ nog even aan. De VNZ vroeg zich af hoe een Wtg-omschrijving kon worden ontworpen. Bovendien stelden de ziekenfondsen na verloop van tijd vast, dat in het geval van het ontbreken van een overeenkomst de medisch specialist in het geheel geen vergoeding van een ziekenfonds kon krijgen. Als er dan ook geen restitutiebesluit van toepassing was, zou de medisch specialist geen enkela vergoeding van een ziekenfonds kunnen ontvangen. ${ }^{73}$ De VNZ koos ervoor de onduidelijkheden over de juridische mogelijkheden van het tweeslagvoorstel in overleg met het COTG weg te nemen. Daarbij viel de VNZ de uitgesproken eigen mening van het COTG op waarvan de herkomst niet altijd duidelijk was. De VNZ voelde een spanning tussen de "beleidsmatige" belangen en pragmatische oplossingen.74 Toch was het een voorstel van de VNZ aan het VPO de onderbouwing van de tweeslag te zocken in aanpassingen van de werkbelasting als onderdeel van de tariefformule. Deze benadering leidde uiteindelijk tot richtlijnwoorstellen aan het COTG. Bovendien raakte de VNZ verwikkeld in een discussie met de LSV over de vormgeving van de medewerkersovereenkomst ten aanzien van de mogelikheid specialisten die niet meewerkten een sanctie van tien procent op te kunnen leggen. De VNZ streefde er naar ook binnen een bestaande medewerkerstelatie een lager tarief unt te kunnen betalen. De LSV vond dat een lagere betaling slechts kon volgen als het gerechtvaardigd zou zijn het contract vanwege het niet nakomen van verplichtingen door de specialist op te zeggen. ${ }^{75}$ De onduidelikheid rond de vormgeving van de weeslag vomde voor de VNZ echler geen beletsel accoord te gaan met het pakket in zijn geheel. De nadruk lag op een integrale afwegings het ging om het gehele pakket en niet om de afzonderlijke onderdelen. " Men vertrouwde op een oplossing in het overleg met hel COTG. Uiteindelijk moest in juridische procedures de houdbaarheid van de afspraken blijken. ${ }^{7}$

De uiteindelijke vormgeving bleek niet tegen de juridische protesten van individuele medisch specialisten bestand te zijn. Voor de ziekenfondsen had dit to gevolg dat specialisten

74 VNZ, notitie anan inteme specialisten overleg, 2 oktober 1989

75 VNZ, notitie Reactie VNZ op notitie LSV, 29 november 1989

76 VNZ, notitie aan leden DB, 12 december 1989

77 DB VNZ, 13 december 1989 
die het contract verbraken toch betaald moesten worden. Bovendien yerviel een drukmiddel om over enkele jaren weer met de LSV te kumen onderhandelen. ${ }^{78}$ Toch wilde de VNZ gewoon doorgaan met het VPO, want het merendeel van de specialisten had toch al een contract getekend.

\section{KLOZ}

Biy het begin van het VPO stond het KLOZ volumebeheersing en het naar elkaar toegroeien van de verschillende soorten van tarieven voor. Daarbij besefte het KLOZ, meer dan de VNZ, dat tariefverlagingen door medisch specialisten konden worden gecompenseerd door een toename van het aantal verrichtingen. Een systeem van budgettering leek het KLOZ een betere mogelijkheid tot volumebeheersing, waarbji een zo laag mogelijk niveau (het ziekenhuis) de voorkeur had vanwege het prisoners' dilemma. Bij het disciplinerend vemogen van de LSV zetten de verzekeraars grote vraagtekens. ${ }^{79}$

Een oplossing te bedenken voor de problemen van collectieve actie van de LSV speelde in de overwegingen van het $\mathrm{KLOZ}$ dus een grote rol. Het belonen wan deelname aan de nieuwe overeenkomst door een financieel voordeel paste in deze gedachtegang. Het KLOZ vond de voorgestelde tweeslag in eerste instantie evenwel 'boterzacht'. Het was maar de vraag of twoe tarieven juridisch mogelijk waren. Bovendien waren de belangen van particuliere verzekeraars er niet mee gediend omdat twee tarieven een administratieve belasting betekenden. Hat afwijzen van de tweeslag zou het overleg echter terug naar af brengen, en dan zou het KLOZ in eem isolement kunnen raken ("de zwarte piet") 80 Met andere woorden, de tweeslag werd door het KLOZ geaccepteerd ondat het onderdeel van het pakket wasi en ondat het KLOZ aandrong op een bonus voor bereidwillige specialisten, maar met de specifieke vormgeving van de bonus in cen tweeslag was het KLOZ niet gelukkig.

Evenals de $\mathrm{VNZ}$ besefte het KLOZ het belang van de administratieve uitvoenbaarheid $\$$ Daarwoor was overleg met het COTG nodig waarin een dusdanige vormgeving moest worden bereikt dat medisch specialisten geen kans in een juridische procedure maakten. Als dit niet zovi gebeuren, zou het KLOZ van het accoord af kunnen zien. In dat gevall werd op de uitvoering wan de kostenrichtlijnen teruggevallen. ${ }^{83}$ Maar het juridische oordeel van het CBB in juni 1990 was voor het KLOZ geen reden om zich van het VPA te ontdoen. De voordelen van andere onderdelen waren te groot. Bovendien kon het KLOZ het zich niet pemitteren als enige partij het VPA vaarwel te zeggen. 84

\section{COTG}

Net als bij de reshuffing vond de beoordeling van de tweeslag door het COTG plaats binnen bet kader dat het al vroegtijdig aangaf. Dat kader hield in dat het COTG niet een van de overleg plegende partijen was, en dat het de onderdelen van het accoord als aparte voorstellen zou beoordelen. Onder deze voorwaarde participeerde het COTG-secretariaat in hel overleg dat de voorstellen witwerkte waarbij slechts technische hulp werd geboden maar geen beleidsmatige instemming. 85 Ten tijde van het VPO formuleerde het COTGmecretariat zijn takopwating als

78 VNZ, notite Consequenties wan ds uitspraak van het CBB inzake de tweeslag in het tarief voor medische specialisien dd 7 juni 1990 KIOZ, notitie ten behoeve van KLOZ/KPZ -onderhandelingscommissie, 19 december 1988

$\$ 0$ KLOZ, notitie Betreft: Van Aardenne=overleg, 26 juni 1989

$81 \mathrm{KLOZ}$, notitie, 30 november 1989

82 KLOZ, interne notitie, 25 september 1989

83 K.LOZ, notitie Betreffende het VPO, 30 oktober 1989

84 KLOZ, nottite Sumd van zaken VPO-accoord, juni 1990

85 COTG, notitie t.b.v. Whet Teclunische Overleg VPO (TOVPO) dd 3-10-89 
volgt. Het COTG diende de Wh uit te voeren. De tak ten opzichte van het VPO bestond er wil te bekijken in hoeverre de tariefwoorstellen impasbaar in de Wtg waren. Daarbij had het COTG zeggenschap over twee onderdelen van het tarief, te weten de werkbelasting en de prakijkkosten. Het inkomensniveau wormde daarentegen een gegeven. Bovendien hanteerde het COTG een nomatieve inwalshoek omdat actuele gegevens over de kosten van medisch specialisten ontbraken en omdat de organisaties zelf met weinig tariefwoorstellen kwamen. 8

Aanvankeljk reageerde het COTG afwizend op de weeslag omdat een bonus van tien procent op het officiele COTG-tarief voor bereidwillige artsen niet paste in het beleid van juiste tarieven. Specialisten die een procedure aanspanden, hadden naar de mening van het COTG veel kans op succes. 87 Mar al snel gaf het COTG and dat er met enige creativiteit een technische oplossing gevonden kon worden. Wel was warschijnlijk een aamwijzing ex artikel 15 Wtg nodig. 88 Mel creatiwiteit bedoelde het COTG dat een aantal activiteiten gedefinieerd moesten worden die een arts met contract wel en een arts zonder contract niet hoefde te verrichten. De onderbouwing wan het VPO - het wel of niet meewerken aan de overeenkomst - voldeed niet. Later zou het COTG aangeven dat een verandering van de werkbelastingsfactor in de tariefformule de enige mogelijkheid was een weeslag vast te stellen zonder een anwwizing van de overheid. In het technisch overleg zou uiteindelik de benadering van het COTG overwinnen. 90 Het COTG behield eigen verantwoordelijkheid voor de vormgeving van de richtlinen, met als gevolg dat de voorstellen van het secretariad op basis van afwijkende juridische incichten niet geheel overeenkwamen met de woorstellen van de partijen. Toen de rechter de onderbouwing van de tweeslag afwees, liet het COTG het besluit echter snel vallen. Ook in cen bodemprocedure verwachte men namelijk weinig succes. ${ }^{91}$

\section{LSY}

De LSV had bij het begin van het VPO enkele wensen. Boven aan de lijst stonden een redelijk uurtarief en een herstructurering en herijking van tarieven. De voomaamste wens was echter dat de uitkomst van het VPO in de plaats zou komen van de kostenrichtlinen die de staatssecretaris van WVC in 1988 had goedgekeurd. ${ }^{92}$

In juni kwam Van Aardenne met zijn voorstellen. Hij bouwde voort op de wens van de ziekenfondsen en verzekerars on artsen voor goed gedrag te belonen en wilde een straftarief invoeren. De LSV zag dit als een onderdeel van de "trouvaille van Van Aardenne' ${ }^{93}$ Hoewel de LSV de tweeslag als én van de nadelen van het VPA beschouwde, aanvaardde de LSV dit als een onderdeel van het pakket. Wel ontspon zich een discussie met de VNZ over de vertaling van het principe van de tweeslag in de medewerkersovereenkomst, overigens zonder dat er grote onenigheid was.

\section{WVC}

In zijn algenten heerste bij de overheid tevredenheid over de afspraken die Van Aardenne wist te bereiken. Met name de kostenbesparende effecten van de macro-budgettering werclen positief

86 COTG, notitie Mogelijkheden en onmogelijkheden ta.v. vrije beroepsbeoefenaren, 14 juli 1989

87 CoTG, notitie, 19 jun 1989

88 COTG, notitic Mogelijkheden en onmogelijkheden ta. wrije beroepsbeoefenaren, 14 juli 1989

89 COTG, Verslag van het overleg van vertegenwoordigers van $L S V, N Z$ r, VNZ, KLOZ, KPZ en het COTG-Secretariaat dd 25-7-89, 3 augustus 1989

90 VNZ, notitie Inpassing van VPO-afspraken in WTG, nowenber 1989

91 COTG, notitie Eerste analyse i.v.m. uitspraken CBB dd 5 juni 1990 inzake medische specialisten, 6 juni 1990

92 CB LSV, 15 december 1988

93 CB LSV, 15 juni 1989 
beoordeeld. Centraal stond daarbij een vergeljking tussen de bezunigingen warin de verlaging wan de kostenvergoeding zou hebben geresulteerd en de besparing die het VPO beloorde. ${ }^{4}$ Daamaast heerste bij WVC onzekerheid over de juridische houdbaarheid van onder meer de Wweeslag in tariewen. Verder was het de vraag of het COTG bereid was creatief nee te werken. Als dit niet het geval was, zou WVC een aanwijzing ex artikel 14 moeten afgeven met betrokkenheid van de overheid als gevolg die juist vermeden moest worden.95 Ambtelik WVC hechte er zeer aan dat de organisaties zelf het accoord uitwerkten. ${ }^{96}$

\section{Tabel 6.3: Handelingsheorieën bij de casus meeslag}

\begin{tabular}{|c|c|c|c|c|}
\hline & situatieschets & handelingsopties & effecten & strategle \\
\hline $\begin{array}{l}v \\
Z \\
Z\end{array}$ & $\begin{array}{l}\text { - } \mathrm{VPO} \text { als reele } \\
\text { mogelijkheid eigen } \\
\text { doelstellingen te halen } \\
\text { - de LSV is niet in staat } \\
\text { de achterban te binden: } \\
\text { daarom is een prikkel } \\
\text { nodig. Bovendien wordt } \\
\text { door de } \\
\text { contractverplichting het } \\
\text { narurastelsel weer } \\
\text { hersteld }\end{array}$ & $\begin{array}{l}\text { - cen eigen voorstel } \\
\text { maken } \\
\text { - steun geven aan } \\
\text { voorstel van Van } \\
\text { Aardenne } \\
\text { - overleg met CoTG } \\
\text { t.b.v. richtlijnvoorstellen }\end{array}$ & $\begin{array}{l}\text { - zowel het eigen } \\
\text { woorstel als dat van Van } \\
\text { Aardenne leidt tot meer } \\
\text { medewerking van. } \\
\text { medisch specialisten } \\
\text { - overleg leidt tot een } \\
\text { betere juridische } \\
\text { onderbouwing }\end{array}$ & $\begin{array}{l}\text { - randgevingen war } \\
\text { Coro opvolgen bij het } \\
\text { vorm geven aan de } \\
\text { weeslag-richthinen } \\
\text { - wootzetting deelname } \\
\text { an vPO na negatieve } \\
\text { juridische uitspraak }\end{array}$ \\
\hline $\begin{array}{l}K \\
\mathbb{L} \\
O \\
Z\end{array}$ & $\begin{array}{l}\text { - VPO als reele } \\
\text { mogelijkheid eigen } \\
\text { doelstellingen te halen } \\
\text { - de LSV is niet in stant } \\
\text { de achterban te binden: } \\
\text { daarom is een prikkel } \\
\text { nodig. }\end{array}$ & $\begin{array}{l}\text { - onderstewnen van } \\
\text { tweeslag-woorstel wan } \\
\text { Van Aardenne } \\
\text { - afwijzen wan het } \\
\text { voorstel van Van } \\
\text { Aardenne } \\
\text { - overleg met COTG } \\
\text { t.b.v. richtlijnvoorstellen } \\
\text { - bij negatieve uitkonst } \\
\text { van juridische procedure } \\
\text { afzien van verdere } \\
\text { uitvoering VPA }\end{array}$ & $\begin{array}{l}\text { - tweeslag-voorstel van } \\
\text { Van Aardenne zal } \\
\text { juridisch niet houdbaar } \\
\text { blijken } \\
\text { - tweeslag-voorstel van } \\
\text { Van Aardenne levert } \\
\text { adrministratieve } \\
\text { problemen op voor } \\
\text { verzekeraars } \\
\text { - afwijzen van voorstel } \\
\text { van Van Aardenne } \\
\text { brengt KLOZ in } \\
\text { isolement } \\
\text { - overleg met COTG zal } \\
\text { juridische houdbarheid } \\
\text { vergroten mar geern } \\
\text { garanties kunnengeven }\end{array}$ & $\begin{array}{l}\text { - raadgevingen van } \\
\text { COTG opvolgen bij het } \\
\text { vorm geven aan } \\
\text { voorstellen van. Van } \\
\text { Aardenne } \\
\text { - voortzetring deelname } \\
\text { aan VPO na negatieve } \\
\text { junidische uitsprak }\end{array}$ \\
\hline
\end{tabular}

94 WVC, concept-nota VPO medisch specialisten, 2 oktober 1989

95 WVC, memorandum naar aanleiding van een overleg tussen Van Aardenne, Sluimers, Uttenbogaard en Van Nederseen op 17 juli 1989.18 juli 1989

WVC, ambtelijk advies aan de staatssecretaris WVC, 4 oktober 1989 


\begin{tabular}{|c|c|c|c|c|}
\hline & situriateschets & hardelingsopties & effecten & trategüe: \\
\hline $\begin{array}{c}\mathrm{C} \\
\mathrm{O} \\
\mathrm{I} \\
\mathrm{G}\end{array}$ & 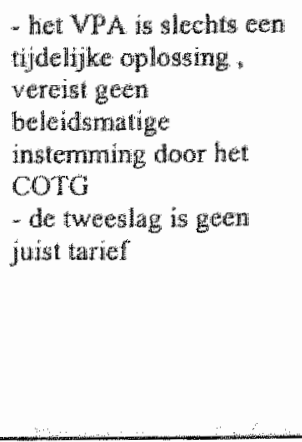 & 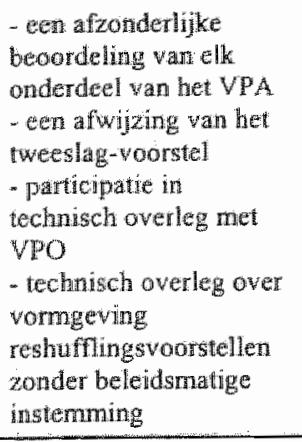 & $\begin{array}{l}\text { - hel VPO-voorstel zal } \\
\text { in juridische procedures } \\
\text { vernietigd worden } \\
\text { - technisch overteg zal } \\
\text { leiden tot een } \\
\text { "creatieve"onderbouwin } \\
\text { g met meer kans op } \\
\text { juridische houdbarheid }\end{array}$ & $\begin{array}{l}\text { - participatie in } \\
\text { technisch overleg met } \\
\text { VPO teneiride } \\
\text { richtijnvoorstellen te } \\
\text { ontwikkelen } \\
\text { - laten vallen van } \\
\text { tweeslag na negaticye } \\
\text { juridische uitsprak }\end{array}$ \\
\hline $\begin{array}{l}L \\
S \\
V\end{array}$ & $\begin{array}{l}\text { - het VO als middel de } \\
\text { richtlijnwoorsiellen in te } \\
\text { laten trekken } \\
\text { - de tweeslag is een } \\
\text { onderdeel wan het } \\
\text { gehelle VPA }\end{array}$ & $\begin{array}{l}\text { - iristernming met } \\
\text { voorstellen van Van } \\
\text { Aardenze en } \\
\text { VNZKLOZ } \\
\text { - aanpassingen van de } \\
\text { voorstellen binnen het } \\
\text { VPO bewerkstelligen } \\
\text { - technisch overleg met } \\
\text { COTO }\end{array}$ & $\begin{array}{l}\text { - instemning met } \\
\text { voorstellen van Van } \\
\text { AardenneVNZ KLOZ } \\
\text { heeft nadelige } \\
\text { consequenties voor } \\
\text { medisch specialisten } \\
\text { - anpassingen. } \\
\text { verminderen de } \\
\text { nadelige gevolgen woor } \\
\text { artsen } \\
\text { - technisch overleg met } \\
\text { COTG vergroot de } \\
\text { juridische houdbaarheid }\end{array}$ & $\begin{array}{l}\text { - aanbrengen van } \\
\text { aanpassingen binnen het } \\
\text { VPO } \\
\text { - presentanie van de } \\
\text { tweeslag als een van de } \\
\text { onvermijdelijke nadielen } \\
\text { van cen wenselijk } \\
\text { accoord } \\
\text { - voortzetting deelname } \\
\text { aan VPO na negatieve } \\
\text { juridische witspraalk }\end{array}$ \\
\hline $\begin{array}{l}W \\
W \\
C\end{array}$ & $\begin{array}{l}\text { - het vPO kan een goed } \\
\text { algernatief vormen voor } \\
\text { de kostenrichtijnen van } \\
1988 \\
\text { - de tweeslag is } \\
\text { "meegenonen"maar is } \\
\text { junidisch twijfelachtig } \\
\text { - zorg over de rol van de } \\
\text { overheid in het } \\
\text { tartevenoverleg }\end{array}$ & $\begin{array}{l}\text { - een actieve rol woor de } \\
\text { overheid un de vorm wan } \\
\text { cen arwwijzing } \\
\text { - een passieve rol: de } \\
\text { verantwoordelijkheid bil } \\
\text { partijen en het CoTG }\end{array}$ & $\begin{array}{l}\text { - bij cen actieve rol zal } \\
\text { de overheid weer deel } \\
\text { gaan uitmaken van het } \\
\text { tariewenoverleg en } \\
\text { doelwit worden wan } \\
\text { juridische procedures. } \\
\text { Bovendien vertraging } \\
\text { van besluitvorming } \\
\text { - bij een passieve rol zal } \\
\text { de overheid zich minder } \\
\text { kwetsbaar opstellen. } \\
\text { Bovendien kunnen } \\
\text { partijen en CoTo in } \\
\text { onderling overleg } \\
\text { houdbare } \\
\text { tariefvoorstellen maken. }\end{array}$ & $\begin{array}{l}\text { - in formele win geen } \\
\text { actieve roll, wel } \\
\text { informele interventie } \\
\text { l.b.v. instemming door } \\
\text { het COTG }\end{array}$ \\
\hline
\end{tabular}

Nog in $1989 \mathrm{kwam}$ WVC tot de conclusie dat twee tarieven nast elkaar zouden kumnen bestaan, mits een antal prestaties kon worden benoend. Daartoe zouden de vijf organisaties in overleg met het COTG richlijnen moeten opstellen. Daarop zou WVC de nadruk gaan leggen. In de ogen van WVC moesten de partien in het overteg met het COTG (en ZFr) tot goede afspraken komen. 7 De voornatamste zarg van WVC was niet zozeer de inhoud van de tweeslag. maar meer de juridische houdbaarheid als onderdeel van een pakket dat voor de overheid voordelen bood. Hel wegvallen van éen onderdeel kon gevolgen hebben voor de gehele overeenkomst. De ambtenaren schreven overeenkomstig aan de staatssecretaris: "Uitgangspunt is 
dat het pakket door de overheid in aansluiting op partijen als een ondeelbaar lotaal wordt gezien. De beshitvorming is derhalwe pas effectief als alle onderdelen bedrifsklaw zin." er van uit dat een besluit juridisch houdbaar was als het COTG er zijn goedkeuring aan hechtte. Bij de uiteindelijke beoordeling van de vormgeving van de tweeslag stond dan ook niet het eigen juridische oordeel voorop. Integendeel, de ambtenaren lieten de staatssecretaris weten voorzichtig positief te zijn ondanks de wetenschap dat de rechter vraagtekens zou zetten bij het besluit Da Dat medisch specialisten onderdelen wan het VPA met succes konden aanvechien was een risico dat maar genomen moest worden. Men wist bij WVC immers, dat de LSV er alles aan zou doen on te voorkomen dat het oude beleid van de kostemrichtlijnen zou worden hervat. ${ }^{100}$ Toen in 1990 de tweeslag inderdaad niet houdbaar bleek, werd duidelijk dat er voor de overheid geen man overboord was. Het macrobudget als belangrijkste doel liep door de witspraak van de rechter geen gevaar. WVC kon wiets worden verweten omdat men zijn goedkeuring had gegeven onder hel voorbehoud van juridische houdbaarheid waarvoor de partijen zelf verantwoordelijk waren. Ook wide WVC niet intervenieren. De partijen moesten zelf wit de situatic zien te komen. 101

\subsection{De handelingstheoricën en de institutionele context}

In de volgende paragrafen geef ik earst een schets van de belangrijkste karakteristieken van de handelingstheorieèn. Daarbij maak ik onderscheid tussen de elementen wan een handelingstheorie: de situatieschets, de handelingsopties en de geformuleerde strategieèn. In de daarop volgende paragraaf komt de logica van de handelingstheorieën aan de orde waana twee andere women van institutionele invloed op de handelingstheorieen worden toegelicht.

\subsubsection{De handelingstheorieën}

Op basis van de beschrijving van de handelingstheorieën wan de actoren kunnen de volgende conclusies getrokken worden. Ten eerste bleek uit de situatieschetsen dat bij elke casus een groep van actoren zich kon vinden in een gedeelde, situatiespecifieke doelstelling die de eigen algemene belangen bevorderde. In deze zin was sprake van coalities van actoren die zich bewust waren van de congruentie en discongruentie van doelstellingen. Men zou kunner spreken van een coalitie van pleitbezorgers ("advocacy coalition") zoalls door Sabatier (1987: 652) beschreven. Een dergelijke coalitie bestaat uit een groep van actoren waarvan de handelingstheorieèn op belangrike elementen overeenstemmen. Deze coalities waren tijdelijk ondat de doelstellingen waarover overeenstemming bestond na enige tijd weer werden ingeruild woor andere die door andere groepen wan actoren onderschreven werden. Bovendien konden sommige actoren zich niet vinden in de tjjelijke overeenstemming. Daarom zou ik willen spraken van dominante coalities en van het ontbreken van algehele overeenstemming over doelstellingen tussen actoren in het netwerk. Ten tweede was binnen de dominante coalities geen sprake van consensus over de te volgen strategieẻn. Elke actor had zijn eigen handelingsopties, beoordeeide deze op zijn eigen maniet en kwam tot een eigen strategie. Daardoor weken de voorgestelde strategieèn vaak van elkaar af. Er was dus, in termen wan Sabatier, geen sprake van volledig

98 WVC, concept-nota VPO medisch specialisten, 2 oktober 1989

99 WVC, nota ten behoeve van de statssecretaris, 18 december 1989

100 WVC, notitie aan de staatssecretaris, 12 januari 1990

101 WVC, memo, 8 juni 1990 
onitwkkelde coalities. Tenslotte was bij zowel de voming van coalities, het formuleren wan handelingsopties en het ontwikkelen van strategieen sprake van processen. Deze conclusies worden hieronder uitgewerkt.

\subsubsection{Simatieschetsen}

Uit de analyse van de situatieschetsen is gebleken dat iedere actor bepaalde algemene belangen bij de totstandkoming van tarieven voor medisch specialisten had die min of meer onveranderlij waren. Het meest duidelijk was dit bij de overheid die het overleg over de tarieven in dienst liet staan van hel bereiken van de "financiele takstelling". De ziekentondsen wilden meer bereiken in de onderhandelingen over de tarieven voor medisch specialistische zorg na jaren waarin het inkomensoverleg tussen overheid en LSV had gedomineerd. Daarnaast heeft voor de VNZ een belangrijke rol gespeeld, dat in het owerleg met de LSV de contractuele relatie weer moesit worden hersteld. De LSV wilde ten allen tijde voorkomen dat het besluitvormingsproces zou leiden tot algemene tariefsdalingen voor medisch specialistische hulp. Het COTG hechtte zeer aan een juiste uitwoering van de Wtg. Daarbij lag de nadruk meer op het totstandbrenging van "juiste" tarieven dan op kostenbesparingen, omdat het laatste in de ogen van het COTG een automatisch gevolg zou zijn van het eerste. Het KLOZ probeerde in het algemeen de bestaande nadelen wan de tarieven voor particuliere verzekeraars onder de aandacht te brengen. Met name de discrepantie tussen de ziekenfondstarieven en de particuliere tarieven was het KLOZ een woorturende doorn in het oog.

Van groot belang was dat een aantal actoren in 1986 gezien hun algenene belangen geen wrede meer kon hebben met de manier waarop het overleg ower de tarieven voor medisch specialisten verliep. Overheid, VNZ en COTG wensten daarin veranderingen tot stand te brengen en zagen daarbij in dat hun belangen tenminste gedeeltelijk overeenkwamen. Daar waar deze drie organisaties mogelijkheden tot wederzijdse ondersteuning zagen, werd de LSV zich na 1986 steeds bewuster van het dreigende isolement. Terwijl anderen een verlaging van de tarieven nastreefden, was de LSV erop gericht deze tegen te gaan. Na 1988 veranderde dit. Het VPO bood, met zijn uitgebreide agenda, mogelijkheden woor de LSV om een algemene tariefverlaging temminste voor enige jaren uit te stellen. Het zeroplus karakter van het VPA gaf elke andere ondertekenaar tevens de mogelikheid de eigen voordelen te benadrukken. Met name de afspraak over het macrobudget sloot goed aan bij de groeiende overtuiging van de financiers dat beperking van het volume van medisch specialistische zorg niet meer bereikt kon worden door aanpassingen vara thet tarief. In de schaduw van de afspraken over het macrobudget voor medisch specialistische zorg veroorzaakten de beslissingen over de reshuffling en de tweeslag nauwelijks grote tegenstellingen tussen de deememers aan het VPO. Het VPO hield voor het COTG in dat de besluilen over de kostenvergoeding niet verder konden worden uitgevoerd. Omdat het COTG het VPA weigerde te zien als een ondeelbaar geheel en onderdelen apart wenste te beoordelen en daarbij vasthield an formeel-juridische standaarden, ontstonden tegenstellingen tussen de leden van het VPO enerzijds en het COTG anderzijds. WVC omarmde het VPA niet alleen omdat hei bestuurlijke nust bracht, maar ook en vooral ondat de afspraken over het macrobudget zouden moeten leiden tot kostenbeheersing die niet onder zou doen voor de besparing door de verlaging van de kostenvergoeding.

Er was sprake van coalities van actoren op basis van situatiespecifieke doelstellingen die zich tijdens het besluitvormingsproces vormden. COTG, WVC, WNZ en $K L O Z$ konden zich al snel vinden in de gedeelde doelstelling de vergoeding voor de praktijkkosten van medisch specialisten te verlagen. Zij wisten dat zij hierdoor in conflict met de LSV konden komen, maar dit werd op de koop toegenomen. Het was hen immers al vrij spoedig duidelijk dat overleg met de LSV niet meer nodig zou zijn teneinde besluiten over de kostenvergoeding tot stand te laten 
komen. We kunnen spreken van een dominante coalitie. Daartoe behoorde de LSV niet. Opmerkelijk is dat deze organisatie weliswar all in 1986 constateerde dat andere actoren er haar onwelgevallige ideeen op nahielden, maar er enkele ontnuchterende confrontaties met WVC en het COTG voor nodig had te ontdekken dat het net zich rond de LSV sloot. Het beeld dringt zich op van een belangenorganisatie die zich niet volledig bewust was van de veranderende verhoudingen.

Bij de besiuiten over de tweeslag en de reshuffling waren de percepties van de situatic anders. Het VPA was typerend voor de opnieuw veranderde verhoudingen warin een afspratk over het macrobudget woor medisch specialistische hulp mogelijk bleek. Nog steeds zagen met name VNZ en KLOZ enerzijds en LSV anderzijds elkaar als organisaties met tegengestelde belangen, maar zij waren niet langer onverzoenbaar. Het COTG daarentegen zag de inspanningen richtlijnen ten aamzien de kostenvergoeding tot stand te brengen niet meer beloond worden en kon de beleidsmatige afspraken nawwelijks in overeenstemming brengen met de formele regels. Voomalige coalitiegenoten bleken er andere meningen en doelstellingen op na te houden. De tegenstelling tussen het COTG en het VPO werd echter slechts geleidelijk duidelijker. Met name bij het VPO was men zeer onzeker over de standpunten van het COTG en de mogelijkheden deze te veranderen.

De consensus over doelstellingen was broos en van voorbijgaande aard. De verlaging van de kostenvergoeding was slechts een tijdelijke doelstelling die nagestreefd werd omdat deze paste in de overwegingen op de lange termijn. De VNZ wilde in de onderhandelingen met do LSV meer tot stand brengen, wellicht zelfs een radicale verandering van de honoreringsstructuur, WVC streefde naar bezuinigingen, en het COTG wilde de tarieven rationeel onderbouwen. De visie van het $\mathrm{KLOZ}$ op de lange termijn was niet geheel uigewerkt, maar de beheersing van de kosten en een uniformering van tarieven werden langzamerhand belangrijker. Een verlaging van de vergoeding voor de praktijkkosten verbond deze actoren met elkaar. De LSV daarentegen was nog niet toe aan een besluit over de hoogte wan de praktijkkostenvergoeding als eigenstandig onderdeel van het tarief voor medisch specialistische hulp.

De verhoudingen waren bij het VPO veranderd. De kostenproblematiek was geen onderwerp van overleg meer, andere zaken kwamen ter tafel. Over deze onderwerpen bleek eweneens overeenstemming mogelijk. Tijdens het besluitwormingsproces over de reshuffling hechten evenwel niet alle betrokkenen in gelijke mate aan deze aanpassing van de tarieven. Terwijl de LSV het belang wan een gedeeltellike inkomstenharmonisatie vanaf het begin af aan benadrukte, beschouwden de financiers het voorstel als iets dat wooral de LSV zelf aanging. De owerheid had vooral oog voor de implementatie van het besiuit over het macrobudget. Zowel financiers als overheid benadrukten hel maaschappelijk belang, maar zagen de reshuffling tegelijk als een overigens welkom 'bijproduct'. Wel hechten alle organisaties aan de reshuffling als onderdeel van het VPA dat op een juridisch verplichtende manier moest worden vormgegever. Het COTG vormde hier de utzondering. Dit organ beschowwde de reshuffing als een apart te beoordelen tariefvoorstel dat gezien de onderbouwing niet acceptabel was.

Bij de tweeslag leken op het eerste oog andere verhoudingen te gelden. Toen waren het voornamelijk de financiers die zich bonden aan deze uitkomst van overleg, en waren het de LSV en WVC die hieraan minder belang toeschreven. Het COTG ontwikkelde in vergelijking met de reshuffling minder oppositie. Toch was de overeenkomst met de reshumfing groot omdal ook hier de adninistratieve uitwoerbaarheid het 'leitmoutiv' voor de meerderheid van de actoren was. Dit niet alleen vanwege de ervaringen met bestuurlijke overeenkomsten in het verleden, maar vooral uit vrees voor de juridische procedures die individuele specialisten konden instellen. Waar in het verleden vaak genoegen werd genomen met een geheel van afspraken dat vervolgens op uitwerking wachtte, bood het VPO het beeld van naar juridische zekerheid strevende organisaties. De achtergrond was hel bevelligen van de afspraken tegen een bedreiging die niet op voorhand door het VPO op de gevolgen kon worden beoordeeld: de juridische procedures die 
in gang gezet zouden kunnen worden. Het beveiligen van deze afspraken werd ondersteund door alle betrokkenen ondat het wegwallen van een onderdeel van het VPA als een bedreiging voor een zorgvuldig in ellkar gezet pakket werd gezien.

\subsubsection{De havdelingsopthes en hun effecten}

Kenmerkend voor de totstandkoming van beshiten over tarieven woor medisch specialisten was dat actoren vaak verschillende handelingsopties zagen. Deze opties konden per actor verschillen. Bowendien vormden ze geen vast gegeven: gedurende het besluitwormingsproces konden zich nieuwe opties aandienen.

Voor de representatieve organisaties verschilden de handelingsopties tot aan het VPO. Toen in 1986 de VNZ zijn beleidsplannen openbaar maakte, gold het onderlinge overleg met de LSV als cen vanzelfsprekendheid. Gedurende de totstandkoming van de besluiten over de kostenvergoeding werd het de VNZ steeds duidelijker, dat het eenzijdig voorleggen van tariefvoorstellen aan het COTG op de korte termijn grote voordelen kon bieden. Ook voor het KLOZ was er de mogelijkheid om met de LSV te gaan onderhandelen en vervolgens de uitkomst voor te leggen aan het COTG of enzijdig voorstellen bij hel COTG neer te leggen. Evenals voor de VNZ werd woor het KLOZ de formele procedure via het COTG een steeds belangrijkere optie toen bleek dat het overleg met de LSV weinig mogelijkheden bood. De LSV hechtte zowel intern als extern zeer aan het overleg net de ziekenfondsen en de particuliere ziektekostenverzekeraars, terwijl de gang wia het COTG in toenemende mate beschouwd werd als een onbegaanbare weg. Daarvoor in de plaats zag de LSV mogelijkheden in juridische procedures, bilateraal overleg thet WVC en politici en acties van individuele medisch specialisten. Voor WVC bestond de keuze uit actieve participatie of distantie. Na een periode van herbezimning op de rol van de overheid bij de besluitvorming over tarieven werd distantie hoog in het vaandel geschreven, maar de formele wettelijke bevoegdheden dwongen WVC tot een continue afweging van de woors en tegens van directe bemoeienis. In het geval van het COTG was nauwelijks sprake van opties; men bleef vasthouden aan de formeel-juridische werkwijze die inhield dat door middel van een discussie in het COTG richtlinen tot stand zouden moeten komen. De totstandbrenging van een besluit over de vergoeding voor praktijkkosten werd gerekend tot de verantwoordelijkheid van het COTG. De resultaten van het onderlinge overleg tussen de representatieve organisaties afwachten, werd als weinig zinvol ervaren.

Hernieuwde deelname aan onderling overleg was tussen 1986 en 1992 een optie woor alle representatieve organisaties. De deur nat mieuw overleg stond voorturend minimaal op een kier. Ondanks de mogelijke tijdeligke voordelen van eenzijdige voonstellen aan het COTG, lonkte steeds de andere onderhandelingspartner. Door een concreet initiatief konden vertegenwoordigers van organisaties die zich in het COTG nog fel tegen elkaar hadden gekeerd, telkens weet bij elkar worden gebracht. Het VPO was daar een voobeeld van. Hoewel aarzelingen aanwezig waren onttrok geen van de partijen zich aan participatie. Toen het WPO van start waS gegaan, had het overleg woor alle betrokkenen een dwingend karakter; eenmaal participerend in een dergelijk breed opgezet platform was het voor elke deelnemer nauwelijks mogelijk zonder grote gevolgen voor de eigen positie in het tarievenoverleg wan verdere deelname af te zien. Wel hadden de financiers in de besluiten over de kostenvergoeding iets om op terug te vallen in geval van mislukking van het overleg. Hierover beschikte de LSV niet. Het VPO bood de LSV juist een mogelikheid deze beshiten in te ruilen voor andere afspraken. Hierdoor was deelname aan het VPO voor de LSV dwingender dan voor de anderen. Deze situatie makkte het tevens voor de VNZ en het KLOZ mogelijk te benadrukken, dat het VPO moest resulteren in "harde afsjraken" en niet in besluiten warvan de implementatie onzeker zou zijn hetgeen in het verleden vaak het geval was geweest. 
Bij de besluiten over onderdelen van hef VPA werd het aantal handelingsopties voor alle deelnemers aan het VPO verkleind. De overheersende optie on de onderlinge afspraken van het VPO rechtstreeks te vertalen in tariefvoorstellen aan het COTG verdween uit het zicht, toen wit informatie van het COTG bleek dat zij de juridische toets niet konden doorstatan zolang de overheid geen aanwijzingen verstuurde of wetgeving veranderde. De weigering van de overtheid op het verzoek van de onderhandelaars om aanwijzingen te versturen dan wel wetgeving anan te passen, dwong de orgamisaties van het VPO tot intensief overleg met het COTG helgeen in het geval van de tweeslag tot een tariefvoorstel in 1990 leidde maar bij de reshuffling uitmondde in een patstelling waaruit men maar moellijk weg raakte.

Hoewel de overheid de beshuitworming over de kostenvergoeding eind 1988 had goedgekeurd, verbond men zich wij snel aan de mogelijke opbrengsten van het nieuwe Vijfpartijen Overleg. WVC had daama weer de keuze tussen actieve betrokkenheid, of de organisaties in overleg met het COTG zelf tariefbesluiten to stand te laten brengen. Toen gaandeweg bleek dat de afspraken van het VPA niet zonder slag of stoot omgezet konden worden in juridisch houdbare tariefbesluiten, kwam een derde optie aan de orde: het wijzigen van wetgeving. Voor het COTG stonden, nadat het VPO levensvatbaar was gebleken an een tussenbalans was opgesteld, twee wegen open waarvan de eerste op gespannen voet stond met de wens van de overheid op afstand te blijven. Deze eerste weg bestond eruit dat een juiste vormgeving van elk VPO-voorstel aan de hand van de criteria van de fomele wetgeving moest plaatsvinden, eventueel met een aanwijzing van de overheid als gevolg. De andere weg hicld in dat het zogenaamde 'beleidsmatige' belang van het VPA werd onderkend en dat alle medewerking en creativiteit aan de dag zou worden gelegd om de onderhandelingsuitkomsten ook juridisch uitvoerbaar te laten zijn.

\subsubsection{Strategieën}

Op basis van hun situatieschets en de afweging van handelingsopties formuleerdien de organisaties een eigen strategie. VNZ en $\mathbb{K L O Z}$ kozen in 1987 voor de weg van de besluitworming in het COTG waarmee de onderlinge onderhandelingen met de LSV vooralsnog tot het verleden behoorden. Daarmee gingen de financiers in op de mogelijkheden die het COTG al enige tijd bood. Daar waar namelijk een initiërende rol van het COTG mogelijk was, zoals bij de praktijkkosten, werden door het COTG zelfstandig initiatieven ontplooid. Tegelijk werden deze woor een groot deel afhankelijk gemaakt van het onderlinge overleg tussen de financiers en de medisch specialisten. De belangrijkste pleitbezorger van dit onderlinge overleg was de LSV, maar de medisch specialisten konden de VNZ en het KUOZ daar steeds minder toe brengen, en Zagen bovendien het nut van het indienen van eigen voorstellen bij het COTG en van hot bilaterale overleg met de overheid steeds kleiner worden. Juridische procedures en acties in het veld" bleven over. WVC tenslotte oordeelde dat het tariefoverleg zonder directe overheids bemoeienis grote voordelen opleverde zodat de optie van ingrijpen door middel wan bijwoorbeeld een aanwijzing steeds minder aantrekkelijk werd. WVC liet het COTG, daarbij gesteund door de VNZ en het KLOZ, zijn werk doen.

Hoewel het VPO niet op gang werd gebracht door de financiers, bleek dat afspraken over een macrobudget voor medisch specialistische zorg zowel voor de VNZ als het KLOZ aanirekkelijker waren dan de kostenbesluiten die in 1988 tot stand waren gebracht. Ten aanzien van de onderdelen van het VPA die hier bestudeerd zijn, kozen zij voor een strategie die erop gericht was de uitvoering zeker te stellen. Deze wens tot 'harde afspraken' betekende dat de uitkomsten omgezet moesten worden in juridisch houdbare tariefvoorstellen aan het COTG. De LSV verbond zich eveneens aan het VPO omdat duidelijk werd dat de uitkomsten in de plaats 
zouden komen van de kostenbesluiten. Daamaast stemde de LSV in met de noodzaak van jundisch houdbare afspraken, met name waar het de reshuffing aanging.

De door de deelnemers an hel VPO gemakte keuze voor een strikte implementatie betekende dat het antal opties tijdens de latere fasen van het besluitvomingsproces geringer werd. Slechts het overleg met het COTG bleef over. Dit overleg werd nog belangrijker toen duidelik werd dat WVC het beleid van distantie bleef hanteren. WVC oordeelde dat bijvoorbeeld en anwijzing een gevaar voor de besluitworming en voor de eigen positie zou inhouden. Het COTG werd, naamate het VPO meer vaste voet aan de grond kreeg en steun ontving van de overheid, gedwongen de kemis aan te wenden voor de realisatie van de witkomsten wan het VPO. In eerste instantie liet het COTG niet na de vele bezwaren tegen het VPA te benadnukken. Dit beleid was steeds moeilijker vol te houden. De grote mate van consensus tussen de vertegenwoordigende organisaties, en de weigering van de overheid om aanwijzingen te geven en wetgeving te veranderen, vergrootte de druk op het COTG om op een creatieve manier mee te werken aan het formuleren van tariefvoorstellen. Hier koos het COTG dar ook uiteindelijk woor.

\subsubsection{De logíca van de handelingstheorieen}

Op basis van de beschrijving van de handelingstheorieèn kan geconcludeerd worden dat zowel bij WVC als bij de belangenorganisaties de logica uit drie overwegingen bestond. Ten eerste stelde elke organisatie zich de vraag: wat gebeurt er, zujn onze belangen in het geding, en welke manier van reageren is, gezien onze doelstellingen, het meest gewenst? Ten tweede vond voortdurend een reflectie op de relationele implicaties van gebeurtenissen plaats. Men vroeg zich af hoe organisaties zich ten opzichte van elkaar dienden op te stellen? Ten derde verwerkten de organisaties de fomelle institutionele context in hun overwegingen. In het vervolg van deze paragaaf zal ik aantonen dat bij de actoren een instrumentele relatie ten aanzien van de bestaande formele regels kan worden geconstateerd. Zij gebruikten de wettelijke bepalingen op een manier die hen hielp voordelen te behalen. De wettelijke bepalingen veranderden aldus van gedragsbepalende factoren in hulpbronnen (Offe 1985: 305). Daamaast werden zij gezien als de belemmerende factoren voor de doelrationele strategieën. Dit was kenmerkend voor de logica van de handelingstheorieën: de doelrationaliteit overheerste de formeel-institutionele en relationele logica. Dit had een instrumenteel gebruik van de Wtg tot gevolg. Ook de relaties met andere organisaties werden voornamelijk beoordeeld op de mate waarin zij konden bijdragen tot de eigen doelbereiking.

Bij WVC kwamen deze logica naar voren in de dominantie van de financièle taakstelling, het beleid van distantio en het gebruik van bestaande wetgeving als pressiemiddel. De leidende doelstelling ontleende WVC in fomele zin weliswaar an de Wtg mar inhoudelijk aan het FOZ. De zogenaamde fnanciele taakstelling was voor WVC allesbepalend bij het ontwikkelen wan een strategische koers. Een juiste onderbouwing van de tarieven voor medisch specialistische hulp speelde daarentegen nauwelijks een rol. 102 Bij WVC ging men ervan uit dat het COTG hiervoor verantwoordelijk was. Tegelijk stond WVC overleg toe dat de COTG-besluitvorning afloste en verving. Het voonamste criterium ter beoordeling van de besluitvorming bleef de financiele

102 Bij vrijwel iedere organisatie overheerste dan ook het gewoel dat "WVC alles best windt" als tariefbesluiten maar bezuinigingen opleverden. Deze houding wordt gedeeltelijk bevestigd in het onderzoek wan de Algemene Rekenkamer naar de untvoering wan de Wtg tussen 1990-1993. Daarin laat WVC weten "...(m)eer geïnteresseerd te zijn in het total van de budgetten en tarieven dan in de juistheid van de hoogte van de individuele budgetten en tarieven." (1995: 10) 
opbrengst. Dit criterium bleef in de overwegingen van WVC overheersen bij de besluitvorming over de reshuflling en de wweeslag. De juridische bezwaren tegen de reshuffing en de tweeslag weerhielden WVC er niet van cen "goedkeuring, mits..." wit te spreken ower de resultaten wan het VPO. Deze bezwaren wogen namelijk bij lange na niet op tegen de voondelen. Deze waren de besparingen als gevolg van de introductie van het macrobudget en het herstel wan de besturilike Ferhoudingen.

Het beleid yan aistantie kwam voort uit een afweging van de voor en nadelen van betrokkenheid van de overheid bij de besluitworming over tarieven. Tijdens de kostenaffaire constateerde WVC een belangenovereenkomst tussen VNZ, COTG en overheid. WVC ventrouwde vervolgens op de uitkomsten van een discussie in lhet COTG ondat verwacht werd zo de eigen doelsteling te kunnem halen. Bovendien bracht betrokkenheid wan de overbeid als altematieve handelingsoptie het gevaar met zich mee dat de verhoudingen met de LSV verstoord raakten. Het beleid van distantie, waarbij WVC weigerde van de weltelijke bevoegdheden gebruik te maken omdat daamee de doelstellingen van de overheid het best gediend waren, zette zich voort tijdens de beslutworming rond de weeslag en de reshuffing. Het geven van aamwizingen zou vertraging in de besluitwoming - en dus in het bereiken van de bezuinigingsdoelstellingen - veroorzaken. Bovendien zou de overheid zich te kwetsbaar opstellen. Juridische procedures zouden aan haar adres gericht worden. Deze overwegingen maken duidelijk dat de zelfregulering door het VPO niet het resultaat was van cen nomatieve afweging over de verhouding tussen de overheid en de samenleving. De aanbevelingen van de Commissie-Dekker over een nieuwe rol van de overheid waren bij WV in goede aarde gevallen, maar steun aan de zelfregulering was vooral de uitkomst wan strategisch beraad binnen WVC. Het departement koos voor een strategie die de overheid het meeste nut opleverde op zowel korte als lange terminn.

Nog duidelijker kwam het instrumentele gebruik van het wettelijk kader naar woren in de argumentatie van WVC om de Wivb na 1990 te laten blijven gelden woor de medisch specialisten. Terwijl binnen de overheid al duidelijk was dat van een actief inkomensbeleid geen sprake meer zou zijn, gebruikte WVC de Wivb als 'stok achter de deur' ten opzichte van de LSV, teneinde de dreiging van een inkomensaanpassing ook ten tijde van het VPA (1990-1992) in stand te kunnen houden.

Evenalls WVC beoordeelden de belangenorganisaties de ontwikkelingen in de tariefbesluitvorming voomamelijk vamuit het eigen belang. Telkens stond de vraag central wat de implicaties van de ontwikkelingen in het licht van de doelstellingen waren. Daarnaast kregen de relaties met de andere organisaties veel aandacht. De wensen en voomemens van andere organisaties werden ingeschat om vervolgens een wook eur voor een bepaalde handelingsoptic te ontwikkelen. Een bijzondere worm was de overweging om bij ontewredenheid met de voortgang van een overleg, zoveel mogelijk te woorkomen dat de organisatie de "zwarte piet" kreeg. Dit leidde regelmatig tot symbolische deelname. Tenslotte was een instrumentele interpretatie wan het formele wettelike kader te herkennen. Enige voorbeelden illustreren dit.

1. Bij de besluitvorming over de praktijkkosten had de VNZ de keuze uit wee handelingsopties: de formele weg via het COTG en het onderlinge overleg met de LSV. De keuze wordt gemaakt op basis van voordelen voor de $\mathrm{VNZ}$, op korte en lange(re) termijn.

2. De waarde die de organisaties hechtten aan de beleidsmatige effecten en de manier warop zij de pragmatische problemen bij de discussies over de tweeslag en de reshufling benaderden was illustratief voor de overheersende houding ten opzichte van de fonmele regels. Deze bestond uit een zodanige toepassing van regels dat de onderhandelingsin en overlegresultaten effectief uitgevoerd konden worden. Dit leidde eveneens tot de eis aan de overheid on wetgeving te veranderen of zelfs af te schaffen.

3. De LSV maakte op een zeer strategische manier gebruik van wettelijke mogelijkheden om de voor medisch specialisten nadelige tariefbesluiten te voorkomen. Met name door het 
instellen van juridische procedures bij de besluitvorming over de praktjkkosten hanteerde de LSV op overduidelijke wijze het formele wettelijke kader als hulpbron.

De logica van de handelingstheorie van het COTG week af ten opzichte van de andere actoren. De formeel-institutionele rationaliteit domineerde want het COTG nam een fomed juridische standpunt in waarbij het zich toelegde op een "...(a)pplication of rules, disregarding content, persons, and ends served, by trained officials in hierarchically ordered positions." (Stryker, 1989: 342). Een betere structurering van de tarieven voor medisch specialisten als doelstelling was volledig afleidbaar wit de Wtg en de daarachter liggende motivatie van de opstellers. Ook de voortdurend voorgestelde weg - het opstellen van richilijnen als basis voor de te nemen tariefbesluiten - voldeed aan de formeelinstitutionele logica Daarbij paste de beschrijving van de eigem bevoegdheden: het beoordelen wan voorstellen van partijen op basis van de Wtg, zonder besluiten te nemen die betrekking hadden op het inkomen van de medisch specialist. Met deze taakopvatting was de houding tegenower de verscheidende bemiddelingspogingen in overeenstemming. Dit waren slechts intermezzo's in de ogen wan het COTG. Alleen de Wtg vormde het structurele kader waraan tariefvoorstellen konden worden getoetst. Het is evenwel zo dat de fomeel-juridische taakopvating door het COTG in de praktijk op verschillende manieren vorm $\mathrm{kreeg}$. Mede door de beleidswrijheid kon het COTG de wetgeving hanteren temeinde de eigen doelstellingen te kunnen nastrewen.

\subsubsection{De invloed van het institutionele kader}

In de vorige paragraaf is naar voren gekomen dat de Wtg vooral als instrument dienst deed. De organisaties hanteerden de wettelijke regels op een manier die hun doelstellingen het beste diende. Naast het instrumentele gebruik van instituties bleken zij ook op twee andere manieren van invloed te zijn op de handelingstheorieën. Ten eerste structureerde het institutionele kader in grote mate de situatiespecifieke belangen alsook het areaal van handelingsopties en strategieèn. Op deze wijze was het institutionele kader van grote inwloed op de handelingstheorieên. Ten tweede had het formele wettelijke kader tot gevolg dat er grenzen werden gesteld aan het opportunisme van de participerende actoren. Er was sprake van de noodzaak van hierarchische beloningen. Van hierarchische beloningen is sprake als formeel verantwoordelijke bestuursorganen de uitkomsten van overleg tussen maatschappelijke organisaties moeten ratificeren (Scharpf, 1993: 145). Hierdoor kreeg de logica van de handelingstheorieên een meervoudig karakter. Naast de mate warin eigen doelen konden worden bereikt moest tevens de juridische tockatbatheid worden overwogen. De actoren dachten en handeldan doelrationeel, maar zij deden dit binnen de grenzen van de instituties. Deze grenzen waren geen objectief gegeven, maar werden athankelijk van de situatie vastgelegd in interacties (zie ook: Windhoff-Heritier 199l: 41). Deze twee vormen van institutionele invloed worden hier verder toegelicht.

Ten eerste beinvloedde het institutionele kader de handelingstheorieèn door de structurering van doelstellingen, en het areaal van handelingsopties en strategieën. Voor het COTG is deze in de vorige paragraaf al duidelijk gemaakt. Zowel de doelstellingen als de handelwijze ontleende het COTG aan de Wig en de daarop gebaseerde jurisprudentie. Maar ook bij de belangenorganisaties en WVC was deze doorwerking duidelijk aanwezig. De vaststelling in paragraaf 6.5.2 dat de logica van de handelingstheorieên voomamelijk doelrationeel was, zegt dus nog weinig over de inhoud van de doelstellingen zelf. Uït de handelingstheorieën blikt dat de algemene belangen nauwelijks richting gaven aan het handelen van de organisaties in concrete situaties. Zij moesten geherdefinieerd worden in termen van de structuur van de Wig hetgeen in de praktik de tussen partijen en COTG overeengekomen invulling van de formele regels bettekende. Dit kwam er in de meeste gevallen op neer, dat voor de concretisering en precisering van het in te nemen standpunt een verwijzing naar de algemene belangen van de achterban niet 
meer voldeed. Zo werden de organisaties gedurende de totstandkoming van de besluiten over de kostenvergoeding onder invloed van de fomele anpak van het COTG gedwongen standpunten in te nemen over de tariefsplitsing, veranderingen in de honoreningsmethodiek, en het onderscheid tussen beroepskosten en praktijkkosten. Bijzonder illustratief was de ontwikkeling bij de VNZ. Begonnen vanuit het standpunt dat de betaling van de medisch specialist wanuit het budget wan het ziekenhuis gedaan moest worden, eindigde de VNZ met een verdediging van thet standpunt dat de betaling van een secretaresse niet tot de beroepskosten van een medisch specialist behoorde. De standpunten van het KLOZ zijn een ander goed voorbeld. De toenemende concretisering van doelstellingen onder invloed van de fomele wettelijke anpak van het COTG, in samenspraak met de VNZ, zorgde ervoor dat de particuliere verzekeraars een doelstelling aanhingen die nauweliks nog direct afleidbaar was van het belang van de individuele particuliere verzekeraar. Toen de juridische houdbaarheid belangrijker werd, nam de noodzaak van een precisering en concretisering van de doelstellingen van de belangenorganisaties toe. Dit bleek bij de reshuffling en de tweeslag waabij standpunten moesten worden ingenomen die wel begripelijk waren vanuit de wens to juridisch houdbare tarieven maar niet vanuit belangenbehartiging.

Naast doelstellingen werden handelingsopties en strategiecin aan de Wtg ontleend. Tyjdens de besluitvorming over de kostenvergoeding vond dit op een duidelijke manier plaats. De vaak al in overleg besproken formele procedures vormden in de handelingstheorieern van VNZ en KLOZ een gedegen alternatief voor het onderlinge overleg met de $\mathbb{L} S V$. Ook WVC definieerde de eigen handelingsopties in termen van de Wtg. Voor het departement was de keuze tussen het COTG zijn formele verantwoordelijkheden waar te laten maken of een eigen deename in de vorm van het geven van aanwijzingen. Beide mogelijkheden werden aangedragen in de Wtg. De LSV ontdekte evenzo de Wtg als structuur waaraan handelingsopties werden ontleend. In tegenstelling tot de oude traditie waarin direct overleg tussen de overheid (WVC) en de LSV tot stand kwam, trok WVC zich nu terug ap haar formele rol, de LSV darmee raar het COTG verwijzend. Bij de reshuffling, maar met name bij de tweeslag was de invloed van de Wtg op de handelingsopties nog aanzienlijker groter. De noodzaak van juridische houdbaarheid dwong de betrokkenen als het ware tot de toepassing van de tariefformule en het formuleren van additionele werkbelastingsfactoren. De vergaande coöperatie tussen het COTG en de belangenorganisaties was hel strategisch pendant. De dreiging met de Wivb en de afweging tussen het wel of niet afgeven van aanwijzingen door WVC gaf aan dat de overheid ook na 1988 door het fomele institutionele kader de handelingsopties werden aangereikt.

Ten tweede werden aan het opportunistische handelen van de interacterende organisaties nomatieve grenzen gesteld. De genomen tariefbesluiten werden voortdurend and juridische toets onderworpen. Hierdoor moest het verloop van de besluitvorming worden gelegitimeerd. De frequente initiatieven tot beroepsprocedures door de LSV waren de belangrijkste oorzaak. De noodzak tot legitimatie nam bovendien toe door de gang naar de rechter door (groepen wan) indiwiduele medisch specialisten. Dil beperkte de mogelijkheid voor de belangenorganisaties om zich door middel wan onderlinge afspraken in te dekken tegen bezwaten van actoren dic niet betrokken waren bij de nationale besprekingen.

Met de Wtg had WVC een vrij eenvoudig hanteerbaar instrument on de eigen aches te legitmeren. De Wtg liet immers verschillende rollen wan de overheid toe. Zowel ingrijpen als het toelaten van langdurig onderling overleg ussen verschillende partijen waren wetteljk gelegitimeerde handelingsoptics. Het departement koos ervoor het onderlinge overleg kans te geven en het COTG zijn rol waar te laten maken. WVC vermed hiemee mogelijke wettelijke verplichtingen, omdat de juridische (tarieftechnische) verantwoordelijkheid bij de partijen en het COTG gelegd werd. Zeer illustratief voor deze handelwijze waarin de legitimatie samenviel met het bevorderen van de eigen belangen, was de houding wan WVC ten opzichte van de LSV in 1988. WVC owerwoog op geen enkel moment tegemoet te komen aan de bezwaren van de $\mathrm{LSV}$ 
ondat de besluitworming op een juridisch zorgwuldige manier was verlopen. Bij deze manier waren eveneens de woordelen voor de overheid evident. Of WVC er in slaagde het handelen te legitimeren, is een andere vrag. IK ben geneigd ontkennend te antwoorden gezien de ontevredenheid bij diverse organisates over de rol van de overheid gedurende de besluitvorming over tarieven tussen 1986 en 1992.

De noodzaak tot legitimatie bertond tevens woor de belangenorganisaties. $Z$ ij wrvoeren dat onderlinge afspraken fomeel goedgekeurd moesten worden. Hievoor waren twee factonen verantwoordelijk. Mern had geleerd van de ervaring met onuitgewerkte accoorden en onwettige afspraken in het verleden. Het was echter wooral de dreiging van juridische procedures bij het CBB en andere rechterlijke instanties, die reden voor VNZ, KLOZ en LSV was te zoeken naar argumentaties die juridisch passende tariefbesluiten tot stand zouden brengen. Ten tweede moest elke onderlinge afspraak de goedkeuring van het COTG wegdragen. Daarvoor traden zij in overleg met het COTC. De tekst van de Wtg (en andere geldende wettelijke regels) gaf de interacterende organisaties weinig houvast. Ook de adwiezen van juridische experts waren niet altijd eenduidig. Over het algemeen heerste de mening dat pas zekerheid tot stand kwam op het moment dat een rechter zich uitsprak. In deze situatie waarin de Wtg zonder translatie geen leidraad woor handelen kon zijn, was de invloed van een formeel tot interpretatie gemachtigde actor groot. Met name bij de reshuffling en de tweeslag lieten actoren zich bij hun beoordeling van de uitkomsten van overleg dientengevolge sturen door de commentaren van het COTG. Deze vornden het voomaamste instrument voor een juiste inschatting van de juridische houdbaarheid die in procedures bij rechters aan de orde zal komen.

\subsection{Conclusies}

Op basis van een analyse en vergelijking van de handelingstheorieën kunnen de volgende conclusies getrokken worden.

Ten eerste bleek uit de situatieschetsen dat groepen van actoren inzagen dat het nastreven van bepaalde gedeelde situatiespecifieke doelstellingen hun algemene, minder veranderlijke belangen zou bevorderen. Kenmerkend voor de besluitvorming over tarieven was tevens dat deze groepen van actoren - door mij in navolging wan Sabatier coalities genoemd - zich geconfronteerd zagen met een belangrijke opponent die de doelstellingen niet wenste te aanvaarden. Bij de praktijkkosten kon een coalitie van VNZ, KLOZ, WVC en KLOZ zich vinden in een verlaging van de praktikkostenvergoeding, en woerde de LSV daartegen oppositie. Ten lijde van het VPO streefden de deelnemers daaraan en WVC naar een spoedige implementatie van de verscheidene onderdelen van het accoord vanwege het beleidsmatige belang, en was het COTG de belangrijke opponent.

Ten tweede ontbrak een algemene, langdurige overeenstemming over de manieren waarop de organisaties tot besluiten over tarieven dienden te komen. Actoren zagen verschillende handelingsopties en de voorstellen lot strategieen van actoren kwamen evenmin overeen. Illustratief voor het ontbreken van overeenstemming over strategieën tussen organisaties ondanks de onderlinge consensus over doelstellingen was bij de praktijkkosten de keuze van de onderhandelingspartners voor onderling overleg op momenten dat volgens het COTG de formele procedures vel succes beloofden. Een ander voorbeeld is de tegenstelling tussen de wens van het VPO de wetgeving te veranderen en het streven van de overheid naar instandhouding van bestande wettelijke regels.

Ten derde oventheerste de doelrationele logica bij de handelingstheorieën. Organisaties stelde zich weliswar de vraag hoe men zich diende op te stellen tegenover anderen (de relationele reflectie) en of éen en ander in overeenstemming was met de wettelijke vereisten, maar bovenal vroeg men zich af hoe de eigen doelstellingen het best gediend konden worden als 
gereageerd moest worden op ontwikkelingen. Het gevolg was dat de Wig op een instrumentele manier en dus als hulpbron gehanteerd werd. Daarnaast had het institutionele kader een meer inhoudelijke invloed op de handelingstheorieën. Doelstellingen, handelingsopties en strategieën werden in belangrijke mate ontleend aan de Wtg en de tot stand gekomen jurisprudentie. Tevens moesten de actoren hun handelen legitimeren in termen van het formele institutionele kader omdat elk tariefbesluit aan een juridische toets werd onderworpen. 


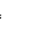




\section{Soorten van interacties}

\subsection{Inleiding}

Dit hoofdstuk bestaat uit de analyse van de interacties die plaatsvonden bij de totstandkoming van de door mij onderzochte tariefbesluiten. Als leidraad fungeert het onderscheid in de Wig tussen soorten van procedures die gevolgd kunnen worden. De beleidsmakers hechtten waarde aan technocratische besluitvorming, wilden thet al lang bestaande onderlinge overleg handhaven, creëerden hiërarchische verhoudingen en maakten juridische procedures mogelijk (zie ook hoofdstuk twee). Deze principes van de wet en de concrete uitwerking hiervan vormen de basis voor een evaluatie van de vaak complexe interactieprocessen. Om de principes van de Wtg en de uitwerking daarvan te verhelderen, zullen de overwegingen achter de Wtg geêxpliciteerd worden (zie ook: Van Erp 1997). Hiermee wordt recht gedaan aan de institutionele invalshoek van het onderzoek.

Bij de analyse van de interacties staat de argumentatieve dimensie centraal. Aan de hand van kenmerken van argumentatie zal worden vastgesteld van welk soort interactie sprake was op een bepaald moment. Bij de kenmerken van argumentatie maak ik onderscheid tussen het forum (de institutionele locus) waar de argumentatieve interactie plaats vindt en de organisatie van de interactic. In de Wtg worden forum en interactieorganisatie met elkaar verbonden. Zo vinden onderhandelingen plaats tussen de representatieve organisaties en dienen ontevreden partijen procedures bij het CBB an te spannen. Door beide aspecten van interacties analytisch te scheiden is het mogelijk vast te stellen of bepaalde interactiesoorten plaatsvinden in wettelijk. niet voorgeschreven loci.

De opbouw van het hoofdstuk is als volgt. Er vindt een analyse per interactiesoort plaats. Telkens zal daarbij het principe van de Wtg worden verduidelijkt. De structuur van de paragrafen komt niet precies overeen. Weliswaar staat telkens een vergelijking tussen de casussen woorop, maar de tekst volgt de voornaamste bevindingen. Tot slot volgt de vaststelling welke interactiesoorten meer, en welke minder dominant waren.

\subsection{De juridische interactie}

Van juridische interactie is sprake als actoren voor hun argumentatie gebruik maken van regeis die afleidbaar zijn uit wettelijke voorschriften en die zich baseren op precedenten en wettelijke verplichtingen (Helistern, 1986: 665). Onder juridische interactie wordt hier verstaan 
"... (a) policy dialogue oriented toward probing the various sources of law in ant effort to construct coherent and defensible interpretations of organizational mandates. "(Bell, 1985: 216)

In dit kader is sprake van een juridische cultuur omdat de interactie zijn wortels heeft in gedeelde normen over datgene dat juridisch relevant is. Argumenten die niet aan gezaghebbende wettelijke bronnen kunnen worden ontleend, verliezen hun relevantie (Bell, 1985: 216).

Hef voomaamste forum voor juridische interactie was het CBB. Op basis van artikel 35 van de Wtg kon tegen de goedkeuring of vaststelling van een tarief door hel COTG door mensen en organisaties in de gezondheidszorg die rechtstreeks in hun belang waren getroffen beroep ingesteld worden bij het College van Beroep voor het Bedrijfsleven (CBB). ${ }^{1}$ Daarnaast bestond de mogelijkheid na een besluit van het COTG een hoorzitting aan te vragen. Deze hoorzitting werden intern binnen het COTG gehouden.

Volgens de bewindslieden was het CBB de meest geschikte beroepsinstantie vanwege de verwantschap tussen de tarieven in de gezondheidszorg en de prijzen voor het bedrijfsleven. 2 De gronden wan beroep waren: strijd met een algemeen verbindend voorschrift, detournement de pouvair, strijd met de redelijkheid en strijd met een in het algemeen rechtsbewustzijn levend begingel van behoorlijk bestuur. ${ }^{3}$ Juridische toetsing wan richtlijnen en aanwijzingen was niet de bedoeling. Alleen tariefbesluiten stonden open woor beroep, waarbij uiteraard ook in beschouwing kon worden genomen of de richtlijnen en aanwijzingen juist waren toegepast. ${ }^{4}$

\subsubsection{Het juridische forum}

Uit tabel 7.1 blijkt dat tegen elke tariefbeslissing in de door mij onderzachte casussen juridisch beroep werd ingesteld. Daarmee werd de juridische procedure een integraal onderdeel van de totstandkoming van tarieven woor medisch specialisten. Omdat beroep pas mogelijk was na een formeel besluit, vormde de juridische uitspraak het sluitstuk van de besluitvorming.

Een tweede conclusie is dat elk beroep tegen een tariefbeschikking werd ingesteld door medisch specialisten. Voor de verzekeraars en de ziekenfondsen vormde geen van de beslissingen reden om een juridische procedure te starten. In de periode 1986-1992 is echter wel een verschuiving te constateren. Bij de besluitvorming over de praktijkkosten was de LSV (met delen van de achterbany juridisch zeer actief, terwijl bij de tweeslag en de reshuffling andere organisaties van specialisten en individuele artsen hun gelijk bij de rechter trachtten te halen. Bowendien besloten werschillende organisaties zich te voegen. Zo besloot de VNZ zich in de juridische procedure te scharen achter het COTG. Bij de procedure ten aanzien van de tweeslag deed ook de LSV dat. Dit had een juridische confrontatie tussen de LSV en de eigen leden tot gevolg.

Ten derde kan worden geconcludeerd dat niet alleen het CBB betrokken raakte. Het College kreeg gezelschap van de rechtbank, het gerechtshof en de Kroon. Dit was het gevolg van de inhoud van de klachten. Deze betroffen niet alleen de tariefbeschikkingen van het $\mathrm{COTG}_{n}$ maar ook de beslissingen van de overheid ten aanzien van richtlijnvoorstellen van het COTG. In de Wig was weliswaar in een adviesfunctie voor de Kamers voorzien, maar door het ontbreken van overeenstemming in Kamer $V$ konden de medisch specialisten weinig invloed uitoefenen op

1 In 1992 is de procedure veranderd. Sindsdien moet eerst bezwaar bij de beslissende organisatie worden gemaakt waarna pas beroep bij een beroepsinstantie kan worden aangetekend.

2 Memorie van Antwoord, Tweede Kamer, 1978-1979, 14182, nr. 6, p. 44-45

3 Memorie van Toelichting, Tweede Kamer, 1976-1977, 14182, nr. 3, p. 24

4 Nadere memorie van antwoord, Tweede Kamer, 1979-1980, 14182, nr.9, p. 20 
de totstandkoming van richtlijnen. Voor het aanvechten van de goedkeuring van richtlijnen viel het $\mathrm{CBB}$ als beroepsinstantie af. Daarvoor moesten de specialisten zich tot de reclitbank richten. Ook voor zaken met betrekking tot de modelovereenkomst en de betaling door ziekenfondsen was het CBB niet geschikt. Het ging hierbij immers om civielrechtelijke aspecten. ${ }^{5}$

Samenvattend bleek dus bij elk tariefbesluit sprake te zijn van juridische procedures. Deze speelden zich niet alleen af bij het CBB als formele rechtsprekende institutie, maar ook bij andere. De juridische interactie werd op gang gebracht door medisch specialisten, collectief dan wel individueel, maar mede als gevolg van voeging was er sprake van collectieve betrokkenheid. Daarom kan worden gesteld dat de juridische interactie een integraal onderdeel van de besluitvorming over tarieven werd, waarin de actoren die ook in eerdere fasen participeerden in juridische termen hun discussie voorzetten.

\subsubsection{Het toenemend belang van de juridische argumentatie}

De juridische interactie heeft een eigen organisatie. Deze bestond bij de besluitvorming over larieven uit de verwijzing naar de regels en normen die golden voor de procedures die gevolgd werden. Typerend voor de totstandkoming van tarieven voor medisch specialisten was dat juridische interacties niet alleen plaats vonden tijdens beroepsprocedures maar ook in andere fasen van het besluitvormingsproces.

Een overzicht van de grieven van verzoekers (tabel 7.2) geeft een indicatie van de argumenten die tijdens zittingen van het CBB werden gehanteerd. Kenmerkend voor de argumenten is de verwijzing naar regels en normen voor de besluitvorming. Onenigheid over de zaak zelf is weliswaar een noodzakelijke maar niet voldoende voorwaarde voor het inschakelen van rechters. Onenigheid is immers in principe oplosbaar door middel van onderling overleg of het inschakelen van een bemiddelaar. In het algemeen raakt een rechter betrokken als er daarnaast ook geen overeenstemming bestaat over de regels en normen voor besluitvorming (zie tevens paragraaf 5.5 ). Regels en normen vormen het domein van de rechter, die zich ais derde partij daardoor onderscheidt van bijvoorbeeld de bemiddelaar. Tegelijk moeten er wel bepaalde regels en normen aanwezig zijn omdat anders elk beroep op een rechter zinloos is. De werkwijze van de rechter houdt namelijk in dat het besluitvormingsproces wordt gereconstrueerd om zo te kunnen vaststellen welk van de partijen in het ongelijk moet worden gesteld. Tijdens de bemiddelingspogingen bij het conflict over de praktijkkosten en de juridische procedures naar aanleiding van de VPO-besluiten bleek vooral overeenstemming te ontbreken over de nomen en regels die gevolgd zouden moeten worden.

Ondat de meningen van de betrokkenen niet alleen afweken ten aanzien wan de hoogte van de tarieven, maar ook met betrekking tot de procedures en normen, volgde de juridische procedure. Deze stap werd zelfs onvermijdelijk bij de beslissingen over de tweeslag en de reshuffling omdat toen de benadeelden, de individuele medisch specialisten, niet in staat waren om eerder in het besluitvormingsproces hun bezwaren kenbaar te maken. Waar het beroep voor de LSV het laatste middel vormde, was het voor de individuele artsen die zich niet neerlegden bij de uitkomsten van het centrale overleg de enige formele mogelijkheid invloed uit te oefenen op de totstandkoming van hun tarieven.

Niet alleen bij de tariefvorming woor medisch specialisten raakten andere rechterlijke instanties dan het $\mathrm{CBB}$ betrokken. Hamilion-Van Hest constateert in haar overzichten van de jurisprudentie in het kader van de Wtg dat dit ook in andere sectoren in de gezondheidszorg op rume sehaal voorkwam (1989:382). 


\begin{tabular}{|c|c|c|c|c|}
\hline & indilenerg & instantie & ets & aitspraak \\
\hline \multirow[t]{4}{*}{$\begin{array}{l}\text { praktigkkog- } \\
\text { ten }\end{array}$} & $\begin{array}{l}\text { LSV Vantal specialis- } \\
\text { ten }\end{array}$ & $\begin{array}{l}\text { Rechibank } \\
\text { 's Graverhage }\end{array}$ & $\begin{array}{l}\text { verbod op goedkeu- } \\
\text { ren van de richlijnen } \\
\text { d.d. } 20 \text { juni } 1988 \text { en } \\
\text { het opzeggen wan het } \\
\text { Generaal Akkoord }\end{array}$ & $\begin{array}{l}27 \text { juni } 1988 \\
\text { Toegewezen m.b.t. } \\
\text { de goedkeuring van } \\
\text { de richdingen; afge- } \\
\text { wezen m.b.t. opzeg- } \\
\text { gen van hes } \\
\text { General A khoord }\end{array}$ \\
\hline & $\begin{array}{l}\text { Landeligk Patenten- } \\
\text { Consumenten Plat- } \\
\text { corm en Nationale } \\
\text { Ziekentuisrat }\end{array}$ & $\begin{array}{l}\text { Rechtbank } \\
\text { Utrecht }\end{array}$ & $\begin{array}{l}\text { verbod op het urvoe- } \\
\text { ren van zondagsdien- } \\
\text { sten door medisch } \\
\text { specialisten }\end{array}$ & $\begin{array}{l}31 \text { okwober } 1988 \\
\text { Toegewezen. }\end{array}$ \\
\hline & $\begin{array}{l}\text { LSV Vaantal specialis- } \\
\text { ter. }\end{array}$ & $\begin{array}{l}\text { Gerechtshof } \\
{ }^{8} \text { s-Cravenhage }\end{array}$ & $\begin{array}{l}\text { ongedaan maker wan } \\
\text { de goedkeuring van } \\
\text { de prakijkkosten- } \\
\text { richtijnen } W / 560 \text { - } \\
0 / 2.1 .1 / 1 \text { en } V / 560 \text { - } \\
0 / 2.2 .1 / 1\end{array}$ & $\begin{array}{l}17 \text { nowember } 1988 \\
\text { Afgewezen }\end{array}$ \\
\hline & $\begin{array}{l}\text { I.SVhatital } \\
\text { specialister }\end{array}$ & $\mathrm{CBB}$ & $\begin{array}{l}\text { verzodk tot schlorsing } \\
\text { en varnietiging van } \\
\text { de tariefbeslissingen } \\
\text { ten aanzien van de } \\
\text { praktijkkostien- } \\
\text { vergoeding d.6. } 21 \\
\text { november } 1988\end{array}$ & $\begin{array}{l}28 \text { december } 1988 \\
\text { Afgewezen } \\
14 \text { nowember } 1991 \\
\text { Afgewezen }\end{array}$ \\
\hline \multirow[t]{2}{*}{$\begin{array}{l}\text { Ratam- } \\
\text { overeen } \\
\text { komst } \\
\text { algemeen }\end{array}$} & $\begin{array}{l}\text { VB3/Vereniging } \\
\text { woor Behoud Privacy } \\
\text { wan Vrjo Be- } \\
\text { woepsbeofenaren/aa- } \\
\text { ntal specialister }\end{array}$ & de Kroon & $\begin{array}{l}\text { schorsing en vernieti- } \\
\text { gimg van goed- } \\
\text { keuring van de } \\
\text { modelovereenkomst } \\
\text { specialist-zie- } \\
\text { kenfonds door } \\
\text { Ziekenfordsrad }\end{array}$ & \\
\hline & $\begin{array}{l}4 \text { medisch } \\
\text { specialisten }\end{array}$ & $\begin{array}{l}\text { Rechtbank } \\
\text { Urecht }\end{array}$ & $\begin{array}{l}\text { ANOZ (ziekenfonds) } \\
\text { mag artsen die nie: } \\
\text { wolgens de mo } \\
\text { deloveneenkomst } \\
\text { willen contracteren, } \\
\text { miet uitsluiten van } \\
\text { betaling en geen } 90 \\
\text { procent tarief bereke- } \\
\text { nen }\end{array}$ & $\begin{array}{l}27 \text { matr } 1990 \\
\text { A Gewezen }\end{array}$ \\
\hline testyufting & $\begin{array}{l}792 \text { inedisch } \\
\text { specialisten }\end{array}$ & $\mathrm{CBB}$ & $\begin{array}{l}\text { verzoek om voor- } \\
\text { lopige wonziening } \\
\text { en ventisting } \\
\text { tarienbeslissing }\end{array}$ & $\begin{array}{l}20 \text { februari } 1991 \\
\text { Afgewezen } \\
19 \text { mei } 1992 \\
\text { Algewezen. }\end{array}$ \\
\hline tweerslag & $\begin{array}{l}\text { mantal medisch speci- } \\
\text { alisten }\end{array}$ & $\mathrm{CBB}$ & $\begin{array}{l}\text { verzoek tot voor } \\
\text { lopige voorziening } \\
\text { en verniefiging van } \\
\text { tarjefbeslissing }\end{array}$ & $\begin{array}{l}5 \text { juni } 1990 \\
\text { Toegewezen } \\
11 \text { februari } 1992 . \\
\text { Toegewezen }\end{array}$ \\
\hline
\end{tabular}


De reactie van de rechters op de bezwaren van de artsen was zoals mocht worden verwacht van een juridisch forum. $\mathrm{Zij}$ deden geen uitspraak over de juistheid van de hoogte van de tarieven, maar beoordeelden slechts de mate waarin de beslissers zich gehouden hadden aan de voor deze besluitvorming geldende normen en regels. Dit leidde tot het oordeel dat praktijkkostenbesluiten en de reshuffing op een correcte manier tot stand waren gekomen, naar dat de tweeslag vanwege detournement de pouvoir niet rechtsgeldig was.

\section{Tabel 7.2: De grieven van verzoekers bij CBB-procedures}

\begin{tabular}{|c|c|c|}
\hline & verwoekers & grieven \\
\hline $\begin{array}{l}\text { praktijk- } \\
\text { kosten }\end{array}$ & LSV & 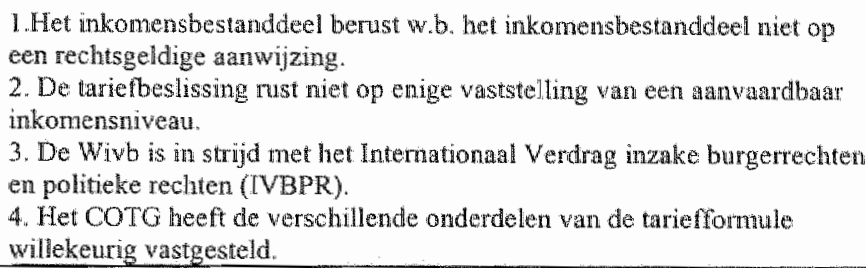 \\
\hline reshuffing & $\begin{array}{l}\text { ind. } \\
\text { specialisten }\end{array}$ & 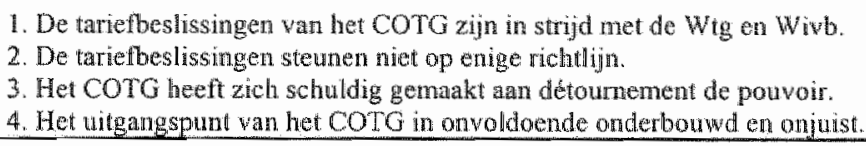 \\
\hline tweeslags & $\begin{array}{l}\text { ind. } \\
\text { speciud listen }\end{array}$ & $\begin{array}{l}\text { 1. De Wtg laat niet toe dat voor eên prestatie twee tarieven worden vastge- } \\
\text { steld. } \\
\text { 2. Het CoTG heeft andere doelemden voor ogen dan die doeleinden } \\
\text { waartoe bewoegdheden zijn gegeven. } \\
\text { 3. Het COTG heeft niel in redelijkheid tot de richlignen en } \\
\text { tariefbeslissingen kunmen komen. } \\
\text { 4. De richtijnen en de tariefbeslissingen zijn strijdig met het WBPR. }\end{array}$ \\
\hline
\end{tabular}

Bron: RZA 1989-1992

Tot dusver heb ik de juridische interactie behandeld als een duidelijk te lokaliseren interactiesoort: voor de rechter en aan het einde van het besluitvormingsproces of toen het besluit al genomen was. Matar de juridische interactievorm trad niet alleen op tijdens zittingen wan het CBB of die bij een andere rechter. Deze organisatie van interacties is ook te herkennen in eerdere fasen van de besluitvorming. Tijdens de totstandkoming van de besluiten over de praktijkkosten werd de discussie in toenemende mate in juridische termen gevoerd. Hoewel in het onderlinge overleg tussen VNZ, KLOZ en LSV nog gesproken werd in bod en tegenbod en in de discussies in het COTG bedrijfseconomische termen cen belangrijke rol speelden, werd in deze fase ook al juridische argumentatie gehanteerd. Daarbij waren twee factoren van groot belang. Ten eerste begon de LSV formele argumenten te hanteren waarmee de procedures in het COTO beinvloed konden worden. Ten tweede wenste WVC zich niet inhoudelijk over de bezwaren van de medisch specialisten tegen een verlaging van de kostenvergoeding uit te laten. WVC wilde de LSV alleen wijzen op de formele mogelijkheden van de Wtg. Terwijl andere organisaties zich op een anpassing van de vergoeding voor de praktijkkosten richtten, probeerde de LSV de onrechtmatigheid van de besluitvorming aan te tonen. Dit kwam met name naar voren in de interacties tussen de LSV en het COTG en in de discussies bimnen het COTG, aangezwengeld door de LSV. Naast de bedrijfseconomische bezwaren benadrukte de LSV de onjuistheid van een verandering van een onderdeel van het tarief zonder daarbij de andere onderdelen te beschouwen, 
en het gebruk van verouderde gegevens.6 Ook in brieven aan WVC hanteerde de LSV juridische argumenten. Naast de bovengenoemde bezwaren lieten de specialisten de staatssecretaris van Voksgezondheid weter dat nat hun mening het COTG misbruk maakte wan de wettelike bevoegdheden door het voorstel te doen een gedeelte van de betaling aan de medisch specialist via het ziekenhuis te laten verlopen. ${ }^{7}$ De statssecretaris reageerde overeenkomstig de juridische interactiestructuur. Zijn antwoord luidde dat de besluitworming naar zijn mening zorgwuldig was verlopen en dat voor de overheid geen comigerende rol was weggelegd. 8

Tekenend woor het grote bellang: van de juridische discussie bij de totstandkoming van de beshuiten over de kostenvergoeding en de initierende rol van de LSV daarbij, was de poging van de LSV de overheid aan de verplichtingen van het Generaal Akkoord te houden door hierover een rechterlijke uitspraak af te dwingen. Een uitspraak van de rechtbank in Den Haag was nodig teneinde duidelijkheid te krijgen over de rechtmatigheid van het voomemen van de overheid de richtlininen wan het COTG goed te keuren.

De discussie over de verplichtingen wan het Generaal Akkoord was illustratief voor de ontwikkeling van de discussie in de latere fasen in de besluitvorming over de praktijkkosten. Er vonden juridische procedures plaats waarvan de invloed zich deed gelden in andere institutionele loci. Datar vond een formalisering van posities plaats. Zo leidde de boven beschreven oproep van de LSV aan de overheid zich aan het Generaal Akkoord te houden tot een uitdrukkelijk beroep op de formele vereisten die de Wtg stelde aan de totstandkoming van tarieven door de VNZ en het KLOZ 9

De inwloed van de juridische argumentatie werd nog groter bij de totstandkoming van de besluiten over de tweeslag en de reshiffling. In het streven van het VPO de onderlinge afspraken te bevelligen tegen de juridische bezwaren van individuele medisch specialisten stonden de interacties al in ten vroeg stadium in het teken van juridische argumentatie. Daarbij ging het initiatief niet uit van enkele actoren zoals bij het kostenconflict, maar wensten alle betrokkenen zich in te dekken tegen de argumenten van individuele medisch specialisten en wilde men implementeerbare afspraken te maken. Nog voordat het VPA in december 1989 getekend zou worden, vonden in het VPO en tussen het VPO en het COTG discussies plaats over mogelijkheden van de wetgeving voor de tweeslag en de reshuffling. Deze discussies werden aangewakkerd door de aanvankelijk negatieve advisering door het COTG en het voorbehoud van WVC ten aanzien van de juridische houdbaarheid van het VPA. Op de agenda stonden nauw met elkaar verbonden onderwerpen: de noodzaak wan nieuwe richtlijnen die zouden voldoen aan de eisen van de Wtg, de vraag of aanwijzingen van de overheid nodig zouden zijn, het intrekken van de Wivb en een verandering van de Wtg. Daarbij vormde de voortdurende onzekerheid een probleem. De argumentatieprocedure had als gevolg van deze onzekerheid een specifiek karakter. Ideaal-typisch zouden besluiten via een juridische redenering afleidbaar moeten zijn

6 CorG, Richtlijnadvezen Kamer V praktijkkostenbestanddelen in tarieven medische specialisten (ziekenfonds en particulier), COTG V 88-11

7 Brief LSV aan Dees, 14 april 1988

$8 \quad$ LSV, Concept-verslag B.O. dd 5 oktober 1988,24 oktober 1988

9 Wadat de Hagsche rechtbank in juni 1988 had besloten dat de overheid ten behoeve van het opzeggen van het Generaal Akkoord overleg moest voeren met de LSV schreef het KLOZ aan verschillende bewindslieden, waaronder de Minister President: "Daarin (in het overleg tussen overtheid en LSV, hl) moeten zo vele verschillende aspecten aan de orde komen dat wij vrezen dat weer een afspraak tussen de overheid en de LSV gemaakt zal worden van een met het Generaal Akkoord vergelijkbare aard. Wij werzoeken u met klem geen toezeggingen te doen en de LSV te verwijzen naar de procedures van de WTG en WIVB." (Brief KLOZ namens KLOZ, KPZ en VNZ aan de Minister President, Minister van Sociale Zaken en Werkgelegenheid, Staatssecretaris van Economische Zaken en Staatssecretaris van Welzijn, Volksgezondheid en Cultuur, 28 juni 1988) 
van de wettelijke bepalingen (Wtg; Wivb, etc) en de bestaande jurisprudentie. Daar kwam nen echter nauwelijks aan toe. Hoewel de jurisprudentie enkele conchusies toeliet - bijvoorbeeld dat het COTG geen besluiten ten aanzien van het inkomen van een medisch specialist mocht nemen of dat de Van Dien-enquête niet gebruikt mocht worden- konden de betrokkenen weinig anders doen dan de onzekerheid beperken door al discussièrend te anticiperen op de mogelijke uitspraken van een rechter. In die discussies was het oordeel van het COTG uiteindelijk van doorsiaggevend belang. Als gevolg hiervan werd de ontwikkeling van de discussies woomamelijk bepaald door veranderingen in de positie van het COTG.

\subsection{De technocratische interactie}

Interacties zijn technocratisch als argumenten worden gehanteerd die gebaseerd zijn op kernis van zaken. Deze kennis wordt ontleend aan objectieve informatie waarover geen verschil van mening bestaat. Besluiten komen tot stand op basis van een zuivere discussie waarin geen plaats is voor pollitieke argumenten. Theoretici hebben echter gewezen op het verhullende karakter van technocratische besluitvorming. Technocratie is valk een instrument voor machtigen teneinde hun belangen te bevorderen. In deze paragraaf zal ik aangeven dat deze algemene conclusie ook geldt voor de totstandkoming van tarieven.

Bij de behandeling van de Wtg in de Tweede Kamer was vooral de PvdA huiverig voor het ontstaan van een netwerk van deskundigen dat op een politiek oncontroleerbare technocratische wijze belangrijke beslissingen over de honorering in de gezondheidszorg zou nemen. Toussaint keerde zich fel tegen het ontstaan van een selecte groep mensen die zich bezig zouden gaan houden met de besluitvorming over tarieven. Hij vreesde voor een 'dictatuur van deskumdigen'. Doelend op het COTG zei hij:

"...(h)et scheppen van een autonoom publiekrechtelik lichaam, warin advisering en beslwitvorming onder één dak plaatswinden, en warbij op alle twee die niveaus een dominerende invloed wordt geschapen van de groeperingen die direct belanghebbenden zijn, achien wij een onaanvaardbare zaak. Op die manier krijgt de Hollandse regentenmaatschappij er een nieuw bolwerk bij."

In hoeverre was Toussaint"s vrees gegrond? Kwamen in de periode 1986-1992 besluiten over tarieven woor medisch specialisten inderdaad in een gesloten groep van mensen, op basis van deskundigheif, tot stand?

Uit de overwegingen van de overheid bij het ontwerp en de invoering van de Witg bleek in leder geval de wens om tot een technocratische besluitvorming over tarieven voor medisch specialisten te komen. De onvrede met de heersende gang van zaken leidde tot een nadruk op rationele afwegingen over tarieven. Die rationele overwegingen zouden betrekking moeten hebben op zowel de grondslagen van tariefbesluiten ais hun gevolgen voor de uitgaven aan gezondheidszorg en de afstemming van zorgvoorzieningen op elkar. ${ }^{1}$ Met de Wtg introduceerde de overheid besluitvormingsprocedures waarin een deskundig, onafhainkelijk orgaan op basis van objectieve maatstaven (richtlijnen) tarieven tot stand zou laten komen. De Wtg was een middel tot betere coördinatie warmee tevens de gevolgen van tariefveranderingen woor de uitgaven aan de gezondheidszorg beheerst zouden moeten worden. De scheiding tussen

10 Handelingen Tweede Kamer, 4 juni 1980, p. 5096 . Toussaint was buitengewoon duidelijk over de nieuwe beshitwormingsstructuur: "Wie in het besluityormende vlak de weg plaveit woor de deskundigen, die plaveit de weg voor de dictatuur. Dat geldt ook woor de gezondheidszorg."

11 Regelen met betrekking tot de tarieven varn organen voor gezondheidszorg (Wet tarieven gezondheidszorg), Memorie van Toelichting, Tweede Kamer, 1976-1977, 14182, nr. 3, p. 17 
politieke besluiten en een technische implementatie, die kenmerkend voor technocratische beleid. is, werd ten wolle onderschreven.

De wens tot deze scheiding sprak uit de discussies in de Tweede Kamer over de verschillende wetsontwerpen. Hierin moesten de bewindslieden antwoord geven op vragen die wel degelijk de politieke dimensies aan de orde stelden en die betrekking hadden op enkele kwesties die al langer tot discussies leidden. Waarom zorgde het wetsontwerp er niet voor dat het onderscheid tussen de tarieven voor ziekenfondspatienten en particuliere patienten werd opgeheven? En waarom werd geen afscheid genomen van de betaling per verrichting en een begin gemaakt met een budgettering woor elk 'orgaan in de gezondheidszorg", zo vroeg de PvdA zich af. En was het wel gewenst dat de Wtg leidde tot regulering van inkomens van artsen terwijl andere sectoren vrije loononderhandelingen kenden, wilden de VVD en CDA weten. 12

De reacties van de verantwoordelijke bewindslieden op dexe vragen waren exemplarisch voor het door hen gewenste technocratische beleid. Ze gaven aan dat een juiste uitvoering van de procedures van de nieuwe wet en het ter beschikking komen van de benodigde gegevens zouden leiden tot maatschappelijk gewenste uitkomsten. In haar reactie op de vragen rond de budgettering in de gezondheidszorg zag staatssecretaris Veder-Smit de Wtg niet als middel dit op grote schaal te introduceren. In plaats daarvan zou een aantal experimenten meer inzicht moeten genereren in de voor- en nadelen wan een systeem van budgettering. 13 Ook het verschil tussen tarieven voor dezelfde verrichtingen was niet een kwestie van politieke besluitworming maar iets dat door middel van uitvoering van de Wtg moest kunnen worden verholpen.

"Het systeem van richtijnen biedt (...) de mogelijkheid om de particuliere en ziekenfondstariewen geleidelijk naar elkaar toe te laten groeien. De vergelijkende gegevens over de particuliere en de ziekenfondspraktij, die daanoor nodig zijn. kumen op basis wan deze wet, bijeengebracht worden." 14

Volgens Veder-Smit was de verwachting gerechtvaardigd dat

"... (o)nderbrenging van de desbetreffende regelingen (de bestaande wettelyke regelingen op het gebied vas tariefvorming. HL.) in één wet, waarop alle tarieven worden gebaseerd, de mogelikheid opent om hieraan een einde te maken. Het onderhavige woorstel strekt hiertoe: éen wettelijke regeling voor alle tarieven, én orgaan en éen geimtegreerd stelsel wan richtijnen." Is

En ook ten aanzien van de inkomens van artsen werd in de Wtg geen keuze gemaakt. Knopen daarover zouden worden doorgehakt, niet in het tariefoverleg maar in gesprekken tussen de overheid en de artsen. $10^{\circ}$

De wens tot technocratisering kwam met name tot uitdrukking in de nadruk op de ontwikkeling van een stelsel van richtlijnen en een onafhankelijke beoordeling van tariefveranderingen. Met een richtlinenstelsel

"...(k)ant de basis worden gelegd voor een geheel nieuwe tariefstructur, die doorzichtiger en evenwichtiger zal zijn en beter aangepast kan worden aan de onwikkelingen in de gezondheidszorg. Daarmede zijn niet alleen de inrichingen, instellingen en individuele beroepsbeofenaren gediend, maar ook degenen die uiteindelijk de kosten van de gezondhendszorg dragen. Uit deze nieuwe structur

12. Regelen met betrekking tot de tarieven wan organen voor gezondheidszorg (Wet tarieven gezondheidszorg), Voorllopig verslag Vaste Commissie voor de Volksgezondheid, Tweede Kamer, 1977 $1978,14182, \mathrm{nr}, 4$

13 Memorie van Antwoord, Tweede Kamer, 1978-1979, 14182, nr. 6, p. 8

14 Regelen met betrekking tot de tarieven wan organen voor gezondheidszorg (Wet tarieven gezondheidszorg), "lweede Kamer, 1976-1977, 14182, nr 3, p. 22

15 Memorie van Antwoord, Tweede Kamer, 1978-1979, 14182, nr. 6, p. 8-9

16 Memorie van Antwoord, Tweede Kamer, 1978-1979, 14182, nr. 6, p. 16 
komt ook een berere beheersbaarheid wan de koster voort omalat de tarienen in onderling verband kwnen worden bezien en onnotige kosten gesignaleerd en voorkomen kunuen worden. "I7

Als garantie voor de betrouwbaarheid van tariefbesluiten gold de samenstelling van het COTO. De beoordeling van de uitkomsten van onderhandelingen moest in handen liggen van personen dic in staat zouden zijn tot een objectieve afweging. Zich afzettend tegen de praktijk met de Commissie Overeenkonsten van de Ziekenfondsraad, stelde Veder-Smit dat

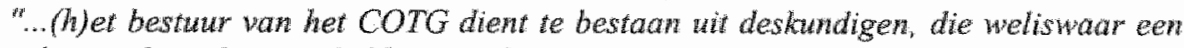
zekere relatie kwmen hebben tot de gezondheidszorg, doch onafhankelijk dawrwa fumctioneren bimen het COTG (...) Al diegenen die betrokken zijn bij tariefonderhandelingew dienen te zin uitgesloten van deelweming in het COTG. Naur de mening wan de ondergetekenden bliff op deze wijze de onafhankelike status van her COTG (..) centrat staan. " 8

Het COTG diende dus als technocratisch centrum. Volgens theoretici is het echter niet juist technocratische interactie te laten plaatsvinden in een specifieke locus. Technocratische besluitvorming is namelijk niet precies localiseerbaar, maar doet zich voor in een bepalde vorrn van argumentatie of discours (Fischer, 1990: 20). De aanhangers wan technocratische beshitvorming leggen de nadruk op de vomeisen waaraan de totstandkoming van beslissingen moet voldoen. De beshutwormers vertrouwen op kennis van zaken waardoor haast vanzelfsprekend overeenstemming over de te nemen besluiten wordt gegenereerd. Wederzijds gerespecteende deskundigheid staat voorop waardoor andere mechanismen als meerderheidsbeshuiten of consensusvorming na onderhandelingen worden uitgesloten. Daardoor is technocratie bij mitstek een vorm van besluitwormende interactie of, zoals Fischer het noemt, een meta-fenomeen, ondat technocratische bestuitworming meer zegt over de vom van de besluiten dan over de inhoud (1990: 21). Deze vorm wijkt af wan met name het traditionele politieke spel waanin het overtuigen van iemand met een andere wereldvisie en het onderhandelen met een witruil van tijdelike politieke woordelen 20 'n grote rol spelen. Bij een ideaal-typische technocratische besluitvorming is geen plaats voor conflicten door onverenigbare tegenstellingen. Eventuele conficten komen voort uit onwetendheid zoals Stone aangeeft.

"Information and lmowledge, in the rational ideal, obviate the need for force because

they can resolve conflict. (...) Most conflict is seen to derive from ignorance, not from

fundamental differences of character or interest." (Sione. 1988: 250)

In het technocratische ideaal zullen de juiste oplossingen voor problemen worden gevonden, zolang er in een context van langdurige sanenwerking en harmonie kennis wordt witgewisseld (Nabandian, 1994: 533).

In het algemeen is techinocratische beshutvorming te herkenmen aan de volgende argumentatieprocedure. Ten eerste is er sprake van probleemoplossende interactie warbij men verschillen wan mening oplost door terug te vallen op gegevens die "woor zich spreken', Gegevens die 'voor zich spreken' zin betrouwbaar, dal wil zeggen dat zij accuraat, objectief, consistent, transparant en waarachtig zijn (Wildawsky en Tenenbaum, 1981: 300-308). Ten weede vinden geen debatten over politieke doelstellingen plaats. Politieke doelstellingen worden als gegeven beschouwd en de toepassing van technische expertise dient er slechts toe om deze doelstellingen te bewerkstelligen. Dit is het 'means-end' karakter wan een technocratie. Teneinde de mate van technocratische besluitvorming vast te kunner stellen zullen dus twee vragen beantwoord moeten worden. Ten eerste: was en bij de interacties sprake van een 'means-end' karakter in die zin dat

17 Regelen mel betrekking tot de tarieven wan organen woor gezondheidszorg (Wet larieven gezondheidszorg), Tweede Kamer, 1976-1977, 14182, nr, 3, p. 21

18 Memorie van Antwoord, Tweede Kamer, 1978-1979, 14182, nor. 6 
de doelstellingen gegeven waren en er slechts over de techwische witvoering daarvan werd gediscussieerd? En ten tweede: was er sprake van probleemoplossende interactie waarbij de actoren de cijfers voor zich lieten spreken?

\subsection{De praktijkkosten}

Van de onderzochte tariefbeshiten werd biy de praktijkkosten het meest uitgebreid geprobeerd de uiteindelijk beslutworming te baseren op inzicht in de kosten die een specialist maakt. Voor het eerst ontwikkelde het COTG voor de betaling van medisch specialisten een stelsel van richtlijnen. waaraan de besluitworming getoetst kon worden. Dit gebeurde in drie stappen. In april 1987 besloot Kamer $\mathrm{V}$ tot een splitsing van tarieven in een inkomensideel en een praktijkkostendeel. Vervolgens stelde het bureau van het COTG in mei 1988 voor de beroepskosten te scheiden van de praktijkkosten. Tenslotte werd voor elk onderdeel van de beroepskosten een bedrag vastgesteld. Daarbij stonden niet de werkelijke kosten van artsen centraal, maar het COTG hanteerde een normatieve aanpak: "Het ging ons om de vaststelling van een norm voor de onkosten. Zo'n bedrag is bij voorbaat omstreden, omdat je over elk onderdeel ervan kunt wisten", zei de woorzitter van het COTG de dag na de vaststelling van de richtlijnen door het

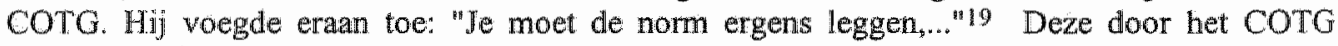
ingezette tationalisering van de betaling van medisch specialisten hield dus een bepaling in van zowel de omvang van de vergoeding als de uitgaven waarvoor de specialist vergoed zou worden.

Met deze aanpak werd het vraagstuk van de relatie tussen de betaling van de arts en de budgetfinanciering van de ziekenhuizen ogenschijnlijk getransformeerd tot een technische kwestie. De eerste voorstellen van de VNZ in 1986 maakten een politieke discussie over het onderbrengen van de medisch specialist in het ziekerihuisbudget heel goed mogelijk, maar zij leidden witeindelijk tot afspraken over geldbedragen voor de verschillende beroepskosten. 20 Deze technische invalshoek was echter pas mogelijk nadat VNZ en COTG hierin een strategie zagen om hun doelstellingen te halen. Zo was de keuze voor het onderscheid tussen beroepskosten en praktijkkosten het resultaat van een afstemmingsproces tussen beide actoren. Het COTG was hierdoor in staat een mantal kostenposten te objectiveren en de VNZ kon een eerste stap naar "de specialist in het ziekenhuisbudget" als succes melden. En WVC was in staat de LSV te verwijzen naar de discussie in het COTG.

De bovenbeschreven aanpak van het COTG leidde evenmin tot een technocratische proces waarin de resulterende besluiten woortkwamen uit woor zich sprekende gegevens. Regelmatig werd het oplossen van de problemen voorgesteld als het vinden en gebruiken van de juiste gegevens zoals blijkt uit de volgende woorden van Plasmans (voorzitter LSV).

De oplossing is heel simpel. Na een enquete rollen er genomeerde praktijkksten wit. Wervolgens is er een normwerkweek, daw waren we het ook eigenlik al over cens. Nou, dan is her toch een kwestie van simpel uitrekenen wat het tarief moet zijn. Dan is het toch total afgelopen.21

De voorzitter van de LSV stelde op het toppunt van het kostenconflict:

"Wij bliwen derthatve bereid, zoals wij de minister ook hebben laten weten, tol een onderzok dat op evenwichtige wize anndach bestedt aan zowel inkomen en

19 Elsen (voorzitter CoTG), in: Algemeen Dagblad, 21 jumi 1988

20 De VNZ kwam al wrij snel tot de conclusie dat de steun bij WVC en andere politici ontoerenkend was voor een succesvolle poging om op korte termijn de medisch specialisten onder te brengen in de budgetten van de ziekenhuizen.

21 Irizet, 1988, nr. 4, p. 24 
kosten, alsook aan de werkbelasting. En (...) als die gegevens voowhanden zijn en zü zouden tot een tariefverlaging aanleiding geven, dan zal dit alsdan ook gebeuren. want afspraak is mu eenmaal afspraak." 2

Maar in de praktijk bleken de gegevens van de verschillende participanten niet als vanzelf overeenstemming over de te nemen besluiten te genereren. De besluitvorming over de kostenvergoeding leed onder de afwezigheid van consensus over gegevens over de werkelijke praktijkkosten van medisch specialisten. Er bleven verschillen van mening bestaan. Met name de discrepantie tussen de gegevens van de LSV aan de ene kant en de informatie van de ziekenfondsen, verzekeraars, WVC en COTG an de andere kant liet zich niet oplossen. De onwetendheid kon niet worden weggenomen door het inbrengen van nieuwe informatie. Dit had een aantal oorzaken. Ten eerste pasten ze niet bij de doelstellingen van de betrokkenen, die zich bleven opstellen als vertegenwoordigers wan een bepaald belang. Overeenstemming over de doeleinden ontbrak. De door het COTG aangevoerde gegevens waren voor de LSV niet acceptabel omdat verwerking hiervan in tarieven zou leiden tot drastische tariefsverlagingen, de gegevens van de LSV waren voor anderen onacceptabel omdat zij de verlaging van tarieven in de weg stonden. Deze doelstellingen stonden bij de aanvang van het conflict in 1986 al vast. Daarmee verdween de mogelijkheid door overeenstemming over gegevens een beshit te nemen. Ten tweede vertrouwde men elkaar niet. Wederzijds twijfelde men aan de waarachtigheid van de informatie die werd aangedragen. In het algemeen was het oordeel dat de andere partijen informatie gebruikten teneinde de eigen doelstellingen te ondersteunen. In plaats van inhoudelijke discussies over ingebrachte gegevens werd er "weinig geloof gehecht aan de rekensommetjes. ${ }^{23}$

De technische onderbouwing in de vorm van een kostenrichtiijn met per kostenpost een nauwkeurige berekening van te declareren bedragen was dus niet een uitvloeisel van een puur technocratische benadering van de tarifering. Deze onderbouwing was pas mogelijk nadat de uitkomsten van de technocratische benadering van het COTG ingebed konden worden in de strategische overwegingen van met name VNZ en WVC. Toen de LSV nieuwe gegevens over de praktijkkosten van internisten en chirurgen overhandigde, verwees WVC de belangenorganisatie dan ook naar het COTG, in de wetenschap dlat daar weinig eer voor de specialisten te belialen viel.

Toen eind 1988 de verhoudingen tussen de actoren veranderden, bleek de invloed van de technocratische benadering sterk afhankelijk te zijn van politiek-strategische overwegingen en de bijbehorende relaties tussen de actoren. De lotgevallen van de voorstellen van het secretariaat van het COTG geven dit duidelijk weer. Ten eerste toonde het bestuur van het COTG zich niet ongevoelig voor de protesten van medisch specialisten tegen de voorstellen van het eigen secretariaat. Hoewel het besturr van het COTG in de uiteindelijke besluitvorming veel onderdelen van deze voorstellen ovemam, stuurde het aan op een compromis. Het bevestigde de juistheid van de berekeningen van het eigen bureau, maar juist op de kostenpostem waartegen de LSV de meeste bezwaren maakte, de administratieve ondersteuning, bleek het bestuur bereid de specialisten tegemoet te komen. De bezwaren van de ziekenhuizen werden daarmee weggenomen. Ten tweede bleef de uitwoering van de besluiten over de praktijkkosten steken in de eerste fase. De stokkende implementatie was het gevolg van een politieke uitruil, waarbij voor WVC, VNZ en KLOZ bezuinigingen op de uitgaven voor medisch specialistische hulp, volumebeheersing en het in stand houden van goede relaties van groter belang waren dan een juiste kostenvergoeding. Weliswaar bleven de ziekenfondsen en verzekeraars ook tijdens het Vijf-partijen Overleg vasthouden aan de richtlijnen voor de kostenvergoeding, maar meer als

22 Medisch Contact, 1988, nr. 16, p. 484

23 Elsen (voorzitter COTG), in: Algemeen Dagblad, 21 juni 1988 
stok achter de deur voor de LSV dan als juiste benadering van tarieven. Veel meer dan ent verantwoorde betaling van de kosten van medisch specialisten stond voor hen de financiele opbrengst van tariefmaturegelen voorop. De aanpak van het COTG dolf als pendant van deze politicke witruil het onderspit.

\section{3 .2 De reshuffling}

Aan de reshufing van de tarieven hechtte de LSV zeer. Door de tarieven van de zogenaamde vel-verdieners te verlagen en van de minder-verdieners te verhogen, zou een herverdeling van inkomens moeten worden bereikt. Een afstemming tussen de inkomsten van groepen van. specialisten is een politiek vraagstuk want hij word bepaald door machtsverhoudingen en. belangentegenstellingen (Glaser 1989a). Het is van oudsher een zware opgave voor de besturen van artsenorganisaties de tegenstellingen in de achterban te minimaliseren.

De oorsprong van de reshuffing lag in een beleidsmatig debat binnen de LSV dat in de Ledenvergadering en gesprekken met Wetenschappelike Verenigingen soms tot felle discussies leidde. Maar in het VPO zorgde de reshuffling voor weinig commotie. De verzekeraars en de ziekenfondsen steunden de ideeen en voorstellen hieromtrent, vooral toen een opbrengst van enkele tientallen miljoenen guldens waarschijnlijk werd geacht. Voor het overige vonden de partijen in het WPO de reshuffling een bijkomend voordeel. $\mathrm{Zij}$ leverde vrijwel geen verschil van mening op. De reshuffing vornde immers geen onderdeel vain het wensenpakket van de financiers. De VNZ deed de reshuffling zelfs af als een technische kwestie waarover weinig discussie nodig was. Daarmee erkenden de ziekenfondsen onvoldoende het politieke karakter van de overeenstemming. Juist door de mutatiepercentages voor kennisgeving aan te nemen, werd de LSV gesteund in de pogingen ongelijke inkomensverhoudingen te veranderen. Bovendien werd de reshuffling beschouwd als onderdeel van een pakket van afspraken dat alleen maar als geheel warde had, zodat ook de ziekenfondsen en verzekeraars verplicht waren aan de realisatie ervan bij te dragen. Deze welwillende, maar in zekere zin afstandelijke houding is ook typerend voor de overheid. WVC zag de voordelen van een herverdeling van inkomens wel, maar wenste zijn vingers niet te branden aan de implementatie.

Op deze manier werd een inherent politiek onderwerp gepresenteerd als een slechts nog uit te voeren agendapunt, ondanks de onheldere onderbouwing van de voorstellen. Hoewel de voorstellen tot forse tariefveranderingen zouden leiden, konden ze vrij geruisloos onderdeel worden wan een overeenkomst waama men de technische uitvoering ter hand moest nemen. Bij deze technische witwoering was de medewerking van het COTG onmisbaar, omdat de inpasbaarheid in de Wtg aan de orde kwam samen met de vraag of de reshuffling inkomenspolitiek wan aard was. Beide vraagstukken moesten naar de mening van thet COTG opgelost worden teneinde houdbare richtlijnen te kunnen ontwikkelen, waarbij uiteraard ook de relatio met de bestuande kostenrichtlijnen bekeken zou moeten worden.

Of de reshufflingswoorstellen van Van Aardenne wel zouden voldoen aan de vereisten van de Wtg was zeker niet de eerste zorg van de deelnemers aan het VPO toen zil daarmee instemden. En al zou dit een eerste zorg zijn geweest, de regels wan de Wtg verschaften hierover weinig duidelijkheid. Deze regels bezaten geen intrinsieke helderheid, maar behoefden interpretatie van gezaghebbende deskundigen. Bovendien had de weigering van WVC zich actief the bemoeien mel de implementatie van het VPA tot gevolg, dat de suggestie van inkomenspolitiek bij de tariefbesluiten moest worden voorkomen. Daardoor kregen de wettelijke regels ten aanzien van de inkomens van medisch specialisten (Wivb) plots relevantie ondanks het ontbreken van een actief inkomensbeleid van de owerheid op dat moment.

Door deze wettelijke context was de bemoeienis van het COTG van een andere aard dan bij de praktijkosten. De gevraagde expertise verschilde. Het COTG beklemtoonde in eerste 
instantie de overbodigheid van de reshuffling omdat deze voorstellen een omweg inhielden. Als het COTG op zijn tariefmhoudelijke inzichten was aangesproken en als doaran door anderen ruimte was gegeven, zou een reshuffing helemaal niet nodig zijn geweest, zo luidde het argument. Maar met mijwel vaststaande mutatiepercentages en cen grote eensgezindheid over de woorstellen werd een tariefinhoudelijke bijdrage van het COTG minder belangrijk. Het COTG was rawwelijks in staat de omvang van de tariefveranderingen als gevolg van de reshuffing mhoudelijk te bemvloeden. Onmiddelijk na het ondertekenen wan het VPA beklemtoonde het secretariaat van het COTG het belang wan een onderbouwing van de mutaties, nuar een transparante becijfering van de percentages waarmee de tarieven van de onder- en bovenverdieners zouden moeten muteren kwam niet tot stand. In het uiteindelike tariefverzoek van 1991 is sprake van gegevens wil verschillende bronnen waaronder de gewrakte Van Dienenquête, maar de percentages stonden al varaf de tussentijdse rapportage vam Van Aardente in juni 1989 vast. Een anderhalf jaar durende discussie had daar niets aan veranderd. Weliswaar gaf de LSV de Wetenschappelike Verenigingen de gelegenheid het voorstel am te passen op basis van gegronde gegevens, maar daarnee werd de bewislast slechts omgedraaid. Het was nu aan do medisch specialisten de onjuistheid van het voorstel aan te tonen. Dit konden zij niet, waarna ook de rechter in zijn oordeel de juistheid van de percentages van het voorstel aan het COTO ondersireepte.

Daar waar bij de besluitvorming over de praktijkkosten een normatieve bepaling van de kosten de aanzet tot een technocratische aanpak van het COTG vomde, was het bij de reshuffling dus de juridisch-technische kennis warop de bemoeienis van het COTG zich concentreerde. Deze technische kennis moest leiden tot een bepaalde vorm wan de tariefoesluiten die hen zouden immuniseren voor de gevolgen van juridische procedures, die ontevreden specialisten ongetwijfeld zouden instellen. Daarbij speelde de volgende tariefromule een belangrijke rol.

$$
\mathrm{K} \text { (osten) }+\mathrm{I}(\mathrm{nkomen})
$$

\section{W(erkbelasting)}

Zoals ik al eerder opmerkte, kreeg deze tariefformule de functie van vertalmiddel. Bij het maken van tariefafspraken redeneerden de onderhandelaars niet in termen van de tariefformule, mati $z i j$ kwamen tot besluiten over tariefaanpassingen waarover overeenstemming bestond. De vraag of deze afspraken juridisch-technisch ook uitgevoerd konden worden, kwam slechts in tweede instantie aan de orde. Bij de beantwoording wan deze vrág bood de tariefformule goede diensten omdat door de formule-technische opsplitsing aanpassingen van het turief mogelijk werden zonder dat elk onderdeel noodzakelijkerwijze eveneens veranderende. Het werd mogelijk de valkuil van het inkomensbeleid en de wellicht problematische verhouding met de bestaande kostenrichtlijnen te omzeilen door het voorstel van de reshufling alleen betrekking te laten hebben op het onderdeel werkbelasting (de noemer) en niet op het inkomens of kostendeel (de teller). Daarmee verdween in formele zin de relatie tussen het reshufflingsvoorstel en het inkomensbeleid alsmede de richtlijnen voor de kostenvergoeding. ${ }^{24}$

24 De ironie is dat de LSV tijtens de besluitworming over de praktikkosten bijzonder fel gekant was tegen een opsplitsing van thun tarieven. De belangerwereniging wilde veranderingen in onderdelen wan het tarief altijd in hum onderlinge samenhang beordelen. De reshuffling werd mogelijk juist door een opdeling wan tarieven warbij de onderdelen niet meer in hun gezamenlijkheid hoetden te veranderen. 
De besprekimgen tussen alle betrokkenen leidden overigens niet tot juridische zekerheid. Nooit kon de geruststelling worden gegeven dat de reshuffing mogelik zou zijn binnen de Wtg (of de Wivb). Zelfs de overtuiging dat de afschaffing van de Wivb de reshufling num baan zou geven - de woomammste reden voor druk op politici door leden van het WPO - werd later minder sterk. Dat er toch een voorstel aan het COTG gedaat werd, kwam door de plotselinge toezegging wan het secretariat van het COTG een toetsing an de bestaande richtlinen voldoende te achten en niewwe richlijnen niet meer noodzakelik te vinden. Deze mededeling had een paradoxaal. effect: de weg was wij woor uitvoening van de reshuffling maar de juridische onzekerheid nam alleen madr toe.

\subsubsection{De tweeslag}

Net als de reshuffling had de tweeslag geen tariefinhoudelije motivatie. Met de tweeslag werd liets anders beoogd dan juiste tarieven. De regeling moest er namelijk woor zorgen dat de centrale afspraken zoweel mogelijk gevolgd zouden worden door de individuele medisch specialisten. Terwijl verzekeraars en ziekenfondsen in het verleden vertrouwden op de disciplinerende macht van de LSV, besloten zij in het VPO tot andere prikkels die gehoorzaamheid wan de leden van de LSV moesten garanderen. In feite weigerden de betrokkenen de rol van de LSV als representatieve organisatie ter discussie te stellen en kozen zij ervoor aan de legitimiteit van de LSV weinig woorden vuil te maken. Daarvoor in de plaats trachtten zij met technische hulpmiddelen als "bonussen" en "penalty"-tarieven de te verwachten problemen met onwillige specialisten op te lossen.

Ook bij de tweeslag opende de tariefformule de weg nar een besluit dat paste binnen de Wig. Door viff kostenposten met betrekking tol de werkbelasting te formuleren konden nieuw veronderstelde verplichtingen woor specialisten ingevoerd worden. Hierdoor werd een onderscheid tussen 'willige' en 'niet-willige' artsen geïntroduceerd. De kunstmatigheid van deze constructie werd all in een vroeg stadium erkend door de ambtenaren van WVC. Zij werd formeel bevestigd in de uitspraak vam het $\mathrm{CBB}$ in mei 1990. Het bleek dat medisch specialisten al jaren werden betaald voor het doen wan handelingen die nu plotseling verplicht werden gesteld. De rechter ontdeed hiemee de politieke kern van de tweeslag van zijn verhullende technocratische vormgeving.

\section{3 .4 Verhullende technocratie}

Voor zowel de praktjkklosten, de reshuffing en de tweeslag werden technische oplossingen bedacht, ondanks de mogelijkheden die de kwesties boden tot een meer gepolitiseerde besluitvorming. Maar tijdens de discussies over de vormgeving van de besluiten was geen sprake van probleemoplossende interactie op basis van voor zich sprekende gegevens. Hiemee bevestigde de totstandkoming van tarieven voor medisch specialisten het verhullende karakter dal technocratische besluitvorming wak heef. De technische oplossingen kregen slechts kans door het bestaan van tijdelijke politiek-strategische verhoudingen binnen het netwerk van actoren. In de technocratische besluitworming kwamen sommige belangen sterker naar voren dan andere waardoor sommige actoren voordelen en andere actoren naclelen ervoeren. Deze conclusie komt overeen met de volgende typering van technocratische besluitvorming door Edelman:

"... (a) semantic space withm which rival groups deploy a conventionat set of tems and assumptions; but neither the language nor the formal adoption of a technical policy defines the antcome of the contention, which fuctuates with changes in the resources of the contenders." (1988: 54) 
Van een werkelijke depolitisering was geen sprake omdat de technische oplossingen de tijelijk heersende machtsverhoudingen reflecteerden.

\subsection{De hiërarchische interactie}

Onder hierarchie als middel voor conflictoplossing wordt verstaan "...(t)he unilateral power of one participant (or of a few participants) to determine the choices of all others. "Scharpf, 1989: 153). In tegenstelling tot het zoeken van oplossingen voor meningsversthillen door wederzijdse aanpassing via onderhandelingen en infomatieverwerking (technocratie) bestaat hiararchische beshitworming uit het eenzijdig nemen van bindende beslissingen voor anderen door wen daartoe bevoegd orgaan of persoon.

Uit bestuurskundig onderzoek is naar voren gekomen dat er sprake kan zijn van een contimuin van volledig verticaal to volledig horizontal bestuur (figuur 7.1). Volgens Hoekena (1984) kan de horizontalisering van bestuur doorschieten maar een situatie waarin de overheid niet meer in staat is zonder feitelijke instemming eenzijdig besluiten te nemen. Dit noemen Burkens en Stroink werkelijke horizontalisening van bestuur. Dat allerlei overleg voorafgaat aan de beslissing, is voor hen niet voldoende on te spreken van horizontalisering. Slechts als, formeel dan wel informeel, medebeslissingsrecht wordt verleend aan anderen dan de overheid komt horizontaal bestuur tot stand (1980: 747).

De instelling van hiërarchische relaties in de Wtg kwam voort uit de wens het primaat van de politiek te herstellen en de goedkeuring van tarieven los te koppelen van het daaraan woorafgande overleg. Voor het herstel van het primat van de politiek kreeg de overheid enkele mogelijkheden in handen: het goedkeuren van richtlinen en het geven van aanwijzingen aan het: COTG. Met deze instrumenten kon de overheid richting geven aan de ontwikkeling van de triefstmctur. Ten behoeve van een onafhankelijke goedkeuringsprocedure werd het COTG opgericht. Niet alleen mocht geen enkel tarief meer worden gehanteerd dat niet door het COTG was goedgekeurd, ook kon het COTG zelfstandig en eenzijdig tariefbesluiten nemen.

Figumr 7.1: Een continuüm van hiërarchisch bestuur

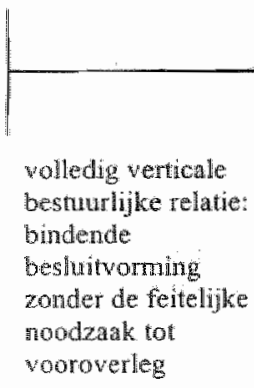

volledig horizontule besturitinge retatio: binderde beshortorming met de feitelijk noodzak tot instemming tijicens vootover lesig.

Het introduceren van verticale relaties gebeurde echter omzichtig. De regering benadnkte het overleg tussen aambieders en financiers als uitgangspunt van de besluitwoming ower tarieven. Hendriks sprak daarom dan ook over cen voorbereidingsfase warin tariefvoorstellen worden ontwikkeld en en beslissingsfase warin, "...gelet op de voorstellew en ecrst na het horen van partijer.." een besluit genomen kon worden. Slechts als het overleg op riets unthep zou het 
COTO een besluit zelfstandig kumnen nemen, matar ook dan slechis na overleg met partijen 23 Dat voorafgand aan de vaststelling van tarieven doo: het COTG overleg met de betrokkenen werd gevoerd, betekende volgens. Hendriks evenmin een negatie van het principe van overleg. ${ }^{26}$ Ondanks deze omzichtige formuleringen waren verdere aanpassingen noodzakelik omdat met name de VVD en het CDA weel kritiek hadden op de geringe betrokkenheid van actoren in de gezondheidszorg en omdat Veder-Smit concessies deed aan de betrokken belangenorganisaties die alsnog hun mening mochten geven over de nieuwe wet. De hiërarchische positie van het COTG werd gaandeweg bij het ontwerpen van de Wtg minder sterk. Zo resulteerde de Inspraaknota in de instelling van Kamers waarin de betrokken organisaties hun opvattingen over richtlijnen konden uiten. Bovendien ging het vaststellen van richtlijnen over wan de overheid naar het COTG, nog wel met de bevoegdheid van de overheid deze goed te keuren en aanwijzingen te geven.

Hoewel de overheid dus gedurende de totstandkoming van de Wtg in toenemende mate met cen vorm van horizontaal bestuur accoord ging, heeft de Wtg wel degelijk gezorgd voor een hiêrarchisering van relaties. De nadruk mag dan liggen op de verschiliende momenten van vooroverleg bij de totstandkoming van besluiten, hel algemeen ontbreken van de eis van overeenstemming maakt hiërarchische beslissingen mogelijk. Het onderlinge overleg over tarieven hoeft niet noodzakelijkerwijze te leiden tot overeenstemming omdat elke onderhandelende partij ook zelfstandig voorstellen kon doen aan het COTG. Consensus in het wooroverleg tussen hel COTG en betrokkenen is niet noodzakelijk. Het COTG kan eenzijdige besluiten nemen. Het advies wan het COTG over richtlijnen is evenmin bindend voor de overheid zodat ook daar zelfstandig besluiten genomen konden worden. Met andere woorden, feitelijke instemming tijdens het vooroverleg in verschillende fasen van het besluitvormingsproces is niet noodzakelijk. Hierdoor kenmerken de bestuurlijke relaties in de Wtg zich niet door voltedige horizontalisering, maar wel door een beperkte vorm van hièrarchisering.

De Wtg biedt de overheid en het COTG verschillende formele mogelijkheden bindende beslissingen over tarieven woor medisch specialisten te nemen. De hiërarchische mogelijkheden van het COTG zijn vooral gebaseerd op het verbod voor medisch specialisten een tarief bij een ziekenfonds of een verzekeraar in rekening te brengen dat niet is goedgekeurd of vastgesteld door het COTG. De overheid kan een aanwijzing aan het COTG sturen die vervolgens in richthinen moet worden omgezet. Diezelfde staatssecretaris kan weigeren hem voorgelegde richtijnvoorstellen goed te keuren. In beide situaties gaat het om de relatie COTG WVC. Het COTG kan richtlijnen ontwikkelen en deze opleggen aan de onderhandelende partijen. Hiervoor is weliswaar advies van Kamer $V$ nodig, maar dit advies is niet bindend. Het COTG kan voofstellen tot verandering van tariewen afkeuren en ook ambtshalve op basis van richtlijen tariefbesluiten nemen. Het forum van de hièrarchische interactie kan dus bestaan uit het COTG an WVC. Dit is volgens De Beus (1991) de context wan het bureaucratisch beheer. Het daarbij passende talgebruik is administratief-ambtelijk. Deze taal wordt gericht tot diegenen die geacht worden zich te houden aan administratieve regels. Tegelijk geeft administratiefambtelijke taal gezag an degene die het bezigt (Edelnan 1985).

25 Memorie van Toelichting, 1976-1977, 14182, nr. 3, p. 20-21

26 Menorie van Toelichting. 1976-1977, 14182, nr. 3, p. 20-21 


\subsubsection{Hërarchie in de daarvoor bestemde fora?}

De hierarchische interacties zijn weergegeven in tabel 7.3. Uit deze tabel walt ten eerste op to maken, dat het COTG regelmatig gebruk makkte wan zijn formele bevoegdheden tariefbesluten te nemen of richtlijnen vast te stellen in afwijking van de wins van (sommige van) de partijen. Ten weede maakte WVC op deze wijze geen gebruik van zijn hiorarchische positie. Beide richtijnvoorstellen van het COTG werden goedgakeurd en van de mogelijkheid om asmwijzittgen te versturen werd geen gebruik gemaakt. Sterker nog, WVC wilde niet toegeven aan de druk wan anderen wel gebruik te maken van de formele bevoegdheden. Zo gal Van Aardenne in juli 1989 aan Dees te kennen dat naar de mening van het VPO een actieve rol van de overheid onmisbaar was, waarbij gedach werd aan mirusteriele aanwijzingen aan hot CorG. ${ }^{27} \mathrm{Het}$ COTG achtte het eveneens zowel juridisch als beleidsmatig verstandig voor de overheid aanwijzingen te geven zolang de Wivb van kracht was. 28 ook de Landsadvocaat achte met name de reshuffling niet mogelik als niet en anwijzing op grond van artikel 15 Wtg zou worden gegeven. ${ }^{29}$ Maar WVC gaf geen gehoor aan de wens van de partjen noch aan de adviezen wan het COTG en de Landsadvocaat.

\subsubsection{WVC: meerderheidsbeslissingen en vooronderstelde unanimiteit}

Verschillende auteurs hebben aangegeven dat hierarchische besluitvorming in een multi-actor setting zowel theoretisch als practisch weing waarschijnlijk is (Scharpf 1989, Mayntz en Scharpf 1995). Aan hiërarchische besluiten, zo blijkt uit allerlei onderzoek, gaan vak onderinandelingsprocessen vooraf. Bovendien openen wettelijke kaders dikwijls de mogelijkheid tot overleg voordat hièrarchisch besloten word. Dit zogenamde horizontaal bestuur ligt vaak wettelijk verankerd, hetgeen ook het geval is bij de Wtg.

Deze algemene theoretische bevinding is van toepassing op de besluitvorming over tarieven voor medisch specialisten. Van hïrarchie in de vorm van het unilateraal determineren van de keuze van anderen. was bij de besluitvorming door WVC nauwelijks sprake. Bij de goedkeuring van de richtlijnen woor de praktijkkosten en de tweeslag leek de overheid zich te beroepen op zijn hërarchische positie, maar zij liet zich leiden door overeenstemming onder partijen. Bij de goedkeuring van de kostenrichtlijnen was reeds een meerderheid gecreẻerd door de zikenfondsen, verzekeraars en het COTG. In plaats van een beslissing op te leggen, sloot WVC zich aan bij een op dat moment overheersende mening. Bij de tweeslag was zelfs sprake van veronderstelde unanimiteit. WVC ging ervan wit dat richtlinen in overleg met het COTG tot stand zouden komen, warna de overheid nog slechts moest goedkenren. Niet de cigen beoordeling stond daarbij woorop, maar de instemming van het COTO.

27 Brief VPO aan Dees, 21 juli 1989

28 COTG, Concept, 22 augustus 1989

29 Adves Landsadvocaal, 7 februari 1990 
praktijk- tweeslag reshuffling

kosten

COTG stelt tarieven vast

a. In overeenstemming met voorstel vam partijen

b. in afwijking van een voorstel wan partijen

\begin{tabular}{rll}
- & - & + \\
+ & + & - \\
\hline
\end{tabular}

COTG legt partijen richtlijn op

a. ha positief advies van Kamer $V$

b. na verdeeld advies van Kamer $V$

c. na negatief advies van Kamer $V$

n. $\mathrm{W} . \mathrm{t}$.

WVC keurt richtlijien

D.V.t.

a. goed

b. af

WVC geeft een anwijzing aan het COTG

Toelichting een + geeft aan dat bij de betreffende casus sprake was van een handeling die in de linker kolom staat aangegeven. Een voorbeeld: bij de praktijkkosten legde het COTG een richtijn voor na een verdeeld advies van Kumer $V$, en bij de tweeslag na een negatief advies. Bij de reshuffling werd geen richtlijn ontwikkeld.

\subsubsection{WVC: toenemende conditionering}

De overheid intervenieerde dus nauwelijks op basis van zijn formeel-hiërarchische positie zonder voorafgaande afstemming, maar er was wel sprake van toenemende conditionering door middel van prikkels. De overheid expliciteerde deze prikkels in haar informatio aan het overleg over tarieven. Hièrarchie trad dus wel op, maar niet in de vorm van volledig verticaal bestuur.

In het begin van 1986 maakte WVC door middel van een brief aan het COTG reeds duidelijk dat de overheid op termijn een besparing van veertig miljoen gulden op de vergoeding voor praktijkkosten verwachtte. Dit was geen aanwijzing in formele zin. Het geven van anwwijzingen paste steeds minder in de strategie wan de overheid. Desalniettemin nam het COTG de wens van de overheid over. Een andere vroege vorm van conditionering bestond uil het aangeven van de noodzaak tot bezuinigingen via Lamers. Deze zette de organisaties $t$ ijdens zijn bemiddeling het mes op de keel door te laten weten dat "de politiek" eiste dat er "een bedrag op tafel werd gelegd. "30 WVC leek even verder te willen gaan dan deze conditionering toen de bemiddeling door Lamers niet het gewenste resultaat had. Een aanwijzing aan het COTG werd voor WVC een reele handelingsoptie. Het COTG kreeg evenwel de kans het werk af te maken binnen de condities die de overheid stelde. Deze condities expliciteerde de staatssecretaris wan Volksgezondheid in zijn brief aan de Tweede Kamer in januari 1988. Daarin nam hij afscheid wan degressieve tarieven als oplossing voor de specialistenproblemen. Bovendien gold het Generaal Akkoord niet meer en de verlaging van de vergoedingen voor praktijkkosten zon doorgang moeten vinden.

De conditionering van het overleg over tarieven kreeg nog duidelijker vorm bij het begin van het VPO. Expliciet eiste WVC van het hemieuwde overleg een beter resultaat dan wat de besluiten over de praktijkkosten beloofden. Om deze voonwaarde kracht bij te zetten steunde 
WVC het COTG in zijn wens de richthjnen voor de vergoeding van praktijkkosten te handhaven zodat deze op elk moment weer konden worden uitgevoerd. Ook legde WVC de onderhandelaars een tijdslimiet op. Binnen maximaal een hall jaar zou een resultaat bekend moeten zijn, dat vervolgens zelfstandig beoordeeld zou worden door het kabinet. Een wweede vorm van conditionering bestond uit de weigering van de overheid de inkomenswetgeving (Wivb) af te schaffen. Daamee kon de overheid een verlaging van de inkomens van medisch specialisten bewerkstelligen als het VPO of de implementatie van de afspraken onverhoopt mocht mishukken. Samen met het in stand houden van de kostenrichtlinhen moest de dreiging van de Wivb zorgen voor een "automatische piloot".31 In werkelijkheid was de regulering van de inkomens van de artsen al een verlaten spoor.

Als middel tot sturing formuleerde WVC dus enkele condities. Deze hadden betrekking op zowel de financiële eisen aan de deelnemers aan het tarievenoverleg als achter de hand gehouden formele, hiërarchische bewoegdheden. De bewering van WVC van deze op elk moment gebruik te kunnen maken zorgde voor een voortdurende politieke dreiging voor het tarievenoverleg.

\subsubsection{COTG: eigen verantwoordelijkheid}

Evenals de overheid bezat het COTG formele middelen andere actoren eenzijdig beslissingen op te leggen. En evenals de overheid participeerde het COTG uitgebreid in overleg voorafgaand aan de formele besluitvorming. Voor een groot deel was dit overleg formeel geinstitutionaliseerd. De omstandige discussies over de hoogte van de kostenvergoeding speelden zich vooral af in Kamer $V$ naar aanleiding van richtlijnwoorstellen. In deze zin was er sprake van geformaliseerd horizontaal bestuur. Voor een ander deel was het vooroverleg veel minder geformaliseerd. Daarbij moet met name gedacht worden aan de afstemming tussen VNZ en COTG die eindigde in het voorstel om nog slechts de beroepskosten van medisch specialisten te gaan vergoeden via het zelfstandig te declareren tarief. Voorafgaand aan de fomele besluitvorming over de reshuffing en de tweeslag nam het COTG deel aan overleg waarin het adviseerde over de formulering van tariefverzoeken. Dit overleg had bijwoorbeeld plaats binnen het TOVPO (Technisch Overleg VPO) waarin de vertegenwoordigers van het secretariaat van het COTG benadrukten dat zij wel technisch advies, maar geen beleidsmatige instemming konden geven.

Hieruit blijkt het verschil tussen de houding van de overheid en die van het COTG. De uitkomsten van vooroverleg garandeerden geenszins dat het COTG zich verplicht voelde ze te volgen bij de formele besluitvoming. In tegenstelling tot de overheid week de besluitvoming door het COTG regelmatig af van de overheersende standpunten in het voorowerleg. Het besluit over de hoogte van de vergoeding voor de praktijkkosten week af van de wensen wan zowel de LSV als de financiers, mar ook van de uitkomsticn van het Kancer V overleg. Dil was eweneens het geval bij de besluitvorming over de tweeslag. Slechts de reshuming kreeg vom overeenkonstig de wensen van de partijen. Bij de besluitvorming over de richthinen ontstond een identieke situatie: zowel bij de prakijkkosten als bij de weeslag verschilden partijen en het COTG van mening en legde het COTG een besluit op. Bij de besluitvorming over de reshuffling werden geen richtlijnen ontwikkeld (zie tabel 7.3).

31 WVC, nota aan Dees, 18 december 1989 


\subsubsection{Hitrarchische argumentatie in beperkte mate}

Bif de totstandkoming van tarieven voor medisch specialisten bleek dus dat in de daarvoor bestende fora slechts in beperkte mate sprake was van hierarchische interactie. De argumentatie van WVC bij het nemen van besluiten op basis van formele bevoegdheden verwees naar consensus tussen werschillende partijen. Wel conditioneerde de overheid het tarievenowerleg. Het COTG maakte vaker dan de owerheid gebruik van de mogelijkeden tot bureaturatisch beheer waarbij men verwees naar de eigen onafhankelijkheid.

\subsection{De onderhandelingsinteractie}

Van onderhandelingen is sprake als woorden gebruikt worden die een wens tot ruil aangeven.

'Onderhandeling is niet meer of minder dan communicatie in de vorm: 'als jij dit doet, dam doe ik dat" waarbij de actoren irachen een uitwisselingsformule te vinden die voor beide partijen relatief aantrekkelijk is." (Godfroij, 1981: 87)

Onderhandelingen vinden meestal in beslotenheid plaats. Een reactie van een breder publiek word vermeden, mede omdat een publiek debat over visies en waarden wan de onderhandelende partijen de onderhandelingen kan verstoren. De doelstelling is namelijk het bewerkstelligen wan een ruil (quid pro quo) en niet het overtuigen van de ander van de juistheid var de eigen witgangspunten. Integendeel, een voorwaarde woor onderhandelen is dat achterliggende waarden niet verenigbaar zijn (Edelman, 1985: 146).

De quid pro quo formulering schiet als enige indicator wan het voorkomen van onderhandelingsacties tekort als het gehele onderhandelingsproces in kaart moet worden gebracht. Theoretische overeenstemming over het proceskarakter van onderhandelingen heel geleid tot brede instemming met het algemene procesmodel van onderhandelen van Susskind en Cruikshank (1987; 93 e.v.). Daarin worden een antal fasen onderscheiden. Bij elke fase hoort een bepaalde organisatie van de interactie (zie tabel 7.4). In de eerste fase wordt de bereidheid tot onderhandelen vastgesteld en wordt de agenda bepaald. Tevens wordt een protocol ontwikkeld. Er vindt met andere woorden een inventarisatie plaats en de onderhandelaars worden het eens over de procedurele afspraken. Men regelt de logistiek van het onderhandelingsproces (Voogd en Woltjer, 1995: 16). In de tweede fase wordt onderhandeld, niet alleen inhoudelijk over de vastgelegde agendapunten, maar ook over het mogelijk verhandelen van agendapunten. In geval van succesvolle onderhandelingen komt een overeenkomst tot stand die door iedereen wordt ondertekend. In de laatste fase worden de afspraken geformaliseerd, hetgeen wil zeggen dat de onderhandelingsutkomsten in formele besluiten door daartoe bevoegde personen of organisaties worden ongezet. Tenslotte zal op de nalewing worden toegezien en worden wellicht mogelijkheden voor nieuwe onderhandelingen geschapen.

Terwijl tijdens het ontwerpen van de Wtg uitgebreide discussies plaatsvonden over de technocratische, juridische en hï̈rarchische elementen van de Wtg, waren de bepalingen over de onderhandelingen nauwelijks onderwerp van debat. De organisatie daarvan werd overgelaten aan de onderhandelende partijen. In deze zin bood de Wtg voor onderhandelingen vooral een formeel-institutionele kader zonder voorschrijvende werking. De opstellers van de wet verwachtten dat onderhandelingen zich zouden voordoen tussen representatieve organisaties. Bovendien werd vastgelegd wie mocht onderhandelen. Door het aanwijzen van representatieve organisaties wend bepaald wie plaats zou mogen nemen aan de onderhandelingstafel. Hiemee stond het fortm voor onderhandelingen vast. 


\begin{tabular}{l|l}
\hline fase & activiteiten \\
\hline de preonderhandelingsfase & $\begin{array}{l}\text { beginnen } \\
\text { selectie van de deelnemers } \\
\text { het opstellen van een protocol } \\
\text { het formuleren wan een agenda }\end{array}$ \\
\hline de onderhandelingsfase & $\begin{array}{l}\text { zoetren van wederzijdse wingt } \\
\text { het opstellen wan cen lijst wan uitkomsten } \\
\text { het wervardigen van cen geschreven overeenkomst } \\
\text { het ontwerp wan bindende bepalingen } \\
\text { de finale ratificatie }\end{array}$ \\
\hline de postonderhandelingsfase & $\begin{array}{l}\text { de formalisatie van de uitkomsten } \\
\text { het monitoren van de implementatie } \\
\text { het creeren van mogelijkheden voor nieuwe } \\
\text { onderhandelingen }\end{array}$ \\
\hline
\end{tabular}

Bron: Susskind en Cnikshank (1987)

\subsubsection{Onderhandelingen binnen het forum}

Interacties die georganiseerd werden door onderhandelingsargumenten deden zich niet alleen voor in het forum dat werd omschreven in de Wtg, maar tevens op andere plaatsen. Zo werd niet alleen door representatieve organisaties onderhandeld maar bleek het ook noodzakelijk voor de deelnemers van het VPO met de overheid en het COTG te onderhandelen over de implenentatie wan de onderhandelingsresultaten. Bovendien was het onderhandelingsfonm veranderlijk, wardoor sprake was van fora voor onderhandelingen. In de hier volgende paragrafen ga ik nader in op de onderhandelingen binnen deze fora. In paragraaf 7.5 .2 komen de onderhandelingen buiten deze fora aan de orde.

\subsubsection{Het veranderlijke forwn}

Tijdens de beshuitworming over de tarieven woor medisch specilatisten tussen 1986 en 1992 veranderde het fortum war onderhandelingen plaatswonden (zie tabel 7.5). Ten eerste ontslond een breed onderhandelingsplatform warin ziekenfondsen, particuliere verzckeraars, specialisten en ziekenhuizen gelijktijdig participeerden. Daarnaast kregen de onderhandelaats te maken met onathankelijke voorzitters.

De onderhandelingen over tarieven yoor medisch specialisten werden $10 t 1986$ in onderhandelingscommissies gevoerd warin de ziekenfondsen, particuliere verzekeraars en de medisch specialisten participeerden. Er was sprake van gescheiden onderhandelingen: er was een commissie voor de particuliere tarieven met deelname van het KLOZ, KPZ en de LSV, en én voor de ziekenfondstarieven met de VNZ en de LSV. Tijdens de besluitvorming over de tarieven tussen 1986 en 1992 bleef van deze organisatiewormen weing over. 


\begin{tabular}{|c|c|c|c|}
\hline & periode & fortum & organisaties \\
\hline 1 & medio 1986 -maart 1987 & $\begin{array}{l}\text { Hede-owe leg } \\
\text { Cie Wijze mannen } \\
\text { Bestuulijk overleg } \\
\text { (Onderhandelingscom-missie } \\
\text { ISV-KLOZKCP) }\end{array}$ & $\begin{array}{l}\text { VNZ-LSV } \\
\text { LSV-KLOZKPZ }\end{array}$ \\
\hline 2 & mei 1987 -jursi 1987 & informeal owelleg & VNZ-LSV \\
\hline 3 & jull 1987-december 1987 & bermiddeling Lamers & VNZLLSV \\
\hline 4 & juli 1988-september 1988 & $\begin{array}{l}\text { informeel overleg } \\
\text { bemiddeling Dekker }\end{array}$ & VNZ-LSW-KLOZ-NZT \\
\hline 5 & $\begin{array}{l}\text { novermber 1988-december } \\
1989\end{array}$ & $\begin{array}{l}\text { vooroverleg } \\
\text { VPO }\end{array}$ & VNZ-LSV-KLOZ-NZT-KPZ \\
\hline
\end{tabular}

De onderhandelingen vonden in eerste instantie voomamelijk platis tussen de LSV en de VNZ. Daaraan ging een periode vooraf waarin moest worden vastgesteld of onderhandelingen zinvol zouden zijn en hoe de agenda enut zou moeten zien. Daartoe werd in 1986 eerst een Commissie van Wijze Mannen ingesteld waarna bestuurlijk overleg volgde. Daarna kwam het spel van bod en tegenbod tot ontwikkeling. De bepaling van de zinvolheid van onderhandelen, het opstellen van een agenda, gevolgd door daadwerkelijke onderhandelingen als niet duidelijk van elkaar te onderscheiden delen van het onderhandelingsproces deden zich ook voor in de periode medjo 1987-december 1987. Na een korte vergeefse informele poging van vertegenwoordigers van VNZ en LSV kwamen onder druk van de overheid nieuwe onderhandelingen op gang. Het grote verschil met de voorgaande periode was de betrokkenheid van een derde partij in de vorm van een bemiddelar. Dit had twee belangrijke gevolgen. Ten eerste kreeg het overleg tussen VNZ en LSV een onafhankelijke voorzitter die op zoek moest gaan naar gemeenschappelijke witgangspunten. Ten tweede ontstond een directe verbinding met de overheid omdat de bemiddelaar de overheild op de hoogte moest brengen van de voortgang van de onderhandelingen. Daarbij probeerden de bemiddelaars de uitkomsten in te passen in het bestaande overheidsbeleid.

De praktijk van onderhandelingen onder leiding van een onafhankelijk voorzitter met verantwoording aan de staatssecretaris van WVC werd daama voortgezet. In de late zoner van 1988 zou Dekker proberen een onderhandelingsresultat te bereiken; het VPO werd voorgezeten door Van Aardenne. Ook het VPO werd voorafgegaan door een inventarisatie van meningen en wensen wan de betrokkenen. Met ingang van de bemiddeling door Dekker breidde het aantal deolnemers zich uit. Van bilaterale onderhandelingen zoals in 1986-1987 was geen sprake meer. Het KLOZ (en darmee de KPZ) maar ook de NZr kreeg een plaats aan de onderhandelingstafel. Uiteindelijk culmineerde dit in een Vijf-partijen Overleg dat de separate onderhandelingscommissies verving. 


\subsubsection{Ferschillen in onderhandelingen}

In overeensterming met het procesmodel van Susskind en Cruikshank zal ik her de onderhandelingsinteracties binnen de bovenbeschreven for beschrijwen aan de hand van de onderdelen wan het gehele onderhandelingsproces. De quid pro quo-argumentatie is uiterard herkenbaar bij de onderhandelingen zelf, maar interacties en de daarbij behorende argumentatio vonden ook voor en na de eigenlijke onderhandelingen plaats. Een analyse van onderhandelingen is dus onvolledig als de interacties ervoor en ema niet worden meegenomen. War vonden deze interacties plaats (de fora van de pre- en postonderhandelingsfase) en welke argumenten werden daar gehanteerd? Dit zijn wragen die ook beantwoord dienen te worden bij een analyse van onderhandelingsacties.

\section{De preonderhandelingsfase}

Kenmerkend voor de onderhandelingen over tarieven voor medisch specialisten was dat het onderhandelingsproces telkens opnieuw moest worden opgestart. Ten behoeve van een begiw waren gesprekken nodig tussen vertegenwoordigers om te onderzoeken of een basis voor nieuwe onderhandelingen aanwezig was. Als gevolg van het ontbreken van wettelijk geregelde iteratieve onderhandelingsprocedure kwamen deze gesprekken afhankelijk van de bestaande situatie tot stand. Het was nooit te voorspellen wie zich geroepen voelde vastgelopen onderhandelingen weer op gang te helpen. Fomele besturders, maar ook invloedrije arisen, ziekenfondsbestuurders en politici konden een - soms - onverwachte rol spelen. Voor iedere potentiele deelnemer stond bij cen nieuw begin de vraag centraal of het in het eigen voordeel was opnieuw te participeren.

Evenals de start was de bepaling van de deelnemers situatiemafhankelijk. De onderhandelingen begonnen tussen de VNZ en de LSV, maar het aantal deetnemers breidde zich allengs uit met het VPO als uiteindelijke resultat. Ondanks deze veranderingen leverde de vaag over de deemame weinig onenigheid op, en kwam het zelden tot uitgebreide discussies. Alleen de arwezigheid van het KLOZ bij de besprekingen over de kostenvergoeding tussen VNZ en LSV en de rol van de overheid bij het VPO waren reden tot enige discussie.

De onderhandelingen werden gestructureerd met behulp van eer prorocol. Bij de argumenten voor een protocol speelde de externe functie hiervan een grote rol. De onderhandelaars konden hiermee verantwoording afleggen zonder meteen de inhoudelijke stand van zaken door te hoeven geven. Dat gold voor de relatie met de achterban, maar ook voot de relatie met de overheid die de onderhandelingen ging conditioneren. De overheid was in vergelijking met de eigen achterban wel strenger. Afwijkingen wan het protocol mocsien beter worden verantwoord, waardoor het protocol steeds strikter werd.

Voordat over de praktijkosten kon worden onderhandeld moesten LSV en VNZ het eens worden over de agenda. Daartoe leverden de partijen afwijkende lijstjes met wensen in. Hierdoor werd ook de agenda al vroegtijdig onderwerp van onderhandelen. Daarbij werd de bereidheid mee te doen afhankeijk gesteld wan de inhoud van de agenda. De omvang van de agenda was een belangrijk verschil tussen de onderhandelingen over de praktijkkostenvergoeding en hed VPO. De agenda bij het kostenoverleg was beperkt tot de hoogte van de vergoeding, hoe deze moest worden berekend, de relatie met de besluitvorming in het COTG en het herstel van de medewerkersovereenkomst. De agenda van het VPO bood meer mogelijkheden.

\section{De onderhandelingsfase}

De onderhandelingen in de casussen verschilden in aanzienlijke mate van elkaar. Ten eerste contrasteerden de besprekingen over de tweeslag en de reshuffing met de harde confrontalies in de bijeenkomsten tussen VNZ en LSV in 1986 en 1987. Als gewolg van de tegenstellingen leidden gesprekken over de kostemvergoeding niet tot overeenstemming. Onderhandelingen 
werden afgebroken. Dit was niet het geval bij de reshuffing en de fweeslag. Sterker nog, van onderhandelingen kon nauweliks gesproken worden. Beide arspraken fungeerden voorall als onderdeel varl een omvangrijk geheel van besluiten waarover overeenstemming kon worden bereikt. In tegenstelling tot bij de praktikkosten ging men bij het VPO wel over in een postonderhandelingsfase. Er was met andere woorden sprake van een volledige cyclus, terwijl de besluitvoming over de hoogte van de kostenvergoeding zich afspeelde in een altematief circuit (COTG). Ten tweede verschilde de rol var de bemiddelaars. Deze verschillen in onderhandelingen tussen de casussen worden hieronder toegelicht.

De herhaude onderhandelingen over de hoogte van praktijkkosten liepen op een mislukking uif. Tijdens de eerste ronde van onderhandelingen tussen VNZ en LSV rond januari 1987 stond de hoogte van de vergoeding voor praktijkkosten centraal. Het verschil in wensen makkte een compromis op korte termijn niet mogelik. Onder leiding van Lamers ontstond een iets andere situatie. Het aantal onderwerpen van overleg breidde zich uit. Naast de hoogte van de kostenvergoeding werd ook gesproken over de manier waarop de hoogte van de kosten kon worden vastgesteld (het accountantsonderzoek met de daarbij behorende tijdsplanning) en hei opstellen wan een nieuwe overeenkomst woor ziekenfondsen en medisch specialisten. Bovendien hadden de onderhandelingen onder Lamers niet alleen betrekking op de hoogte van de kostenvergoeding en hoe deze vastgesteld zou moeten worden, maar ook op de procedure van de besluitvorming.

De voortdurende dreiging van vertrek van één van de partijen uit de onderhandelingen naar het COTG als alternatieve handelingsoptie maakte de onderhandelingen over de kostenvergoeding breckbaar. De combinatie van het COTG als alternatief voor onderlinge onderhandelingen en de lange-temijn voorstellen van de LSV zorgde voor onderhandelingsinteracties warin ontwijking met betrekking tot een besluit over de hoogte wan de kostenvergoeding de boventoon voercle.

Het VPO had een meer uitgebreide agenda dan het overleg over de praktijkkosten. Op basis van de hijst van onderwerpen die Van Aardenne als bemiddelar had samengesteld kon de gedachte post watten, dat de uikomst van de onderhandelingen een 'package deal' zou moeten zijn. Een meerwoudige ruil behoorde ru tot de mogelijkheden. Het onderhandelingskarakter van het VPO als geheel is evenwel moeilik herkenbaar bij zowel de tweeslag als bij de reshuffing. Bij de reshuffling ontbrak in belangrijke mate een "mixed-motive" situatie. In een dergelijke situatie is men afhankelijk van elkar maar zijn de doelstellingen tegengesteld. Onderhandelingen zijn dan het onvermijdelijke gevolg. De ziekenfondsen en de ziektekostenverzekeraars hechtten echter weel minder aan de reshuffling dan de LSV waardoor de afhankelijkheid enzijdiger werd. Bovendien konden zij met de voorstellen voor de reshuffing goed loven.

De besprckingen over de weeslag kumen op hun beurt als transformatief worden getypeend hetgeen de veranderingen van een onderwerp van onderhandeling aangeeft (Putmam, 1994: 339). Begonner werd met gedachten over een bonus voor meewerkende artsen, men eindigde met en technisch gecompliceerd besluit over een tweeshg in tarieven. Gedurende deze ontwilkeling kwamen vragen aan de orde die men zich van te voren niet had gesteld. Over de tweeslag was wel meer onenigheid dan over de reshuffling. Een laag tarief was namelijk voor veel specialisten nadelig. Bovendien verschilde men van mening over de keuze van twee tarieven of éen tariel en een bonus, en over de contractuele implicaties. Maar ook over de tweeslag waren de deelnemers het vrij snel eens; de totstandkoming wan het besluit had meer weg van een zoektocht nat en juiste vormgeving dan van onderhandelingen tussen partijen met verschillende wensen. In overeenstemning met het meer integratieve karakter van de besprekingen in het VPO kenmerkten de discussies over de tweeslag en de reshuffing zich door een gerichtheid op de mogelijkheden on afspraken over deze wwee punten af te ruilen met afspraken over andere zaken. 
Evenals het karakter wan de onderhandelingen verschilde de rol wan de bewiddwar. Door een bepaalde rolopvatting en -invulling heef een bemiddelatar een grote invloed op de onderhandelingen. Volgens de onderhandelingstheorie kan een bemiddelaar te werk gaan als iemand die goede omstandigheden creeer (een "facilitator'), maar ook als een arbifer die nietbindende uitspraken doet. Tussen deze uitersten liggen andere invahingen (Susskind en Cruikshank. 1987: 150 e.v.). Een vergelijking tussen Lamers en Van Aardenne leid tot de conclusie dat Van Aardenne meer neigde nar het voorleggen van lijsten met resulaten dan Lamers. De "trowvaille van Van Aardenne' was hiervoor illustratief. Door zijn tussentidse overeenkomst gaf Van Aardenne het uiteindelijke VPA voortijdig vorm wat in de continuteit in het voorstel to de reshuffling tot uiting kwam.

Waar de conventionele onderhandelingsliteratuur namwelijks oog voor heef, is de situationele context van de onderhandelingen. Zo wordt over het algemeen de rolopvatting err invulling wan de bemiddelaar nauwelijks verbonden aan de omgeving warin hij zin werk moet doen. In het geval van Lamers, maar meer nog in het geval van Van Aardene ging het niet om een neutrale bemiddelaar, maar om een door de politiek gecontroleerde agent. Het functioneren van de bemiddelaar werd in belangrijke mate bepaald door de eisen die zowel de politioke partijen als bewindslieden stelden. Was bij Lamers de politieke controle nog nauwelijks openbaar, over de structurering van het VPO werd verschillende keren in de Tweede Kamer gesproken. De door Van Aardenne gekozen rol als beniddelaar had daarom munder te maken met zijn persoonlijke keuze voor een bepaalde aanpak dan met de politiek-maatschappelijke wens tot affectieve afspraken op de korte temijn.

\section{De postonderhandelingsfase}

In de onderhandelingsliteratum komt het negeren van het complexe karakter van de postonderhandelingstase naar voren in de omschrijving ervan als een technisch implementatieproces (Voogd \& Wolljer 1995, Susskind \& Cruikshark 1987). Door te weinig aandachi te schenken aan de mogelijkheden en moellijkheden van de formalisatie van de onderhandelingsuitkomsten wordt gesuggereerd dat aan de onderhandelingen geen grenzen worden gesteld. Men negeert ten eerste het tegelijkertijd voorkomen van verschillende conflictoplossingsmechanismen en ten tweede de competitieve relatie tussen deze mechanismen. Dat zijn belangrijke tekortkomingen, zeker als het onderhandelingen botreft die plats vinden in een omgeving met formele instituties.

De besluitvoming over de tweeslag en de reshuffling liet onderhandelingen zien na het bereiken wan een compromis. Er moest onderhandeld worden over de omzetting hiervan in formele besluiten. Actoren die niet hadden geparticipeerd (WVC en COTG) bleken andere opvaltingen over deze omzetting te liebben dan het VPO zelf. In de implementatiefase moest vooral worden onderhandeld over de verantwoordelijkheden van de overheid en het COTG. Als gevolg van de combinatie van juridische onzekerheid en de noodzaak van waterdichte tariefbesluiten ontstonden uitgebreide discussies over de rol wan WVC en COTG. Het VPO stelde zich op het standpunt dat de overheid de formele bevoegdheden moest anwenden tencinde de besluithoming over de voorstellen van het VPO te versnellen. Het VPO gaf verschillende keren aan niet in te kunnen staan voor een succesvolle implementatic van het VPA als de overheid bleef weigeren bepalde maatregelen te nemen. De overheid zou tevens hel COTO moeten disciplineren. WVC deed kleme concessies. Stalatssecretaris Simons probeende door informele gesprekken met de voorzitter het COTG een soepeler standpunt in te laten memen. Tevens liet WVC doorschemeren dat de Wivb ingetrokken zou kunnen worden. Tegelijkertijd weigerde WVC echter van formele handelingsopties gebruik te maken en bleef men schemen met inkomenswetgeving, hoewel die al door de andere ministeries als afgedaan werd beschouwd. Het gevolg was dat het VPO aangewezen raakte op het COTG. Het COTG op zijn beurt moest in de ogen van het VPO meer betrokkenheid tonen bij de resultaten van hun inspanningen. Zich 
ontirckken aan de brede maatschappelijke instemming paste volgens het VPO niet. Als de partijen de voorschriften van de Wtg zouden volgen, luidde het weerwoord, kon het COTG zijn werk doen. Het COTG wilde meewerken als de juridische houdbaarheid van de voorstellen gegarandeerd was. Tevens benadrukte het COTG dat de deemame aan het technisch overleg (het TOVPOJ in geen geval beleidsmatige instemming betekende.

Het scherpst kwamen de onderhandelingen over de rol wan het COTG aan het lich toen het voorbestaan wan de richtijnen woor de verlaging van de praktijkkostenvergoeding aan de orde werd gesteld. De belangrijkste doelstelling van de LSV bij de deelname aan het VPO was deze richtlijnen in te laten trekken. Maar de belofte van de owerheid de besluiten over de kostenvergoeding in geval wan een gunstig VPO-resultaat niet uit te voeren bleek niet garant te staan voor het intrekken van de richilijnen door het COTG. Er vond een incomplete ruil plaats. De verlagingen van de kostenvergoeding gingen weliswaar niet door, maar de richtlijnen bleven bestaan. Het COTG was bereid tot concessies bij de uitwerking van enkele onderdelen van het VPA, mar een inruil van de formele besluitvorming over de kostenvergoeding was te veel gevraagd. Bij de tweeslag kostte het de deelnemers axn het VPO minder moeite te voldoen aan de voorwarden van het COTG. Het bedenken van extra kostenposten ter rechtvaardiging van het verschil tussen de twee tarieven gebourde vrij snel. Bij de reshuffling was de tegenstelling tussen COTG en VPO groter. De veelwuldige interacties leidden witeindelijk tot een ruil. Het COTG liet onder meer na een interventie door de staatssecretaris de aanvankelijk strikte houding varen. Na eersit de eis tot een aanwijzing te hebben laten vallen, legde het COTG tenslotte de verantwoordelijkheid voor de vormgeving van de besluiten in handen van het VPO.

\subsubsection{Onderhandelingen buiten de fora}

In de vorige paragraaf is al aangegeven dat onderhandelingen ook voorkwamen tijdens de postonderhandelingsfase. Daarmee is tevens duidelijk geworden dat onderhandelingen niet slechts werden gevoerd tussen de representatieve organisaties. Tijdens de formalisatie van de onderhandelingsresultaten dwongen de hoge eisen aan de tariefbesluiten sommige actoren tot een herbeoordeling van de eigen rol waarbij concessies onvermijdelijk waren. Daarnaast vonden nog meer onderhandelingen buiten de daarvoor bestemde fora plaats en wel in processen van ruil tussen de overheid en de representatieve organisaties. Ofschoon. WVC naar distantie streefde, bleck men verscheidene keren bereid uitkomsten wan matschappelijk overleg uit te ruilen teger de formeel tot stand gekomen besluiten, of besluitvorming uit te stellen teneinde de representatieve organisaties de lijd te gever zelf een besluit tot stand te brengen. Ondanks de goede vooruitzichten van formele besluiten kon de overheid op kritieke momenten de wens to nieuw overleg niet weerstan. Dat matschappelijke organisaties veronderstelden dat zij met bewindslicten afspraken over tarieven voor medisch specialister konden maken was niet zo wreend. Tijdens de jaren tachtig waren onderlinge besprekingen tussen bewindslieden en de LSV en afspraken over zaken waarbij eigenlijk de Wtg moest worden gevolgd niet ongewoon. Het meest aansprekende voorbeeld, het Generaal Akkoord, werd in 1984 gesloten en bevatte onder andere afspraken over tarieven warvoor de betrokkenheid van thet KLOZ wettelijk was vereist.

Dat de overheid in onderhandelingen met de belangenorganisaties was verwikkeld, kwam bij de bemiddeling door Dekker in september 1988 aan het licht. Dekker deed een duidelijk voorstel: als de overheid zich bereid toonde de goedkeuring van de richtlijnen van het COTG een maand op te schorten, zouden vier organisaties onder zijn leiding zelf een voorstel bedenken ter vervanging wan de richilijnen van het COTG. WVC reageerde in overeenkomstig onderhandelingsidioom: de uitkomsten van het overleg onder leiding van Dekker zujn alleen acceptabel als het COTG daaraan zijn goedkeuring kan hechten, dus als met andere woorden de praktijkkostenvergoeding niet hoger wit zou vallen dan in de bestaande richtlijnen. De overheid 
trad voor een tweede keer onderhandelend op bij het begin van het VPO. Toen was de overheid bereid de witkomsten van het VPO in te nilen tegen de besiluiten over de kostenvergoeding van 1988. Enkele Kamerleden spraken verontwaardigd van een 'glijdende' overheid.32 Mar ze vergisten zich in het soort interactie. Er was geen sprake van hierarchische beslutvoming maar wan onderhandelingen waarin concessies niet alleen kenmerkend, maar ook onvernijdelijk waren.

Niet elke poging tot onderhandelingen met de overheid lukte. De LSV ving bot in het door de rechter bevolen bilaterale overleg in 1988 nadat overheid had laten weten het Generial Akkoord eenzijdig op te willen zeggen. En na de goedkeuring van de richtlinnen ten aanzien wan de kostenvergoeding in oktober 1988 was WVC wederom niel bereid te gam onderhandelen over nieuwe voorstellen van de specialisten. Dees gaf duidelijk aan dat het niet de plaats was nieuwe mogelijkheden te bespreken: het kabinet kon slechts ja of nee antwoorden op de voorstellen van het $\mathrm{COTG}^{33}$ De bereidheid van de overheid om beshiten wit te ruilen was duidelijk groter bij een verzoek van verschillende organisaties dan bij individuele verzoeken. Het bilaterale overleg met de LSV was verleden tijd. Daamee stonden de rol van de overheid en het niet door de Wig: gereguleerde informele contact evenwel niet vast. Integendeel de mislakte onderhandelingen gaven aan dat de organisatie van de interactie bij betrokkenen niet a priori duidelijk was. Waar de LSV in 1988 mogelijkheden tot het doen van voorstellen aan de overheid veronderstelde, verwezen de bewindslieden slechts naar de formele procedures. Dit uiteenlopen van verwachtingen kwam niet voort uit een vergissing van de LSV of een juiste interpretatie doot de bewindslieden, maar was een gevolg van de onduidelijkheid wan de regels van het forum waarbinnen de interactie zich afspeelde. Niet overeenkonende percepties van regels zijn kenmerkend voor interacties in form. Waarvan van te voren miet bekend is welke interactieorganisatie overheerst. Het overleg tussen overheid en belangengroepen werd op dat moment niet geregeld door de Wtg. Evenmin was er sprake van geinstitutionaliseerde, ongeschreven, en historisch bepaalde regels. Daarom kon slechts tijdens de interactie worden vastgesteld waar de organisaties zich aan dienden te houden. En voelden buitenstaanders als VNZ en KLOZ met grote belangen in de uitkomsten van het overleg zich geroepen de interactiesoort aan te geven. ${ }^{34}$

\subsection{Conclusies}

De interacties tijdens de totstandkoming wan tarieven woor medisch specialisten kenmerkten zich door juridisering. Niet alleen werd elk tartefbesluit wan het CoTG gevolgd door een beroepsprocedure bij het CBB, ook won de jurdische argumentatic terrein in andere fora.

32 Toen de bewindslieden voorstelden het nieuwe overteg tijd te gunnen wroeg Bummeijer ( $P$ wa $\mathrm{A}$ of de beroepskosten nu wel per 1 januari verlaagd konden worden, zoals het kabimet in het bestuit valn 7 oktober had gesteld. De Koning reageerie daarop met: "Ik denk dat de termijn van twee maanden gebruikt kan worden on tor overleg te komen. Tegelijkertijd zal er doorgegaan moeten worden met het effectueren van besluiten." Marar dat antwoord stelde Butrmeijer niet tevreden. Hij constateerde: "Nu gaat u alweer gligden. U zult een deel van de besluitvorming per I januari moeten effectueren. $U$ hebt gesproken over twee maanden. Dat is dus na 1 januari. Een deel van de besluitworming die u zegt te zullen handhaven, voert $u$ dan al niet uit." (Verslag Mondeling owerleg Vaste Commissies voor Sociale Zaken on Werkgelegenheid en voor de Volkggezondherd met de Minister van Sociale Zaken en Werkgelegenheid, 3 november 1988)

33 LSV, Concept-verslag van het bestuurlijk overleg tussen de LSV en de overheid van 5 oktober 1988,24 oktober 1988

34 Zie noot 9 
Daarnaast benadrukten de deelnemers het belang wan technocratische besluituoming, maar in de praktijk vond deze verhullend plats. Van hitrarchie was sprake in de relatie tussen COTG en partijen, maar de bestuurlijke relaties tussen WVC en anderen raakten in belangrijke gehorizontaliseerd hoewel de overheid het tarievenoverleg conditioneerde. Bij de onderhandelingen veranderde het forum van bilaterale bijecnkomsten naar een meer-partijen vergadering onder leiding van een bemiddelaar. Bowendien strekten de onderhandelingen zich uit naar andere loci waarin de rol van de overheid en het COTG centraal kwam te staan. Deze conclusies worden hieronder besproken.

Uit de analyse van interacties is gebleken dat een juridisering wan het besluitwormingsproces is opgetreden. Ten eerste was bij de totstandkoming van elk tariefbesluit sprake van een juridische procedure voor een rechter. Niet alleen het CBB, maar ook andere rechters werden om een uitspraak gevraagd. Buj de besluitvorming over de vergoeding van de praktikkosten gebeurde dit in latere fasen van het proces. Toen bleek dat via de procedures in het COTG of via onderhandelingen met de financiers een voor specialisten nadelige uitkomst niet te voorkomen zou zijn, ging de LSV over tot juridische procedures. Bij de reshuffling en de tweeslag stapten individuele medisch specialistem en groepen van medisch specialisten naar de rechter. Omdat de LSV delen van de ontevreden achterban er niet van kon weerhouden juridisch protest aan te tekenen, waren de deelnemers aan het VPO gedwongen al tijdens het ontwerpen van de besluiten rekening te houden met de juridische houdbaarheid ervan. Hierdoor kregen de interacties in het VPO en tussen het VPO en het COTG dan wel WVC een juridische argumentatieorganisatie. Bij de totstandkoming van de besluiten over de kostenvergoeding was tevens sprake van juridische argumentatie voorafgaand en nast de confrontaties woor de rechtbank, maar deze hadden een minder collectief karakter dan bij de tweeslag en de reshuffling.

Terwijl de juridische argumentatie in belang en frequentie toenam, was van techmocratische besluitworming nauwelijks sprake. Over besluiten kon geen consensus bereikt worden door het uitwisselen van informatie. 35 Weliswar werden de besluiten vam thet COTG en WVC over de praktijkkostenvergoeding onderbouwd met precieze berekeningen per kostenpost, maar deze konden slechts genomen worden omdat een overheersende coalitie zich kon vinden in de voordelen van de cijfermatige onderbouwing. Daardoor was het mogelijk een discussie met de LSV ower de door de medisch specialisten ingebrachte gegevens te ontlopen. Bij de weeslag en de reshuffling verschoof het onderwerp van debat. Noch de mutatiepercentages van de reshuffling-voorstellen vam Van Aardenne noch het 10 procent tariefverschil bij de tweeslag kwam voort uit technische discussies. Beide waren thet resultaat van overeenstemming in een dominante groep van actoren die wel een andere samenstelling kende dan de coalitie in 1988 . Omdal de juridische houdbaarheid van groot belang werd geacht, was niet een bedrij/seconomische onderbouwing gewenst mar een formeel-juridische. Deze werd na de noodzakelijke onderhandelingen aangeleverd door het COTG. Overeenkomstig met de beslutvorming over de praktijkkosten werd technische kennis gebruikt om de doelstellingen wan een fijdelijk dominante coalitie te bewerkstelligen.

Hoewel het COTG zijn kennis in dienst stelde of moesl stellen van andere actoren, vonden hièrarchische interacties vooral plaats tussen dit orgaan en de partijen. Het CoTG makkte

35 Deze conclusie kan warschijnlijk ook worden getrokken ten aanzien van het gehele financiele beleid van de overheid ten anzien van medisch specialistische zorg. Het opstellen van de desbetreffende voorstellen in het Financieel Overzicht Zorg (sinds 1997: Jaaroverzicht Zorg) kenmerkt zich door het gebrek aan feitelijke informatie. "Van feitelijke kosten van specialistische hulp bestat geen nawwkeurig beeld. Ook het antal in Nederland werkame specialisten is niet exact bekend. Ten behoeve van de gegevensverzameling wordt wrijwel nooit de wettelike mogelijkheid ex art. 30 WTG gehanteerd." (Onderzoek besluitvorming volksgezondheid, Tweede Kamer, $1993-1994,23666$, nr. 2, p. 35-36) 
regelmatig gebruik van zin formele bevoegdheden tariefbesluiten te nemen of richtijnen vast te stellen in afwijking van de wens van (sommige van) de partien. De nitkomsten wan hel geregeld platswindende wooroverleg waren niet verplichtend voor het CoTG bij de fomele besluitworming. De besluitwoming doot het COTG week regelmatig af van de overheersende standpunten in het vooroverleg. WVC darentegen makte op deze wijze geen gebuik van zun hërarchische positie. In de relatie tussen WVC en de belangenorganisaties trad honizontalisering van bestuur op omdat direct betrokkenen vaak feitelijk instemden alvorens de overheid een boslissing nam. Horizontalisering van besturlijke talaties in de zin dat de overheid geen besluiten meer kon nemen zonder voorafgaande feitelijke instemming van anderen had niet plaats omdat WVC op verschillende momenten zijn autonomie behield. Evenmin mondde de horizontalisering wit in het ontbreken van sturing door de overheid. Naast de overreding in het directe overleg formuleerde WVC condities die grenzen stelden aan de vrijheid van de andere actoren. De condities bestonden uit financiële eisen waaraan de deelnemers aan het larievenoverleg zich zouden moeten bouden en wit formele thiërarchische bewoegdheden.

Tenslotte bleken onderhandelingen op verschillende manieren plaats te vinden. Hot forum voor onderhandelingen veranderde. Er ontstond een breed onderhandelingsplatform warin ziekenfondsen, particuliere verzekeraars, specialisten en ziekenhuizen gelijkijdig participeerden. Bovendien kregen de onderhandelaars te maken met onafhankelijke woorzitters die informatie moesten verschaffen aar de politiek verantwoordeliken. De start en de bepaling van de deelnemers waren afhankelijk van de situatie warin het overleg over tarieven zich bevond. De agenda stond daarom evemin vast en verschilde per onderhandelingsronde. Uit de vergelijkende analyse is gebleken dat de agenda van het VPO meer mogelijkheden to uitruil bood dan de agenda's van de jaren daarvoor. Hierdoot kregen de besprekingen in het VPO in tegensitelling tot de onderhandelingen tussen VNZ en LSV een integratief karakter. De bilaterale onderhandelingen leidden dan ook niet tot een overeenkomst. Verhoudingen verhardden zich daarentegen. Bovendien vormde het COTG voor de VNZ een aantrekkelijke BATNA (Best. Altenative to the Negotiated Agreement) waandoor de wederzijdse afhankelijkheid tussen de YNZ en de LSV verminderde. Tijdens het VPO was ten aanzien van de tweeslag en de reshuffling nawwelijks sprake van een 'mixed-motive' situatie. In overeenstemming met het meer" integratieve karakter van de besprekingen in het VPO kenmerkten de discussies over de tweeslag en de reshuffling zich door mogelijkheden afspraken over deze twee punten af te ruilen mot afspraken over andere zaken.

Onderhandelen als interactieorganisatie vond niet alleen plaats in het boven bescheven onderhandelingsforum. Na het totstandkomen van een compromis moest nog onderhandeld worden over de omzetting hiervan in formele beshiten. Daarbij kwamen de verantwoordelijkheden van de overheid en het COTG aan de orde. Bovendien was de overheid op verschillende ijjdstippen bereid de uitkomsten van de formele beshuitvorming in te ruilen voor te verwachten urtkomsten van nieuw onderling overleg.

In het algemeen kan worden geconcludeerd dat met het VPO de relatie tussen fora voor interacties en interactiesoorten minder sterk werd. Bij de totstandkoning on uitvoering van het VPA kwamen interactiessoorten meer synchroon woor dan bij hot ecrdere tarievenoverleg. Terwijl bij de praktijkkosten vaak nog sprake was van een besluivormingsproces in asen met de daarbij behorende interactiesoorten en fora, kwamen bij de totstandkoming van de besluiten over de reshufning en de tweeslag interactiesoorten meer gelijktijdig voor, terwijl de grenzen wan de loci voor interacties regelmatig werden overschreden. 



\title{
Het bespelen van instituties
}

\author{
Samenvattende conclusies en enkele aanzetten tot theorievorming,
}

\subsection{Inleiding}

In dit hoofdstuk zullen de belangrijkste conclusies van de voorgaande hoofdstukken ten aanzien van de drie dimensies van de besluitvorming over tarieven voor medisch specialisten worden samengevat. In de eerste paragraaf ga $i k$ in op de participatie van actoren, daarna op de handelingstheorieèn die gehanteerd werden en vervolgens de interacties die optraden bij de totstandkoming van tarieven. Bij elk van deze dimensies zal ik anangeven welke rol de Wtg als formeel institutioneel kader heeft gespeeld. Daarnaast zullen additionele factoren aan de orde komen die naast de Wtg een grote invloed uitoefenden op de ontwikkeling van de aangegeven dimensies. Hiervoor schiet soms het begrippenapparaat van het nog anvolledig ontwikkelde actorgerichte institutionalisme tekort. De aangegeven factoren dienen dan ook gezien te worden als toevoegingen op deze theoretische invalshoek.

Daarnaast worden in dit laatste hoofdstuk pogingen ondernomen om de dimensies van de totstandkoming van tarieven met elkaar te verbinden. De ontwikkelingen in de participatie van actoren, hun handelingstheorieën en de interacties stonden met elkaar in relatie. Deze relatie zal hier tentatief worden aangegeven en theoretisch worden onderbouwd. Hiermee wordt geprobeerd te voldoen aan de theoretische doetstelling van dit boek. Deze doelstelling is na te gaan in hoeverre en op welke manier besluitvorming beïnvloed wordt door de formele institutionele inbedding. Hiervoor is meer nodig dan het actorgerichte institutionalisme op dit moment biedt. Er bestaan theoretische inzichten die bruikbaar zijn zonder de aannames van het actorgerichte institutionalisme ter discussie te moeten stellen. De kern van mijn theoretische uitwerking van het actorgerichte institutionalisme bestaat uit de bewering dat de actoren bij de besluitvorming gelijktijdig twee zaken probeerden te bereiken. Zij trachtten allereerst de eigen belangen veilig te stellen maar moesten tevens anderen van de legitimiteit van het eigen handelen overtuigen. Dit kon door gebruik te maken van de institutionele mogelijkheden en door institutionele onmogelijkheden op te heffen hetgeen resulteerde in een door actoren in grote mate zelf bepaalde vorm van naleving van de formele regels. 


\subsection{Ontwikkelingen in de participatie van actoren en hun oorzaken}

\section{Ontwikkellingen in de participatie}

Uit de analyse van de patronen van participatie is natr voren gekomen dat de actoren die in de Wtg genoemd worden, dadwerkelijk deehamen aan de besluitworming over de tarieven voor medisch specialisten. In het vijfde hoofdstuk is aangetoond dat er gesproken kan worden van een groep van wij kemactoren: KLOZ, LSV, VNZ, COTG, WVC. De dynamische opzet van de analyse stelde mij tevens in statit te concluderen dat het tot in 1987 dominerende bilaterale overleg langzamerhand vervangen werd door multilateraal overleg. Dit kreeg vorm in het VPO. Dit is een belangrijke conclusie, want in de naoorlogse periode was het centrale tarievenoverleg voorbehouden aan twee organisaties; de verenigde ziekenfondsen en de LSV. In de jaren 1986 1992 werd afscheid genomen van deze traditie. Daamaast is duidelik geworden dat ook actoren deelnamen die niet bij name in de formele regelgeving genoemd werden. De meest duidelijke voorbeeld zijn de Nationale Ziekenhuisraad die een formele plaats kreeg toegewezen aan de vergadertafel wan het VPO en de bemiddelaars. Tenslotte is aangetoond dat er weliswaar een groep van kernactoren was, maar het moment van hun participatie kon verschillen.

\section{De invloed van liet formele institutionele kader en andere factoren op de participatie}

Voor de deelname van actoren aan de totstandkoming wan tarieven waren verschillende factoren verantwoordelijk. Ten eerste speelde het formele institutionele kader een belangrijke rol. Dit kader legde in belangrijke mate de grenzen van het netwerk vast. Dit betekende tevens dat sommige actoren die de besluitvorming over tarieven wilden beïnvloeden werden buitengesloten. Daarnaast werden actoren in de besluitvorming betrokken omdat zij op basis van hun juridische kennis de mogelijkheden en beperkingen van de Wtg konden aangeven. Ten tweede zijn factoren te noemen die de dynamiek van de participatie kunnen verklaren. Deze betreffen de strategische overwegingen ten aanzien van deelname, het onvermogen van partijen het onderlinge overleg succeswol af te ronden, en het optreden van externe effecten. De deelname van actoren hing af van hun wens om gebruik te maken van de formele mogelijkheden tot participatie. Deze werns was onderdeel van de strategische overwegingen van organisaties. Dat partijen het eigen onderlinge overleg niet succesvol konden afsluiten had de deelmame van zogenaamde derde partijen (bemiddelaars, rechters) tot gevolg. Tenslotte had de besluitvorming tussen direct betrokken actoren vaak gevolgen voor anderen die (tijdelijk) niet betrokken waren waardoor negatieve externe effecten konden optreden. Deze effecten leidden tot de wens bij degenen die nict betrokken waren de totstandkoming van tarieven te beinvloeden.

In hoofdstuk vijf is inzichtelijk gemaakt dat formele regels voor bepaalde actoren het recht op deelname aan bes:uitvorming vast'legden. Daarnaast verplichte de wet actoren tot participatie. Maar zowel bij het opeisen van het recht tot deelname als bij het invullen van de plicht is gebleken dat actoren strategische overwegingen hanteerden, waarbij zij nagingen of het volgen van de formele regels in bun belang was. Dit bevestigt de centrale veronderstelling van het actorgerichte institutionalisme van Mayntz en Scharpf (1995b). Die veronderstelling luidt dat het volgen van regels afhankelijk is wan de strategische inzichten van actoren. Hierdoor kumen veranderingen in de deelname aan besluitwoming ook worden begrepen in perioden waarin thet fomele institutionele kader zelf weinig of niet veranderd wordt. Dat actoren deelnemen aan besluitvomingsprocessen als twan belangen in het geding zijn is reeds verschillende keren geconcludeerd in onderzoek naar besluitvormingsprocessen (Laumann en Knoke 1987 , Berveling 1994). Tijdens de besluitvorming over tarieven voor medisch specialisten kwam dit op twee manieren naar voren. Ten eerste participeerden actoren omdat zij zo een bepaalde doelstelling dachten te kunnen realiseren. Ten tweede waren andere actoren gedwongen mee te gatan doen, ondat hun belangen geschaad zouden wotden als zij anderen de besluiten zouden laten nemen. In deze zin lokten gebeurtenissen tijdens een besluitvomingsproces de participatie 
van actoren uit (Mayntz en Scharpf, 1995b: 85). Tenslotte is duidelijk geworden, dat actoren die van het begin af aan deetramen aan de besluitwoming in toenemende mate gedwongen werden andere actoren vroegtijdig te betrekken in de besluitworming. In eerste instantie buitengesloten actoren konden namelijk via de recher de vaak moeizaram tot stand gekomen besiuiten alsnog ter discussie stellen. Door zoveel mogelijk belanghebbenden te laten overleggen, kon dit gedeeltelijk voorkomen worden. Deze ontwikkeling geef aan dat actoren in sifuaties van interdependentie bereid zijn kosten ten behoeve van meer coordinatie te maken als hierdoor de opbrengst op de langere temijn meer waarschijnlijk wordt (Ostrom, 1990: 38-45).

\subsection{De handelingstheorieën}

In hoofdstuk zes zijn de handelingstheorieen van de actorem geanalyseerd. Elk element kwam daarbij afzonderlijk aan de orde alsook de logica van de handelingstheorieen. In de volgende paragraaf vat ik de conclusies per element samen wama in de daarop volgende paragraaf de conclusies over de logica besproken worden.

\subsubsection{De elementen van de handelingstheorieën}

\section{Sitwatieschetsen}

Uit de analyse van de handelingstheorieèn is gebleken dat de actoren woor zichzelf enkele algemene, min of meer onweranderlijke belangen hadden gedefinieerd. De overheid, de VNZ en het COTG constateerden in 1986 en 1987 dat de besluitworming over tarieven thun belangen niet diende. Hun wens tot verandering daarin botste met de mening van de LSV die de aigen belangen bedreigd zag worden. $\mathrm{Na} 1988$ constateerden de organisaties een congruentie van belangen toen het VPO een zero-plus situatie creëerde.

De algemene belangen boden echter weinig houvast voor handelen. Volgens Mayntz en Scharpf (1995b) moet elke actor voor het handelen zijn algemene belangen herdefiniexen in concrete doelstellingen die situatieafhankelijk zijn. De bij de tariefvoming betrokken actoren bevestigden deze veronderstelling. Uit de reconstructie van de situatieschetsen is gebleken dat organisaties mogelikheden zagen hun algemene belangen te dienen als zij zich zonden aansluiten bij situatiespecifieke doelstellingen. Hiervoor was woor elke organisatie een vertaalslag van algemeen belang naat" concrete doelstelling nodig. Een belangrijke overweging van de organisaties was dan ook: hoe kunnen we de ontwikkelingen in de beslutwoming over larieven het beste laten aansluiten bij onze algemene belangen? Het antwoord op deze vrag was voor de ene actor moeilijker te geven dan voor de andere. Vaak waren de geformuleerde doelstellingen nameljk nauwelijk afleidbaar van de algemene belangen, natrom wom ze eerder de resultante van afwegingen binnen de tijdsspecifieke context van het besiluitvormingsproces.

\section{Handelingsopties en hun wardering}

Actoren formuleerden vak verschillende handelingsopties. Uit de vargelijking van de handelingstheorieen kwam tevens naar voren dat zij per actor konden verschillen. Ook is gebleken dat handelingsopties zich gedurende het beshitvormingsproces aandienden.

In het algemeen kenden de VNZ en KLOZ tot aan het VPO twee opties: het onderlinge overleg met de LSV en het eenzijdig voorleggen van tariefwoorstellen aan het COTG. De laatste optie werd voor zowel de WNZ als het KLOZ steeds belangrijker toen hel overleg met de LSV weing opbrengsten beloofde. Voor de LSV bleven juridische procedures, bilateral owerleg met WVC en politici en acties van individuele medisch speciallisten ower toen het door de specialisten 
geprefereerde onderlinge overleg door de anderen werd opgezegd. Voor WVC bestond de keuze uit actieve participatie of distantie. Bij het COTG domineerde de formeeljuridische werkwijze conform de Wtg; andere opties werden nauwelijks gezien.

Dat het onderlinge overleg tussen financiers en specialisten een optie voor alle representatieve organisaties bleef, kwam bij het VPO naar voren. Eenmaal aan de tafel van het VPO dangeschoven was het voor elke deelnemer nauwelijks mogelijk zonder grote gevolgen voor de eigen positie in het tarievenoverleg van verdere deelname af te zien. Wel vormden de besluiten over de kostenvergoeding voor $\mathrm{VNZ}$ en $\mathrm{KLOZ}$ een alternatief mooht het VPO mislukken.

Deelname aan het VPO beperkte de handelingsopties voor de deelnemers. De rechtstreekse vertaling van de onderhandelingsuitkomsten werd steeds minder als realistisch gezien toen de overheid ten behoeve van een juridische onderbouwing geen aanwijzingen wilde versturen en weigerde de wetgeving te veranderen. Intensief overleg met het COTG en beraadslagingen in het VPO bleven als opties over.

Ook bij het VPO had WVC de keuze tussen actieve betrokkenheid en de organisaties in overleg met het COTG tariefbesluiten tot stand te laten brengen. Daarnaast kwam een derde optie aan de orde: het wijzigen van wetgeving. Zowel het wijziging van wetgeving als actieve betrokkenheid zouden de overheid in een kwwetsbare positie brengen. Het COTG moest uit twee alternatieven kiezen: een beoordeling van de onderdelen van het VPA aan de hand van formele wettelijke criteria of erkenning van het 'beleidsmatig' belang van het VPA. Een erkenning van het 'beleidsmatig' belang zou het COTG als het ware partij van het VPO maken.

\section{Strategieẽn}

Hoewel de tijdelijke overeenstemming over situatiespecifieke doelstellingen de ontwikkeling van gezamenlijke strategieën zou moeten vereenvoudigen, ontstonden daarover werschillen van mening. Tijdens de discussies over de vergoeding voor praktijkkosten stond het COTG een formeeljuridische weg voor. Naar de mening van het COTG moest op basis van de Wtg op een normatieve manier een besluit over de hoogte van de beroepskosten tot stand komen. Daarin werd het orgaan slechts gedeeltelijk gevolgd door de VNZ, het KLOZ en WVC. Regelmatig gaven zij hun goedkeuring aan overleg met de LSV terwijl het COTG op die momenten op basis van de formele besluitvormingsprocedures grote vooruitgang kon boeken. Deze strategische keuze leidde uiteindelijk in 1989 tot het stopzetten van de implementatie van de richtlijnen voor de kostenvergoeding.

Ook bij de reshuffling ontstond over de strategie verschil van mening. De deelnemers aan het VPO kozen voor overleg met het COTG teneinde een strikte implementatie van de onderhandelingsuitkomsten mogelijk te maken. Zij vonden tevens dat de overheid zich diende te committeren en zijn wettelijke bevoegdheden moest gebruiken teneinde de uitvoering te garanderen en desnoods het wettelijk kader moest veranderen. Het COTG vond een aanwijzing van de overheid eveneens noodzakelijk. WVC weigerde zijn bevoegdheden te gebruiken en de wetgeving onmiddellijk aan te passen, maar was van mening dat de organisaties zelf in overleg met het COTG oplossingen moesten bedenken. Hetzelfde gold voor de besluitvorming over de tweeslag. Wederom was sprake van een overheid die weigerde actief te participeren en organisaties die zich - noodgedwongen - gezamenlijk met het COTG concentreerden op de formulering van juridisch houdbare tariefvoorstellen. 


\subsubsection{De logica van de handelingstheorieên}

\section{De logica}

In hoofdstuk zes was mijn conclusie dat de logica van de handelingstheorieon bestond uit drie overwegingen van een actor: hoe worden in een specifieke situatie onze belangen het best behartigd, welke mogelijkheden en beperkingen bieden de relaties met andere actoren, en hoe kunnen en dienen wij te anticiperen op de vereisten van de formele wetgeving? Deze owerwegingen waren hièrarchisch geordend. Van het grootste belang voor alle betrokkenen was het halen van de situatiespeciffeke doelstelling die op een gegewen moment voorop stond. De relaties met de andere actoren en de omgang mel de formele regelgeving werden daanaan ondergeschikt gemaakt. Wetgeving fungeerde als een hulpbron. Dit hield in dat de mogelijkheden en beperkingen van de wetgeving werden beoordeeld op hun effecten ten aanzien van de doelbereiking.

\section{De inwloed van interacties op handelingstheorieën}

De overhessing van de doelrationaliteit in de logica's zegt nog weinig over de herkomst van de doelstellingen, handelingsopties en de gevolgde strategieèn. Uit mijn onderzoek is gebleken dat de handelingstheorieên zich vormden gedurende relaties en interacties met anderen on dal daarbij sprake was van institutionele invloed. Dit wordt in de volgende paragrafen verduidelijkt.

De doelen die de deelnemers aan het besluitwomingsproces zich stelden waren situatiespecifiek, en kregen vorm gedurende het besluitwormingsproces. Ze noesten als het ware ontdekt an in overeenstemming gebracht worden met de algemene belangen. Pas tujdens het besluitvormingsproces bleek wat eigenlijk met enig uitzicht op succes nagestreefd kon worden. Welke doelstellingen handelingsleidend konden zijn, was in grote mate afhankelijk van de mogelijkheid tot onderlinge verengbaarheid van concrete doelstellingen. Tijdens de besluitvorming kwamen actoren tot de vaststelling dat sommige doelstelingen zonden worden ondersteund door groepen van actoren en andere niet. Dit leidde tot coalities die doelstellingen central stelden die, hoewel soms slechts gedeeltelijk, pasten binnen de algenene, minder veranderlijke doelstellingen van elke actor afzonderlijk.

Het bestaan van coalities die zich hadden verenigd op basis van gezamenlijke, concrete doelstellingen gaf hen macht, maar sloot tevens actoren buiten die zich niet konden verenigen met deze doelstellingen. Dit waren ten tijde van de praktijkkosten de LSV, en ten tijde van de reshuffling/tweeslag het COTG. Bovendien hield het bestaan van coalities niet in dat alle belangen van de aanges loten leden veilig konden worden gesteld. Soms dreigden door het vooropstellen van een bepaalde concrete doelstelling andere doelstellingen onder te sneeuwen.

Het grote belang van de aaneenshuiting van actoren op basis van een lijdelijke overeenstemming over doelstellingen was niet slechts dat het handelen richting gegeven kon worden maar tevens dat situaties gestructureerd werden. Dominante coalities schiepen de voorwaarden voor anderen, door aan te geven over welke onderwerpen de actoren een standpunt moesten innemen. Situaties drongen zich op aan organisaties doordat zij door actoren met bepaalde doelstelingen waren voorgestmuctureerd, daarmee het aantal keuzemogelijkheden voor anderen beperkend.

Evenals de doelstellingen kwamen strategieën van de afzonderljke organisaties interactief tot stand. Tussen 1986 en 1988 legden VNZ, KLOZ en COTG de nadruk op een afsplitsing van het kostendeel van het tarief om vervolgens op nomatieve basis per post van de zogenaamde beroepskosten een bedrag vast te stellen. De weg die daarbij gevolgd werd was die van het eenzijdig voorstellen doen aan het COTG warbij vooraf al duidelijk was of zij op steun van het COTG konden rekenen. De LSV werd butten gesloten. De weg die de medisch specialisten voorstonden - via onderlinge onderhandelingen tot owereenstemming komen - werd afgewezen. 
Bif de beide VPAbesluiten, de reshuffing en de weeslag, werd een andere weg: ingeslagen. Nu waren het de financiers, de ziokewhizen en de medisch specialisten die elkar vonden in onderlnge onderhandelingen. Zij stelden het 'beleidsmatige' belang van de uitkomsten van deze onderhandelingen voorop en makkten de formele besluitworming in het COTG daaraan ondergeschikt. Dimal wenste het COTG niet aan te haken, hetgeen net verwonderlik was omdat het resultaat zou zijn dat de besluiten over de verlaging van de vergoeding voor de praktikkosten niet verder uitgevoerd konden worden.

Uit de analyse is gebleken dat een algemene overeenstemming ontbrak over hoe besluiten over tarieven tot stand ditenen te komen in het netwerk: Er was sprake wan een pluralisme in visies, hetgeen niet ongebruikelijk is in dergelike newerken van organisaties (Torenvlied 1995: 338). Wiet alleen ging de discussie over het primaat van de onderhandelingen iussen representatieve organisaties, ook was onduidelijk welke rol de overheid en het COTG dienden te spelen. Aangezien veel afhing van de keuzen die een tijdelijk dominante coalitie van actoren maakte, was de weg die uiteindelijk op collectief niveau gekozen werd zeer veranderlik. Dit bied een nieuw zicht op de collectieve besluitworming in de gezondheidszorg die door anderen wel als neocorporatistisch wordt getypeerd. Daarbij zou een nomatieve overeenstemming over collecticve actiestrategieën moeten horen (Hemerijck 1994). Mijn studie heef duidelijk gemaakt dat daarvan geen sprake was tijdens de besluitvorming over tarieven voor medisch specialisten tussen 1986 en 1992.

\section{De invloed van instituties op de handelingstheorieen}

Naast de invloed van interacties met anderen was bij de ontwikkeling van handelingstheorieën het formele kader wan groot belang. Actoren anticipeerden op de wettelijke kaders hetgeen in hun handelingstheorieen op twee sterk aan elkaar gerelateerde manieren gestalte kreeg. Ten eerste ontleenden zij hun doelstellingen, handelingsopties en strategieẻn aan het formele wettelijke kader. Ten tweede moesten de actoren hun keuzen legitimeren als het gevolg van de noodzaak van hiërarchische beloningen. In deze twee vormen van invloed van de formele institutionele inbedding op de overwegingen en handelingen wan de deelnemende organisaties komt de invloed van instituties op collectieve besluitwormingsprocessen duidelijk naar voren. De organisaties bezaten de vrijheid om de mogelijkheden wan de formele regels in hun eigen voordeel te gebruiken maar waren tegelijkertijd gebonden aan beperkingen.

De actoren ontleenden de elementen van hun handelingstheorieën vaak aan het institutionele kader. Het overleg over tarieven stond tot 1986 in het teken van het inkomensoverleg. Als eerder aangegeven, was het tarievenoverieg in feite een afgeleide van de ühkomsten van het overleg tussen de overheid en de LSV. Jurispnudentie had uitgewezen dat het COTO geen besluiten mocht nemen die betrekking hadden op het inkomen van de medisch specialisten. De formele splitsing van het tarief in twee onafhankelijke onderdelen die door het COTG in 1987 werd voorgesteld, gaf de VNZ en het COTG de mogelijkheid een actieve rol te gatan spelen in de besluitvoming over tarieven voom medisch specialisten. Dit leidde er toe dat voor zowel de VNZ als de het COTG de verlaging van de zogenaamde beroepskosten als een subcategonie van het tarief voor een medisch specialist als doelstelling centraal kwam te staan. Do consensus over deze doelstelling leidde vervolgens tot een strategie warin gebruik werd gemaakt wan de mogelijkheid om eenzjidig tariefwoorstellen in te dienen. Bij de besluiten die wit het VPA wolgden werd eveneens gebruik gemaakt van de mogelijkheden die door de formele regels werden geboden. Dit gebeurde met name door de onderdelen van de tariefformule apart van elkaan te bezien on zo te bewerkstelligen dat de beleidsmatig gewenste uitkomsten tot formele tariefbesluiten konden leiden.

Terwijl de actoren de wet gebruikten, waren zij zich tevens bewust wan de noodzaak om hun inspanningen hiërarchisch beloond te zien worden. Met andere woorden ${ }_{\text {, }}$ de organisaties werden door de institutionele inbedding gedwongen te zoeken naar legitmaties. Daarin waren de 
actoren amankelijk wan de oordelen wan juridische adviseurs en WVC, maar vooral van het COTG en het CBB. Omdat het CBB pas zekerheid na de besluitvorming kon geven, was opname van het COTG in de dominante coalities tijdens het besluitvomingsproces van groot belang. De legitimerende rol van het COTG gaf aan de doelstellingen van een coalitie een lomeeljurdische basis die nodig was voor de onvermijelijk volgende juridische procedures. Het gevolg was dat bij het bepalen van doelstellingen vooral in de latere fasen van het besluitwormingsproces ean juridischtechnische boordeling en verantwoording een grote rol speelde.

\section{Het geringe houvast van individuele algemene belangen}

Uit de voorgaande analyses is gebleken hoe weinig de algemene belangen handleiding boden aan de participerende actoren. Zij waren niet meer dan uitgangspunten. De besluitvorming over tarieven voor medisch specialisten $\mathrm{kreeg}$ vom doordat actoren sitwatiespecifieke doelstellingen moesten formuleren, die nauweliks afleidbaar waren wan algemene wensen. Deze wensen vormden weliswaar een algemeen referentiekader waamee de concrete doelstellingen in overeenstemming moesten worden gebracht, maar ze gaven nauweljks howwast voor do opstelling van de actor in concrete interacties. Daarvoor waren situatiespecifieke doelstellingen noodzakelijk. Die situatiespecifieke doelstellingen ontstonden in interactie en werden inlhoudelijk sterk beinvloed door de mogelijkheden en beperkingen die de institutionele context oplegde. Dit proces verwijst naar de interdependente relaties tussen handelingstheoriecs $n_{\text {, interacties en }}$ instituties die ook elders al werden verondersteld (Torenvlied, 1995: 338)

Deze constatering is van groot belang. Eruit blikt mamelijk how weing zinvol het is complexe besluitvormingsprocessen in een institutionele omgeving te benaderen vanuit hel decisionisme. In het decisionisme wordt publieke besluitvorming opgevat als de uitkomst van het maken van berekende keuzen door een beperkt aantal actoren die heldere, consistente en stabiele preferenties hebben. De inconsistentie van preferenties, het proces van besluitworning en andere waarden dan de kosten en baten van besluiten komen naweljjks aan de orce (Ringeling, 1995: 259-260j. En wat nog veel belangrijker is, de vragg waar de preferentieg van actoren vandaan kcomen wordt niet gesteld ("t Har e.a, 1995: 9). Mijn onderzoek heeft laten zien dat de oorsprong van de handelingsleidende doelstellingen van de actoren in belangrijke mate lag in de constellatie van actoren die interacteerden binnen een tijd- en plaatsgebonden institutionele context. Daarmee is de endogeniteil van preferenties van de actoren die deelnamen aan institutioneel ingebedde besluitvormingsprocessen aangetoond.

\subsection{Soorten van interacties}

Ten aanzien van het optreden van soorten van interacties tijdens de totstandkoming van bestuiten kunnen drie algemene conclusies getrokken worden. Ten eerste is geblaken dat 30 mmige interactiesoorten tijdelijk dominant waren en dat weer andere steeds belangrijker werden. "Ten tweede kan geconstateerd worden dat de verschillende conflictoplossingsmechanismen die in de Wtg stonden vermeld in de praktijk slechts verenigbaar waren onder bepaalde omstandigheden. Er bestond een voortdurende spanning tussen met name de onderlinge onderhandelingen en de besluifworming via het COTG. Wat in de wet als een logische sequentie werd gezien - eerst onderhandelen en vervolgens de uitkomsten laten beoordelen op basis van richuijnen ontwikkelde zich tot concurrentie tussen manieren om besluiten tot stand te brengen. Tijdens de besluitworming over de kostenvergoeding verplatsten VNZ, KLOZ en COTG de discussie naar het COTG door eenzijdige woorstellen te doen wardoor de onderlinge onderhandelingen op het tweede plan rakten. Ten tijde van het VPO kregen de onderhandelingen ussen de belangenorganisaties het primat en stond de juridischtechnische discussie in he COTG in dienst van de realisatie wan de onderhandelingsovereenkomst. Ten derde is bij de vergelijking van de 
casurtstiek opgevallen dat tijdens het beslutwormingsproces over de kostenvergoeding een dudidelikere afscheiding en sequentie van interactiesoorten te constateren valt dan tijdens de besluitvoming over de reshuffling en de tweeslag. Bij de kostenvergoeding wonden onderhandelingen gescheiden plaats van de technocratische discussie in het COTG warin nauwelijks werd ingegaan op de juridische bezwaren van de LSV. De LSV was gedwongen de eigen juridische bezwaren bij de overheid, het COTG en uiteraard de rechter neer te leggen. Met andere wootden, onderhandelingen entechnocratische en juridische discussies vonden gescheiden in hum eigen fora plaats. Dit gold minder voor de hierarchische interactie. Door de gelijkgerichtheid van de doelstellingen van COTG, VNZ en KLOZ en het afstemmen van alkars activiteiten konden de belangenorganisaties bij het indienen van tariefvoorstellen inspelen op de te verwachten meningsvoming in het COTG. Bij de beide VPA-onderdelen leidde wooral de consensus onder de onderhandelaars en de instemming door WVC er toe dat interacties gelijktijdig meersoortig waren. Met name tijcens de vormgeving van de reshuffing vielen verschillende interactiesoorten samen: nadat het VPO het eens was geworden over een reshufflingvoorstel noest door middel van onderhandelen en het voeren van een juridischtechnische discussie met het COTG zeker gesteld worden dat het voorstel ook in een tariefvoorstel gegoten kon worden. Hierdoor traden interacties ook buiten de voor hen opgestelde fora op. Een heldere sequentie wan interactiesoorten die bij de kostenvergoeding nog min of meer optrad, ontbrak bij de totstandkoming van de besluten over de reshuffling en de tweeslag.

De belangrijkste conclusie ten aanzien van interactiesoorten is dat de besluitvorming over tarieven voor medisch specialisten in sterke mate gejuridiseerd raakte. Deze juridisering kreeg op wee manieren vorm. Ten eerste werd tegen alk tariefbesluit van het COTG geprocedeerd. De bemoeienis wan de rechter heef er toe geleid dat de gehanteerde regels en onderlinge verhoudinger van de woorheen zo gesloten onderhandelingen publiekelijk aandacht kregen. In termen van Breminkmeijer (1997: 936) werd het "kleine vrijstaatje" van de onderhandelaars over tarieven gedwongen de "bedgeheimen" te onthullen waardoor een woorheen private verhouding gejuridiseerd rakkte. Ten tweede kregen interacties een juridische invalshoek. Tijdens de besluitvorming over de kostenvergoeding kwamen juridische argumenten vooral van de kant van de LSW in een poging de besluitvorming in het COTG te beinvloeden. Tijdens het VPO kwam de discussie over de reshuffing en de tweeslag geheel in het teken te staan van de juridische houdbaarheid. Het overheersende juridische karakter van de interacties $\mathrm{kwam}$ volledig tot uiting in de dwingende contracten die door het VPO aan individuele medisch specialisten werden opgelegd. Waar vroeger vertrouwd moest worden op uitvoering door de achterban van de door belangenorganisaties genomen collectieve besluiten, streefde men na 1989 naar juridische zekerheid.

In het algemeen worden de oorzaken van juridisering gezocht in de uitbreiding van de normen waraan bestuurlijk handelen moet voldoen, een toename van de mogelijkheden tot rechtsbescherming tegen bestuurshandelingen en de groei van het aantal handelingen dat aan rechtsbescherming wordt onderworpen (Versteden, 1997: 944). Ook bij de besluitworming over tarieven was hiervan sprake: de rechtsbescherming via het CBB werd een integraal onderdeel van de totstandkoming van besluiten. Van groter belang was echter dat sommige actoren in overeenstemming met de hun doelrationaliteit gebruik wensten te maken van de mogelijkheden voor beroep. Daarin was men zeer creatief; niet alleen het CBB naar ook andere, civiele rechters konden rekenen op verzoeken tot het starten van beroepsprocedures.

Naast deze juridisering werd de totstandkoming van de tariefbesluiten over de reshufling en de tweeslag gekenmerkt door een volledig afgewerkte cyclus van onderhandelingen. In hoofdstuk zeven is naar voren gekomen dat bij deze tariefbesluiten nauwelijks sprake was van een mixed-motive situatie. Beide onderwerpen waren wel onderwerp van onderhandeling als onderdeel van cen breder geheel van afspraken (het uiteindelijke VPA) maar de doelstellingen waren nawwelijks tegengesteld en het belang dat aan beide besluiten werd gehecht was 
onevenredig verdeeld. Tegenstellingen ontstonden wel ussen het COTG en het VPO die voortkwamen uit een verschil van mening over de verwerking van de ondefhandelingsuikomsten in formele tariefbesluiten. Tijdens deze verwerking kwamen onderhandelingen tot stand die ik heb getypeerd als interacties buiten het daarvoor bedoelde form optraden. Tijdens de besluitvorming na 1989 was dus niet alleen sprake van afgeronde onderhandelingen in het onderhandelingsforum (het VPO) maar ook van onderhandelingen tussen COTG en VPO. De voomaamste drijfveren achter deze onderhandelingen waren de wens van het VPO om jurdisch houdbare tariefbesluiten tot stand te brengen en de matschappelijke druk op het COTO om het 'beleidsmatige' belang van het VPA te erkennen. Beide partijen waren to elkaar veroordeeld, onder meer door de afstandelijke houding van WVC dat alle inhoudelike verantwoordelikheid bij de belangenorganisaties en het COTG neerlegde, maar er waren ook tegengestelde belangern.

Van afgeronde onderhandelingen was bij de praktijkkostenaffaire geen sprake. Alspraken over agenda"s en protocollen waren weliswaar mogelljk maar overeenstemming kon niet worden bereikt. Naarmate de weg van het doen van eenzijdige woorstellen aan het COTG woor de VNZ en het $\mathrm{KLOZ}$ aantrekkelijker werd, verloren de onderhandelingen steeds meer aan aantrekkingskracht. In plaats van compromis zoekend gedrag was in toenemende mate sprake van symbolische onderhandelingen. Na initieel serieuze pogingen in $1986 \mathrm{mn} 1987 \mathrm{nam}$ de LSV deel or de besluitvorming in het COTG uit te stellen en participeerde de VNZ om naderhand. niet van een weinig constructieve houding beschuldigd te kunnen worden.

Het onderhandelen over tarieven werd tussen 1986 en 1988 vervangen door een op het eerste oog technocratische discussie over de hoogte van verschillende kostenposten wan medisch specialisten. Dit besluitvormingsproces was echter ogenschijnlik technocratisch. De voorstellen werden gedragen door degenen die daar woordeel bij hadden. De berekeningen vonden geen instemming bij de medisch specialisten die vergeefs hun eigen gegevens inbrachten.

Bij de tweeslag en de reshuffling was tevens sprake van een cijfermatige onderbouwing van de voorstellen zonder dat deze vanzelfsprekend voortkwam uit gegevens waarover brede overeenstemming bestond. Ondat over de doelstelling van beide tariefvoorstellen in het VPO brede overeenstemming bestond, restte het COTG weinig anders dan een juridischtechnische bijdrage te leveren. Door enige creativiteit aan de dag te leggen konden met behulp van de tariefformule tariefvoorstellen ontwikkeld worden, die de toets der juridische kritiek op het eerste oog konden doorstaan. Opnieuw stond het hanteren van technische kennis in dienst van voorgenomen tariefaanpassingen en moest dit de politieke doelstellingen maskeren.

Kenmerkend voor de totstandkoming van tarieven was dat de overheid nauwelijks gebruik maakte van de hiërarchische mogelijkheden. In plaats daarvan werd het overleg over de tarieven tussen de belangenorganisaties onderling en tussen deze organisaties en het COTG door WVC geconditioneerd. Het departement stelde voorwaarden aan de beshuivoming zonder direct betrokken te raken. Het COTG daarentegen nam verschillende keren op basis van formele bevoegdheden besluiten die afweken van de consensus onder partijen.

In het algemeen ontstond een ingewikkeld patroon van interactiesoorten dat nauwelijks aan te duiden is als een sociale praktijk die owereenkwam met de principes van de wet. Er kan slechts worden geconstateerd dat de actoren procedures voorbrachten warin sommige interactiesoorten $1 i j d e l i j k$ meer nadruk kregen dan andere zonder dat de leiter van de wet dit determineerde. Dit wil niet zeggen dat de bes/uitvorming over tarieven door een grote mate van onrechmatigheid gekenmerkt werd. Met uitzondering van de tweslag werd geen van de tariefbesluiten van het COTG en geen van de richtlinbesluiten door WVC door de rechter als onrechtmatig beoordeeld. 


\subsection{De noodzaak van het bespelen van de instituties}

Het ontstaan van een sociale praktik als het geheel van soorten van interacties kan volgens Mayntz en Scharpf niet op het conto geschreven worden van een enkele actor als het gaat om besluitvorming in constellaties van verschillende actoren met wederzijds afhankelijke handelingsopties. Evenmin vormt het geheel van soonten van interacties simpelweg het geaggregeerde effect van een veelvoud van niet aan elkaar gerelateerd handelingen maar ontstaat dit geheel uit de interdependentie wan op elkaar afgestemde handelingen (1995b: 60). De vraag hoe dit heeft plaatsgevonden tijdens de totstandkoming van tariefbesluiten wordt in deze paragraf beantwoord.

Het uitgangspunt bij deze beantwoording dient de waststelling te zijn dat de actoren de interactiesoorter niet opriepen door wettelijke regels te reproduceren op basis van normatieve instemming. Ower het algemeen stelden de actoren hun interacties in dienst van de strategische overwegingen in de hoop dat dit in geldige en gunstige tariefbesluiten zou resulteren. De beleidsdoelstellingen stonden woorop. Of wettelijke regels gevolgd moesten worden, kwam later aan de orde, hetgeen niet ongewoon is bij bestuurlijk handelen (zie bijvoorbeeld ook: Van Zoest, 1992: 477). Actoren die juridische procedures startten, deden dit meestal niet ondat zij wilden dat besiuiten rechtmatig tot stand zouden komen, maar omdat het eigen belang geschaad werd. De juridische discussie in de eerste jaren negentig werd niet gevoerd omdat men hechtte aan juridische zuiverheid, maar omdat dit noodzakelijk was om de onderhandelingsuitkomsten te beschermen tegen juridische procedures. De technocratische discussie in het COTG was voor de VNZ niet aantrekkelijk vanwege het technocratische karakter maar vanwege de mogelijke opbrengst. Evenzo werd het gebruik van de formele hierarchische mogelijkheden door WVC afhankelijk gemakt van hun bijdrage aan de doelstellingen. De zelfregulering die in het VPO gestalte kreeg, had hierdoor nauwelijks een normatieve basis. Deze onafhankelijkheid van interactiesoorten ten opzichte van een nomatieve overeenstemming verklaart tevens de waargenomen veranderlijkheid in interacties.

Als interactiesoorten niet voortkwamen wit een normatieve consensus over de juistheid van de te ontwikkelen interacties, wat sloeg dan nog de brug tussen de handelingstheorieën en de opgetreden interactiesoorten? In eerste instantie de instrumentele visie op de Wtg die in vrijwel alle handelingstheorieèn overheerste, maar wooral de bevestiging van deze visie door de op collectief niveau heersende mening over hoe er met de Wtg mocht worden omgegaan. Het ontbreken van consensus over nomen hoeft geen belemmering te zijn een bepaalde interactesoort te laten domineren. Het gaat namelijk niet om de individuele motieven maar wel on de gehanteende regels voor interactie. "It is not to the motives of individual actors that we must look but to the rules and standards that define the arena in which these motives are played out." (Bell. $1985: 217)$.

De belangrijkste standaard die de interactiesoorten bij de totstandkoming van tarieven voor medisch specialisten tussen 1986 en 1992 bepaalde, was het wettelijk opportunisme. Het basale regulerende mechanisme dat er voor zorgde dat bepaalde interactiesoorten tijdelijk domineerden was de permanente drang om de eigen particularistische belangen woorop to stellen en vervolgens te legitmeren in termen van de fomele wetgeving. Het gaat daarbij om een scala aan activiteiten:

"...(1) Whe active imtent to use institutional processes and relations opporumistically, to comopt and neutralize institutional constivents, to shape and redefine institutionalized noms and external criteria of evaluation, and to control or dominate the source, allocation, or expression of social approval." (Otiver, 1991: 159).

Toegepast op min onderzoek betekent het gebruik van instituties dat actoren in hun poging de besluitvorming over tarieven te beheersen zich aansloten bij groepen die kozen voor een 
collectieve actiestrategie waarbij en doelrationele hantering van de instivtionele regels vooropstond. De Whg werd niet als gegeven geaccepteerd natar de actoren stelden zich actief op ten aanzien wan de fomele regels. Als deze beperkingen oplegden, werd er maar gestreefd ze aan te passen of te verwijderen, als de regels mogelijkheden boden werden ze zonder meer gebruikt teneinde de kans op realisatie van de eigen doelstellingen te vergroten. Daarbij was het nodig het handelen te legitimeren in temen van de formele wetgeving. De actoren construederden een bepaalde vorm wan naleving, hetgeen in het algemeen inhondt dat organisaties door hun reactio op wetgeving bepalen hoe de naleving van de wet er de facto uitziet (Edelman, 1992: 1568). Volgens Wassenberg gaat het daarbij om twee zaken: anderen overtuigen van de legitimiteit van de eigen handelingen en het veilig stellen van eigen belangen. Wassenberg wil geen intentionaliteil vooronderstellen hetgeen ik op basis van mijn studie wel zou willen doen, maar hij slaat de spijker op de kop door te stellen dat netwerken van particuliere en publieke organisaties een gezamenljk belang hebben bij het overtuigen van anderan van de legitimiteit (1988: 29). Daarmee wordt namelijk geprobeerd de omgeving te beheersen teneinde bijvoorbeeld de uitkomsten van het onderling overleg af te schermen tegen al te lastige vragen van andere belanghebbende actoren. Anderen overtuigen van de legitimiteit van het handelen is niet alleen in het belang wan belangenorganisaties maar is eveneens onnisbaar voor de overheid en het zelfstandig bestuursorgaan. In de volgende paragrafen hoop ik duidelijk te maken waarom dit zo is.

\section{De noodzaak tot het bespelen wan instituties woor de overheid}

In het algemeen zijn theoretici het erover eens dat een moderne overheid niet meer kan vertrouwen op juridische normen teneinde het eigen handellen te legitimeren. De overheid wordt steeds meer beoordeeld op wat werkelik bereikt word en in hoeverre dit gesteund wordt door de matschappelijke actoren. Offe heeft de overwegingen achter het overheidshandelen onderverdeeld in drie rationaliteiten. Ten eerste kunnen overheidsorganisaties het gedrag laten sturen door formele (rechts-)nomen wardoor sprake is van conditionele programmering. Ten. tweede kan de effectiviteit van het eigen handelen voorop staan (finale of doelprogrammering). In een geconditioneerd programma vindt het bevoegd bestuursorgaan

"...(d)e normen voor zijn handelen in de algemene rechtsregel, in 'de wet". "Politiek" en 'bestwu' liggen hier wit elkaar en deze fructies zijn aaw verschillende maatschappelijke instituten toegedeeld." (Hoekema, 1984: 562).

Een finale doelprogrammering daarentegen

*... (h) oudt in dat een orgaan de brede opgawe heef om in de toekomst bepaalde resulwaten te bereiken gemeten aan de behartiging wan een haa opgegeven belang of belangencomplex. De wet geef hooguit een doel adn warna gestreef moet worden en delegeert de wagg wanneer precies welk middel/welk rechtsgevalg moet volgen aan het dagelijhs bestum. Er is wijheld on de beste middelen daartoe in te zetten ..." (Hoekema, 1984: 562 ).

Ofle spreekt hier van systemische rationaliteit die hij definieent als "...(1)he bureaucratic fulfiment of the functional requirements of their societal environment." (1987: 302). Volgens Offe is het belang van de systemische rationaliteit voor overheden steeds groter geworden. Waar de "oude overheidsbureancratieesn gericht waren op gehoorzaamheid aan de regels van het positieve recht, rechtvaardigen de moderne zich door te voldoen aan de functionele eisen van een vakk complexe en dicht bevolkte ongeving.

Naast de conditionerende factoren en de steeds belangrijker wordende doelprogrammering moet aen overheidsbureaucratic politieke consensus opbouwen. Dit is de derde vorm van rationaliteit. De behoefte aan steun bij andere politieke actoren ontstaat haast dwangmatig bij cen op effecten gerichte overheid ondat een doelgerichte aanpak snel stuit op juridische grenzen. De onvermujdelijkheid van het overtreden van regels leidt ertoe dat de uitvoerende overheid overeen- 
stemming mat maatschappelike actoren moet zien te bereiken. Deze overeenstemming dient als legitmering van beleid waar de oude, conditionerende momen tekort schieten. Naamate de doelprogrammering het gedrag van de overheid gaat oveneersen, wordt dus vanzelfsprekend de afhankelijkheid van de overheid ten opzichte van de maatschappij groter: de overheid verandert van ". (h)oheitlichen Souverän zum primus inter pares, vom unpartelichen Dritten zum engagierten Beteiligten." (Wilke, 1982: 201). De afhankelikheid tussen staat en samenleving resulteert in een noodzaak tot onderhandelingen tussen bestuurders en maatschappelijke groeperingen waarbij veelal cen ruill plaats vindt, en in een vertroebeling van de taakafbakening vars politick verantwoordelijken en ambtelijke uitvoerders.

Bij de besluitworming over tarieven is gebleken dat hiermee de kous nog niet af was. Offe besteedt weinig aandacht aan het tekortschieten van politieke consensus bij besluitwoming waarbij het uiteindelijke juridische oordeel door een onafhankelijke rechter doorslaggevend is. Aan deze onafhankelijke derde is sterk behoefte als gevolg van de opkomst van de onderhandelende overheid en de verplaatsing van de politiek (Derksen 1997). Een belangrijke rol van de onafhankelijke rechter kan negatieve gewolgen hebben. De overheid loopt in een sterk gejuridiseerde omgeving het gevaar beticht te worden van ontechtmatige daden. Bovendien kan een negatieve uitspraak van de rechter tot grote vertraging in de besluitworming leiden (Versteden, 1997: 945-946). Dit wordt nog waarschijnlijker bij het ontbreken van brede consensus. Zo bleek bij de besluitvorming over de tarieven dat sommige actoren, zoals bijvoorbeeld individuele medisch specialisten, niet betrokken konden worden bij politieke afspraken waardoor de juridische dreiging niet op een politieke manier kon worden afgewend. Maat ook rechtsnormen bieden geen zekerheid. Het bestur

"...(h)eft daarvoor slechis een indicatie, een algemeen richtsnoer, en het is aan het eind wan het proces de rechter die bepaalt wat die betekenis in concreto is. Voor het bestur schuilt or in de algemene beginselen van behoorlijk bestuur dus een flink element van rechtsonzekerheid; en dit beheerst het besturen continu." (Versieden. 1997: 945 ).

Teneinde de politieke en juridische onzekerheid te beheersen dient een overheid een strategie te ontwikkelen die zowel het gewenste besluit als de juridische houdbaarheid ervan tot stand brengt.

In de onderzochte casus is meerdere keren naar voren gekomen dat de gevolgen van ondoordacht overheidshandelen een belangrijk motief voor WVC vormden zich niet intensier in formele zin te bemoeien met een juridische onderbouwing van de besluitvorming over tarieven. WVC koos voor een beleid van distantie. Het departement omarnde de initiatieven van dominante coalities die vervolgens onderdeel van het overheidsbeleid werden waardoor een politieke rationalisering plats vond. Dit werd vergezeld door het toeschuiven van de verantwoordelijkheid voor de juridische vormgeving aan de belangenorganisaties en het $C O T G$. Dit was geen vorm van passiviteit, van een op-hoop-van-zegen strategie, maar een bewuste poging om tegemoet te kunnen komen aan formeeljuridische eisen. Het bewust niet gebruik maken van de formele mogelijkheden tot interwentie en de verdeling van de verantwoordelijkheden ten aanzien van de juridische houdbaarheid waren de peilers van de manier warrop WVC het formele institutionele kader bespeelde teneinde aanvardbare tariefbesluiten tot stand te laten komen.

\section{De noodzaak voor de belangenorganisaties}

Belangenorganisaties stellen niet de formele voorschriften van de wet maar hun eigen belangen voorop. Hierdoor komen ze in de loop van besluitvormingsprocessen moeilijkheden op het spoor die niet meer oplosbaar zijn door symbolische gehoorzaamheid aan de wet. Ze zullen zich moeten conformeren aan normen, niet door eenzijdige aanpassing maar door de eigen doelstellingen en formele vereisten te verenigen in de collectieve besluiten. 
Er zijn theoretici die benadrukken dat een symbolische navolging wan de formele regels op zich voldoet voor het voortbestaan van bestum lijke praktijken, en daar zelfs op zou zun gericht. Lippendienst an de formele vereisten malkt het mogelijk dat door middel wan de bestuurspraktijk de beshuiten tot stand komen die er werkelijk toe doen (Edelman 1985, Wassenberg 1988). Symbolische gehoorzamheid voldeed echter niet bij de besinitvorming over tarieven. Er was een noodzaak tot formele goedkeuring van de overleg-en onderhandelingsresultaten. Uiteindelijk moesten actoren, voorzien van formele bevoegdheden (overheid en COTG), goedkeuring hechten aan de voorstellen wan partijen. Bovendien legde de mogelikheid tot beroep tegen beslissingen van het COTG een grote druk op alle betrokkenen om juridisch houdbare redeneringen en procedures te volgen. Scharpf spreekt wan 'hierarchische beloningen' die noodzakelijk zijn in bestuurlijke netwerken. De noodzaak tot formele ratificatie wan onderlinge overeenkomsten beperkt namelijk de kans op kergaand opportunisme en geeft hiërarchisch hoger geplatste organen nog enige invloed op de collectieve uitkomsten (Scharpf, 1993:146). De hiërarchische beloningen stellen grenzen aan het vrije onderhandelingsspel on dwingen de actoren tot meer dan lippendienst aan de formele vereisten.

In deze studie is aan het licht gekomen dat het niet de overheid was die de hierarchische beloningen verstrekte. Ook het COTG bleek bij met name de tweeslag en de reshuffling niet de actor te zijn die een definitieve hiërarchische beloning kon geven. De hierarchische beloningeth waren uiteindelijk athankelijk van het rechterlijke oordeel. Door de toenemende juridisering van de besluitworming ontstond er een "baas boven baas". Het oordeel wan WVC en COTG werd weliswaar als onmisbaar beschouwd als er geanticipeerd moest worden op rechterlijke uitspraken over de rechtmatigheid van een tariefbesluit, maar de uiteindelijke uitsprak deed de rechter. De onzekerheid, de onwoorspelbaarheid en de onbeïnvloedbaarheid van de rechters heeft ervoor gezorgd dat er zoveel overleg nodig was over de vorm wan tariefvoorstellen en tariefbesluiten hetgeen betekende dat ook de pogingen tot het gebruik van de instituties veel tijd vroegen.

\section{De noodzaak voor het zelfstandig bestuursorgaan}

Tijdens de totstandkoming van tarieven voor medisch specialisten probeerde het COTG het beeld te creèren dat het alleen maar streefde naar "juiste" tarieven, tariefbesluiten die de juridische toets konden weerstaan en pasten binnen een beleid gericht op kostenbeheersing. Het was deze rol wan het COTG die WVC zo waardeerde en ondersteunde in de door ambtenaren gehanteerde strategie van distantie. Een dergelijke taakopvatting maakt het de onderzoeker echter ook moelijk na te gaan of dan nog sprake is van het bespelen van instituties. Dit veronderstelt immers dat de doelstellingen van de actor en de wettelijke vereisten waaraan de actor moet voldoen te onderscheiden zijin. En niet alleen de onderzoeker heef dit probleen. Gedurende de totstandkoming van bestuiten was het voor de direct betrokken actoren weneens regelmatig nauwelijks mogelijk vast te stellen of het commentaar van het COTG op tariefroorstellen ingegewen was door en objectieve interpretatie van de formele regels of door cugen doelstellingen.

De door het COTG uitgedragen eigen takopvatting is kenmerkend voor organisaties die hun taakstelling aan een wet ontlenen en die toezien op een juiste witwoening ervan. Zw hanteren veelal een formalistisch standpunt warin een algehele naleving van duidelijk wetlelijke voorschriften centraal staat. Daar waar de institutionele inbedding gekenmerkit word door ambiguiteit en politiek gebruik van regels dienen formalistische organisaties standpunten in te nemen op basis van eigen beleidsvoorkeuren en interne agenda"s (Suchman \& Edelman, 1997. 934). Dit gold ook woor het COTG. Ten eerste bood de formele takomschrijuing het COTG een belangrijke mate wan discretie. Het COTG had belleidswijheid, waarvan het gebruik onder meer uimondde in eigen initiatieven om de vergoeding voor praktijkkosten te verlagen. Ten behoeve van dat eigen beleid. was het voor het COTG noodzakelijk tariefbesluiten een vorm te geven die zowel de verlaging tot stand zou brengen als binnen de Wtg en de bestaande jurisprudentie zou 
passen. De aranak die gekozen werd, makte beide doelstellingen mogelijk. Deze aanpak gaf het COTG meteen de mogelikheid alle opties van de Wig ten volle uit te buiten. De voorgestelde beperking van de vergoeding voor de praktijkkosten van medisch specialisten tot de beroepskosten ten de welwillende houding ten opzichte van de eenzijdige voorstellen van de VNZ geven alan dat het COTG de beshitvoming over tarieven wilde sturen met behulp van de wetlelijke kaders. Ten tweede kon het COTG zich niet onttrekken aan de praktijk van het bespelen van instituties. Dit deed zich voor bij de totstandkoming wan de tariefbesluiten op basis van het VPA. Toen bevond het COTG zich als het ware tussen het netwerk van maatschappelike organisaties, de overheid en de rechter in. Aan het COTG werd gevraagd mee te denken over een dusdanige vormgeving van tariefbesluiten dat zowel aan de zogenaamde beleidsmatige wensen wan de onderhandelaars als de juridische eisen tegemoet werd gekomen. Met andere woorden, het COTG als orgaan met en grote formele juridische autoriteit moest de bestaande formele regels 20 interpreteren en representeren in formele besluiten, dat de rechter uiteindelijk zijn goedkeuring kon hechten aan politieke tariefbesluitem. Zo beschreven zijn deze activiteiten een bijna ideatlypische vorm van het bespelen van de institutionele omgeving.

\subsection{Conclusies ten aanzien van het actorgerichte institutionalisme}

Het nieuwe institutionalisme is een optelsom van een aantal benaderingen die ondanks de gemeenschappelijke kenmerken op verschillende manieren de wisselwerking tussen interacties en instituties bestuderen. Mijn invalshoek heeft zich beperkt tot het actorgerichte institutionalisme waardoor ik in staat ben de volgende conclusies over de relatie tussen institutionele kaders en daarbinnen plaatsvindende besluitworming op te stellen.

Ten eerste is duidelijk geworden dat instituties in de vorm van formele wettelijke kaders gedeeltelijk bepalen welke actoren participeren in besluitvormingsprocessen omdat zijj bevoegdheden toegewezen hebben gekregen. De relatie tussen instituties en interacties wordt hiemee echter statisch aangeduid. Er wordt namelijk slechts aangegeven dat bepaalde actoren participeren op basis van hun formele bevoegdheid, maar de dynamiek in de participatie blijft onderbelicht. Van belang voor meer inzicht in de veranderlijkheid van de participatie is vooral kennis van da mate warin actoren zich realiseren dat de behartiging van hun belangen gebaat is bij meer of minder deelname. Ook ontstaat dan meer inzicht in de achtergronden van pogingen tot zelforganisatie.

Institutionele kaderg hebben een invloed op handelingstheorieën, mear zij hoeven op de kcorte terrijin niet te leiden tot normatieve consensus over regels voor gedrag. Of actoren zich houden an tregels hangt af van de mate waarin ze gebruikt kunten worden om de eigen doelstellingen te bereiken. Deze doelstellingen zijn niet exogeen bepaald. De deelname aan besllitwoming in een netwerk implicent dat er afstemming plats vind met andere actoren warin handelingsleidende doelstellingen en strategieén worden gegenereerd. Tegelijk hebben de doelstellingen en strategieèn een institutionele herkomst hetgeen wil zeggen dat ze door de actoren ontleend worden ande fomele kaders.

Welke interactiesoorten op het collectieve niveau uiteindelijk tot stand komen hangt in sterke mate af wan de manier waarop organisaties menen te mogen omgaan met de formele regels. Mijn onderzoek legt de nadruk op het strategisch gebruik van de institutionele omgeving hetgeen inhoudt dat actoren de beperkingen en mogelijkheden van wettelijke regels niet passief ondergaan, maar ze proberen te gebruken en te veranderen als dit het bereiken van de doelstellingen naderbij brengt. De noodzaak tot dergelijk strategisch gedrag wordt groter naarmate besluitvorming meer gejuridiseerd raakt. Dat het uiteindelijk een onafluankelijke rechter is die een uitspraak doet over de rechtmatigheid van een besluit, leidt er toe dat de traditionele 
hïrarchische beloning door de overheid of door een daartoe gemachtigd zelstandig beshursorgaan niet meer voldoende is.

De voomaamste krachten achter de juridisering van publieke besluitworming die bij de lariefvorming optrad zouden dus niet zozeer gezocht moeten worden in veranderingen van de formele mogelikheden tot bestuursbescherming, maar wel in de manier wamop wordt ongegaan met deze mogelijkheid. Evenzo komt de imwloed van de formele regelgeving op de uiteindelijk tot stand gekomen besluiten niet tot stand door het al dan niet vasthouden aan de regels, maar door de collectieve productie van een bepaalde vorm van naleving.

\subsection{De besluitvorming na 1992: het hangt er maar van af....}

Mijn analyse stopt in 1992. Na 1992 heeft de overheid in toenemende mate gebruik gemaakt van de mogelijkheden van de Wtg budgetoverschrijdingen te laten volgen door tariefkortingen. In 1992 werd namelijk een wijziging doorgevoerd die het mogelijk maakte op basis van het nacrobudget voor medisch specialistische hulp aanwijzingen aan het COTG te geven om verlagingen van tarieven tot stand to brengen. Na enkele jaren heef de overheid dit beleid stopgezet. Omdat de medisch specialisten op regional en plaatselyjk niveau samen met ziekenhuisdirecties en zorgverzekeringsmaatschappijen afspraken wilden maken over budgetten voor maatschappen, besloot de overheid af te zien van verdere verlagingen van tarieven. Weer stond de besluitvorming over tarieven in dienst van beleid gericht op kostenbeheersing.

Gelijktijdig vonden enkele andere ontwikkelingen plaats. De Wtg als kader waarbinnen besluiten over tarieven in de gezondheidszorg dienen te worden genomen bleef bestaan. De zorgverzekeraars maakten daarvan gebruik on de verschillen tussen de particuliere en ziekenfondstarieven door middel van een besluit van het COTG te kumnen laten verdwingen. Maar nieuwe ideeèn kregen vaste voet aan de grond. Ten eerste heeft de gedachte dat in de gezondheidszorg marktwerking kon worden geintroducerd geleid tot de vraag of er sprake zou kunnen zijn van vrije prijsvorming voor bepaalde onderdelen wan de gezondheidszorg (Commissie Prijsvorming in de Zorgsector 1992). In toenemende mate bleek de overheid deze vraag bevestigend te willen beantwoorden. Voor bijvootbeeld de thuiszorg zijn initiatieven genomen de prijsvorming meer wrij te laten. Ten aanzien van de tariefvorming woor medisch specialistische zorg lijkt men het eens te zijn dat algehelle vrijheid bij de prijsworming nog niet wenselijk is. Maar ook in deze sector wordt nagedacht over nieuwe structuren. De discussie staat in het teken van de zogenaamde productypering en outputpricing, waarbij de onderliggende gedachte is dat de vele duizenden verrichtingen van medisch specialisten samen zouden zijn te vatten in een aanzienlijk beperkter aantal 'producten', met elk een eigen tarief. Dit tarief zou tot stand moeten komen door middel van een technocratische aanpak, waarbij woor de verschillende onderdelen wan het product em prijs wordt vastgesteld op basis van objectiverbare factoren. Tenslotte is het rapport van de commissie-Biesheuvel van grote invloed geweest. Deze commissie bepleitte het afschaffen wan de betaling per verrichting en adviseerde om do betaling wan de medisch specialist in handen te leggen van het ziekenhuis. Elke specialist zou recht moeten hebben op een bepaald basisinkomen dat eventueel verhoogd zou kunnen worden door loeslagen in verband met bijwoorbeeld extra activiteiten (Commissie Modemisering curatieve zorg 1994$)$. Het advies van de commissie viel bijzonder slecht bij de medisch specialisten, mat de overheid heeft het tot doelstelling wan beleid verheven.

Deze ontwikkelingen drukken verschillende wensen ten aanzien van de tariefvorming voor medisch specialistische hulp uit. De wens tot invoering van vrije prijsvorming en de adviezen wan Biesheuvel zijn moelijk verenigbaar, maar ze hebben een algemene doelstelling gemeen: de institutionele context van de tariefvorming voor medisch specialisten in Nederland moet drastisch worden hervormd. Wrije prijswoming kan alleen bestaan binnen de instituties van de 
markt waarmee de Wtg op gespannen voet werkeert, terwijl de introductie van een basisinkomen voor medisch specialisten niet mogelijk is zolang het medisch specialisten toegestaan is vrijgevestigd te zijn en er een systeem van betaling per verrichting bestaat. Slechts het systeem van outputpricing is mogelijk binnen het bestaande institutionele kader omdat het wooral een technocratisering van de besluitvorming over tarieven behelst waarbij de kennis van het COTG van groot belang zal zijn. Een keuze voor iets anders dan de outputpricing betekent dus een keuze voor een nieuwe besluitvormingstructuur.

Zolang deze nieuwe structuur er niet is, zullen keuzen gemaakt worden als in de jaren daarvoor. Dominante coalities maken het op bastis van het instrumenteel gebruik van de wet mogelijk dat de besluitvorming een bepaalde worm krijgt. Met de vaststelling dat de besluitvorming over tarieven binnen het bestaande systeem van de Wtg bepaald wordt door het bespelen van instituties wordt het vrijwel onmogelijk een ontwikkeling in een bepaalde richting te voorspellen. Veel hangt af wan de toevalligheid van onderlinge verhoudingen, van tijdelijke configuraties van actoren en hun strategieën van bespeling van de instituties die de invloed van formele regels op de besluitvorming vastleggen. Van der Veen heeft de eigen dynamiek van instituties besproken. Als gevolg van de anticipatie van actoren op instituties op basis van doelrationele calculaties valt nauwelijks nog te voorspellen welke gevolgen het gebruik van instituties zal hebben (1997: 14). De totstandkoming van besluiten over tarieven voor medisch specialisten heeft deze dynamiek ten volle geillustreerd. Er is bovendien geen reden te veronderstellen dat dit gebruik niet aanwezig was in de jaren na 1992 of dat het de komende tijd afwezig zal zijn. 


\section{Summary}

Although in the Netherlands the majority of medical specialists is paid fee for service the decision making on fees for specialist care has rarelly been the object of scientific studies. Insight in how decisions on fees are made is to a large extent missing. This situation has lead to the first aim of my study: to gain understanding of the decision making on fees for medical specialists in the Netherlands. The second goal is theoretical: to clarify the relationship between the decision making process and the formal legal rules developed for it. Most of these formal rules are mentioned in the Health Care Tariffs Act of 1982 (Wet Tarieven Gezondheidszorg, WTG).

Starting from these objectives $I$ have formulated the following research questions. First, what actors and which constellations of actors participated in the decision making on fees for medical specialists since the introduction of the WTG in 1982 and to what extent was the participation determined by the formal rules? Second, what were the action theories of these actors and how did they refer to the WTG? Third, what kind of interactions took place during the decision making process and to what extent did they correspond to the principles of the WTG?

These questions relate to the core elements of the actor-centered institutionalism (acteurzentrierten Institutionalismus) of Mayntz and Scharpf that is used to conceptualize the relationship between decision making and formal institutions. The first element is the institutional embeddedness of the process of decision making. Although the schools in institutional political science mention various kinds of institutions this study addresses only the formal institutions: the rules of the WTG (and the broader setting of relevant administrative law). It is assumed that these formal rules do not determine the thinking and actions of people and organizations. Especially in administrative domains where strategic decision making prevails institutional creativity empowers people and organizations to mediate the impact of law on society. The second element is de participation of constellations of actors. Political scientists increasingly doubt the existence of centers of governmental power in public decision making. This doubt is most strongly expressed in policy network analyses and postmodern public administration. Institutionalists however stress the importance of formal structures in which the right or duty to participate is laid down. The third core element of the actor-centered institutionalism is the action theory (or conceptual map, frame or policy belief) each actor employs. An action theory comprises the actor's assessment of the situation he is in, an overview of the ways to act, and his strategy. Based on his action theory an actor participates in interactions (the fourth element). To describe the interactions I have made a distinction between four conflict solving mechanisms: technocratic, hierarchical and judicial decision making, and negotiations.

With respect to the methodology 1 have used sequence modeling of events in decision making to conceptualize the coming about of fees as a dynamic process. Second, an inductive way of reasoning has been followed. The central theoretical concepts of institutionalism lave guided the study but were given meaning by interpretations of empirical research results. Data were collected by doing a multiple case study: three important fee decisions in the period between 1986 and 1992 were the main object of research. Documents in the archives of five core actors were analyzed. The reports of this analysis were discussed extensively with representatives of the organizations who were directly involved in the decision making process.

The objectives, methodology and theoretical background are discussed in the first two chapters. In chapter three I describe the development of the rules for decision making on fees for medical specialist care in the Netherlands during this century. I summarize this development in paragraph 3.5 by summing up the changes on the following themes:

- who decides? 
In the beginning of the century specialists were able to detemine fees for private patients themselves. For the payment for care for sickness fund patients medical specialists were dependent on regional funds that were fed by sickness funds and administered by local specialists organizations. After the Second World War representative organizations of sickness funds and medical specialists took over and negotiated on nationwide fees. The centralization of the decision making on private fees lasted until the late sixties when the Dutch Association of Medical Specialists (LSV) took the initiative to develop national guidelines for private fees. In the eighties the private insurer organization and (semi-)governmental organizations joined the sickness fund and specialists organizations in their deliberations on fees. A dense network unfolded in which decision making on fees took place.

- what is the object of decision making?

Since the beginning medical specialists were always paid differently for the treatment of sickness fund patients and for the treatment of private patients. For medical specialists especially the low level of sickness fund payments was wery hard to accept. In the period before the Second World War also some additional issues had to be settled (e.g. the payment system) but after the war only the level of fees remained to be under discussion. With the introduction of the WTG attention was given to the decision making structure but it was in the late eighties and early nineties that the payment structure again reached the political agenda, however without resulting in structural adjustments so far.

- how are decisions taken?

The fee decision rules were not laid down in formal law for a long time. For private payers doctors employed a system of price discrimination. This meant that wealthier people had to pay more for health services than less well to do. For sickness fund payments regional differences were characteristic. After the Second World War decision making on fees for sickness funds became centralized as a consequence of the regulation of social health insurance. Private fees still remained to be determined individually within the margins set by local specialist organizations but in the sixties the LSV developed guidelines. In the eighties decision making on fees for private and sickness fund patient came together under the rules of the WT.

- where are these decisions taken?

While in the first half of this century decision making took place on a regional level and within the medical practice nowadays a national forum consisting of peak organizations and (semi)govemmental organizations determines the fees. The locus of the decision making on fees has shifted from the local to the national level, mainly as a consequence of the development of collective structures in health care.

In chapter foun an extensive overview is given of the events that took place between 1986 and. 1992 during the coming about of three fee decisions. The first decision regarded the costs of practice for medical specialists. The second decision became known as the 'teshuffling' of fees. It was decided that through changes in fees the differences in income between specialties should decrease. By designing two fees for one treatment (the third decision) it was made possible to pay lower fees to physicians who refused to sign a contract with sickness funds based on a national agreement between five parties (the Five-party Agreement, (VPA).

Chapter five gives a quantitative description of the participation of organizations between 1986 and 1992. First I picture the individual participation. It was found that seven actors participated intensively: the peak organizations of medical specialists (LSV), sickness funds (VNZ), private health insurers (KLOZ) (and their related collective health insurers, KPZ), the hospitals (NZR), and the department of Health (WVC) and the Central Agency for Health Care Tariffs (COTGi). The chapter also provides insight in the patterns of participation described as the participation of groups of organizations. Using clusteranalysis I come to the main finding that bilateral deliberations in $1986 / 1987$ were replaced by multiateral negotiations. The fifth chapter finishes with an explanation of the causes of the (changes in) participation. The formal rules determined 
more or less the boundaries of the network of participants. The dynamic of the participation however can not be explained by such a static variable. The strategic use of legall rulles, the inability of the peak organizations to find solutions in conflict situations, and the occumence of external effects of fee decisions caused changes in the participation of (groups of) actors.

In the sixth chapter the action theories of the group of core organizations are described and analyzed. I conclude that dominant temporary coalitions of organizations tried to reach energent specific goals that were congruent with the particularistic higher interests. These coalitions were fluent and had to face opposition of other organizations. The existence of dominant coalitions however did not produce consensus on the ways to act during the decision naking process. Thus strategies diverged. Common to all action theories was the dominance of goal rationality. As a consequence the WTG was seen as a resource.

The instrumental use of legal provisions was only one forn of influence of institutions on the action theories. The analysis shows that the stated goals were derived from formal nules and decisions of courts. In the higher interests organizations could not find guidelines to formulate concrete goals for action. It also shows that the institutions provided organizations for ways to act and possible strategies. Finally the institutional context obliged the organizations to legitimize continuously their actions and decisions, especially because of the need for hierarchical rewards.

What kind of interactions took place during the decision making process is the topic of chapter seven. Interactions became judicialized. Not only were the courts engaged in every fee decision, but also the organizations increasingly used judicial arguments in their deliberations. Technocratic decision making in the sense of taking decisions through open discussions in which transparent information is exchanged did not occur. Technical knowledge was used by the temporary dominant coalitions to promote a successful implementation of their negotiated fee decisions, especially to immunize them against judicial objections. Hierarchical interactions were not frequent. The COTG regularly used its hierarchical position to disapprove of the proposals of the negotiating organizations. The relationships between the govemment and the other network organizations however were more or less horizontal, although the department of Health conditioned the fee negotiations. Negotiations, as a fourth form of interactions, took place in the bilateral meetings in the first years (1986-1987) and in the meetings of five organizations beginning in 1989. In addition there was another locus for negotiations. During the implementation of the results of fee bargaining negotiations between the peak organizations, the COTG and the department of Health were necessary to reach agreement on the responsibilities of the COTG and the government.

In chapter eight I first summarize the main findings of the study. Then in paragraph 8.51 go into the question what forces were responsible for the complex structure of interactions dung the decision making on fees. I hypothesize that the collectively and constantly acknowledged rule of legal opportunism played an important role. Coalitions of organizations of which also the govemment and the COTG were part of employed strategies wherein formal rules were used to reach their temporary emergent goals. In doing this the organizations construed a specific type of compliance. This construction was intentional: it had to satisfy interests but it also had to convince critical participants and observers. The chapter ends with stating that the strategic use of institutions makes it almost impossible to forecast the development of the decision making on fees. This depends on the temporary configurations of actors and their strategies. 



\section{Bibliografie}

Abbott, A. (1990). A primer on sequence methods. Organizatian Science. 1 (4) $375-392$

Abrams, P. (1982). Historical soctology. Near Shepton Mallet (Somerset): Open Books

Algemene Rekenkamer. (1995). Het funcrioneren van het Centrab Organ Tarieven Gezondheidszorg. 's-Gravenhage

Alford, R.R., Friedland. R. (1985). Powers of theory. Capitalism, the state, and dewocracy. Cambridge: Cambridge University Press

Aminzade, R. (1992). Historical sociology and time. Sociologrical Methods \& Research. 20 (4) $456 \sim 480$

Anbeek, A.J. (1965). Problemen en aanrakingspunten van de ziekenfondsen bij de revalidatie en reactivering wan bejaarden. Tidschrift voor Sociale Geneeskunde. 43 (8) 294298

Baakman, N.A.A. (1990). Kritiek van hel openbare bestuw. Amsterdam: Thesis Publishers

Baajens, J.M.J. (1988). Beleidsnetwerken in actie. Deventer: Kluwer

Bardach, E. (1977). The implementation game: what happens after a bill becomes a law. Cambridge/London: MTT Press

Beck, U. (1986). Risk society. Towards a new modernity. London/Newbury Park/New Delhi: Sage

Bell, R. (1985). The culture of policy deliberations. New Brunswick (NY): Rutgers University Press

Berg, C. van den (1966). De betekenis die het Ziekenfondsbesluit heeft gehad voor de volksgezondheid. Tijdschrift woor Sociale Geneeskunde. 44 (22) 864 -866

'Beroepsorganisaties handhaven bezwaren tegen Tarievenwet. Gezamenlijk memorandum artsen, apothekers en tandartsen inzake gewijzigd Wetsontwerp Tarieven Gezondheidszorg" (1980). Medisch Contact. 35 (10) 299-303

Berveling, J. (1994). Het stempel op de besluitvorming. Amusterdam: Thesis

Beus, J.W. de (1991). De ontroning van het etgenbelang in de harde politieke wetenschap. Acta Politica. 27 (4) $383-423$

Brenninkmeijer, A.F.M. (1997). Tussen kadi en juridisch-mathematicus. Nederlands Juristenblad 72 (21) $936-942$

Bruijn, J.A. de, Heuvelhof, E.F. ten. (1991). Recht en netwerken: en bestuurskundige beschouwing, in: Bestuurswetenschappen. 45 (2) 105-116

Brüne, M. de, Schut, F.T. (1989). Overheidsbeleid en ziektekostenverzekering. In J.A.M. Maarse, I.M. Mur-Veeman (red.). Beleid en beheer in de gezondheidszorg. Assen/Maastricht: Van Gorcum 114-149

Burg, A.P.J. van der (1966). Practiserende artsen in de Volksgezondheidsnota. Tijdschriff voop Sociale Geneeskunde. 44 (8) 304-308

Burkens, M.C., Stroink, A.M. (1980), Sociale verzorgingsstart en consensuele besluitvorming. Nederlands Juristenblad. 55 (29) $743-750$ 
Coburn, D. (1993). State anthority, medical dominance, and trends in the regulation of the health professions: the Ontario case. Social Science and Medicine. 37 (7) $841-850$

Commissie-Ziektekosten-voorziening boven de loongrens (1957). Rapport. Medisch Contact. 12 (21) $360-370$

Commissie modernisening curatieve zorg (1994). Gedeelde zorg: betere zorg (rapport). Rijswijk: Ministerie van WVC

Commissie Prijsvorming in de zorgsector (1992). Op zoek naar een passende prijs. Rijswijk: WVC

Companje, K.P. (1997). Over artsen en verzekerars. Een historische stwdie naar de factoren. die de relatie ziekenfondsen-arlsen wanaf 1827 op landelijk en regionaal niveau hebben beinvloed. Utrecht (proefschrift)

Crouch, C. (1985). Corporatism in industrial relations: a formal model. In W. Grant (ed.). The political economy of corporatism. Basingsioke/London: MacMillan $63-88$

Czada, R.M. Windhoff-Heritier, A. (Eds.) (1991). Political choice mstitutions, rutes and the limiss of rationality. Frank furt am Main/Boulder (Col.): Campus Verlag/Westview Press

Derksen, W. (1997), De rechtscultuur als maatschappelijk fenomeen. Nederlands Tijdschrift voor Bestuwrspecht. 7 (1) 23-29

Dery, D. (1990). Data and policy change. Boston/Dordrecht/London: Kluwer Academic Publishers

Dove, H.G. (1994). Use of the Resource-Based Relative Value Scale for private insurers. Health Affairs. $13(5) 193-201$

Dunk. H.W. won der. (1996). Elke tijd is overgangstijd. Opstellen over onze omgang met de geschiedenis. Amsterdam: Promotheus

Dunn, W.N. (1993). Public policy analysis: an introduction. Englewood Cliffs (N.J.): Prentice Hall

Eckhoff, T. (1966). The mediator, the judge and the administrator in conflict-resolution. Acta Sociologica. $10148-172$

Eckstein, H. (1960). Pressure group poltics. London: George Allen \& Unwin

Edelman, L.B. (1992). Legal ambiguity and symbolic structures: organizational mediation of Civil Rights Law. Americam Jownal for Sociology. 97 (6) 1531-1576

Edelman, L.B. (1996). Introduction to symposium on the law and the new institutionalism. Sindies in Law, Politics and Society. 15 3-7

Edelman, M. (1980). Restricted and general political communication networks. Communication. $5205-217$

Edelman, M. (1985). The symbolic uses of politics. Urbana/Chicago: University of lllinois Press

Edelman, M. (1988). Constructing the political spectacle. Chicaga: The University of Chicago Press

Emerson, R.M. (1992). Disputes in public bureaucracies. Stadies in Law, Politics, and Society. $12 \quad 3-29$

Elster, J (1989). The cement of society. Cambridge: Cambridge University Press 
Erp, I. wan (1997). Beoordeling wan interactergimes op basis van het principe van de wet. Ben Regionaal Bestuur woor de Arbeidswoorziening als casus. Beleidswetenschop. 11 (3) 261 280

Festen, H. (1964a). De totstandkoming van een afzonderlijke organisatie voor specialisten binnen de Maatschappij (I). Medisch Contact. 19 (39) 643-646

Festen, H. (1964b). De totstandkoming van een afzonderlijke organisatie voor specialisten bimnen de Maatschappij (11). Medisch Contact. 19 (40) 664.666

Festen, H. (1964c). De totstandkoming van een afzonderlijke organisatie voor specialisten binnen de Maatschappij (III). Medisch Contact. 19 (41) $681-683$

Festen, H. (1964d). De totstandkoming wan een afzonderlijke organisatie voor specialisten binnen de Maatschappij (IV). Medisch Contact. 19 (42) 717-720

Festen, H. (1974). 125 jaar geneeshunst en maatschappij: geschiedenis van de Koninklike Nederlandsche Maatschappij tot bevordertng der Geneeskunst. Utrech: KNMG

Fischer, F. (1990). Technocracy and the politics of expertise. Newbury Park/London/New Delli: Sage

Fischer, F., Forester, J. (1993). The argumentative turn in policy analysis and planning. London: UCL, Press

Fischer, F. (1995). Evaluating public policy. Chicago: Nelson-Hall Publishers

Freidson, E. (1970). Profession of Medicine. New York: Dodd, Mead \& Company

Frissen, P.H.A. (1996). De wirtuele staat. Schoonhoven: Academic Service

Frouws, J. (1994). Mest en Macht. Een politiek-soctologische studie naur belangenbehartiging en beleidswoming inzake de mestproblemaniek in Nederland vanaf 1970 . Wageningen (proefschrift)

Fuldauer, A. (1998). Het rekeningboek van dr. J.B. Schoemaker. Bron voor de geschiedenis van de plattelandsgeneeskunde. Geschiedenis der Geneeskunde. 4 (5) 277-283

Gabel, J.R., Rice, T.H. (1985). Reducing public expenditures for physician services: the price of paying less. Joumal for Heath Policy, Politics and Law. 10 (4) 595-609

Gäfgen, G. (1988). Kollectiwerhandlungen als konstitutiver Allokationsmechanismus korporatistischer Ordnungen. In G. Gafgen (Hrsg.). Neokorporarismus und Gesundheitswesen. Baden-Baden: Nomos 61-89

Gezondheidstad (1991). Medisch handelen in de praktik Gesprekken met medische beroeps beoefenorem. Den Haag: Gezondheidsraad

Glaser, W.A. (1960). Doctors and politics. American Joumal of Sociology. 66 (3) $230-245$

Glaser, W.A. (1970). Paying the doctor. Systems of remmenation and their effects. Baltimore London: The Johns Hopkins Press

Glaser, W.A. (1989a). Commentary. The politics of paying American physicians. Health Affairs. 8 (3) 129.146

Glaser, W.A. (1989b). Perspective. The politics of physician payment: the author responds. Healh Affarws. 8 (4) $87-96$ 
Glaser, W.A. (1990). Designing fee schedules by formulae, politics, and negotiations. American Jounal for Public Healih. 80 (7) 804-809

Glaser. W.A. (1993). How expenditure caps and expenditure targets really work. The Milbank Quarterly. 71 (1) $97-127$

Glaser, W.A. (1994). Doctors and public authonities: the trend toward collaboration. Jowmal of Healh Policy, Polticis and Law 19 (4) 705-727

Glaser, B.G., Strauss, A.L. (1967). The discovery of grounded theory. strategies for qualiative resedrch. New York: Aldine de Gruyter

Godefroi (1963). Het Ziekenfondswezen in Nederland. 's-Gravenhage: Martinus Nijhoff

Godfroij, A.J.A. (1981). Netwerken van arganisaties. "s-Gravenhage: VUGA

Godfroij, A. Y.A. (1993), Sturing en marktwerking in de gezondheidszorg. In A.J.A. Godfroij, N.J.M. Nelissen. Verschuivingen in de besturing van de samenleving. Bussum: Coutinho $125-159$

Griffin, $\mathbb{L} . \mathbb{J}$ (1993). Narrative, event-structure analysis, and causal interpretation in historical sociology. American Journal of Sociology. 98 (5) 1094-1133

Grin, J., Graaf, H. van de. (1994). Handelingstheorieèn en netwerken: ongelijksoortige rationaliteiten en congruente betekenissen. Beleudswetenschap. 8 (4) 349-366

Grinten, $T$. van der (1993).Veranderingen in het maatschappelik middenveld. Over nut en noodzaak wan beleidsnetwerken in de gezondheidszorg. Gezondheid. 1 (3) $245-263$

Grinten, T.E.D. van der (1994). Delen van de macht. Bewegingen in het beleidsbestel van de gezondheidszorg. Beleid en Maatschappij. 21 (4) 182-188

Groot, G.R.J. de, Daalder, E.J. (1985). De Wet tarieven gezondheidszorg. Deventer: Klluwer

Grünwald, C.A. (1987). Beheersing van de gezondheidszorg. 's-Gravenhage: VUGA

Hall, P.A., Taylor, S.C.R. (1994). Political science and the four new instimutionalisms. Paper prepared for the Annual Meeting of the American Political Science Association. New York.

Hamilton-Van Hest. I. (1989). Jurisprudentie WTG. Tijdschrift voor Gezondheidsrecht. 13 (6) $382-428$

Hanf, K.,Toonen, Th.A.J. (1988). Politieke vervlechting; institutionele structuren en het probleemoplossend vermogen van het opanbaar bestuur. Het werk van Fritz W. Scharpf. In A.F.A. Korsten, A.J. Toonen (red.). Bestuurskunde. Hoofdfigupen en kerwihema's. Leiden/Antwerpen: Stenfert Kroese 163-184

Harrison, M.I. (1993). Medical dominance or proletarization? Evidence from Israel. Research in the Sociology of Health Care. $1073-96$

Harrison, M.I. (1994). Professional control as process: beyond structural theories. Human Relations. 47 (10) 2101-1231

Hart, P. "t. (1992). Politiek-bestuurlike besluitvorming in Nederland: Een decennium van onderzoek in beeld. Beleidswetenschap. 6 (3) 199-227

Hart, P. 't, Metselaar, M., Verbeek, B. (red.) (1995). Publieke beshinoming. "s-Gravenhage: VUGA 
Heffen, 0 . van. (1993). Beleidsontwerp, reswlant en omgewing. Universiteit Twente (proefschrift)

Hellstern, G-M. (1986). When courts intervene: judicial control in a comparative institutional perspective. In F.X. Kaufmann, G. Majone, Kaufman, Y. Ostrom (eds). Guidance, control, and evaluation in the public sector. Berlin/New York: Aldine de Gruyter 663 688

Hemenjck, A.C. (1994). Hardnekkigheid van corporatistisch beleid in Nederland. Belet en Maatschappij. 21 (1-2) $23-47$

Hendriks, F. (1996a). Het belang van instituties betwist: Actie en reactio in de beleidswetenschappen. Beleidswetenschap. 10 (1) 23-39

Hendriks, F. (1996b). Beleid, cultum en instituties: het verhaal van twee steden. Leiden: DSWO Press:

Heringa, G.C. (1955). Nieuwjaar 1955 (redactioneel). Medisch Contact. 10 (1) I-3

Heijermans, H.L. (1961). Medische overwegingen en wensen omtrent het ziekenfondswezen. Tijdschrift voor Sociale Geneeskunde. 39 (14) 433-436

Hoekema, A.J. (1984). Het vertrouwensbeginsel en de spanning tussen formele bevoegdheid en materiële effectiviteit van het overheidshandelen. RM Themis. (5/6) 550-574

Hoeven, H.C. wan der, Hoeven, E.W. van der (1993). Om welzinn of winst. 100 Jaor ziekenfondsen en sociale zekerheid. Deventer: Kluwer

Honeyman, C. (1988). Five elements of mediation. Negotiation Journal, 4 149-160

Hoogerwerf, A. (1984). Beleid berust op veronderstellingen: de beleidstheorie. Acta Politica. 17 (4) $493-532$

Hoogerwerf, A. (1989). De beleidstheorie uit de beleidspraktijk: Een tussenbalans. Beleidswetenschap. 3 (4) $320-341$

Huizenga, F.D. (1993) Regime-analyse: contouren van een onderzoeksstrategie. Beleid en Maatschappij. 20 (2) $81-92$

Idenburg, Ph. A., Loo, H.R. van der. (1994). In alle staten. Een beschowwing over de rol en betekenis van overheidsbeelden. Den Hag: VUGA

Iglehart, J.K. (1990). The new law on medicare's payments to physicians. The Now England Jownal Of Medicine. 322 (17) 1247.1252

Inmergut, E.M. (1992a). Health politics. Interests and institurions in Western Europe. Cambridge: Cambridge University Press

Immergut, E.M. (1992b). The rules of the game: The logic of health pollicy-making in France, Switzerland, and Sweden. In S. Steinmo, K. Thelen, F. Longstreth (eds.). Struchuring politics. Historical institutionalism in comparative analysis. Cambridge: Cambridge University Press

Jaarverslagen van de Secretaris der Landelijke Specialisten Vereniging over het verenigingsjaar 1952-1979. Medisch Contact. Vol. 8 (1953) Vol. 34 (1979)

Japenga, C.J., Velden, H.F. van der. (1992). Het geneeskundig beroep en de regionale differentiatie in de organisatie en financiering wan de gezondheidszorg in Nederland (1900-1941). Tijdschrift voor Sociale Geschiedenis. 18 (4) $502-524$ 
Japenga, $C$, Velden, H. van der. (1993). Access to curative healh care: sickness funds versus medical relief in the Netherlands (1850-1941). In H. Binneveld, R. Dekker (eds.). Curing and insuring. Essays on ilness in past times: the Netherlands, Belgium, England and Italy, 16 th 20 th centuries. Hilversum: Verloren

Jaspers, J.B. (1985). Het medische circuit. Een sociologische studie wan de ontwikkeling van afhankelikheid iussen clienten, artsen, centrale overheid, ziekenfondsen en ziekewhuizen in Nederland (1865-1980). Utrecht/Antwerpen: Bohn, Scheltema \& Hokema

Johnson, T. (1982). The state and the professions: peculiarities of the British. A. Giddens, $G$. Mackenzie (eds.). Social class and the division of labour. Cambridge: Cambridge University Press

Johnson, T. (1995). Govermmentality and the institutionalization of expertise. In T. Johnson, G. Larkin, M. Saks (eds.). Health professions and the state in Europe. London/New York: Routledge

Juch, A. (1997). De medisch specialisten in de Nederlandse gezonalheidszorg. Hum manifestatie en consolidatie, 1890-1941. Rotterdam: Erasmus Publishing

Juffermans, P. (1982). Stad en gezondheidszorg in Nederland. Nijmegen: SUN

Kagan, R.A. (1991). Adversarial Legalism and American Government. Joumal of Policy Analysis and Management. 10 (3) 369-406

Kelman, S. (1992). Adversary and cooperationist institutions for conflict resolution in public policymaking. Joumal of Policy Analysis and Management. 11 (2) 178-206

Kenis, P., Schneider, V. (1991). Policy networks and policy analysis: scrutinizing a new analytical toolbox. In B. Marin, R. Mayntz (Eds). Policy networks. Frankfurt an Main/Coulder (Col.): Campus Verlag/Westview Press

Kessel, R.A. (1958). Price discrimination in medicine. The Journal of Law and Economics. 1 (1) $20-53$

Kirkman-Liff, B.L. (1989). Cost containment and physician payment methods in the Netherlands. Inquiry. 26 (..) $468-482$

Kiser, L.L., Ostrom, E. (1982). The Three Worlds of Action. A metatheoretical synthesis of institutional approaches. In E. Ostrom (Ed.). Strategies of political inquiry. Beverly Hills: Sage 179-222

Klij, E-H. (1996). Regels en stwring in metwerken. Delft: Eburon

KNMG-Memorandum -. Wetsontwerp Tarieven Gezondheidszorg (1977). Medisch Conact 32 (8) $239-341$

Knoke, D. (1990). Organizing for collective action. the political economy of associations. New York: Aldine de Gruyter

Koppenjan, J. (1993). De duur wan beleidsvorming als probleem. In O. Van Heffen, M. I. W. van Twist (red.). Beleid en wetenschap. Alphen aan den Rijn: Samsom/H.D. Tjeenk Willink, $169-185$

Lane, J-E. (1995). The public sector: concepts, models and approaches. London: Sage

Lapre, R.M. (1980). De Wet Tarieven Gezondheidszorg: totstandkoming en betekenis. Tijdschrifo voor Sociale Geneeskunde. 58 (24) 846-855 
Laumann, E. O., Knoke, D. (1987). The organizational state: Social choice in motional policy domains. Madison: The University of Wisconsin Press

Laumann, E.O., Heinz, J.P., Nelson, R., Salisbury, R. (1991). Organizations in political action: representing interests in national policy making. In $\mathrm{B}$. Marin, $\mathrm{R}$. Mayntz (Bds). Policy networks. Empirical evidence and theoretical considerations. Frankfurt am Main/Boulder (Col.): Camous Verlag/Westview Press 63-95

Lieburg, M.J. van. (1995), Overheid, medisch beroep en instellingswezen. In R.B.M. Rigter (red.). Overheid en gezondheidszorg in de wwintigste eew Rotterdam: Erasmus Publishing 59-76

Lieverdink, H. (1994). De totstandkoming van tarieven voor medisch specialisten. In R.M. Lapré et al. Handboek structur en finahciering gezondheidszorg. Utrecht: De Tijdstroom

Lieverdink, H., Made, J. van der, Merode, F. van (1995). The waning of cooperative bargaining in the Netherlands. Paper gepresenteerd op de APSA bijeenkomst van 31 augustus-3 september 1995. Chicago

Lieverdink, H., Maarse, H. (1995). Negotiating fees for medical specialists in the Netherlands. Health Policy. 31 (2) 81-101

Lieverdink, H., Merode, F. van. (1997). De participatie in besluitworming. Beleidswetenschap. 10 (4) $360-379$

Lomas, J., Charles, C., Greb, C. (1992). The price of peace. The structure and pracess of physician fee negotiations in Carada. Hamilton. McMaster University Centre for Healdh Economics and Policy Analysis (Working Paper $\$ 92-17$ )

Loo, H.R. wan der, Idenburg, Ph.A. (1994). Voorbij de vanzelfsprekendheid van tijd. Bestuutskinde. 3 (7) 278-294

Maarse, J.A.M. (1988). Planning en uitvoering van overheidsbeteid. Het werk van Renate Mayntz. A.F.A. Korsten, A.J. Toonen (red.), Besturtskunde. Hoofdfiguren en kernthema's. Leiden/Antwerpen: Stenfert Kroese 377-393

Maarse, J.A.M. (1990). Overheid en volksgezondheid. In J.A.M. Maarse, I.M. Mur-Veeman. Beleid en beheer in de gezondheidszorg. Assen/Mastricht: Van Gorcum 52-70

Maarse, J.A.M., Moen, J. (1991). Instrumenten van beleid: De doorwerking vanuit cen organisatie-theoretisch perspectief. Beleidswetenschap. $5(2) 132.147$

MacRae, D. Jr. (1993). Guidelines for policy discourse; consensual versus adversarial. In F. Fischer, J. Forester. The argumentative umn in policy analysis and plaming. London: UCL Press Limited 291-318

Majone, G. (1989). Evidence, argument, and persuasion in the policy process. New Haven: Yale University Press

Mansvelt, J, wan (1974), Is de invoering van een volksverzekering tegen ziektekosten gew enst? Tijdschifi voor Sociale Geneeskunde. 52 (9) $302-306 / 328$

March, J.G. (1994). A primer on decision making. How decisions happen. New York: The Free Press

March, J.G., Olsen, J.P. (1994). Instituitonal Perspectives on Political Institutions. Paper presented at the IPSA meeting in August 1994. Berlin 


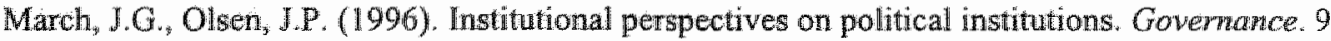
(3) $247-264$

Marin, B., Mayntz, R. (1991). Introduction: studying policy networks. In B. Marin, R. Mayntz (Ed.). Policy networks. Enpirical ewidence and heoretical considerations. Frankfur am Main/Bioulder (Col) : Campus Verlag/Westwiew Press

Mamor, Th.R. Thomas, D. (1972). Doctors, politics and pay disputes. British Jownal for Political Science. 2 421-442

Marmor, Th., Oberlander, J. (1995). Review essay. Political analysis and the welfare state: can we leam from history? Joumal for Health Policy, Politics and Law. 20 (1) 211.225

Mason, R.O. Mutrof, II. (1981). Challenging strategic planning assumptions: theory, cases and techingues. New York: Willey

Mayntz, R. (1992). Modemisierung und die Logik von interorganisatorischen Netzwerken. Journal fir Sozialforschung. 32 (1) 19-32

Mayntz, R., Scharpl, F.W. (1995a). Steuerung und Selbstorganisation in staatsnahen Sektoren. In R. Mayntz, F.W. Scharpf (Hg.), Gesellschaftiche Selbstregelung und politische Stewerung. Frankfurt: Campus 9-38

Mayntz, R., Scharpf, F.W. (1995b). Der Ansatz des akteurzentrierten Institutionalismus. In R. Mayntz, F.W. Scharpf ( $\mathrm{Hg}$ ), Gesellschaftiche Selbstregelung und politische Stewerang. Frankfurt: Campus 39-72

Mierlo, J.G.A. van (1988). Een politiek-economische analyse van exteme adwiesorganen in de Nederlandse gezondheidszorg. In J.G.A. van Mierlo, L.G. Gerrichhauzen (red.). Het particulier initiatief in de Nederlandse verzorgingsmaatschappuj. Lochem: De Tijdstroom

Miles, M.B., Huberman, A.M. (1994). Qualitative data analysis. Thousand Oaks/London/New Delli: Sage

Miller, $\mathrm{G}_{\text {., }}$ Holstein, J.A. (1995). Dispute domains. Organizational contexts and dispute processing. The Sociological Quarterly. 36 (1) $37-59$

Ministerie van VWS (1995). De prijs die zorg verdient. Rijswijk: Ministerie van VWS

Mijn, W.B. van der. (1974). Vrijheid en doelmatigheid in het kader van een volksverzekering tegen ziektekosten. Tijdschrifi voor Sociale Geneeskunde. 52 (9) $307-313$

Nalbandian, $J$ (1994). Reflections of a "pracademic" on the logics of politics and administration. Public Administration Review, 54 (6) $531-536$

Navarro, V. (1985). Medical history as justification rather than explanation: A critique of Pau Starr's "The social transformation of American medicine". In V. Navarro. Crisis health and medicine. A social critigue. New York: Tavistock Publications 185-211

Nieuwenhuzen, C.L.C. van. (1971). Bij het 25-jarig bestaan van de Landelijke Specialisten Vereniging (feestrede op 23 oktober 1971). Medisch Contact. 26 (46) 1201-1209

North, D.C. (1990). Mnstimatons, insritutional change and economic performance. Cambridge: Cambridge University Press

N2i (1996). Specialisten gebudgetteerd!? De effecten wan lokale imitiatieven geinventariseerd. Utrecht: $\mathrm{NZi}$ 
OECD (1992). The reform of healh care. A comparative andysis of seven OECD commin: (Health Policy Studies No. 2). Paris: OECD

Offe, C. (1975). The theory of the capitalist state and the problen of policy formation. In L.N. Lindberg, R. Alford, C. Crouch, C.Offe (eds). Stress and contradrotion in modem capialism. Lexington:. Lexington Books $125-144$

Offe, C. (1981). The atribution of public status to interest groups: observations on the West German case. In S. Berger (ed.). Orgonizing interests in Western Europe. Pluralism. corporatism, and the transformation of politics. Cambridge. Cambridge University Press $123-158$

Offe, C. (1985). Disorganized capitalism. Contemporary transformations of work and pollitics. Cambridge: Polity Press

Oliver, C. (1991). Strategic responses to institutional processes. Academy of Management Review. 16 (1) 145-179

Ostrom, E. (1986). A method of institutional aualysis. In F-X. Kaufmann, G. Majone, V.Ostrom. Guidance, control, and evaluation in the public sector. New York/Berlin: De Gruyter $459-475$

Ostrom, E. (1990). Governing the commons. Cambridge: Cambridge University Press

Pen, J. (1995). Padafhankelijkheid. Hollands Maandblad. (2) $29-33$

Peterson, M.A. (1993). Political influence in the 1990s: from iron triangles to policy networks. Journal of Health Policy, Politics and Law. 18 (2) 395-438

Poel, L.C.J. van der. (1987). Het Centraal Orgaan Tarieven Gezondheidszorg. In R. Janssen, P. Kocken, J. van der Made (red.). Exteme adviesorganen in de gezondheidszorg. Lochem: De Tijdstroom 119-130

Pressman, J.L., Wildavsky, A. (1973). Implementation: how great expectations in Washington are dashed in Oakland: or, why it is amazing that federal programs work at all, this being a siga of the Economic Development Administration as told by two sympathetic observers who seek to build morals on a foundation of ruined hopes. Berkeley: University of California Press

Propper, I.M.A.M., Blejenbergh, I.L. (1995). Argumenteren in politek en bestuar. Alphen aan den Rijin: Samsom H.D. Tjeenk Willink

Rapporl wigebracht door de op 27 februan 1975 op veraek van de Sidarssecretaris van Folksgezondheid en milieuhygiene door de Ziekenfondsraad ingestelde commissie (Commissie Becht") (1976). Amstelveen: Ziekenfondsraad

Rein, M., Schön, D. (1993). Reframing policy discourse. In F. Fischer, J. Forester. The argumentative rum in policy analysis and planning. London: UCL Press 145-166

Reinhardt, U.E. (1987). Resource allocation in heall care: the allocation of lifestyles to providers. The Milbank Quarterly. 65 (2) 153-176

Rejjen, J.P. van der. (1987). Onze kosielike gezondheid. Amsterdan: Uitgeverij Balans

Ringeling, A. (1994). Het tmago van de overheid. 's-Gravenhage: VUGA

Roscam Abbing, H.D.C. (1987). Bestuursaccoorden in de gezondheidszorg. Reche der werkelijkhed. Themanummer Horizontal bestwur. 8 54-70 
Roo, A.A. de, Maarse, J.A.M. (1990). Understanding the central-local relationship in health care - a new approach. International Jowmal of Healh Planning and Managemeni. 5 (1) 15 25

Rose, R, Davies, Ph.L. (1994). Yheritance in public policy: change without choice in Britain. New Haven/London: Yale University Press

Rosewitz, B.,Webber, D. (1990), Reformversuche und Reformblockaden im deutschen Gesundhetiswesen. Frankfurt: Campus Verlag

Sabatier, P.A. (1987). Knowledge, policy oriented learning, and policy change. Knowledge: Creation, Diffusion, Utilization. 8 (4) 649-692

Scharpf, F.W. (1989). Decision rules, decision styles and policy choices. Joumal of Theoretical Politics. 1 (2) 149-176

Scharpf, F.W. (1993). Coordination in hierarchies and networks. In F. W. Scharpf (ed.). Games in hierarchies and neworks. Frankfurt an Main: Campus Verlag 125-165

Schattschneider, E.E. (1975). The semisovereign people. A realist's view on democracy in America. Hinsdale (III): The Dryden Press

Schepers, $\mathbb{R}$, Klazinga, $N$. (1993). Professionele autonomie in een veranderende gezondheidszorg. Gezondheid. 1 (2) 283-295

Schmitter, W. (1986). Neo-comporatism and the state. In W. Grant (ed.). The political economy of corporatism. London: Macmillan $32-62$

Schnabel, P. (1988). De gezondheidszorg: van immuniteit tot publiek domein. In A.M.J. Kreukels, J.B.D. Simonis (redactie). Publiek domein. De veranderende balans tussen staat en samenleving. Meppel/Amsterdam: Boom 172-200

Scholten, G. (1994). De onsingeling van medische specialisten. Rotterdam (proefschrift)

Scholtens, H. (1993). Het concept beleidstheorie in onderzoek: afbakening en kwaliteit. In 0 . Van Heffen, M.J.W van Twist. Beleid en wetenschap. Alphen aan den Rijn: Samsom H.D. Tjeenk Willink 96-106

Schön, D.A. (1983). The reflective practitioner. How professionals think im action. New York: Basic Books

Schut, F.T. (1995). Comperinion in the Dutch health care sector. Rotterdam (proefschrift)

Scott, W.R. (1995). Institutions and organizations. Thousand Oaks/New Delhi/London: Sage

Snellen, $\mathbb{1}$.Th.M. (1987). Boeiend en geboeid. Ambivalenties en ambities in de bestumskunde. Alphen aan den Rijn: Samsom H.D. Tjeenk Willink

Starr, P. (1982). The social transformation of American medicine. New York: Basic Books

Steinmo, S., Watts, J. (1995). It's the institutions, stupid! Why comprehensive national health insurance always fails in America. Journal for Health Policy, Politics and Law. 20 (2) $329-372$

Stone, D.A. (1980). The limits of professional power. National Health Care in the Federal Republic of Germany. Chicago: Chicago Press

Stone, D. (1988/1995), Policy paradox and polilical reason. Glenwiew (III.): Scott, Pressman and Company 
Stryker, R. (1989). Limits on technocratzation of the law: the elimination of the National Labor Relations Board's division of economic research. American Sociologidal Review. 54 (4) $341-358$

Stryker, R. (1994). Rules, resources, and legitimacy processes: some inuplications for social conflict, order and change. American Joumal of Sociology. 99 (4) 847-910

Subcommissie Onderzoek beshitvorming volksgezondheid (1994). Roppont. 's-Gravenhage: Sdu

Suchman, M.C., Edelman, L.B. (1997). Legal rational myths: the new institutionalisin and the Law and Society Tradition. Law and Social Inquiry. 21 (4) 903-942

Susskind, L., Cruikshank, J. (1987). Consensual approaches to resolving public disputes. New York: Basic Books

Swaan, A. de. (1989). Zorg en de stant. Welzin, onderwis en gezondheidszorg in Europa en do Verenigde Staten in de nieuwe vijd. Ansterdam: Bert Bakker

Tatenhove, J. van., Leroy, P. (1995). Beleidsnetwerken: Een kritische analyse. Beleidswerenschap. 9 (2) 128 -145

Teisman, G.R. (1992). Complexe beshitvorming: een pluricentisch perspektief op beslwitworming over rumtelije investeringen. Den Hag: VUGA

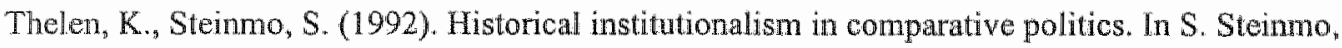
K.Thelen, F. Longstreth (eds). Structwing politios. Historical instituionalism in comparative analysis. Cambridge: Cambridge University Press 1-31

Therbon, G. (1978). What does the ruling class do when in rules? London: NLB

Torenvlied, R. (1995). De inbedding van beleidsvisies in belleidsnetwerken. Beleidswetenschap. 9 (4) $323-341$

Toulmin, S., Rieke, R., Janik, A. (1979). An introduction to reasoning. Now York: Macmillan Publishing Co.

Vallinder, T. (1994). The judicialization of politics-A world-wide phenomenon: Intraduction. Intenational Political Science Review. $15(2) 91-99$

Veen, R.J. van der. (1997). Een geregelde toekomst. Over veranderingen in de inrichting van het publicke domein. Enschede (oratie)

Velden, H. van der. (1993a). Financhele toegankelykheid tot gezondhetdsorg in Nederland, 1850-1941. Amsterdam: Stichting beheer TISG

Velden, H. van der. (1993b). Collectivisering en solidariteit in de Nederlandse gezondheidszorg: een historisch perspectief. Gezondheid. 1 (3) $265-281$

Ven, A.H. van de, Poole, MS. (1990). Methods for studying innovation. Organization Science. (3)

Versteden, CJ.N. (1997). Juridisering: de democratische rechtsstaat uit balans. Nederlands Muristemblad $72(21) 943-949$

Volti, R. (1992). Society and technological change. New York: St. Martin's Press

Voogd, H., Woltjer, I. (1995). Beshitvorming via onderhandelen: een oud gebruik in een nieuw perspectief. Beleidsanalyse. 24 (4) $12-23$ 
Waarden, B.F. van. (1989). Organisatiemacht van belangenverenigingen: de ondernemersorganisaties in de bowwnijvertheid als voorbeeld Amersfoort: Acco

Wassenberg, A.P.P. (1988). Strategie en beleid. Onderhandelingsgedrag in netwerken. Vladardingen: Nederlands Studie Centrum

Weick, K.E. (1995), Sensemaking in organizations. Thousand Oaks/New Delhi/London: Sage

Wielen, Y van der. (1963), Het ontwerp ziekenfondswet. Tijdschrift voor Sociale Geneeskunde. $41(1) 15-19$

Wildavsky, A., Tenenbaum, E. (1981). The politics of mistrust. Estimating American oil and gas resources. Beverly Hills/London: Sage

Willke, H. (1982). Die Disjunktion von Rechtsformen und Machtformen - am Beispiel der Konzertierten Aktion. In V. Gessner, $G$. Winter (Herausg.). Rechtsformen der Werflechtung von Staat und Wirtschaft. Opladen: Westdeutscher Verlag 200-212

Willke, $H_{.}$(1989). Systemtheorie entwickelter Gesellschaften. Dynamik und Riskanz modemer gesellschafiticher Selbstorganisation. Weinheim/München: Juwenta Verlag

Wilike, H. (1992). Ironie des Staates. Grundlinen einer Staarstheorie polyzentrischer Gesellschaft. Frankfurt am Main: Suhrkamp Verlag

Wilsford, D. (1991). Doctors and the state. The politics of health care in France and the United States. Durham and London: Duke University Press

Wilsford, D. (1994). Path dependency, or why history makes it difficult but not impossible to reform health care system in a big way. Joumal for Public Policy. 14 (3) $251-283$

Windhoff-Heritier, A. (1991), Institutions, interests, and political choice. In R.M. Czada, A. Windhoff-Heritier (Eds.). Political choice. Institutions, rules, and the limits of rationality. Frank furt am Main/ Boulder (Col.): Campus Verlag/Westview Press 27-52

Witteveen, W.J. (1988). Babel en de politieke theorie. Acta Politica. 23 (2) 177-198

Wolters, T.J.J.B. (1990). Bemiddeling als terrein van wetenschappelijk onderzoek. Negotrotion Magazine. 3 (4) 171-181

Ziekenfondsraad. (1998). Evaluatie experiment specialistenhonorering. Amstelveen: Ziekenfondsrad

Zoest, A.J. van. (1992). Doorwerking wan jurisprudentie in het beslissingsgedrag van gemeenten. Bestuurswetenschappen. $46(6) 465-479$

Zweifel, P. $\mathbb{E}$ ichenberger, P. (1992). The political economy of corporatism in medicine: selfregulation or cartel management. Jownal of Regulatory Economics. 4 (4) 89-108 


\section{Curriculum vitae}

Harm Jan Lieverdink werd op 16 februari 1963 geboren in Winterswijk. Na de lagere school ging hij naar het Atheneum. Het examen legde hij met succes af aan de Nijmeegse Scholengemeenschap. Nadat een toelatingscommissie van de Kunstacademie in Den Bosch terecht had geconcludeerd dat hij over te weinig teken-en schildertalenten beschikte, begon hij in 1981 aan de studie Politicologie aan de Katholieke Uniwersiteit Nijmegen. Tijdens deze studie koos hij voor de specialisatie bestuurskunde. Het diploma kon in 1988 met lof worden uitgereikt. Daarna riep de overheid hem onder de wapenen waardoor pas in 1990 een wetenschappelijke carrière gestart kon worden. In september van dat jaar begon hij als assistent-in-opleiding aan een onderzoek naar de tariefvorming in de gezondheidszorg bij de vakgroep Beleidswetenschap van de Universiteit van Maastricht. Vanaf 1992 werkt hij als universitair docent bij dezelfde vakgroep die sinds 1997 Beleid, Economie en Organisatie van Zorg (BEOZ) heet. Naast de onderzoeks- en onderwijsactiviteiten heeft hij zich bezig gehouden met bestuurlijke aangelegenheden door lid te zijn van de faculteitsraad. Bovendien is hij actief in de studiegroep Comparative Health Policy van de International Political Science Association (IPSA). Hij heeft gepubliceerd over de besluitvorming over tarieven voor medisch specialisten en overheidsbelleid ten aanzien van het ziektekostenverzekeringsstelsel in tijdschriften en boeken. 